UNIVERSIDADE DE SÃO PAULO
ESCOLA DE ENGENHARIA DE SÃO CARLOS
PROGRAMA DE PÓS-GRADUAÇÃO EM ENGENHARIA HIDRÁULICA E SANEAMENTO

GIOVANNA LOVATO

Produção De Biohidrogênio E Biometano Em AnSBbR A Partir Da Codigestão De Glicerina E Soro De LeITe

VERSÃO CORRIGIDA

SÃO CARLOS

2018 



\section{Produção de Biohidrogênio E Biometano Em AnSBbr a Partir da Codigestão De Glicerina E SORo De LeITE}

Tese apresentada à Escola de Engenharia de São Carlos, da Universidade de São Paulo, como parte dos requisitos para obtenção do título de Doutor em Ciências: Engenharia Hidráulica e Saneamento.

Orientador: Prof. Dr. José Alberto Domingues Rodrigues

\section{VERSÃO CORRIGIDA}




\section{FICHA CATALOGRÁFICA}

AUTORIZO A REPRODUÇÃO TOTAL OU PARCIAL DESTE TRABALHO, POR QUALQUER MEIO CONVENCIONAL OU ELETRÔNICO, PARA FINS DE ESTUDO E PESQUISA, DESDE QUE CITADA A FONTE.
Lovato, Giovanna
L896p Produção de biohidrogênio e biometano em AnSBBR a partir da codigestão de glicerina e soro de leite / Giovanna Lovato; orientador José Alberto Domingues Rodrigues. São Carlos, 2018.

Tese (Doutorado) - Programa de Pós-Graduação em Engenharia Hidráulica e Saneamento e Área de Concentração em Hidráulica e Saneamento -- Escola de Engenharia de São Carlos da Universidade de São Paulo, 2018 .

1. AnsBBR. 2. Biohidrogênio. 3. Carga Orgânica. 4. Codigestão. 5. Glicerina. 6. Soro de Leite. 7. Temperatura. I. Título. 


\section{FOLHA DE JULGAMENTO}

Candidata: Engenheira GIOVANNA LOVATO.

Título da tese: "Produção de biohidrogênio e biometano em AnSBBR a partir da codigestão de glicerina e soro de leite".

Data da defesa: 23/02/2018.

Comissão Julgadora:

Prof. Dr. José Alberło Domingues Rodrigues

(Orientador)

(Escola de Engenharia Mauá/EEM)

Prof. Dr. Edson Luiz Silva

(Universidade Federal de São Carlos/UFSCar)

Prof. Dr. Ronan Cleber Contrera

(Escola Politécnica/EP-USP)

Prof. Dr. Sérgio Francisco de Aquino

(Universidade Federal de Ouro Preto/UFOP)

Prof. Dr. Leonardo Henrique Soares Damasceno

(Universidade Federal de Alfenas/UNIFAL)
Resultado:

APRONASAT

APROVADA

APROVADA

APROVADA

APROVADA

Coordenador do Programa de Pós-Graduação em Engenharia Hidráulica e Saneamento:

Prof. Dr. Eduardo Mario Mendiondo

Presidente da Comissão de Pós-Graduação:

Prof. Associado Luis Fernando Costa Alberto 



\section{AGRADECIMENTOS}

Em primeiro lugar, à minha mãe Lucimara, pelo apoio, paciência e amor incondicional. Ela é a minha heroína e o meu orgulho.

À minha família, por todo o amor e apoio sempre.

Ao Rodrigo, meu namorado, que acredita no meu potencial e que me incentiva todos os dias.

Ao Dr. José Alberto Domingues Rodrigues, pela orientação, pela disponibilidade, pelo apoio, pela dedicação e, acima de tudo, pela grande amizade desde o começo da faculdade. Devo toda minha carreira acadêmica a ele.

À Dra. Suzana Maria Ratusznei, pela orientação e pela amizade. Uma pessoa sempre disposta a ajudar no crescimento profissional e pessoal de cada um de seus alunos.

À Dra. Roberta Albanez, colega de doutorado que virou uma amiga, pela força e disposição de trabalhar.

Aos colegas de laboratório Weriskiney, Victor, Juliane, Marcela, Natalia e Túlio pelo apoio durante os experimentos e pelas boas risadas.

Ao Departamento de Hidráulica e Saneamento da Escola de Engenharia de São Carlos da Universidade de São Paulo SHS/EESC/USP e a Escola de Engenharia Mauá do Instituto Mauá de Tecnologia EEM/IMT que disponibilizaram o espaço e o apoio necessário para a realização deste projeto.

À FAPESP, pela bolsa de doutorado concedida (processo $\mathrm{n}^{\circ}$ 2014/07.692-8) e pelo auxílio financeiro nos Projetos Temáticos "Produção de Bioenergia no Tratamento de Águas Residuárias e Adequação Ambiental dos Efluentes e Resíduos Gerados" (processo ${ }^{\circ}$ 2009/15.984-0) e "Aplicação do Conceito de Biorrefinaria a Estações de Tratamento Biológico de Águas Residuárias: O Controle da Poluição Ambiental Aliado à Recuperação de Matéria e Energia" (processo no 2015/06.246-7).

Às pessoas que, cada uma a sua maneira, contribuíram para realização deste trabalho, minha sincera gratidão. 



\section{RESUMO}

LOVATO, G. Produção de biohidrogênio e biometano em AnSBBR a partir da codigestão de glicerina e soro de leite. 2018. 257 p. Tese (Doutorado) - Escola de Engenharia de São Carlos - Departamento de Hidráulica e Saneamento, Universidade de São Paulo, 2018.

A presente pesquisa teve como proposta avaliar o reator anaeróbio, operado de forma descontínua ou descontínua alimentada, contendo biomassa imobilizada em suporte inerte e com recirculação da fase líquida (AnSBBR) aplicado à produção de biohidrogênio a partir da codigestão de glicerina (efluente da produção de biodiesel) e soro de leite (efluente da produção de laticínios). A estabilidade, os índices de desempenho (referentes à produtividade e rendimento molar do hidrogênio) e o fator de conversão (entre biogás produzido e matéria orgânica consumida) foram analisados em função da composição afluente (porcentagem de cada substrato alimentado ao sistema), da variação da carga orgânica, do tempo de enchimento e da temperatura $\left(20,25,30\right.$ e $\left.35^{\circ} \mathrm{C}\right)$. Os ensaios foram realizados em diferentes proporções dos substratos utilizando-se variadas cargas orgânicas volumétricas $(10,3 ; 17,1$ e 24,0 gDQO. $\left.\mathrm{L}^{-1} \cdot \mathrm{d}^{-1}\right)$, as quais foram modificadas em função: $(i)$ da concentração afluente $(3,5$ e 7 gDQO.L $\left.\mathrm{L}^{-1}\right)$ e (ii) do tempo de ciclo (4, 3 e 2 h, ou seja, 6, 8 e 12 ciclos diários). Também foram realizados ensaios para a produção de biometano a partir da codigestão proposta nesta pesquisa (com COAV de 7,6 gDQO. $\mathrm{L}^{-1} \cdot \mathrm{d}^{-1}$ ) em diferentes proporções de mistura. Para a produção de biometano, a condição com $75 \%$ de soro e $25 \%$ de glicerina (base DQO) obteve os melhores resultados: produtividade molar de $101,8 \mathrm{molCH}_{4} \cdot \mathrm{m}^{-3} \cdot \mathrm{d}^{-1}$ e rendimento por carga aplicada de 13,3 molCH $4 . \mathrm{kgDQO}^{-1}$; o que representa um aumento de produtividade de cerca de $9 \%$ e $30 \%$ quando comparado com a digestão anaeróbia de soro e glicerina puros, respectivamente. A produção de metano no melhor ensaio aconteceu predominantemente pela rota hidrogenotrófica. Para a produção de biohidrogênio, a maior produtividade e rendimento do reator foram obtidas no ensaio operado com razão de mistura de $75 \%$ soro e $25 \%$ glicerina, com 7 gDQO.L $\mathrm{L}^{-1}$ de concentração afluente, tempo de ciclo de $3 \mathrm{~h}$ e tempo de enchimento de 1,5 h (modo batelada alimentada - COAV de 23,9 kgDQO. $\mathrm{m}^{-3} \cdot \mathrm{d}^{-1}$ ), a $30^{\circ} \mathrm{C}$ : foi obtida uma produtividade molar de $129,0 \mathrm{molH}_{2} \cdot \mathrm{m}^{-3} \cdot \mathrm{d}^{-1}$ e rendimento de $5.4 \mathrm{molH}_{2} \cdot \mathrm{kgDQO}^{-1}$. Esses resultados representam um aumento de produtividade de $145 \%$ em relação a mono-digestão do soro na condição inicial, o que indica o benefício significativo da adição de glicerina ao afluente, provavelmente devido à sua capacidade tamponante, e a otimização das condições 
operacionais. A adição de glicerina e o aumento da COAV balancearam as rotas de produção de hidrogênio, sendo produzido de forma mais equilibrada pelas vias do ácido acético, butírico e valérico. A caracterização do consórcio microbiano desse ensaio indicou que a comunidade microbiana presente no AnSBBR foi dominada por Ethanoligenens e Megasphaera.

Palavras-chave: AnSBBR; biohidrogênio; carga orgânica; codigestão; glicerina; soro de leite; temperatura. 


\begin{abstract}
LOVATO, G. Co-digestion of glycerin and whey in AnSBBR for biohydrogen and biomethane production. 2018. 257 p. Thesis (Doctor's degree) - School of Engineering of São Carlos - Department of Hydraulics and Sanitation, University of São Paulo, 2018.

The current research evaluated an anaerobic reactor, operated in batch or fed-batch mode, containing immobilized biomass in inert support and with recirculation of the liquid phase (AnSBBR), applied to the production of biohydrogen co-digesting glycerin (effluent from biodiesel production process) and whey (effluent from dairy industry). Stability, performance (regarding productivity and molar hydrogen yield) and conversion factor (between biogas produced and organic matter consumed) were analyzed according to the percentage of each substrate fed to the system, organic loading rate, filling time and temperature $(20,25,30$ and $35^{\circ} \mathrm{C}$ ). Assays were carried out using different substrates proportions and organic loading rates $\left(10.3 ; 17.1\right.$ and 24.0 gCOD. $\left.\mathrm{L}^{-1} \cdot \mathrm{d}^{-1}\right)$, which have been modified in function of: (i) influent concentration (3, 5 and 7 gCOD.L $\left.{ }^{-1}\right)$ and (ii) cycle length $(4,3$ and 2 h, i.e. 6, 8 and 12 cycles daily). Assays were also carried out aiming for biomethane production using the proposed codigestion (with AVOL of 7.6 gDQO.L $\mathrm{L}^{-1} . \mathrm{d}^{-1}$ ) with different proportions of substrate mixture. For biomethane production, the assay conducted with $75 \%$ whey and $25 \%$ glycerin (COD basis) obtained the best results: molar productivity of $101.8 \mathrm{molCH}_{4} \cdot \mathrm{m}^{-3} \cdot \mathrm{d}^{-1}$ and yield per applied load of $13.3 \mathrm{molCH}_{4} . \mathrm{kgCOD}^{-1}$; which is an increase in productivity of about $9 \%$ and $30 \%$ when compared with the anaerobic mono-digestion of whey and glycerin, respectively. Methane production in this assay came mainly from the hydrogenotrophic route. For biohydrogen production, the highest productivity and yield were achieved in the assay operated with $75 \%$ whey and $25 \%$ glycerin, with 7 gCOD.L $\mathrm{g}^{-1}$ of influent concentration, $3 \mathrm{~h}$ of cycle time and filling time of $1.5 \mathrm{~h}$ (fed batch mode - AVOL of $23.9 \mathrm{kgCOD} \cdot \mathrm{m}^{-3} \cdot \mathrm{d}^{-1}$ ), at $30^{\circ} \mathrm{C}$ : a molar productivity of $129.0 \mathrm{molH}_{2} \cdot \mathrm{m}^{-3} \cdot \mathrm{d}^{-1}$ and yield of $5.4 \mathrm{molH}_{2} \cdot \mathrm{kgCOD}^{-1}$ were obtained. These results represent a productivity increase of $145 \%$ in relation to whey mono-digestion at its initial condition, which indicates the significant benefit of glycerin addition to the influent, probably due to its buffering capacity, and improvement of operational conditions. The addition of glycerin and the increase in AVOL balanced the hydrogen production routes, since hydrogen was produced similarly by the acetic, butyric and valeric acid routes. The characterization of the microbial consortium of this assay indicated that the microbial community present in the AnSBBR was dominated by Ethanoligenens and Megasphaera.
\end{abstract}


Keywords: AnSBBR; biohydrogen; co-digestion; glycerin; organic loading rate; temperature; whey. 


\section{LISTA DE FIGURAS}

Figura 3.1. Conversão da DQO disponível em resíduos biodegradáveis.........................................................42

Figura 3.2. Caminho metabólico durante a fermentação de vários substratos pelo Clostridium sp..................45

Figura 3.3. Reação de transesterificação de glicerídeos que produz glicerina.......................................................46

Figura 3.4. Evolução do número de artigos publicados com a palavra codigestão em seus títulos. .................49

Figura 3.5. Diferentes tipos de resíduos usados em codigestão para a produção de biogás................................49

Figura 4.1. Esquema do AnSBBR com recirculação utilizado nos ensaios.........................................................66

Figura 4.2. Detalhes do: $(a)$ reator, $(b)$ suporte da tela de aço, $(c)$ tela de aço, $(d)$ reservatório.........................66

Figura 4.3. Fotografia do aparato experimental utilizado nos ensaios.................................................................67

Figura 4.4. Fotografia do material suporte PEBD sem (esquerda) e com (direita) biomassa...........................68

Figura 4.5. Fotografia do material suporte PU sem (esquerda) e com (direita) biomassa. ...............................68

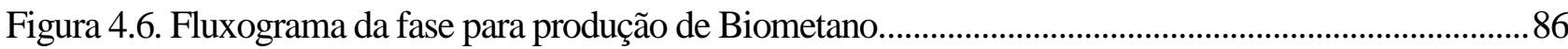

Figura 4.7. Fluxograma das Fases para produção de Biohidrogênio...................................................................8

Figura 5.1. Concentração de matéria orgânica e eficiências de remoção na forma de DQO no Ensaio 1:

- - afluente amostras não filtradas; • - efluente amostras não filtradas; ○ - efluente

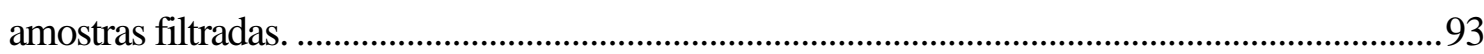

Figura 5.2. Concentração e eficiências de remoção de carboidratos no Ensaio 1: a - afluente amostras não filtradas; • - efluente amostras não filtradas; ○ - efluente amostras filtradas.........................93

Figura 5.3. Volume de biogás $\left(\mathrm{V}_{\mathrm{G}}\right)$ e de metano $\left(\mathrm{V}_{\mathrm{CH} 4}\right)$ nas $\mathrm{CNTP}$ e concentrações dos componentes do biogás no final do ciclo $\left(\mathrm{C}_{\mathrm{G}}\right)$ no Ensaio 1: $\diamond-$ Biogás; - Metano; 0 -Hidrogênio; $\Delta$ - Dióxido de Carbono.

Figura 5.4. Concentração de matéria orgânica e de carboidratos durante o ciclo no Ensaio 1: • - $\mathrm{C}_{\mathrm{SF}}$; O

$-\mathrm{C}_{\mathrm{CF}}$. .94

Figura 5.5. Valores de $\mathrm{pH}$, alcalinidade a bicarbonato (AB) e ácidos voláteis totais (AVT) no Ensaio 1.......95

Figura 5.6. Concentração dos compostos intermediários ao longo do ciclo no Ensaio 1: $\Delta$ - etanol; $\diamond$ butanol; $\square$ - ácido acético ; -X-ácido propiônico; $\mathbf{-}$-ácido isobutírico; • - ácido butírico;

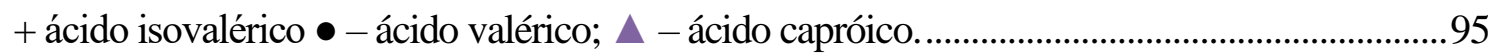

Figura 5.7. Produção volumétrica média acumulada do biogás durante o ciclo no Ensaio 1 . .96

Figura 5.8. Concentração dos compostos do biogás durante o ciclo e suas respectivas porcentagens no

Ensaio 1: $\circ-\mathrm{H}_{2} ; \bullet-\mathrm{CH}_{4} ; \Delta-\mathrm{CO}_{2}$. .96

Figura 5.9. Concentração e eficiência de remoção de matéria orgânica na forma de DQO no Ensaio 2:

- - afluente amostras não filtradas; • - efluente amostras não filtradas; ○ - efluente amostras filtradas. 
Figura 5.10. Concentração e eficiência de remoção na forma de carboidratos no Ensaio 2: a - afluente amostras não filtradas; • - efluente amostras não filtradas; ○ - efluente amostras filtradas.

Figura 5.11. Concentração e eficiência de remoção na forma de glicerina no Ensaio 2: a - afluente amostras não filtradas; • - efluente amostras não filtradas; ○ - efluente amostras filtradas.

Figura 5.12. Volume de biogás $\left(\mathrm{V}_{\mathrm{G}}\right)$ e de metano $\left(\mathrm{V}_{\mathrm{CH} 4}\right)$ na CNTP e concentrações dos componentes do biogás no final do ciclo $\left(\mathrm{C}_{\mathrm{G}}\right)$ no Ensaio 2: $\diamond$-Biogás; - Metano; o -Hidrogênio; $\Delta$ - Dióxido de Carbono.

Figura 5.13. Concentração de matéria orgânica, carboidratos e glicerina durante o ciclo no Ensaio 2:

$-\mathrm{C}_{\mathrm{SF}} ; \mathrm{O}-\mathrm{C}_{\mathrm{CF}} ;-\mathrm{C}_{\mathrm{GF}}$

Figura 5.14. Valores de $\mathrm{pH}$, alcalinidade a bicarbonato $(\mathrm{AB})$ e ácidos voláteis totais (AVT) no Ensaio 2.

Figura 5.15. Concentração dos compostos intermediários ao longo do ciclo no Ensaio 2: $\Delta$ - etanol; $\diamond$ butanol; - - ácido acético ; -X-ácido propiônico; - - ácido isobutírico; - - ácido butírico; + ácido isovalérico $\bullet$ - ácido valérico; $\boldsymbol{\Delta}$ - ácido capróico.

Figura 5.16. Produção volumétrica média acumulada do biogás durante o ciclo no Ensaio 2. 102

Figura 5.17. Concentração dos compostos do biogás durante o ciclo e suas respectivas porcentagens no Ensaio 2: $\odot-\mathrm{H}_{2} ; \bullet-\mathrm{CH}_{4} ; \Delta-\mathrm{CO}_{2}$

Figura 5.18. Concentração e eficiência de remoção de matéria orgânica na forma de DQO no Ensaio 3: 匹 - afluente amostras não filtradas; • - efluente amostras não filtradas; ○ efluente amostras filtradas.

Figura 5.19. Concentração e eficiência de remoção na forma de carboidratos no Ensaio 3: a - afluente amostras não filtradas; $\bullet$ - efluente amostras não filtradas; ○ - efluente amostras filtradas. .... 105

Figura 5.20. Concentração e eficiência de remoção na forma de glicerina no Ensaio 3: a - afluente amostras não filtradas; • - efluente amostras não filtradas; ○ - efluente amostras filtradas. .... 106

Figura 5.21. Volume de biogás $\left(\mathrm{V}_{\mathrm{G}}\right)$ e de metano $\left(\mathrm{V}_{\mathrm{CH} 4}\right)$ na CNTP e concentrações dos componentes do biogás no final do ciclo $\left(\mathrm{C}_{\mathrm{G}}\right)$ no Ensaio 3: $\diamond$-Biogás; - Metano; $~$ -Hidrogênio; $\Delta$ - Dióxido de Carbono.

Figura 5.22. Concentração de matéria orgânica, carboidratos e glicerina durante o ciclo no Ensaio 3: $-\mathrm{C}_{\mathrm{SF}} ; \mathrm{O}-\mathrm{C}_{\mathrm{CF}} ; \mathbf{-}-\mathrm{C}_{\mathrm{GF}}$

Figura 5.23. Valores de pH, alcalinidade total (AT) e ácidos voláteis totais (AVT) no Ensaio 3. 107

Figura 5.24. Concentração dos compostos intermediários ao longo do ciclo no Ensaio 3: $\Delta$ - etanol; $\diamond$ butanol; - - ácido acético ; -X-ácido propiônico; - - ácido isobutírico; • - ácido butírico; + ácido isovalérico $\bullet$ - ácido valérico; $\boldsymbol{\Delta}$ - ácido capróico. 108

Figura 5.25. Produção volumétrica média acumulada do biogás durante o ciclo no Ensaio 3. 
Figura 5.26. Concentração dos compostos do biogás durante o ciclo e suas respectivas porcentagens no Ensaio 3: ○ $-\mathrm{H}_{2} ; \bullet-\mathrm{CH}_{4} ; \Delta-\mathrm{CO}_{2}$.

Figura 5.27. Concentração e eficiência de remoção de matéria orgânica na forma de DQO no Ensaio 4: - - afluente amostras não filtradas; • - efluente amostras não filtradas; ○ efluente amostras filtradas.

Figura 5.28. Concentração e eficiência de remoção na forma de carboidratos no Ensaio 4: a - afluente amostras não filtradas; • - efluente amostras não filtradas; ○ - efluente amostras filtradas.......111

Figura 5.29. Concentração e eficiência de remoção na forma de glicerina no Ensaio 4: - - afluente amostras não filtradas; • - efluente amostras não filtradas; ○ - efluente amostras filtradas.......111

Figura 5.30. Volume de biogás $\left(\mathrm{V}_{\mathrm{G}}\right)$ e de metano $\left(\mathrm{V}_{\mathrm{CH} 4}\right)$ na CNTP e concentrações dos componentes do biogás no final do ciclo $\left(\mathrm{C}_{\mathrm{G}}\right)$ no Ensaio 4: $\diamond$-Biogás; $\bullet-$ Metano; 0 -Hidrogênio; $\Delta$ - Dióxido de Carbono.

Figura 5.31. Concentração de matéria orgânica, carboidratos e glicerina durante o ciclo no Ensaio 4:

$-\mathrm{C}_{\mathrm{SF}} ; \mathrm{O}-\mathrm{C}_{\mathrm{CF}} ;-\mathrm{C}_{\mathrm{GF}}$.

Figura 5.32. Valores de $\mathrm{pH}$, alcalinidade a bicarbonato $(\mathrm{AB})$ e ácidos voláteis totais (AVT) no Ensaio 4

Figura 5.33. Concentração dos compostos intermediários ao longo do ciclo no Ensaio 4: $\Delta$ - etanol; $\diamond$ butanol; - - ácido acético ; -X-ácido propiônico; - ácido isobutírico; • - ácido butírico; + ácido isovalérico $\bullet$-ácido valérico; $\Delta$ - ácido capróico.

Figura 5.34. Produção volumétrica média acumulada do biogás durante o ciclo no Ensaio 4.

Figura 5.35. Concentração dos compostos do biogás durante o ciclo e suas respectivas porcentagens no Ensaio 4: ○- $\mathrm{H}_{2} ; \bullet-\mathrm{CH}_{4} ; \Delta-\mathrm{CO}_{2}$.

Figura 5.36. Concentração e eficiência de remoção de matéria orgânica na forma de DQO no Ensaio 5: $\mathbf{~ - ~ a f l u e n t e ~ a m o s t r a s ~ n a ̃ o ~ f i l t r a d a s ; ~ • ~ - ~ e f l u e n t e ~ a m o s t r a s ~ n a ̃ o ~ f i l t r a d a s ; ~ ○ ~ - ~}$ efluente amostras filtradas

Figura 5.37. Concentração e eficiência de remoção na forma de glicerina no Ensaio 5: a - afluente amostras não filtradas; • - efluente amostras não filtradas; ○ - efluente amostras filtradas.

Figura 5.38. Volume de biogás $\left(\mathrm{V}_{\mathrm{G}}\right)$ e de metano $\left(\mathrm{V}_{\mathrm{CH} 4}\right)$ na CNTP e concentrações dos componentes do biogás no final do ciclo $\left(\mathrm{C}_{\mathrm{G}}\right)$ no Ensaio 5: $\diamond$-Biogás; $\downarrow-$ Metano; 0 -Hidrogênio; $\Delta$ - Dióxido de Carbono.

Figura 5.39. Concentração de matéria orgânica e glicerina durante o ciclo no Ensaio 5: • - $\mathrm{C}_{\mathrm{MOF}}$;

- $-\mathrm{C}_{\mathrm{GF}}$.

Figura 5.40. Valores de $\mathrm{pH}$, alcalinidade a bicarbonato $(\mathrm{AB})$ e ácidos voláteis totais (AVT) no Ensaio 5. 
Figura 5.41. Concentração dos compostos intermediários ao longo do ciclo no Ensaio 5: $\Delta$ - etanol; $\diamond$ butanol; $\square$ - ácido acético; -X-ácido propiônico; - - ácido isobutírico; • - ácido butírico; + ácido isovalérico $\bullet$ - ácido valérico; $\boldsymbol{\Delta}$ - ácido capróico.

Figura 5.42. Produção volumétrica média acumulada do biogás durante o ciclo no Ensaio 5.

Figura 5.43. Concentração dos compostos do biogás durante o ciclo e suas respectivas porcentagens no Ensaio 5: ○- $\mathrm{H}_{2} ; \bullet-\mathrm{CH}_{4} ; \Delta-\mathrm{CO}_{2}$

Figura 5.44. Monitoramento da DQO, dos carboidratos e da glicerina nos Ensaios de 1 a 5: afluente amostras não filtradas; ○ - efluente amostras não filtradas; • - efluente amostras filtradas.

Figura 5.45. Monitoramento do $\mathrm{pH}$, da $\mathrm{AB}$ e dos AVT nos Ensaios de 1 a 5: a - afluente amostras não filtradas; ○ - efluente amostras não filtradas.

Figura 5.46. Produção volumétrica por ciclo de Biogás $(\diamond)$ e Metano $(\diamond)$

Figura 5.47. Perfis de concentração de substrato no afluente (๘), efluente filtrado (○), ácido acético $(\bullet)$, ácido propiônico $(\boldsymbol{\Delta})$, ácido butírico $(\bullet)$ e metano $(\diamond)$ (valores experimentais marcadores e calculados pelo modelo cinético - linhas).

Figura 5.48. Concentração de matéria orgânica e eficiências de remoção na forma de DQO no Ensaio 6: - - afluente amostras não filtradas; • - efluente amostras não filtradas; ○ efluente amostras filtradas.

Figura 5.49. Concentração e eficiências de remoção de carboidratos no Ensaio 6: a - afluente amostras não filtradas; • - efluente amostras não filtradas; ○ - efluente amostras filtradas. .... 132

Figura 5.50. Volume de biogás $\left(\mathrm{V}_{\mathrm{G}}\right)$ e de hidrogênio $\left(\mathrm{V}_{\mathrm{H} 2}\right)$ nas CNTP e concentrações dos componentes do biogás no final do ciclo $\left(\mathrm{C}_{\mathrm{G}}\right)$ no Ensaio 6: $\diamond$-Biogás; $\bullet-$ Metano; $~$ -Hidrogênio; $\Delta$ - Dióxido de Carbono.

Figura 5.51. Concentração de matéria orgânica e de carboidratos durante o ciclo no Ensaio 6. 133

Figura 5.52. Valores de pH, alcalinidade total (AT) e ácidos voláteis totais (AVT) no Ensaio 6. 134

Figura 5.53. Concentração dos compostos intermediários ao longo do ciclo no Ensaio 6: $\Delta$ - etanol; $\diamond$ butanol; - - ácido acético; -X- ácido propiônico; - - ácido isobutírico; - - ácido butírico; + ácido isovalérico $\bullet-$ ácido valérico; $\boldsymbol{\Delta}$ - ácido capróico.

Figura 5.54. Produção volumétrica média acumulada do biogás durante o ciclo no Ensaio 6.

Figura 5.55. Concentração dos compostos do biogás durante o ciclo e suas respectivas porcentagens no Ensaio 6: ○- $-\mathrm{H}_{2} ; \bullet-\mathrm{CH}_{4} ; \Delta-\mathrm{CO}_{2}$

Figura 5.56. Concentração e eficiência de remoção de matéria orgânica na forma de DQO no Ensaio 7: — - afluente amostras não filtradas; • - efluente amostras não filtradas; ○ efluente amostras filtradas. 
Figura 5.57. Concentração e eficiência de remoção na forma de carboidratos no Ensaio 7: - afluente amostras não filtradas; • - efluente amostras não filtradas; ○ - efluente amostras filtradas. 138

Figura 5.58. Concentração e eficiência de remoção na forma de glicerina no Ensaio 7: - - afluente amostras não filtradas; • - efluente amostras não filtradas; ○ - efluente amostras filtradas....... 138

Figura 5.59. Volume de biogás $\left(\mathrm{V}_{\mathrm{G}}\right)$ e de hidrogênio $\left(\mathrm{V}_{\mathrm{H} 2}\right)$ nas CNTP e concentrações dos componentes do biogás no final do ciclo $\left(\mathrm{C}_{\mathrm{G}}\right)$ no Ensaio 7: $\diamond$-Biogás; - Metano; $\bigcirc$ -Hidrogênio; $\Delta$ - Dióxido de Carbono.

Figura 5.60. Concentração de matéria orgânica, carboidratos e de glicerina durante o ciclo no Ensaio 7.

Figura 5.61. Valores de pH, alcalinidade total(AT) e ácidos voláteis totais (AVT) no Ensaio 7

Figura 5.62. Concentração dos compostos intermediários ao longo do ciclo no Ensaio 7: $\Delta$ - etanol; $\diamond$ butanol; - - ácido acético; -X- ácido propiônico; - - ácido isobutírico; • - ácido butírico; + ácido isovalérico $\bullet$ - ácido valérico; $\boldsymbol{\Delta}$ - ácido capróico.

Figura 5.63. Produção volumétrica média acumulada do biogás durante o ciclo no Ensaio 7.

Figura 5.64. Concentração dos compostos do biogás durante o ciclo e suas respectivas porcentagens no Ensaio 7: ○- $\mathrm{H}_{2} ; \bullet-\mathrm{CH}_{4} ; \Delta-\mathrm{CO}_{2}$

Figura 5.65. Concentração e eficiência de remoção de matéria orgânica na forma de DQO no Ensaio 8: - - afluente amostras não filtradas; • - efluente amostras não filtradas; ○ efluente amostras filtradas.

Figura 5.66. Concentração e eficiência de remoção na forma de carboidratos no Ensaio 8: a - afluente amostras não filtradas; • - efluente amostras não filtradas; ○ - efluente amostras filtradas...... 144

Figura 5.67. Concentração e eficiência de remoção na forma de glicerina no Ensaio 8: - - afluente amostras não filtradas; • - efluente amostras não filtradas; $\bigcirc-$ efluente amostras filtradas

Figura 5.68. Volume de biogás $\left(\mathrm{V}_{\mathrm{G}}\right)$ e de hidrogênio $\left(\mathrm{V}_{\mathrm{H} 2}\right)$ nas CNTP e concentrações dos componentes do biogás no final do ciclo $\left(\mathrm{C}_{\mathrm{G}}\right)$ no Ensaio 8: $\diamond$ - Biogás; - Metano; $\bigcirc$ -Hidrogênio; $\Delta$ - Dióxido de Carbono.

Figura 5.69. Concentração de matéria orgânica, carboidratos e de glicerina durante o ciclo no Ensaio 8.

Figura 5.70. Valores de pH, alcalinidade total(AT) e ácidos voláteis totais (AVT) no Ensaio 8. .146

Figura 5.71. Concentração dos compostos intermediários ao longo do ciclo no Ensaio 8: $\Delta$ - etanol; $\diamond$ butanol; - - ácido acético; -X- ácido propiônico; - - ácido isobutírico; • - ácido butírico; + ácido isovalérico $\bullet$ - ácido valérico; $\boldsymbol{\Delta}$ - ácido capróico.

Figura 5.72. Produção volumétrica média acumulada do biogás durante o ciclo no Ensaio 8 
Figura 5.73. Concentração dos compostos do biogás durante o ciclo e suas respectivas porcentagens no Ensaio 8: ○ $-\mathrm{H}_{2} ; \bullet-\mathrm{CH}_{4} ; \Delta-\mathrm{CO}_{2}$

Figura 5.74. Concentração e eficiência de remoção de matéria orgânica na forma de DQO no Ensaio 9: - - afluente amostras não filtradas; • - efluente amostras não filtradas; ○ efluente amostras filtradas

Figura 5.75. Concentração e eficiência de remoção na forma de carboidratos no Ensaio 9: a - afluente amostras não filtradas; • - efluente amostras não filtradas; ○ - efluente amostras filtradas. .... 149

Figura 5.76. Concentração e eficiência de remoção na forma de glicerina no Ensaio 9: a - afluente amostras não filtradas; • - efluente amostras não filtradas; ○ - efluente amostras filtradas. .... 150

Figura 5.77. Volume de biogás $\left(\mathrm{V}_{\mathrm{G}}\right)$ e de hidrogênio $\left(\mathrm{V}_{\mathrm{H} 2}\right)$ nas CNTP e concentrações dos componentes do biogás no final do ciclo $\left(\mathrm{C}_{\mathrm{G}}\right)$ no Ensaio 9: $\diamond-$ Biogás; $\downarrow-$ Metano; 0 -Hidrogênio; $\Delta$ - Dióxido de Carbono.

Figura 5.78. Concentração de matéria orgânica, carboidratos e de glicerina durante o ciclo no Ensaio 9.

Figura 5.79. Valores de pH, alcalinidade total(AT) e ácidos voláteis totais (AVT) no Ensaio 9. 152

Figura 5.80. Concentração dos compostos intermediários ao longo do ciclo no Ensaio 9: $\Delta$ - etanol; $\diamond$ butanol; - - ácido acético ; -X- ácido propiônico; - ácido isobutírico; • - ácido butírico; + ácido isovalérico $\bullet$ - ácido valérico; $\boldsymbol{\Delta}$ - ácido capróico.

Figura 5.81. Produção volumétrica média acumulada do biogás durante o ciclo no Ensaio 9. 153

Figura 5.82. Concentração dos compostos do biogás durante o ciclo e suas respectivas porcentagens no Ensaio 9: ○- $-\mathrm{H}_{2} ; \bullet-\mathrm{CH}_{4} ; \Delta-\mathrm{CO}_{2}$

Figura 5.83. Concentração e eficiência de remoção de matéria orgânica na forma de DQO no Ensaio 10: — - afluente amostras não filtradas; • - efluente amostras não filtradas; ○ efluente amostras filtradas.

Figura 5.84. Concentração e eficiência de remoção na forma de glicerina no Ensaio 10: - - afluente amostras não filtradas; • - efluente amostras não filtradas; ○ - efluente amostras filtradas. .... 155

Figura 5.85. Volume de biogás $\left(\mathrm{V}_{\mathrm{G}}\right)$ e de hidrogênio $\left(\mathrm{V}_{\mathrm{H} 2}\right)$ nas $\mathrm{CNTP}$ e concentrações dos componentes do biogás no final do ciclo $\left(\mathrm{C}_{\mathrm{G}}\right)$ no Ensaio 9: $\diamond-$ Biogás; - Metano; $\bigcirc$ - Hidrogênio; $\Delta$ - Dióxido de Carbono.

Figura 5.86. Concentração de matéria orgânica, carboidratos e de glicerina durante o ciclo no Ensaio 10.

Figura 5.87. Valores de pH, alcalinidade total(AT) e ácidos voláteis totais (AVT) no Ensaio 10. 
Figura 5.88. Concentração dos compostos intermediários ao longo do ciclo no Ensaio 10: $\Delta$ - etanol; $\diamond$ butanol; - - ácido acético ; -X- ácido propiônico; - - ácido isobutírico; • - ácido butírico; + ácido isovalérico $\bullet$ - ácido valérico; $\Delta$ - ácido capróico.

Figura 5.89. Produção volumétrica média acumulada do biogás durante o ciclo no Ensaio 10 158

Figura 5.90. Concentração dos compostos do biogás durante o ciclo e suas respectivas porcentagens no Ensaio 10: $\odot-\mathrm{H}_{2} ; \bullet-\mathrm{CH}_{4} ; \Delta-\mathrm{CO}_{2}$.

Figura 5.91. Monitoramento da DQO, dos carboidratos e da glicerina nos Ensaios 6 a 10: - afluente amostras não filtradas; $\bigcirc$ - efluente amostras não filtradas; $\bullet$ - efluente amostras filtradas.

Figura 5.92. Monitoramento do pH, da AT e dos AVT nos Ensaios 6 a 10: a - afluente amostras não filtradas; $\bigcirc$ - efluente amostras não filtradas.

Figura 5.93. Produção volumétrica por ciclo de Biogás $(\diamond)$ e Hidrogênio (०).

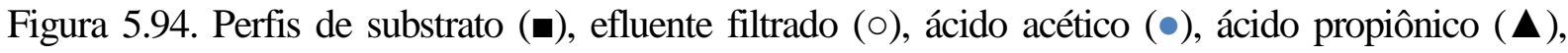
ácido butírico $(\bullet)$, etanol $(\Delta)$, ácido valérico $(\bullet)$ e hidrogênio $(\diamond)$ (valores experimentais e calculados pelo modelo)

Figura 5.95. Concentração e eficiência de remoção de matéria orgânica na forma de DQO no Ensaio 11: - - afluente amostras não filtradas; • - efluente amostras não filtradas; ○ efluente amostras filtradas.

Figura 5.96. Concentração e eficiência de remoção na forma de carboidratos no Ensaio 11: afluente amostras não filtradas; • - efluente amostras não filtradas; ○ - efluente amostras filtradas.

Figura 5.97. Concentração e eficiência de remoção na forma de glicerina no Ensaio 11: a - afluente amostras não filtradas; • - efluente amostras não filtradas; ○ - efluente amostras filtradas.

Figura 5.98. Volume de biogás $\left(\mathrm{V}_{\mathrm{G}}\right)$ e de hidrogênio $\left(\mathrm{V}_{\mathrm{H} 2}\right)$ nas $\mathrm{CNTP}$ e concentrações dos componentes do biogás no final do ciclo $\left(\mathrm{C}_{\mathrm{G}}\right)$ no Ensaio 11: $\diamond$ - Biogás; - Metano; o - Hidrogênio; $\Delta$ - Dióxido de Carbono.

Figura 5.99. Concentração de matéria orgânica, carboidratos e de glicerina durante o ciclo no Ensaio 11

Figura 5.100. Valores de pH, alcalinidade total (AT) e ácidos voláteis totais (AVT) no Ensaio 11.

Figura 5.101. Concentração dos compostos intermediários ao longo do ciclo no Ensaio 11: $\Delta$ - etanol;

$\diamond$ butanol; - - ácido acético; -X- ácido propiônico; - - ácido isobutírico; • - ácido butírico; + ácido isovalérico $\bullet$ - ácido valérico; $\boldsymbol{\Delta}$ - ácido capróico.

Figura 5.102. Produção volumétrica média acumulada do biogás durante o ciclo no Ensaio 11 175

Figura 5.103. Concentração dos compostos do biogás durante o ciclo e suas respectivas porcentagens no Ensaio 11: $\odot-\mathrm{H}_{2} ; \bullet-\mathrm{CH}_{4} ; \Delta-\mathrm{CO}_{2}$ 
Figura 5.104. Concentração e eficiência de remoção de matéria orgânica na forma de DQO no Ensaio 12: 匹 - afluente amostras não filtradas; • - efluente amostras não filtradas; ○ efluente amostras filtradas.

Figura 5.105. Concentração e eficiência de remoção na forma de carboidratos no Ensaio 12: afluente amostras não filtradas; • - efluente amostras não filtradas; ○ - efluente amostras filtradas.

Figura 5.106. Concentração e eficiência de remoção na forma de glicerina no Ensaio 12: — - afluente amostras não filtradas; • - efluente amostras não filtradas; ○ - efluente amostras filtradas ..... 178

Figura 5.107. Medidas de pH no afluente e efluente no Ensaio 12: • - Efluente; ○ - Afluente. 179

Figura 5.108. Volume de biogás $\left(\mathrm{V}_{\mathrm{G}}\right)$ e de hidrogênio $\left(\mathrm{V}_{\mathrm{H} 2}\right)$ nas CNTP e concentrações dos componentes do biogás no final do ciclo $\left(\mathrm{C}_{\mathrm{G}}\right)$ no Ensaio 12: $\diamond$ - Biogás; - Metano; ○- Hidrogênio; $\Delta$ - Dióxido de Carbono

Figura 5.109. Concentração de matéria orgânica, carboidratos e de glicerina durante o ciclo no Ensaio 12. 180

Figura 5.110. Valores de pH, alcalinidade total(AT) e ácidos voláteis totais (AVT) no Ensaio 12. 180

Figura 5.111. Concentração dos compostos intermediários ao longo do ciclo no Ensaio 12: $\Delta$ - etanol; $\diamond$ butanol; $\square$ - ácido acético; -X- ácido propiônico; - - ácido isobutírico; • - ácido butírico; + ácido isovalérico $\bullet$ - ácido valérico; $\Delta$-ácido capróico.

Figura 5.112. Produção volumétrica média acumulada do biogás durante o ciclo no Ensaio 12. 181

Figura 5.113. Concentração dos compostos do biogás durante o ciclo e suas respectivas porcentagens no Ensaio 12: $\circ-\mathrm{H}_{2} ; \bullet-\mathrm{CH}_{4} ; \Delta-\mathrm{CO}_{2}$

Figura 5.114. Monitoramento da DQO, dos carboidratos e da glicerina nos Ensaios 11, 7 e 12: afluente amostras não filtradas; $\bigcirc$ - efluente amostras não filtradas; • - efluente amostras filtradas.

Figura 5.115. Monitoramento do pH, da AT e dos AVT nos Ensaios 11, 7 e 12: a - afluente amostras não filtradas; 0 - efluente amostras não filtradas. 185

Figura 5.116. Produção volumétrica por ciclo de Biogás $(\diamond)$ e Hidrogênio (○) nos Ensaios 11, 7 e 12........ 186

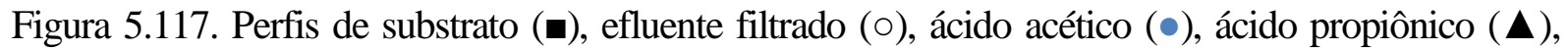
ácido butírico $(\bullet)$, etanol $(\Delta)$, ácido valérico $(\bullet)$ e hidrogênio $(\diamond)$ (valores experimentais e calculados pelo modelo)

Figura 5.118. Concentração e eficiência de remoção de matéria orgânica na forma de DQO no Ensaio 13: - - afluente amostras não filtradas; • - efluente amostras não filtradas; ○ efluente amostras filtradas. 
Figura 5.119. Concentração e eficiência de remoção na forma de carboidratos no Ensaio 13: afluente amostras não filtradas; • - efluente amostras não filtradas; ○ - efluente amostras filtradas.

Figura 5.120. Concentração e eficiência de remoção na forma de glicerina no Ensaio 13: a - afluente amostras não filtradas; • - efluente amostras não filtradas; ○ - efluente amostras filtradas

Figura 5.121. Volume de biogás $\left(\mathrm{V}_{\mathrm{G}}\right)$ e de hidrogênio $\left(\mathrm{V}_{\mathrm{H} 2}\right)$ nas $\mathrm{CNTP}$ e concentrações dos componentes do biogás no final do ciclo $\left(\mathrm{C}_{\mathrm{G}}\right)$ no Ensaio 13: $\diamond$ - Biogás; - Metano; o - Hidrogênio; $\Delta$ - Dióxido de Carbono.

Figura 5.122. Concentração de matéria orgânica, carboidratos e de glicerina durante o ciclo no Ensaio 13.

Figura 5.123. Valores de pH, alcalinidade total (AT) e ácidos voláteis totais (AVT) no Ensaio 13

Figura 5.124. Concentração dos compostos intermediários ao longo do ciclo no Ensaio 13: $\Delta$ - etanol;

$\diamond$ butanol; - - ácido acético; -X- ácido propiônico; - - ácido isobutírico; • - ácido butírico; + ácido isovalérico $\bullet$ - ácido valérico; $\boldsymbol{\Delta}$ - ácido capróico

Figura 5.125. Produção volumétrica média acumulada do biogás durante o ciclo no Ensaio 13 .194

Figura 5.126. Concentração dos compostos do biogás durante o ciclo e suas respectivas porcentagens no Ensaio 13: $\circ-\mathrm{H}_{2} ; \bullet-\mathrm{CH}_{4} ; \Delta-\mathrm{CO}_{2}$

Figura 5.127. Concentração e eficiência de remoção de matéria orgânica na forma de DQO no Ensaio 14: - - afluente amostras não filtradas; • - efluente amostras não filtradas; ○ efluente amostras filtradas.

Figura 5.128. Concentração e eficiência de remoção na forma de carboidratos no Ensaio 14: afluente amostras não filtradas; • - efluente amostras não filtradas; ○ - efluente amostras filtradas.

Figura 5.129. Concentração e eficiência de remoção na forma de glicerina no Ensaio 14: a - afluente amostras não filtradas; • - efluente amostras não filtradas; $\bigcirc-$ efluente amostras filtradas

Figura 5.130. Volume de biogás $\left(\mathrm{V}_{\mathrm{G}}\right)$ e de hidrogênio $\left(\mathrm{V}_{\mathrm{H} 2}\right)$ nas CNTP e concentrações dos componentes do biogás no final do ciclo $\left(\mathrm{C}_{\mathrm{G}}\right)$ no Ensaio 14: $\diamond$ - Biogás; $\bullet-$ Metano; ○- Hidrogênio; $\Delta$ - Dióxido de Carbono.

Figura 5.131. Concentração de matéria orgânica, carboidratos e de glicerina durante o ciclo no Ensaio 14.

Figura 5.132. Valores de $\mathrm{pH}$, alcalinidade total (AT) e ácidos voláteis totais (AVT) no Ensaio 14

Figura 5.133. Concentração dos compostos intermediários ao longo do ciclo no Ensaio 14: $\Delta$ - etanol;

$\diamond$ butanol; - - ácido acético; -X- ácido propiônico; - - ácido isobutírico; • - ácido butírico; + ácido isovalérico $\bullet$ - ácido valérico; $\boldsymbol{\Delta}$ - ácido capróico 
Figura 5.134. Produção volumétrica média acumulada do biogás durante o ciclo no Ensaio 14.

Figura 5.135. Concentração dos compostos do biogás durante o ciclo e suas respectivas porcentagens no Ensaio 14: ○- $\mathrm{H}_{2} ; \bullet-\mathrm{CH}_{4} ; \Delta-\mathrm{CO}_{2}$

Figura 5.136. Concentração e eficiência de remoção de matéria orgânica na forma de DQO no Ensaio 15: - - afluente amostras não filtradas; • - efluente amostras não filtradas; ○ efluente amostras filtradas

Figura 5.137. Concentração e eficiência de remoção na forma de carboidratos no Ensaio 15: afluente amostras não filtradas; • - efluente amostras não filtradas; ○ - efluente amostras filtradas.

Figura 5.138. Concentração e eficiência de remoção na forma de glicerina no Ensaio 15: — - afluente amostras não filtradas; • - efluente amostras não filtradas; ○ - efluente amostras filtradas .....203

Figura 5.139. Volume de biogás $\left(\mathrm{V}_{\mathrm{G}}\right)$ e de hidrogênio $\left(\mathrm{V}_{\mathrm{H} 2}\right)$ nas CNTP e concentrações dos componentes do biogás no final do ciclo $\left(\mathrm{C}_{\mathrm{G}}\right)$ no Ensaio 15: $\diamond$ - Biogás; $\bullet-$ Metano; ○ Hidrogênio; $\Delta$ - Dióxido de Carbono.

Figura 5.140. Concentração de matéria orgânica, carboidratos e de glicerina durante o ciclo no Ensaio 15

Figura 5.141. Valores de pH, alcalinidade total (AT) e ácidos voláteis totais (AVT) no Ensaio 15. .205

Figura 5.142. Concentração dos compostos intermediários ao longo do ciclo no Ensaio 15: $\Delta$ - etanol;

$\diamond$ butanol; $\square$ - ácido acético; -X- ácido propiônico; - - ácido isobutírico; • - ácido butírico; + ácido isovalérico $\bullet$ - ácido valérico; $\boldsymbol{\Delta}$-ácido capróico. 206

Figura 5.143. Produção volumétrica média acumulada do biogás durante o ciclo no Ensaio 15. 206

Figura 5.144. Concentração dos compostos do biogás durante o ciclo e suas respectivas porcentagens no Ensaio 15: ○- $\mathrm{H}_{2} ; \bullet-\mathrm{CH}_{4} ; \Delta-\mathrm{CO}_{2}$

Figura 5.145. Produção volumétrica por ciclo de Biogás $(\diamond)$ e Hidrogênio (○) nos Ensaios 12 a 15. 209

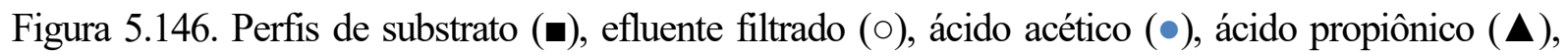
ácido butírico $(\bullet)$, etanol $(\Delta)$, ácido valérico $(\bullet)$ e hidrogênio $(\diamond)$ (valores experimentais e calculados pelo modelo).

Figura 5.147. Concentração $\left(\mathrm{C}_{S}\right)$ e eficiência de remoção na forma de DQO $\left(\varepsilon_{S}\right)$ no Ensaio 16: afluente amostras não filtradas; • - efluente amostras não filtradas; $\bigcirc-$ efluente amostras filtradas.

Figura 5.148. Concentração $\left(\mathrm{C}_{\mathrm{C}}\right)$ e eficiência de remoção na forma de carboidratos $\left(\varepsilon_{\mathrm{C}}\right)$ no Ensaio 16: - - afluente amostras não filtradas; • - efluente amostras não filtradas; $\bigcirc$ - efluente amostras filtradas. 
Figura 5.149. Concentração $\left(\mathrm{C}_{\mathrm{G}}\right)$ e eficiência de remoção na forma de glicerina $\left(\varepsilon_{\mathrm{G}}\right)$ no Ensaio 16 : afluente amostras não filtradas; • - efluente amostras não filtradas; $\bigcirc-$ efluente amostras filtradas.

Figura 5.150. Volume de biogás $\left(\mathrm{V}_{\mathrm{G}}\right)$ e de hidrogênio $\left(\mathrm{V}_{\mathrm{H} 2}\right)$ nas CNTP e concentrações dos componentes do biogás no final do ciclo $\left(\mathrm{C}_{\mathrm{G}}\right)$ no Ensaio 16: $\diamond$ - Biogás; $\bullet-$ Metano; ○ Hidrogênio; $\Delta$ - Dióxido de Carbono.

Figura 5.151. Concentrações de matéria orgânica na forma de DQO $\left(\mathrm{C}_{\mathrm{S}}\right)$, carboidratos $\left(\mathrm{C}_{\mathrm{C}}\right)$ e de glicerina $\left(\mathrm{C}_{\mathrm{G}}\right)$ durante o ciclo no Ensaio 16 .

Figura 5.152. Valores de pH, alcalinidade total (AT)e de ácidos voláteis totais (AVT) no Ensaio 16.

Figura 5.153. Concentração dos compostos intermediários ao longo do ciclo no Ensaio 16: $\Delta$ - etanol; $\diamond$ butanol; - - ácido acético; -X- ácido propiônico; - - ácido isobutírico; • - ácido butírico; + ácido isovalérico $\bullet$ - ácido valérico; $\boldsymbol{\Delta}$ - ácido capróico.

Figura 5.154. Produção volumétrica média acumulada do biogás $\left(\mathrm{V}_{\mathrm{G}}\right)$ durante o ciclo no Ensaio 16. .218

Figura 5.155. Concentração dos compostos do biogás durante o ciclo $\left(\mathrm{C}_{\mathrm{G}}\right)$ e suas respectivas porcentagens $\left(\mathrm{Y}_{\mathrm{G}}\right)$ no Ensaio 16: $\odot-\mathrm{H}_{2} ; \bullet-\mathrm{CH}_{4} ; \Delta-\mathrm{CO}_{2}$.

Figura 5.156. Concentração $\left(\mathrm{CS}_{S}\right)$ e eficiência de remoção na forma de DQO ( $\left.\varepsilon_{S}\right)$ no Ensaio 17: afluente amostras não filtradas; • - efluente amostras não filtradas; ○ - efluente amostras filtradas.

Figura 5.157. Concentração $\left(\mathrm{C}_{\mathrm{C}}\right)$ e eficiência de remoção na forma de carboidratos $\left(\varepsilon_{\mathrm{C}}\right)$ no Ensaio 17:

- - afluente amostras não filtradas; • - efluente amostras não filtradas; ○ - efluente amostras filtradas.

Figura 5.158. Concentração $\left(\mathrm{C}_{\mathrm{G}}\right)$ e eficiência de remoção na forma de glicerina $\left(\varepsilon_{\mathrm{G}}\right)$ no Ensaio 17: afluente amostras não filtradas; • - efluente amostras não filtradas; ○ - efluente amostras filtradas.

Figura 5.159. Volume de biogás $\left(\mathrm{V}_{\mathrm{G}}\right)$ e de hidrogênio $\left(\mathrm{V}_{\mathrm{H} 2}\right)$ nas CNTP e concentrações dos componentes do biogás no final do ciclo $\left(\mathrm{C}_{\mathrm{G}}\right)$ no Ensaio 17: $\diamond$-biogás; • - metano; ○ hidrogênio; $\Delta$ - dióxido de carbono.

Figura 5.160. Concentrações de matéria orgânica na forma de DQO $\left(\mathrm{C}_{S}\right)$, carboidratos $\left(\mathrm{C}_{\mathrm{C}}\right)$ e de glicerina $\left(\mathrm{C}_{\mathrm{G}}\right)$ durante o ciclo no Ensaio 17.

Figura 5.161. Valores de $\mathrm{pH}$, alcalinidade total (AT) e de ácidos voláteis totais (AVT) no Ensaio 17.........222

Figura 5.162. Concentração dos compostos intermediários ao longo do ciclo no Ensaio 17: $\Delta$ - etanol;

$\diamond$ butanol; - - ácido acético; -X- ácido propiônico; - - ácido isobutírico; • - ácido butírico; + ácido isovalérico $\bullet$-ácido valérico; $\boldsymbol{\Delta}$ - ácido capróico.

Figura 5.163. Produção volumétrica média acumulada do biogás $\left(\mathrm{V}_{\mathrm{G}}\right)$ durante o ciclo no Ensaio 17 
Figura 5.164. Concentração dos compostos do biogás durante o ciclo $\left(\mathrm{C}_{\mathrm{G}}\right)$ e suas respectivas porcentagens $\left(\mathrm{Y}_{\mathrm{G}}\right)$ no Ensaio 17: ○ $-\mathrm{H}_{2} ; \bullet-\mathrm{CH}_{4} ; \Delta-\mathrm{CO}_{2}$.

Figura 5.165. Concentração $\left(\mathrm{C}_{S}\right)$ e eficiência de remoção na forma de DQO $\left(\varepsilon_{S}\right)$ no Ensaio 18:

afluente amostras não filtradas; • - efluente amostras não filtradas; $\circ$ - efluente amostras

filtradas. 226

Figura 5.166. Concentração $\left(\mathrm{C}_{\mathrm{C}}\right)$ e eficiência de remoção na forma de carboidratos $\left(\varepsilon_{\mathrm{C}}\right)$ no Ensaio 18 :

- - afluente amostras não filtradas; • - efluente amostras não filtradas; ○ - efluente amostras filtradas.

Figura 5.167. Concentração $\left(\mathrm{C}_{\mathrm{G}}\right)$ e eficiência de remoção na forma de glicerina $\left(\varepsilon_{\mathrm{G}}\right)$ no Ensaio 18:

afluente amostras não filtradas; • - efluente amostras não filtradas; ○ - efluente amostras filtradas.

Figura 5.168. Volume de biogás $\left(\mathrm{V}_{\mathrm{G}}\right)$ e de hidrogênio $\left(\mathrm{V}_{\mathrm{H} 2}\right)$ nas CNTP e concentrações dos componentes do biogás no final do ciclo $\left(\mathrm{C}_{\mathrm{G}}\right)$ no Ensaio 18: $\diamond$-Biogás; • - Metano; ○ Hidrogênio; $\Delta$ - Dióxido de Carbono.

Figura 5.169. Concentrações de matéria orgânica na forma de DQO $\left(\mathrm{C}_{S}\right)$, carboidratos $\left(\mathrm{C}_{\mathrm{C}}\right)$ e de glicerina $\left(\mathrm{C}_{\mathrm{G}}\right)$ durante o ciclo no Ensaio 18

Figura 5.170. Valores de pH, alcalinidade total (AT) e de ácidos voláteis totais (AVT) no Ensaio 18.........228

Figura 5.171. Concentração dos compostos intermediários ao longo do ciclo no Ensaio 18: $\Delta$ - etanol;

$\diamond$ butanol; - - ácido acético; -x-ácido propiônico; - - ácido isobutírico; - - ácido

butírico; + ácido isovalérico $\bullet$ - ácido valérico; $\boldsymbol{\Delta}$ - ácido capróico.

Figura 5.172. Produção volumétrica média acumulada do biogás $\left(\mathrm{V}_{\mathrm{G}}\right)$ durante o ciclo no Ensaio 18.

Figura 5.173. Concentração dos compostos do biogás durante o ciclo $\left(\mathrm{C}_{\mathrm{G}}\right)$ e suas respectivas porcentagens $\left(\mathrm{Y}_{\mathrm{G}}\right)$ no Ensaio 18: ○ $-\mathrm{H}_{2} ; \bullet-\mathrm{CH}_{4} ; \Delta-\mathrm{CO}_{2}$.

Figura 5.174. Produção volumétrica por ciclo de biogás (०) e hidrogênio $(\diamond)$ nos Ensaios da Fase V. 233

Figura 5.175. Perfis de substrato (๘), efluente filtrado (०), ácido acético $(\bullet)$, ácido propiônico $(\boldsymbol{\Delta})$, ácido butírico $(\bullet)$, etanol $(\Delta)$, ácido valérico $(\bullet)$ e hidrogênio $(\diamond)$ (valores experimentais e calculados pelo modelo).

Figura 5.176. Ajuste das constantes cinéticas ao modelo linearizado da equação de Arrhenius.

Figura 5.177. Árvore filogenética construída com 30 sequências de nucleotídeos a partir de distâncias evolutivas inferidas usando o método Neighbor-Joining (Saitou e Nei, 1987). A porcentagem de réplicas da árvore está apresentada próximo aos ramos e foi calculada com base em teste de bootstrap com 1000 réplicas (Felsenstein, 1985). As distâncias evolutivas foram calculadas usando o método de Jukes e Cantor (1969). 


\section{LISTA DE TABELAS}

Tabela 3.1. Matérias minerais contidas no soro. .48

Tabela 3.2. Características dos substratos usados em Kacprzak et al. (2010)....................................................52

Tabela 3.3. Características principais do lodo de esgoto e da glicerina.................................................................53

Tabela 3.4. Composição das amostras de FORSM coletadas em diferentes meses do ano................................57

Tabela 3.5. Características físico-químicas médias de cada fração. .57

Tabela 3.6. Comparação entre estudos que realizaram codigestão de resíduos para produção de metano 61

Tabela 4.1. Parâmetros operacionais do biorreator. 67

Tabela 4.2. Tipos de suporte utilizados nos experimentos. .....................................................................................68

Tabela 4.3. Inóculo e pré-tratamento utilizados nos experimentos.........................................................................69

Tabela 4.4. Tipos de glicerina utilizados nos experimentos. 69

Tabela 4.5. Composição do soro desidratado (em pó) comercial (Marca Elegê) utilizado nos ensaios. ..........70

Tabela 4.6. Composição da água residuária utilizada nos ensaios........................................................................70

Tabela 4.7. Cronograma das análises realizadas nos ensaios..........................................................................71

Tabela 4.8. Resumo das condições experimentais na Fase I................................................................................ 85

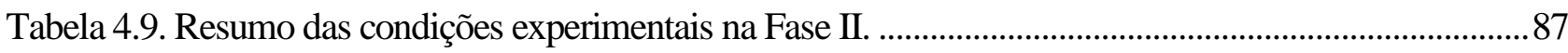

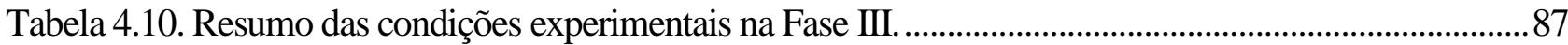

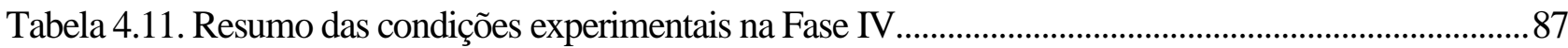

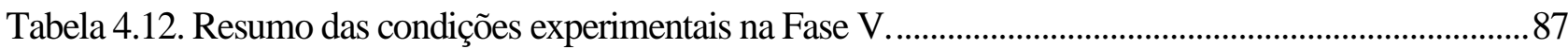

Tabela 5.1. Parâmetros médios monitorados no Ensaio 1....................................................................................92

Tabela 5.2. Parâmetros médios monitorados no Ensaio 2 2...............................................................................98

Tabela 5.3. Parâmetros médios monitorados no Ensaio 3 …….............................................................................. 104

Tabela 5.4. Parâmetros médios monitorados no Ensaio 4...................................................................................... 110

Tabela 5.5. Valores médios dos parâmetros monitorados no Ensaio 5............................................................116

Tabela 5.6. Comparação entre os valores médios da série de sólidos entre os Ensaios da Fase I. ...................124

Tabela 5.7. Estabilidade e desempenho nas variáveis monitoradas nos Ensaios de 1 a 5................................ 126

Tabela 5.8. Comparação entre os resultados obtidos neste trabalho na Fase I com resultados publicados na literatura que utilizaram soro ou glicerina para a produção de biometano. .........127

Tabela 5.9. Parâmetros do modelo cinético para a Fase I...................................................................................... 128

Tabela 5.10. Parâmetros médios monitorados no Ensaio 6.................................................................................... 131

Tabela 5.11. Parâmetros médios monitorados no Ensaio 7 ..................................................................................... 136

Tabela 5.12. Parâmetros médios monitorados no Ensaio 8.................................................................................. 142 
Tabela 5.13. Parâmetros médios monitorados no Ensaio 9.

Tabela 5.14. Parâmetros médios monitorados no Ensaio 10.

Tabela 5.15. Comparação entre os valores médios da série de sólidos entre os Ensaios da Fase II................ 163

Tabela 5.16. Estabilidade e desempenho nas variáveis monitoradas nos ensaios de 6 a 10 .......................... 165

Tabela 5.17. Comparação entre os resultados obtidos neste trabalho na Fase II com resultados publicados na literatura que utilizaram soro ou glicerina para a produção de biohidrogênio.

Tabela 5.18. Parâmetros do modelo cinético para a Fase II.......................................................................... 168

Tabela 5.19. Parâmetros médios monitorados no Ensaio 11 ............................................................................. 171

Tabela 5.20. Parâmetros médios monitorados no Ensaio 12 .......................................................................... 177

Tabela 5.21. Estabilidade e desempenho nas variáveis monitoradas nos Ensaios 11, 7 e 12........................ 183

Tabela 5.22. Comparação entre os valores médios da série de sólidos entre os Ensaios 11, 7 e 12................ 183

Tabela 5.23. Parâmetros do modelo cinético para a Fase III. ……................................................................... 188

Tabela 5.24. Parâmetros médios monitorados no Ensaio 13 .................................................................................. 190

Tabela 5.25. Parâmetros médios monitorados no Ensaio 14 ............................................................................. 196

Tabela 5.26. Parâmetros médios monitorados no Ensaio 15..........................................................................202

Tabela 5.27. Resumo das condições experimentais para comparação da Fase IV .........................................207

Tabela 5.28. Estabilidade e desempenho nas variáveis monitoradas nos Ensaios 12 a 15...........................208

Tabela 5.29. Comparação entre os valores médios da série de sólidos entre os Ensaios 12 e 15...................208

Tabela 5.30. Parâmetros do modelo cinéticos para a Fase IV . .......................................................................211

Tabela 5.31. Parâmetros médios monitorados no Ensaio 16.........................................................................213

Tabela 5.32. Parâmetros médios monitorados no Ensaio 17 .............................................................................219

Tabela 5.33. Parâmetros médios monitorados no Ensaio 18 ...............................................................................225

Tabela 5.34. Resumo das condições experimentais para comparação da Fase V. .........................................230

Tabela 5.35. Estabilidade e desempenho nas variáveis monitoradas na Fase V ............................................231

Tabela 5.36. Comparação entre os valores médios da série de sólidos entre os Ensaios 16, 17, 12

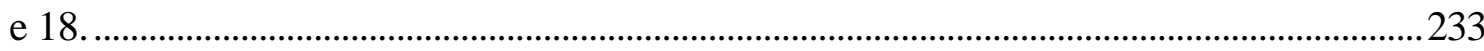

Tabela 5.37. Parâmetros do modelo cinético para a Fase V. ...........................................................................235

Tabela 5.38. Constantes cinéticas usadas para o ajuste na Equação de Arrhenius...........................................237

Tabela 5.39. Caracterização filogenética do consórcio microbiano no AnSBBR (Ensaio 12)......................239 


\section{LISTA DEABREVIATURAS E SIGLAS}

AAB: Água de abatedouro;

$\mathrm{AB}: \quad$ Alcalinidade a bicarbonato $\left(\mathrm{mgCaCO}_{3} \cdot \mathrm{L}^{-1}\right)$

AGCL: Ácidos graxos de cadeia longa;

AGV: Ácidos graxos voláteis;

AI: $\quad$ Alcalinidade intermediária $\left(\mathrm{mgCaCO}_{3} \cdot \mathrm{L}^{-1}\right)$

AnSBBR: Reator Anaeróbio Operado em Batelada Sequencial com Biomassa Imobilizada em Suporte Inerte (Anaerobic Sequencing Batch Biofilm Reactor)

AP: $\quad$ Alcalinidade parcial $\left(\mathrm{mgCaCO}_{3} \cdot \mathrm{L}^{-1}\right)$

APB: $\quad$ Água de processamento de batatas;

ASBR: $\quad$ Reator Anaeróbio Operado em Batelada Sequencial (Anaerobic Sequencing Batch Reactor)

AT: $\quad$ Alcalinidade total $\left(\mathrm{mgCaCO}_{3} \cdot \mathrm{L}^{-1}\right)$

AVI: $\quad$ Ácidos voláteis intermediários $\left(\mathrm{mmol} . \mathrm{L}^{-1}\right)$

AVT: $\quad$ Ácidos voláteis totais $\left(\mathrm{mgHAc} . \mathrm{L}^{-1}\right)$

C: $\quad$ Carboidratos

$\mathrm{C}_{\mathrm{CF}}$ : $\quad$ Concentração de matéria orgânica filtrada na forma de carboidratos (mgCarboidratos. $\mathrm{L}^{-1}$ )

$\mathrm{C}_{\text {Ст: }} \quad$ Concentração de matéria orgânica não filtrada na forma de carboidratos (mgCarboidratos. $\left.\mathrm{L}^{-1}\right)$

C $\mathrm{C}_{\mathrm{GF}}$ : Concentração de matéria orgânica filtrada na forma de glicerina (mgGlicerina. $\mathrm{L}^{-1}$ )

C $\mathrm{C}_{\mathrm{GT}}$ : $\quad$ Concentração de matéria orgânica não filtrada na forma de glicerina (mgGlicerina. $\mathrm{L}^{-1}$ )

$\mathrm{C}_{\mathrm{MOF}}$ : $\quad$ Concentração de matéria orgânica filtrada na forma de DQO (mgDQO.L-1)

$\mathrm{C}_{\mathrm{MOT}}$ : $\quad$ Concentração de matéria orgânica não filtrada na forma de DQO (mgDQO.L $\left.L^{-1}\right)$

CNTP: Condições normais de temperatura e pressão $\left(0^{\circ} \mathrm{C}\right.$ e $\left.1 \mathrm{~atm}\right)$

COAE: Carga orgânica aplicada específica em termos de matéria orgânica, carboidratos ou glicerina $\left(\mathrm{g} \cdot \mathrm{gSVT}^{-1} \cdot \mathrm{d}^{-1}\right)$

COAV: Carga orgânica aplicada volumétrica em termos de matéria orgânica, carboidratos ou glicerina $\left(\mathrm{g} \cdot \mathrm{L}^{-1} \cdot \mathrm{d}^{-1}\right)$

CoDA: Codigestão anaeróbia;

CORE: Carga orgânica removida específica em termos de matéria orgânica, carboidratos ou glicerina $\left(\mathrm{g} . \mathrm{gSVT} \mathrm{SV}^{-1} \cdot \mathrm{d}^{-1}\right)$

CORV: Carga orgânica removida volumétrica em termos de matéria orgânica, carboidratos ou glicerina $\left(\mathrm{g} \cdot \mathrm{L}^{-1} \cdot \mathrm{d}^{-1}\right)$

CS: $\quad$ Silagem de milho; 
CSTR: $\quad$ Reator em tanque perfeitamente agitado (Continuous Stirred Tank Reactor);

$\mathrm{C}_{\mathrm{X}}$ : $\quad$ Massa de sólidos voláteis totais (SVT) por volume de meio líquido (g.L $\mathrm{L}^{-1}$ )

$\mathrm{C}_{\mathrm{X}}$ : $\quad$ Massa de sólidos voláteis totais (SVT) por massa de material suporte (g.gsuporte ${ }^{-1}$ )

DA: Digestão anaeróbia;

DQO: Demanda química de oxigênio

EG: $\quad$ Esterco de gado;

ES: $\quad$ Esterco suíno;

FORSM: Fração orgânica de resíduos sólidos municipais;

FSS: $\quad$ Logo de floresta secundário;

G: $\quad$ Glicerina

GLI: $\quad$ Glicerol;

GOG: $\quad$ Gorduras, óleos e graxas;

LE: $\quad$ Lodo de esgoto;

LF: $\quad$ Lodo da indústria de couros;

MO: $\quad$ Matéria Orgânica

Msvt: $\quad$ Massa de sólidos voláteis totais (SVT) no interior do reator (g)

N: $\quad$ Número de ciclos por dia,

n $\mathrm{n}_{\mathrm{CH} 4}$ Vazão molar de metano diária $\left(\mathrm{molCH}_{4} \cdot \mathrm{d}^{-1}\right)$

$\mathrm{n}_{\mathrm{H} 2}$ : Vazão molar de hidrogênio diária $\left(\mathrm{molH}_{2} \cdot \mathrm{d}^{-1}\right)$

PEBD: $\quad$ Polietileno de baixa densidade

pH: $\quad$ Potencial hidrogeniônico

PrM: $\quad$ Produtividade molar de hidrogênio ou metano volumétrica $\left(m o l \cdot \mathrm{m}^{-3} \cdot \mathrm{d}^{-1}\right)$

PrME: $\quad$ Produtividade molar de hidrogênio ou metano específica $\left(\right.$ mol.kgSVT $\left.^{-1} \cdot \mathrm{d}^{-1}\right)$

RA: Resíduo alimentício;

RFV: Resíduos de frutas e vegetais;

RLA: Resíduo de lama ativadas;

RMCA: Rendimento entre hidrogênio ou metano (molar) produzido e matéria orgânica (massa) aplicada na forma de DQO (mol.kgDQO-1)

RMSA: Rendimento entre hidrogênio ou metano (molar) produzido e substrato (molar) aplicado $\left(\right.$ mol.kgDQO $\left.{ }^{-1}\right)$

RMSR: Rendimento entre hidrogênio ou metano (molar) produzido e substrato (molar) removido $\left(\mathrm{mol} \mathrm{kgDQO}{ }^{-1}\right)$

ROM: Resíduo orgânico municipal;

RSU: Resíduos sólidos urbanos 
SBP: $\quad$ Polpa de beterraba;

SST: $\quad$ Sólidos suspensos totais $\left(\mathrm{mgSST} . \mathrm{L}^{-1}\right)$

SSV: $\quad$ Sólidos suspensos voláteis $\left(\mathrm{mgSSV} . \mathrm{L}^{-1}\right)$

ST: $\quad$ Sólidos totais $\left(\mathrm{mgST} . \mathrm{L}^{-1}\right)$

SVT: $\quad$ Sólidos voláteis totais $\left(\mathrm{mgSVT} . \mathrm{L}^{-1}\right)$

TDH: $\quad$ Tempo de detenção hidráulica;

UASB: $\quad$ Reator anaeróbio de fluxo ascendente e manta de lodo (Upflow Anaerobic Sludge Blanket Reactor);

$\mathrm{V}_{\mathrm{A}}: \quad$ Volume de água residuária alimentado por ciclo $(\mathrm{L})$

$\mathrm{V}_{\mathrm{CH} 4}$ : $\quad$ Volume de metano gerado por ciclo $\left(\mathrm{mL} \cdot \mathrm{ciclo}^{-1}\right)$

$\mathrm{V}_{\mathrm{G}}$ : $\quad$ Volume de biogás gerado por ciclo $\left(\mathrm{mL} \cdot \mathrm{ciclo}^{-1}\right)$

$\mathrm{V}_{\mathrm{H} 2}: \quad \quad \quad \quad$ Volume de hidrogênio gerado por ciclo $\left(\mathrm{mL} . \mathrm{ciclo}^{-1}\right)$

$\mathrm{V}_{\mathrm{R}}: \quad$ Volume de meio líquido total no reator $(\mathrm{L})$

VRES: $\quad$ Volume de meio líquido residual no reator após a etapa de descarga (L)

$\varepsilon_{\mathrm{CF}}: \quad$ Eficiência de remoção de matéria orgânica filtrada na forma de carboidratos (\%)

$\varepsilon_{\mathrm{CT}}$ : $\quad$ Eficiência de remoção de matéria orgânica não filtrada na forma de carboidratos (\%)

$\varepsilon_{\mathrm{GF}}: \quad$ Eficiência de remoção de matéria orgânica filtrada na forma de glicerina (\%)

EGT: $\quad$ Eficiência de remoção de matéria orgânica não filtrada na forma de glicerina (\%)

$\varepsilon_{\mathrm{MOF}}$ : $\quad$ Eficiência de remoção de matéria orgânica filtrada na forma de DQO (\%)

$\varepsilon_{\mathrm{MOT}}$ : $\quad$ Eficiência de remoção de matéria orgânica não filtrada na forma de DQO (\%) 



\section{SUMÁRIO}

1 INTRODUÇÃO ..........................................................................................................

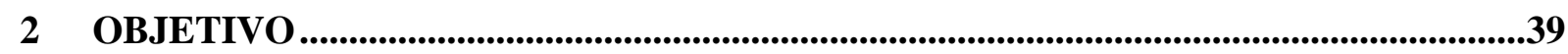

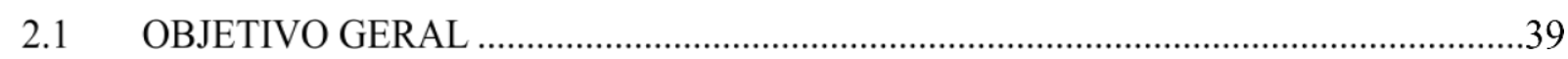

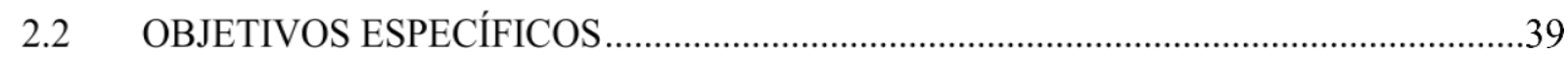

3 REVISÃO BIBLIOGRÁFICA.....................................................................................41

3.1 PRODUÇÃO BIOLÓGICA DE METANO ……………………………….................

3.2 PRODUÇÃO BIOLÓGICA DE HIDROGÊNIO ..........................................................43

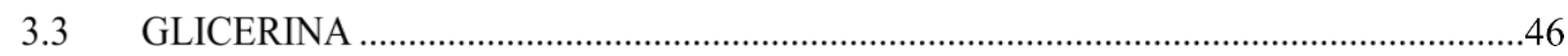

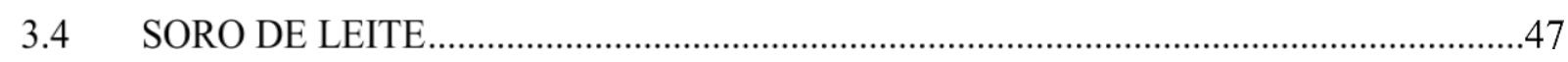

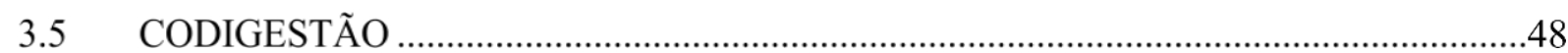

3.5.1 Resíduos industriais biodegradáveis ……………………………….......

3.5.2 Cultivos agrícolas e seus resíduos ..........................................................5

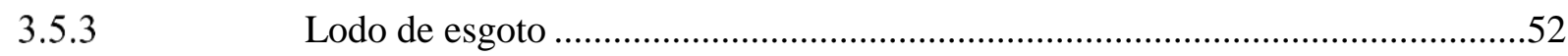

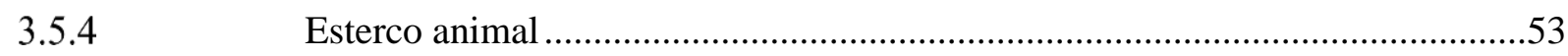

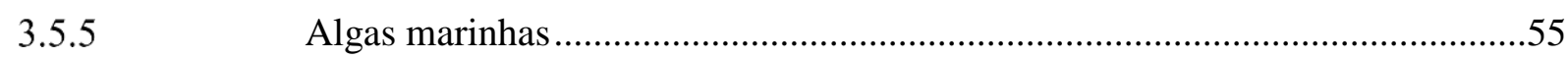

3.5.6 Resíduo sólido municipal .........................................................................5

3.5.7 Cultivos florestais e seus resíduos.....................................................................

3.6 MODELAGEM DE CODIGESTÃO ANAERÓBIA ……………………………….....59

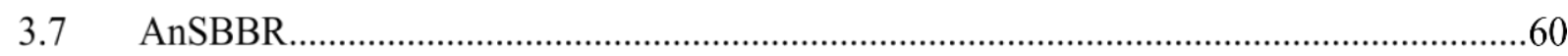

3.8 CONSIDERAÇÕES FINAIS...................................................................................64

4 MATERIAIS E MÉTODOS .......................................................................................65

4.1 ANSBBR COM BIOMASSA IMOBILIZADA E RECIRCULAÇÃO DA FASE

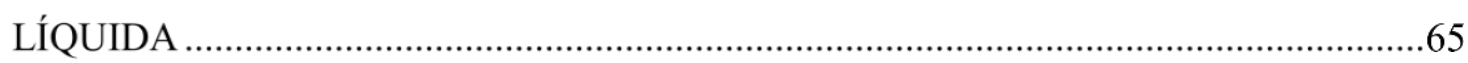

4.2 SUPORTE DE IMOBILIZAÇÃO DA BIOMASSA ANAERÓBIA E INÓCULO .............68

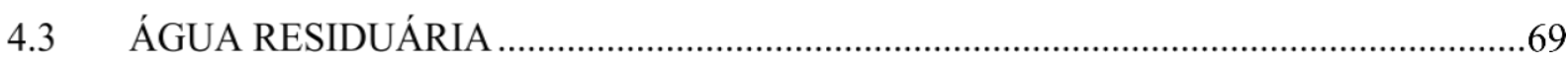

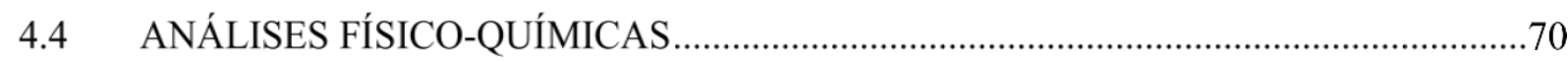

4.5 FUNDAMENTOS TEÓRICOS ..............................................................................

4.5.1 Indicadores de desempenho ..................................................................

4.5.2 Modelagem cinética para a produção de biometano …………………………......78

4.5.3 Modelagem cinética para a produção de biohidrogênio.........................................80

4.5.4 Ajuste da Equação de Arrhenius à Modelagem Cinética de Produção de

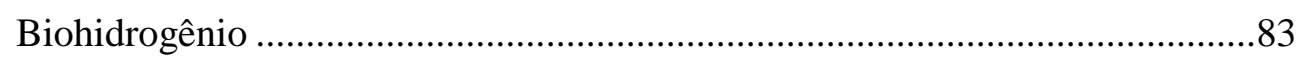


4.6 EXAMES MICROBIOLÓGICOS E CARACTERIZAÇÃO FILOGENÉTICA ................83

4.7 PROCEDIMENTO EXPERIMENTAL DA OPERAÇÃO DO REATOR ...........................84

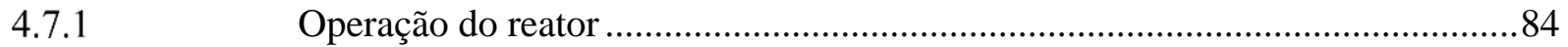

4.7.2 Ensaios para a produção de biometano (Fase I) .............................................85

4.7.3 Ensaios para a produção de biohidrogênio (Fase II, III, IV e V) .......................86

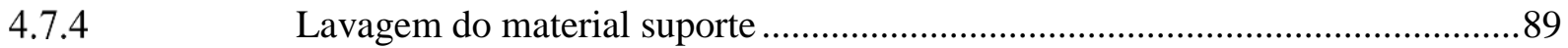

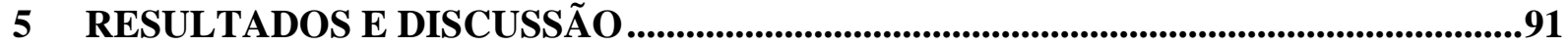

5.1 FASE I - PRODUÇÃO DE BIOMETANO _.......................................................................

5.1.1 Ensaio $1\left(100 \%\right.$ Soro $\left.-5000 \mathrm{mgDQO} \cdot \mathrm{L}^{-1}-8 \mathrm{~h}-\mathrm{BA}\right)$.....................................

5.1.2 Ensaio $2\left(75 \%\right.$ Soro e $25 \%$ Glicerina -5000 mgDQO.L $\left.{ }^{-1}-8 \mathrm{~h}-\mathrm{BA}\right)$............97

5.1.3 Ensaio 3 (50\% Soro e 50\% Glicerina - 5000 mgDQO.L $\left.{ }^{-1}-8 \mathrm{~h}-\mathrm{BA}\right)$............103

5.1.4 Ensaio 4 (25\% Soro e 75\% Glicerina - 5000 mgDQO.L $\left.{ }^{-1}-8 \mathrm{~h}-\mathrm{BA}\right)$............109

5.1.5 Ensaio $5\left(100 \%\right.$ Glicerina - 5000 mgDQO.L $\left.{ }^{-1}-8 \mathrm{~h}-\mathrm{BA}\right)$.............................115

5.1.6 Análise comparativa entre os Ensaios de 1 a 5 (Fase I) ..................................120

5.1.7 Modelagem Cinética para os Ensaios de 1 a 5..............................................128

5.2 FASE II - PRODUÇÃO DE BIOHIDROGÊNIO - INFLUÊNCIA DA RAZÃO DE

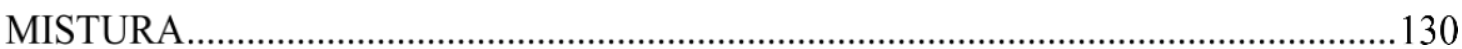

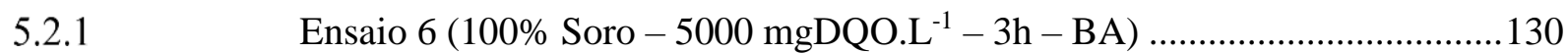

5.2.2 Ensaio 7 (75\% Soro e $25 \%$ Glicerina - $\left.5000 \mathrm{mgDQO} . \mathrm{L}^{-1}-3 \mathrm{~h}-\mathrm{BA}\right) \ldots \ldots \ldots . .135$

5.2.3 Ensaio 8 (50\% Soro e 50\% Glicerina - 5000 mgDQO.L - $\left.^{-1}-3 \mathrm{~h}-\mathrm{BA}\right)$............141

5.2.4 Ensaio 9 (25\% Soro e $75 \%$ Glicerina - $\left.5000 \mathrm{mgDQO} . \mathrm{L}^{-1}-3 \mathrm{~h}-\mathrm{BA}\right)$........... 147

5.2.5 Ensaio $10\left(100 \%\right.$ Glicerina -5000 mgDQO.L $\left.L^{-1}-3 \mathrm{~h}-\mathrm{BA}\right)$............................ 153

5.2.6 Análise comparativa entre os Ensaios de 6 a 10 (Fase II)..............................159

5.2.7 Modelagem Cinética para os Ensaios de 6 a 10 ...........................................167

5.3 FASE III - PRODUÇÃO DE BIOHIDROGÊNIO - INFLUÊNCIA DA

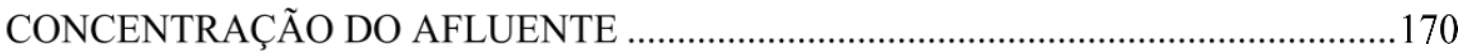

5.3.1 Ensaio $11\left(75 \%\right.$ Soro e $25 \%$ Glicerina - 3000 mgDQO.L $\left.{ }^{-1}-3 h-B A\right) \ldots \ldots \ldots .170$

5.3.2 Ensaio $12\left(75 \%\right.$ Soro e $25 \%$ Glicerina - 7000 mgDQO.L $\left.{ }^{-1}-3 \mathrm{~h}-\mathrm{BA}\right)$..........176

5.3.3 Análise comparativa entre os Ensaios 11 e 12 (Fase III) .................................182

5.3.4 Modelagem Cinética para os Ensaios 11 e 12..................................................187

5.4 FASE IV - PRODUÇÃO DE BIOHIDROGÊNIO - INFLUÊNCIA DO TEMPO DE

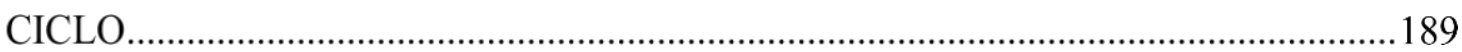

5.4.1 Ensaio $13\left(75 \%\right.$ Soro e $25 \%$ Glicerina $\left.-7000 \mathrm{mgDQO} . \mathrm{L}^{-1}-4 \mathrm{~h}-\mathrm{BA}\right) \ldots \ldots . .189$

5.4.2 Ensaio $14\left(75 \%\right.$ Soro e $25 \%$ Glicerina - 7000 mgDQO.L $\left.{ }^{-1}-2 \mathrm{~h}-\mathrm{BA}\right)$.........195

5.4.3 Ensaio $15\left(75 \%\right.$ Soro e $25 \%$ Glicerina -7000 mgDQO.L $\left.{ }^{-1}-3 \mathrm{~h}-\mathrm{B}\right) \ldots \ldots \ldots \ldots . .201$ 
5.4.5 Modelagem Cinética para os Ensaios 13, 14 e 15 ............................................

5.5 FASE V - PRODUÇÃO DE BIOHIDROGÊNIO - INFLUÊNCIA DA TEMPERATURA.

5.5.1 Ensaio $16\left(75 \%\right.$ Soro e $25 \%$ Glicerina $\left.-7000 \mathrm{mgDQO} . \mathrm{L}^{-1}-3 \mathrm{~h}-\mathrm{BA}-20^{\circ} \mathrm{C}\right) 212$ Ensaio 17 (75\% Soro e 25\% Glicerina - 7000 mgDQO.L $\left.{ }^{-1}-3 \mathrm{~h}-\mathrm{BA}-25^{\circ} \mathrm{C}\right) 218$ Ensaio 18 (75\% Soro e 25\% Glicerina - $\left.7000 \mathrm{mgDQO} . \mathrm{L}^{-1}-3 \mathrm{~h}-\mathrm{BA}-35^{\circ} \mathrm{C}\right) 224$

5.6 CARACTERIZAÇÃO FILOGENÉTICA DO CONSÓRCIO MICROBIANO -

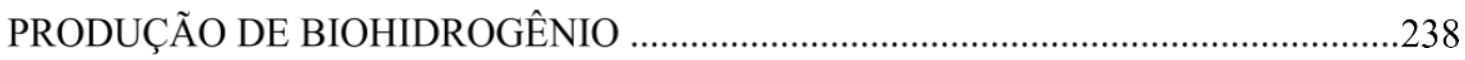

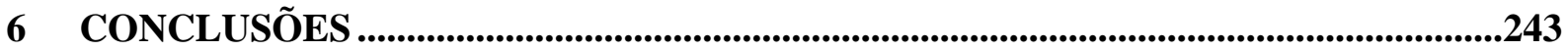

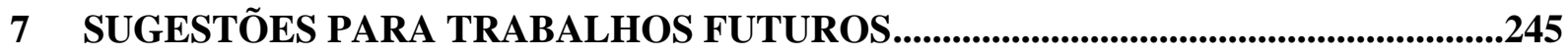

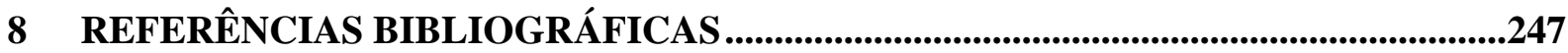





\section{INTRODUÇÃO}

A produção de energia a partir de recursos renováveis e a utilização (ou adoção) de processos com baixa demanda de energia tem um papel importante contra a mudança climática e na criação de um mundo mais sustentável. A transição para um sistema desse tipo foi estimada para ser viabilizada por volta do ano de 2050, quando se poderia utilizar grande parte de energia sustentável sem afetar as atividades cotidianas que empregam fontes de energia (Deng et al., 2012; Shah et al., 2015).

O biogás gerado na anaerobiose de vários substratos degradáveis serve como energia limpa, reduzindo efetivamente as emissões causadoras do efeito estuda pelo uso de energia fóssil. Além do biogás, o produto final da digestão anaeróbia (efluente líquido tratado) pode servir como fonte de nutrientes para a agricultura (Shah et al., 2015).

A digestão anaeróbia é um tratamento biológico realizado na ausência de oxigênio para estabilizar a matéria orgânica enquanto gera biogás, que consiste de uma mistura formada principalmente por metano, hidrogênio e dióxido de carbono. A digestão anaeróbia sofreu um crescimento importante depois da crise de energia de 1970, especialmente com o surgimento do sistema com biomassa imobilizada para tratar efluentes solúveis. Embora possa ser considerada como uma tecnologia estabelecida, a digestão anaeróbia de um único substrato apresenta alguns inconvenientes ligados às propriedades dos substratos, como (i) baixas cargas orgânicas; (ii) concentrações de nutrientes ou muito altas ou muito baixas; (iii) substratos impróprios; (iv) presença de metais pesados; (v) substratos sazonais e (vi) altas concentrações de ácidos graxos, que são potenciais inibidores da atividade metanogênica. A maior parte desses problemas pode ser resolvida pela codigestão anaeróbia, que consiste na adiação de um cosubstrato ao substrato que apresenta tais inconvenientes (Mata-Alvarez et al., 2014).

Desta forma, a codigestão anaeróbia é a digestão anaeróbia de dois ou mais substratos, sendo uma opção viável para superar as desvantagens da mono-digestão e melhorar a viabilidade econômica das plantas. Assim, a codigestão pode oferecer os seguintes benefícios: (i) diluição de substâncias tóxicas; (ii) balanceamento dos nutrientes; (iii) sinergia entre microrganismos; (iv) aumento da carga de matéria orgânica biodegradável; e (v) maior rendimento de biogás por unidade de volume de digestor (Shah et al., 2015).

Diferentes águas residuárias são utilizadas como substrato para a produção de biogás, nas quais a fonte de matéria orgânica carbonácea consta de sacarose, amido de trigo, fração orgânica de resíduos sólidos, efluente de reatores biológicos, óleos vegetais, resíduos da 
produção de biodiesel, entre outras. O objetivo comum de tais estudos consta da avaliação da produtividade de biogás, da estabilidade do reator, e da melhoria da composição das águas residuárias em termos do equilíbrio de nutrientes, no intuito de possibilitar acréscimo de produtividade de biogás e, assim, otimizar a aplicação desses diversos efluentes (Lin e Lay, 2005; Argun et al., 2008; Turcot et al., 2008).

Uma água residuária que vem sendo largamente utilizada em reatores anaeróbios é o soro de leite (ou soro de queijo), que é um subproduto do leite, obtido durante a produção de queijo. Consiste em 80-90\% do volume do leite utilizado para a produção de queijo e contém cerca de $50 \%$ dos nutrientes do leite que o originou. É considerado um efluente altamente poluente devido à sua elevada carga orgânica e volume gerado, o que representa um impacto ambiental significativo para a indústria de laticínios. Em escala mundial, apenas $50 \%$ do soro produzido é utilizado. O soro vem sendo utilizado em reatores metanogênicos e acidogênicos como substrato para a digestão anaeróbia, mas sua alta biodegradabilidade pode causar picos de ácidos que causam a instabilidade do processo (Bezerra et al., 2009, Lima et al., 2015 e Lima et al., 2016). Portanto, o uso de um cosubstrato com capacidade tamponante no tratamento do soro de queijo poderia ser de grande ajuda.

Neste sentido a glicerina, que é o maior subproduto da indústria de biodiesel, poderia ser um bom cosubstrato para o soro de leite, pois além do seu conteúdo de álcalis pode ainda melhorar a relação $\mathrm{C} / \mathrm{N}$ da mistura que compõe o afluente (Rivero et al., 2014). O glicerol bruto gerado pela transesterificação homogênea catalisada por base contém, aproximadamente: 50-60\% de glicerol, 2-6\% de álcalis, especialmente na forma de sabão alcalino e hidróxidos, $15-18 \%$ de ésteres metílicos, $8-12 \%$ de metanol e 2-3\% de água. No geral, para cada $100 \mathrm{~kg}$ de biodiesel produzidos, aproximadamente $10 \mathrm{~kg}$ de glicerol bruto é gerado.

Desta forma, essa pesquisa teve por objetivo principal a aplicação do reator anaeróbio operado em batelada e/ou batelada alimentada sequenciais com recirculação da fase líquida e biomassa imobilizada em suporte inerte (AnSBBR), aplicado à produção de biometano ou biohidrogênio a partir da codigestão entre glicerina (efluente da produção de biodiesel) e soro (soro de leite/queijo, efluente da produção de laticínios). Inicialmente foi dada ênfase na produção de biometano, avaliando-se a influência da composição dos substratos glicerina e soro (fração mássica da mistura). Posteriormente, foi dada ênfase na produção de biohidrogênio, avaliando-se a influência da composição (fração mássica da mistura), da concentração dos substratos glicerina e soro, da influência de diferentes tempos de ciclo e de enchimento, e da temperatura. Ambos estudos (produção de biometano e biohidrogênio) 
foram analisados considerando como indicadores de desempenho a estabilidade, a produtividade e composição de biogás, e o fator de conversão (entre biogás produzido e matéria orgânica consumida) para obter conhecimento sobre a viabilidade biotecnológica do sistema. 


\section{OBJETIVO}

\subsection{OBJETIVO GERAL}

Esse projeto tem como objetivo principal avaliar a aplicação do AnSBBR no processo de produção de biometano ou biohidrogênio a partir da codigestão de glicerina e soro. Os indicadores de desempenho (estabilidade, remoção de matéria orgânica, distribuição de compostos intermediários, produtividade e composição de molar/volumétrica de biogás, e o fator de conversão entre o biogás produzido e a matéria orgânica consumida) foram analisados em função da codigestão dos substratos para diferentes frações mássicas da mistura, cargas orgânicas (pela modificação da concentração afluente e do tempo de ciclo do reator), tempos de enchimento e temperaturas.

\subsection{OBJETIVOS ESPECÍFICOS}

Os objetivos específicos do trabalho são:

- Avaliar os indicadores de desempenho da codigestão para a produção de biometano com glicerina e soro para diferentes proporções entre os substratos mantendo-se a carga orgânica aplicada (concentração afluente e o tempo de ciclo iguais);

- Avaliar os indicadores de desempenho da codigestão para a produção de biohidrogênio com glicerina e soro para diferentes proporções entre os substratos mantendo-se a carga orgânica aplicada (concentração afluente e o tempo de ciclo iguais);

- Avaliar os indicadores de desempenho da codigestão para a produção de biohidrogênio com glicerina e soro para diferentes cargas orgânicas aplicadas modificando-se a concentração afluente e o tempo de ciclo utilizando o valor ótimo de mistura determinado anteriormente;

- Avaliar os indicadores de desempenho da codigestão para a produção de biohidrogênio com glicerina e soro para diferentes tempos de enchimento mantendose a carga orgânica aplicada (concentração afluente e o tempo de ciclo iguais) no valor ótimo determinado anteriormente; 
- Avaliar os indicadores de desempenho da codigestão para a produção de biohidrogênio com glicerina e soro em diferentes temperaturas mantendo-se a carga orgânica aplicada (concentração afluente e o tempo de ciclo iguais) e o tempo de enchimento nos valores ótimos determinados anteriormente;

- Avaliar a diversidade microbiana envolvida no sistema. 


\section{REVISÃO BIBLIOGRÁFICA}

A seguinte revisão bibliográfica relaciona o contexto científico referente ao desenvolvimento do AnSBBR com os avanços realizados no uso de processos anaeróbios de codigestão para a produção de bioenergia, utilizando os substratos estudados nesta tese.

\subsection{PRODUÇÃO BIOLÓGICA DE METANO}

A produção de metano a partir de uma variedade de resíduos biológicos por digestão anaeróbia está crescendo globalmente e é considerada ideal em muitos casos por causa de seus benefícios ambientais e econômicos. Além disso, os benefícios cruciais oferecidos pelo uso de biogás ao invés do gás natural são: (i) é produzido por fontes renováveis; (ii) é produzido localmente e sem dependência de óleo importado ou reservas de gás natural; (iii) ajuda a reduzir a poluição produzida por resíduos orgânicos, o que é responsável pela maior parte da poluição das águas naturais; e (iv) ajuda a retardar os problemas de gerenciamento de resíduos (Chandra et al., 2012). Além disso, o poder calorífico do metano é de $55,6 \mathrm{~kJ} \mathrm{~g}^{-1}$, o que representa um aumento de $17 \%$ em relação ao poder calorífico da gasolina $\left(47,5 \mathrm{~kJ} . \mathrm{g}^{-1}\right)$.

$\mathrm{O}$ processo metanogênico de tratamento de águas residuárias baseadas em carbono inclui as seguintes atividades microbiológicas: hidrólise, acidogênise, acetogênese, metanogênese e lise da célula. A primeira e a última dessas atividades são consideradas processos de não-crescimento, enquanto as outras são consideradas processos de crescimento. Esses processos podem ser divididos em subprocessos baseados no sistema e componentes de interesse.

Uma vez que os microrganismos não são capazes de assimilar a matéria orgânica particulada, a primeira fase no processo de degradação anaeróbia consiste na hidrólise de materiais particulados complexos em materiais dissolvidos mais simples, os quais podem atravessar as paredes/membranas celulares das bactérias fermentativas. Essa conversão de materiais particulados em materiais dissolvidos é conseguida pela ação de exoenzimas excretadas pelas bactérias hidrolíticas. Na anaerobiose, a hidrólise dos polímeros usualmente ocorre de forma lenta, sendo vários os fatores que podem afetar o grau e a velocidade em que o substrato é hidrolisado: temperatura, tempo de reação, composição do substrato, tamanho das partículas, $\mathrm{pH}$ do meio e concentração de produtos da hidrólise (ácidos voláteis, etc).

$\mathrm{Na}$ acidogênese, um grande grupo de microrganismos faz a biotransformação de açúcares em ácidos lático, valérico, butírico, propiônico e acético com ou sem a liberação de 
hidrogênio. Na acetogênese, um grupo de microrganismos acetogênicos produtores de hidrogênio converte ácidos voláteis em acetato, hidrogênio e dióxido de carbono; é um processo termodinamicamente desfavorável a menos que a pressão parcial do hidrogênio seja mantida menor que $10^{-3}$ atm. Essa pressão normalmente é conseguida devido aos microrganismos consumidores de hidrogênio como é o caso das arqueias metanogênicas hidrogenotróficas e das bactérias homoacetogênicas. No processo metanogênico, os microrganismos metanogênicos acetoclásticos e hidrogenotróficos são responsáveis pela conversão de ácido acético em dióxido de carbono e metano e pela redução do dióxido de carbono com o hidrogênio para formar metano, respectivamente (Rittman e McCarty, 2001; Kumar, 2008; Chernicharo, 1997).

Tanto a metanogênese acetoclástica quanto a hidrogenotrófica são muito importantes na manutenção da digestão anaeróbia, uma vez que estas são responsáveis pela função essencial de consumir o hidrogênio produzido nas fases anteriores. Com isso é propiciado o abaixamento da pressão parcial de hidrogênio no meio.

A fase final do processo é a lise da célula, que é o processo pelo qual células vivas são convertidas em partículas não vivas e material solúvel (Rodrigues et al., 2004).

A Figura 3.1 ilustra o processo de conversão da DQO e as respectivas porcentagens de conversão de cada etapa da degradação da parte volátil de resíduos biodegradáveis.

Resíduos Biodegradáveis

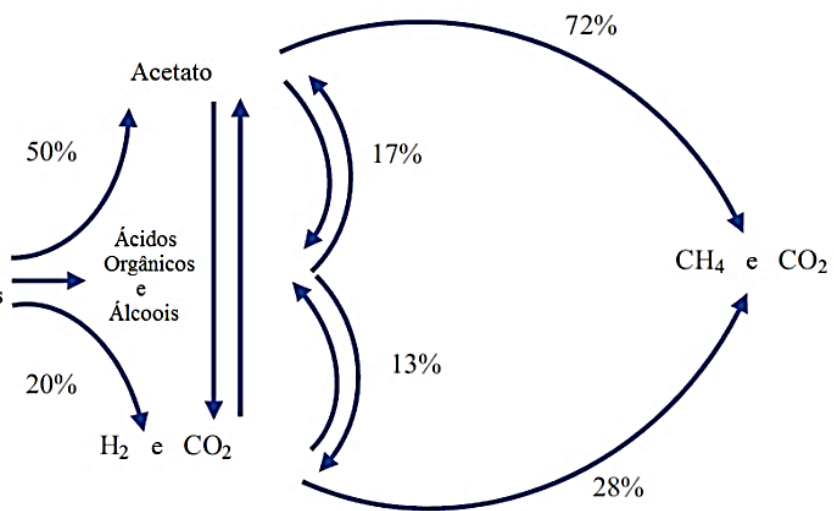

Figura 3.1. Conversão da DQO disponível em resíduos biodegradáveis.

Fonte: Adaptado de Chandra et al., 2012. 


\subsection{PRODUÇÃO BIOLÓGICA DE HIDROGÊNIO}

Cerca de $80 \%$ da demanda de energia global vem de combustíveis fósseis (petróleo, gás natural e carvão). Os óxidos resultantes, tais como COx, NOx e SOx causam o efeito estufa, destruição da camada de ozônio, chuva ácida e poluição. Recentemente, os esforços têm-se centrado no desenvolvimento de alternativas de energia limpa e, entre todos os potenciais candidatos, o hidrogênio $\left(\mathrm{H}_{2}\right)$ destaca-se como promissor para a energia do futuro por seu alto poder calorífico por massa $\left(141,9 \mathrm{~kJ} \mathrm{~g}^{-1}\right)$ e, mais importante, por só produzir água ao reagir com o oxigênio em células combustíveis. Seguindo essa linha, a substituição da energia proveniente de combustíveis fósseis por $\mathrm{H}_{2}$ parece ser uma opção razoável para sustentar o contínuo crescimento da economia global e, ao mesmo tempo, amenizar a situação do agravamento do clima global (Leite et al., 2008 e Wu et al., 2013).

A produção biológica de hidrogênio é uma forma interessante de produção desse gás, pois é uma tecnologia de baixo custo quando comparada a outras técnicas e requer menos energia para sua geração, podendo ocorrer por meio de dois processos: fotossíntese e processo fermentativo. A fermentação é tecnicamente mais simples e o hidrogênio pode ser obtido de matéria orgânica presente em águas residuárias. Diversas pesquisas demonstram a viabilidade da utilização do $\mathrm{H}_{2}$, produzido biologicamente, para geração de energia (Wu et al., 2009; Alzate-Gaviria et al., 2007; Leite et al., 2008).

Segundo Tanisho (2001) e Lee et al. (2011) o hidrogênio molecular pode ser formado por duas rotas, pela via de decomposição do ácido fórmico (Equação 3.3) ou pela re-oxidação da nicotinamida adenina dinucleotídeo $\left(\mathrm{NADH}\right.$ para $\left.\mathrm{NAD}^{+}\right)$.

$$
\mathrm{HCOOH} \rightarrow \mathrm{H}_{2}+\mathrm{CO}_{2}
$$

Esta via é intimamente relacionada com a fermentação via acetato, pois o piruvato é transformado em acetato e ácido fórmico (Equação 3.4).

$$
\begin{aligned}
& \mathrm{CH}_{3} \mathrm{COCOOH}+\mathrm{H}_{2} \mathrm{O} \rightarrow \mathrm{CH}_{3} \mathrm{COOH}+\mathrm{HCOOH} \\
& \text { Piruvato Ácido Ácido } \\
& \text { Acético Fórmico }
\end{aligned}
$$

No segundo caso, o hidrogênio é formado pela reoxidação do $\mathrm{NADH}$, que segundo Tanisho (2001), ocorre nas fermentações da via acetona-butanol e na via butirato. 
A concentração de hidrogênio obtida pelo processo depende diretamente da via metabólica seguida pelas bactérias fermentativas (Equações 3.5 e 3.6) (Das e Veziroglu, 2001; Lee et al., 2011).

$$
\begin{gathered}
\mathrm{C}_{6} \mathrm{H}_{12} \mathrm{O}_{6}+2 \mathrm{H}_{2} \mathrm{O} \rightarrow 2 \mathrm{CH}_{3} \mathrm{COOH}+2 \mathrm{CO}_{2}+4 \mathrm{H}_{2} \\
\text { Glicose } \\
\text { Ácido Acético } \\
\mathrm{C}_{6} \mathrm{H}_{12} \mathrm{O}_{6} \rightarrow \mathrm{CH}_{3} \mathrm{CH}_{2} \mathrm{CH}_{2} \mathrm{COOH}+2 \mathrm{CO}_{2}+2 \mathrm{H}_{2} \\
\text { Glicose Ácido Butírico }
\end{gathered}
$$

O ideal seria que o processo seguisse sempre a via do acetato garantindo a produção máxima. Porém, isso não é possível devido ao equilíbrio nas concentrações de NADH e $\mathrm{NAD}^{+}$que precisa ser mantido no sistema. Um mol de acetato é gerado pelo consumo de dois mols de $\mathrm{NAD}^{+}$. Um mol de butirato não consome e nem gera $\mathrm{NAD}^{+}$. Um mol de etanol ou um mol de propionato formam dois mols de $\mathrm{NAD}^{+}$(Ren et al., 2006).

Para que o equilíbrio dinâmico na oxidação e redução de $\mathrm{NAD}^{+} / \mathrm{NADH}$ seja mantido, o NADH deve ser consumido, gerando propionato, lactato, etanol, butanol; consequentemente diminuindo o rendimento na produção do $\mathrm{H}_{2}$ (Lee et al., 2011; Ren et al., 2006). Assim, a única maneira de influenciar o metabolismo no sentido de favorecer a realização da rota desejada é pela estratégia de operação do reator.

Sá et al. (2013) estudaram os caminhos metabólicos dos organismos do gênero Clostridium na conversão dos substratos glicerol, sacarose glicose, frutose e xilose para a produção de hidrogênio. A Figura 3.2 ilustra os processos. É interessante notar que, no caminho metabólico feito a partir da sacarose até o gliceraldeído-3-fostato, há reações que apenas liberam energia, enquanto no caminho a partir do glicerol até o mesmo composto há a reação da NAD para $\mathrm{NADH}^{+}$(que consome energia); portanto é um processo termodinamicamente desfavorável e mais difícil de ser realizado. 


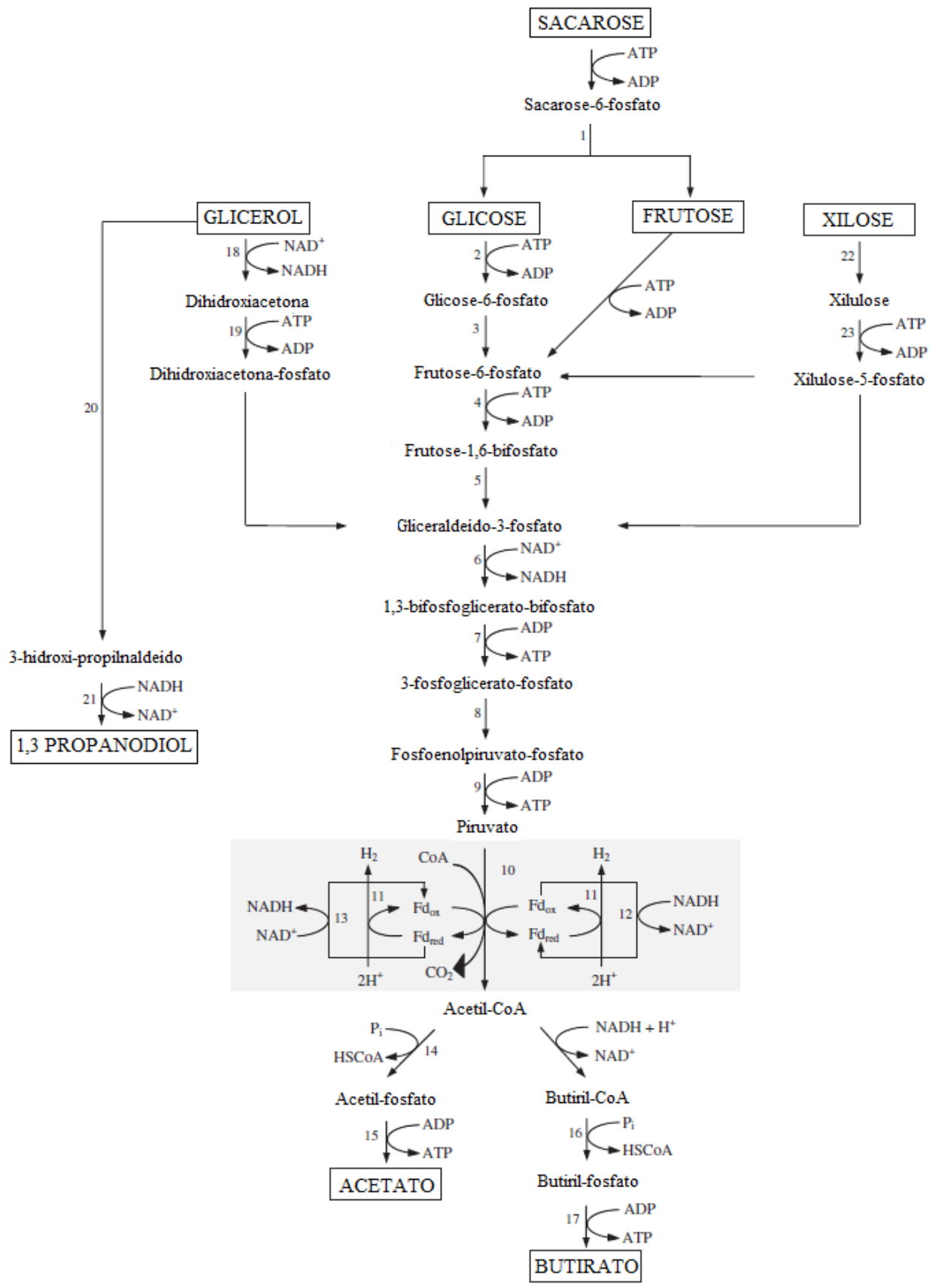

Figura 3.2. Caminho metabólico durante a fermentação de vários substratos pelo Clostridium sp.

Fonte: Adaptado de Sá et al., 2013.

Notação: [1:Sacarose 6-P hidrolase; 2: Hexoquinase; 3: Fosforoglicose isomerase; 4: Fosforofructoquinase; 5: Aldolase; 6: Gliceraldeído-3-P-dehidrogenase; 7: Fosfogliceroquinase; 8: Enolase; 9: Piruvato quinase; 10: Piruvato-ferredoxin oxidoreductase; 11: Hidrogenase; 12: NAD(P)H-ferredoxin redutase; 13: Ferredoxin-NAP $(\mathrm{P})^{+}$redutase; 14: Fosfotranscetilase quinase; 15: Acetato linase; 16: Fosfotransbutilase quinase; 17: Butirato quinase; 18: Glicerol dehidrogenase; 19: DNA quinase; 20: Glicerol dehidratase; 21: 1,3-propanodiol dehidrogenase; 22: Xilose isomerase; 23: Xiluloquinase.] 


\subsection{GLICERINA}

A glicerina, ou glicerol, é o maior subproduto da indústria de biodiesel. No geral, para cada $100 \mathrm{~kg}$ de biodiesel produzidos, aproximadamente $10 \mathrm{~kg}$ de glicerol bruto é gerado. $\mathrm{O}$ glicerol bruto gerado pela transesterificação homogênea catalisada por base contém (Figura 3.3), aproximadamente: 50-60\% de glicerol, 2-6\% de álcalis, especialmente na forma de sabão alcalino e hidróxidos, 15-18\% de ésteres metílicos, 8-12\% de metanol e 2-3\% de água. Em adição ao metanol e ao sabão, o glicerol bruto ainda contém uma variedade de elementos como Ca, Mg, P e S (Rivero et al., 2014).

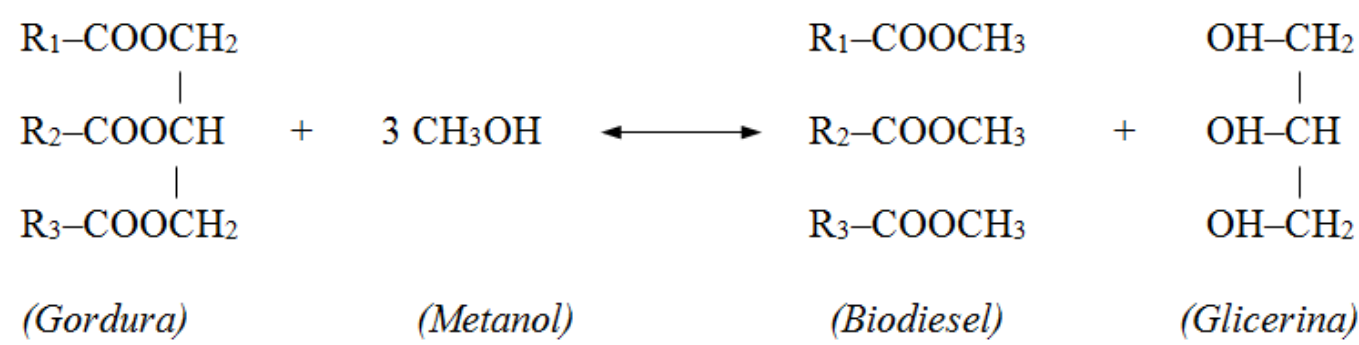

Figura 3.3. Reação de transesterificação de glicerídeos que produz glicerina.

O preço do glicerol tem caído significativamente nos anos recentes. O declínio contínuo é devido ao aumento do consumo de biodiesel e, portanto, aumento na geração deste resíduo. Diretrizes da União Europeia determinaram que o uso de biodiesel deve atingir $20 \%$ dos combustíveis usados em 2020 (Rivero et al., 2014). Atualmente, no Brasil, é obrigatória a mistura de $7 \%$ de biodiesel no diesel comercializado, segundo a lei $\mathrm{N}^{\circ} 13.033$, de setembro de 2014. A mesma lei prevê que o biodiesel necessário à adição obrigatória ao óleo diesel deverá ser fabricado preferencialmente a partir de matérias-primas produzidas pela agricultura familiar, e caberá ao Poder Executivo Federal estabelecer mecanismos para assegurar sua participação prioritária na comercialização no mercado interno. Se constatada a sua viabilidade técnica, o governo federal planeja elevar o percentual da mistura a até $27,5 \%$.

Mesmo com a grande aplicação de glicerol puro na indústria farmacêutica, alimentícia e de cosméticos, o refino do glicerol bruto até a alta pureza apresenta custo elevado, especialmente para o pequeno e médio produtor de biodiesel. Opções alternativas para o uso da glicerina bruta têm sido estudadas, como combustão, co-queima, compostagem, alimentação de animais, conversão termoquímica e conversão biológica (Rivero et al., 2014). 
Dentre as diferentes opções, a produção biológica de biogás a partir de glicerol bruto por digestão anaeróbia tem várias vantagens. Além da produção de metano ou hidrogênio, as vantagens incluem baixos requerimentos de nutrientes, economia de energia e geração de um efluente estabilizado que aprimora a qualidade do solo. Portanto, o glicerol é uma alternativa atrativa para o uso e recuperação por sua codigestão com outro resíduo, que é uma substância prontamente biodegradável, tem um pH que condiz com as condições da digestão anaeróbia e há uma grande variedade de microrganismos anaeróbios que usam glicerina como fonte de carbono. Além disso, a elevada concentração de $\mathrm{C}$ do glicerol aumenta a razão $\mathrm{C} / \mathrm{N}$ da mistura, evitando a inibição de processos por um excesso de $\mathrm{N}$ e aumentando a produção de digestores entre 50-200\% (Rivero et al., 2014).

\subsection{SORO DE LEITE}

O soro de leite, ou soro de queijo, é um subproduto do leite, obtido durante a produção de queijo. Ele consiste em $80-90 \%$ do volume do leite utilizado para a produção de queijo e contém cerca de $50 \%$ dos nutrientes do leite que o originou. É composto principalmente por lactose (70-72\%), proteína (8-10\%) e sais minerais (12-15\%) (Ottaviano, 2014).

O queijo é um dos principais produtos agroindustriais e o soro de queijo é considerado um efluente altamente poluente devido à sua elevada carga orgânica e volume gerado, o que representa um impacto ambiental significativo para a indústria de laticínios. Em escala mundial, apenas $50 \%$ do soro de queijo produzido é utilizado. A composição do soro de queijo é relacionada com a produtividade do queijo, método empregado na fabricação do queijo, tratamento térmico de leite, manipulação, entre outros (Ottaviano, 2014). Segundo Carvalho et al. (2013), podem ser produzidos, em média, $873 \mathrm{~mL}$ de soro para cada litro de leite de vaca processado.

A matéria orgânica elevada é devido ao conteúdo de lactose, proteína e gorduras, e é em torno de 99\% biodegradável. As matérias minerais mais importantes do soro estão representadas na Tabela 3.1. Levando-se em consideração o alto custo do descarte do efluente e o valor nutricional do soro, é interessante a utilização do soro na indústria de alimentos e, devido à composição nutricional apropriada para o metabolismo de diversos microrganismos, é ideal o uso do soro para a fermentação. 
Tabela 3.1. Matérias minerais contidas no soro.

\begin{tabular}{cc}
\hline Minerais & $\mathrm{mg} .100 \mathrm{~g}^{-1}$ soro \\
\hline Cálcio & $500-725$ \\
Sódio & $650-950$ \\
Magnésio & $880-1600$ \\
Potássio & $2400-2900$ \\
Fósforo & $700-800$ \\
\hline
\end{tabular}

Fonte: Ottaviano (2014).

\subsection{CODIGESTÃO}

A digestão anaeróbia (DA) é um tratamento biológico realizado na ausência de oxigênio para estabilizar matéria orgânica enquanto gera biogás, uma mistura formada principalmente por metano e dióxido de carbono e pode, atualmente, ser considerada como uma tecnologia madura. Mesmo assim, a DA de um único substrato pode apresentar alguns inconvenientes ligados às propriedades dos substratos. Por exemplo:

- Baixas cargas orgânicas;

- Concentrações de nutrientes ou muito altas ou muito baixas;

- Materiais impróprios;

- Substâncias tóxicas;

- Os substratos podem ser sazonais;

- Altas concentrações de ácidos graxos (AGCL), que são potenciais inibidores da atividade metanogênica.

A maior parte desses problemas pode ser resolvida pela adição de um cosubstrato no que tem recentemente sido chamada de codigestão anaeróbia (CoDA) (Mata-Alvarez et al., 2014).

A CoDA, a DA de dois ou mais substratos, é uma opção viável para superar as desvantagens da mono-digestão e melhorar a viabilidade econômica das plantas de DA. Além de melhorar a confiabilidade do afluente, a codigestão pode oferecer os seguintes benefícios (Shah et al., 2015):

- Diluição de substâncias tóxicas;

- Balanceamento dos nutrientes;

- Sinergia entre microrganismos;

- Aumento da carga de matéria orgânica biodegradável; 
- Maior rendimento de metano por unidade de volume de digestor.

O custo de transporte do cosubstrato a partir do ponto de geração até a planta de DA é um critério importante de seleção. Apesar disso, necessita-se selecionar o melhor cosubstrato e razão de mistura com o intuito de favorecer as vantagens listadas acima (Mata-Alvarez et al., 2014).

Como ilustrado na Figura 3.4, as publicações de CoDA tem subido consideravelmente nos últimos anos. Nota-se que $87 \%$ de todas as publicações foram feitas a partir de 2011 . Até o final de 2017, haviam 296 artigos publicados na base SCOPUS sobre codigestão.

Diferentes tipos de resíduos são codigeridos para a otimização da produção de biogás, como apresentado na Figura 3.5. Nas seções seguintes, são apresentadas breves descrições de cada um deles e exemplos de casos que usaram a CoDA.

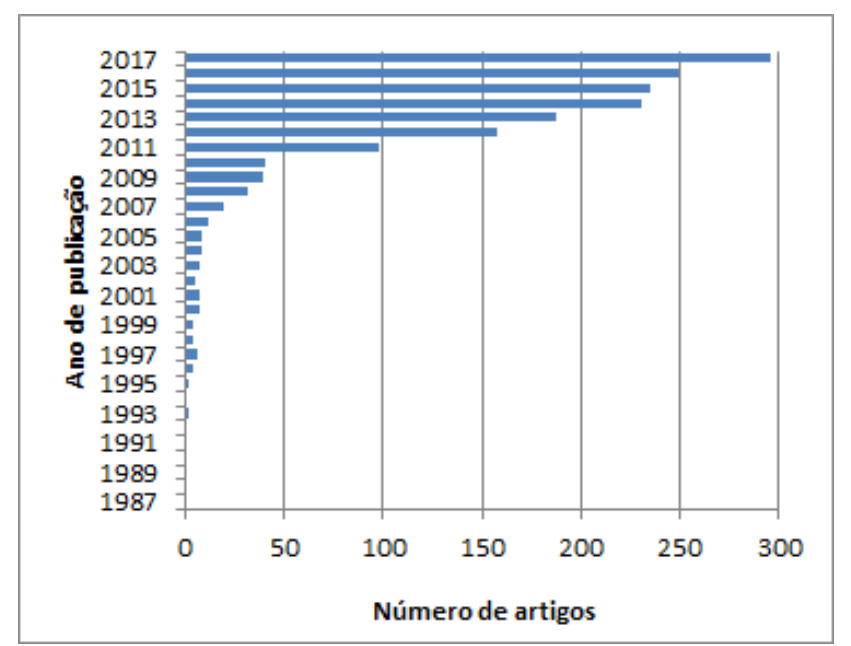

Figura 3.4. Evolução do número de artigos publicados com a palavra codigestão em seus títulos. Fonte: Adaptado de Mata-Alvarez et al., 2014.

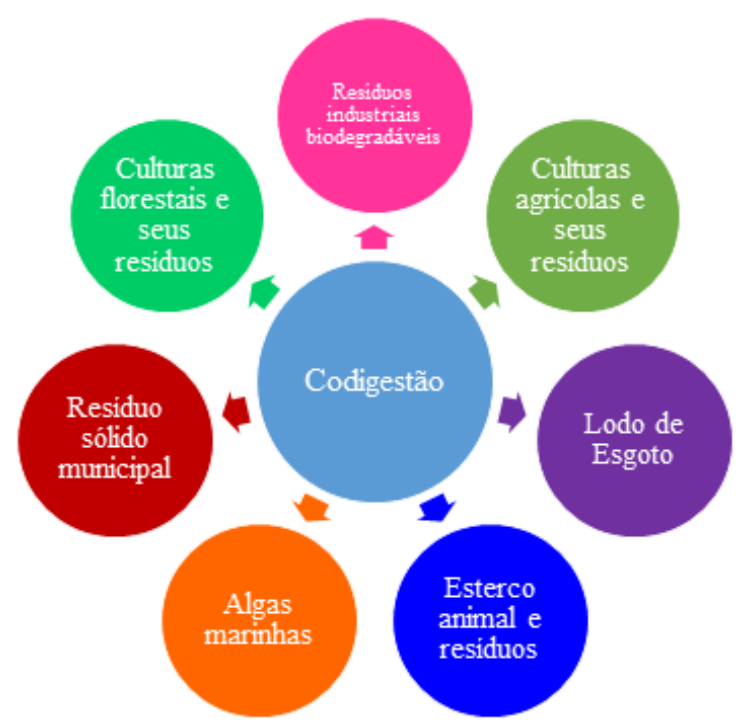

Figura 3.5. Diferentes tipos de resíduos usados em codigestão para a produção de biogás.

Fonte: Adaptado de Shah et al., 2015. 


\subsubsection{Resíduos industriais biodegradáveis}

Há inúmeros resíduos industriais que são produzidos diariamente em abundância que podem causar grandes impactos ambientais. No entanto, para usá-los na DA, eles precisam ser biodegradáveis e baixos em toxicidade, o que reduz grandemente a gama de resíduos que podem ser utilizados.

O resíduo industrial biodegradável mais pesquisado para codigestão, segundo levantamento na base SCOPUS, é o glicerol (GLI). Ao longo desta revisão, serão descritos vários casos onde a glicerina é utilizada como cosubstrato. Outros exemplos de resíduos industriais que podem ser utilizados na codigestão incluem água residuária da indústria petroquímica e resíduos de argila.

Siddique et al. (2014) é um dos poucos artigos que trazem um estudo sobre uso de água de indústria petroquímica pré-tratada com esterco de gado leiteiro e de corte para produção de biometano. A codigestão dessas águas residuárias contribuiu para o aumento em $50 \%$ da produção de metano, seguido por uma redução de $98 \%$ da demanda química de oxigênio em um tempo de detenção hidráulica (TDH) de 10 dias. Em comparação com a digestão da água residuária da indústria petroquímica sozinha, o rendimento de metano aumentou entre 50-60\% sob condições mesofílicas e entre 50-65\% sob condições termofílicas devido à codigestão.

Resíduos de argila foram usados por Jiménez et al. (2015) na codigestão de esterco de suínos com palha de arroz. Foi descoberto que esses resíduos tem um efeito positivo na redução da inibição da atividade metanogênica específica causada pelas altas concentrações de esterco de suínos, devido às propriedades adsorventes da argila em relação ao nitrogênio amoniacal.

\subsubsection{Cultivos agrícolas e seus resíduos}

Resíduos agrícolas, que incluem resíduos naturais (orgânicos) e não naturais, é um termo generalizado para descrever resíduos produzidos em uma fazenda em diversas atividades. Essas atividades podem incluir, mas não são limitadas a criação de gado leiteiro, de corte, horticultura, produção de sementes, pastagens e até mesmo florestas. Resíduos e rejeitos das indústrias alimentícia e agrícola constituem uma parcela significativa (por volta de 30\%) da produtividade da agricultura mundial (Ashworth e Azevedo, 2009).

Vários estudos têm mostrado que misturas multicomponentes entre resíduos da agricultura e resíduos industriais podem ser digeridas com sucesso; embora, com algumas 
misturas, podem ocorrer tanto sinergismos quanto antagonismos (Ma et al., 2008; Bouallagui et al., 2009). No setor rural, uma possível solução para processar biomassa agrícola é sua codigestão com esterco animal, a maior corrente de resíduos dessa indústria. A codigestão de resíduos agroindustriais com esterco animal tem sido reportada a algum tempo, com interesse particular na codigestão do esterco com soro, silagem de milho (CR) e silagem de beterraba. No entanto, há pouco material publicado sobre a codigestão somente entre culturas energéticas e resíduos industriais (Kacprzak et al., 2010).

Kacprzak et al. (2010) examinou a codigestão de silagem de milho, silagem de polpa de beterraba, resíduos de cenoura (CR) e soro em diferentes configurações juntamente com uma fração de glicerina em um biorreator de $25 \mathrm{~L}$ operado mesofilicamente em modo semicontínuo. Cinco experimentos de codigestão com diferentes combinações de substrato foram conduzidos com o objetivo de maximizar a produção de metano. A digestão anaeróbia apenas da silagem de milho resultou em uma produtividade de gás igual a 3,4 L.L $\mathrm{L}^{-1} \cdot \mathrm{d}^{-1}$ e em um biogás contendo $51 \%$ de metano. A adição de um segundo substrato (soro ou resíduo de cenouras) à silagem de milho mudou a produtividade do biogás e o conteúdo de metano. Esses experimentos mostraram que os resíduos de cenoura são um cosubstrato melhor do que o soro para a silagem de milho, resultando em uma produtividade igual a $5,9 \mathrm{~L} . \mathrm{L}^{-1} \cdot \mathrm{d}^{-1}$. A porcentagem de metano no biogás se manteve em nível similar nos três experimentos $(51,0$ $53,8 \%$ ). Adicionalmente, como a codigestão entre silagem de milho e soro não se mostrou muito eficiente, foi adicionada glicerina a essa mistura em um quarto experimento, o que aumento a produtividade de biogás assim como a porcentagem de metano. A combinação desses três substratos fez com que o biogás ficasse com $61 \%$ de metano. O último experimento mostrou que a silagem de polpa de beterraba combinada com soro de queijo e glicerina resultou em uma maior produtividade que a de silagem de milho; no entanto, a porcentagem de metano diminuiu em 10\%. A Tabela 3.2 mostra as características dos resíduos usados por Kacprzak et al. (2010).

Ma et al. (2008) investigou a codigestão da água de processamento de batatas com diferentes tipos de glicerol (puro, bruto e de alta condutividade) em um reator UASB de 2,3 L a $33^{\circ} \mathrm{C}$. Foi observado que a adição de $2 \mathrm{~mL} \cdot \mathrm{L}^{-1}$ de glicerol na mistura aumentou a produção de biogás em $50 \%$. 
Tabela 3.2. Características dos substratos usados em Kacprzak et al. (2010).

\begin{tabular}{cccccc}
\hline Parâmetro & $\begin{array}{c}\text { Silagem de } \\
\text { milho }\end{array}$ & $\begin{array}{c}\text { Polpa de } \\
\text { beterraba }\end{array}$ & Cenouras & Soro & Glicerina \\
\hline pH & 3,70 & 4,00 & - & 4,48 & 7,23 \\
Sólidos totais (\%) & 27,5 & 19,93 & 14,03 & 6,10 & 11,00 \\
Sólidos voláteis & 26,14 & 18,87 & 5,06 & 5,26 & 7,20 \\
$(\%)$ & 376 & - & - & 66,7 & - \\
DQO (g.L L $\left.^{-1}\right)$ & 1,36 & 10,63 & 8,97 & 0,84 & 3,80 \\
Cinzas (\%) & 1950 & - & - & 2220 & 1296 \\
AVT (mgAcH.L L $\left.^{-1}\right)$ & $60: 1$ & $20: 1$ & $30: 1$ & $21: 1$ & $25: 1$ \\
Razão molar C/N & & & & & \\
\hline
\end{tabular}

Bouallagui et al. (2009) demostrou que a digestão anaeróbia de resíduos de frutas e vegetais (RFV) e água de abatedouro (AAB) aumentaram a produtividade e o rendimento de biogás quando comparados com a digestão desses resíduos separadamente. Os efeitos de tempo de detenção hidráulica (TDH) e de variações de temperatura no digestor também foram examinados. Os TDHs de 10 e 20 dias mostraram produção de biogás maior graças ao balanço de nutrientes fornecido pela codigestão. O máximo rendimento e produtividade obtidos foram a $35^{\circ} \mathrm{C}$ com 10 dias de $\mathrm{TDH}$, foram eles, respectivamente: $299 \mathrm{mLCH}_{4} \mathrm{gSV}^{-1}$ in e $1772 \mathrm{mLCH}_{4} \cdot \mathrm{L}^{-1} \cdot \mathrm{d}^{-1}$, o que é quase 10 vezes mais do que a produtividade obtida com a digestão de $\mathrm{AAB}$ pura.

\subsubsection{Lodo de esgoto}

O lodo de esgoto (LE) ocupa a posição de segundo principal substrato para CoDA. Historicamente, a CoDA entre LE e FORSM (fração orgânica de resíduos sólidos municipais) é a pesquisa de codigestão mais relatada. No entanto, entre 2010 e 2013 as publicações relacionadas a gorduras, óleos e graxas (GOG) como cosubstrato do LE tiveram um forte aumento. No mesmo prazo, outros cosubstratos tais como resíduos de frutas e vegetais (RFV), AAB, GLI e algas também têm sido amplamente relatados (Mata-Alvarez et al., 2014).

A baixa carga orgânica do LE junto com a capacidade dos digestores das plantas de tratamento de água residuárias que ainda não foram utilizados, que frequentemente chegam a $30 \%$, é a principal força por trás da codigestão de LE. O LE é caracterizado por uma razão $\mathrm{C} / \mathrm{N}$ relativamente baixa e grande capacidade de tamponamento. Portanto, é capaz de aguentar cosubstratos com grandes quantidades de matéria orgânica facilmente biodegradável e com baixos valores de alcalinidade. Ainda, em muitos casos, a codigestão com LE pode levar a diluição de alguns componentes indesejados do lodo como metais pesados, compostos 
farmacêuticos e/ou patogênicos. Levando em consideração esses fatos e considerando o custo de transporte, tanto o FORSM e o GOG, produzidos em todos os municípios são substratos muito convenientes para o LE. Não é necessário dizer que qualquer resíduo agroindustrial gerado em parques industriais próximos a estação de tratamento também seriam cosubstratos convenientes.

A viabilidade da adição do glicerol bruto a um digestor anaeróbio que trata lodo de esgoto foi estudada por Fountoulakis et al. (2010). Em um CSTR com 1 L de volume útil a $35^{\circ} \mathrm{C}$, a adição de 1 e $3 \%$ de glicerina (base volumétrica) em lodo de esgoto foi testada. Os resultados obtidos mostram que a adição de $1 \%$ de glicerina dobra a produção de metano (de 1106 para $2353 \mathrm{mLCH}_{4} \cdot \mathrm{d}^{-1}$ ), mas qualquer incremento a mais de glicerina causa um grande desbalanceamento no processo. A Tabela 3.3 mostra características do lodo de esgoto e o do glicerol estudados neste artigo.

Dai et al. (2013), por outro lado, estudou a adição de resíduo alimentício (RA) a lodo de esgoto drenado. Para a digestão de altos sólidos do LE, a adição de RA não apenas melhorou a estabilidade do sistema como aumentou grandemente a produção de biogás.

Tabela 3.3. Características principais do lodo de esgoto e da glicerina

\begin{tabular}{ccc}
\hline Parâmetros & Lodo de esgoto & Glicerina \\
\hline $\mathrm{pH}$ & 6,8 & 5,0 \\
$\mathrm{ST}\left(\mathrm{g} . \mathrm{L}^{-1}\right)$ & 35,4 & - \\
$\mathrm{SV}\left(\mathrm{g} . \mathrm{L}^{-1}\right)$ & 26,1 & - \\
DQO total $\left(\mathrm{g} . \mathrm{L}^{-1}\right)$ & 35,2 & - \\
DQO solúvel $\left(\mathrm{g} . \mathrm{L}^{-1}\right)$ & 1,9 & - \\
$\mathrm{N}\left(\mathrm{mg} . \mathrm{L}^{-1}\right)$ & 1042 & 372 \\
P $\left(\mathrm{mg} . \mathrm{L}^{-1}\right)$ & 845 & 9,6 \\
\hline
\end{tabular}

Fonte: Fountoulakis et al. (2010)

\subsubsection{Esterco animal}

O esterco animal é uma valiosa fonte de nutrientes e energia renovável. No entanto, a maior parte do esterco é coletado em lagoas ou deixado para se decompor no aberto. Os poluentes atmosféricos emitidos a partir de esterco incluem metano, óxido nitroso, amônia, sulfeto de hidrogênio, compostos orgânicos voláteis e material particulado, o que pode causar sérios problemas ambientais e problemas de saúde. No passado, os resíduos de gado eram recuperados e vendidos como adubo ou simplesmente espalhados em terrenos agrícolas. A introdução de controles ambientais mais rigorosos sobre odor e poluição da água significam 
que alguma forma de gestão desses resíduos é necessária, o que proporciona mais incentivos para a conversão de biomassa em energia (Zafar, 2015).

O estabelecimento de sistemas de digestão anaeróbia para a estabilização de esterco animal e produção de energia acelerou substancialmente nos últimos anos. Existem milhares de digestores operando em instalações de gado comercial na Europa, Estados Unidos e Ásia (Zafar, 2015)

No entanto, estercos são frequentemente associados com baixos rendimentos de metano. A CoDA de estercos com outros substratos tem sido aplicada como uma alternativa de baixo custo para melhorar a eficiência do processo e, consequentemente, tornar as plantas mais viáveis economicamente (Mata-Alvarez et al., 2014).

Nas publicações de CoDA, estercos animais se referem principalmente a esterco suíno (EP) a de gado (EG), pois pouca atenção tem sido voltada para outras criações (cabras, cavalos, aves, etc). Em relação aos cosubstratos utilizados, os resíduos agroindustriais são os mais aplicados. Cosubtratos adequados para estercos são ricos em $\mathrm{C}$ e, quando possível, com grandes quantidades de matéria orgânica facilmente biodegradável. Esses substratos são caracterizados por uma razão $\mathrm{C} / \mathrm{N}$ alta, baixa capacidade de tamponamento e, dependendo de sua biodegradabilidade, capacidade de produzir grandes quantidades de ácidos voláteis (AVT) durante o processo de digestão anaeróbia. Em contraste, estercos tem boa capacidade de tamponamento e razão $\mathrm{C} / \mathrm{N}$ baixa, onde concentrações de amônia usualmente superam os requerimentos para o crescimento microbiano e podem se tornar inibitórias para microrganismos metanogênicos (Mata-Alvarez et al., 2014).

Astals et al. (2012) estudaram a codigestão de esterco de porco com glicerol bruto em um CSTR semi-contínuo de $4 \mathrm{~L}$ a $35^{\circ} \mathrm{C}$. Um aumento de cerca de $400 \%$ na produção de biogás foi obtido sob condições mesofílicas quando dejetos suínos foram co-digeridos com 4\% de glicerol, em base úmida, em comparação com a mono-digestão. O aumento na produção de biogás foi principalmente uma consequência do aumento da carga orgânica, devido à adição de glicerol, que também balanceou relação carbono- nitrogênio e diminuiu a concentração de amônia livre no meio de digestor. A disparidade entre a eficiência de remoção de matéria orgânica e a produção de biogás deixou claro que a digestão anaeróbia dos dejetos de suínos é limitada pelo passo desintegração-hidrólise, sendo que a codigestão transformou claramente carboidratos solúveis em biogás.

Goberna et al. (2010) investigou a codigestão entre esterco de gado com resíduos bifásicos de moinho de azeite em uma proporção de 3:1 em dois CSTR de $75 \mathrm{~L}$ a 37 e $55^{\circ} \mathrm{C}$. A fermentação mesofílica de esterco de gado com ROM (resíduo orgânico municipal) com 
uma carga orgânica (COAV) de 5,5 gDQO.L $\mathrm{L}^{-1} \cdot \mathrm{d}^{-1}$ rendeu $1096 \mathrm{~mL}$ de biogás por litro de lodo por dia. Isso significa um aumento de $337 \%$ em relação a digestão de apenas esterco. O rendimento de metano resultante da codigestão foi $179 \mathrm{LCH}_{4} \cdot \mathrm{kgSSV}_{\mathrm{in}}{ }^{-1}$, dos quais $42 \%$ foram atribuídos ao quarto de reator correspondente ao ROM. Sob condições termofílicas, a codigestão rendeu 17,3\% mais metano do que mesofilicamente. A digestão de esterco de animais em escala de fazenda com ROM deveria ser promovida em países mediterrâneos como uma opção ambientalmente boa para reciclo de resíduos e produção de energia renovável.

Finalmente, a influência de glicerina bruta na produção de biogás e seu produção de metano foi estudada por Robra et al. (2010), quando adicionado a esterco de gado. Os experimentos foram de $5 \%$ em peso (Gli5), $10 \%$ em peso (Gli10), e 15\% em peso (Gli15) de glicerina bruta adicionada ao esterco de gado, e um digestor controle sem adição da mesma. A digestão anaeróbia foi realizada em escala de laboratório em 4 CSTRs com volumes de trabalho de $3 \mathrm{~L}$ em condições mesofilicas. Os maiores rendimentos de biogás (825,3 mL.gSV ${ }_{\text {in }}{ }^{-1}$ e $825,7 \mathrm{~mL} \cdot \mathrm{gSV}_{\mathrm{in}}{ }^{-1}$, respectivamente) foram produzidos pelos tratamentos Gli5 e Gli10. O tratamento controle produziu 268,67 $\mathrm{mL}_{\mathrm{gSV}} \mathrm{gn}^{-1}$, enquanto que o tratamento Gli15 produziu 387,97 mL.gSV ${ }^{-1}{ }^{-1}$. Este valor foi baixo devido à ruptura do processo. Em comparação com o controle, o conteúdo de metano foi aumentando em 9,5, para 14,3, e $14,6 \%$, respectivamente, para os tratamentos Gli5, Gli10 e Gli15.

\subsubsection{Algas marinhas}

O potencial de microrganismos fotossintéticos como uma alternativa para a produção de biocombustível, juntamente com o seu potencial como uma tecnologia promissora para a fixação de $\mathrm{CO}_{2}$, é um assunto de grande interesse. De fato, algumas microalgas eucarióticas e microrganismos procarióticos (cianobactérias - abusivamente reunidos sob o termo de microalgas na seguinte) podem sintetizar lipídios sob determinadas condições ambientais. A perspectiva de produção em larga escala de microalgas para aplicações de biocombustível é motivada pela alta produtividade que pode ser alcançada considerando um cenário onde produções de até 127 tons.ha- ${ }^{-1}$.ano ${ }^{-1}$ podem ser conseguidas em lagoas de alta taxa ou até 150 toneladas.ha ${ }^{-1} \cdot$ ano $^{-1}$ em um fotobiorreactor (Sialve et al., 2009).

Microalgas, no entanto, vão exigir enormes quantidades de nitrogênio e fosfato devido a sua composição $\left(\mathrm{CO}_{0.48} \mathrm{H}_{1.83} \mathrm{~N}_{0.11} \mathrm{P}_{0.01}\right)$, gerando um impacto ambiental e econômico que pode não ser sustentável. Um processo para reciclar nitrogênio e fósforo contidos nos resíduos de 
algas depois de extração de lipídeos é, portanto, necessário. A digestão anaeróbia pode ser uma resposta a este problema, uma vez que este processo biotecnológico pode mineralizar resíduos de algas contendo nitrogênio orgânica e fósforo, o que resulta num fluxo de amônia e fosfato que podem ser utilizados como um substrato para as microalgas. Além disso, para atingir um equilíbrio econômico, é necessário que a biomassa resultante após a extração de lipídeos seja transformada em metano. Assim, se a digestão anaeróbia for usada para processar resíduos de algas, ela irá não somente reciclar nitrogênio e fósforo, mas também produzir metano. O valor energético do metano produzido pode potencialmente levar a um balanceamento energético da produção de microalgas para o processo de biocombustíveis (Silvae et al., 2009).

Assim, para codigerir lodo de algas, é necessário que o cosubstrato tenha uma relação $\mathrm{C} / \mathrm{N}$ adequada para equilibrar o afluente. Razões $\mathrm{C} / \mathrm{N}$ ótimas para digestores anaeróbicos ficam entre 20 e 30. Uma elevada relação $\mathrm{C} / \mathrm{N}$ é uma indicação de consumo rápido de nitrogênio por metanogênicas, e resulta em baixa produção de gás. Por outro lado, uma relação $\mathrm{C} / \mathrm{N}$ baixa causa acúmulo de amônia e valores de $\mathrm{pH}$ superiores a 8,5, o que é tóxico para arqueias metanogênicas (Tokumoto et al., 2012).

Yen e Brune (2007) estudaram a adição de um resíduo de papel com elevada porcentagem de carbono em uma corrente com lodo de algas em um digestor alimentado semi-continuamente com um TDH de 10 dias a $35^{\circ} \mathrm{C}$. Verificou-se que para uma mistura de $50 \%$ de resíduos de papel e 50\% de lama de algas (com base em sólidos voláteis) a produção de metano aumentou em 104\% (573-1170 mlCH $\left.4 . \mathrm{L}^{-1} \cdot \mathrm{d}^{-1}\right)$ com uma carga orgânica de $4 \mathrm{gSV} . \mathrm{L}^{-1} \cdot \mathrm{d}^{-1}$. Nas mesmas condições, com uma COAV de $5 \mathrm{gSV} \cdot \mathrm{L}^{-1} \cdot \mathrm{d}^{-1}$, o lodo de algas misturado com $60 \%$ de resíduos de papel, leva a uma taxa máxima de produção de metano de $1607 \mathrm{mlCH}_{4} \cdot \mathrm{L}^{-1} \cdot \mathrm{d}^{-1}$. A variação da razão $\mathrm{C} / \mathrm{N}$ otimizada para a codigestão foi entre 20-25.

Wang et al. (2013) investigaram a codigestão da cepa de algas ambientais, Chlorella, com resíduos de lamas ativadas (RLA). Os resultados mostram que quando se realiza somente a digestão anaeróbia mesofílica de algas é necessário um período de digestão prolongado para produzir metano, com um rendimento de biogás igual a $262 \mathrm{~mL} \mathrm{gSV}_{\text {in }}{ }^{-1}$ após 45 dias de digestão. Quando as algas foram codigeridas com quantidades variadas de RLA, 59-96\% em massa, o rendimento de biogás melhorou, juntamente com a redução de sólidos e taxa de desidratação da lama digerida. 


\subsubsection{Resíduo sólido municipal}

O aterramento é uma das formas mais comuns de disposição de resíduos sólidos urbanos (RSU) em países em desenvolvimento. O RSU é composto de diferentes frações orgânicas e inorgânicas, como alimentos, vegetais, papel, madeira, plásticos, vidro, metal e outros materiais inertes. Nas cidades, são recolhidos pelas municipalidades e transportados para locais designados (Mor et al., 2006).

Nos países desenvolvidos, por outro lado, o que é coletado é a fração orgânica dos resíduos sólidos urbanos, uma vez que o lixo é separado nos domicílios em sacos de papel e depois é co-digerido juntamente com lodo de esgoto na ETE local (Hartmann e Ahring, 2005). Isso é muito melhor para a digestão anaeróbia, pois os materiais inertes e os potencialmente prejudiciais foram descartados.

A FORSM é caracterizada por alto teor de umidade e alta biodegradabilidade, sua composição depende grandemente do local e época da coleta para um determinado município ou área. Alibardi e Cossu (2015) coletaram amostras de FORSM em diferentes meses do ano para determinar sua composição e características físico-químcas. A Tabela 3.4 e a Tabela 3.5 mostram seus resultados.

Tabela 3.4. Composição das amostras de FORSM coletadas em diferentes meses do ano.

\begin{tabular}{cccccc}
\hline Fração & Fevereiro & Maio & Julho & Outubro & Novembro \\
\hline Carne-peixe-queijo & 10,2 & 6,8 & 0,3 & 3,4 & 12,0 \\
Fruta & 24,8 & 18,9 & 28,7 & 12,7 & 16,3 \\
Vegetal & 18,2 & 32,4 & 33,2 & 42,3 & 28,7 \\
Massa-pão & 12,3 & 7,7 & 1,3 & 8,0 & 4,4 \\
Outros & 34,5 & 34,2 & 36,5 & 33,6 & 38,6 \\
Total & 100,0 & 100,0 & 100,0 & 100,0 & 100,0 \\
\hline
\end{tabular}

Dados são reportados em \% em base úmida. Fonte: Alibardi e Cossu (2015).

Tabela 3.5. Características físico-químicas médias de cada fração.

\begin{tabular}{ccccc}
\hline Parâmetro & Carne-peixe-queijo & Fruta & Vegetal & Massa-pão \\
\hline ST (\%) & 57 & 17 & 19 & 71 \\
SV (\% of ST) & 95 & 90 & 89 & 95 \\
COT (\% of ST) & 60 & 46 & 51 & 50 \\
$\mathrm{DQO}\left(\mathrm{mgO}_{2} / \mathrm{gST}\right)$ & 1906 & 1261 & 1403 & 1598 \\
$\mathrm{~N}(\mathrm{mgN} / \mathrm{gST})$ & 40,2 & 16,1 & 25,3 & 17,5 \\
$\mathrm{P}(\mathrm{mgP} / \mathrm{gST})$ & 4,8 & 2,0 & 3,3 & 1,8 \\
\hline
\end{tabular}

Fonte: Alibardi e Cossu (2015). 
Shanmugam e Horan (2009) usaram FORSM para codigerir resíduos da indústria de couros (LF), que têm baixa relação $\mathrm{C} / \mathrm{N}(3,2)$ e pH alcalino do 11,4. As condições ótimas encontradas foram as que providenciaram uma relação $\mathrm{C} / \mathrm{N}$ de 15 e $\mathrm{pH}$ de 6,5 , o rendimento acumulativo de biogás aumentou de $560 \mathrm{~mL}$ usando somente a fração do resíduo de couros para $6518 \mathrm{~mL}$ com a mistura ótima.

Um experimento realizado em escala real sobre a codigestão anaeróbia de resíduos orgânicos a partir de lixo doméstico e logo de esgoto foi feito por Zupančič et al. (2008). Em uma planta de tratamento de águas residuárias, equivalente a uma população de 50.000 pessoas, dois digestores mesofílicos convencionais com um volume combinado de $2000 \mathrm{~m}^{3} \mathrm{e}$ TDH de 20 dias foram usados. No experimento, resíduo orgânico foi adicionado ao afluente do digestor para aumentar a carga orgânica do mesmo em 25\% (1,0 kgSSV.m $\left.{ }^{-3} \cdot \mathrm{d}^{-1}\right)$ A quantidade de biogás aumentou em $80 \%$ e o rendimento de biogás aumentou de $0,39 \mathrm{~m}^{3} \cdot \mathrm{kgSSV}_{\text {in }}{ }^{-1}$ para mais de $0,60 \mathrm{~m}^{3} \cdot \mathrm{kgSSV}_{\text {in }}{ }^{-1}$, com um pico de $0,89 \mathrm{~m}^{3} \cdot \mathrm{kgSSV}_{\text {in }}{ }^{-1}$. O excesso de biogás foi usado em uma caldeira e um motor de calor e potência de $50 \mathrm{~kW}$. A produção elétrica aumentou em $130 \%$ e a produção de calor, em 55\%. A eficiência de degradação de sólidos suspensos voláteis aumentou de $71 \%$ para $81 \%$ sem aumentar a concentração de SSV no efluente do digestor. Virtualmente, todo o resíduo orgânico foi degradado.

\subsubsection{Cultivos florestais e seus resíduos}

Resíduos florestais e da indústria da madeira, incluem a casca, lâminas, serragem, pó de painéis, lama da indústria de papel e cortiça bruta (Ak, 2013). Estes são materiais ricos em lignocelulose e têm um grande potencial como uma matéria-prima alternativa para a digestão anaeróbia, uma vez que são encontrados em abundância globalmente (Teghammar et al., 2014).

A degradação de lignocelulose em biogás é um processo complicado, pois a lignocelulose tem uma estrutura recalcitrante que é naturalmente desenhada para prevenir a degradação enzimática. A lignocelulose é formada em uma estrutura compacta e cristalina que contém uma grande quantidade de lignina. Para se conseguir a degradação desse tipo de material em um digestor anaeróbio, é necessário que essa estrutura se abra e/ou que a lignina seja degradada ou removida. Isso pode ser realizado utilizando diferentes tipos de prétratamento, como mecânicos (moagem); fisicamente (vapor ou radiação); quimicamente (ácidos, bases ou solventes); e biologicamente (enzimas ou fungos). 
A literatura disponível sobre codigestão de resíduos florestais é escassa. Hagelqvist (2013) investigou a codigestão de lodo secundário de indústria florestal com lodo de esgoto municipal. O lodo puro não fibroso da indústria florestal mostrou produção específica de metano mais baixa que a de lodo de esgoto municipal (53-84 NmL.g ${ }^{-1}$ ) em condições mesofílicas com TDH de 19 dias. Quando a codigestão foi aplicada, foi notado que a produção específica de metano permaneceu praticamente igual a do lodo de esgoto municipal quando $50 \%$ dos sólidos voláteis foram substituídos pelo lodo da indústria florestal. Também foi notado que o sólido residual da digestão anaeróbia do lodo de indústria florestal é adequado para aprimorar a qualidade solo em terras que não são utilizadas para o cultivo de alimento.

\subsection{MODELAGEM DE CODIGESTÃO ANAERÓBIA}

Atualmente, existem poucos trabalhos com foco em modelagem de CoDA. Isto é muito prejudicial para o estudo completo deste processo, pois uma modelagem confiável é necessária para prever, de um modo claro e quantificável, o efeito da mistura de dois ou mais resíduos em um digestor e remover impactos potencialmente negativos devido a uma mistura baseada em decisões aleatórias ou heurísticas (Mata-Alvarez et al., 2014).

No entanto, para este efeito, modelos de monosubstratos típicos não são adequados, uma vez que não são capazes de simular o comportamento da biodegradação de substratos diferentes em termos de cinética, tamanho de partícula, equilíbrio de nutrientes, etc (Esposito et al., 2012).

O Modelo de Digestão Anaeróbia $n^{\circ} .1$ da IWA (ADM1) projetado para ser fácil de entender, fornece uma estrutura comum de conversão bioquímica, equações de balanço de massa, cinética do processo e estequiometria para modelagem de DA. Desde 2002, o ADM1 tornou-se um quadro comum em modelos de CoDA. O modelo estruturado inclui várias etapas que descrevem tanto processos bioquímicos como físico-químicos. Os passos bioquímicos incluem desintegração de partículas homogêneas para carboidratos, proteínas e lipídios; hidrólise extracelular destes substratos particulados para açúcares, aminoácidos e ácidos graxos de cadeia longa (AGCL), respectivamente; acidogênese de açúcares e aminoácidos para os ácidos graxos voláteis $(\mathrm{AGV})$ e hidrogênio; acetogênese de AGV e AGCL para acetato; e passos metanogênicos separados do acetato e hidrogênio/ $\mathrm{CO}_{2}$. As equações físico-químicas descrevem associação e dissociação iônica, e a transferência gáslíquido. Implementado como um conjunto de equações algébricas e diferenciais, existem 26 
variáveis de estado de concentração dinâmicas e 8 variáveis algébricas implícitas por volume de reator ou elemento. Implementado como apenas equações diferenciais, há 32 variáveis de estado de concentração dinâmicas (Batstone et al., 2002).

Nesse sentido, as duas premissas citadas por Mata-Alvarez et al. (2014) para os modelos CoDA devem ser utilizadas: (i) A caracterização do substrato deve ser, em termos de carboidratos, proteínas, lipídeos e gases inertes, e (ii) o passo de desintegração/hidrólise é geralmente considerado como o passo limitante da velocidade.

É importante dizer que o estudo que tem como objetivo modelar o processo de CoDA baseado no ADM1 precisa para calibrar os seus parâmetros, como em Boubaker e Ridha (2008), Shi et al. (2014) e Astals et al. (2011).

Depois de abordada a revisão da literatura sobre codigestão anaeróbia, é apresentada a Tabela 3.6 que mostra uma comparação entre trabalhos que utilizaram esse processo para otimizar a produção de biogás.

\subsection{AnSBBR}

O reator anaeróbio operado em batelada sequencial (ASBR) apresenta algumas características apontadas como vantagens sobre os reatores contínuos: boa retenção de sólidos, eficiência no controle de operação, eficiência na remoção de substâncias orgânicas, simples operação e baixo custo para tratamento de esgoto industrial e doméstico (Oliveira et al., 2008; Oliveira et al., 2010). No entanto, é mais adequado para o pequeno e médio produtor de resíduos devido à sua menor capacidade de tratamento.

De acordo com Dague (1992), a características básica do ASBR é a de ser preenchido com água residuária no início e esvaziado ao final do tratamento, repetindo-se a operação com nova batelada. O conteúdo no interior do reator é misturado, permitindo um bom contato substrato/biomassa. O tratamento é efetuado em tanque único, em uma sequência operacional que compreende as seguintes etapas: (i) enchimento com água residuária. (ii) tratamento propriamente dito, por meio de transformações dos constituintes da água residuária pela ação de microrganismos; (iii) sedimentação do lodo biológico; (iv) esvaziamento do tanque, com a retirada do líquido tratado e clarificado (Oliveira et al., 2008; Oliveira et al., 2010). 
Tabela 3.6. Comparação entre estudos que realizaram codigestão de resíduos para produção de metano

\begin{tabular}{|c|c|c|c|c|c|c|c|c|}
\hline Substratos & $\begin{array}{l}\text { Razão de } \\
\text { mistura }\end{array}$ & $\begin{array}{l}\text { Configuração } \\
\text { do reator }\end{array}$ & $\begin{array}{c}\mathrm{T} \\
\left({ }^{\circ} \mathrm{C}\right)\end{array}$ & $\begin{array}{c}\text { Carga } \\
\text { orgânica } \\
\left(\mathrm{g} \cdot \mathrm{L}^{-1} \cdot \mathrm{d}^{-1}\right)\end{array}$ & $\begin{array}{c}\text { Produtividade de } \\
\text { Metano } \\
\left(\mathrm{mLCH}_{4} \cdot \mathrm{L}^{-1} \cdot \mathrm{d}^{-1}\right) \\
\end{array}$ & $\begin{array}{l}\text { Rendimento de } \\
\text { metano } \\
\left(\mathrm{mLCH}_{4} \cdot \mathrm{gSV}_{\mathrm{in}}{ }^{-1}\right)\end{array}$ & $\begin{array}{l}\text { Melhoria com } \\
\text { codigestão }\end{array}$ & Referências \\
\hline \multirow{2}{*}{$\begin{array}{l}\text { Lodo de algas: } \\
\text { Resíduo de } \\
\text { papel }\end{array}$} & $\begin{array}{c}50 / 50 \\
\text { (Base SV) }\end{array}$ & \multirow{2}{*}{$\begin{array}{l}\text { Reator alimentado } \\
\text { de modo semi- } \\
\text { contínuo }\end{array}$} & \multirow{2}{*}{35} & $4(\mathrm{SV})$ & 1170 & 290 & $x 2,0$ & \multirow{2}{*}{$\begin{array}{l}\text { Yen e Brune } \\
\text { (2007) }\end{array}$} \\
\hline & $\begin{array}{c}40 / 60 \\
\text { (Base SV) }\end{array}$ & & & $5(\mathrm{SV})$ & 1607 & 320 & n.d. & \\
\hline FSS:RSU & $\begin{array}{c}50 / 50 \\
\text { (Base SV) }\end{array}$ & $\begin{array}{c}\text { Reator em } \\
\text { batelada }\end{array}$ & 38 & n.d. & n.d. & 84 & $\mathrm{x} 1,0$ & $\begin{array}{l}\text { Hagelqvist } \\
\text { (2014) }\end{array}$ \\
\hline $\begin{array}{c}\text { CS:CR } \\
\text { CS:EG:GLI } \\
\text { SBP:EG:GLI }\end{array}$ & $\begin{array}{l}\text { n.d. } \\
\text { n.d. } \\
\text { n.d. }\end{array}$ & $\begin{array}{l}\text { Reator alimentado } \\
\text { de modo semi- } \\
\text { contínuo }\end{array}$ & 37 & $\begin{array}{l}0,12 \\
0,12 \\
0,15\end{array}$ & $\begin{array}{l}3174 \\
1098 \\
1144\end{array}$ & n.d. & $\begin{array}{l}\mathrm{x} 1,76 \\
\mathrm{x} 0,61 \\
\mathrm{x} 1,04\end{array}$ & $\begin{array}{l}\text { Kacprzak et } \\
\text { al. }(2010)\end{array}$ \\
\hline APB: GLI & $\begin{array}{c}\text { 64/36 } \\
\text { (Base DQO) }\end{array}$ & UASB & 33 & 7,6 (DQO) & n.d. & $\begin{array}{c}2,8 \\
\mathrm{mLCH}_{4},(\mathrm{~L} \text { efluente) })^{-1}\end{array}$ & $\mathrm{x} 1,5$ & $\begin{array}{l}\text { Ma et al. } \\
\text { (2008) }\end{array}$ \\
\hline \multirow{2}{*}{ AAB:RFV } & 70/30 & \multirow{2}{*}{ ASBR } & 35 & 1,28 (SVT) & 772 & 299 & $x 9,9$ & \multirow{2}{*}{$\begin{array}{c}\text { Bouallagui et } \\
\text { al. }(2009)\end{array}$} \\
\hline & volumétrica) & & 55 & 1,28 (SVT) & 583 & 453 & $x 8,4$ & \\
\hline LE:GLI & $\begin{array}{c}99 / 1 \\
\text { (Base } \\
\text { volumétrica) }\end{array}$ & CSTR & 35 & n.d. & 2353 & n.d. & $x 2,1$ & $\begin{array}{l}\text { Fountoulakis } \\
\text { et al. (2010) }\end{array}$ \\
\hline ES:GLI & $\begin{array}{c}96 / 4 \\
\text { (Base úmida) }\end{array}$ & Semi-CSTR & 35 & 1,90 (SV) & 1400 & 740 & $x 4,8$ & $\begin{array}{l}\text { Astals et al. } \\
\quad(2012)\end{array}$ \\
\hline LE:RA & $\begin{array}{c}0.4 / 1 \\
\text { (Base SV) }\end{array}$ & CSTR & 35 & $6(\mathrm{SV})$ & 2400 & 400 & $x 2,5$ & $\begin{array}{l}\text { Dai et al. } \\
\text { (2013) }\end{array}$ \\
\hline EG:ROM & $\begin{array}{c}3 / 1 \\
\text { (Base úmida) } \\
3 / 1 \\
\text { (Base úmida) }\end{array}$ & CSTR & $\begin{array}{l}37 \\
55\end{array}$ & 5,5 (DQO) & $\begin{array}{l}1096 \\
1289\end{array}$ & $\begin{array}{l}179 \\
210\end{array}$ & $\begin{array}{l}x 4,4 \\
\text { n.d. }\end{array}$ & $\begin{array}{c}\text { Goberna et al. } \\
\quad(2010)\end{array}$ \\
\hline LF:FORSM & $\mathrm{C} / \mathrm{N} 15$ & Batch & n.d. & n.d. & n.d. & $\begin{array}{c}0,15 \\
\mathrm{mLCH}_{4}, \mathrm{gSSV}_{\text {out }}{ }^{-1}\end{array}$ & $\mathrm{x} 1,6$ & $\begin{array}{l}\text { Shanmugam e } \\
\text { Horan (2009) }\end{array}$ \\
\hline EG:GLI & $\begin{array}{c}90 / 10 \\
\text { (wet basis) }\end{array}$ & CSTR & $35-37$ & 2,3 (SV) & n.d. & 826 & $\mathrm{x} 3,1$ & $\begin{array}{l}\text { Robra et al. } \\
\quad(2010)\end{array}$ \\
\hline
\end{tabular}


Essa configuração de reator possibilita a obtenção de uma baixa razão entre as concentrações de substrato e biomassa, ao mesmo tempo em que consegue processar esgoto com elevadas velocidades de reação. A concentração de matéria orgânica é máxima logo após alimentação, diminuindo com o tempo de reação. A concentração final de substrato geralmente é mais baixa nesse tipo de configuração do que em sistemas contínuos. Dessa forma, em reatores operados em batelada, a formação de grânulos, a biodegradação e a capacidade de sedimentação podem ser mais eficientes que nos sistemas anaeróbios contínuos, como o de contato, por exemplo (Bagley e Brodkorb, 1999).

A busca pelo melhoramento dos processos no ASBR levou ao desenvolvimento de uma nova configuração, na qual foi introduzido material suporte para imobilização da biomassa. O reator foi chamado de reator anaeróbio operado em batelada sequencial com agitação mecânica e biomassa imobilizada (AnSBBR) (Ratusznei et al., 2000).

Garcia et al. (2008) estudaram alguns tipos de suporte para reatores AnSBBR e encontraram que, comparativamente, a espuma de poliuretano foi o melhor material suporte nos quesitos desempenho do reator, análise cinética e adesão de bactérias metanogênicas.

Comparando-se o ASBR com o AnSBBR, a imobilização da biomassa melhora a retenção de sólidos e não requer a formação de grânulos nem a etapa de sedimentação, o que leva a um tempo de operação menor (Ratusznei et al., 2000). Além disso, a biomassa autoimobilizada pode flotar pela presença de polímeros, como aqueles relatados por Mockaitis et al. (2006) e Fuzzato et al. (2009). Por outro lado, uma desvantagem dos sistemas com biomassa imobilizada é a dificuldade de transferência de massa, mas operações de recirculação, por exemplo, podem remediar isso (Ramos et al., 2003).

Uma das variáveis mais relevantes dos reatores descontínuos é a estratégia de alimentação dos mesmos. Utilizar o tempo de enchimento mais adequado ao sistema permite uma melhor eficiência e estabilidade; enquanto o modo batelada consegue atingir concentrações maiores de biogás, o modo batelada alimentada permite manter baixas concentrações dos compostos no meio reacional e, portanto, inibir os efeitos da degradação do substrato; além disso, é possível realizar o tratamento de efluentes contendo elevadas cargas orgânicas, absorvendo elevados picos de ácidos voláteis que normalmente desestabilizariam o processo (Damasceno et al., 2007 e Rodrigues et al., 2011).

A tendência é que a utilização do modo batelada alimentada aumente a eficiência do reator em relação à remoção de matéria orgânica e nutrientes, especialmente com a razão tempo de enchimento por tempo de ciclo $\left(\mathrm{t}_{\mathrm{F}} / \mathrm{t}_{\mathrm{C}}\right) \leq 0,5$, mas há exceções como no caso de Carvalhinha et al. (2010). Neste caso, o decréscimo na eficiência de remoção de matéria 
orgânica e o decréscimo na concentração de metano no biogás no modo batelada alimentada foi creditado ao substrato de difícil degradação e a não haver efeito inibitório com o efluente de indústria metalúrgica; então a velocidade de reação foi menor no modo batelada alimentada (devido a concentrações menores de substrato) e ainda não havia composto que inibisse a reação no modo batelada. Razões $t_{\mathrm{F}} / \mathrm{t}_{\mathrm{C}}>0,5$, apesar da estabilidade, tendem a perder eficiência de remoção de matéria orgânica e a formar um material viscoso que pode ser prejudicial à operação, como demonstrado por Borges et al. (2004).

O uso e influência do tempo de enchimento relacionado à produção de biometano podem ser averiguados em vários trabalhos da literatura. Selma et al. (2010), Silva et al. (2013), Rodrigues et al. (2011) e Oliveira et al. (2010) encontraram biogás com concentrações de biometano muito próximas nos modos batelada e batelada alimentada, sendo os resultados deste modo, na maior parte dos casos, ligeiramente inferior. No entanto, comparando os trabalhos com batelada sequencial de Bezerra et al. (2011) e batelada alimentada de Lovato et al. (2012), que trabalharam com AnSBBR tratando efluente sintético do processo de produção de biodiesel, percebe-se uma melhora significativa com o uso do modo batelada alimentada. Lovato et al. (2012) atingiu concentrações entre 9,2 e 12,2 mmol. $\mathrm{L}^{-1}$ de metano no biogás gerado pelo processo contra 1,4 a $2,4 \mathrm{mmol} . \mathrm{L}^{-1}$ encontrados por Bezerra et al. (2011). Cheong e Hansen (2008) também encontraram uma melhora significativa na produtividade molar de metano com a utilização do modo batelada alimentada, pois enquanto no modo batelada a produtividade máxima chegou a 32 mol $_{\mathrm{CH}_{4} \cdot \mathrm{m}^{-}}$ ${ }^{3} \cdot \mathrm{d}^{-1}$, no modo batelada alimentada, a mesma chegou a atingir $141 \mathrm{~mol}_{\mathrm{CH} 4} \cdot \mathrm{m}^{-3} \cdot \mathrm{d}^{-1}$. Isso demonstra a necessidade do experimento em escala laboratorial para determinação do melhor modo de operação do biorreator.

O uso e influência do modo batelada alimentada para a produção de hidrogênio em reatores ASBR/AnSBBR ainda é escasso na literatura. Inoue et al. (2014) conseguiu resultados melhores do que Manssouri et al. (2013) ao utilizar o modo batelada alimentada $\left(\mathrm{t}_{\mathrm{F}} / \mathrm{t}_{\mathrm{C}}=0,5\right)$ no tratamento de efluente sintético a base de sacarose em AnSBBR com agitação mecânica; o uso da batelada alimentada interferiu nas velocidades de consumo de substrato [Inoue et al. (2014) atingiram remoções de sacarose em torno de 98-99\% e Manssouri et al. (2013) atingiram remoções de sacarose em torno de 97-89\%] e na formação de biohidrogênio [a produtividade máxima alcançada por Inoue et al. (2014) foi de $81,2 \mathrm{molH}_{2} \cdot \mathrm{m}^{-3} \cdot \mathrm{d}^{-1}$ contra $38,9 \mathrm{molH}_{2} \cdot \mathrm{m}^{-3} \cdot \mathrm{d}^{-1}$ de Manssouri et al. (2013)], minimizando a inibição causada pelo excesso de substrato. 
Lovato et al. (2015) e Bravo et al. (2015) também realizaram trabalhos com condições similares no modo batelada alimentada e batelada, respectivamente; o objetivo desses dois trabalhos era a produção de biohidrogênio em AnSBBR com recirculação da fase líquida tratando efluente do processo de produção de biodiesel. Lovato et al. (2015), no modo batelada alimentada com $\mathrm{t}_{\mathrm{F}} / \mathrm{t}_{\mathrm{C}}=0,5$, chegaram a atingir $100,9 \mathrm{molH}_{2} \cdot \mathrm{m}^{-3} \cdot \mathrm{d}^{-1}$ contra 67,5 $\mathrm{molH}_{2} \cdot \mathrm{m}^{-3} \cdot \mathrm{d}^{-1}$ de Bravo et al. (2015) tratando glicerina comercial pura; quando os dois trabalhos utilizaram o efluente industrial, o resultado foi que o modo batelada alimentada atingiu $9,7 \mathrm{molH}_{2} \cdot \mathrm{m}^{-3} \cdot \mathrm{d}^{-1}$ e o modo batelada atingiu $8,3 \mathrm{molH} 2 \cdot \mathrm{m}^{-3} \cdot \mathrm{d}^{-1}$.

\subsection{CONSIDERAÇÕES FINAIS}

De acordo com a revisão bibliográfica feita nesta tese, a codigestão anaeróbia de resíduos parece ser uma tecnologia promissora para otimizar a produção de biogás, pois promove o balanceamento dos nutrientes, diluição de compostos tóxicos, sinergismos entre microrganismos e melhoria da carga orgânica biodegradável. A literatura apresenta casos de aumento na produção de biogás de até $900 \%$ em relação à produção obtida com monodigestão.

Neste contexto, a Escola de Engenharia de São Carlos da Universidade de São Paulo (EESC/USP) e a Escola de Engenharia Mauá do Instituto Mauá de Tecnologia (EEM/IMT) iniciaram a investigação da produção de hidrogênio e metano a partir do resíduo do processo de produção de biodiesel em AnSBBR por mono-digestão (Lovato et al., 2015; Bravo et al., 2015). Assim, visando dar continuidade ao estudo, esse projeto objetiva a aplicação do AnSBBR ao tratamento de glicerina para a produção de biohidrogênio ou biometano codigerido com soro, no intuito que a codigestão desses dois substratos melhore significativamente a estabilidade do processo e a produtividade de hidrogênio/metano, avaliando-se a influência da razão de mistura, da carga orgânica, do tempo de ciclo, do tempo de enchimento e da temperatura sobre a estabilidade, eficiência de remoção de matéria orgânica, produtividade e composição de biogás, e fator de conversão entre biogás produzido e matéria orgânica removida.

Dessa forma, é esperado que a codigestão do soro com a glicerina ajude a realizar um balanceamento de nutrientes do afluente, resultando em melhores indicadores de desempenho e em informações úteis para o projeto desse bioprocesso em escala plena. 


\section{MATERIAIS E MÉTODOS}

A seguir, são descritos todos os equipamentos e procedimentos utilizados para realizar a parte experimental do projeto.

\subsection{ANSBBR COM BIOMASSA IMOBILIZADA E RECIRCULAÇÃO DA FASE LÍQUIDA}

A Figura 4.1 e 4.2 mostram o esquema do AnSBBR com recirculação utilizado nos ensaios. O reator, com capacidade para 2,0 L de meio líquido além do suporte inerte e biomassa, foi constituído por um frasco de acrílico, cilíndrico, com as seguintes dimensões: $540 \mathrm{~mm}$ de altura, $100 \mathrm{~mm}$ de diâmetro externo e 3,5 $\mathrm{mm}$ de espessura de parede (volume total de 3,5 L). Foi utilizada uma unidade de controle para automatizar as operações de carga, descarga e recirculação.

O suporte de imobilização da biomassa foi acondicionado entre telas de aço Inox - 314, dividindo a altura de $540 \mathrm{~mm}$ do reator em 4 estágios para evitar a compactação do leito. $\mathrm{Na}$ parte inferior do reator houve um compartimento de $50 \mathrm{~mm}$ de altura destinado a favorecer a distribuição da água residuária e, na parte superior, um compartimento com $50 \mathrm{~mm}$ de altura que funcionou como câmara coletora de biogás $\left(\mathrm{H}_{2}, \mathrm{CH}_{4}\right.$ e $\left.\mathrm{CO}_{2}\right)$.

O sistema de recirculação foi composto (i) por um reservatório lateral, o qual conteve um volume de meio de 1,5 L, constituído por um frasco de acrílico, cilíndrico, com as seguintes dimensões: $300 \mathrm{~mm}$ de altura, $100 \mathrm{~mm}$ de diâmetro externo e 3,5 $\mathrm{mm}$ de espessura de parede (volume total de 2,0 L); e (ii) de uma bomba peristáltica marca Ismatec ${ }^{\circledR}$ modelo

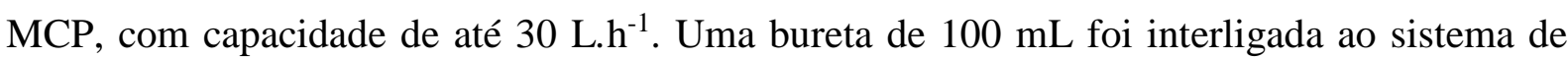
recirculação para medidas da vazão de recirculação. $O$ volume total de meio reacional, resultante da soma do volume de meio contido no reator $(2,0 \mathrm{~L})$ e no reservatório paralelo (1,5 L) foi de 3,5 L.

A alimentação e descarga foram realizadas por bombas tipo diafragma marca Prominent ${ }^{\circledR}$, modelos Beta/4 (com capacidade de até 23 L.h ${ }^{-1}$ ) e Beta/5 (com capacidade de até $\left.30 \mathrm{~L} \cdot \mathrm{h}^{-1}\right)$, respectivamente, auxiliadas por um sistema de automação composto por temporizadores marca $\mathrm{Coel}^{\circledR}$, modelo RTST/20. 


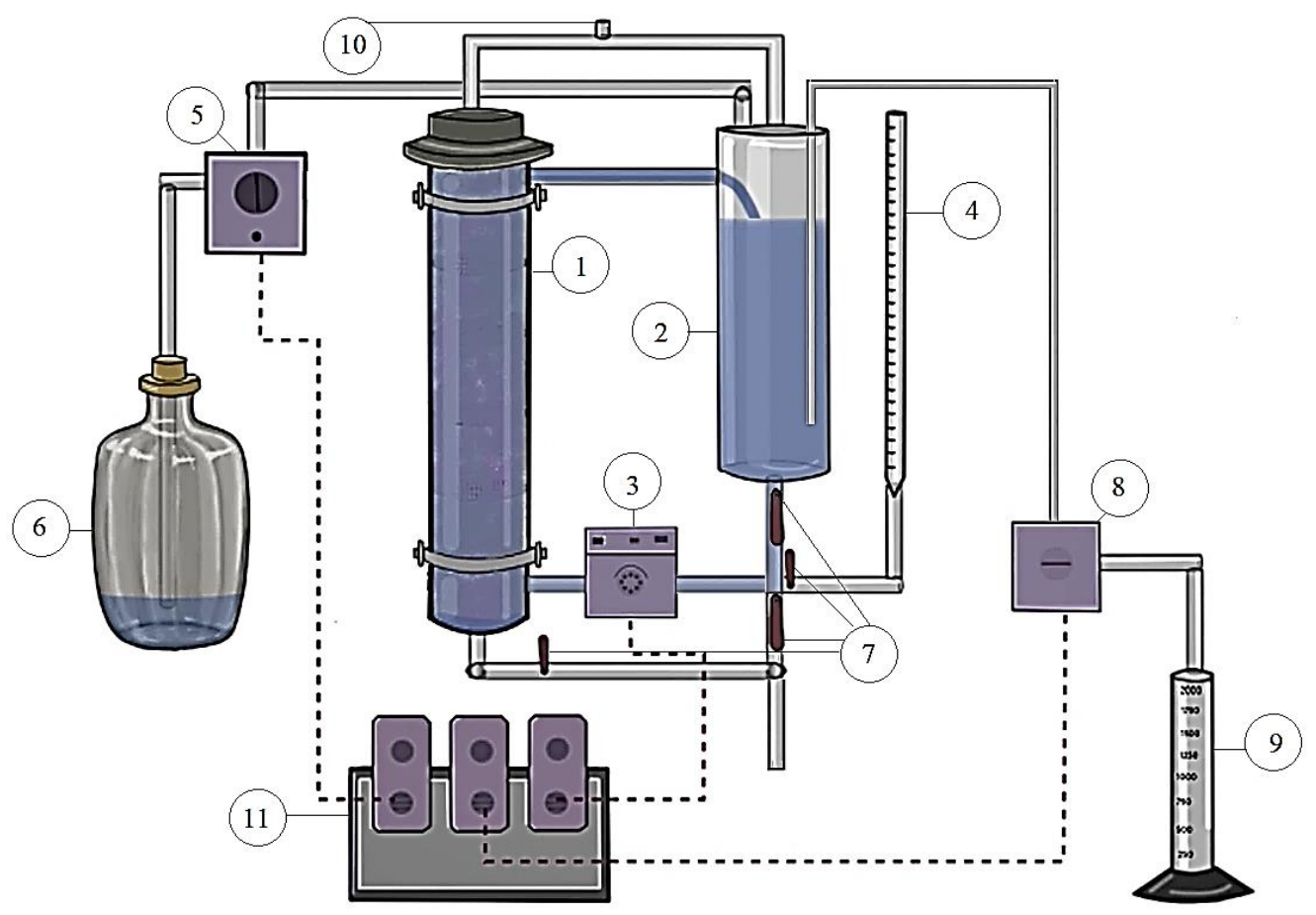

Figura 4.1. Esquema do AnSBBR com recirculação utilizado nos ensaios.

[Notação: 1 - reator contendo biomassa imobilizada; 2 - reservatório lateral; 3 - bomba de reciclo; 4 - medidor de vazão; 5 - bombas de alimentação; 6 - reservatório de água residuária; 7 - válvulas de controle; 8 - bomba de descarga; 9 - saída do efluente; 10 - saída de biogás e ponto de retirada de amostra; 11- unidade de controle].
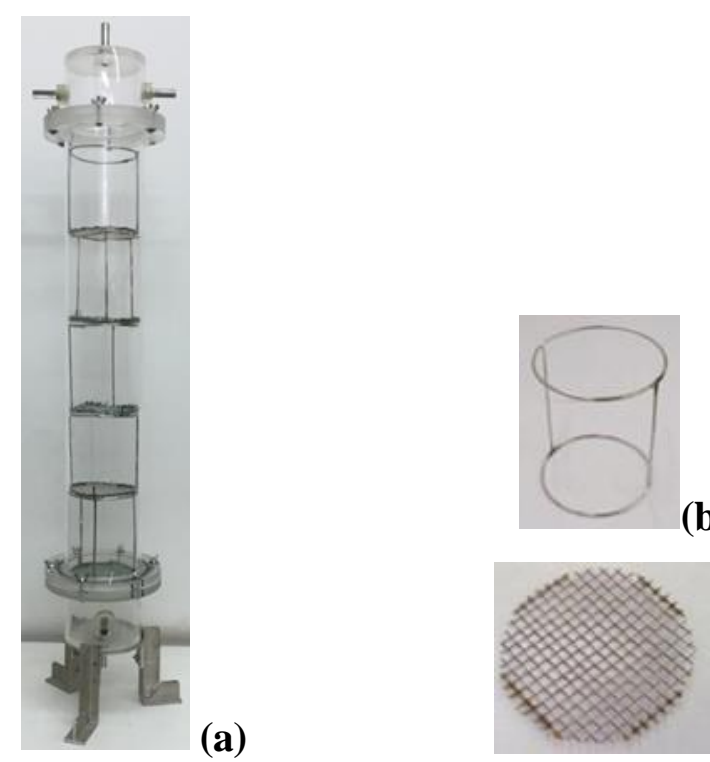

(b)
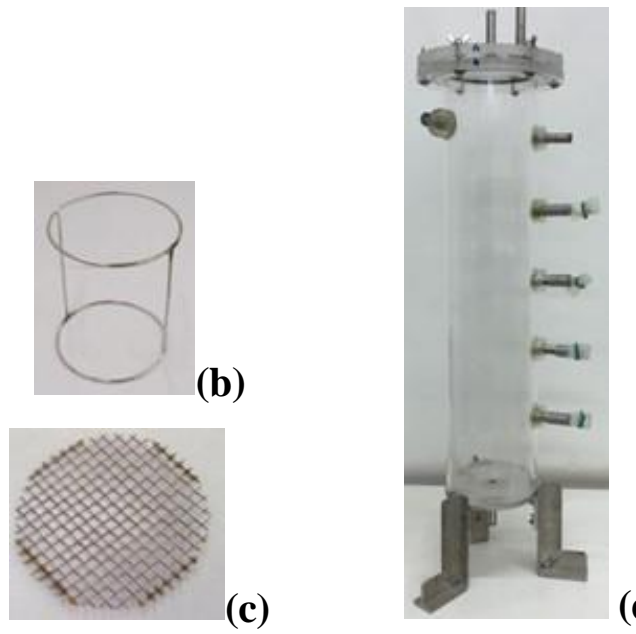

(d)

Figura 4.2. Detalhes do: $(a)$ reator, $(b)$ suporte da tela de aço, $(c)$ tela de aço, $(d)$ reservatório.

O reator foi colocado em uma câmara mantida a $30 \pm 1^{\circ} \mathrm{C}$, na qual a manutenção da temperatura foi realizada por um sistema composto de sensor, controlador (Novus ${ }^{\circledR}$, modelo N480), ventilador e resistência elétrica. A Figura 4.3 mostra uma fotografia da aparelhagem experimental e a Tabela 4.1 sumariza os aspectos de projeto do reator. 


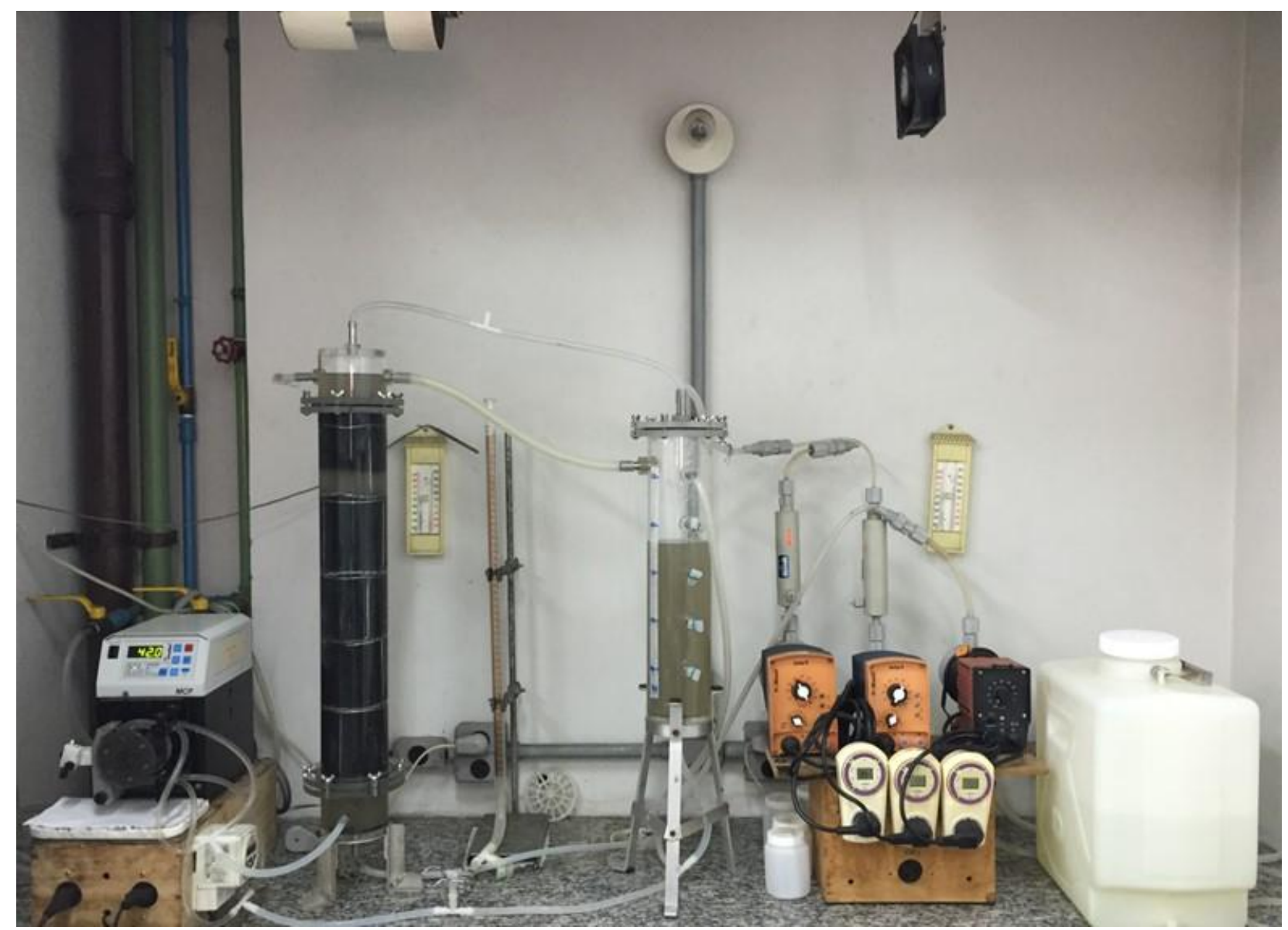

Figura 4.3. Fotografia do aparato experimental utilizado nos ensaios.

Tabela 4.1. Parâmetros operacionais do biorreator.

\begin{tabular}{cc}
\hline Parâmetro & Valor \\
\hline Volume da fase líquida (reator e reservatório) & $3,5 \mathrm{~L}$ \\
Volume do inóculo com suporte inerte (reator) & $3,0 \mathrm{~L}$ \\
Volume da fase líquida (reator) & $2,0 \mathrm{~L}$ \\
Volume da fase líquida (reservatório) & $1,5 \mathrm{~L}$ \\
Volume alimentado/descarregado por ciclo & $1,5 \mathrm{~L}$ \\
(reservatório) & $2,0 \mathrm{~L}$ \\
Volume da fase líquida residual entre ciclos (reator) & $6,9 \mathrm{~m} \cdot \mathrm{h}^{-1}$ \\
Velocidade ascensional do líquido (v) & $0,2 \mathrm{~cm} \cdot \mathrm{s}^{-1}$ \\
Velocidade de recirculação intersticial & $10 \mathrm{~min}$ \\
Tempo de descarga &
\end{tabular}




\subsection{SUPORTE DE IMOBILIZAÇÃO DA BIOMASSA ANAERÓBIA E INÓCULO}

Foram utilizados dois tipos de suporte inerte para imobilização da biomassa: (1) grânulos de polietileno de baixa densidade (PEBD), conforme Figura 4.4, e (2) cubos de espuma de poliuretano (PU), Figura 4.5. A Tabela 4.2 mostra as características de cada suporte e onde cada um foi utilizado, cabem destacar o baixo custo, a disponibilidade e a adequação ambiental de ambos os materiais.

Tabela 4.2. Tipos de suporte utilizados nos experimentos.

\begin{tabular}{cc}
\hline & Características \\
\hline$P U$ & Adquirido a partir de espumas utilizadas; \\
Fase I & Cubos de $1 \mathrm{~cm}$ de aresta; \\
(Produção de metano) & Densidade de $23 \mathrm{~kg} \cdot \mathrm{m}^{-3} ;$ \\
& Porosidade do leito de $50 \% ;$ \\
$P E B D$ & Flutuante e autocompactante. \\
Fase II & Produto intermediário do processo de reciclagem de plásticos; \\
Fase III & Diâmetro de $3 \mathrm{~mm} ;$ \\
Fase IV & Comprimento de $6 \mathrm{~mm} ;$ \\
Fase V & Densidade de $825 \mathrm{~kg} \cdot \mathrm{m}^{-3}$ \\
(Produção de hidrogênio) & Porosidade do leito de $40 \% ;$ \\
\hline
\end{tabular}

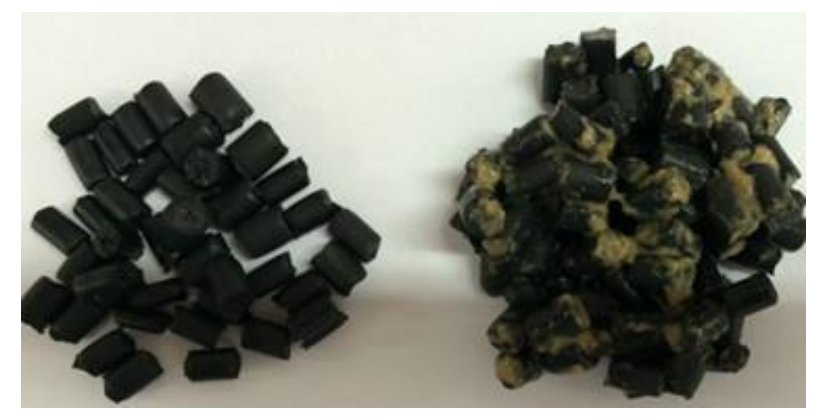

Figura 4.4. Fotografia do material suporte PEBD sem (esquerda) e com (direita) biomassa.

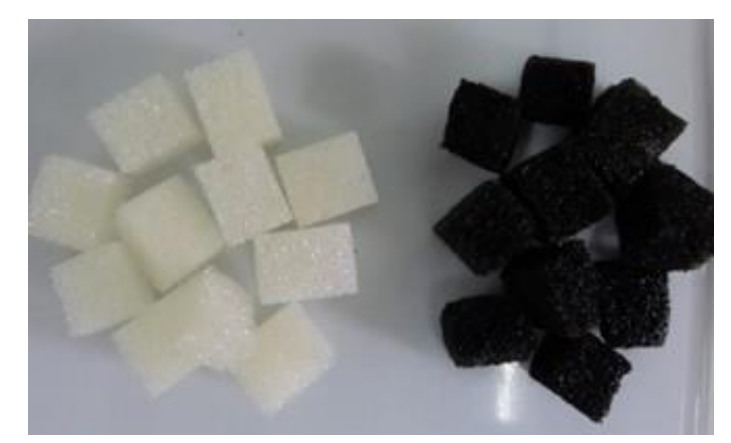

Figura 4.5. Fotografia do material suporte PU sem (esquerda) e com (direita) biomassa. 
Foi utilizado um único inóculo que recebeu ou não pré-tratamento térmico dependendo da condição experimental imposta ao reator, como mostrado na Tabela 4.3.

Tabela 4.3. Inóculo e pré-tratamento utilizados nos experimentos.

\begin{tabular}{ccc} 
& Fonte & Pré-Tratamento \\
\hline Inóculo 1 & & Nenhum \\
Fase I & & \\
(Produção de metano) & Grânulos de UASB tratando & \\
Inóculo 2 & água residuária de abatedouro & \\
Fase II & de aves & Heat Shock Treatment $\left(90^{\circ} \mathrm{C}\right.$ por \\
Fase III & (Dacar Industrial S.A.) & 10 minutos e depois banho de gelo \\
Fase IV & & até atingir $\left.25^{\circ} \mathrm{C}\right)$, método \\
Fase V & & adaptado de Kim et al . $(2006)$ \\
\hline
\end{tabular}

\section{3 ÁGUA RESIDUÁRIA}

A água residuária utilizada foi formulada a base de glicerina e soro, variando a porcentagem de cada um desses componentes de acordo com a condição experimental proposta. A Tabela 4.4 mostra os dois tipos de glicerina utilizados nos experimentos.

Tabela 4.4. Tipos de glicerina utilizados nos experimentos.

\begin{tabular}{cc}
\hline & Tipo \\
\hline Fase I & Glicerina bruta efluente do processo de produção em laboratório \\
Fases II, III, IV e V & Glicerina bruta bidestilada do processo de produção industrial \\
\hline
\end{tabular}

O soro utilizado foi o desidratado em pó comercial da Marca Elegê, cuja composição é mostrada na Tabela 4.5. A água residuária era formulada a partir de sua dissolução com água de torneira.

A Tabela 4.6 mostra a composição da água residuária utilizada nos ensaios, a solução de micronutrientes utilizada foi adaptada de Del Nery (1987). A relação $\mathrm{NaHCO}_{3} / \mathrm{DQO}$ era variada posteriormente conforme o $\mathrm{pH}$ do efluente. 
Tabela 4.5. Composição do soro desidratado (em pó) comercial (Marca Elegê) utilizado nos ensaios.

\begin{tabular}{cc}
\hline Composição & $\%$ \\
\hline Carboidrato & 73,1 \\
Proteína & 11,2 \\
Gorduras Totais & 2,0 \\
Fibra & 0,0 \\
Cálcio & 0,4 \\
Sódio & 0,7 \\
Outros minerais & 7,6 \\
Umidade & 5,0 \\
\hline
\end{tabular}

Tabela 4.6. Composição da água residuária utilizada nos ensaios.

\begin{tabular}{ccc}
\hline Composto & \multicolumn{2}{c}{ Concentração $\left(\mathrm{mg}^{-1}\right)$} \\
Glicerina & Fase I & Fases II, III, IV e V \\
\hline Soro & 822 & 822 \\
(relação teórica: 1000 mg-DQO $=822$ mg-glicerina) & & \\
(relação teórica: 1000 mg-DQO $=891$ mg-lactose) & 891 & 891 \\
\hline Ureia $\left(\mathrm{CH}_{4} \mathrm{~N}_{2} \mathrm{O}\right)$ & - & 5,8 \\
\hline Sulfato de níquel $\left(\mathrm{NiSO}_{4} \cdot 6 \mathrm{H}_{2} \mathrm{O}\right)$ & - & 0,50 \\
Sulfato ferroso $\left(\mathrm{FeSO}_{4} \cdot 7 \mathrm{H}_{2} \mathrm{O}\right)$ & - & 2,50 \\
Cloreto férrico $\left(\mathrm{FeCl}_{3} \cdot 6 \mathrm{H}_{2} \mathrm{O}\right)$ & - & 0,25 \\
Cloreto de cálcio $\left(\mathrm{CaCl}_{2} \cdot 2 \mathrm{H}_{2} \mathrm{O}\right)$ & - & 2,06 \\
Cloreto de cobalto $\left(\mathrm{CoCl}_{2} \cdot 6 \mathrm{H}_{2} \mathrm{O}\right)$ & - & 0,04 \\
Dióxido de selênio $\left(\mathrm{SeO}_{2}\right)$ & - & 0,04 \\
Fosfato de potássio monobásico $\left(\mathrm{KH}_{2} \mathrm{PO}_{4}\right)$ & - & 5,36 \\
Fosfato de potássio dibásico $\left(\mathrm{K}_{2} \mathrm{HPO}_{4}\right)$ & - & 1,30 \\
Fosfato de sódio dibásico $\left(\mathrm{Na}_{2} \mathrm{HPO}_{4}\right)$ & - & 2,70 \\
Bicarbonato de Sódio $\left(\mathrm{NaHCO}_{3}\right) / \mathrm{DQO}^{2}$ & 0,7 & 0,02 \\
\hline
\end{tabular}

\subsection{ANÁLISES FÍSICO-QUÍMICAS}

O monitoramento do reator foi efetuado medindo-se, em amostras do afluente e do efluente, as concentrações de matéria orgânica nas formas não filtrada $\left(\mathrm{C}_{\mathrm{MOT}}, \mathrm{C}_{\mathrm{CT}}\right.$ e $\left.\mathrm{C}_{\mathrm{GT}}\right) \mathrm{e}$ filtrada $\left(\mathrm{C}_{\mathrm{MOF}}, \mathrm{C}_{\mathrm{CF}}\right.$ e $\mathrm{C}_{\mathrm{GF}}$ ) (como demanda química de oxigênio - método de DQO, carboidratos - método de Dubois et al. (1956) e glicerina - método adaptado de Bondioli e Bella (2005), respectivamente), alcalinidade parcial (AP), alcalinidade intermediária (AI), 
alcalinidade total (AT), alcalinidade a bicarbonato (AB), ácidos voláteis totais (AVT), sólidos totais (ST), sólidos totais voláteis (SVT), sólidos suspensos totais (SST) e sólidos suspensos voláteis (SSV), além da medida do $\mathrm{pH}$ e do volume de meio alimentado/descarregado por ciclo $\left(\mathrm{V}_{\mathrm{A}}\right)$. Tais análises foram realizadas de acordo com o Standard Methods for the Examination of Water and Wastewater (2012), considerando também a adaptação de Ripley et al. (1986) na determinação da alcalinidade.

O método adaptado de Bondioli e Bela (2005) para determinação de glicerina consistiu em seguir exatamente o método proposto pelos autores com a exceção que a etapa de extração da glicerina do biodiesel foi excluída, pois neste projeto a glicerina estava dissolvida em água.

A frequência das análises está descrita na Tabela 4.7.

Tabela 4.7. Cronograma das análises realizadas nos ensaios.

\begin{tabular}{cccc}
\hline Análise & Amostra & Frequência & Método \\
\hline DQO & Afluente e Efluente & Diariamente & Standard Methods (1995) \\
Carboidratos & Afluente e Efluente & Diariamente & Dubois et al. (1956) \\
Glicerina & Afluente e Efluente & Diariamente & Bondioli e Bella et al. (2005) \\
Alcalinidade/AVT & Afluente e Efluente & Diariamente & Ripley et al. (1986) \\
Série de sólidos & Afluente e Efluente & 2 vezes por semana & Standard Methods (2012) \\
Ácidos e álcoois & Afluente e Efluente & 1 vez por condição & Cromatografia gasosa \\
Volume de gás & Saída de gás & Diariamente & Medidor de gás Ritter \\
Composição do gás & Saída de gás & Diariamente & Cromatografia gasosa \\
\hline
\end{tabular}

Os compostos intermediários do metabolismo anaeróbio (solventes: acetona, metanol, etanol, n-butanol; ácidos voláteis: ácidos acético, propiônico, butírico, iso-butírico, valérico, iso-valérico e capróico) foram analisados por cromatografia em fase gasosa com padrão externo (iso-butanol para os solventes e ácido crotônico para os ácidos voláteis) utilizando-se um cromatógrafo Hewlett Packard ${ }^{\circledR}$ modelo 7890 equipado com detector de ionização de chama e coluna HP-Innowax com $30 \mathrm{~m} \times 0,25 \mathrm{~mm} \times 0,25 \mu \mathrm{m}$ de espessura do filme. $\mathrm{O}$ gás de arraste utilizado foi o hidrogênio com vazão de 1,56 mL. $\mathrm{min}^{-1}$ (velocidade linear constante de $41,8 \mathrm{~cm} \cdot \mathrm{s}^{-1}$ ), a temperatura do injetor foi de $250^{\circ} \mathrm{C}$, a razão de "split" de 10 ("head-space") e o volume de injeção de $400 \mu \mathrm{L}$, utilizando-se injetor automático. A temperatura do forno foi programada da seguinte forma: de $35^{\circ} \mathrm{C}$ à $38^{\circ} \mathrm{C} \mathrm{em} 2^{\circ} \mathrm{C} \cdot \mathrm{min}^{-1}$, de $38^{\circ} \mathrm{C}$ à $75^{\circ} \mathrm{C} \mathrm{em} 10^{\circ} \mathrm{C} \cdot \mathrm{min}^{-1}$, 
de $75^{\circ} \mathrm{C}$ à $120^{\circ} \mathrm{C} \mathrm{em} 35^{\circ} \mathrm{C} \cdot \mathrm{min}^{-1}$, em $120^{\circ} \mathrm{C}$ por $1 \mathrm{~min}$, de $120^{\circ} \mathrm{C}$ à $170^{\circ} \mathrm{C}$ em $10^{\circ} \mathrm{C} \cdot \mathrm{min}^{-1} \mathrm{e} \mathrm{em}$ $170^{\circ} \mathrm{C}$ por 2 min ("head-space”). A temperatura do detector foi de $280^{\circ} \mathrm{C}$ ("head-space”) com fluxo de hidrogênio (combustível) de $30 \mathrm{~mL} \cdot \mathrm{min}^{-1}$, de ar sintético (comburente) de 300 mL.min ${ }^{-1}$ e vazão de "make up" de nitrogênio de $30 \mathrm{~mL} \cdot \mathrm{min}^{-1}$. Foi utilizado nessa análise o método por "head-space".

A composição do biogás formado pelo metabolismo anaeróbio (hidrogênio, metano e dióxido de carbono) foi analisada por cromatografia em fase gasosa utilizando-se um cromatógrafo Agilent ${ }^{\circledR}$ modelo 7890 equipado com detector de condutividade térmica e coluna GS-Carbonplot com $30 \mathrm{~m} \times 0,53 \mathrm{~mm} \times 3,0 \mu \mathrm{m}$ de espessura do filme. $O$ gás de arraste utilizado foi o argônio com vazão de $3,67 \mathrm{~mL} \cdot \mathrm{min}^{-1}$, a temperatura do injetor foi de $185^{\circ} \mathrm{C}$, a razão de "split" de 10 e o volume de injeção de $200 \mu \mathrm{L}$. A temperatura do forno foi programada em $40^{\circ} \mathrm{C}$ isotérmico em $5 \mathrm{~min}$. A temperatura do detector foi de $150^{\circ} \mathrm{C}$, com vazão de "make up" de argônio de 8,33 mL.min"-

A produção total do biogás durante o ciclo $\left(\mathrm{V}_{\mathrm{G}}\right)$ foi analisada por medidor de gás Ritter modelo MilligasCounter, sendo que tais medições foram realizadas na forma de perfis ao longo do ciclo em medida acumulada de volume. A medição era feita a cada 30 minutos.

Os ensaios realizados continham dois períodos distintos em termos de modo de operação: batelada alimentada (BA) e batelada (B). No período em que o sistema foi operado em batelada, o volume de biogás produzido foi quantificado diretamente pelo medidor de gás Ritter, pois durante a quantificação do biogás não ocorre à entrada de afluente e saída de efluente. Entretanto, tal procedimento não pôde ser realizado da mesma maneira para o período em que o sistema foi operado em batelada alimentada, pois nesse período a produção de biogás ocorria concomitantemente com a alimentação de afluente ao reator. Desta forma, o medidor de gás quantificava tanto o volume referente à produção do biogás quanto o volume de afluente alimentado ao reator durante o ciclo. Para que fosse obtido apenas o volume da produção do biogás, após o termino do ciclo, foi feita medição do volume alimentado durante o mesmo ciclo para que esta medida pudesse ser subtraída do valor obtido pelo medidor de gás.

Como a vazão de alimentação era constante e ocorreu desde o início até a metade do período do ciclo, os volumes acumulados em cada ponto puderam ser obtidos pela Equação (4.1) para o período em batelada alimentada e pela Equação (4.2) para o período em batelada, sendo $\mathrm{V}_{\mathrm{Gi}-\mathrm{BA}}$ o volume acumulado de biogás obtido em determinado ponto do período em batelada alimentada, $\mathrm{V}_{\mathrm{M}-\mathrm{i}} \mathrm{O}$ volume obtido pelo medidor de biogás, $\mathrm{N}_{\mathrm{i}} \mathrm{o}$ número do ponto do perfil do biogás, $\mathrm{N}_{\mathrm{t}-\mathrm{BA}} \mathrm{O}$ número total de pontos do perfil durante a batelada alimentada, $\mathrm{V}_{\mathrm{A}} \mathrm{O}$ 
volume de afluente alimentado durante o ciclo, e $\mathrm{V}_{\text {Gi-B }} \mathrm{o}$ volume acumulado de biogás obtido em determinado ponto do período em batelada.

$$
\begin{gathered}
V_{G i-B A}=V_{M-i}-\frac{N_{i}}{N_{t-B A}} V_{A} \\
V_{G i-B}=V_{M-i}
\end{gathered}
$$

Após a correção do volume obtido pelo medidor de biogás em relação ao volume alimentado, foi necessária a conversão desse volume para as CNTP (tanto para os ensaios em batelada quanto para batelada alimentada), uma vez que o volume depende das condições de operação existentes no momento em que é realizada a medição. A conversão foi feita de acordo com a lei geral dos gases pela Equação (4.3), que se encontra no manual do equipamento, sendo $\mathrm{V}_{\mathrm{N}}$ o volume nas CNTP, $\mathrm{V}_{\mathrm{i}}$ o volume de biogás a ser convertido (ou seja $\mathrm{V}_{\mathrm{Gi}-\mathrm{BA}}$ ou $\mathrm{V}_{\mathrm{Gi}-\mathrm{B}}$ ), $\mathrm{P}_{\mathrm{a}}$ a pressão do ar no local da medição, $\mathrm{P}_{\mathrm{V}}$ a pressão parcial de vapor d’água, $\mathrm{P}_{\mathrm{L}}$ a pressão da coluna líquida acima da câmara de medição (2 mbar), $\mathrm{P}_{\mathrm{N}}$ a pressão normal (1013,25 mbar), $T_{N}$ a temperatura normal $(273,15 \mathrm{~K})$ e $\mathrm{T}_{\mathrm{a}}$ a temperatura no local da medição.

$$
V_{N}=V_{i} \frac{\left(P_{a}-P_{V}+P_{L}\right)}{P_{N}} \frac{T_{N}}{T_{a}}
$$

Ao final de cada condição experimental foi realizada a quantificação da biomassa no interior do reator. Primeiramente foi feita a drenagem do sistema, sendo verificado o volume de meio líquido do reator $\left(V_{R}\right)$. Em seguida, todo o suporte inerte junto com a biomassa foi retirado do tubo de acrílico e quantificados $\left(\mathrm{M}_{\mathrm{T}-\mathrm{SI}+\mathrm{B}}\right)$, esse material foi homogeneizado para que fosse coletada uma amostra de suporte inerte com biomassa e quantificada $\left(\mathrm{M}_{\mathrm{A}-\mathrm{SI}+\mathrm{B}}\right)$. A partir dessa amostra foi realizada uma "lavagem" com água destilada do suporte inerte, dividindo essa amostra em duas partes, uma fase sólida apenas com as partículas de suporte inerte (de PU ou de PEBD) e uma fase líquida contendo a biomassa do reator. Na fase sólida foi realizada a análise de ST e na fase líquida as análises de ST e SVT. A partir da quantidade de ST com as partículas de suporte inerte (de PU ou de PEBD) $\left(\mathrm{M}_{\mathrm{A}-\mathrm{ST}}\right)$ e a quantidade de SVT da amostra (M-SVT), foi possível estimar a quantidade de biomassa do reator, sendo tal informação apresentada por três diferentes formas.

$\mathrm{Na}$ quantidade total de biomassa do reator $\left(\mathrm{M}_{\mathrm{SVT}}\right)$, calculada pela Equação (4.4): 


$$
\mathrm{M}_{\mathrm{SVT}}=\frac{\mathrm{M}_{\mathrm{A}-\mathrm{SVT}} \cdot \mathrm{M}_{\mathrm{T}-\mathrm{SI}+\mathrm{B}}}{\mathrm{M}_{\mathrm{A}-\mathrm{SI}+\mathrm{B}}}
$$

Pela quantidade total de biomassa do reator $\left(\mathrm{M}_{\mathrm{SVT}}\right)$ mede-se a capacidade do reator na retenção da biomassa, sendo essa variável importante também devido à sua utilização em outros indicadores utilizados na análise do reator, como a carga orgânica específica aplicada (COAE), a carga orgânica específica removida (CORE) e a produtividade molar específica (PrME).

Na relação entre a quantidade de biomassa e o volume de meio líquido do reator $\left(\mathrm{C}_{X}\right)$, calculada pela Equação (4.5):

$$
\mathrm{C}_{\mathrm{X}}=\frac{\mathrm{M}_{\mathrm{SVT}}}{\mathrm{V}_{\mathrm{R}}}
$$

Pela concentração de biomassa no reator por volume de meio líquido tratado por ciclo $\left(\mathrm{C}_{\mathrm{X}}\right)$ mede-se a relação entre a quantidade de meio líquido disponível ao tratamento e a biomassa envolvida nas biotransformações inerentes ao processo biológico em estudo.

Na relação entre a quantidade de biomassa e a quantidade de suporte inerte presente no reator $\left(\mathrm{C}_{\mathrm{X}}{ }^{\prime}\right)$, calculada pela Equação (4.6):

$$
C_{X}^{\prime}=\frac{M_{A-S V T}}{M_{A-S I}}
$$

Pela concentração de biomassa no reator por massa de suporte inerte presente no reator (CX') mede-se a relação entre a quantidade de suporte inerte disponível para a imobilização/retenção da biomassa e a biomassa envolvida nas biotransformações inerentes ao processo biológico em estudo.

\subsection{FUNDAMENTOS TEÓRICOS}

\subsubsection{Indicadores de desempenho}

As eficiências de remoção de matéria orgânica, carboidrato e glicerina de amostras não filtradas ( $\varepsilon_{\mathrm{MOT}}, \varepsilon_{\mathrm{CT}}$ e $\varepsilon_{\mathrm{GT}}$ ) no sistema foram calculadas pelas Equações (4.7), (4.8) e (4.9), nas quais $\mathrm{C}_{\mathrm{MOAFL}}, \mathrm{C}_{\mathrm{CAFL}}$ e $\mathrm{C}_{\mathrm{GAFL}}$ são as concentrações de matéria orgânica, de carboidratos e de 
glicerina em amostras não filtradas no afluente e $\mathrm{C}_{\mathrm{MOT}}$, e $\mathrm{C}_{\mathrm{CT}}$ e $\mathrm{C}_{\mathrm{GT}}$ são as concentrações de matéria orgânica, carboidrato e glicerina de amostras não filtradas no efluente.

$$
\begin{gathered}
\varepsilon_{\mathrm{MOT}}(\%)=\frac{\mathrm{C}_{\mathrm{MOAFL}}-\mathrm{C}_{\mathrm{MOT}}}{\mathrm{C}_{\mathrm{SAFL}}} .100 \\
\varepsilon_{\mathrm{CT}}(\%)=\frac{\mathrm{C}_{\mathrm{CAFL}}-\mathrm{C}_{\mathrm{CT}}}{\mathrm{C}_{\mathrm{CAFL}}} .100 \\
\varepsilon_{\mathrm{GT}}(\%)=\frac{\mathrm{C}_{\mathrm{GAFL}}-\mathrm{C}_{\mathrm{GT}}}{\mathrm{C}_{\mathrm{GAFL}}} .100
\end{gathered}
$$

As eficiências de remoção de matéria orgânica, carboidrato e glicerina de amostras filtradas ( $\varepsilon_{\mathrm{MOF}}, \varepsilon_{\mathrm{CF}}$ e $\left.\varepsilon_{\mathrm{GF}}\right)$ no sistema foram calculadas pelas Equações (4.10), (4.11) e (4.12) nas quais $\mathrm{C}_{\mathrm{MOF}}, \mathrm{C}_{\mathrm{CE}}$ e $\mathrm{C}_{\mathrm{GE}}$ são as concentrações de matéria orgânica, carboidrato e glicerina de amostras filtradas no efluente.

$$
\begin{gathered}
\varepsilon_{\mathrm{MOF}}(\%)=\frac{\mathrm{C}_{\mathrm{MOAFL}}-\mathrm{C}_{\mathrm{MOF}}}{\mathrm{C}_{\mathrm{SAFL}}} .100 \\
\varepsilon_{\mathrm{CF}}(\%)=\frac{\mathrm{C}_{\mathrm{CAFL}}-\mathrm{C}_{\mathrm{CF}}}{\mathrm{C}_{\mathrm{CAFL}}} .100 \\
\varepsilon_{\mathrm{GF}}(\%)=\frac{\mathrm{C}_{\mathrm{GAFL}}-\mathrm{C}_{\mathrm{GF}}}{\mathrm{C}_{\mathrm{GAFL}}} .100
\end{gathered}
$$

As cargas orgânicas aplicadas volumétricas $\left(\mathrm{COAV}_{\mathrm{MO}}, \mathrm{COAV}_{\mathrm{C}}\right.$ e $\left.\mathrm{COAV}_{\mathrm{G}}\right)$, expressas em $\mathrm{kgDQO} \cdot \mathrm{m}^{-3} \cdot \mathrm{d}^{-1}, \mathrm{kgCarboidrato} \cdot \mathrm{m}^{-3} \cdot \mathrm{d}^{-1}$ e $\mathrm{kgGlicerina} \cdot \mathrm{m}^{-3} \cdot \mathrm{d}^{-1}$, foram definidas como as quantidades de matéria orgânica, carboidrato e glicerina aplicadas ao reator por unidade de tempo e por volume de meio do reator. Para reatores operados em batelada e/ou batelada alimentada podem ser calculadas pelas Equações (4.13), (4.14) e (4.15), nas quais $\mathrm{V}_{\mathrm{A}}$ é o volume de água residuária alimentada no ciclo, $\mathrm{N}$ é o número de ciclos por dia, e $\mathrm{V}_{\mathrm{R}}$ é o volume de água residuária no reator.

$$
\begin{aligned}
\operatorname{COAV}_{M O} & =\frac{\left(\mathrm{V}_{\mathrm{A}} \cdot \mathrm{N}\right) \cdot \mathrm{C}_{\mathrm{MOAFL}}}{\mathrm{V}_{\mathrm{R}}} \\
\operatorname{COAV}_{C} & =\frac{\left(\mathrm{V}_{\mathrm{A}} \cdot \mathrm{N}\right) \cdot \mathrm{C}_{\mathrm{CAFL}}}{\mathrm{V}_{\mathrm{R}}} \\
\operatorname{COAV}_{G} & =\frac{\left(\mathrm{V}_{\mathrm{A}} \cdot \mathrm{N}\right) \cdot \mathrm{C}_{\mathrm{GAFL}}}{\mathrm{V}_{\mathrm{R}}}
\end{aligned}
$$


As cargas orgânicas aplicadas específicas $\left(\mathrm{COAE}_{\mathrm{MO}}, \mathrm{COAE}_{\mathrm{C}}\right.$ e $\left.\mathrm{COAE}_{\mathrm{G}}\right)$, expressas em kgDQO.gSVT. $\mathrm{d}^{-1}$, kgCarboidrato.gSVT. $\mathrm{d}^{-1}$ e kgGlicerina.gSVT. $\mathrm{d}^{-1}$ foram definidas como as quantidades de matéria orgânica, carboidrato e glicerina aplicadas ao reator por unidade de tempo e por massa de sólidos totais voláteis no reator. Para reatores operados em batelada e/ou batelada alimentada podem ser calculadas pelas Equações (4.16), (4.17) e (4.18), nas quais $\mathrm{M}_{\mathrm{SvT}}$ é a massa de sólidos voláteis totais no interior do reator.

$$
\begin{aligned}
\operatorname{COAE}_{M O} & =\frac{\left(\mathrm{V}_{\mathrm{A}} \cdot \mathrm{N}\right) \cdot \mathrm{C}_{\mathrm{MOAFL}}}{\mathrm{M}_{\mathrm{SVT}}} \\
\mathrm{COAE}_{C} & =\frac{\left(\mathrm{V}_{\mathrm{A}} \cdot \mathrm{N}\right) \cdot \mathrm{C}_{\mathrm{CAFL}}}{\mathrm{M}_{\mathrm{SVT}}} \\
\operatorname{COAE}_{G} & =\frac{\left(\mathrm{V}_{\mathrm{A}} \cdot \mathrm{N}\right) \cdot \mathrm{C}_{\mathrm{GAFL}}}{\mathrm{M}_{\mathrm{SVT}}}
\end{aligned}
$$

As cargas orgânicas removidas volumétricas $\left(\mathrm{CORV}_{\mathrm{MO}}, \mathrm{CORV}_{\mathrm{C}}\right.$ e $\left.\mathrm{CORV}_{\mathrm{G}}\right)$, expressas em kgDQO. $\mathrm{m}^{-3} \cdot \mathrm{d}^{-1}$, kgCarboidrato. $\mathrm{m}^{-3} \cdot \mathrm{d}^{-1}$ e kgGlicerina. $\mathrm{m}^{-3} \cdot \mathrm{d}^{-1}$ foram definidas como as quantidades de matéria orgânica, carboidrato e glicerina removidas pelo reator por unidade de tempo e por volume de meio do reator. Para reatores operados em batelada e/ou batelada alimentada podem ser calculadas pelas Equações (4.19), (4.20) e (4.21).

$$
\begin{aligned}
\operatorname{CORV}_{M O} & =\frac{\left(\mathrm{V}_{\mathrm{A}} \cdot \mathrm{N}\right) \cdot\left(\mathrm{C}_{\mathrm{MOAFL}}-\mathrm{C}_{\mathrm{MOF}}\right)}{\mathrm{V}_{\mathrm{R}}} \\
\operatorname{CORV}_{C} & =\frac{\left(\mathrm{V}_{\mathrm{A}} \cdot \mathrm{N}\right) \cdot\left(\mathrm{C}_{\mathrm{CAFL}}-\mathrm{C}_{\mathrm{CF}}\right)}{\mathrm{V}_{\mathrm{R}}} \\
\operatorname{CORV}_{G} & =\frac{\left(\mathrm{V}_{\mathrm{A}} \cdot \mathrm{N}\right) \cdot\left(\mathrm{C}_{\mathrm{GAFL}}-\mathrm{C}_{\mathrm{GF}}\right)}{\mathrm{V}_{\mathrm{R}}}
\end{aligned}
$$

As cargas orgânicas removidas específicas (COREMO, CORE e CORE $\mathrm{C}_{\mathrm{G}}$ ), expressas em kgDQO.gSVT. $\mathrm{d}^{-1}$, kgCarboidrato.gSVT. $\mathrm{d}^{-1}$ e kgGlicerina.gSVT. $\mathrm{d}^{-1}$ foram definidas como as quantidades de matéria orgânica, carboidrato e glicerina removidas reator por unidade de tempo e por massa de sólidos totais voláteis no reator. Para reatores operados em batelada e/ou batelada alimentada podem ser calculadas pelas Equações (4.22), (4.23) e (4.24). 


$$
\begin{aligned}
& \operatorname{CORE}_{S}=\frac{\left(\mathrm{V}_{\mathrm{A}} \cdot \mathrm{N}\right) \cdot\left(\mathrm{C}_{\mathrm{SAFL}}-\mathrm{C}_{\mathrm{MOF}}\right)}{\mathrm{M}_{\mathrm{SVT}}} \\
& \operatorname{CORE}_{C}=\frac{\left(\mathrm{V}_{\mathrm{A}} \cdot \mathrm{N}\right) \cdot\left(\mathrm{C}_{\mathrm{CAFL}}-\mathrm{C}_{\mathrm{CF}}\right)}{\mathrm{M}_{\mathrm{SVT}}} \\
& \operatorname{CORE}_{G}=\frac{\left(\mathrm{V}_{\mathrm{A}} \cdot \mathrm{N}\right) \cdot\left(\mathrm{C}_{\mathrm{GAFL}}-\mathrm{C}_{\mathrm{GF}}\right)}{\mathrm{M}_{\mathrm{SVT}}}
\end{aligned}
$$

A produtividade molar (PrM), expressa em $\mathrm{molH}_{2} \cdot \mathrm{m}^{-3} \cdot \mathrm{d}^{-1}$ ou $\mathrm{molCH}_{4} \cdot \mathrm{m}^{-3} \cdot \mathrm{d}^{-1}$, foi definida pela relação entre biogás produzido por unidade de tempo e o volume de meio do reator. Para reatores operados em batelada e/ou batelada alimentada, podem ser calculadas pelas equações (4.25) e (4.26), na qual $\mathrm{n}_{\mathrm{H} 2}$ e $\mathrm{n}_{\mathrm{CH} 4}$ representam, respectivamente, o número de moles de hidrogênio e metano produzidos por dia.

$$
\begin{aligned}
\operatorname{PrM}_{H 2} & =\frac{\mathrm{n}_{\mathrm{H} 2}}{\mathrm{~V}_{\mathrm{R}}} \\
\operatorname{PrM}_{C H 4} & =\frac{\mathrm{n}_{\mathrm{CH} 4}}{\mathrm{~V}_{\mathrm{R}}}
\end{aligned}
$$

A produtividade molar específica (PrME) é definida pela quantidade de biogás $\left(\mathrm{H}_{2} \mathrm{ou}\right.$ $\mathrm{CH}_{4}$ ) produzida por unidade de tempo e por massa de sólidos voláteis totais no interior do reator $\left(\mathrm{molH}_{2} \cdot \mathrm{kgSVT}^{-1} \cdot \mathrm{d}^{-1}\right.$ ou molCH $\left.4 \cdot \mathrm{kgSVT}^{-1} \cdot \mathrm{d}^{-1}\right)$, calculada pela Equação (4.27) e (4.28). A produtividade é um parâmetro particularmente interessante, permitindo avaliar a capacidade de produção de um reator a partir do volume (ou massa de microrganismos presente) ou, ao contrário, de estimar volume (ou massa de microrganismos) necessário para alcançar uma produção desejada.

$$
\begin{aligned}
\operatorname{PrME}_{H 2} & =\frac{\mathrm{n}_{\mathrm{H} 2}}{\mathrm{M}_{\mathrm{SVT}}} \\
\operatorname{PrME}_{C H 4} & =\frac{\mathrm{n}_{\mathrm{CH} 4}}{\mathrm{M}_{\mathrm{SVT}}}
\end{aligned}
$$

$\mathrm{O}$ rendimento molar por carga aplicada (RMCAs), expresso em $\mathrm{molH}_{2} \cdot \mathrm{kgDQO}^{-1}$ ou $\mathrm{molCH}_{4} \cdot \mathrm{kgDQO}^{-1}$, foi definido pela relação entre biogás produzido e matéria orgânica alimentada ao reator. Para reatores operados em batelada e/ou batelada alimentada pode ser calculado pelas equações (4.29) e (4.30). 


$$
\begin{aligned}
\operatorname{RMCA}_{M O, H 2} & =\frac{\mathrm{n}_{\mathrm{H} 2}}{\mathrm{~N} \cdot \mathrm{V}_{\mathrm{A}} \cdot \mathrm{C}_{\mathrm{MOAFL}}} \\
\mathrm{RMCA}_{M O, C H 4} & =\frac{\mathrm{n}_{\mathrm{CH} 4}}{\mathrm{~N} \cdot \mathrm{V}_{\mathrm{A}} \cdot \mathrm{C}_{\mathrm{SAFL}}}
\end{aligned}
$$

O rendimento molar por carga aplicada $\left(\mathrm{RMCA}_{\mathrm{S}}\right)$, expresso em $\mathrm{molH}_{2} \cdot \mathrm{kgSubstrato}^{-1}$ ou $\mathrm{molCH}_{4} \cdot \mathrm{kgSubstrato}^{-1}$, foi definido pela relação entre biogás produzido e substrato alimentado ao reator. Para reatores operados em batelada e/ou batelada alimentada pode ser calculado pelas equações (4.31) e (4.32).

$$
\begin{aligned}
\mathrm{RMCA}_{S, H 2} & =\frac{\mathrm{n}_{\mathrm{H} 2}}{\mathrm{~N} \cdot \mathrm{V}_{\mathrm{A}} \cdot\left(\mathrm{C}_{\mathrm{CAFL}}+\mathrm{C}_{\mathrm{GAFL}}\right)} \\
\mathrm{RMCA}_{S, C H 4} & =\frac{\mathrm{n}_{\mathrm{CH} 4}}{\mathrm{~N} \cdot \mathrm{V}_{\mathrm{A}} \cdot\left(\mathrm{C}_{\mathrm{CAFL}}+\mathrm{C}_{\mathrm{GAFL}}\right)}
\end{aligned}
$$

\subsubsection{Modelagem cinética para a produção de biometano}

O cálculo das velocidades das reações para a metanogênese segue o modelo cinético de degradação de matéria orgânica desenvolvido por Rodrigues et al. (2004), com base no modelo de Bagley e Brodkorb (1999). Este último é uma adaptação de outro modelo, proposto pela International Water Association (IWA) e aplicado a sistemas de tratamento com lodo ativado. É importante ressaltar que o modelo proposto (tanto para produção de metano quanto para produção de hidrogênio) visa compreender as vias macro metabólicas do sistema e não prever dados experimentais e projetar um possível aumento de escala, como o ADM1 (Batstone et al., 2002).

No modelo cinético adotado, desenvolvido para reatores anaeróbios operados em batelada sequencial, o processo de degradação da matéria orgânica é simplificado em 7 etapas (Equações de 4.33 a 4.39). Nas primeiras 3 etapas paralelas, o substrato ( $\mathrm{S}$, que é considerado como uma combinação de glicerina e lactose - o carboidrato principal do soro) é convertido em ácido acético (HAc), ácido propiônico (HPr) e ácido butírico (HBu). Nas etapas 4-5 temse o consumo de ácido propiônico e ácido butírico para formar acetato e hidrogênio. Nas etapas 6-7 tem-se as rotas acetoclástica e hidrogenotrófica de produção de metano. Em todas as etapas, as reações de conversão são consideradas como sendo de primeira ordem.

As Equações de 4.40 a 4.44 apresentam as equações de velocidade de reação para o consumo de substrato ( $\mathrm{r}_{\mathrm{S}}$ ), formação e consumo de ácido acético ( $\mathrm{r}_{\mathrm{HAc}}$ ), ácido propiônico 
$\left(\mathrm{r}_{\mathrm{HPr}}\right)$, ácido butírico $\left(\mathrm{r}_{\mathrm{HBu}}\right)$ e formação de metano $\left(\mathrm{r}_{\mathrm{M}}\right)$, respectivamente, sendo que $\mathrm{k}_{1 \mathrm{~S}}, \mathrm{k}_{2 \mathrm{~S}}$, $\mathrm{k}_{3 \mathrm{~S}}$, $\mathrm{k}_{1 \mathrm{HAc}}, \mathrm{k}_{4 \mathrm{HAc}}, \mathrm{k}_{5 \mathrm{HAc}}, \mathrm{k}_{6 \mathrm{HAc}}, \mathrm{k}_{2 \mathrm{HPr}}, \mathrm{k}_{4 \mathrm{HPr}}, \mathrm{k}_{3 \mathrm{HBu}}, \mathrm{k}_{5 \mathrm{HBu}}, \mathrm{k}_{6 \mathrm{M}} \mathrm{e} \mathrm{k}_{7 \mathrm{M}}$ são os mesmos parâmetros cinéticos aparentes, só que associados ao consumo de substrato, formação e consumo de ácidos voláteis, e formação de metano. O parâmetro cinético " $\mathrm{k}$ " é relacionado com a velocidade de reação, indicando uma relação com o tempo que é necessário para a concentração (S, HAc, HPr, HBu e M) atingir um valor residual de acordo com a hipótese do modelo cinético. Os índices “1, 2, 3, 4, 5, 6 e 7” estão relacionados com as reações. Os índices “S, HAc, HPr, HBu e M" estão relacionados com os valores experimentais usados para calcular esses parâmetros.

$$
\begin{aligned}
& \mathrm{C}_{12} \mathrm{H}_{22} \mathrm{O}_{11}+2 \mathrm{C}_{3} \mathrm{H}_{8} \mathrm{O}_{3}+5 \mathrm{H}_{2} \mathrm{O} \stackrel{k_{1}}{\rightarrow} 7 \mathrm{CH}_{3} \mathrm{COOH}+4 \mathrm{CO}_{2}+10 \mathrm{H}_{2} \\
& \mathrm{C}_{12} \mathrm{H}_{22} \mathrm{O}_{11}+\mathrm{C}_{3} \mathrm{H}_{8} \mathrm{O}_{3}+4 \mathrm{H}_{2} \stackrel{k_{2}}{\rightarrow} 5 \mathrm{CH}_{3} \mathrm{CH}_{2} \mathrm{COOH}+4 \mathrm{H}_{2} \mathrm{O} \\
& \mathrm{C}_{12} \mathrm{H}_{22} \mathrm{O}_{11}+3 \mathrm{C}_{3} \mathrm{H}_{8} \mathrm{O}_{3}+4 \mathrm{H}_{2} \mathrm{O} \stackrel{k_{3}}{\rightarrow} 3 \mathrm{CH}_{3} \mathrm{CH}_{2} \mathrm{CH}_{2} \mathrm{COOH}+9 \mathrm{CO}_{2}+15 \mathrm{H}_{2} \\
& \mathrm{CH}_{3} \mathrm{CH}_{2} \mathrm{COOH}+2 \mathrm{H}_{2} \mathrm{O} \stackrel{k_{4}}{\rightarrow} \mathrm{CH}_{3} \mathrm{COOH}+\mathrm{CO}_{2}+3 \mathrm{H}_{2} \\
& \mathrm{CH}_{3} \mathrm{CH}_{2} \mathrm{CH}_{2} \mathrm{COOH}+2 \mathrm{H}_{2} \mathrm{O} \stackrel{k_{7}}{\rightarrow} \mathrm{CH}_{3} \mathrm{CH}_{2} \mathrm{COOH}+\mathrm{CO}_{2}+3 \mathrm{H}_{2} \\
& \mathrm{CH}_{3} \mathrm{COOH}_{2}^{\rightarrow} \mathrm{CH}_{4}+\mathrm{CO}_{2} \\
& 4 \mathrm{H}_{2}+\mathrm{CO}_{2} \stackrel{k_{7}}{\rightarrow} \mathrm{CH}_{4}+2 \mathrm{H}_{2} \mathrm{O} \\
& \mathrm{r}_{\mathrm{S}} \quad=-\left(\mathrm{k}_{1 \mathrm{~S}}+\mathrm{k}_{2} \mathrm{~S}+\mathrm{k}_{33}\right) \cdot \mathrm{C}_{\mathrm{S}}=\mathrm{k}_{1 \mathrm{~S}} \cdot \mathrm{C}_{\mathrm{S}} \\
& \mathrm{r}_{\mathrm{HAc}}=\mathrm{k}_{1 \mathrm{HAc}} \cdot \mathrm{C}_{\mathrm{S}}+\mathrm{k}_{4 \mathrm{HAc}} \cdot \mathrm{C}_{\mathrm{HPr}}-\mathrm{k}_{6 \mathrm{HAc}} \cdot \mathrm{C}_{\mathrm{HAc}} \\
& \mathrm{r}_{\mathrm{HPr}}=\mathrm{k}_{2 \mathrm{HPr}} \cdot \mathrm{C}_{\mathrm{S}}-\mathrm{k}_{4 \mathrm{HPr}} \cdot \mathrm{C}_{\mathrm{HPr}}+\mathrm{k}_{5 \mathrm{HPr}} \cdot \mathrm{C}_{\mathrm{HBu}} \\
& \mathrm{r}_{\mathrm{HBu}}=\mathrm{k}_{3 \mathrm{HBu}} \cdot \mathrm{C}_{\mathrm{S}}-\mathrm{k}_{5 \mathrm{HBu}} \cdot \mathrm{C}_{\mathrm{HBu}} \\
& \mathrm{r}_{\mathrm{M}}=\mathrm{k}_{6 \mathrm{M}} \cdot \mathrm{C}_{\mathrm{HAc}}+\mathrm{k}_{7 \mathrm{M}} \cdot \mathrm{C}_{\mathrm{S}}
\end{aligned}
$$

As Equações de 4.45 a 4.50 apresentam o balanço de massa do reator no modo batelada $(\mathrm{F}=0)$ e batelada alimentada $(\mathrm{F} \neq 0)$ com o modelo cinético (substrato, ácidos voláteis e metano). Essas equações foram usadas para determinar os parâmetros cinéticos do modelo. Os índices "INF" estão relacionados com as concentrações dos compostos no afluente. 
Por se tratarem de equações diferenciais, foi utilizado o método de integração de Euler implementado em planilha do software Excel ${ }^{\circledR}$, com a determinação dos parâmetros cinéticos pelo método GRG não linear, utilizando como critério de otimização a minimização da somatória dos erros (entre valores experimentais e calculados pelo modelo cinético) ao quadrado.

$\frac{d V}{d t}=F$

$\frac{d C_{S}}{d t}=\frac{F}{V} \cdot\left(C_{S I N F}-C_{S F}\right)+r_{S}$

$\frac{d C_{H A C}}{d t}=\frac{F}{V} \cdot\left(C_{H A C I N F}-C_{H A C}\right)+r_{H A C}$

$\frac{d C_{H P r}}{d t}=\frac{F}{V} \cdot\left(C_{H P r I N F}-C_{H P r}\right)+r_{H P r}$

$\frac{d C_{H B u}}{d t}=\frac{F}{V} \cdot\left(C_{H B u I N F}-C_{H B u}\right)+r_{H B u}$

$\frac{d C_{M}}{d t}=-\frac{F}{V} \cdot\left(C_{M}\right)+r_{M}$

\subsubsection{Modelagem cinética para a produção de biohidrogênio}

O cálculo das velocidades das reações para a acidogênse segue o mesmo modelo cinético de degradação de matéria orgânica desenvolvido por Rodrigues et al. (2004), com base no modelo de Bagley e Brodkorb (1999) que foi utilizado para a metanogênese, a diferença é que foram considerados a produção de um álcool - o etanol - e de um ácido volátil de cadeia maior - o ácido valérico.

No modelo cinético adotado, o processo de degradação da matéria orgânica é simplificado em onze etapas (Equações de 4.51 a 4.61). Nas primeiras 5 etapas paralelas, o substrato ( $\mathrm{S}$, que novamente é considerado como uma combinação de glicerina e lactose) é convertido em ácido acético (HAc), ácido propiônico (HPr), ácido butírico (HBu), ácido valérico $(\mathrm{HVa})$ e etanol $(\mathrm{EtOH})$. Nas etapas 6-8 tem-se o consumo dos ácidos propiônico, butírico e valérico para formar ácidos menores e hidrogênio. Vale destacar que o etanol é considerado como produto final, não contribuindo para a produção de hidrogênio, pois consome substrato e não libera biogás na sua formação. Nas etapas 9-10 tem-se as rotas acetoclástica e hidrogenotrófica se a inibição da metanogênse não for atingida. Na etapa 11 
tem-se o consumo de ácido acético para crescimento celular e produção de metabólitos intermediários para microrganismos como Megasphera (Hino et al., 1991). Em todas as etapas, as reações de conversão são consideradas como sendo de primeira ordem.

As Equações de 4.62 a 4.69 apresentam as equações de velocidade de reação para o consumo de substrato $\left(\mathrm{r}_{\mathrm{S}}\right)$, formação e consumo de ácido acético $\left(\mathrm{r}_{\mathrm{HAc}}\right)$, ácido propiônico $\left(\mathrm{r}_{\mathrm{HPr}}\right)$, ácido butírico $\left(\mathrm{r}_{\mathrm{HBu}}\right)$, ácido valérico $\left(\mathrm{r}_{\mathrm{HVA}}\right)$, etanol $\left(\mathrm{r}_{\mathrm{EtOH}}\right)$, hidrogênio $\left(\mathrm{r}_{\mathrm{H}}\right)$ e metano $\left(\mathrm{r}_{\mathrm{M}}\right)$, respectivamente, sendo que $\mathrm{k}_{1 \mathrm{~S}}$, $\mathrm{k}_{1 \mathrm{HAc}}, \mathrm{k}_{6 \mathrm{HAc}}, \mathrm{k}_{9 \mathrm{HAc}}, \mathrm{k}_{11 \mathrm{HAc}}, \mathrm{k}_{2 \mathrm{HPr}}, \mathrm{k}_{6 \mathrm{HPr}}, \mathrm{k}_{7 \mathrm{HPr}}, \mathrm{k}_{3 \mathrm{HBu}}, \mathrm{k}_{7 \mathrm{HBu}}$, $\mathrm{k}_{8 \mathrm{HBu}}, \mathrm{k}_{4 \mathrm{HVa}}, \mathrm{k}_{8 \mathrm{HVa}}, \mathrm{k}_{5 \mathrm{EtOH}}, \mathrm{k}_{1 \mathrm{H}}, \mathrm{k}_{2 \mathrm{H}}, \mathrm{k}_{3 \mathrm{H}}, \mathrm{k}_{4 \mathrm{H}}, \mathrm{k}_{6 \mathrm{H}}, \mathrm{k}_{7 \mathrm{H}}, \mathrm{k}_{8 \mathrm{H}}, \mathrm{k}_{10 \mathrm{H}}, \mathrm{k}_{9 \mathrm{M}}, \mathrm{k}_{10 \mathrm{M}}$ são os mesmos parâmetros cinéticos aparentes, só que associados ao consumo de substrato, formação e consumo de ácidos voláteis, álcool, hidrogênio e metano. O parâmetro cinético " $k$ " é relacionado com a velocidade de reação, indicando uma relação com o tempo que é necessário para a concentração (S, HAc, $\mathrm{HPr}, \mathrm{HBu}, \mathrm{HVa}, \mathrm{EtOH}, \mathrm{H}$ e M) atingir um valor residual de acordo com a hipótese do modelo cinético. Os índices “1, 2, 3, 4, 5, 6, 7, 8, 9, 10, 11, 12 e 13” estão relacionados com as reações. Os índices “S, HAc, $\mathrm{HPr}, \mathrm{HBu}, \mathrm{HVa}, \mathrm{HCa}, \mathrm{H}$ e M" estão relacionados com os valores experimentais usados para calcular esses parâmetros.

$$
\begin{aligned}
& \mathrm{C}_{12} \mathrm{H}_{22} \mathrm{O}_{11}+2 \mathrm{C}_{3} \mathrm{H}_{8} \mathrm{O}_{3}+5 \mathrm{H}_{2} \mathrm{O} \stackrel{k_{1}}{\rightarrow} 7 \mathrm{CH}_{3} \mathrm{COOH}+4 \mathrm{CO}_{2}+10 \mathrm{H}_{2} \\
& \mathrm{C}_{12} \mathrm{H}_{22} \mathrm{O}_{11}+\mathrm{C}_{3} \mathrm{H}_{8} \mathrm{O}_{3}+4 \mathrm{H}_{2} \stackrel{k_{2}}{\rightarrow} 5 \mathrm{CH}_{3} \mathrm{CH}_{2} \mathrm{COOH}+4 \mathrm{H}_{2} \mathrm{O} \\
& \mathrm{C}_{12} \mathrm{H}_{22} \mathrm{O}_{11}+3 \mathrm{C}_{3} \mathrm{H}_{8} \mathrm{O}_{3}+4 \mathrm{H}_{2} \mathrm{O} \stackrel{k_{3}}{\rightarrow} 3 \mathrm{CH}_{3} \mathrm{CH}_{2} \mathrm{CH}_{2} \mathrm{COOH}+9 \mathrm{CO}_{2}+15 \mathrm{H}_{2} \\
& 8 \mathrm{C}_{12} \mathrm{H}_{22} \mathrm{O}_{11}+8 \mathrm{C}_{3} \mathrm{H}_{8} \mathrm{O}_{3} \stackrel{k_{4}}{\rightarrow} 16 \mathrm{CH}_{3} \mathrm{CH}_{2} \mathrm{CH}_{2} \mathrm{CH}_{2} \mathrm{COOH}+40 \mathrm{CO}_{2}+40 \mathrm{H}_{2} \\
& \mathrm{C}_{12} \mathrm{H}_{22} \mathrm{O}_{11}+6 \mathrm{C}_{3} \mathrm{H}_{8} \mathrm{O}_{3} \stackrel{k_{5}}{\rightarrow} 11 \mathrm{CH}_{3} \mathrm{CH}_{2} \mathrm{OH}+8 \mathrm{CO}_{2}+2 \mathrm{H}_{2} \mathrm{O} \\
& \mathrm{CH}_{3} \mathrm{CH}_{2} \mathrm{COOH}+2 \mathrm{H}_{2} \mathrm{O} \stackrel{k_{6}}{\rightarrow} \mathrm{CH}_{3} \mathrm{COOH}+\mathrm{CO}_{2}+3 \mathrm{H}_{2} \\
& \mathrm{CH}_{3} \mathrm{CH}_{2} \mathrm{CH}_{2} \mathrm{COOH}+2 \mathrm{H}_{2} \mathrm{O} \stackrel{k_{7}}{\rightarrow} \mathrm{CH}_{3} \mathrm{CH}_{2} \mathrm{COOH}+\mathrm{CO}_{2}+3 \mathrm{H}_{2} \\
& \mathrm{CH}_{3} \mathrm{CH}_{2} \mathrm{CH}_{2} \mathrm{CH}_{2} \mathrm{COOH}+2 \mathrm{H}_{2} \mathrm{O} \stackrel{k_{8}}{\rightarrow} \mathrm{CH}_{3} \mathrm{CH}_{2} \mathrm{CH}_{2} \mathrm{COOH}+\mathrm{CO}_{2}+3 \mathrm{H}_{2} \\
& \mathrm{CH}_{3} \mathrm{COOH} \stackrel{k_{9}}{\rightarrow} \mathrm{CH}_{4}+\mathrm{CO}_{2} \\
& 4 \mathrm{H}_{2}+\mathrm{CO}_{2} \stackrel{k_{10}}{\longrightarrow} \mathrm{CH}_{4}+2 \mathrm{H}_{2} \mathrm{O} \\
& \mathrm{CH}_{3} \mathrm{COOH} \stackrel{k_{11}}{\rightarrow} \text { Biomassa }+ \text { Metabólitos Intermediários }
\end{aligned}
$$




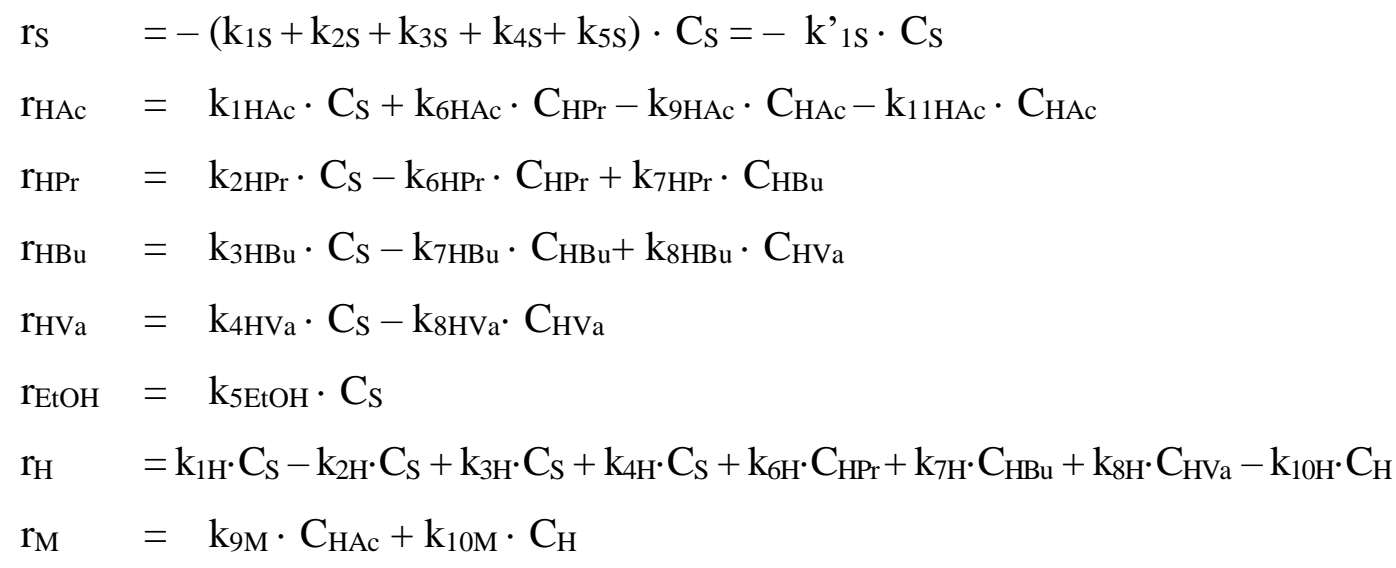

As Equações de 4.70 a 4.78 apresentam o balanço de massa do reator no modo batelada $(\mathrm{F}=0)$ e batelada alimentada $(\mathrm{F} \neq 0)$ com o modelo cinético (substrato, ácidos voláteis, álcoois, hidrogênio e metano). Essas equações foram usadas para determinar os parâmetros cinéticos do modelo. Os índices "INF" estão relacionados com as concentrações dos compostos no afluente.

Por se tratarem de equações diferenciais, foi utilizado o método de integração de Euler implementado em planilha do software Excel ${ }^{\circledR}$, com a determinação dos parâmetros cinéticos pela método GRG não linear, utilizando como critério de otimização a minimização da somatória dos erros (entre valores experimentais e calculados pelo modelo cinético) ao quadrado.

$$
\begin{aligned}
& \frac{d V}{d t}=F \\
& \frac{d C_{S}}{d t}=\frac{F}{V} \cdot\left(C_{S I N F}-C_{S}\right)+r_{S} \\
& \frac{d C_{H A c}}{d t}=\frac{F}{V} \cdot\left(C_{H A C I N F}-C_{H A c}\right)+r_{H A c} \\
& \frac{d C_{H P r}}{d t}=\frac{F}{V} \cdot\left(C_{H P r I N F}-C_{H P r}\right)+r_{H P r} \\
& \frac{d C_{H B u}}{d t}=\frac{F}{V} \cdot\left(C_{H B u I N F}-C_{H B u}\right)+r_{H B u} \\
& \frac{d C_{H V a}}{d t}=\frac{F}{V} \cdot\left(C_{H V a I N F}-C_{H V a}\right)+r_{H V a} \\
& \frac{d C_{E t O H}}{d t}=\frac{F}{V} \cdot\left(C_{H E t O H I N F}-C_{E t O H}\right)+r_{E t O H} \\
& \frac{d C_{H}}{d t}=-\frac{F}{V} \cdot\left(C_{H}\right)+r_{H} \\
& \frac{d C_{M}}{d t}=-\frac{F}{V} \cdot\left(C_{M}\right)+r_{M}
\end{aligned}
$$


4.5.4 Ajuste da Equação de Arrhenius à Modelagem Cinética de Produção de Biohidrogênio

Em muitos casos a velocidade observada de uma reação química aumenta com o aumento da temperatura, mas a extensão deste aumento varia muito de reação para reação.

Em termos da equação de velocidade, a causa da variação da velocidade de reação com a temperatura reside em que a constante de velocidade $k$ varia quando se altera a temperatura. A relação entre ambas foi descoberta em 1887 por van’t Hoff e, independentemente, em 1889, por Arrhenius. Arrhenius realizou um estudo extensivo da sua aplicação para muitas reações. A relação, conhecida como equação de Arrhenius, é:

$k=A \cdot e^{-\frac{E a}{R T}}$

Em que A é denominado fator de frequência, Ea é a energia de ativação da reação, $\mathrm{R}$ é a constante dos gases ideias e T é a temperatura absoluta. A equação de Arrhenius é útil porque expressa a relação quantitativa entre temperatura, energia de ativação e constante de velocidade (Russel, 1980).

Assim sendo, foi feita uma tentativa de ajuste da equação de Arrhenius às quatro equações bioquímicas principais de produção e consumo de hidrogênio (Equações de 4.51 a 4.54).

\subsection{EXAMES MICROBIOLÓGICOS E CARACTERIZAÇÃO FILOGENÉTICA}

Para a caracterização filogenética, amostra de biomassa foi retirada do reator AnSBBR ao final do período operacional, centrifugada $(6.000 \mathrm{rpm}$ por $10 \mathrm{~min})$, congelada até o momento das análises de biologia molecular. O ácido nucléico foi extraído, amplificado por PCR (com set de primers 27F (AGAGTTTGATCMTGGCTCAG) e 1492R (TACGGYTACCTTGTTACGACTT)), clonado em vetor apropriado (T-vector) e, posteriormente, os clones foram sequenciados em analisador automático de DNA modelo ABI3730XL (Applied Biosystems).

As sequências foram averiguadas manualmente com auxílio do software DNASTAR package (Lasergene Sequence Analysis). A presença de vetores e de quimeras nas sequências foi averiguada com o auxílio das ferramentas VECSCREEN (http://www.ncbi.nlm.nih.gov/tools/vecscreen/) e DECIPHER's FIND CHIMERAS (http://decipher.cee.wisc.edu/FindChimeras.html), respectivamente. As sequências verificadas 
foram então alinhadas usando-se a ferramenta ALIGNER e, agrupadas em Unidades Taxonômicas Operacionais (UTOs) usando-se a ferramenta COMPLETE LINKAGE CLUSTERING. Posteriormente, usou-se a ferramenta REPRESENTATIVE SEQUENCE para determinar a sequências representativas de cada UTO, as quais foram utilizadas para a análise filogenética. As sequências representativas de cada UTO foram comparadas com as sequências depositadas no banco de dados usando-se a ferramenta SEQMATCH. Todas as referidas análises foram realizadas usando-se ferramentas disponíveis no website Ribosomal Database Project (http://rdp.cme.msu.edu/).

A árvore filogenética foi construída com auxílio do software MEGA versão 6 (Tamura et al., 2013) usando o método Neighbor-Joining (Saitou e Nei, 1987). As distâncias evolutivas foram calculadas usando o método Jukes-Cantor (Jukes e Cantor, 1969). A confiabilidade da árvore foi avaliada pelo teste de bootstrap para 1000 repetições (Felsenstein, 1985). Escherichia coli (DQ118017) foi utilizada como espécie outgroup. As sequências representativas de cada UTO (UTO_1-KU565476, UTO_2-KU565477, UTO_3-KU565478, UTO_4-KU565479, UTO_5-KU565480, UTO_6-KU565481, UTO_7-KU565482, UTO_8KU565483, UTO_9-KU565484) foram depositadas na base de dados do NCBI.

\subsection{PROCEDIMENTO EXPERIMENTAL DA OPERAÇÃO DO REATOR}

\subsubsection{Operação do reator}

Os ensaios foram realizados utilizando-se diferentes cargas orgânicas volumétricas $(6,4$; 10,3; 17,1; e 24,0), modificadas em função: (i) da concentração afluente (3000, 5000 e $\left.7000 \mathrm{mgDQO} . \mathrm{L}^{-1}\right)$ e (ii) do tempo de ciclo (8, 4, 3 e 2 h, ou seja, 3, 6, 8 e 12 ciclos diários).

A operação do reator foi realizada da seguinte maneira: ao final de um ciclo, são descarregados 1,5 L de meio (em $10 \mathrm{~min}$ ), sendo mantidos no reator mais 2,0 L (denominado volume residual), ou seja, o volume total de meio no sistema é de 3,5 L. Logo após essa descarga, um novo ciclo tem início com a alimentação (com vazão constante) de 1,5 L de meio em tempo variável conforme a condição estudada, e a simultânea recirculação da fase líquida $(0,3 \mathrm{~cm} / \mathrm{s})$. Ao término do ciclo, a recirculação é interrompida e, em seguida, inicia-se a descarga do reator. Assim, o ciclo é repetido, caracterizando as bateladas sequenciais.

Uma vez atingida a estabilidade nas condições experimentais, foram obtidos perfis ao longo do ciclo de operação de algumas das variáveis monitoradas. Nestes perfis foram retiradas amostras ao longo do tempo de operação de um ciclo. As variáveis de interesse 
foram: concentrações de matéria orgânica na forma filtrada, de alcalinidade a bicarbonato, de ácidos voláteis totais, de metabólitos intermediários (acetona, ácidos voláteis e álcoois), de biogás (composição e produção), além do pH. Desta forma, é possível obter uma melhor compreensão das rotas metabólicas ao longo de um ciclo. As amostras retiradas para obtenção dos perfis anteriormente citados foram colhidas em intervalos de 30 a 60 min ao longo do ciclo. O volume total retirado nas amostragens foi de, no máximo, $350 \mathrm{~mL}$, ou seja, $10 \%$ do volume de meio reacional do sistema. Após cada operação, amostras do lodo foram retiradas do reator para análise microbiológica. Dessa forma, uma nova condição experimental foi implementada alterando-se alguma condição experimental (proporção entre os substratos, concentração afluente, tempo de ciclo, tempo de enchimento ou temperatura).

Os resultados experimentais obtidos no monitoramento do sistema e nos perfis ao longo de um ciclo, em cada condição operacional, foram analisados considerando-se a influência das variáveis estudadas sobre a estabilidade, o desempenho (produtividade molar/volumétrica de metano ou hidrogênio em base volumétrica/específica), o fator de conversão (entre o metano ou hidrogênio produzido e a matéria orgânica consumida) e a relação entre hidrogênio, metano e dióxido de carbono formados.

\subsubsection{Ensaios para a produção de biometano (Fase I)}

Os ensaios para a produção de biometano compreendem uma única fase:

- Fase I: Reator operando com concentração afluente, tempo de ciclo e de enchimentos constantes (conforme Tabela 4.8) para a produção de metano (Bezerra et al., 2009 e Lovato et al., 2012). Essa fase foi feita com o objetivo de encontrar as melhores porcentagens de cada substrato para realizar a codigestão para produção de metano (Figura 4.6).

Tabela 4.8. Resumo das condições experimentais na Fase I.

\begin{tabular}{ccccccc}
\hline Ensaio & $\begin{array}{c}\text { Concentração } \\
\text { Afluente } \\
\left(\mathrm{mgDQO} . \mathrm{L}^{-1}\right)\end{array}$ & $\begin{array}{c}\text { Glicerina } \\
(\%)\end{array}$ & $\begin{array}{c}\text { Soro } \\
(\%)\end{array}$ & $\begin{array}{r}\text { Tempo de } \\
\text { Ciclo } \\
(\mathrm{h})\end{array}$ & $\begin{array}{c}\text { Tempo de } \\
\text { Enchimento }\end{array}$ & $\begin{array}{c}\text { Temperatura } \\
(\mathrm{h})\end{array}$ \\
\hline 1 & 5000 & 0 & 100 & 8,0 & 4,0 & 30 \\
2 & 5000 & 25 & 75 & 8,0 & 4,0 & 30 \\
3 & 5000 & 50 & 50 & 8,0 & 4,0 & 30 \\
4 & 5000 & 75 & 25 & 8,0 & 4,0 & 30 \\
5 & 5000 & 100 & 0 & 8,0 & 4,0 & 30 \\
\hline
\end{tabular}




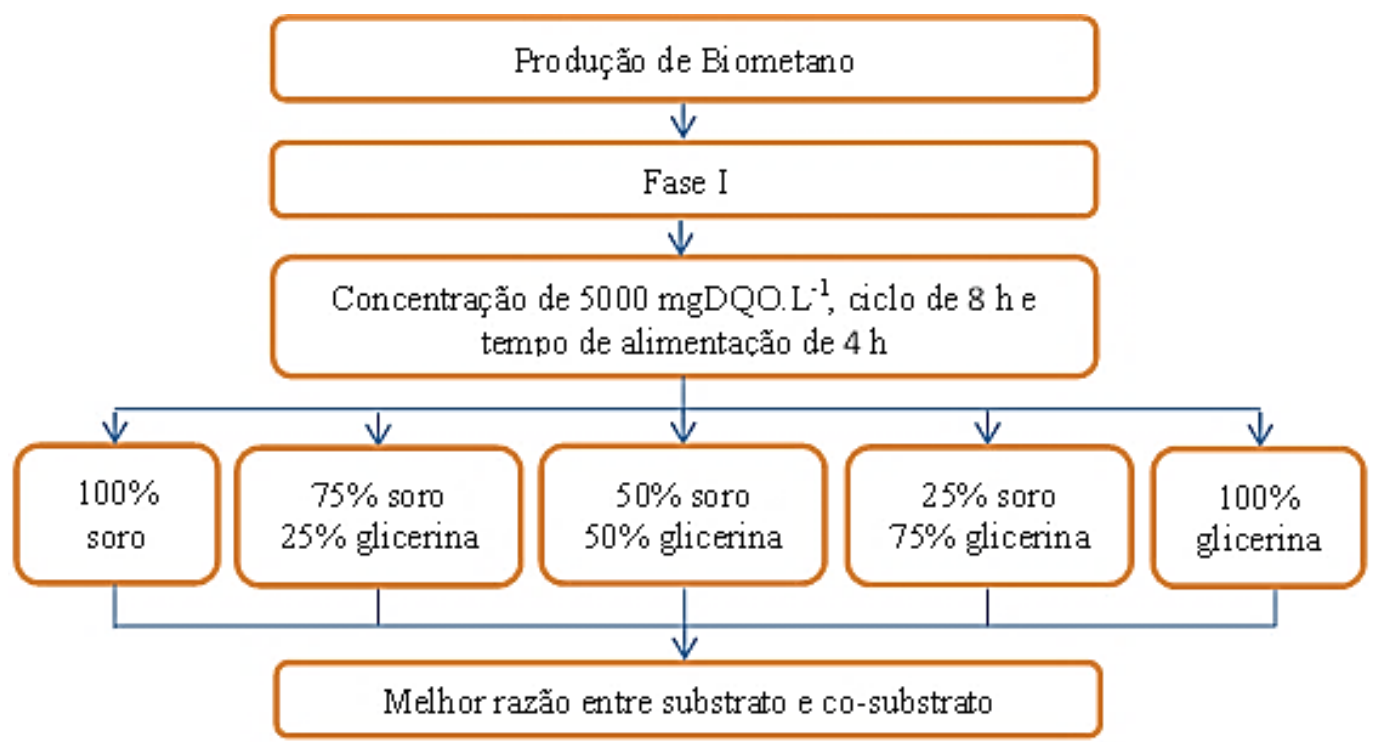

Figura 4.6. Fluxograma da fase para produção de Biometano.

\subsubsection{Ensaios para a produção de biohidrogênio (Fase II, III, IV e V)}

Os ensaios para a produção de biohidrogênio compreendem quatro fases:

- Fase II: Reator operando com concentração afluente, tempo de ciclo e de enchimentos constantes (conforme Tabela 4.9) para a produção de hidrogênio (Lovato et al., 2015). Essa fase foi feita com o objetivo de encontrar as melhores porcentagens de cada substrato (Figura 4.7);

- Fase III: Estudar a influência da concentração do afluente na produção de hidrogênio utilizando a melhor condição de codigestão encontrada na Fase II (conforme Tabela 4.10 e Figura 4.7);

- Fase IV: Estudar a influência do tempo de ciclo e do tempo de enchimento na produção de hidrogênio utilizando as melhores condições de codigestão encontradas nas Fase II e III (conforme Tabela 4.11 e Figura 4.7);

- Fase V: Estudar a influência da temperatura na produção de hidrogênio utilizando as melhores condições de codigestão encontradas na Fase II, III e IV (conforme Tabela 4.12 e Figura 4.7). 
Tabela 4.9. Resumo das condições experimentais na Fase II.

\begin{tabular}{|c|c|c|c|c|c|c|}
\hline Ensaio & $\begin{array}{c}\text { Concentração } \\
\text { Afluente } \\
\left(\mathrm{mgDQO} \mathrm{L}^{-1}\right)\end{array}$ & $\begin{array}{c}\text { Glicerina } \\
(\%)\end{array}$ & $\begin{array}{l}\text { Soro } \\
(\%)\end{array}$ & $\begin{array}{c}\text { Tempo de } \\
\text { Ciclo } \\
\text { (h) }\end{array}$ & $\begin{array}{c}\text { Tempo de } \\
\text { Enchimento } \\
\text { (h) }\end{array}$ & $\begin{array}{c}\text { Temperatura } \\
\left({ }^{\circ} \mathrm{C}\right)\end{array}$ \\
\hline 6 & 5000 & 0 & 100 & 3,0 & 1,5 & 30 \\
\hline 7 & 5000 & 25 & 75 & 3,0 & 1,5 & 30 \\
\hline 8 & 5000 & 50 & 50 & 3,0 & 1,5 & 30 \\
\hline 9 & 5000 & 75 & 25 & 3,0 & 1,5 & 30 \\
\hline 10 & 5000 & 100 & 0 & 3,0 & 1,5 & 30 \\
\hline
\end{tabular}

Tabela 4.10. Resumo das condições experimentais na Fase III.

\begin{tabular}{ccccccc}
\hline Ensaio & $\begin{array}{c}\text { Concentração } \\
\text { Afluente } \\
\left(\mathrm{mgDQO} \mathrm{L}^{-1}\right)\end{array}$ & $\begin{array}{c}\text { Glicerina } \\
(\%)\end{array}$ & $\begin{array}{c}\text { Soro } \\
(\%)\end{array}$ & $\begin{array}{c}\text { Tempo de } \\
\text { Ciclo } \\
(\mathrm{h})\end{array}$ & $\begin{array}{c}\text { Tempo de } \\
\text { Enchimento }\end{array}$ & $\begin{array}{c}\text { Temperatura } \\
(\mathrm{h})\end{array}$ \\
\hline 11 & 3000 & $(\%)_{\text {ótima }}$ & $(\%)_{\text {ótima }}$ & 3,0 & 1,5 & 30 \\
12 & 7000 & $(\%)_{\text {ótima }}$ & $(\%)_{\text {ótima }}$ & 3,0 & 1,5 & 30 \\
\hline
\end{tabular}

* $(\%)_{\text {ótima }}$ foi igual a melhor porcentagem de glicerina e soro encontrada na Fase II.

Tabela 4.11. Resumo das condições experimentais na Fase IV.

\begin{tabular}{|c|c|c|c|c|c|c|}
\hline Ensaio & $\begin{array}{c}\text { Concentração } \\
\text { Afluente } \\
\left(\mathrm{mgDQO} . \mathrm{L}^{-1}\right)\end{array}$ & $\begin{array}{c}\text { Glicerina } \\
(\%)\end{array}$ & $\begin{array}{l}\text { Soro } \\
(\%)\end{array}$ & $\begin{array}{l}\text { Tempo de } \\
\text { Ciclo } \\
\text { (h) }\end{array}$ & $\begin{array}{c}\text { Tempo de } \\
\text { Enchimento } \\
\text { (h) }\end{array}$ & $\begin{array}{c}\text { Temperatura } \\
\left({ }^{\circ} \mathrm{C}\right)\end{array}$ \\
\hline 13 & $\mathrm{C}_{\text {ótima }}$ & (\%)ótima & (\%)ótima & 4,0 & 2,0 & 30 \\
\hline 14 & Cótima & (\%)ótima & (\%)ótima & 2,0 & 1,0 & 30 \\
\hline 15 & Cótima & (\%)ótima & (\%)ótima & 3,0 & 0,2 & 30 \\
\hline
\end{tabular}

* $\quad \mathrm{C}_{\text {ótima }}$ foi igual a melhor concentração do afluente encontrada na Fase III;

(\%)ótima foi igual a melhor porcentagem de glicerina e soro encontrada na Fase II.

Tabela 4.12. Resumo das condições experimentais na Fase V.

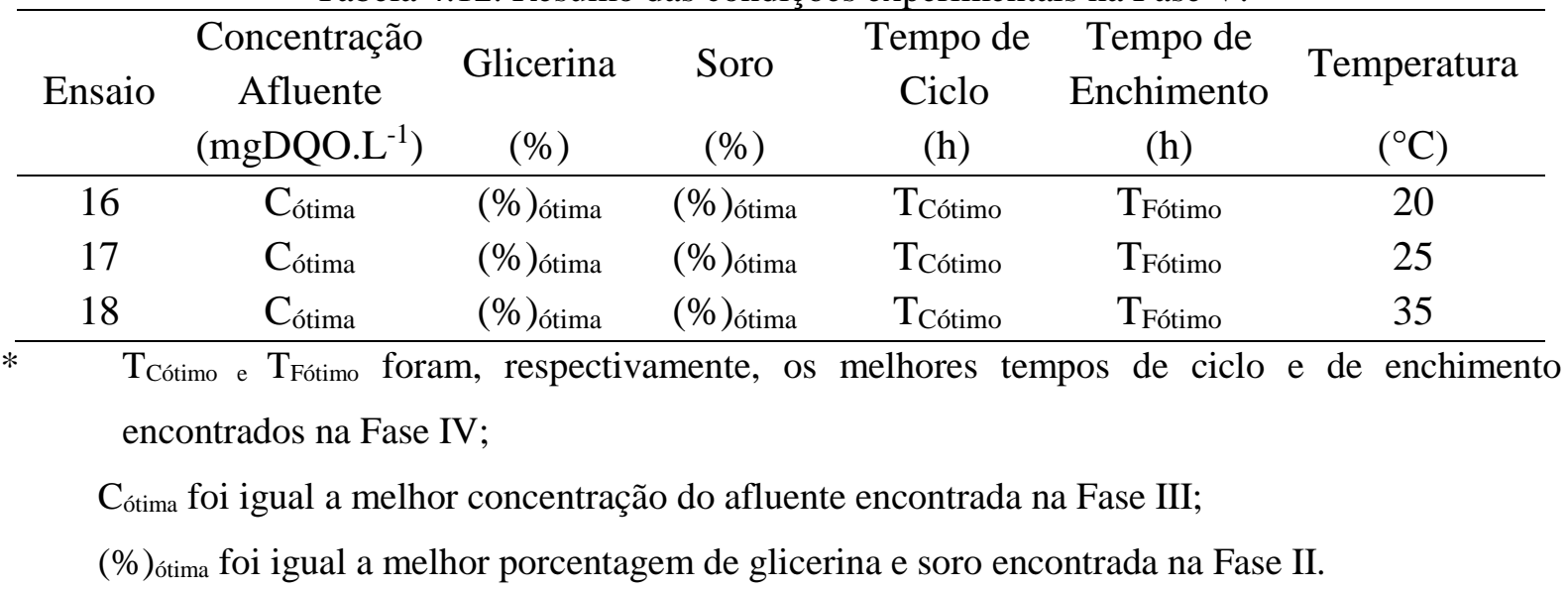




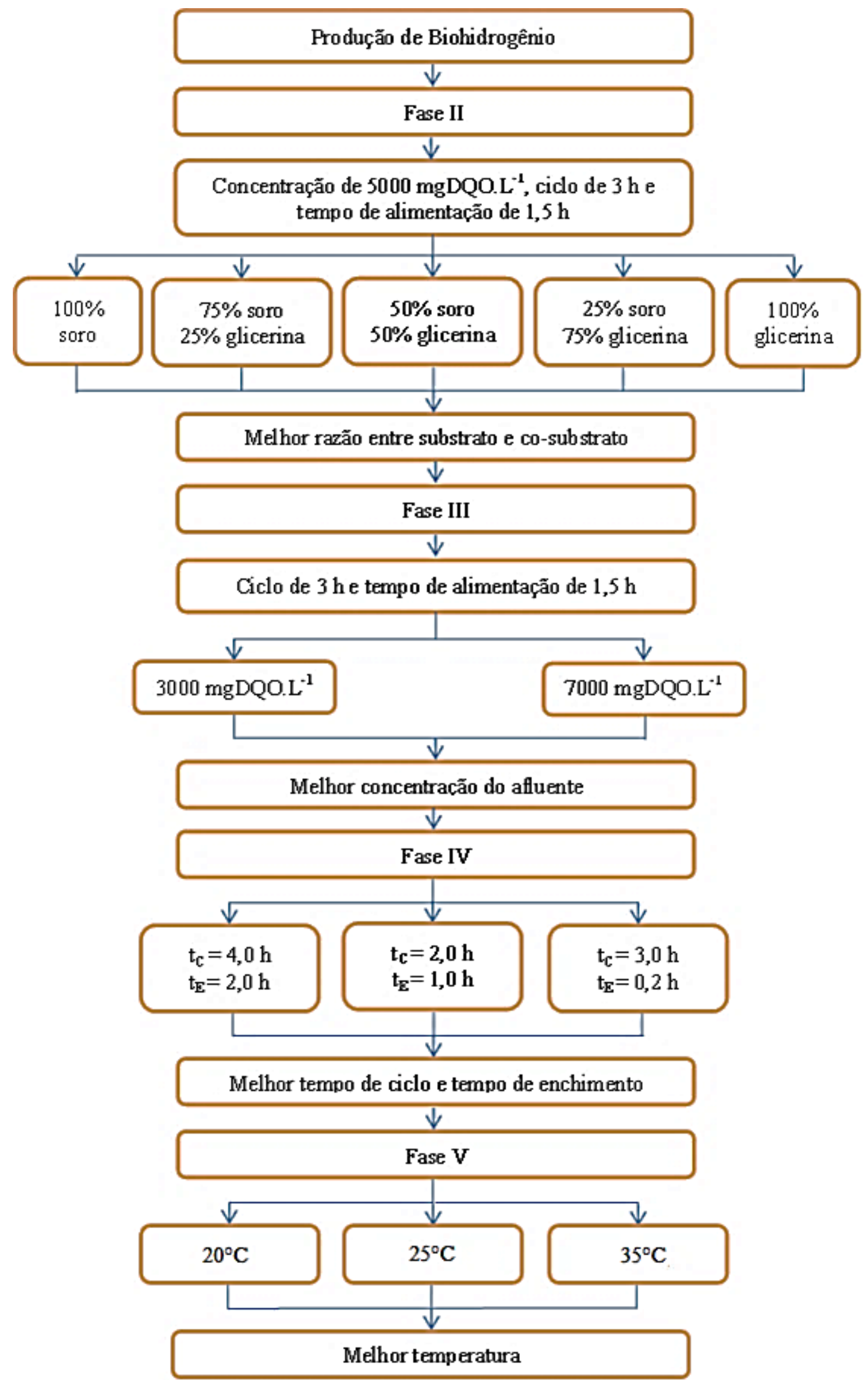

Figura 4.7. Fluxograma das Fases para produção de Biohidrogênio 


\subsubsection{Lavagem do material suporte}

A partir da Fase II, que são as fases de operação do AnSBBR para produzir biohidrogênio, foram realizadas lavagem sistemáticas (uma vez por semana) do material suporte buscando um melhor controle do crescimento da biomassa. O objetivo deste procedimento é estabelecer um protocolo experimental de retirada desta biomassa que é gerada durante a operação do sistema, sendo este crescimento celular devido às características metabólicas dos microrganismos acidogênicos e à alta carga orgânica aplicada/removida (cinética de crescimento). Desta forma o intuito é melhorar a estabilidade e a eficiência do processo de produção de biohidrogênio.

O primeiro passo do procedimento foi descarregar todo o meio líquido contido no reator, medindo-se o volume e os sólidos totais e voláteis totais $\left(\mathrm{m}_{\mathrm{BL} 1}\right)$. Após, retirou-se todo o suporte inerte juntamente com a biomassa contidos dentro do reator, medindo-se a massa total. Uma pequena amostra desta massa foi retirada com o intuito de calcular os valores de $\mathrm{C}_{\mathrm{X}}$ e de $\mathrm{C}_{\mathrm{X}}$ ' (indicadores da quantidade de biomassa por volume de meio reacional e por massa de material suporte, respectivamente) antes da lavagem do material suporte, de acordo com metodologia descrita anteriormente.

O passo seguinte foi realizar a lavagem propriamente dita do sistema "suporte inerte + bimassa", adicionando-se 1 litro de água de torneira e separando-se a água da lavagem do material suporte com o auxílio de uma peneira. Uma amostra de $50 \mathrm{~mL}$ foi retirada desta água de lavagem para análise de sólidos totais e voláteis totais no intuito de calcular a biomassa removida do sistema (m $\left.\mathrm{m}_{\mathrm{BL} 2}\right)$.

A quantidade de biomassa removida com a lavagem (em gSVT) foi a soma de mBL1 (calculado multiplicando a concentração em SVT.L ${ }^{-1}$ pelo volume de líquido descarregado do reator) com $\mathrm{m}_{\mathrm{BL} 2}$ (calculado multiplicando a concentração em SVT.L $\mathrm{L}^{-1}$ pelo volume de água usado para lavar o sistema "suporte inerte + biomassa", ou seja, 1 litro). Sabendo os valores de $\mathrm{C}_{X}$ e de $\mathrm{C}_{X}$ ' em lavagens consecutivas é possível realizar uma comparação e analisar se a biomassa retornou à quantidade antes da lavagem e se foi possível controlar seu valor. 


\section{RESULTADOS E DISCUSSÃO}

A seguir serão discutidos e analisados os resultados obtidos em todas as etapas experimentais desde projeto.

\subsection{FASE I - PRODUÇÃO DE BIOMETANO}

A Fase I compreendeu os ensaios de 1 a 5 e teve como objetivo encontrar a melhor razão de mistura entre o soro e a glicerina para a produção de metano. Todos os ensaios foram operados com concentração afluente de $5000 \mathrm{mgDQO} . \mathrm{L}^{-1}$, tempo de ciclo igual a 8 h e tempo de alimentação igual a $4 \mathrm{~h}\left(\mathrm{COAV}\right.$ nominal de 7,5 gDQO.L $\left.\mathrm{L}^{-1} \cdot \mathrm{d}^{-1}\right)$.

A montagem do reator, a partida da operação e todo o período até a estabilidade do sistema ser atingida foram considerados como etapa preliminar. Esse período foi utilizado também para a preparação das curvas de calibração dos métodos analíticos (DQO, Carboidratos, Glicerina, alcalinidade e ácidos voláteis totais) e ajuste dos detalhes referente ao procedimento experimental.

Como é característica para sistemas metanogênicos, o reator foi iniciado com uma concentração de apenas 1000 mgDQO.L ${ }^{-1}$ (água residuária a base de soro) para adaptação do inóculo. A concentração do afluente foi aumentada dia-a-dia conforme se verificava a estabilidade do sistema, ou seja, uma variação média dentro da precisão das medidas efetuadas e, após 23 dias da partida do sistema, o Ensaio 1 foi iniciado.

\subsubsection{Ensaio 1 (100\% Soro - $\left.5000 \mathrm{mgDQO} . \mathrm{L}^{-1}-8 \mathrm{~h}-\mathrm{BA}\right)$}

O valor real da COAV para o Ensaio 1 foi de 7,5 gDQO.L ${ }^{-1} \cdot \mathrm{d}^{-1}$ e a CORV atingida foi de 6,7 gDQO. $\mathrm{L}^{-1} \cdot \mathrm{d}^{-1}$, o que representa uma boa remoção e é coerente com os resultados esperados para um reator metanogênico. Isso representou uma COAV de 5,3 gCarboidratos. $\mathrm{L}^{-1} \cdot \mathrm{d}^{-1}$ que foi completamente removida (CORV 5,3 gCarboidratos. $\mathrm{L}^{-1} \cdot \mathrm{d}^{-1}$ ). A Tabela 5.1 apresenta a média dos parâmetros monitorados.

O monitoramento diário apresentou um bom consumo de matéria orgânica na forma de DQO, com média de concentração afluente não filtrada de $4934 \mathrm{mgDQO} . \mathrm{L}^{-1}$, efluente não filtrada $823 \mathrm{mgDQO} . \mathrm{L}^{-1}$ e de efluente filtrada de $500 \mathrm{mgDQO} . \mathrm{L}^{-1}$, o que representa um bom rendimento em relação a esse parâmetro, com remoção média para amostras não filtradas de $83 \%$ e para amostras filtradas de $90 \%$ (Figura 5.1). 
Tabela 5.1. Parâmetros médios monitorados no Ensaio 1.

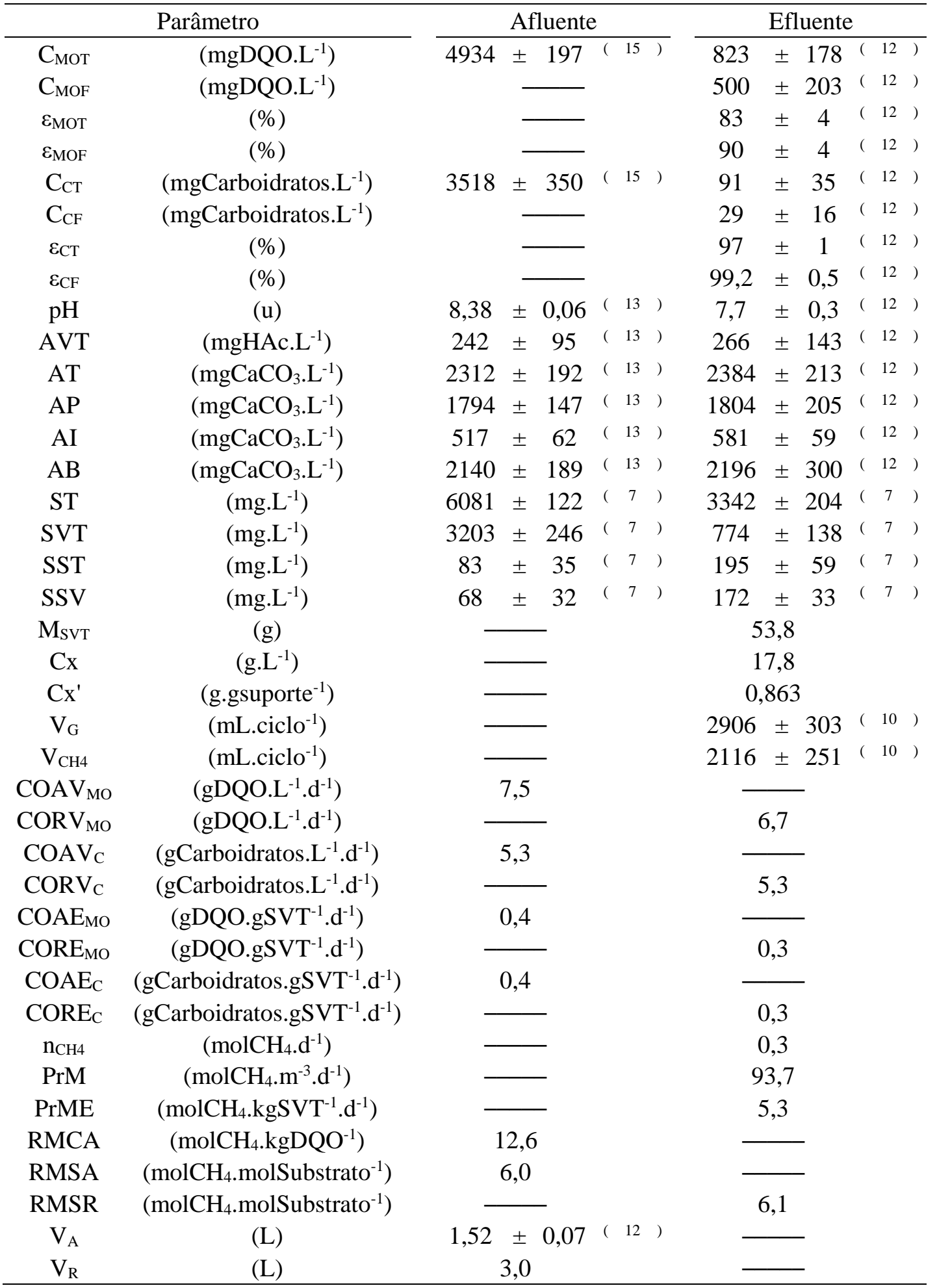

(*) Entre parênteses o número de amostras considerado no cálculo da média 

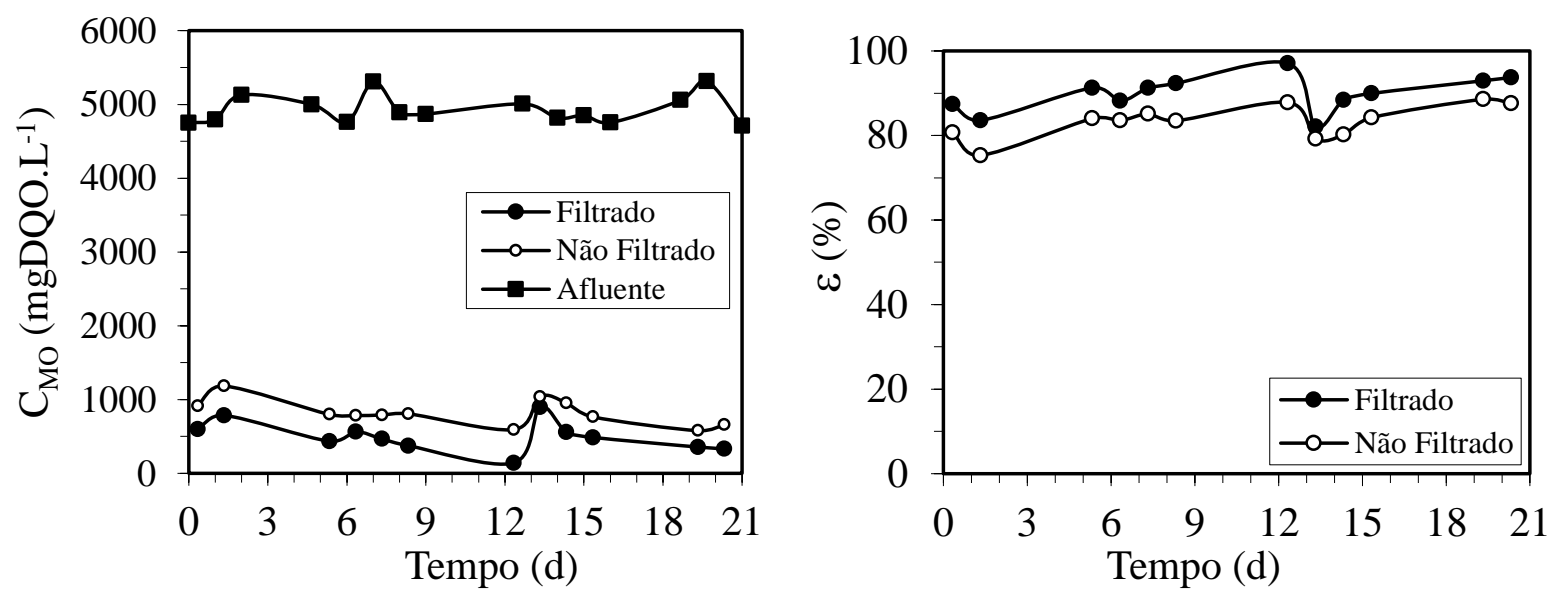

Figura 5.1. Concentração de matéria orgânica e eficiências de remoção na forma de DQO no Ensaio 1: - - afluente amostras não filtradas; • - efluente amostras não filtradas; ○ - efluente amostras filtradas.

Em relação ao monitoramento diário de carboidratos, o mesmo apresentou um excelente

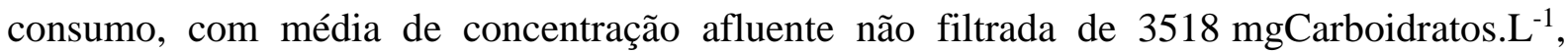

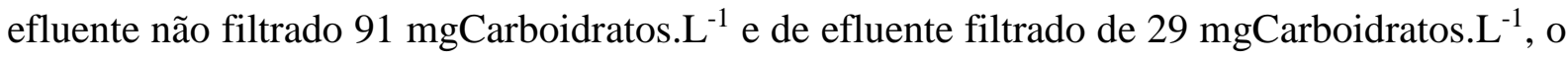
que representa eficiência média de remoção para amostras não filtradas de $97 \%$ e para amostras filtradas de 99,2\% (Figura 5.2).
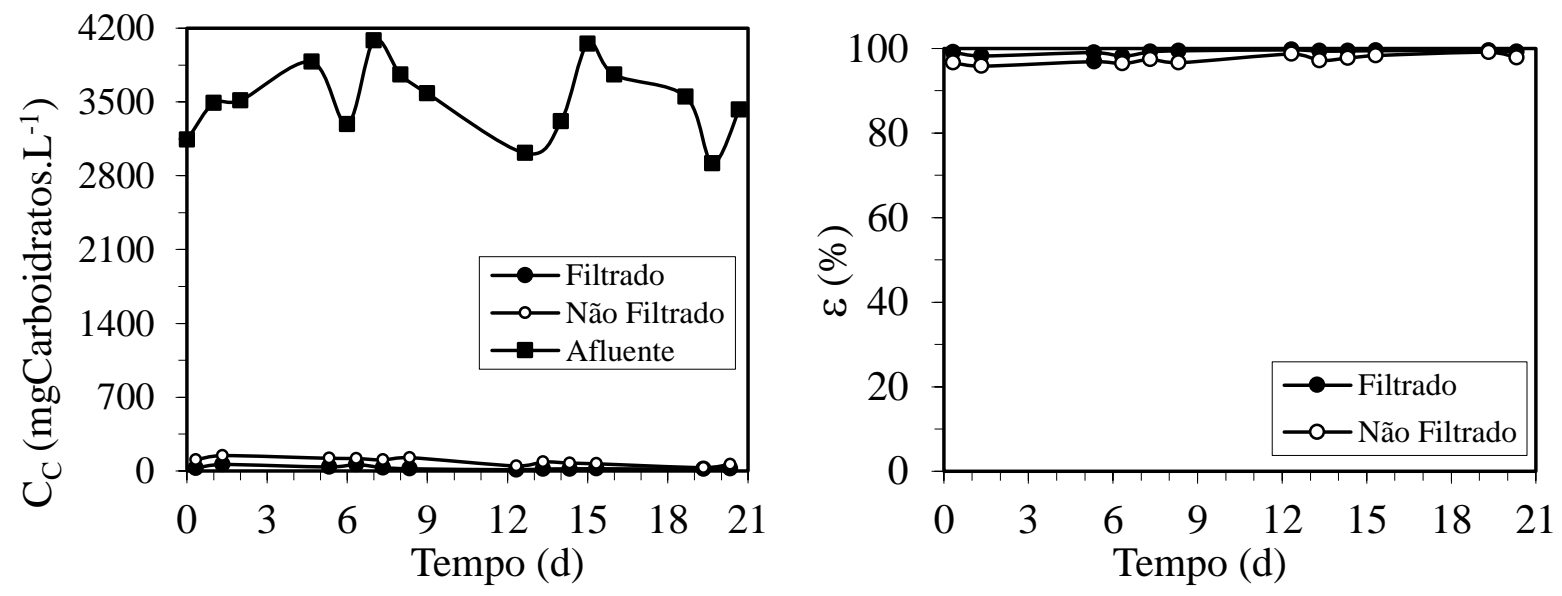

Figura 5.2. Concentração e eficiências de remoção de carboidratos no Ensaio 1: - - afluente amostras não filtradas; • - efluente amostras não filtradas; ○ - efluente amostras filtradas.

A média do $\mathrm{pH}$ afluente foi de 8,38 e do efluente de 7,7. A alcalinidade a bicarbonato do afluente teve média de $2140 \mathrm{mgCaCO}_{3} \cdot \mathrm{L}^{-1}$ sendo que a mesma se manteve no efluente com uma média de $2196 \mathrm{mgCaCO}_{3} \cdot \mathrm{L}^{-1}$. A média de AVT do afluente foi de $242 \mathrm{mgHAc} . \mathrm{L}^{-1}$ e a média de AVT do efluente de 266 mgHAc. $\mathrm{L}^{-1}$. Devido à grande degradabilidade do soro, houve instabilidade no monitoramento dos ácidos voláteis, mas essa questão foi resolvida com a adição da glicerina, como será visto mais adiante. 
A produção de biogás, em aspecto quantitativo, e a distribuição dos gases que compõem o biogás no final do ciclo podem ser observadas pela Figura 5.3, com média de $2906 \mathrm{~mL}$ de biogás e $2116 \mathrm{~mL}$ de metano, sendo que a porcentagem média de metano foi igual a $73 \%$.
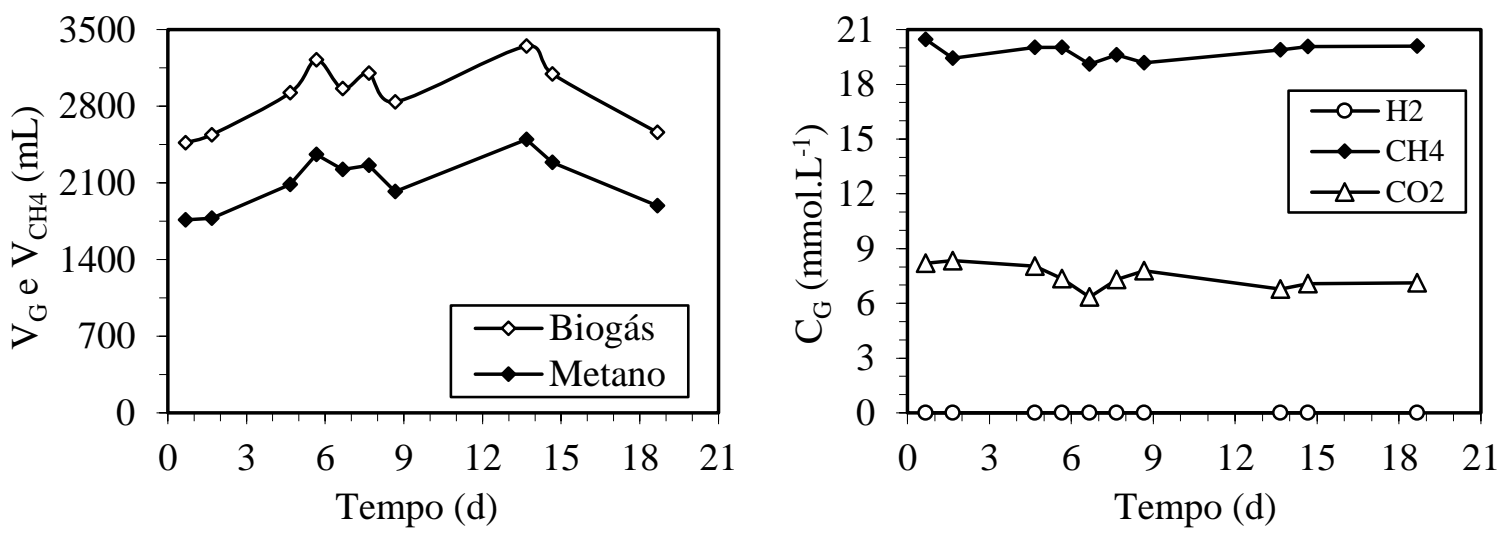

Figura 5.3. Volume de biogás $\left(\mathrm{V}_{\mathrm{G}}\right)$ e de metano $\left(\mathrm{V}_{\mathrm{CH} 4}\right)$ nas $\mathrm{CNTP}$ e concentrações dos componentes do

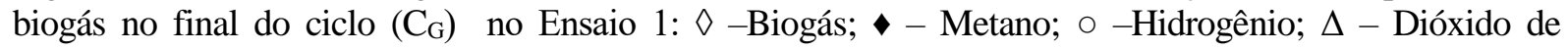
Carbono.

Após a estabilização dos parâmetros monitorados, foram realizados perfis ao longo do ciclo para que fosse feita uma análise de comportamento durante o consumo do substrato. A Figura 5.4 apresenta o perfil de DQO e de Carboidratos; nota-se que há grandes variações na medida de DQO durante o ciclo, com seu ponto máximo sendo atingido nas 4 h (que é quando a alimentação do afluente termina) e, o período seguinte, há apenas o consumo da mesma, como era esperado. Em relação aos carboidratos, há uma baixa variação, indicando que o consumo do mesmo ocorre rapidamente assim que o afluente entra no sistema. A diferença entre os dois perfis é explicada pela formação e consumo de ácidos que ocorrem durante o processo.
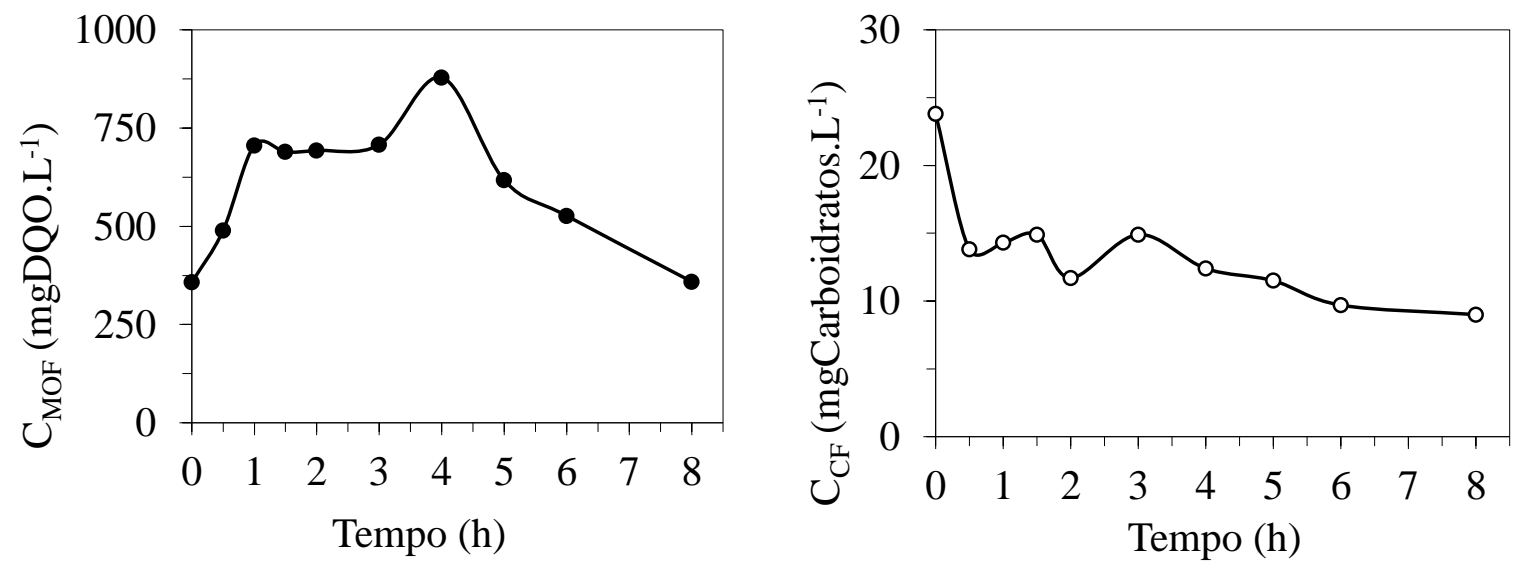

Figura 5.4. Concentração de matéria orgânica e de carboidratos durante o ciclo no Ensaio 1: • - $\mathrm{C}_{\mathrm{SF}}$; 0 $-\mathrm{C}_{\mathrm{CF}}$. 
A Figura 5.5 apresenta os perfis de $\mathrm{pH}$, alcalinidade a bicarbonato e ácidos voláteis totais ao longo do ciclo. $\mathrm{O}$ pH permanece constante ao longo do ciclo por volta de 7,7, devido à presença da alcalinidade que é fornecida gradualmente pelo afluente e se mantém pelo processo.
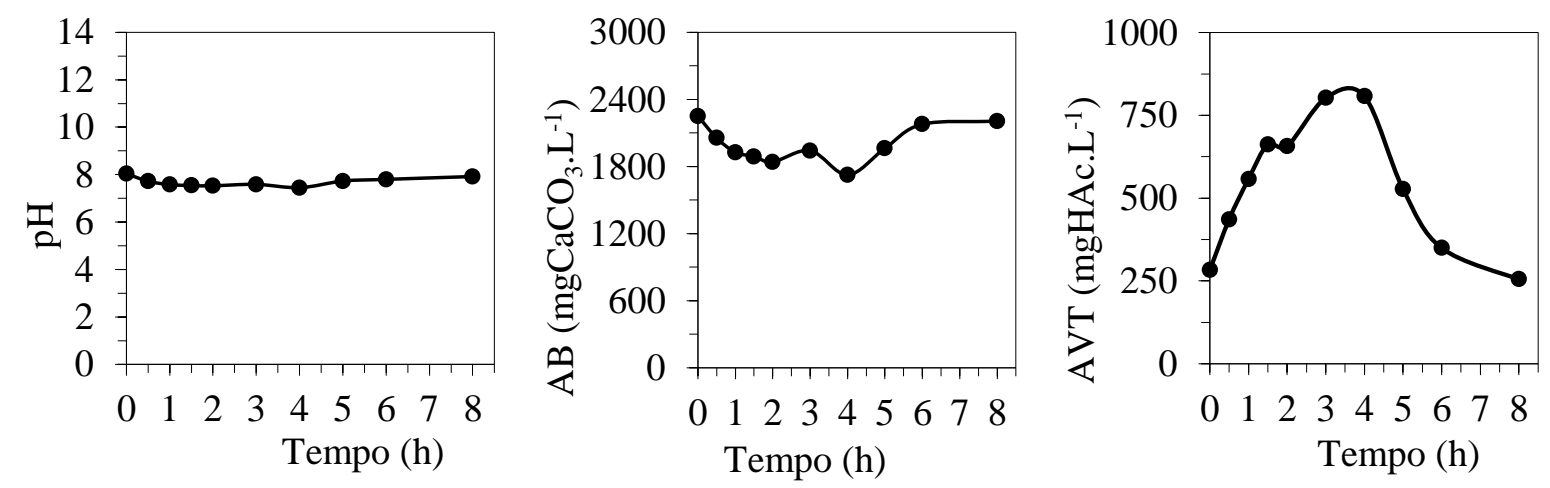

Figura 5.5. Valores de pH, alcalinidade a bicarbonato $(\mathrm{AB})$ e ácidos voláteis totais (AVT) no Ensaio 1.

O perfil dos compostos intermediários do metabolismo é apresentado na Figura 5.6. É possível verificar que há a produção dos mesmos enquanto o afluente é alimentado (primeiras 4 h do ciclo) e, depois do término da alimentação, há o consumo desses compostos para a produção de metano. Os ácidos voláteis intermediários com maiores concentrações molares foram o ácido acético e o ácido propiônico.

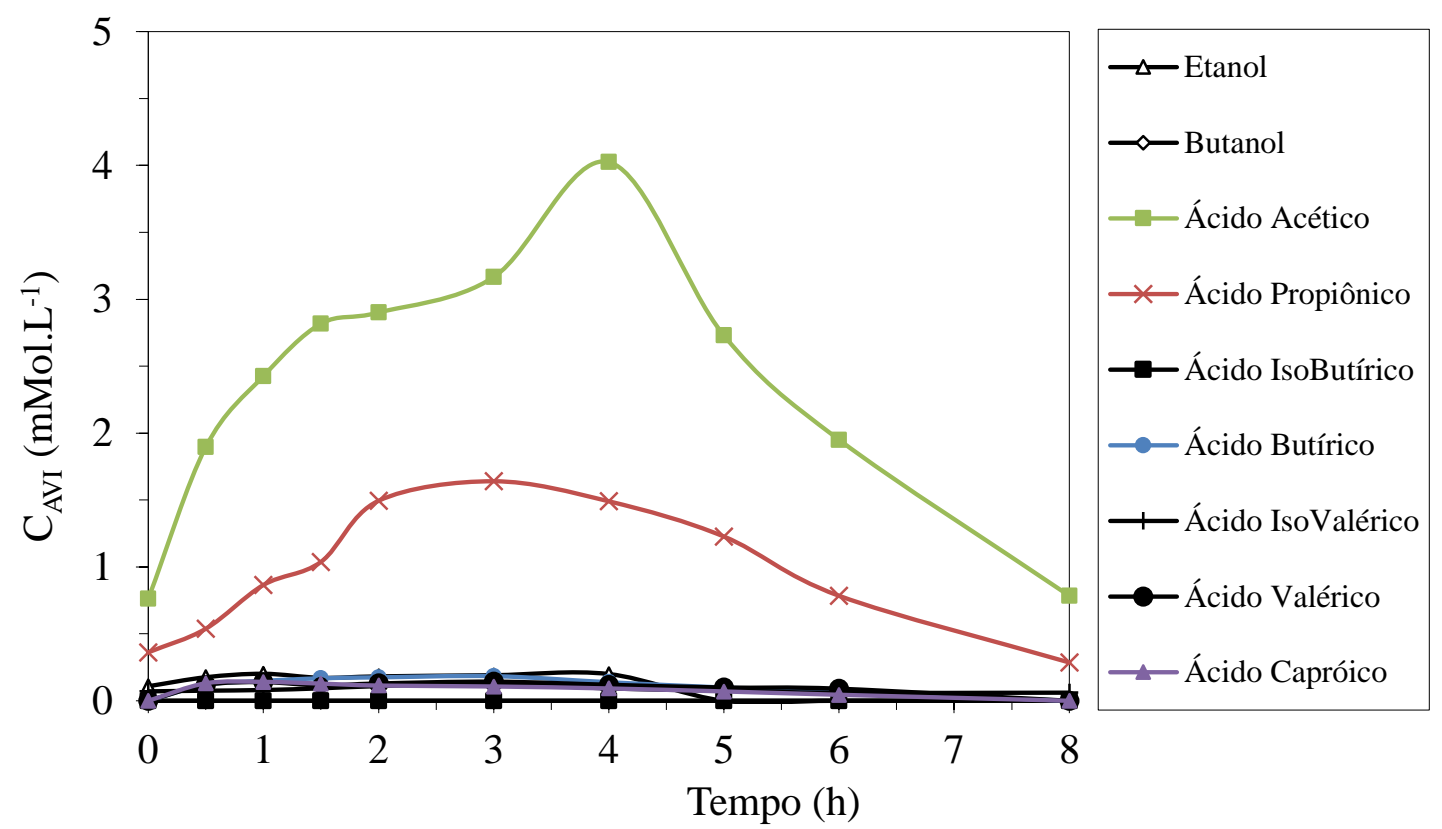

Figura 5.6. Concentração dos compostos intermediários ao longo do ciclo no Ensaio 1: $\Delta$ - etanol; $\diamond$ butanol; - - ácido acético ; -x-ácido propiônico; - ácido isobutírico; • - ácido butírico; + ácido isovalérico $\bullet$ - ácido valérico; $\Delta$ - ácido capróico. 
A produção volumétrica acumulada de biogás e os desvios padrões de cada um dos pontos podem ser observados na Figura 5.7 e o perfil das concentrações de cada um dos gases e suas respectivas porcentagens podem ser observados na Figura 5.8. Houve baixa variação no volume de gás recolhido diariamente em relação à média desse parâmetro e, ao final do ensaio, tinha-se $27 \%$ de $\mathrm{CO}_{2}$ e $73 \%$ de $\mathrm{CH}_{4}$.

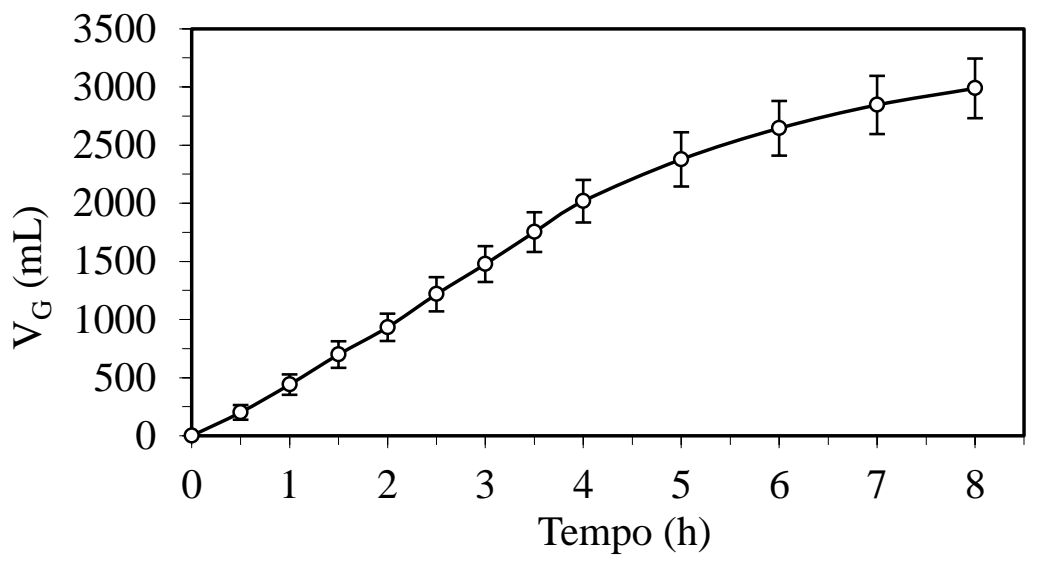

Figura 5.7. Produção volumétrica média acumulada do biogás durante o ciclo no Ensaio 1.
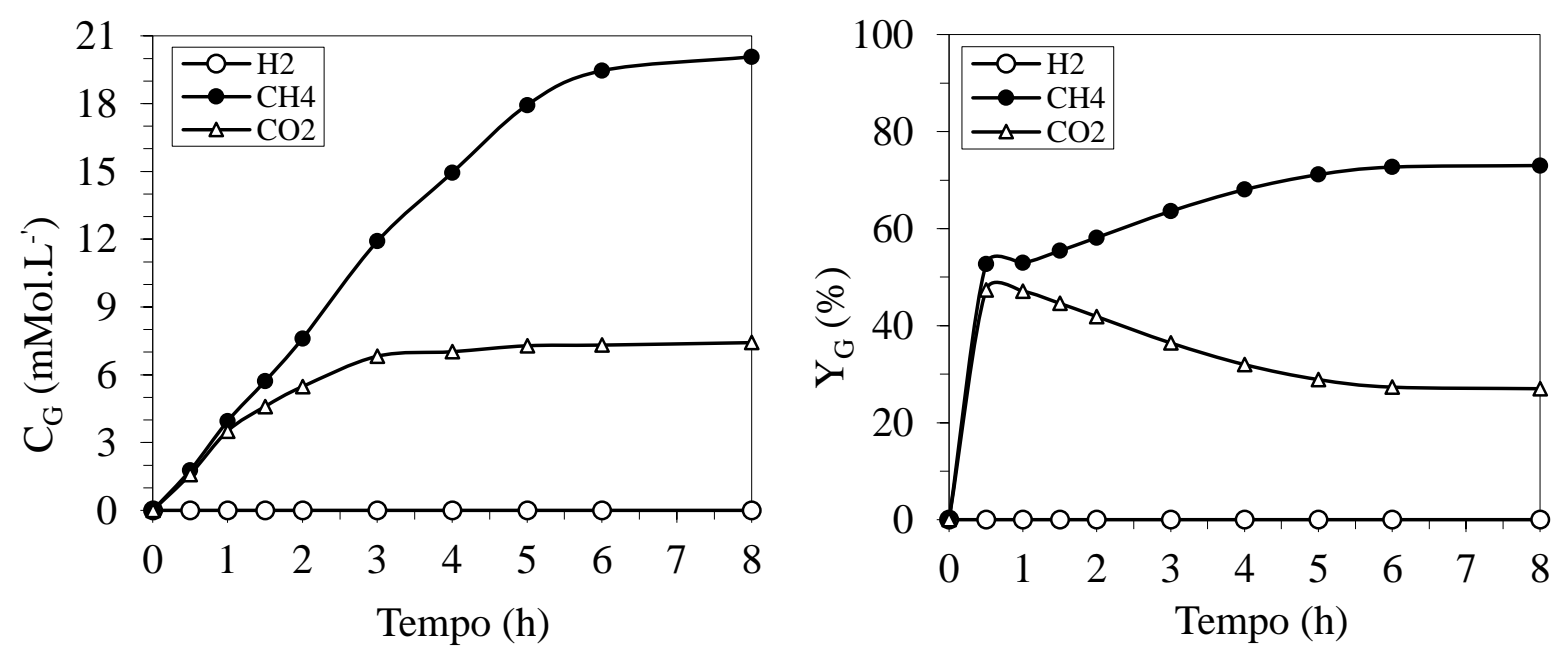

Figura 5.8. Concentração dos compostos do biogás durante o ciclo e suas respectivas porcentagens no Ensaio 1: $\circ-\mathrm{H}_{2} ; \bullet-\mathrm{CH}_{4} ; \Delta-\mathrm{CO}_{2}$. 


\subsubsection{Ensaio 2 (75\% Soro e 25\% Glicerina - $\left.5000 \mathrm{mgDQO} . \mathrm{L}^{-1}-8 \mathrm{~h}-\mathrm{BA}\right)$}

O Ensaio 2 representa a primeira condição realizada com codigestão. Neste ensaio, o afluente foi feito contendo $75 \%$, em base de DQO, de soro e $25 \%$ de glicerina. O valor real da COAV foi de 7,7 gDQO.L $\mathrm{L}^{-1} \cdot \mathrm{d}^{-1}$ e a CORV atingida foi de $6,8 \mathrm{gDQO} . \mathrm{L}^{-1} \cdot \mathrm{d}^{-1}$, novamente, o sistema apresentou uma boa remoção de matéria orgânica.

Adicionar $75 \%$ da DQO total em soro, significou que o afluente teve, em média, $2448 \mathrm{mgCarboidratos} . \mathrm{L}^{-1}$ e $421 \mathrm{mgGlicerina.} \mathrm{L}^{-1}$. Lembrando que a glicerina utilizada nos ensaios focados na produção de biometano foi separada de biodiesel produzido em laboratório. A Tabela 5.2 apresenta a média dos parâmetros monitorados.

O monitoramento diário apresentou um bom consumo de matéria orgânica na forma de DQO, com média de concentração afluente não filtrada de $5077 \mathrm{mgDQO} . \mathrm{L}^{-1}$, efluente não filtrada $816 \mathrm{mgDQO} . \mathrm{L}^{-1}$ e de efluente filtrada de $576 \mathrm{mgDQO} . \mathrm{L}^{-1}$, o que representa um bom rendimento em relação a esse parâmetro, com remoção média para amostras não filtradas de $84 \%$ e para amostras filtradas de $89 \%$ (Figura 5.9) - valores próximos aos obtidos no Ensaio 1.

Em relação ao monitoramento diário de carboidratos, o mesmo novamente apresentou um excelente consumo, com média de concentração afluente não filtrada de $2448 \mathrm{mgCarboidratos.} \mathrm{L}^{-1}$, efluente não filtrado $30 \mathrm{mgCarboidratos.} \mathrm{L}^{-1}$ e de efluente filtrado 10 mgCarboidratos. $\mathrm{L}^{-1}$, o que representa eficiência média de remoção para amostras não filtradas de 98,8\% e para amostras filtradas de 99,6\% (Figura 5.10).

Neste ensaio houve também o monitoramento diário de glicerina, que apresentou média de concentração afluente não filtrada de $421 \mathrm{mgGlicerina} . \mathrm{L}^{-1}$, efluente não filtrado $17 \mathrm{mgGlicerina} . \mathrm{L}^{-1}$ e de efluente filtrado de $7 \mathrm{mgGlicerina} . \mathrm{L}^{-1}$, o que representa uma eficiência média de remoção para amostras não filtradas de 96,0\% e para amostras filtradas de 98,2\% (Figura 5.11).

A média do $\mathrm{pH}$ afluente foi de 8,51 e do efluente de 7,4. A alcalinidade a bicarbonato no afluente teve média de $1905 \mathrm{mgCaCO}_{3} \cdot \mathrm{L}^{-1}$ sendo que a mesma praticamente se manteve no efluente com uma média de $1766 \mathrm{mgCaCO}_{3} \cdot \mathrm{L}^{-1}$. A média de AVT no afluente foi de 132 mgHAc. $L^{-1}$ e a média de AVT no efluente de 325 mgHAc.L ${ }^{-1}$. Devido à adição de glicerina, os ácidos voláteis do afluente apresentaram uma estabilidade maior do que os AVT monitorados no afluente do Ensaio 1. 
Tabela 5.2. Parâmetros médios monitorados no Ensaio 2.

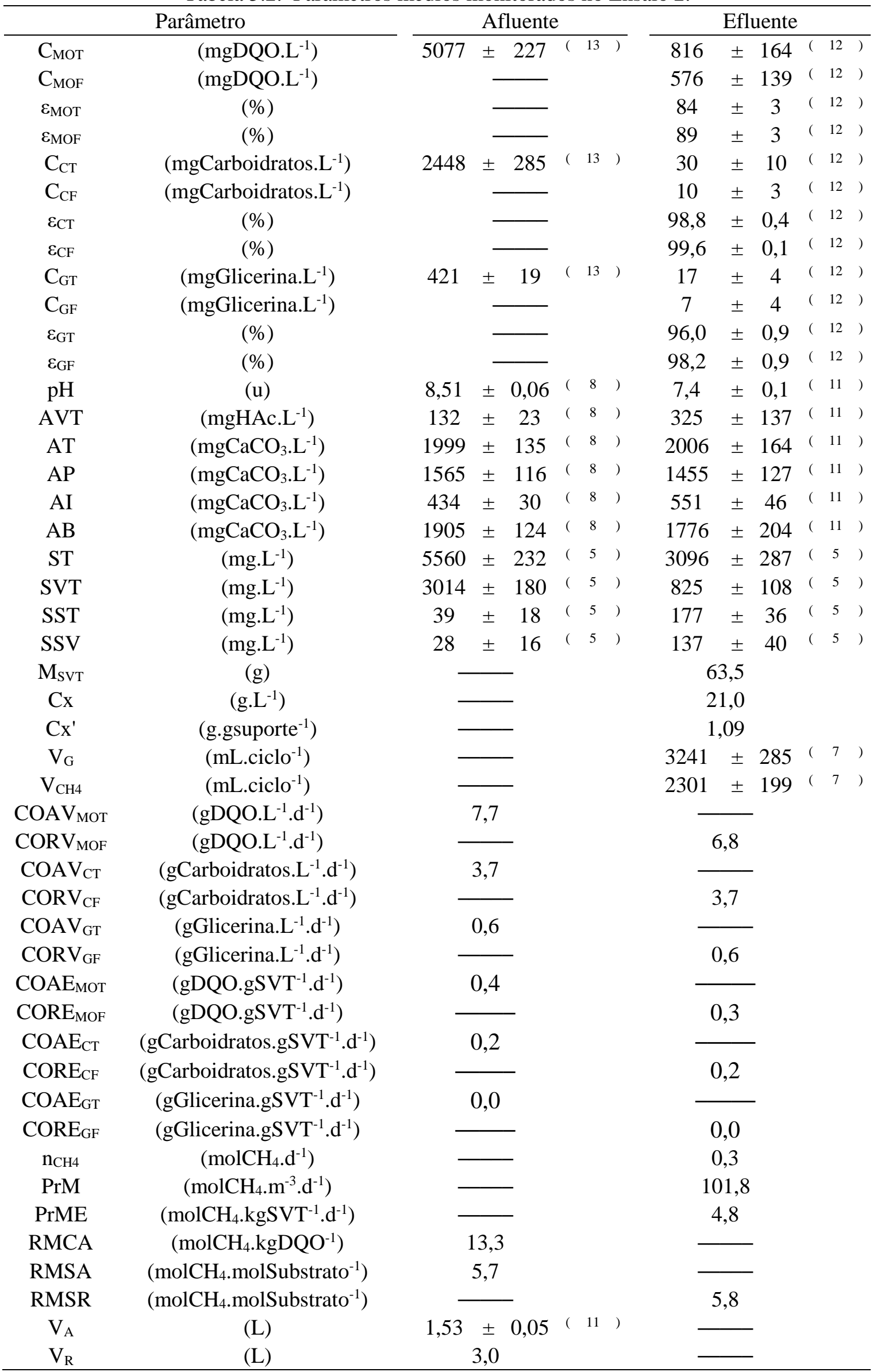

(*) Entre parênteses o número de amostras considerado no cálculo da média 

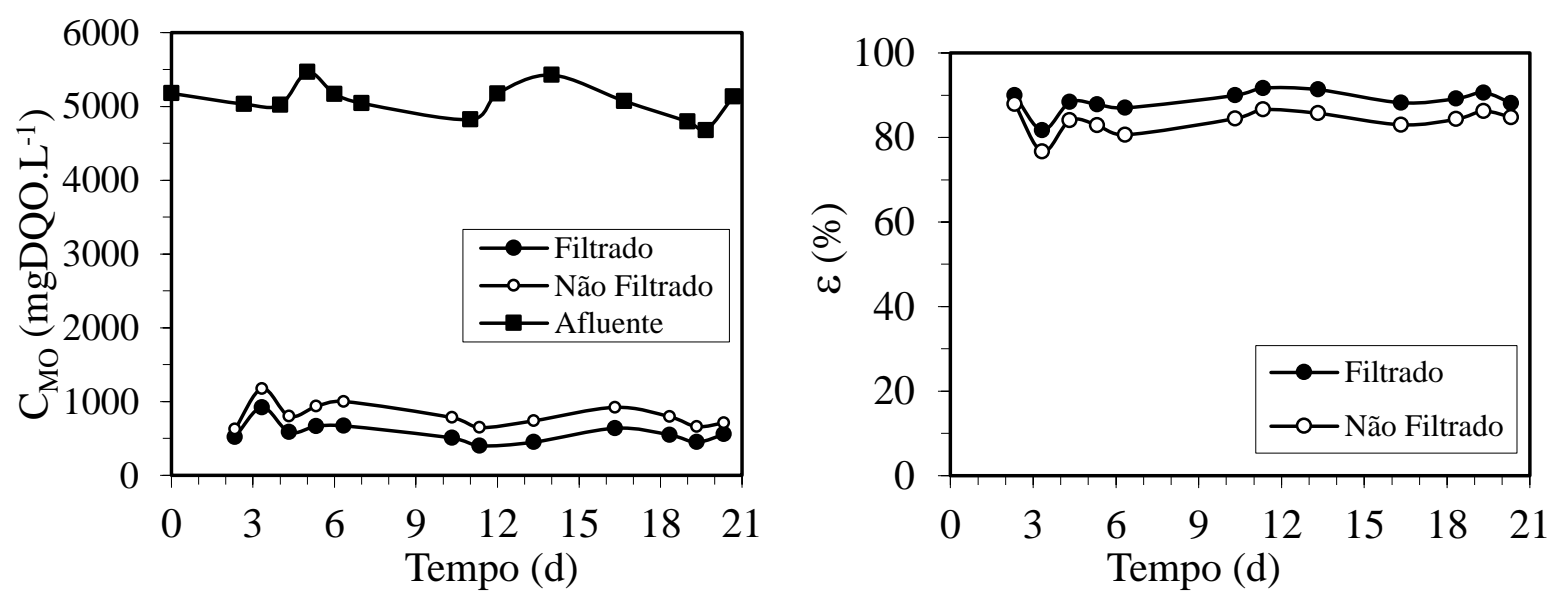

Figura 5.9. Concentração e eficiência de remoção de matéria orgânica na forma de DQO no Ensaio 2: - - afluente amostras não filtradas; • - efluente amostras não filtradas; ○ - efluente amostras filtradas.
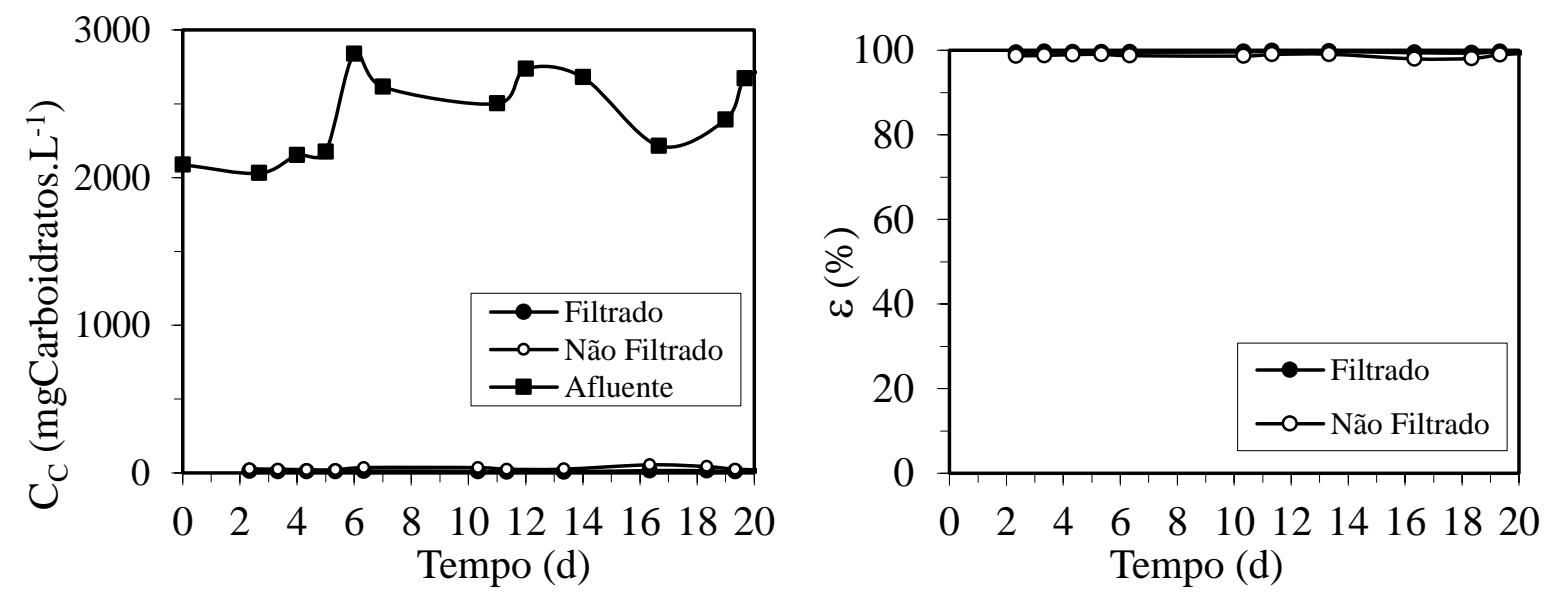

Figura 5.10. Concentração e eficiência de remoção na forma de carboidratos no Ensaio 2: a - afluente amostras não filtradas; $\bullet$ - efluente amostras não filtradas; $\bigcirc-$ efluente amostras filtradas.
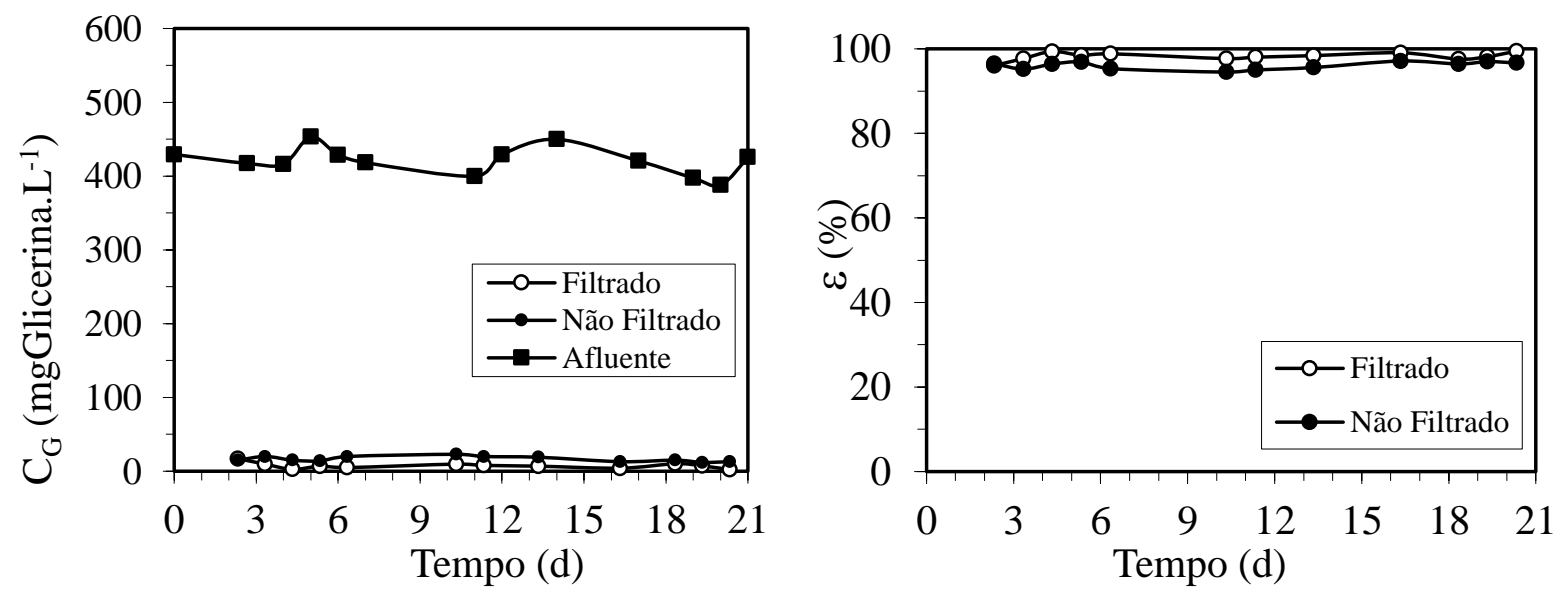

Figura 5.11. Concentração e eficiência de remoção na forma de glicerina no Ensaio 2: - - afluente amostras não filtradas; • - efluente amostras não filtradas; ○ - efluente amostras filtradas. 
A produção de biogás, em aspecto quantitativo, e a distribuição dos gases que compõem o biogás no final do ciclo podem ser observadas pela Figura 5.12, com média de $3241 \mathrm{~mL}$ de biogás e $2301 \mathrm{~mL}$ de metano, sendo que a porcentagem média de metano foi igual a $71 \%$. Embora a porcentagem de metano obtida ao final do ciclo seja menor do que a obtida no ensaio anterior, a produtividade molar de metano foi igual a $101,8 \mathrm{molCH}_{4} \cdot \mathrm{m}^{-3} \cdot \mathrm{d}^{-1}$, o que representa um aumento de $8,7 \%$ em relação a produtividade atingida com água residuária composta unicamente por soro. Esse acréscimo demonstra que a codigestão foi eficiente em melhorar o processo, pois a remoção de substrato foi mantida e a produção de biogás foi aprimorada.
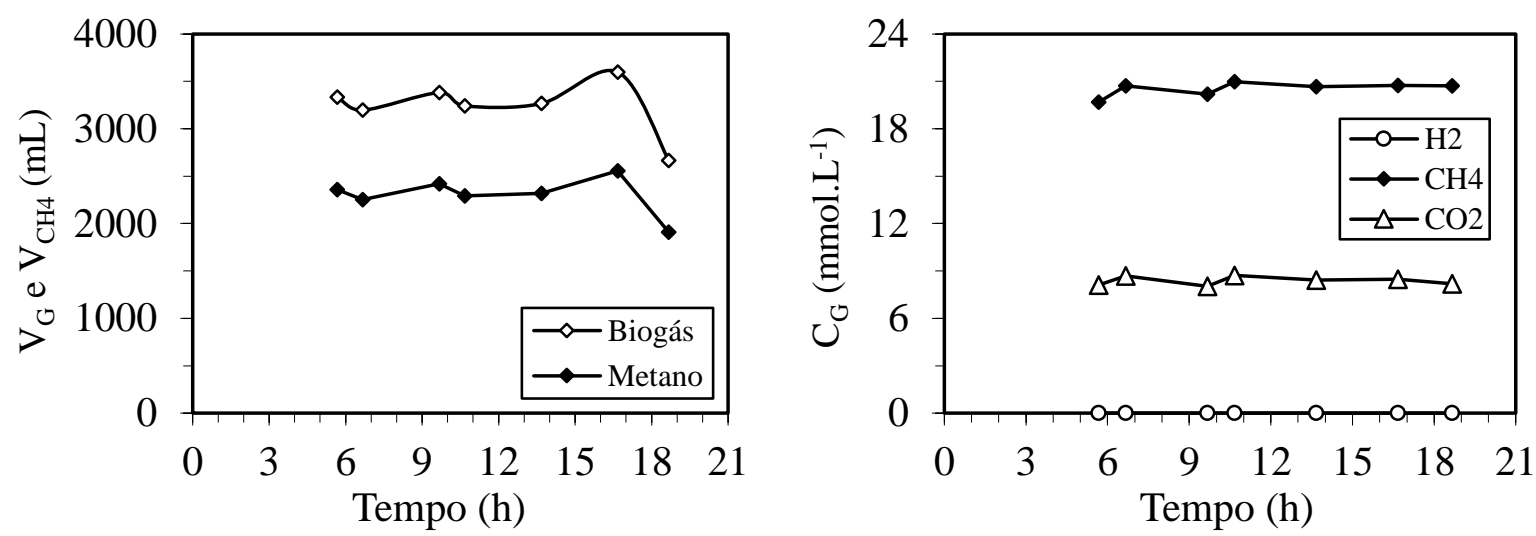

Figura 5.12. Volume de biogás $\left(\mathrm{V}_{\mathrm{G}}\right)$ e de metano $\left(\mathrm{V}_{\mathrm{CH} 4}\right)$ na $\mathrm{CNTP}$ e concentrações dos componentes do

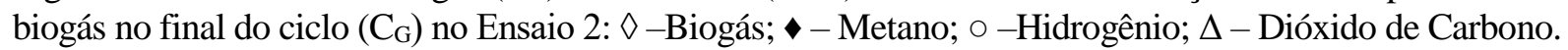

A Figura 5.13 apresenta o perfil de DQO, de Carboidratos e de Glicerina, nota-se, novamente, que há grandes variações na medida de DQO durante o ciclo e pequenas variações nos perfis de carboidratos e glicerina, o que indica grande velocidade de consumo de substrato. 


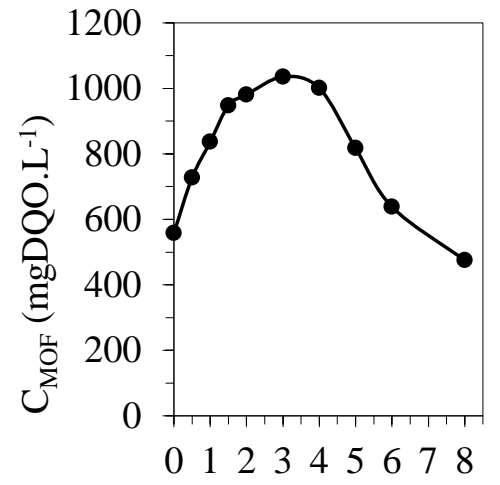

Tempo (h)
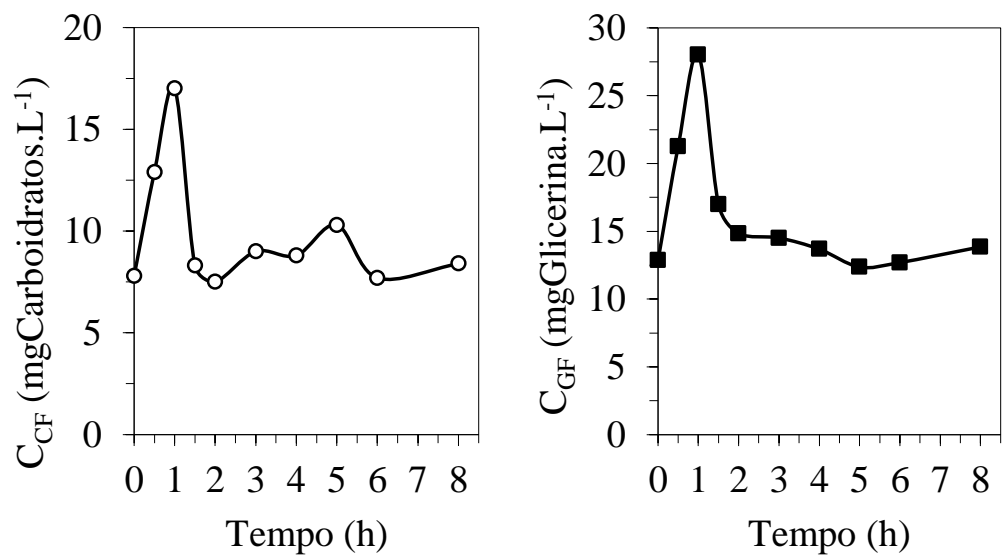

Figura 5.13. Concentração de matéria orgânica, carboidratos e glicerina durante o ciclo no Ensaio 2: $-\mathrm{C}_{\mathrm{SF}} ; \circ-\mathrm{C}_{\mathrm{CF}} ; \mathbf{\square}-\mathrm{C}_{\mathrm{GF}}$.

A Figura 5.14 apresenta os perfis de $\mathrm{pH}$, alcalinidade a bicarbonato e ácidos voláteis totais ao longo do ciclo. $\mathrm{O}$ pH permanece constante ao longo do ciclo por volta de 7,3, devido à presença da alcalinidade que é fornecida gradualmente pelo afluente e que induz a produção de ácidos voláteis, sendo que nas últimas 4 h de tempo de ciclo há o consumo dos AVTs.
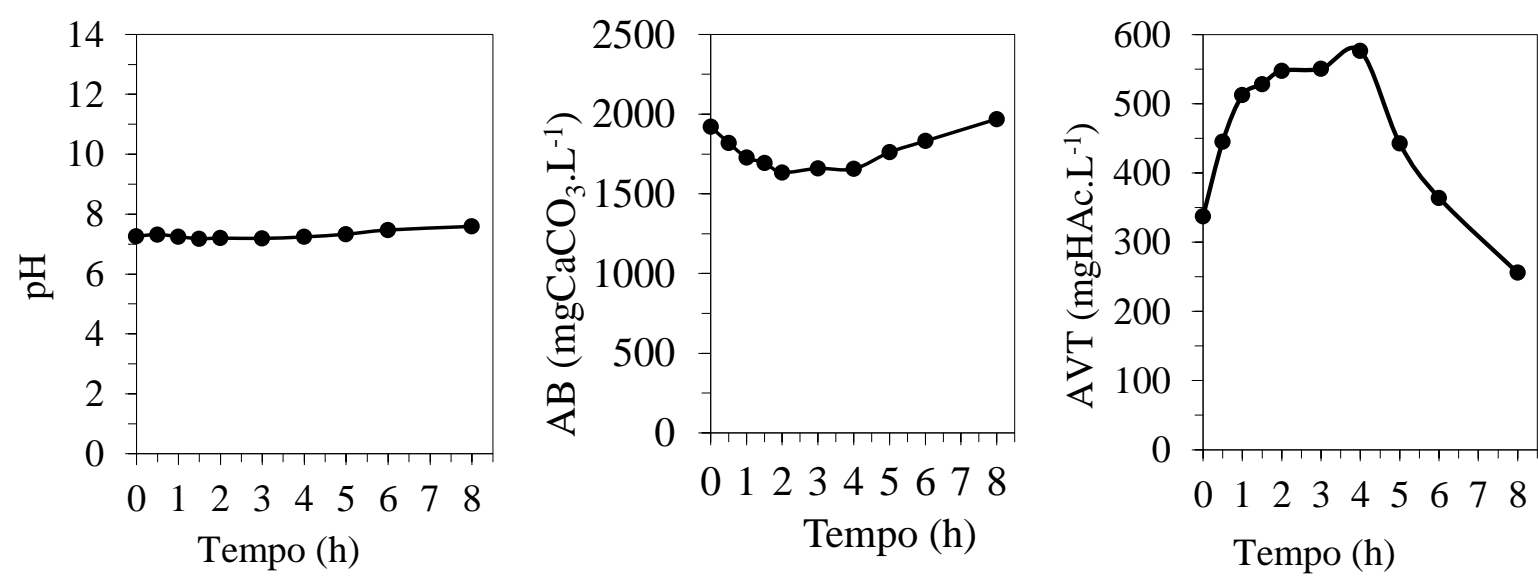

Figura 5.14. Valores de pH, alcalinidade a bicarbonato (AB) e ácidos voláteis totais (AVT) no Ensaio 2.

O perfil dos compostos intermediários do metabolismo é apresentado na Figura 5.15. Novamente, é possível verificar que há a produção dos mesmos enquanto o afluente é alimentado (primeiras $4 \mathrm{~h}$ do ciclo) e, depois do término da alimentação, há o consumo desses compostos para a produção de metano. Neste ensaio, o ácido acético e o ácido propiônico foram predominantes assim como no Ensaio 1. 


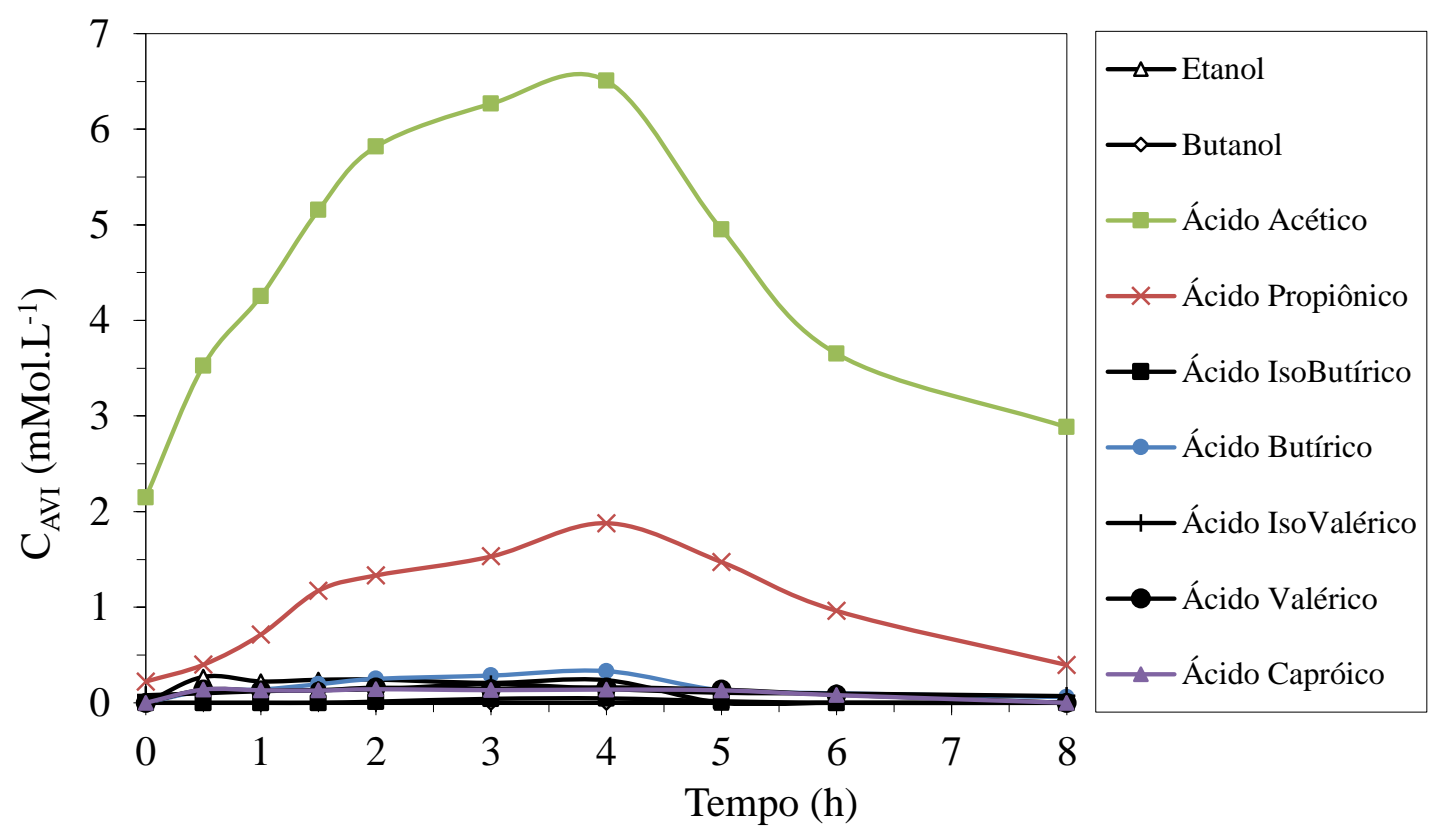

Figura 5.15. Concentração dos compostos intermediários ao longo do ciclo no Ensaio 2: $\Delta$ - etanol; $\diamond$ butanol; $\square$ - ácido acético ; -x-ácido propiônico; - ácido isobutírico; • - ácido butírico; + ácido isovalérico $\bullet$ - ácido valérico; $\Delta$ - ácido capróico.

A produção volumétrica acumulada de biogás e os desvios padrões de cada um dos pontos podem ser observados na Figura 5.16 e o perfil das concentrações de cada um dos gases e suas respectivas porcentagens podem ser observados na Figura 5.17. Houve baixa variação no volume de gás recolhido diariamente e que se manteve estável ao longo do tempo e, ao final do perfil, tinha-se $28 \%$ de $\mathrm{CO}_{2}$ e $72 \%$ de $\mathrm{CH}_{4}$.

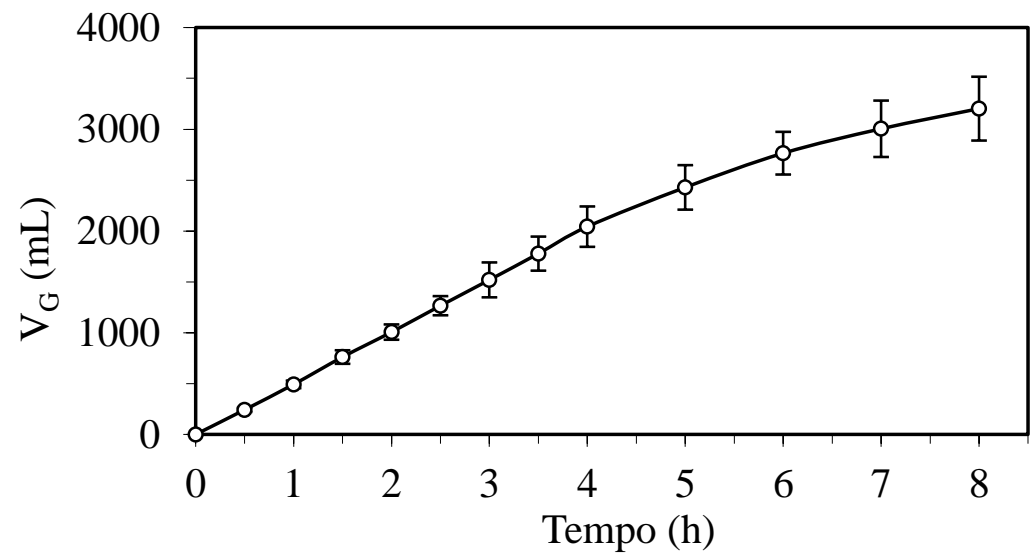

Figura 5.16. Produção volumétrica média acumulada do biogás durante o ciclo no Ensaio 2. 

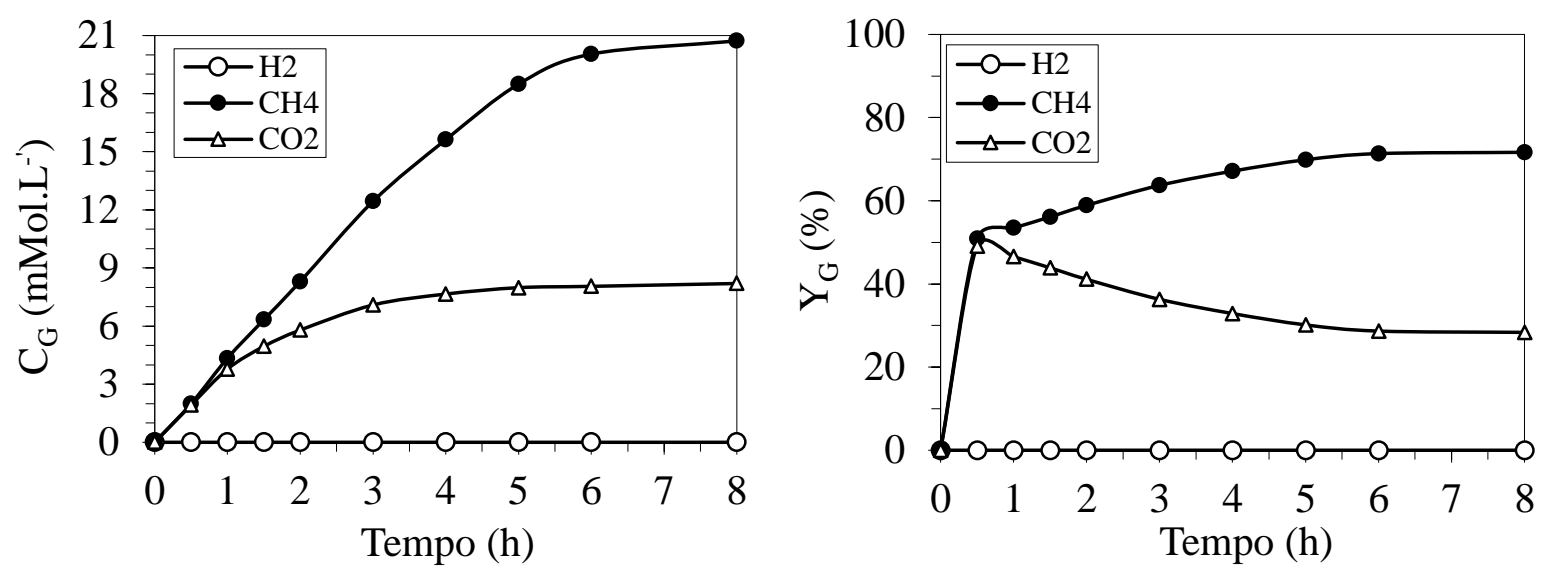

Figura 5.17. Concentração dos compostos do biogás durante o ciclo e suas respectivas porcentagens no Ensaio 2: $\odot-\mathrm{H}_{2} ; \bullet-\mathrm{CH}_{4} ; \Delta-\mathrm{CO}_{2}$.

\subsubsection{Ensaio 3 (50\% Soro e 50\% Glicerina - 5000 mgDQO.L $\left.L^{-1}-8 \mathrm{~h}-\mathrm{BA}\right)$}

No Ensaio 3, soro e glicerina foram adicionados a uma proporção de 1:1 (base de DQO). O valor real da COAV foi de 7,9 gDQO.L $\mathrm{L}^{-1} \cdot \mathrm{d}^{-1}$ e a CORV atingida foi de 7,4 gDQO.L ${ }^{1} . \mathrm{d}^{-1}$. Adicionar $50 \%$ da DQO total em soro significou que o afluente teve, em média, 1268 mgCarboidratos. $\mathrm{L}^{-1}$ e $835 \mathrm{mgGlicerina.L^{-1 }}$. A Tabela 5.3 apresenta a média dos parâmetros monitorados.

O monitoramento diário apresentou um bom consumo de matéria orgânica na forma de DQO, com média de concentração afluente não filtrada de $5239 \mathrm{mgDQO} . \mathrm{L}^{-1}$, efluente não filtrada $499 \mathrm{mgDQO} . \mathrm{L}^{-1}$ e de efluente filtrada de $302 \mathrm{mgDQO} . \mathrm{L}^{-1}$, o que representa um bom rendimento em relação a esse parâmetro, com remoção média para amostras não filtradas de 90\% e para amostras filtradas de $94 \%$ (Figura 5.18) - valores ligeiramente melhores do que os obtidos nos ensaios anteriores.

O monitoramento diário de carboidratos apresentou, mais uma vez, um excelente

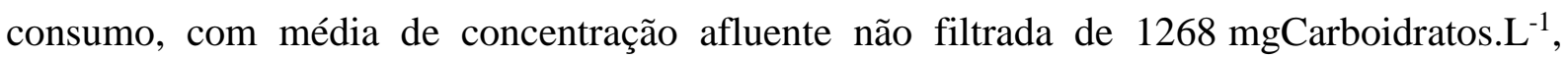
efluente não filtrado $15 \mathrm{mgCarboidratos} . \mathrm{L}^{-1} \mathrm{e}$ de efluente filtrado $6 \mathrm{mgCarboidratos} . \mathrm{L}^{-1}$, o que representa uma eficiência média de remoção para amostras não filtradas de 98,6\% e para amostras filtradas de 99,5\% (Figura 5.19) - basicamente as mesmas eficiências de remoção encontradas no Ensaio 2. 
Tabela 5.3. Parâmetros médios monitorados no Ensaio 3.

\begin{tabular}{|c|c|c|c|c|c|c|c|c|c|c|c|c|c|}
\hline \multicolumn{2}{|r|}{ Parâmetro } & \multicolumn{6}{|c|}{ Afluente } & \multicolumn{6}{|c|}{ Efluente } \\
\hline $\mathrm{C}_{\text {MOT }}$ & $\left(\mathrm{mgDQO} \cdot \mathrm{L}^{-1}\right)$ & 5239 & \pm & 489 & ( & 15 & ) & 499 & \pm 1 & 139 & $(1$ & 12 & \\
\hline $\mathrm{C}_{\mathrm{MOF}}$ & $\left(\mathrm{mgDQO} \cdot \mathrm{L}^{-1}\right)$ & & & & & & & 302 & \pm & 81 & $(1$ & 12 & \\
\hline$\varepsilon_{\mathrm{MOT}}$ & $(\%)$ & & & & & & & 90 & \pm & 3 & $(1$ & 12 & ) \\
\hline$\varepsilon_{\mathrm{MOF}}$ & $(\%)$ & & & 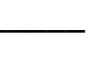 & & & & 94 & \pm & 1 & $(1$ & 12 & \\
\hline $\mathrm{C}_{\mathrm{CT}}$ & (mgCarboidratos. $\mathrm{L}^{-1}$ ) & 1268 & \pm & 358 & ( & 15 & ) & 15 & \pm & 7 & $(1$ & 12 & ) \\
\hline $\mathrm{C}_{\mathrm{CF}}$ & (mgCarboidratos. $\mathrm{L}^{-1}$ ) & & & & & & & 6 & \pm & 2 & $(1$ & 12 & \\
\hline$\varepsilon_{\mathrm{CT}}$ & $(\%)$ & & & - & & & & 98,6 & \pm & 0,9 & $(1$ & 12 & 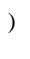 \\
\hline$\varepsilon_{\mathrm{CF}}$ & $(\%)$ & & & & & & & 99,5 & \pm & 0,3 & $(1$ & 12 & ) \\
\hline $\mathrm{C}_{\mathrm{GT}}$ & (mgGlicerina. $\left.\mathrm{L}^{-1}\right)$ & 835 & \pm & 24 & \pm & 12 & ) & 24 & \pm & 12 & $(1$ & 12 & ) \\
\hline $\mathrm{C}_{\mathrm{GF}}$ & (mgGlicerina. $\mathrm{L}^{-1}$ ) & & & & & & & 13 & \pm & 5 & $(1$ & 12 & \\
\hline$\varepsilon_{\mathrm{GT}}$ & $(\%)$ & & & 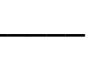 & & & & 97 & \pm & 2 & $(1$ & 12 & 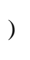 \\
\hline$\varepsilon_{\mathrm{GF}}$ & $(\%)$ & & & & & & & 98,4 & \pm & 0,6 & $(1$ & 12 & ) \\
\hline $\mathrm{pH}$ & $(\mathrm{u})$ & 8,54 & \pm & 0,08 & ( & 10 & ) & 7,5 & \pm & 0,2 & $(1$ & 10 & ) \\
\hline AVT & $\left(\mathrm{mgHAc} . \mathrm{L}^{-1}\right)$ & 117 & \pm & 36 & ( & 10 & ) & 107 & \pm & 17 & $(1$ & 10 & ) \\
\hline AT & $\left(\mathrm{mgCaCO}_{3} \cdot \mathrm{L}^{-1}\right)$ & 2200 & \pm & 43 & ( & 10 & ) & 2220 & \pm 1 & 115 & $(1)$ & 10 & ) \\
\hline AP & $\left(\mathrm{mgCaCO}_{3} \cdot \mathrm{L}^{-1}\right)$ & 1724 & \pm & 84 & ( & 10 & ) & 1703 & \pm 1 & 114 & $(1$ & 10 & ) \\
\hline $\mathrm{AI}$ & $\left(\mathrm{mgCaCO}_{3} \cdot \mathrm{L}^{-1}\right)$ & 476 & \pm & 53 & ( & 10 & ) & 517 & \pm & 90 & $(1$ & 10 & ) \\
\hline $\mathrm{AB}$ & $\left(\mathrm{mgCaCO}_{3} \cdot \mathrm{L}^{-1}\right)$ & 2117 & \pm & 44 & ( & 10 & ) & 2144 & \pm 1 & 107 & $(1$ & 10 & ) \\
\hline ST & $\left(\mathrm{mg} \cdot \mathrm{L}^{-1}\right)$ & 5002 & \pm & 129 & ( & 5 & ) & 3043 & \pm & 97 & ( & 5 & ) \\
\hline SVT & $\left(\mathrm{mg} \cdot \mathrm{L}^{-1}\right)$ & 2536 & \pm & 122 & ( & 5 & ) & 922 & \pm 3 & 320 & ( & 5 & ) \\
\hline SST & $\left(\mathrm{mg} \cdot \mathrm{L}^{-1}\right)$ & 90 & \pm & 22 & ( & 5 & ) & 133 & \pm & 51 & ( & 5 & ) \\
\hline SSV & $\left(\mathrm{mg} \cdot \mathrm{L}^{-1}\right)$ & 77 & \pm & 24 & ( & 5 & ) & 114 & \pm & 44 & ( & 5 & ) \\
\hline $\mathrm{M}_{\mathrm{SVT}}$ & (g) & & . & & & & & & 55,7 & & & & \\
\hline $\mathrm{Cx}$ & $\left(\mathrm{g} \cdot \mathrm{L}^{-1}\right)$ & & - & & & & & & 18,5 & & & & \\
\hline $\mathrm{Cx}^{\prime}$ & (g.gsuporte ${ }^{-1}$ ) & & - & & & & & & 0,942 & & & & \\
\hline $\mathrm{V}_{\mathrm{G}}$ & $\left(\mathrm{mL} \cdot\right.$ ciclo $\left.^{-1}\right)$ & & - & & & & & 2758 & \pm 1 & 170 & $(1$ & 12 & \\
\hline $\mathrm{V}_{\mathrm{CH} 4}$ & $\left(\mathrm{~mL} \cdot \mathrm{ciclo}^{-1}\right)$ & & 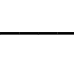 & & & & & 2115 & \pm 1 & 122 & $(1$ & 12 & \\
\hline $\mathrm{COAV}_{\mathrm{MOT}}$ & $\left(\right.$ gDQO.L $\left.L^{-1} \cdot d^{-1}\right)$ & & 7,9 & & & & & & - & & & & \\
\hline $\mathrm{CORV}_{\mathrm{MOF}}$ & $\left(\mathrm{gDQO} \cdot \mathrm{L}^{-1} \cdot \mathrm{d}^{-1}\right)$ & & & & & & & & 7,4 & & & & \\
\hline $\mathrm{COAV}_{\mathrm{CT}}$ & (gCarboidratos. $\left.\mathrm{L}^{-1} \cdot \mathrm{d}^{-1}\right)$ & & 1,9 & & & & & & 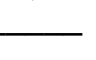 & & & & \\
\hline $\mathrm{CORV}_{\mathrm{CF}}$ & (gCarboidratos. $\mathrm{L}^{-1} \cdot \mathrm{d}^{-1}$ ) & & & & & & & & 1,9 & & & & \\
\hline $\mathrm{COAV}_{\mathrm{GT}}$ & (gGlicerina. $\mathrm{L}^{-1} \cdot \mathrm{d}^{-1}$ ) & & 1,3 & & & & & & & & & & \\
\hline $\mathrm{CORV}_{\mathrm{GF}}$ & (gGlicerina. $L^{-1} \cdot d^{-1}$ ) & & & & & & & & 1,2 & & & & \\
\hline $\mathrm{COAE}_{\mathrm{ST}}$ & $\left(\mathrm{gDQO} \mathrm{gSVT}^{-1} \cdot \mathrm{d}^{-1}\right)$ & & 0,4 & & & & & & 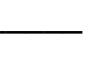 & & & & \\
\hline $\mathrm{CORE}_{\mathrm{SF}}$ & $\left(\right.$ gDQO.gSVT $\left.{ }^{-1} \cdot \mathrm{d}^{-1}\right)$ & & & & & & & & 0,4 & & & & \\
\hline COAE $_{\mathrm{CT}}$ & (gCarboidratos.gSVT ${ }^{-1} \cdot \mathrm{d}^{-1}$ ) & & 0,1 & & & & & & & & & & \\
\hline $\mathrm{CORE}_{\mathrm{CF}}$ & (gCarboidratos.gSVT ${ }^{-1} \cdot \mathrm{d}^{-1}$ ) & & 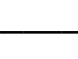 & & & & & & 0,1 & & & & \\
\hline $\mathrm{COAE}_{\mathrm{GT}}$ & (gGlicerina.gSVT ${ }^{-1} \cdot \mathrm{d}^{-1}$ ) & & 0,1 & & & & & & $\overline{ }$ & & & & \\
\hline $\mathrm{CORE}_{\mathrm{GF}}$ & (gGlicerina.gSVT ${ }^{-1} \cdot \mathrm{d}^{-1}$ ) & & & & & & & & 0,1 & & & & \\
\hline $\mathrm{n}_{\mathrm{CH} 4}$ & $\left(\mathrm{molCH}_{4} \cdot \mathrm{d}^{-1}\right)$ & & 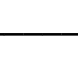 & & & & & & 0,3 & & & & \\
\hline $\operatorname{PrM}$ & $\left(\mathrm{molCH}_{4} \cdot \mathrm{m}^{-3} \cdot \mathrm{d}^{-1}\right)$ & & - & & & & & & 94,2 & & & & \\
\hline PrME & $\left(\mathrm{molCH}_{4} \cdot \mathrm{kgSVT}^{-1} \cdot \mathrm{d}^{-1}\right)$ & & - & & & & & & 5,1 & & & & \\
\hline RMCA & $\left(\mathrm{molCH}_{4} \cdot \mathrm{kgDQO}^{-1}\right)$ & & 12,0 & & & & & & & & & & \\
\hline RMSA & $\left(\mathrm{molCH}_{4} \cdot \mathrm{molSubstrato}^{-1}\right)$ & & 4,9 & & & & & & - & & & & \\
\hline RMSR & $\left(\mathrm{molCH}_{4} \cdot \mathrm{molSubstrato}^{-1}\right)$ & & - & & & & & & 5,0 & & & & \\
\hline $\mathrm{V}_{\mathrm{A}}$ & (L) & 1,50 & \pm & 0,05 & ( & 11 & ) & & & & & & \\
\hline$V_{R}$ & $(\mathrm{~L})$ & & 3,0 & & & & & & $\square$ & & & & \\
\hline
\end{tabular}

(*) Entre parênteses o número de amostras considerado no cálculo da média 

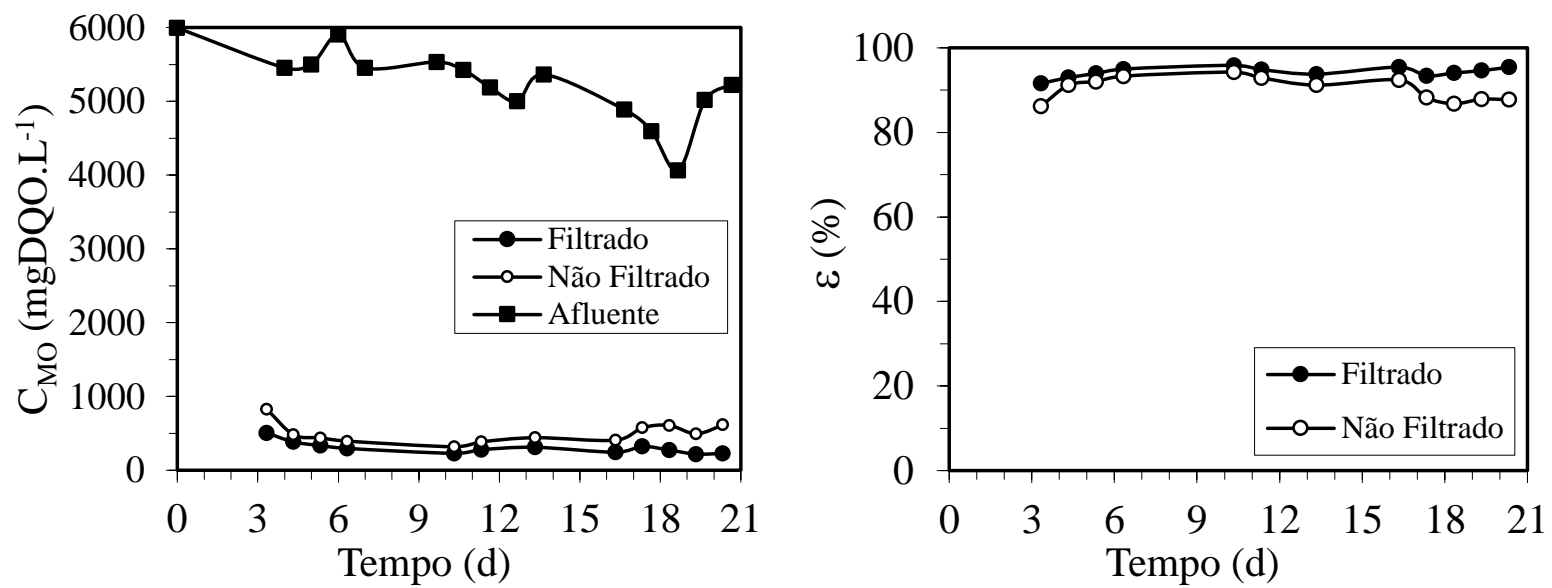

Figura 5.18. Concentração e eficiência de remoção de matéria orgânica na forma de DQO no Ensaio 3: - - afluente amostras não filtradas; • - efluente amostras não filtradas; ○ - efluente amostras filtradas.
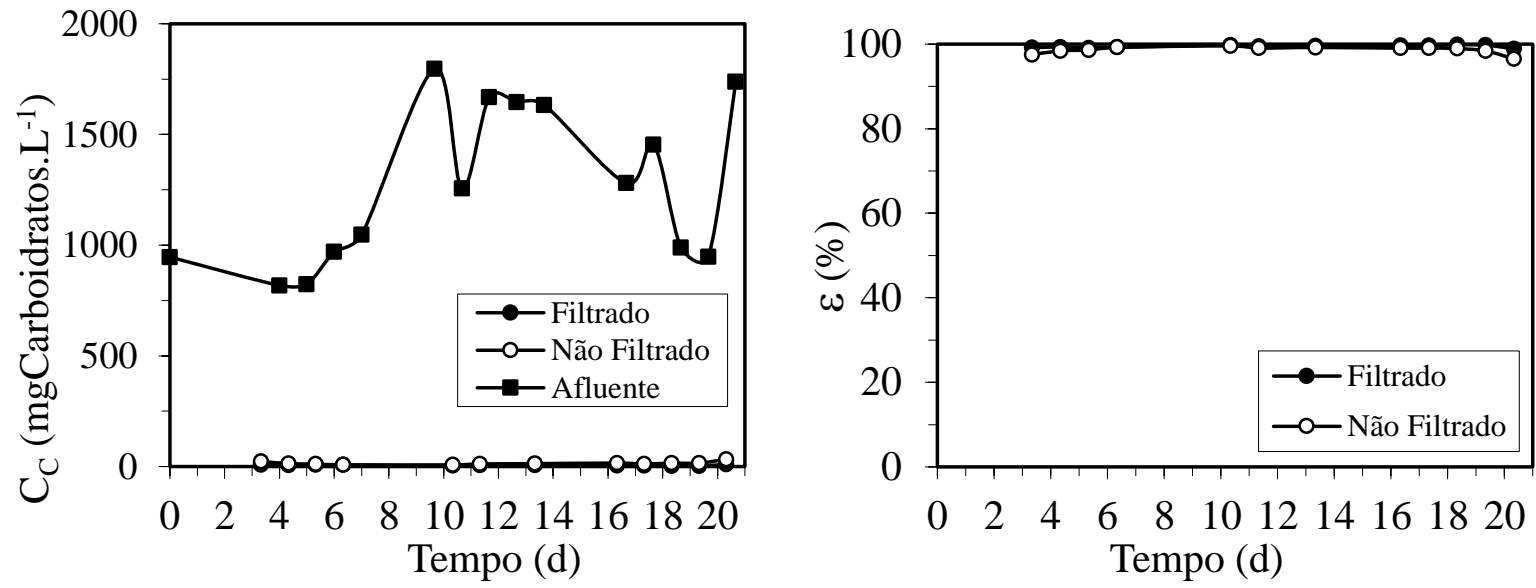

Figura 5.19. Concentração e eficiência de remoção na forma de carboidratos no Ensaio 3: - - afluente amostras não filtradas; • - efluente amostras não filtradas; $\odot$ - efluente amostras filtradas.

Em relação ao monitoramento diário de glicerina, a média de concentração afluente não filtrada foi igual a $835 \mathrm{mgCarboidratos.} \mathrm{L}^{-1}$, efluente não filtrado $24 \mathrm{mgCarboidratos. \textrm {L } ^ { - 1 } \mathrm { e }}$

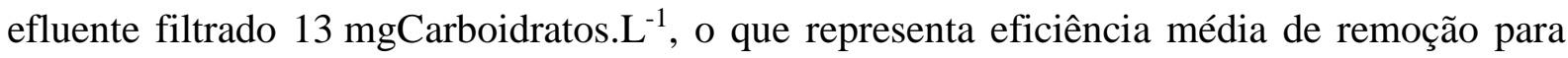
amostras não filtradas de 97,0\% e para amostras filtradas de 98,4\% (Figura 5.20) - um ótimo consumo desse substrato.

A média do $\mathrm{pH}$ afluente foi de 8,54 e do efluente de 7,5. A alcalinidade a bicarbonato do afluente teve média de $2117 \mathrm{mgCaCO}_{3} \cdot \mathrm{L}^{-1}$ sendo que a mesma se manteve no efluente com uma média de $2144 \mathrm{mgCaCO} 3 . \mathrm{L}^{-1}$. A média de AVT do afluente foi de $117 \mathrm{mgHAc} . \mathrm{L}^{-1}$ e a média de AVT do efluente de 107 mgHAc.L ${ }^{-1}$. Nesta condição, finalmente, houve um comportamento estável dos ácidos voláteis totais tanto no afluente quanto no efluente graças ao efeito tampão fornecido pela glicerina. 

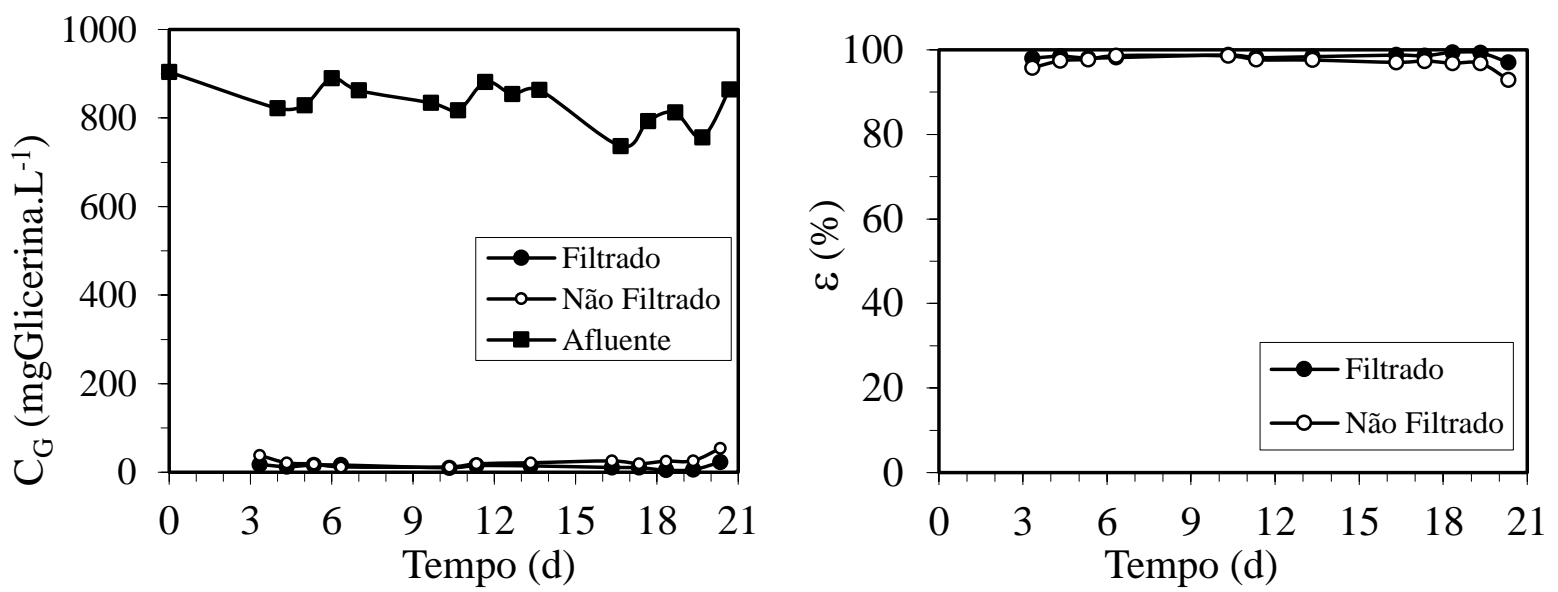

Figura 5.20. Concentração e eficiência de remoção na forma de glicerina no Ensaio 3: - - afluente amostras não filtradas; • - efluente amostras não filtradas; $\bigcirc$ - efluente amostras filtradas.

A produção de biogás, em aspecto quantitativo, e a distribuição dos gases que compõem o biogás no final do ciclo podem ser observadas na Figura 5.21, com média de $2758 \mathrm{~mL}$ de biogás e $2115 \mathrm{~mL}$ de metano, sendo que a porcentagem média de metano foi igual a $77 \%$. Embora a porcentagem de metano obtida ao final do ciclo seja a maior obtida até agora, a produtividade molar de metano foi igual a $94,2 \mathrm{molCH}_{4} \cdot \mathrm{m}^{-3} \cdot \mathrm{d}^{-1}$, o que é um decréscimo em relação ao Ensaio 2 , mas ainda é $0,5 \%$ maior do que a produtividade obtida no Ensaio 1.
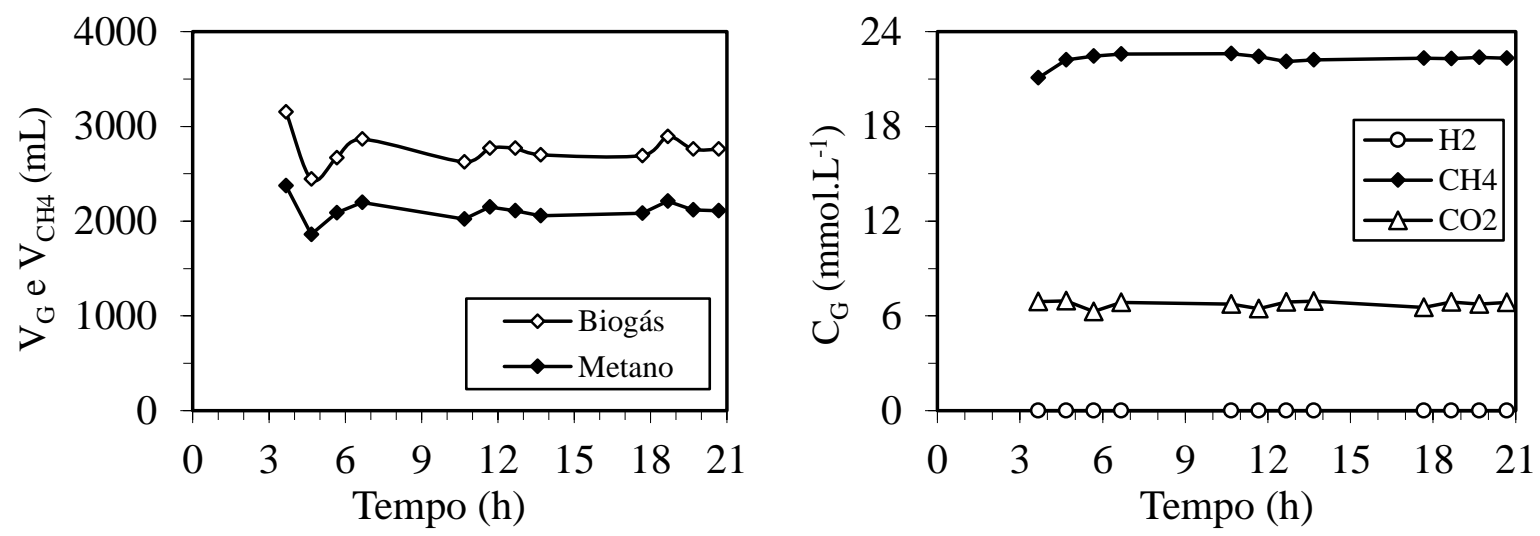

Figura 5.21. Volume de biogás $\left(\mathrm{V}_{\mathrm{G}}\right)$ e de metano $\left(\mathrm{V}_{\mathrm{CH} 4}\right)$ na $\mathrm{CNTP}$ e concentrações dos componentes do biogás no final do ciclo $\left(\mathrm{C}_{\mathrm{G}}\right)$ no Ensaio 3: $\diamond$-Biogás; - Metano; ○-Hidrogênio; $\Delta$ - Dióxido de Carbono.

Em relação aos perfis, a Figura 5.22 apresenta o perfil de DQO, de Carboidratos e de Glicerina. O mesmo comportamento observado nos Ensaios 1 e 2 pode ser notado aqui. 

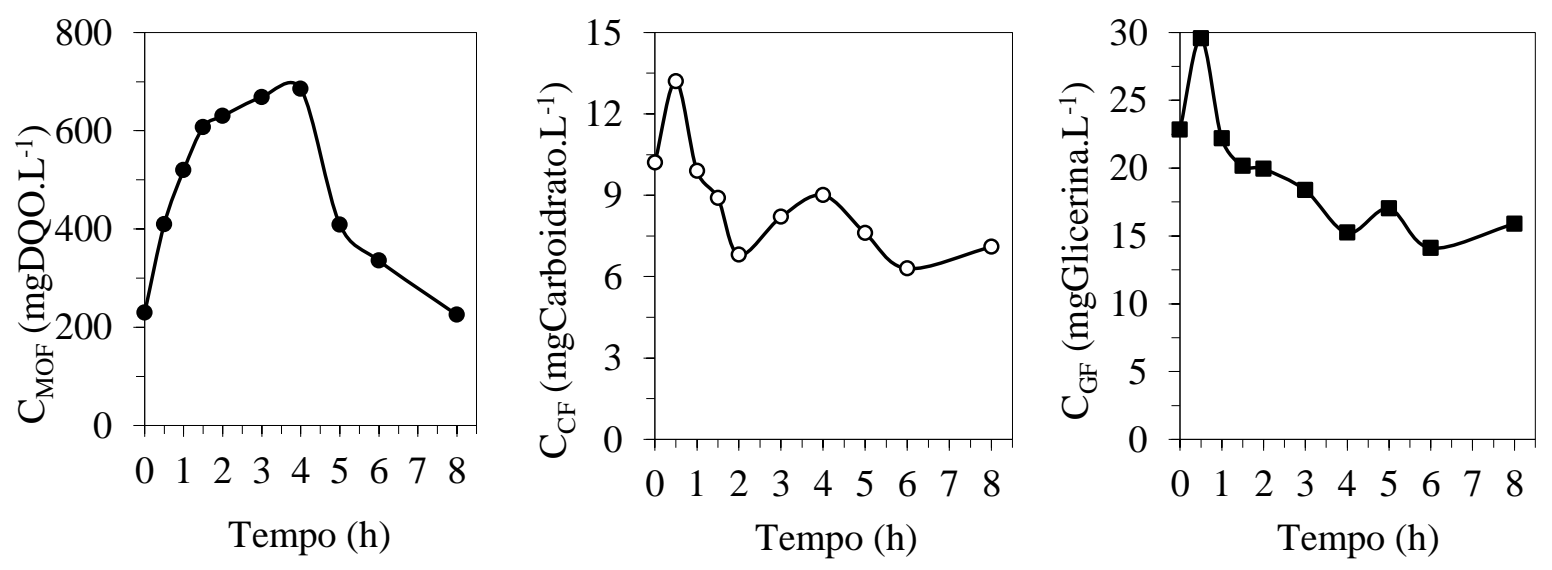

Figura 5.22. Concentração de matéria orgânica, carboidratos e glicerina durante o ciclo no Ensaio 3: $-\mathrm{C}_{\mathrm{SF}} ; \circ-\mathrm{C}_{\mathrm{CF}} ; \mathbf{\square}-\mathrm{C}_{\mathrm{GF}}$.

A Figura 5.23 apresenta os perfis de $\mathrm{pH}$, alcalinidade a bicarbonato e ácidos voláteis totais ao longo do ciclo. $\mathrm{O}$ pH permanece constante ao longo do ciclo por volta de 7,2, juntamente com a alcalinidade total (que fica por volta de $3330 \mathrm{mgCaCO}_{3} \cdot \mathrm{L}^{-1}$ ). Os ácidos voláteis totais apresentam valores mais baixos dos que os obtidos nos Ensaios 1 e 2, mas mostram o mesmo comportamento de produção até a metade do tempo de ciclo e, nas últimas $4 \mathrm{~h}$ houve predominantemente o consumo dos mesmos.
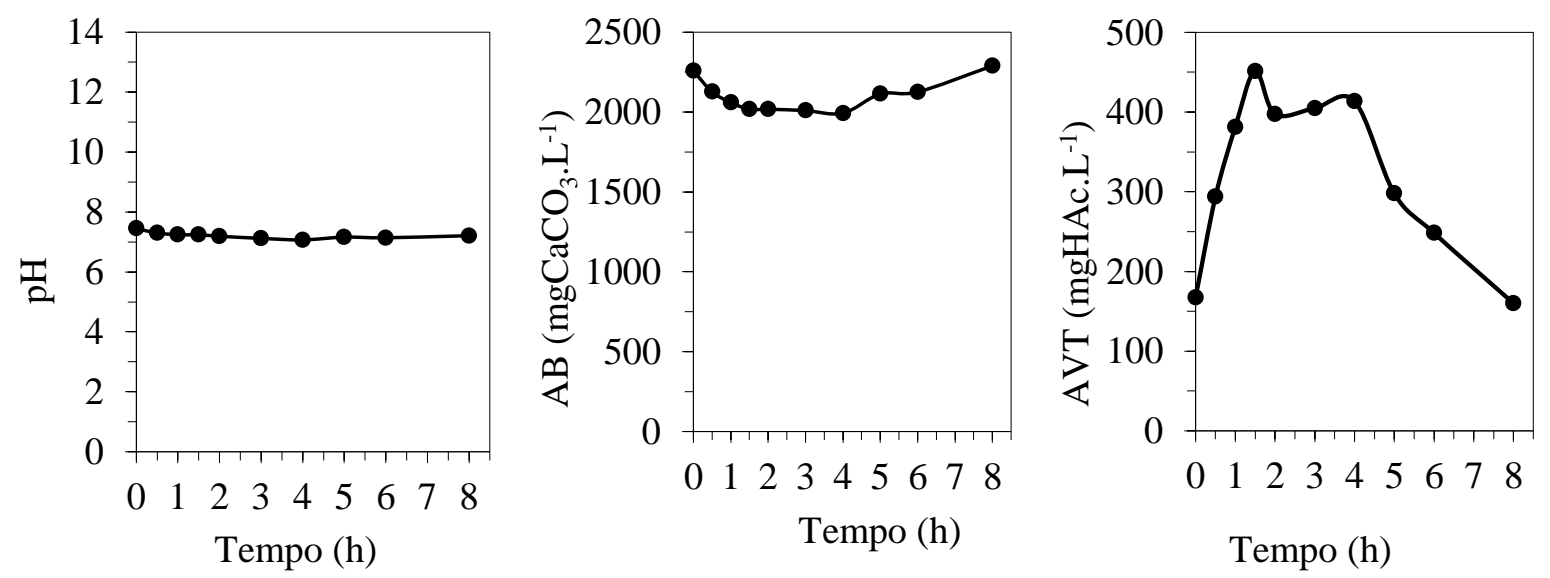

Figura 5.23. Valores de pH, alcalinidade total (AT) e ácidos voláteis totais (AVT) no Ensaio 3.

O perfil dos compostos intermediários do metabolismo é apresentado na Figura 5.24. Assim como nos Ensaios 1 e 2, há a predominância dos ácidos acético e propiônico, com o mesmo comportamento visto anteriormente: produção dos mesmos enquanto o afluente é alimentado (primeiras $4 \mathrm{~h}$ do ciclo) e, depois do término da alimentação, há o consumo desses compostos para a produção de metano. 


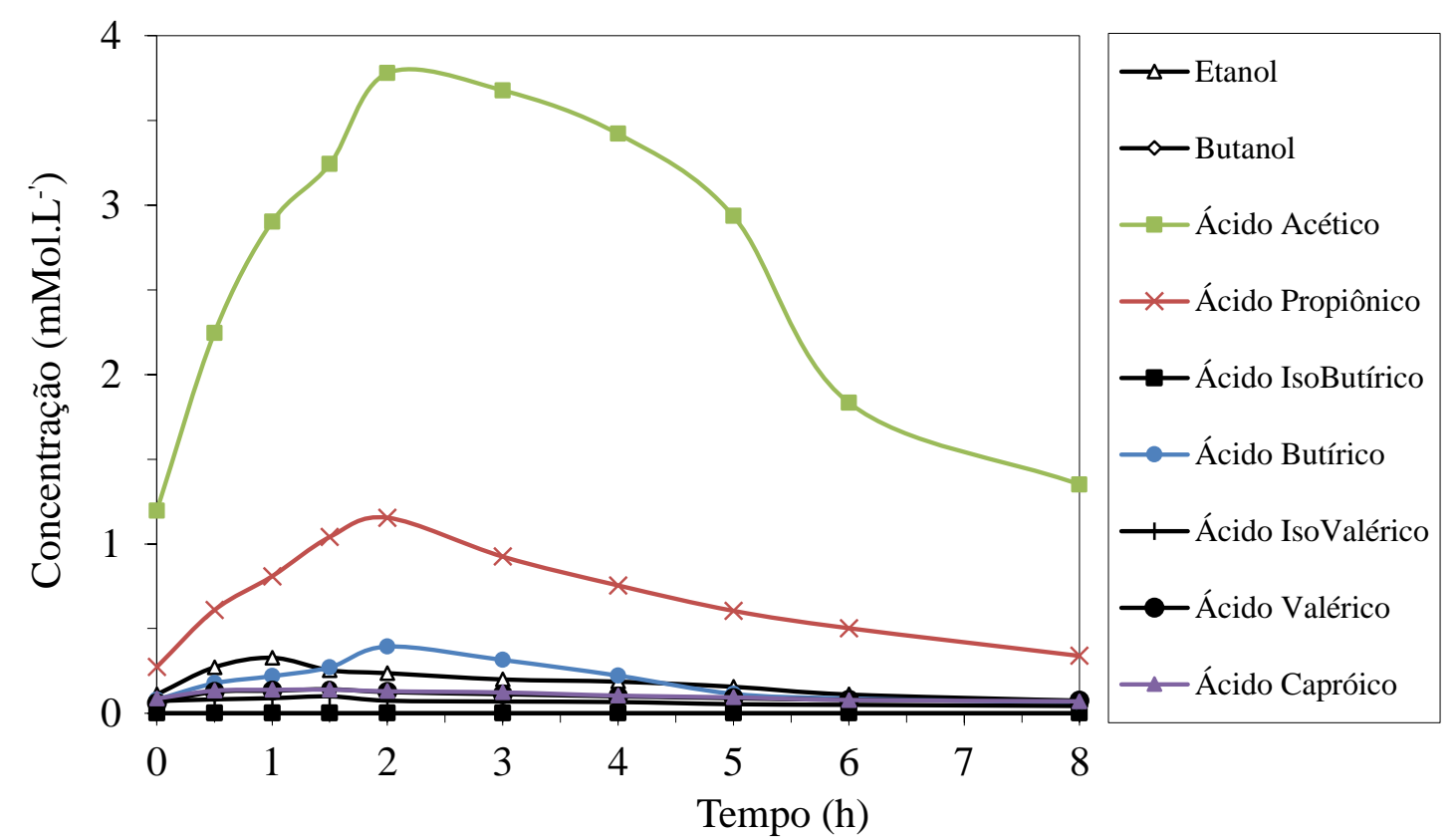

Figura 5.24. Concentração dos compostos intermediários ao longo do ciclo no Ensaio 3: $\Delta$ - etanol; $\diamond$ butanol; $\square$ - ácido acético ; -x-ácido propiônico; - - ácido isobutírico; • - ácido butírico; + ácido isovalérico $\bullet$ - ácido valérico; $\Delta$ - ácido capróico.

A produção volumétrica acumulada de biogás e os desvios padrões de cada um dos pontos podem ser observados na Figura 5.25 e o perfil das concentrações de cada um dos gases e suas respectivas porcentagens podem ser observados na Figura 5.26. Novamente, nota-se baixa variação no volume de gás recolhido diariamente, o que é um bom indicador da estabilidade do sistema e, ao final do perfil, tinha-se $24 \%$ de $\mathrm{CO}_{2}$ e $76 \%$ de $\mathrm{CH}_{4}-$ a melhor qualidade de biogás obtida até o momento.

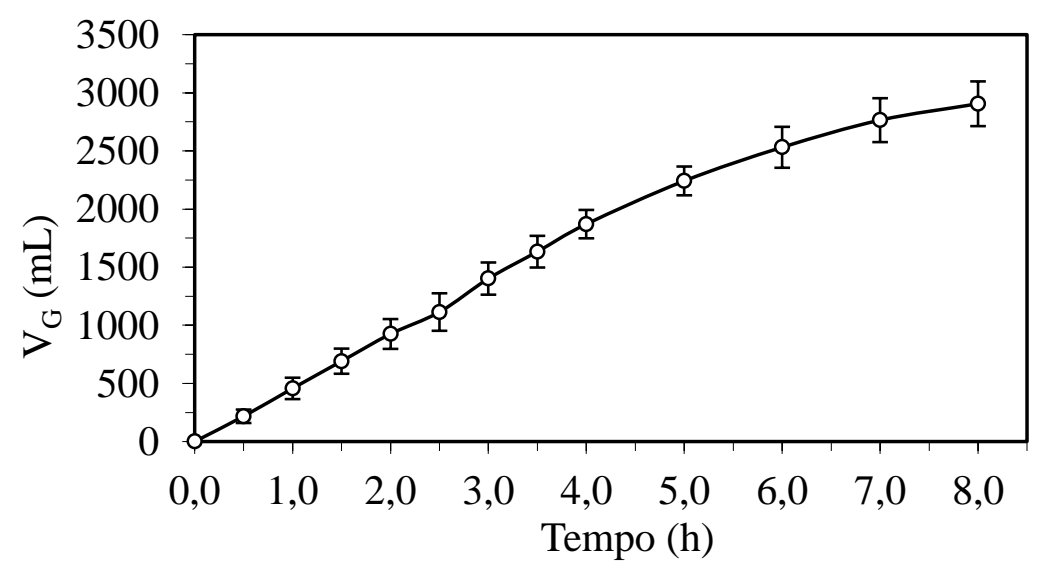

Figura 5.25. Produção volumétrica média acumulada do biogás durante o ciclo no Ensaio 3. 

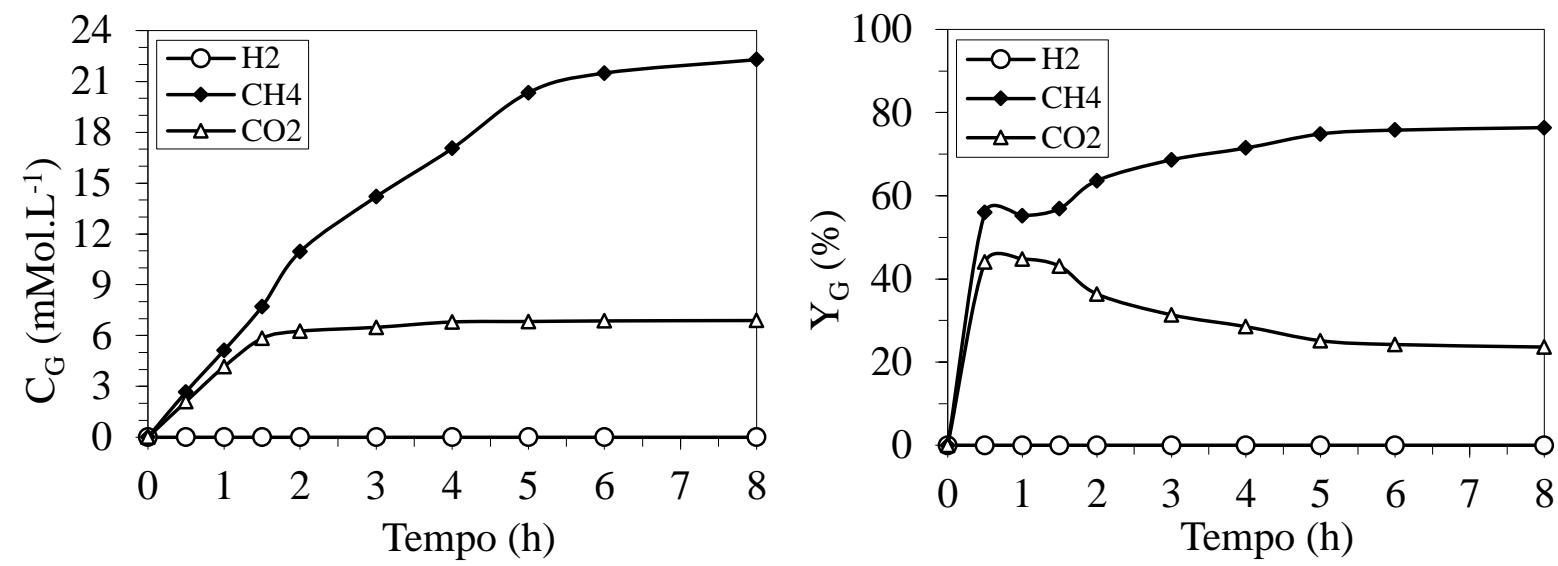

Figura 5.26. Concentração dos compostos do biogás durante o ciclo e suas respectivas porcentagens no Ensaio 3: $\odot-\mathrm{H}_{2} ; \bullet-\mathrm{CH}_{4} ; \Delta-\mathrm{CO}_{2}$.

\subsubsection{Ensaio 4 (25\% Soro e 75\% Glicerina - $\left.5000 \mathrm{mgDQO} . \mathrm{L}^{-1}-8 \mathrm{~h}-\mathrm{BA}\right)$}

O Ensaio 4 representa a última condição que avalia a codigestão entre soro e glicerina com foco na produção de biometano. O valor real da COAV foi de 7,8 gDQO.L $\mathrm{L}^{-1} \cdot \mathrm{d}^{-1}$ e a CORV atingida foi de 7,3 gDQO.L $\mathrm{L}^{-1} \cdot \mathrm{d}^{-1}$. A Tabela 5.4 apresenta a média dos parâmetros monitorados.

O monitoramento diário apresentou um ótimo consumo de matéria orgânica na forma de DQO, com média de concentração afluente não filtrada de $5194 \mathrm{mgDQO} . \mathrm{L}^{-1}$, efluente não filtrada $384 \mathrm{mgDQO} . \mathrm{L}^{-1}$ e de efluente filtrada de $298 \mathrm{mgDQO} . \mathrm{L}^{-1}$, o que representa um bom rendimento em relação a esse parâmetro, com remoção média para amostras não filtradas de 93\% e para amostras filtradas de 94\% (Figura 5.27).

O monitoramento diário de carboidratos, apresentou, mais uma vez, um excelente

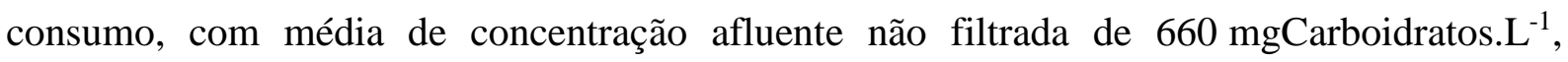
efluente não filtrado $11 \mathrm{mgCarboidratos.} \mathrm{L}^{-1} \mathrm{e}$ de efluente filtrado $7 \mathrm{mgCarboidratos.} \mathrm{L}^{-1}$, o que representa eficiência média de remoção para amostras não filtradas de 98,2\% e para amostras filtradas de 98,9\% (Figura 5.28).

Finalmente, no monitoramento diário de glicerina, a média de concentração afluente não filtrada foi igual a $1151 \mathrm{mgCarboidratos.} \mathrm{L}^{-1}$, efluente não filtrado $3 \mathrm{mgCarboidratos.} \mathrm{L}^{-1} \mathrm{e}$

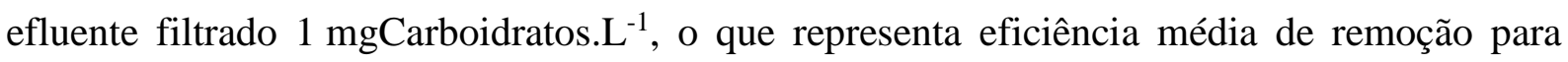
amostras não filtradas de 99,7\% e para amostras filtradas de 99,9\% (Figura 5.29) - um excelente consumo desse substrato. 
Tabela 5.4. Parâmetros médios monitorados no Ensaio 4.

\begin{tabular}{|c|c|c|c|c|c|c|c|c|c|c|c|c|c|}
\hline \multicolumn{2}{|r|}{ Parâmetro } & \multicolumn{6}{|c|}{ Afluente } & \multicolumn{6}{|c|}{ Efluente } \\
\hline $\mathrm{C}_{\mathrm{MO}}$ & $\left(\mathrm{mgDQO} \cdot \mathrm{L}^{-1}\right)$ & 5194 & \pm & 465 & ( & 10 & ) & 384 & \pm 1 & 169 & $(1$ & 10 & () \\
\hline $\mathrm{C}_{\mathrm{MOF}}$ & (mgDQO.L-1) & & & & & & & 298 & \pm 1 & 120 & ( & 10 & ) \\
\hline$\varepsilon_{\mathrm{MOT}}$ & $(\%)$ & & & 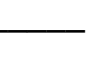 & & & & 93 & \pm & 3 & $(1$ & 10 & ) \\
\hline$\varepsilon_{\mathrm{MOF}}$ & $(\%)$ & & & & & & & 94 & \pm & 2 & $(1$ & 10 & ) \\
\hline $\mathrm{C}_{\mathrm{CT}}$ & $\left(\right.$ mgCarboidratos. $\left.\mathrm{L}^{-1}\right)$ & 660 & \pm & 116 & ( & 10 & ) & 11 & \pm & 5 & $(1$ & 10 & ) \\
\hline $\mathrm{C}_{\mathrm{CF}}$ & (mgCarboidratos. $\mathrm{L}^{-1}$ ) & & & & & & & 7 & \pm & 3 & $(1$ & 10 & ) \\
\hline$\varepsilon_{\mathrm{CT}}$ & $(\%)$ & & & & & & & 98,2 & \pm & 0,8 & $(1$ & 10 & ) \\
\hline$\varepsilon_{\mathrm{CF}}$ & $(\%)$ & & & - & & & & 98,9 & \pm & 0,5 & $(1$ & 10 & ) \\
\hline $\mathrm{C}_{\mathrm{GT}}$ & (mgGlicerina. $\mathrm{L}^{-1}$ ) & 1151 & \pm & 175 & ( & 10 & ) & 3 & \pm & 3 & $(1$ & 10 & ) \\
\hline $\mathrm{C}_{\mathrm{GF}}$ & (mgGlicerina. $\left.\mathrm{L}^{-1}\right)$ & & & & & & & 1 & \pm & 1 & $(1$ & 10 & ) \\
\hline$\varepsilon_{\mathrm{GT}}$ & $(\%)$ & & & . & & & & 99,7 & \pm & 0,3 & $(1$ & 10 & ) \\
\hline$\varepsilon_{\mathrm{GF}}$ & $(\%)$ & & & 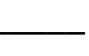 & & & & 99,9 & \pm & 0,1 & $(1$ & 10 & ) \\
\hline $\mathrm{pH}$ & (u) & 8,80 & \pm & 0,08 & ( & 8 & ) & 7,4 & \pm & 0,1 & $(1$ & 10 & ) \\
\hline AVT & $\left(\mathrm{mgHAc} . \mathrm{L}^{-1}\right)$ & 106 & \pm & 37 & ( & 8 & ) & 131 & \pm & 36 & $(1$ & 10 & ) \\
\hline $\mathrm{AT}$ & $\left(\mathrm{mgCaCO} 3 \cdot \mathrm{L}^{-1}\right)$ & 2125 & \pm & 195 & ( & 8 & ) & 2110 & \pm 1 & 143 & $(1$ & 10 & ) \\
\hline AP & $\left(\mathrm{mgCaCO}_{3} \cdot \mathrm{L}^{-1}\right)$ & 1726 & \pm & 164 & ( & 8 & ) & 1636 & \pm 1 & 129 & $(1$ & 10 & ) \\
\hline AI & $\left(\mathrm{mgCaCO}_{3} \cdot \mathrm{L}^{-1}\right)$ & 400 & \pm & 41 & ( & 8 & ) & 474 & \pm & 44 & $(1$ & 10 & ) \\
\hline $\mathrm{AB}$ & $\left(\mathrm{mgCaCO} 3 \cdot \mathrm{L}^{-1}\right)$ & 2050 & \pm & 192 & ( & 8 & ) & 2017 & \pm 1 & 151 & $(1$ & 10 & ) \\
\hline ST & $\left(\mathrm{mg} \cdot \mathrm{L}^{-1}\right)$ & 4373 & \pm & 196 & ( & 5 & ) & 2742 & \pm 1 & 187 & ( & 5 & ) \\
\hline SVT & $\left(\mathrm{mg} \cdot \mathrm{L}^{-1}\right)$ & 1973 & \pm & 149 & ( & 5 & ) & 523 & \pm 1 & 145 & ( & 5 & ) \\
\hline SST & $\left(m g . L^{-1}\right)$ & 202 & \pm & 49 & ( & 5 & ) & 85 & \pm & 53 & ( & 5 & ) \\
\hline SSV & $\left(\mathrm{mg} \cdot \mathrm{L}^{-1}\right)$ & 176 & \pm & 52 & ( & 5 & ) & 66 & \pm & 60 & ( & 5 & ) \\
\hline $\mathrm{M}_{\mathrm{SVT}}$ & (g) & & 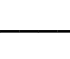 & & & & & & 55,7 & & & & \\
\hline $\mathrm{Cx}$ & $\left(\right.$ g. $\left.\mathrm{L}^{-1}\right)$ & & - & & & & & & 18,6 & & & & \\
\hline $\mathrm{Cx}^{\prime}$ & (g.gsuporte ${ }^{-1}$ ) & & 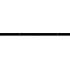 & & & & & & 027 & & & & \\
\hline $\mathrm{V}_{\mathrm{G}}$ & $\left(\mathrm{mL} . \mathrm{ciclo}^{-1}\right)$ & & 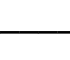 & & & & & 2257 & \pm 1 & 133 & $(1$ & 10 & ) \\
\hline $\mathrm{V}_{\mathrm{CH} 4}$ & $\left(\mathrm{~mL} \cdot \mathrm{ciclo}^{-1}\right)$ & & 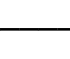 & & & & & 1745 & \pm 1 & 108 & $(1$ & 10 & ) \\
\hline $\mathrm{COAV}_{\text {мот }}$ & $\left(\mathrm{gDQO} \cdot \mathrm{L}^{-1} \cdot \mathrm{d}^{-1}\right)$ & & 7,8 & & & & & & - & & & & \\
\hline $\mathrm{CORV}_{\mathrm{MOF}}$ & $\left(\mathrm{gDQO} \cdot \mathrm{L}^{-1} \cdot \mathrm{d}^{-1}\right)$ & & & & & & & & 7,3 & & & & \\
\hline $\mathrm{COAV}_{\mathrm{CT}}$ & $\left(\right.$ gCarboidratos. $\left.\mathrm{L}^{-1} \cdot \mathrm{d}^{-1}\right)$ & & 1,0 & & & & & & & & & & \\
\hline $\mathrm{CORV}_{\mathrm{CF}}$ & (gCarboidratos. $\mathrm{L}^{-1} \cdot \mathrm{d}^{-1}$ ) & & 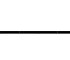 & & & & & & 1,0 & & & & \\
\hline $\mathrm{COAV}_{\mathrm{GT}}$ & (gGlicerina. $L^{-1} \cdot d^{-1}$ ) & & 1,7 & & & & & & & & & & \\
\hline $\mathrm{CORV}_{\mathrm{GF}}$ & (gGlicerina. $\mathrm{L}^{-1} \cdot \mathrm{d}^{-1}$ ) & & & & & & & & 1,7 & & & & \\
\hline COAE $_{S T}$ & $\left(\mathrm{gDQO} \mathrm{gSVT}^{-1} \cdot \mathrm{d}^{-1}\right)$ & & 0,4 & & & & & & 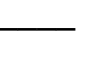 & & & & \\
\hline $\mathrm{CORE}_{\mathrm{SF}}$ & (gDQO.gSVT $\left.{ }^{-1} \cdot \mathrm{d}^{-1}\right)$ & & & & & & & & 0,4 & & & & \\
\hline COAE $_{\mathrm{CT}}$ & (gCarboidratos.gSVT ${ }^{-1} \cdot \mathrm{d}^{-1}$ ) & & 0,1 & & & & & & & & & & \\
\hline $\mathrm{CORE}_{\mathrm{CF}}$ & (gCarboidratos.gSVT ${ }^{-1} \cdot \mathrm{d}^{-1}$ ) & & 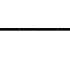 & & & & & & 0,1 & & & & \\
\hline $\mathrm{COAE}_{\mathrm{GT}}$ & (gGlicerina.gSVT ${ }^{-1} \cdot \mathrm{d}^{-1}$ ) & & 0,1 & & & & & & 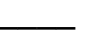 & & & & \\
\hline $\mathrm{CORE}_{\mathrm{GF}}$ & (gGlicerina.gSVT ${ }^{-1} \cdot \mathrm{d}^{-1}$ ) & & & & & & & & 0,1 & & & & \\
\hline $\mathrm{n}_{\mathrm{CH} 4}$ & $\left(\mathrm{molCH}_{4} \cdot \mathrm{d}^{-1}\right)$ & & - & & & & & & 0,2 & & & & \\
\hline PrM & $\left(\mathrm{molCH}_{4} \cdot \mathrm{m}^{-3} \cdot \mathrm{d}^{-1}\right)$ & & - & & & & & & 78,2 & & & & \\
\hline PrME & $\left(\mathrm{molCH}_{4} \cdot \mathrm{kgSVT}^{-1} \cdot \mathrm{d}^{-1}\right)$ & & - & & & & & & 4,2 & & & & \\
\hline RMCA & $\left(\mathrm{molCH}_{4} \cdot \mathrm{kgDQO}^{-1}\right)$ & & 10,1 & & & & & & & & & & \\
\hline RMSA & $\left(\mathrm{molCH}_{4} \cdot \mathrm{molSubstrato}^{-1}\right)$ & & 3,6 & & & & & & - & & & & \\
\hline RMSR & $\left(\mathrm{molCH}_{4} \cdot \mathrm{molSubstrato}^{-1}\right)$ & & 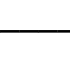 & & & & & & 3,6 & & & & \\
\hline $\mathrm{V}_{\mathrm{A}}$ & $(\mathrm{L})$ & 1,49 & \pm & 0,05 & ( & 11 & ) & & & & & & \\
\hline$V_{R}$ & $(\mathrm{~L})$ & & 3,0 & & & & & & 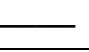 & & & & \\
\hline
\end{tabular}

(*) Entre parênteses o número de amostras considerado no cálculo da média 

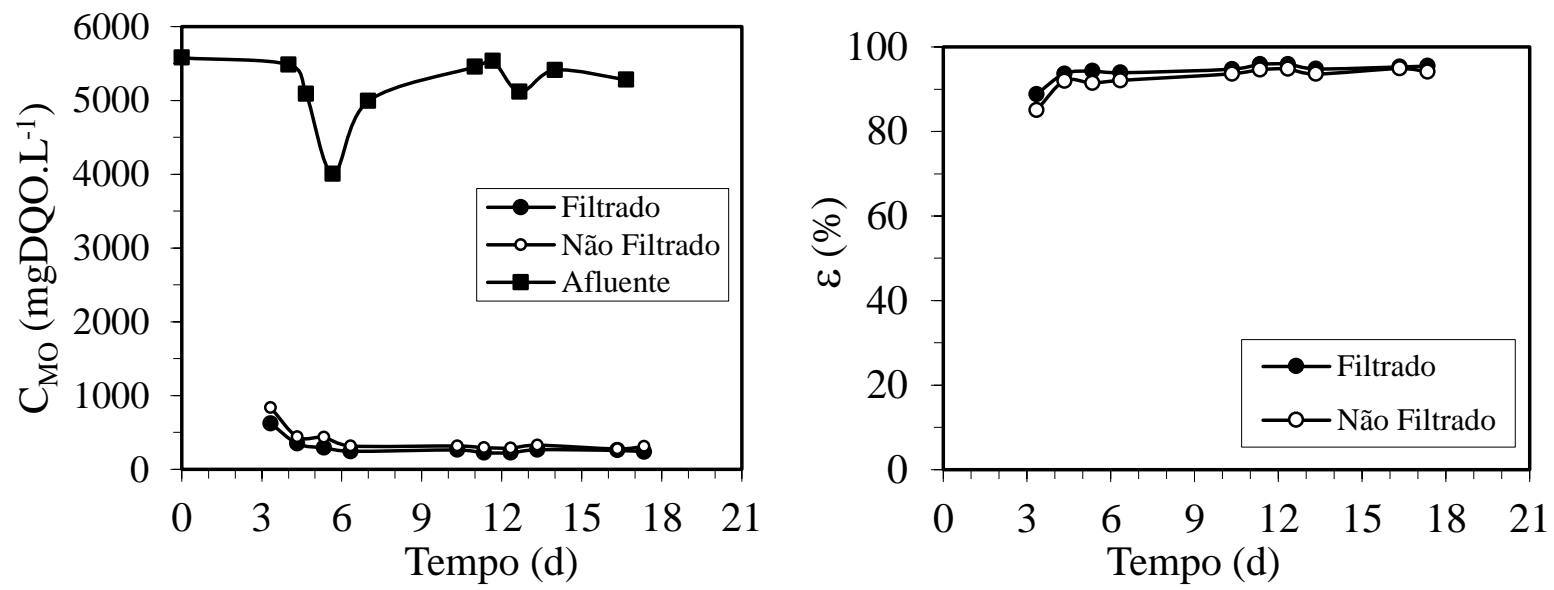

Figura 5.27. Concentração e eficiência de remoção de matéria orgânica na forma de DQO no Ensaio 4: - - afluente amostras não filtradas; • - efluente amostras não filtradas; ○ - efluente amostras filtradas.
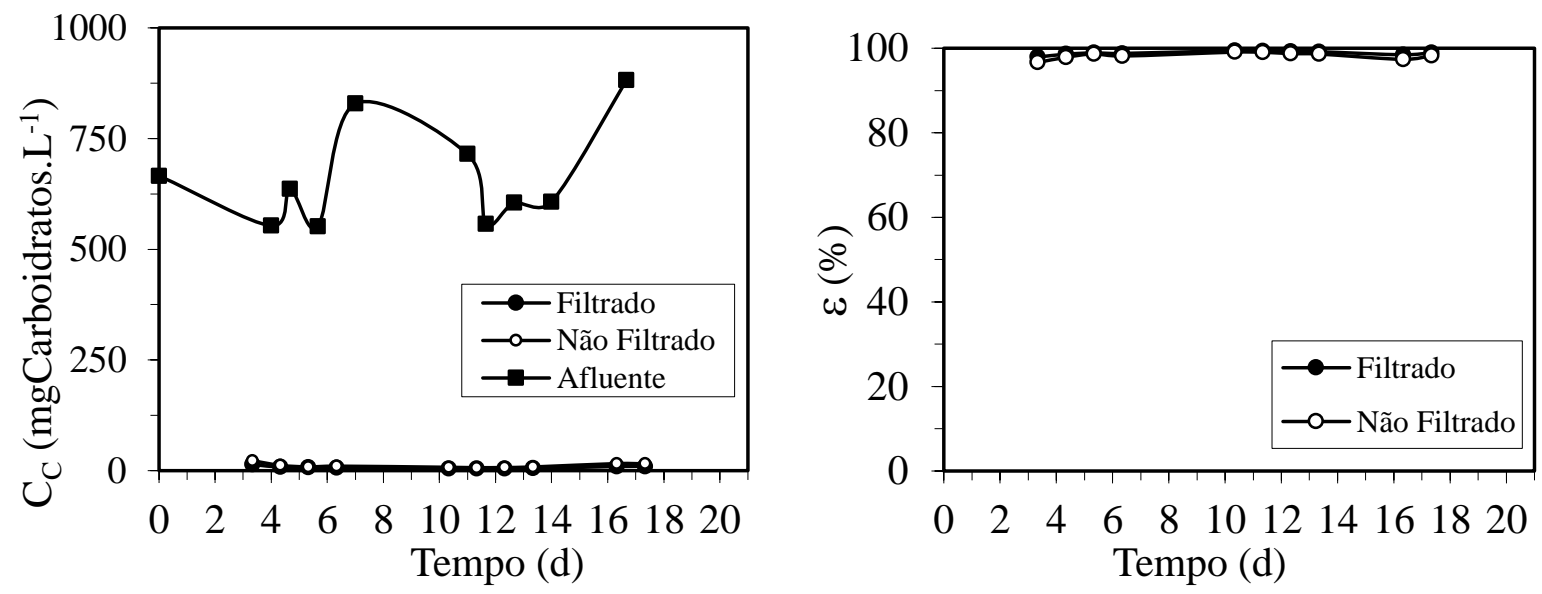

Figura 5.28. Concentração e eficiência de remoção na forma de carboidratos no Ensaio 4: - - afluente amostras não filtradas; $\bullet$ - efluente amostras não filtradas; $\bigcirc-$ efluente amostras filtradas.
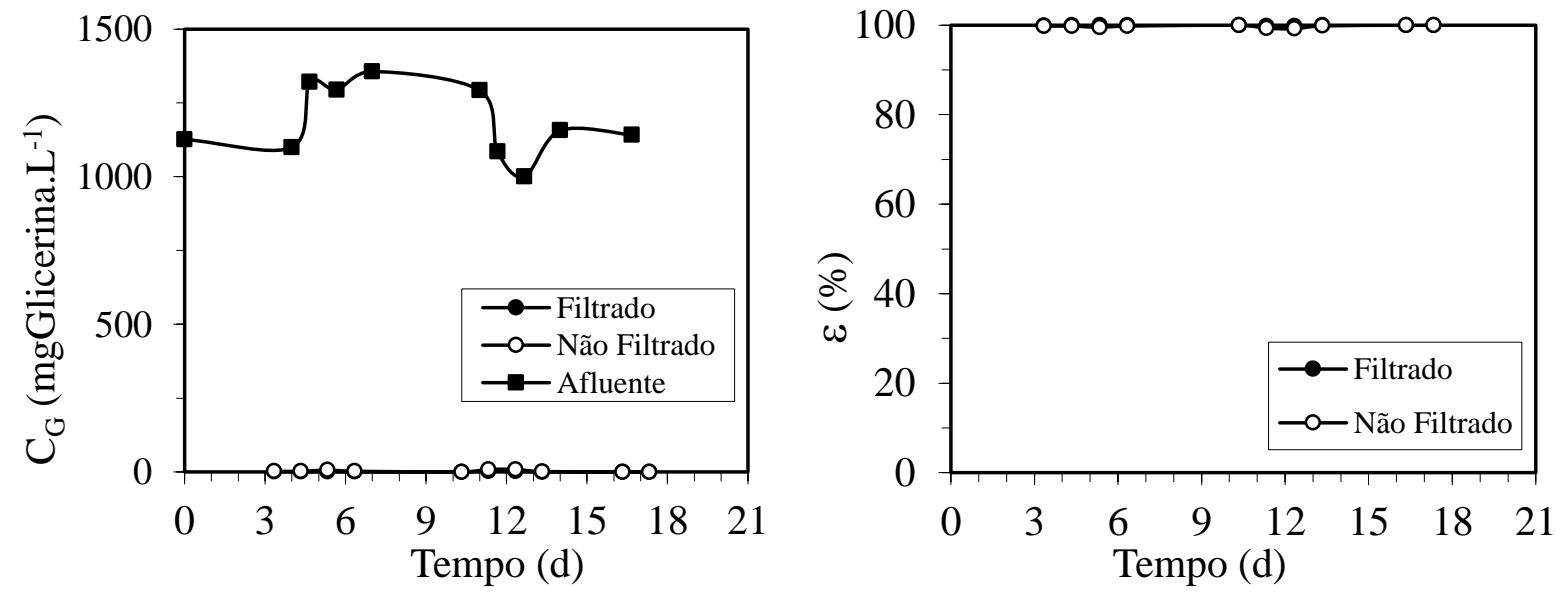

Figura 5.29. Concentração e eficiência de remoção na forma de glicerina no Ensaio 4: a - afluente amostras não filtradas; $\bullet$ - efluente amostras não filtradas; $\bigcirc-$ efluente amostras filtradas. 
A média do $\mathrm{pH}$ afluente foi de 8,80 e do efluente de 7,4. A alcalinidade a bicarbonato afluente teve média de $2050 \mathrm{mgCaCO}_{3} \cdot \mathrm{L}^{-1}$ sendo que a mesma se manteve no efluente com uma média de $2017 \mathrm{mgCaCO}_{3} \cdot \mathrm{L}^{-1}$. A média de AVT do afluente foi de $106 \mathrm{mgHAc} . \mathrm{L}^{-1}$ e a média de AVT do efluente de $131 \mathrm{mgHAc} . \mathrm{L}^{-1}$. É interessante notar que, embora esta condição tenha uma quantidade significativa de glicerina, os AVT voltaram a apresentar um comportamento mais instável, mas isso provavelmente ocorreu devido ao baixo valor de ácidos voláteis encontrados nessa condição, então o erro devido ao método influencia muito na análise realizada.

A produção de biogás, em aspecto quantitativo, e a distribuição dos gases que compõem o biogás no final do ciclo são observadas na Figura 5.30, com média de $2257 \mathrm{~mL}$ de biogás e $1745 \mathrm{~mL}$ de metano, sendo que a porcentagem média de metano foi igual a $77 \%$. Sendo assim, a produtividade molar de metano foi igual a $78,2 \mathrm{molCH}_{4} \cdot \mathrm{m}^{-3} \cdot \mathrm{d}^{-1}$ - a menor obtida dentre todos os ensaios de codigestão realizados, inclusive quando comparado com a DA de soro puro. Um resultado esperado, pois o soro é um substrato de biodegradabilidade notadamente mais fácil do que a glicerina crua.
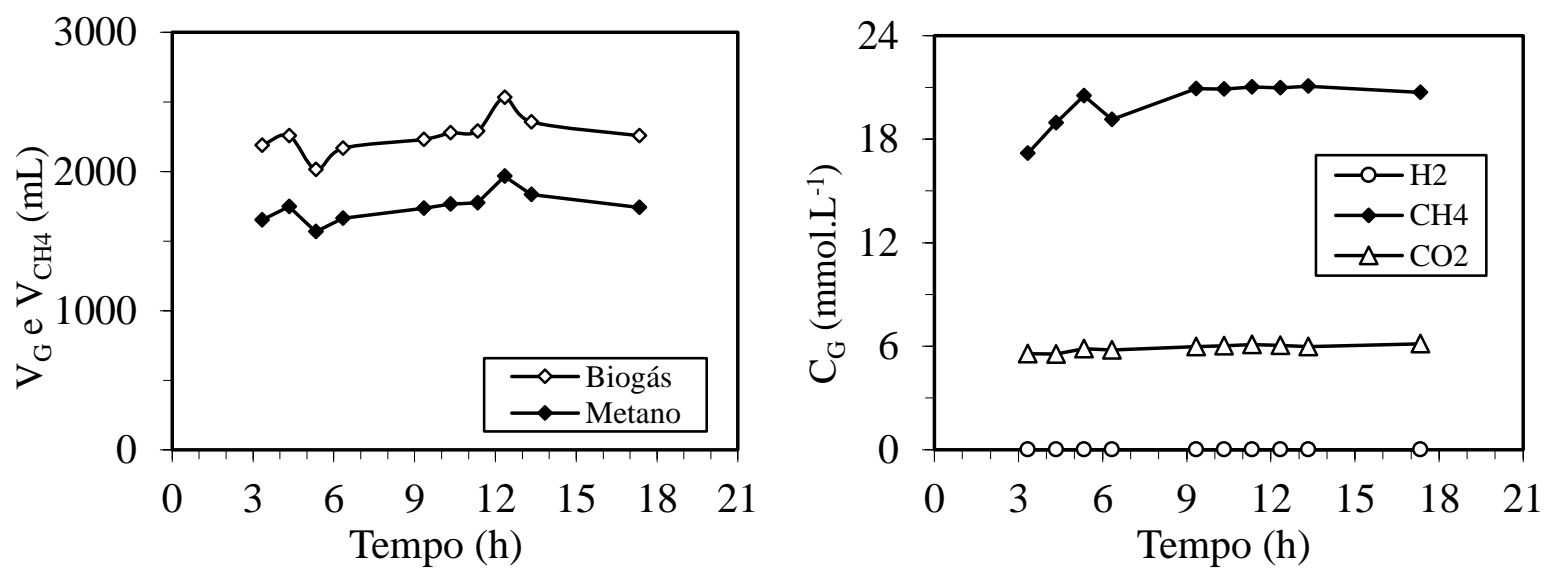

Figura 5.30. Volume de biogás $\left(\mathrm{V}_{\mathrm{G}}\right)$ e de metano $\left(\mathrm{V}_{\mathrm{CH} 4}\right)$ na $\mathrm{CNTP}$ e concentrações dos componentes do

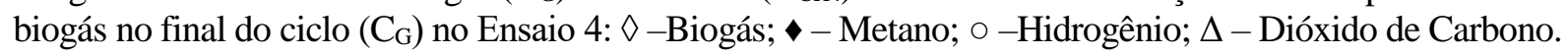

Em relação aos perfis, a Figura 5.31 apresenta o perfil de DQO, de Carboidratos e de Glicerina. Nota-se que os perfis seguem a mesma tendência dos ensaios passados, embora haja uma concentração bem baixa dos substratos ao longo do ciclo. 

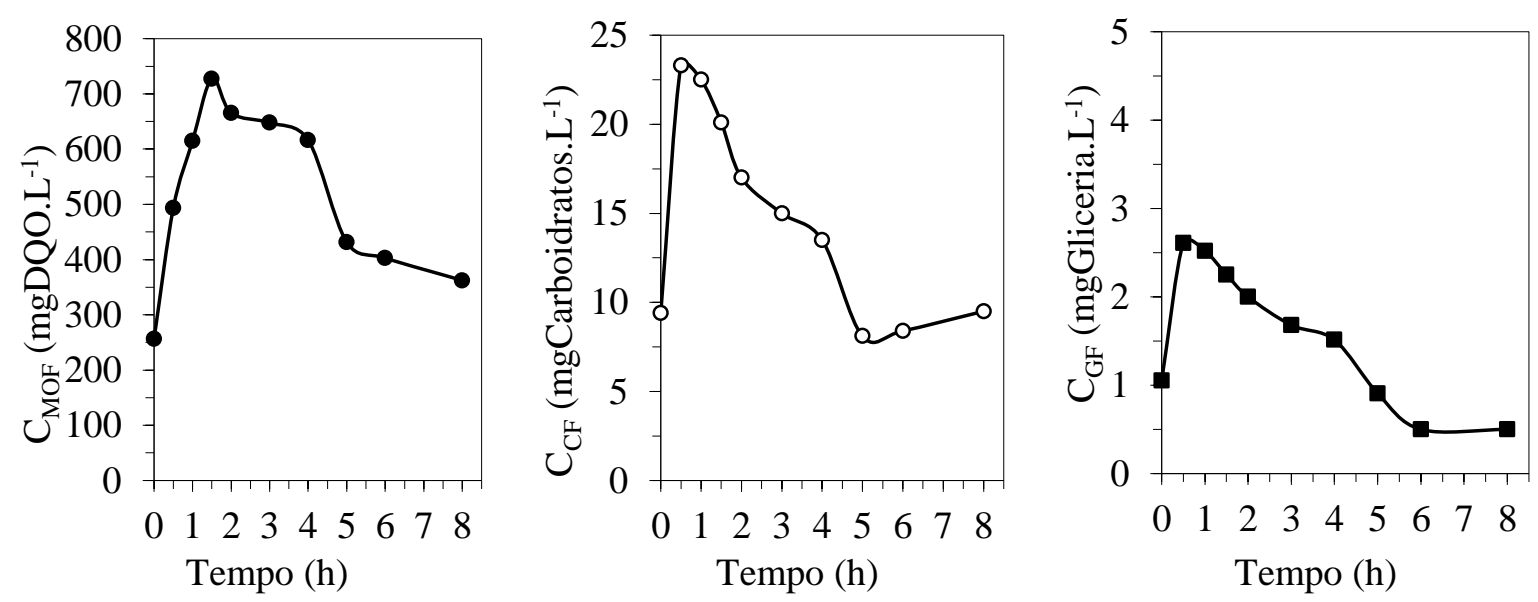

Figura 5.31. Concentração de matéria orgânica, carboidratos e glicerina durante o ciclo no Ensaio 4: $-\mathrm{C}_{\mathrm{SF}} ; \circ-\mathrm{C}_{\mathrm{CF}} ; \mathbf{-}-\mathrm{C}_{\mathrm{GF}}$.

A Figura 5.32 apresenta os perfis de $\mathrm{pH}$, alcalinidade a bicarbonato e ácidos voláteis totais ao longo do ciclo. O pH permanece constante ao longo do ciclo por volta de 7,4, graças a alcalinidade fornecida pelo afluente que é alimentado gradualmente e é consumida durante o ciclo. Os ácidos voláteis totais mostram o mesmo comportamento observado nos outros ensaios.
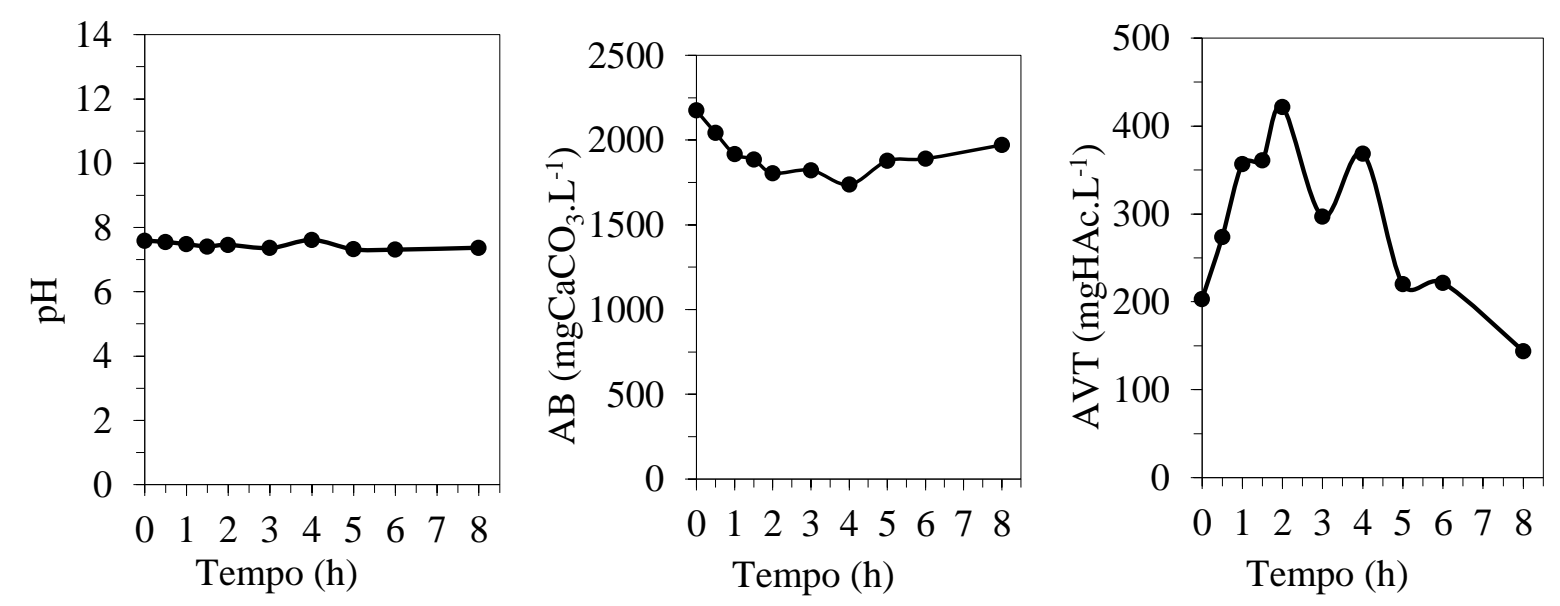

Figura 5.32. Valores de pH, alcalinidade a bicarbonato (AB) e ácidos voláteis totais (AVT) no Ensaio 4.

O perfil dos compostos intermediários do metabolismo é apresentado na Figura 5.33. Assim como nos outros ensaios, há a predominância de ácido acético e ácido propiônico, embora em menores concentrações. 


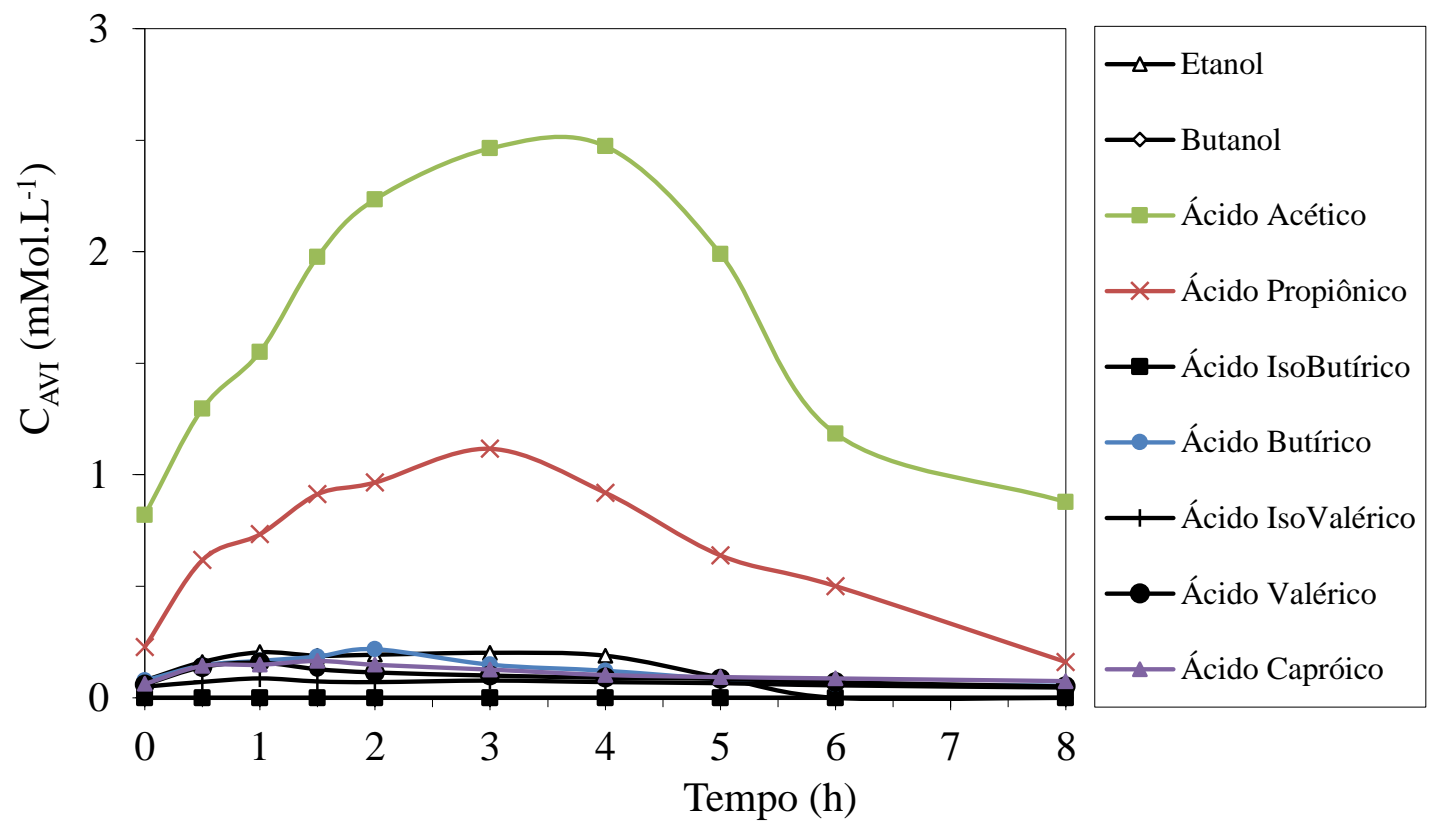

Figura 5.33. Concentração dos compostos intermediários ao longo do ciclo no Ensaio 4: $\Delta$ - etanol; $\diamond$ butanol; $\square$ - ácido acético ; -x-ácido propiônico; - ácido isobutírico; • - ácido butírico; + ácido isovalérico $\bullet$ - ácido valérico; $\Delta$ - ácido capróico.

A produção volumétrica acumulada de biogás e os desvios padrões de cada um dos pontos podem ser observados na Figura 5.34 e o perfil das concentrações de cada um dos gases e suas respectivas porcentagens estão ilustrados na Figura 5.35. Houve baixíssima variação no volume de biogás recolhido diariamente e, ao final do ensaio, tinha-se $23 \%$ de $\mathrm{CO}_{2}$ e $77 \%$ de $\mathrm{CH}_{4}$ - uma excelente qualidade de biogás, mas com baixa quantidade de volume produzido quando é feita sua comparação com outros ensaios.

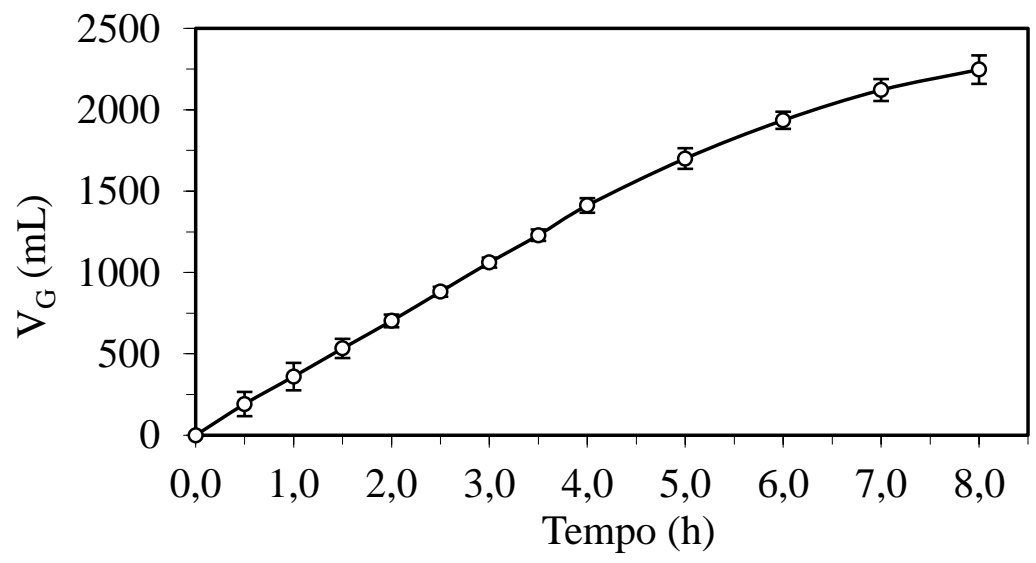

Figura 5.34. Produção volumétrica média acumulada do biogás durante o ciclo no Ensaio 4. 

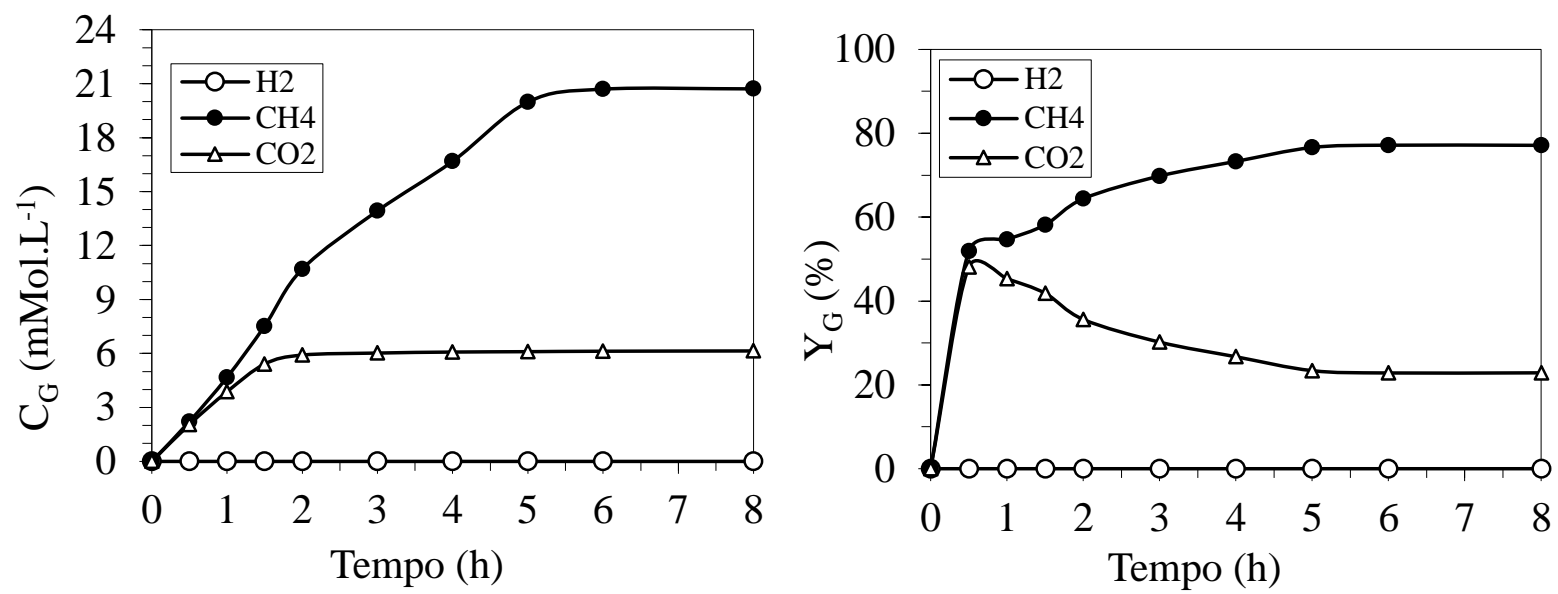

Figura 5.35. Concentração dos compostos do biogás durante o ciclo e suas respectivas porcentagens no Ensaio 4: $\circ-\mathrm{H}_{2} ; \bullet-\mathrm{CH}_{4} ; \Delta-\mathrm{CO}_{2}$.

\subsubsection{Ensaio 5 (100\% Glicerina - 5000 mgDQO.L $\left.{ }^{-1}-8 \mathrm{~h}-\mathrm{BA}\right)$}

O Ensaio 5 é a última condição da Fase I. Ele foi realizado com um afluente contendo $100 \%$ de glicerina, o que foram, em média, $1724 \mathrm{mgGlicerina} . \mathrm{L}^{-1}$, e ele teve como objetivo servir como comparação para os Ensaios onde houve codigestão, assim como o Ensaio 1 (100\% soro).

O valor real da COAV foi de 7,9 gDQO. $\mathrm{L}^{-1} \cdot \mathrm{d}^{-1}$ e a CORV atingida foi de 7,9 gDQO.L ${ }^{1} . \mathrm{d}^{-1}$. A Tabela 5.5 apresenta a média dos parâmetros monitorados.

O monitoramento diário apresentou um bom consumo de matéria orgânica na forma de DQO, com média de concentração afluente não filtrada de $5286 \mathrm{mgDQO} \cdot \mathrm{L}^{-1}$, efluente não filtrada $808 \mathrm{mgDQO} . \mathrm{L}^{-1}$ e de efluente filtrada de $673 \mathrm{mgDQO} . \mathrm{L}^{-1}$, com remoção média para amostras não filtradas de $85 \%$ e para amostras filtradas de $87 \%$ (Figura 5.36). Isso representa as piores eficiências de remoção de matéria orgânica dentre todos os ensaios da Fase I.

Em relação ao monitoramento diário de glicerina, a média de concentração afluente não filtrada foi igual a $1724 \mathrm{mgGlicerina} \cdot \mathrm{L}^{-1}$. Neste ensaio, o processo consumiu praticamente toda a glicerina alimentada, mas seus valores residuais ainda são altos quando comparados aos obtidos nos outros ensaios. Os valores das amostras de efluente não filtrado ficaram em $105 \mathrm{mgGlicerina} . \mathrm{L}^{-1} \mathrm{e}$ os valores para o filtrado ficaram em torno de $103 \mathrm{mgGlicerina} . \mathrm{L}^{-1}$, o que representa uma eficiência média de remoção para amostras não filtradas e filtradas de 94\% (Figura 5.37). 
Tabela 5.5. Valores médios dos parâmetros monitorados no Ensaio 5.

\begin{tabular}{|c|c|c|c|c|c|c|c|c|c|}
\hline \multicolumn{2}{|r|}{ Parâmetro } & \multicolumn{4}{|c|}{ Afluente } & \multicolumn{4}{|c|}{ Efluente } \\
\hline $\mathrm{C}_{\text {MOT }}$ & $\left(\mathrm{mgDQO} \cdot \mathrm{L}^{-1}\right)$ & 5286 & \pm 275 & $(1)$ & 0 ) & 808 & \pm 257 & $(10$ & $10 \quad$ \\
\hline $\mathrm{C}_{\mathrm{MOF}}$ & $\left(\mathrm{mgDQO} \cdot \mathrm{L}^{-1}\right)$ & & & & & 673 & \pm 191 & $(10$ & $10)$ \\
\hline$\varepsilon_{\text {МOT }}$ & $(\%)$ & & & & & 85 & \pm 5 & $(10$ & $10)$ \\
\hline$\varepsilon_{\mathrm{MOF}}$ & $(\%)$ & & & & & 87 & & $(10$ & $10)$ \\
\hline $\mathrm{C}_{\mathrm{GT}}$ & (mgGlicerina. $\mathrm{L}^{-1}$ ) & 1724 & \pm 91 & $(1)$ & 0 ) & 105 & \pm 47 & $(9$ & $9)$ \\
\hline $\mathrm{C}_{\mathrm{GF}}$ & (mgGlicerina.L $\mathrm{L}^{-1}$ ) & & & & & 103 & \pm 47 & ( 9 & $9 \quad)$ \\
\hline$\varepsilon_{\mathrm{GT}}$ & $(\%)$ & & & & & 94 & \pm 3 & ( 9 & 9 ) \\
\hline$\varepsilon_{\mathrm{GF}}$ & $(\%)$ & & & & & 94 & \pm 3 & $(9$ & $9 \quad)$ \\
\hline $\mathrm{pH}$ & (u) & 8,9 & $\pm 0,1$ & $(1)$ & $0)$ & 7,8 & $\pm 0,2$ & $(10$ & $10)$ \\
\hline AVT & $\left(\mathrm{mgHAc} . \mathrm{L}^{-1}\right)$ & 115 & \pm 50 & $(1)$ & 0 ) & 142 & \pm 24 & $(10$ & $10)$ \\
\hline $\mathrm{AT}$ & $\left(\mathrm{mgCaCO}_{3} \cdot \mathrm{L}^{-1}\right)$ & 2201 & \pm 52 & $(1)$ & 0 ) & 2149 & $9 \pm 61$ & $(10$ & $10)$ \\
\hline $\mathrm{AP}$ & $\left(\mathrm{mgCaCO}_{3} \cdot \mathrm{L}^{-1}\right)$ & 1747 & \pm 93 & $(1)$ & $0)$ & 1668 & $8 \pm 67$ & $(10$ & $10)$ \\
\hline AI & $\left(\mathrm{mgCaCO}_{3} \cdot \mathrm{L}^{-1}\right)$ & 454 & \pm 94 & $(1)$ & $0)$ & 482 & \pm 48 & $(10$ & $10)$ \\
\hline $\mathrm{AB}$ & $\left(\mathrm{mgCaCO}_{3} \cdot \mathrm{L}^{-1}\right)$ & 2120 & \pm 49 & $(1)$ & 0 ) & 2048 & $8 \pm 69$ & $(10$ & $10)$ \\
\hline ST & $\left(\mathrm{mg} \cdot \mathrm{L}^{-1}\right)$ & 3681 & \pm 97 & $(4$ & ) & 2891 & $1 \pm 111$ & ( 4 & $4)$ \\
\hline SVT & $\left(\mathrm{mg} \cdot \mathrm{L}^{-1}\right)$ & 1275 & \pm 105 & $(4$ & ) & 581 & \pm 108 & ( 4 & $4)$ \\
\hline SST & $\left(\mathrm{mg} \cdot \mathrm{L}^{-1}\right)$ & 33 & \pm 31 & $(4$ & ) & 57 & \pm 25 & ( 4 & $4)$ \\
\hline SSV & $\left(\mathrm{mg} \cdot \mathrm{L}^{-1}\right)$ & 21 & \pm 21 & $(4$ & ) & 36 & \pm 20 & ( 4 & $4)$ \\
\hline $\mathrm{M}_{\mathrm{sVT}}$ & (g) & & & & & & 65,6 & & \\
\hline $\mathrm{Cx}$ & $\left(\mathrm{g} \cdot \mathrm{L}^{-1}\right)$ & & - & & & & 22,0 & & \\
\hline $\mathrm{Cx}^{\prime}$ & (g.gsuporte $\left.{ }^{-1}\right)$ & & 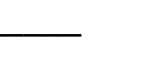 & & & & 0,959 & & \\
\hline $\mathrm{V}_{\mathrm{G}}$ & $\left(\mathrm{mL} . \mathrm{ciclo}^{-1}\right)$ & & 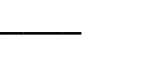 & & & 2196 & $6 \pm 166$ & ( 8 & $8)$ \\
\hline $\mathrm{V}_{\mathrm{CH} 4}$ & $\left(\mathrm{~mL} \cdot \mathrm{ciclo}^{-1}\right)$ & & 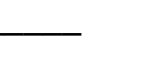 & & & 1751 & $1 \pm 122$ & $(8$ & $8)$ \\
\hline $\mathrm{COAV}_{\text {MOT }}$ & $\left(\mathrm{gDQO} \cdot \mathrm{L}^{-1} \cdot \mathrm{d}^{-1}\right)$ & & 7,9 & & & & - & & \\
\hline $\mathrm{CORV}_{\mathrm{MOF}}$ & $\left(\mathrm{gDQO} \cdot \mathrm{L}^{-1} \cdot \mathrm{d}^{-1}\right)$ & & 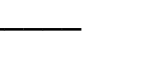 & & & & 6,9 & & \\
\hline $\mathrm{COAV}_{\mathrm{GT}}$ & (gGlicerina. $\mathrm{L}^{-1} \cdot \mathrm{d}^{-1}$ ) & & 2,6 & & & & & & \\
\hline $\mathrm{CORV}_{\mathrm{GF}}$ & (gGlicerina. $L^{-1} \cdot d^{-1}$ ) & & 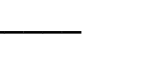 & & & & 2,6 & & \\
\hline COAE $_{S T}$ & $\left(\right.$ gDQO.gSVT $\left.{ }^{-1} \cdot \mathrm{d}^{-1}\right)$ & & 0,4 & & & & & & \\
\hline $\mathrm{CORE}_{\mathrm{SF}}$ & $\left(\mathrm{gDQO} \mathrm{gSVT}^{-1} \cdot \mathrm{d}^{-1}\right)$ & & & & & & 0,3 & & \\
\hline $\mathrm{COAE}_{\mathrm{GT}}$ & (gGlicerina.gSVT ${ }^{-1} \cdot \mathrm{d}^{-1}$ ) & & 0,1 & & & & 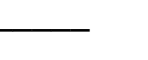 & & \\
\hline $\mathrm{CORE}_{\mathrm{GF}}$ & (gGlicerina.gSVT ${ }^{-1} \cdot \mathrm{d}^{-1}$ ) & & & & & & 0,1 & & \\
\hline $\mathrm{n}_{\mathrm{CH} 4}$ & $\left(\mathrm{molCH}_{4} \cdot \mathrm{d}^{-1}\right)$ & & - & & & & 0,2 & & \\
\hline PrM & $\left(\mathrm{molCH}_{4} \cdot \mathrm{m}^{-3} \cdot \mathrm{d}^{-1}\right)$ & & 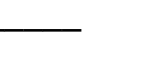 & & & & 78,7 & & \\
\hline PrME & $\left(\mathrm{molCH}_{4} \cdot \mathrm{kgSVT}^{-1} \cdot \mathrm{d}^{-1}\right)$ & & - & & & & 3,6 & & \\
\hline RMCA & $\left(\mathrm{molCH}_{4} \cdot \mathrm{kgDQO}^{-1}\right)$ & & 10,0 & & & & & & \\
\hline RMSA & $\left(\mathrm{molCH}_{4} \cdot \mathrm{molSubstrato}^{-1}\right)$ & & 2,8 & & & & 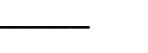 & & \\
\hline RMSR & $\left(\mathrm{molCH}_{4} \cdot \mathrm{molSubstrato}^{-1}\right)$ & & - & & & & 2,8 & & \\
\hline $\mathrm{V}_{\mathrm{A}}$ & $(\mathrm{L})$ & 1,48 & $\pm 0,04$ & 9 & ) & & & & \\
\hline $\mathrm{V}_{\mathrm{R}}$ & $(\mathrm{L})$ & & 3,0 & & & & 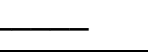 & & \\
\hline
\end{tabular}

(*) Entre parênteses o número de amostras considerado no cálculo da média 

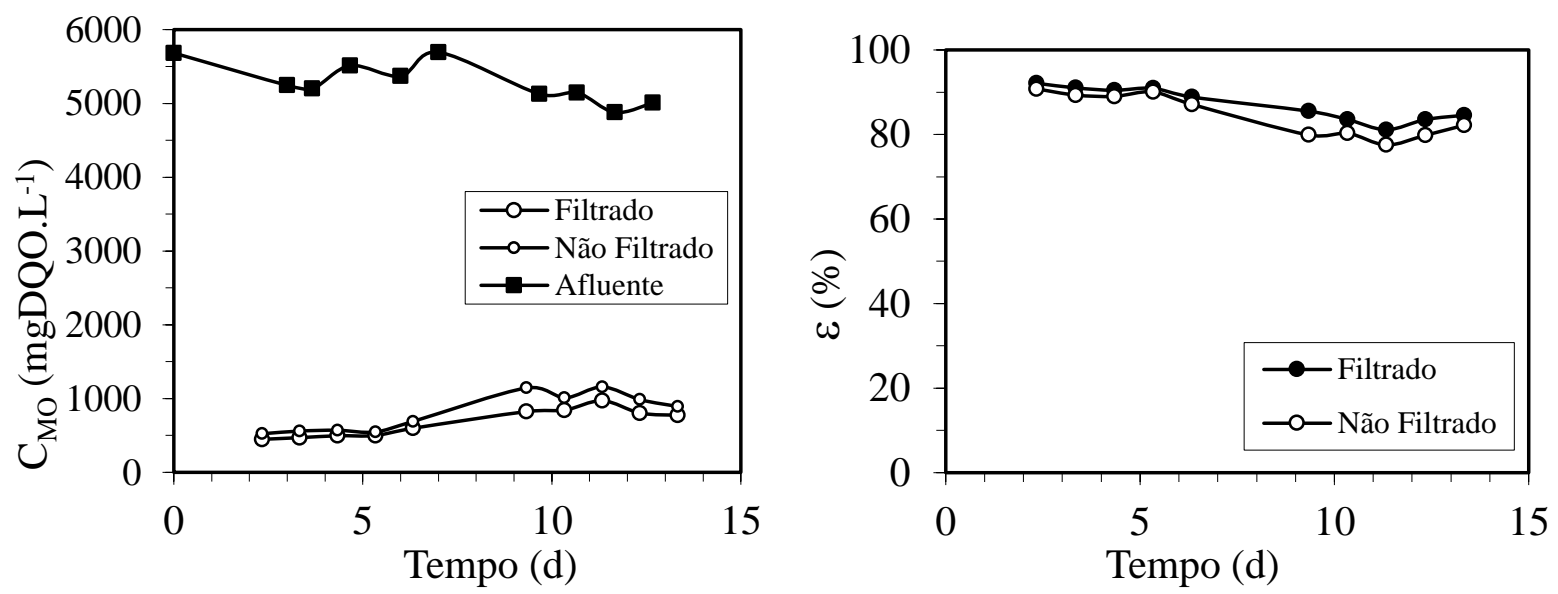

Figura 5.36. Concentração e eficiência de remoção de matéria orgânica na forma de DQO no Ensaio 5: - - afluente amostras não filtradas; • - efluente amostras não filtradas; ○ - efluente amostras filtradas
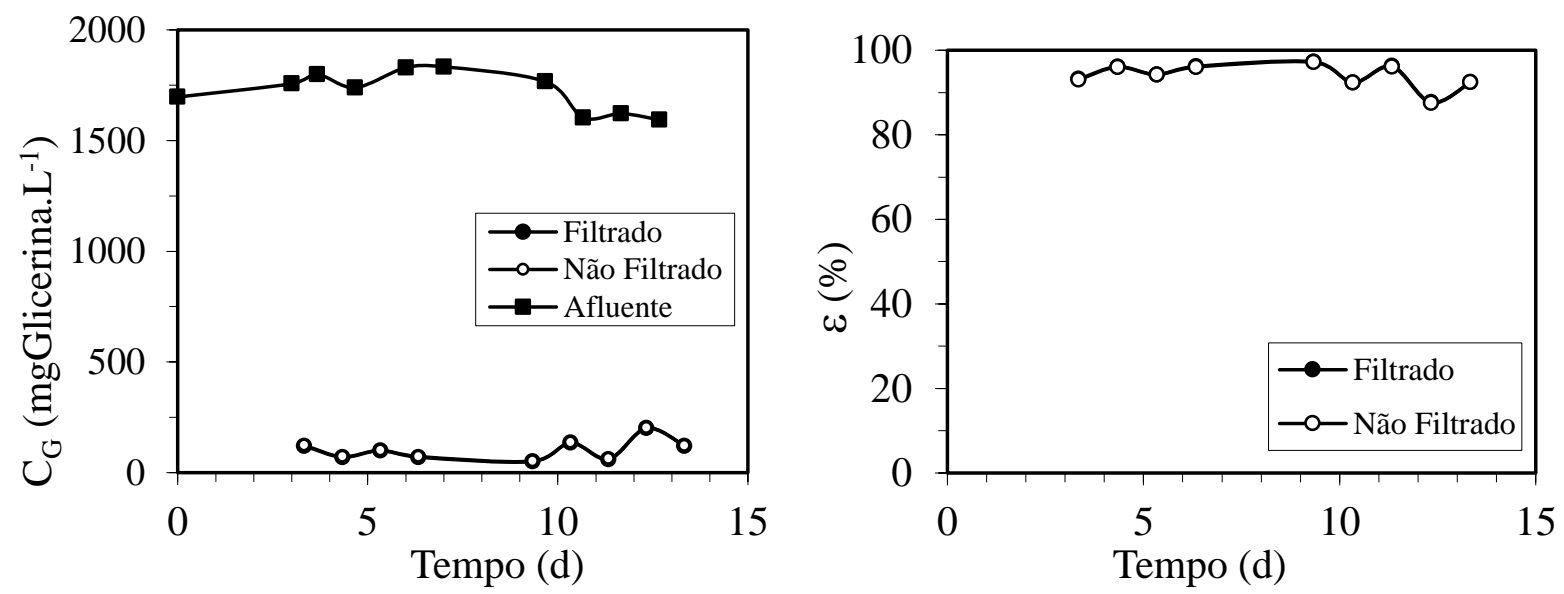

Figura 5.37. Concentração e eficiência de remoção na forma de glicerina no Ensaio 5: a - afluente amostras não filtradas; $\bullet$ - efluente amostras não filtradas; $\bigcirc-$ efluente amostras filtradas.

A média do $\mathrm{pH}$ afluente foi de 8,89 e do efluente de 7,8. A alcalinidade a bicarbonato do afluente teve média de $2120 \mathrm{mgCaCO}_{3} \cdot \mathrm{L}^{-1}$ sendo que a mesma se manteve no efluente com uma média de $2048 \mathrm{mgCaCO} 3 . \mathrm{L}^{-1}$. A média de AVT do afluente foi de $115 \mathrm{mgHAc} . \mathrm{L}^{-1}$ e a média de AVT do efluente de 142 mgHAc. $\mathrm{L}^{-1}$.

A produção de biogás, em aspecto quantitativo, e a distribuição dos gases que compõem o biogás no final do ciclo são observadas na Figura 5.38, com média de $2196 \mathrm{~mL}$ de biogás e $1751 \mathrm{~mL}$ de metano, sendo que a porcentagem média de metano foi igual a $80 \%$. Sendo assim, a produtividade molar de metano foi igual a $78,7 \mathrm{molCH}_{4} \cdot \mathrm{m}^{-3} \cdot \mathrm{d}^{-1}$, o que é ligeiramente maior do que a produtividade obtida no Ensaio 4. Comparando todas as produtividades obtidas na Fase I, encontra-se que o maior índice foi o encontrado no Ensaio 2 $\left(101,8 \mathrm{molCH}_{4} \cdot \mathrm{m}^{-3} \cdot \mathrm{d}^{-1}\right)$, sendo $29,4 \%$ maior que o Ensaio 5 . 

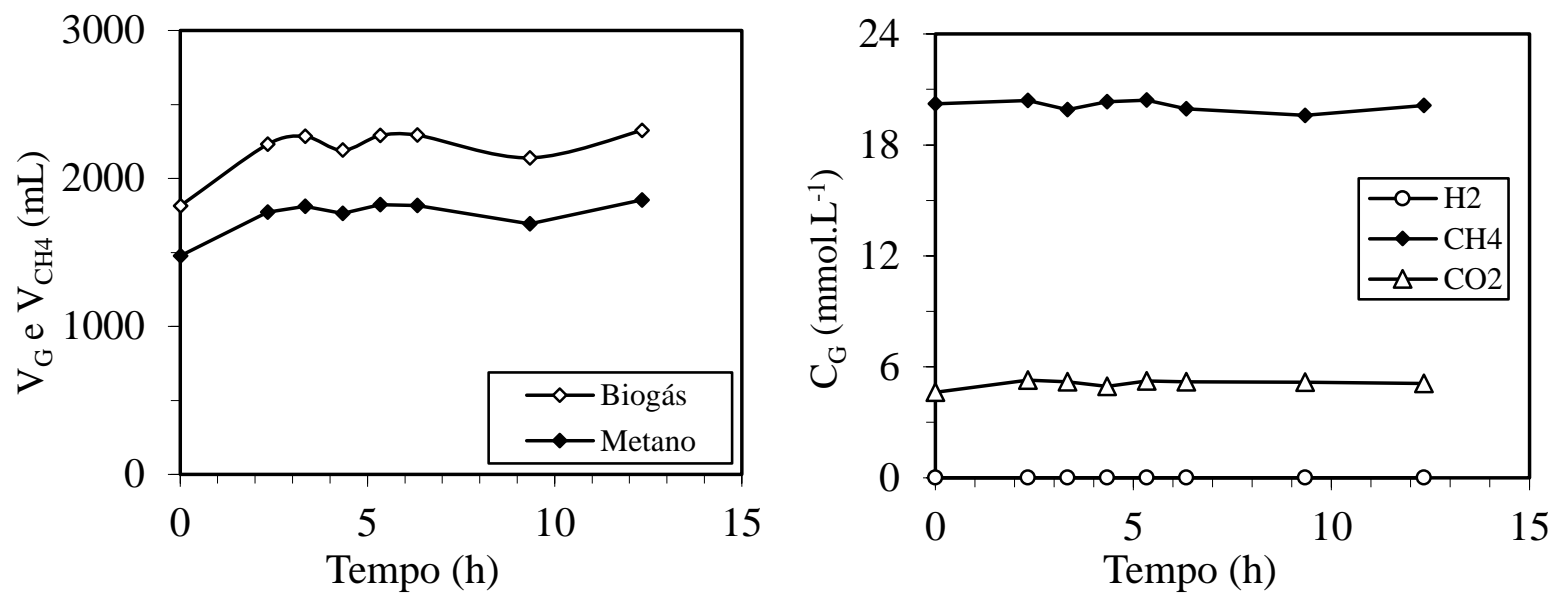

Figura 5.38. Volume de biogás $\left(\mathrm{V}_{\mathrm{G}}\right)$ e de metano $\left(\mathrm{V}_{\mathrm{CH} 4}\right)$ na $\mathrm{CNTP}$ e concentrações dos componentes do biogás no final do ciclo $\left(\mathrm{C}_{\mathrm{G}}\right)$ no Ensaio 5: $\diamond$-Biogás; $\downarrow$-Metano; ○-Hidrogênio; $\Delta$ - Dióxido de Carbono.

Em relação aos perfis, a Figura 5.39 apresenta o perfil de DQO e de Glicerina.
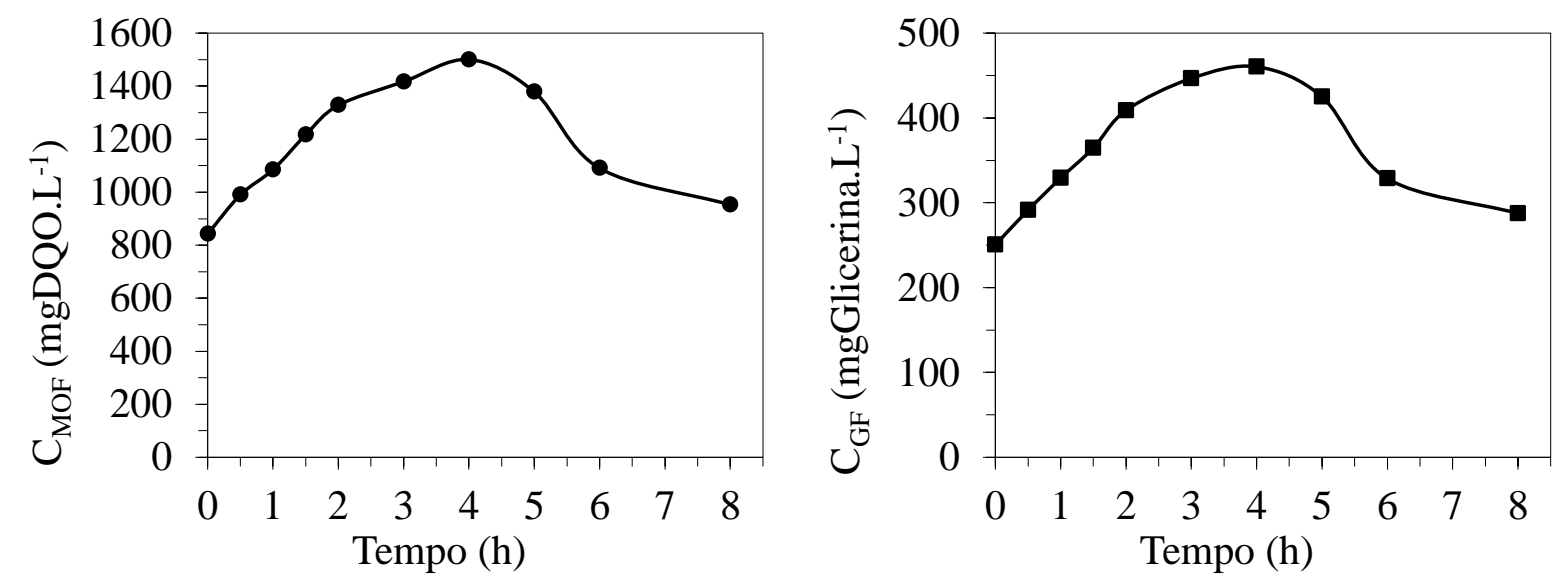

Figura 5.39. Concentração de matéria orgânica e glicerina durante o ciclo no Ensaio 5: $\bullet-\mathrm{C}_{\mathrm{MOF}}$; - $-\mathrm{C}_{\mathrm{GF}}$.

A Figura 5.40 apresenta os perfis de $\mathrm{pH}$, alcalinidade a bicarbonato e ácidos voláteis totais ao longo do ciclo. $\mathrm{O}$ pH permanece constante ao longo do ciclo por volta de 7,7, juntamente com a alcalinidade $\left(2071 \mathrm{mgCaCO}_{3} \cdot \mathrm{L}^{-1}\right)$. Os ácidos voláteis totais mostram um comportamento um pouco instável durante o ciclo, mas, como ocorreu anteriormente, deve-se lembrar que os valores obtidos são muito baixos e, portanto, mais influenciáveis pelo erro experimental. 

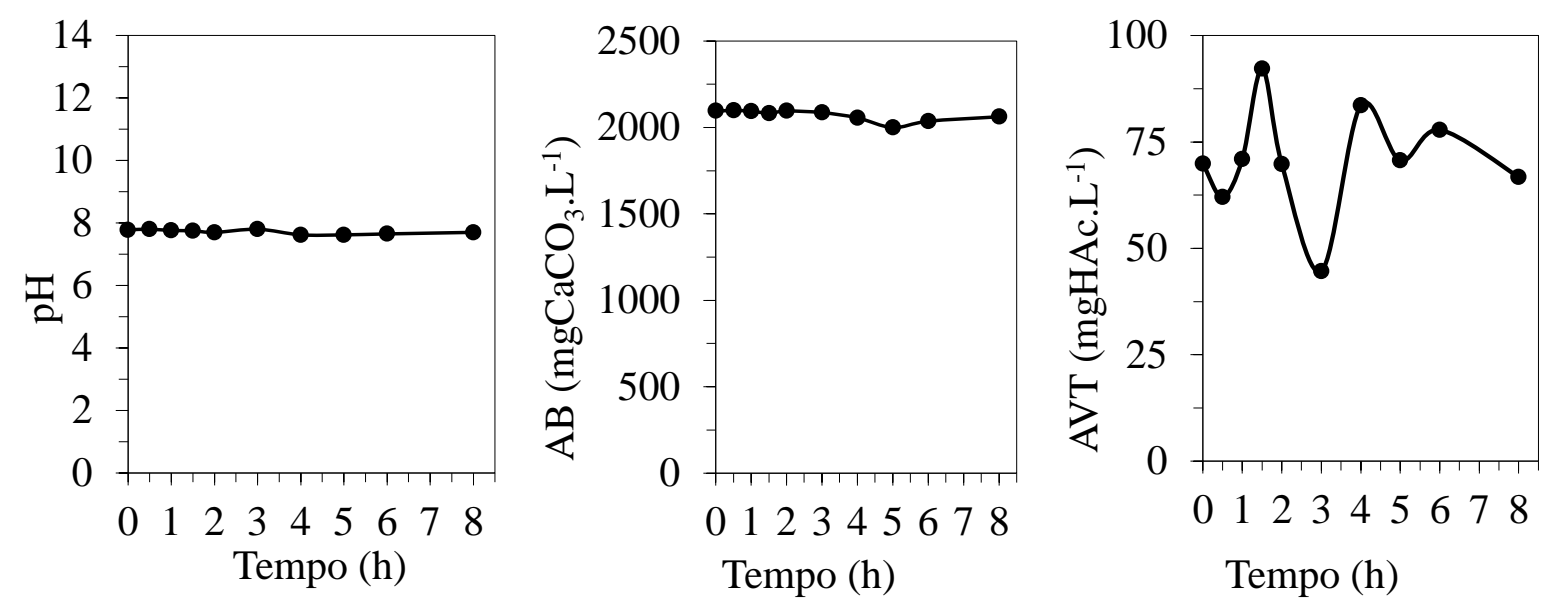

Figura 5.40. Valores de $\mathrm{pH}$, alcalinidade a bicarbonato $(\mathrm{AB})$ e ácidos voláteis totais (AVT) no Ensaio 5.

O perfil dos compostos intermediários do metabolismo é apresentado na Figura 5.41. Assim como nos outros ensaios, há a predominância de ácido propiônico e de ácido acético, mas com maior quantidade de propiônico, o que ocorreu apenas neste ensaio.

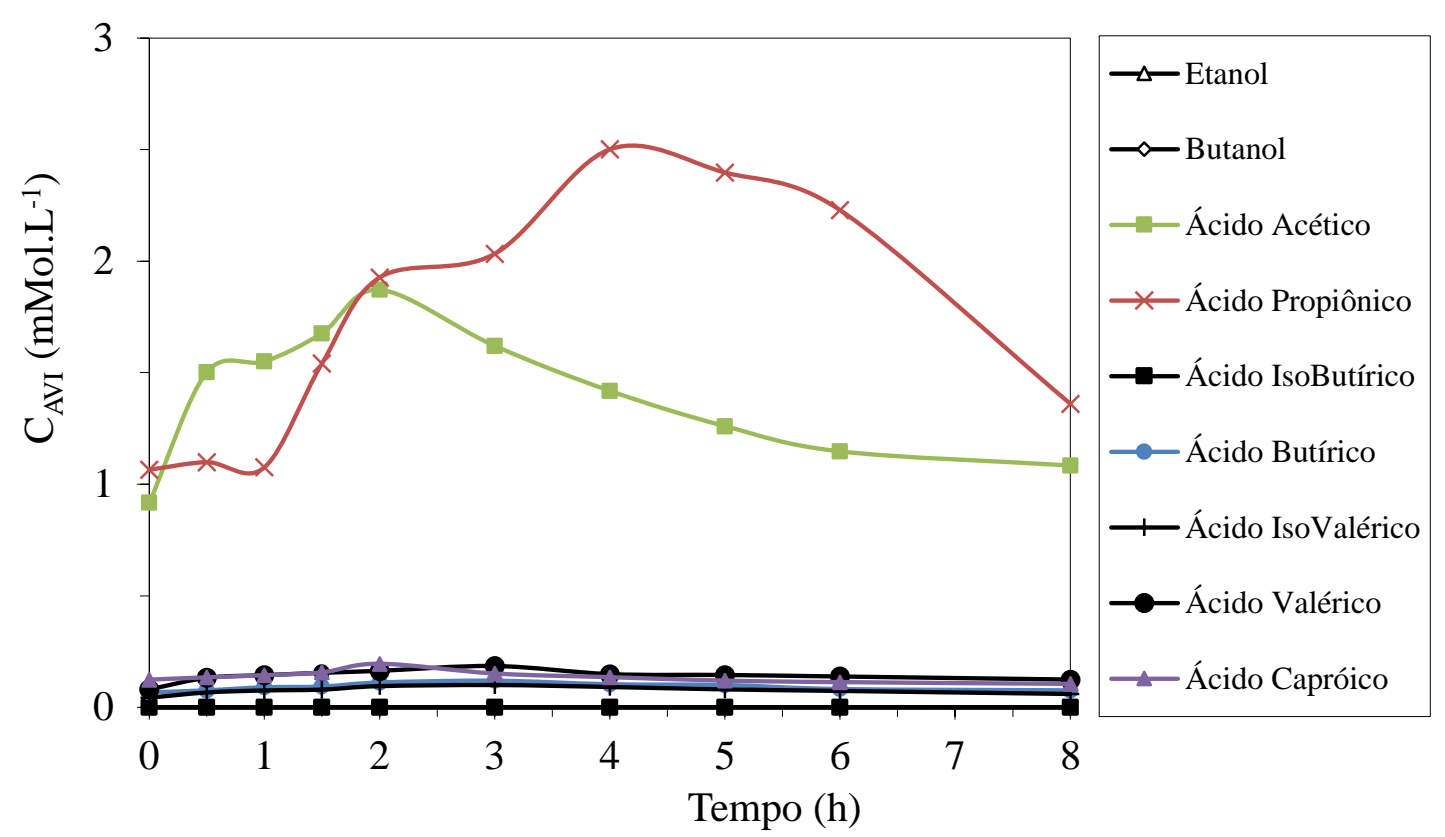

Figura 5.41. Concentração dos compostos intermediários ao longo do ciclo no Ensaio 5: $\Delta$ - etanol; $\diamond$ butanol; $\square$ - ácido acético; -x-ácido propiônico; - - ácido isobutírico; • - ácido butírico; + ácido isovalérico $\bullet$ - ácido valérico; $\boldsymbol{\Delta}$ - ácido capróico.

A produção volumétrica acumulada de biogás e os desvios padrões de cada um dos pontos podem ser observados na Figura 5.42 e o perfil das concentrações de cada um dos gases e suas respectivas porcentagens estão ilustrados na Figura 5.43. Houve baixíssima variação no volume de biogás recolhido diariamente e, ao final do ensaio, tinha-se $21 \%$ de $\mathrm{CO}_{2}$ e $79 \%$ de $\mathrm{CH}_{4}$. 


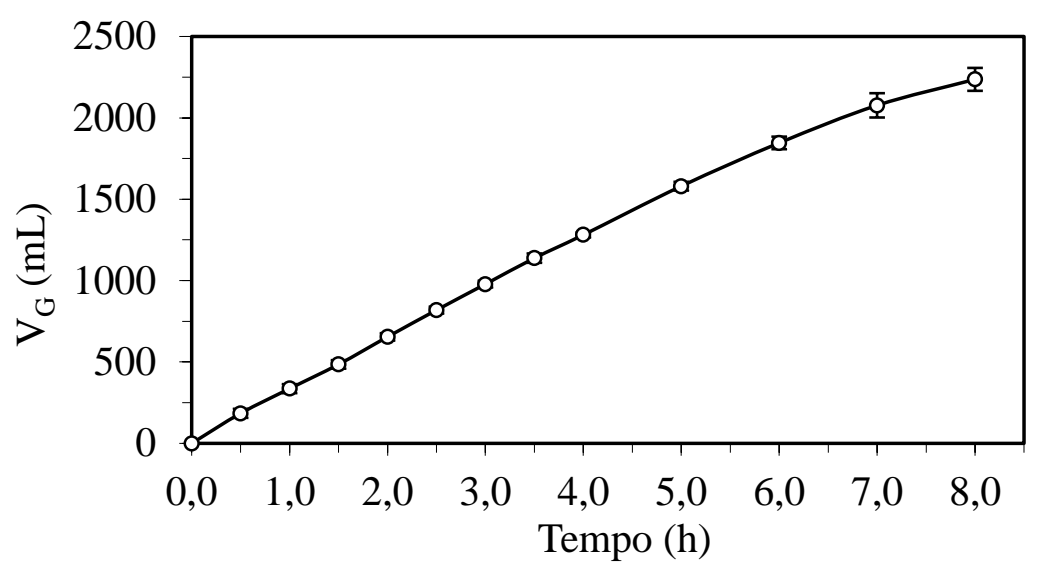

Figura 5.42. Produção volumétrica média acumulada do biogás durante o ciclo no Ensaio 5.
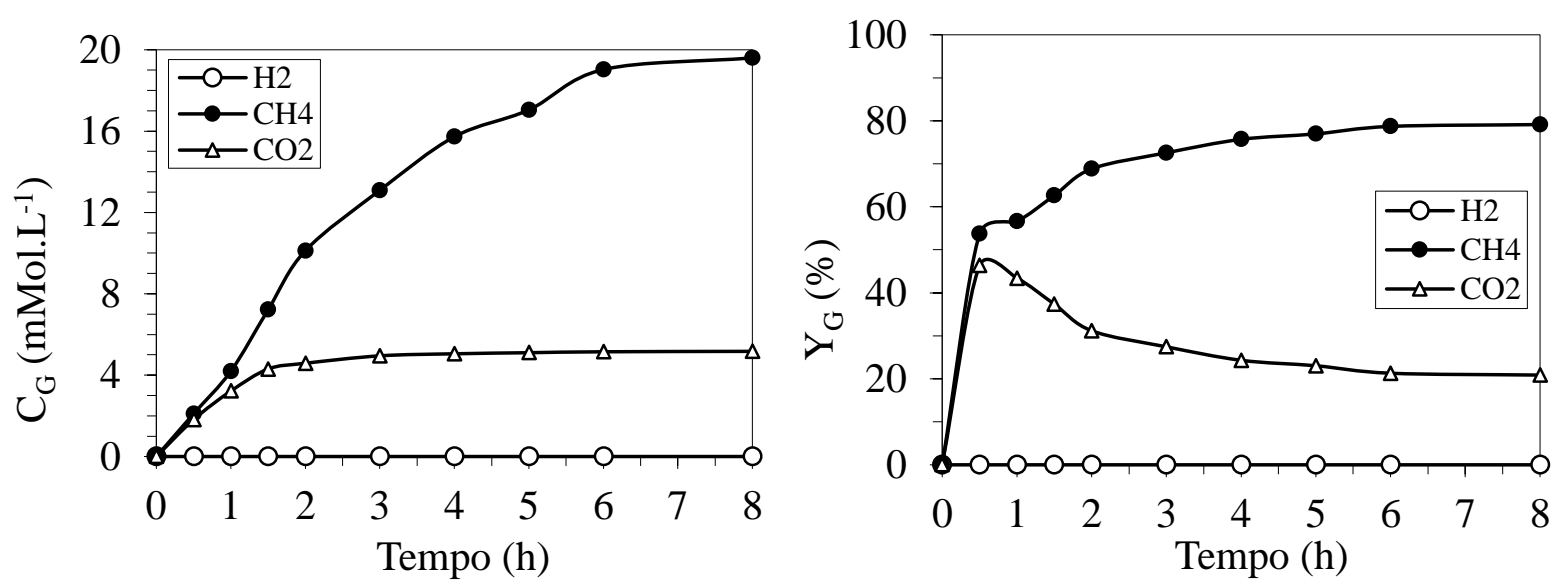

Figura 5.43. Concentração dos compostos do biogás durante o ciclo e suas respectivas porcentagens no Ensaio 5: $\odot-\mathrm{H}_{2} ; \bullet-\mathrm{CH}_{4} ; \Delta-\mathrm{CO}_{2}$.

\subsubsection{Análise comparativa entre os Ensaios de 1 a 5 (Fase I)}

O objetivo desta seção é comparar os Ensaios de 1 a 5 para verificar quais parâmetros foram favorecidos em cada ensaio. Os parâmetros comparados serão a matéria orgânica, carboidratos, glicerina (englobando carga aplicada e removida), $\mathrm{pH}$, alcalinidade e ácidos (AVT e AVI), sólidos e, por último, parâmetros relativos à produção de biometano.

A Figura 5.44 e Figura 5.45 mostram os dados experimentais dos Ensaios de 1 a 5. Os dados são mostrados continuamente para observar as mudanças entre uma condição e outra.

Em relação à remoção de matéria orgânica na forma de DQO, a Figura 5.44 mostra a diferença entre as concentrações do afluente e efluente, indicando que houve adequada e estável remoção de matéria orgânica em todos os ensaios, sendo a eficiência mínima de remoção de DQO atingida no Ensaio 5 (87\%) e a máxima, nos Ensaios 3 e 4 (94\%). Essa 
remoção mostra a estabilidade e desempenho do reator metanogênico, havendo o consumo de matéria orgânica (DQO) e a geração/consumo de ácidos intermediários para a produção de metano e dióxido de carbono. Além disso, também é possível notar o consumo dos dois substratos utilizados, com remoção acima de $94 \%$ tanto para o soro quanto para a glicerina em todos os ensaios.

Quanto ao pH, observa-se pela Figura 5.45 um comportamento estável nos ensaios. O afluente apresentou um valor mínimo de 8,4 no Ensaio 1 (100\% soro) e um valor máximo de 8,9 para o Ensaio 5 (100\% glicerina), pois a glicerina ainda contém traços de hidróxido de sódio (catalisador no processo de produção de biodiesel). O efluente apresentou um valor mínimo de pH de 7,4 nos Ensaios 2 e 4 (75\% soro e 25\% soro, respectivamente) e um valor máximo de 7,8 no Ensaio 5 (100\% glicerina), o que representa uma reduzida variação. Vale mencionar que tais valores de $\mathrm{pH}$ do efluente estão de acordo com o ideal para reatores metanogênicos (Lettinga e Haandel, 1993). A alcalinidade a bicarbonato se manteve próxima entre afluente (1905-2140 $\left.\mathrm{mgCaCO}_{3} \cdot \mathrm{L}^{-1}\right)$ e efluente $\left(2776-2196 \mathrm{mgCaCO}_{3} \cdot \mathrm{L}^{-1}\right)$ em todos os ensaios (Tabela 5.7), corroborando para o comportamento estável do processo, sendo também observado tal comportamento com relação aos ácidos voláteis totais no afluente (106242 mgHAc. $\mathrm{L}^{-1}$ ) e efluente (107-325 mgHAc. $\left.\mathrm{L}^{-1}\right)$. 

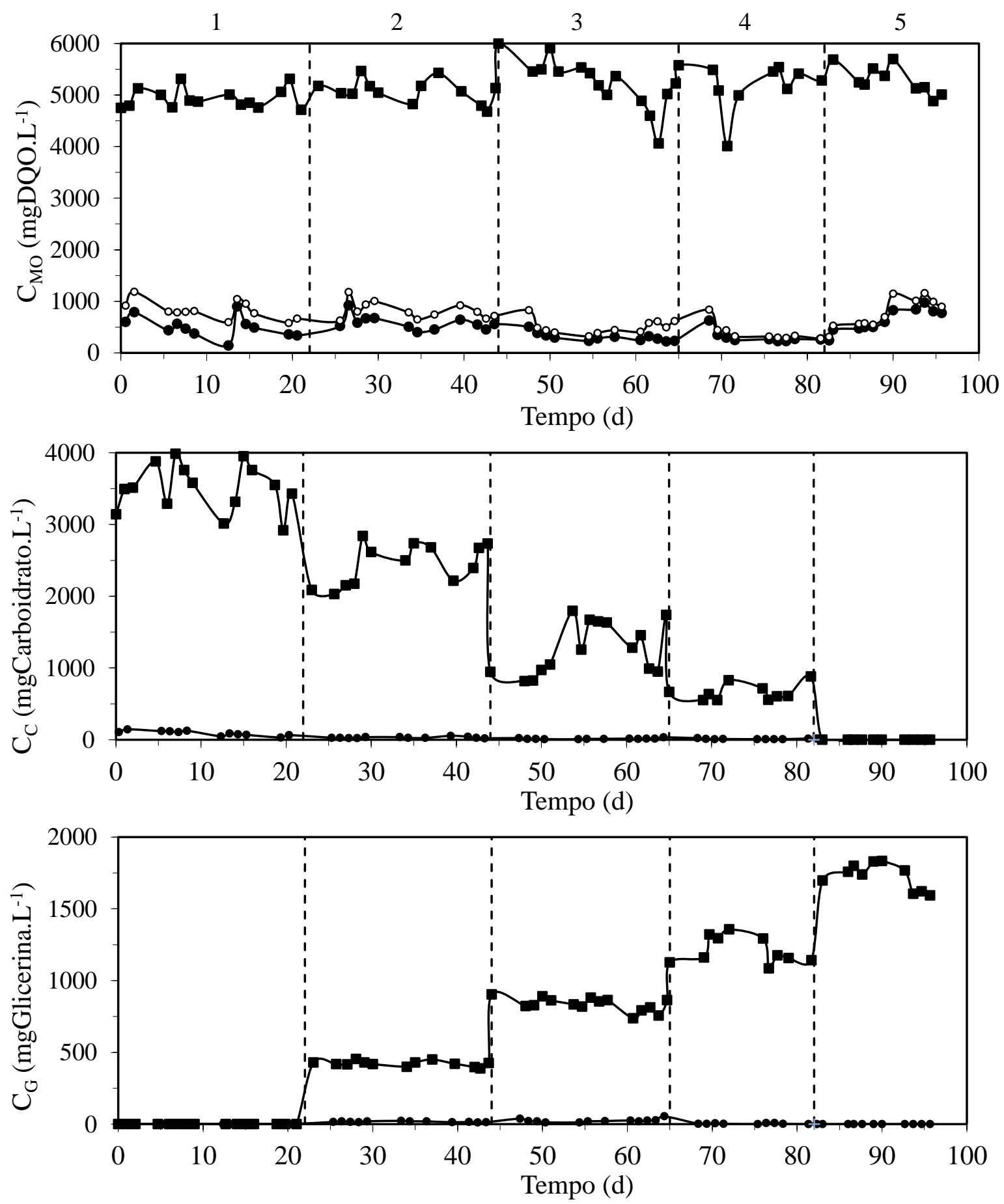

Figura 5.44. Monitoramento da DQO, dos carboidratos e da glicerina nos Ensaios de 1 a 5: - - afluente amostras não filtradas; $\bigcirc$ - efluente amostras não filtradas; • - efluente amostras filtradas. 

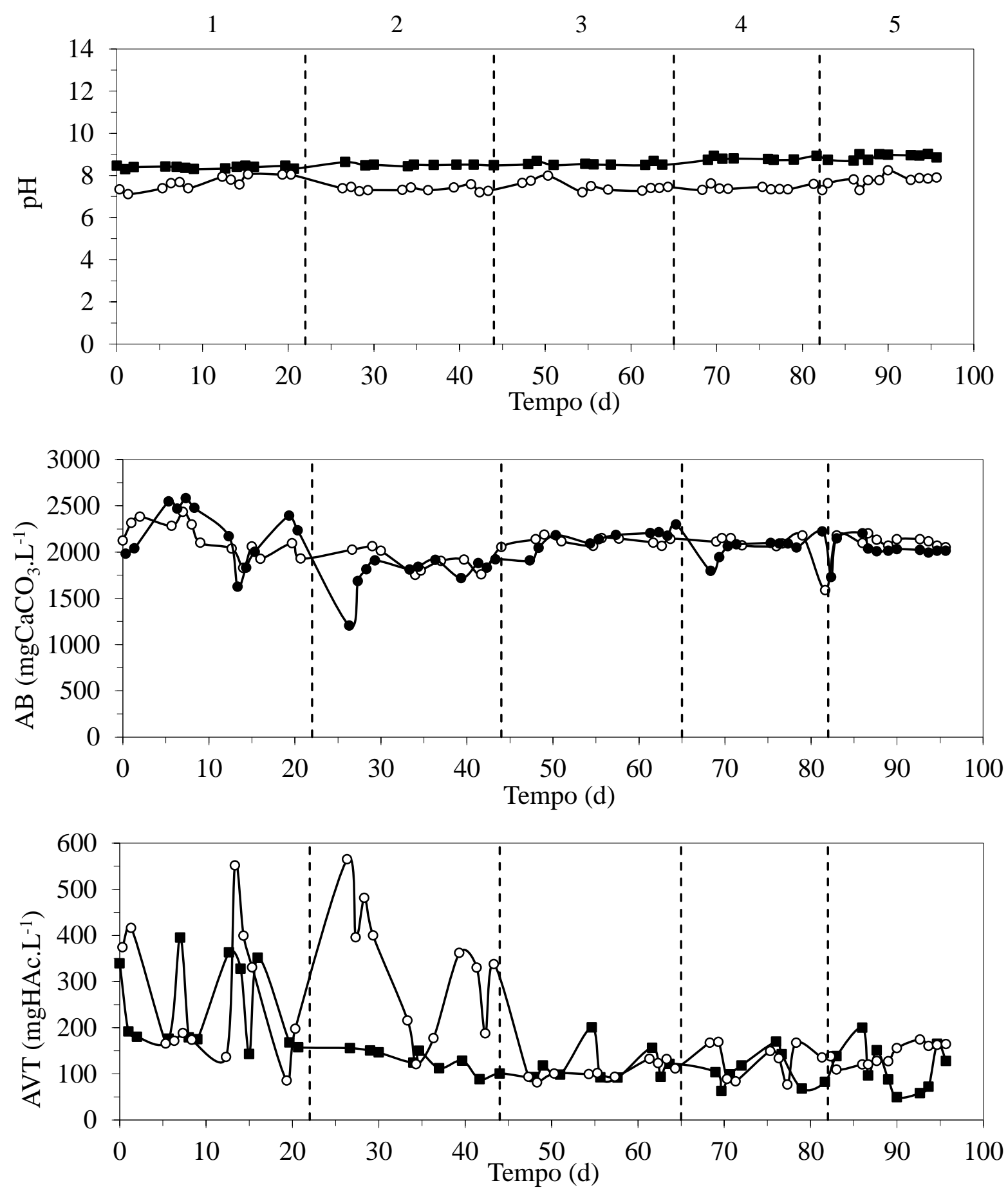

Figura 5.45. Monitoramento do pH, da AB e dos AVT nos Ensaios de 1 a 5: - - afluente amostras não filtradas; $\bigcirc$ - efluente amostras não filtradas.

Analisando a série de sólidos e a quantidade de biomassa presente no reator em cada ensaio (Tabela 5.6) nota-se que não houve perda de sólidos significativa em nenhuma das condições estudadas, principalmente quando se trata de sólidos voláteis totais e sólidos totais, ou seja, o sistema não foi submetido a nenhuma condição crítica o suficiente para que houvesse o desprendimento da biomassa do suporte inerte, o que é um ótimo resultado. 
Observando a quantidade de biomassa dentro do reator ( $\left.\mathrm{M}_{\mathrm{SVT}}\right)$, é possível dizer que não há uma correlação direta entre essa quantidade e a produtividade de biogás atingida.

Tabela 5.6. Comparação entre os valores médios da série de sólidos entre os Ensaios da Fase I.

\begin{tabular}{|c|c|c|c|c|c|c|c|c|c|c|}
\hline \multirow{2}{*}{ Parâmetro } & \multicolumn{2}{|c|}{1} & \multicolumn{2}{|c|}{2} & \multicolumn{2}{|c|}{3} & \multicolumn{2}{|c|}{4} & \multicolumn{2}{|c|}{5} \\
\hline & Afluente & Efluente & Afluente & Efluente & Afluente & Efluente & Afluente & Efluente & Afluente & Efluente \\
\hline $\begin{array}{c}\mathrm{M}_{\mathrm{SVT}} \\
(\mathrm{g})\end{array}$ & \multicolumn{2}{|c|}{53,8} & \multicolumn{2}{|c|}{63,5} & \multicolumn{2}{|c|}{55,7} & \multicolumn{2}{|c|}{55,7} & \multicolumn{2}{|c|}{65,6} \\
\hline $\begin{array}{c}\mathrm{ST} \\
\left(\mathrm{mg} \cdot \mathrm{L}^{-1}\right)\end{array}$ & 6081 & 3342 & 5560 & 3096 & 5002 & 3043 & 4373 & 2742 & 3680 & 2890 \\
\hline $\begin{array}{c}\mathrm{SVT} \\
\left(\mathrm{mg} . \mathrm{L}^{-1}\right)\end{array}$ & 3203 & 774 & 3014 & 825 & 2536 & 922 & 1973 & 523 & 1274 & 581 \\
\hline $\begin{array}{c}\text { SST } \\
\left(\mathrm{mg} . \mathrm{L}^{-1}\right)\end{array}$ & 83 & 195 & 39 & 177 & 90 & 133 & 202 & 85 & 34 & 57 \\
\hline $\begin{array}{c}\text { SSV } \\
\left(\mathrm{mg} . \mathrm{L}^{-1}\right)\end{array}$ & 68 & 172 & 28 & 137 & 77 & 114 & 176 & 66 & 21 & 36 \\
\hline
\end{tabular}

O desempenho do reator quanto à produção de biogás é mostrado na Figura 5.46 e na Tabela 5.7, as quais indicam um comportamento estável em todos os ensaios, obtendo-se valores de produtividade de 78.2-101.8 $\mathrm{molCH}_{4} \cdot \mathrm{m}^{-3} \cdot \mathrm{d}^{-1}$ com composição de metano de 71.7$79.1 \%$, cujo valor máximo foi obtido no Ensaio 2 (75\% soro, $3241 \mathrm{~mL} . c i c l o^{-1}, 101.8$ $\mathrm{molCH}_{4} \cdot \mathrm{m}^{-3} \cdot \mathrm{d}^{-1}$ e $71.7 \%$ de metano), o que representa um aumento de $7,9 \%$ em relação a produtividade alcançada com a digestão de soro puro e de $29,4 \%$ quando comparada com a produtividade de digestão de glicerina pura, ou seja, a codigestão entre soro e glicerina foi eficiente em melhorar o desempenho do reator, provavelmente por causa da capacidade tamponante da glicerina. No Ensaio 2 obteve-se o melhor rendimento em relação à carga orgânica aplicada $\left(13,3 \mathrm{molH}_{2} \cdot \mathrm{kgDQO}^{-1}\right)$.

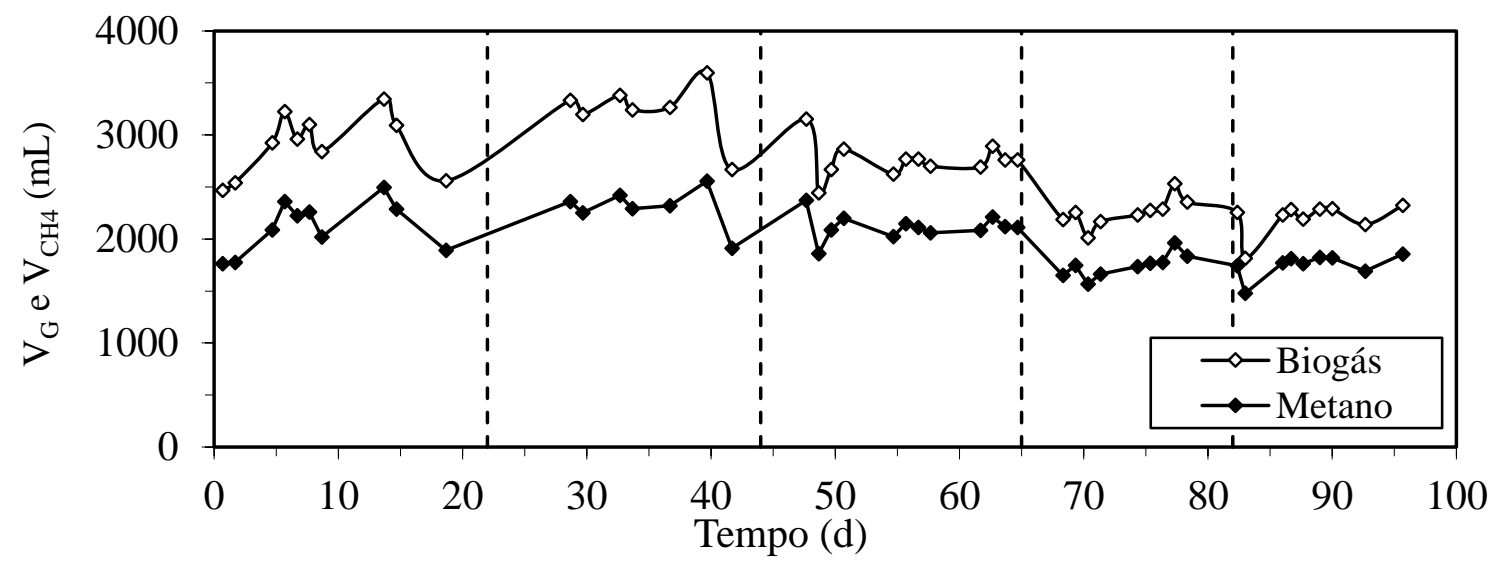

Figura 5.46. Produção volumétrica por ciclo de Biogás ( $\diamond)$ e Metano (४). 
Analisando os rendimentos em relação ao substrato aplicado (Tabela 5.7), o Ensaio 1 foi o que obteve o melhor parâmetro com $6,0 \mathrm{molCH}_{4} \cdot \mathrm{molSubstrato}^{-1}$, o que é igual ao rendimento máximo teórico do soro $\left(6,0 \mathrm{molCH}_{4} \cdot \mathrm{molSoro}^{-1}\right)$. Nota-se também uma diminuição do rendimento conforme se adiciona glicerina ao afluente, pois o rendimento máximo teórico da glicerina $\left(1,75 \mathrm{molCH}_{4} \cdot \mathrm{molGlicerina}^{-1}\right)$ é menor do que o do soro. No entanto, o ensaio com $100 \%$ de glicerina apresentou um rendimento maior do que o teoricamente possível $\left(2,8 \mathrm{molCH}_{4} \cdot \mathrm{molSubstrato}^{-1}\right)$ devido à presença de impurezas na glicerina utilizada (o teor de pureza da glicerina utilizada era de $40 \%$ ) que provavelmente foram digeridas e utilizadas para a produção de metano. Isso mostra que é necessário cuidado quando se compara o rendimento teórico de um substrato puro com um substrato industrial.

Em relação aos compostos intermediários mostrados na Tabela 5.7, a produção de ácido acético $(43,0-86,4 \%)$ e ácido propiônico (11,9-54,0\%), foram predominantes em todos os ensaios, com reduzida parcela de ácido butírico (0-5,0\%), sendo que a maior concentração de ácido acético foi observada no Ensaio 2 (75\% soro, 86,4\%) no qual obteve-se a maior produção de metano, mostrando o favorecimento da codigestão ao metabolismo acidogênico/acetogênico/metanogênico. Esse comportamento pode estar diretamente relacionado à metanogênese hidrogenotrófica (uso do hidrogênio formado na acidogênese e acetogênese para formar metano - Equações 4.33/35, 36/37 e 39, respectivamente), pois temse uma alta quantidade de ácido acético presente no efluente, ou seja, ele não foi consumido para a produção de metano. Esses resultados são corroborados com a modelagem ajustada ao processo, como é visto mais adiante. 
Tabela 5.7. Estabilidade e desempenho nas variáveis monitoradas nos Ensaios de 1 a 5 .

\begin{tabular}{|c|c|c|c|c|c|c|}
\hline & Parâmetro & 1 & 2 & 3 & 4 & 5 \\
\hline$\varepsilon_{\mathrm{MO}, \mathrm{F}}$ & $(\%)$ & $90 \pm 4^{(12)}$ & $89 \pm 3^{(12)}$ & $94 \pm 1^{(12)}$ & $94 \pm 2^{(10)}$ & $87 \pm 4^{(10)}$ \\
\hline$\varepsilon_{\mathrm{C}, \mathrm{F}}$ & $(\%)$ & $99,2 \pm 0,5^{(12)}$ & $99,6 \pm 0,1^{(12)}$ & $99,5 \pm 0,3^{(12)}$ & $98,9 \pm 0,5^{(10)}$ & - \\
\hline$\varepsilon_{\mathrm{G}, \mathrm{F}}$ & $(\%)$ & - & $98,2 \pm 0,9^{(12)}$ & $98,4 \pm 0,6^{(12)}$ & $99,9 \pm 0,1^{(10)}$ & $94 \pm 3^{(10)}$ \\
\hline $\mathrm{M}_{\mathrm{SVT}}$ & $(g)$ & 53,8 & 63,5 & 55,7 & 55,7 & 65,6 \\
\hline COAV & $\left(\mathrm{kgDQO} \cdot \mathrm{m}^{-3} \cdot \mathrm{d}^{-1}\right)$ & 7,5 & 7,7 & 7,9 & 7,8 & 7,9 \\
\hline CORV & $\left(\mathrm{kgDQO} \cdot \mathrm{m}^{-3} \cdot \mathrm{d}^{-1}\right)$ & 6,7 & 6,8 & 7,4 & 7,3 & 6,9 \\
\hline \multirow{4}{*}{ Afluente } & $\mathrm{pH}(\mathrm{u})$ & $8,38 \pm 0,06^{(13)}$ & $8,51 \pm 0,05^{(8)}$ & $8,54 \pm 0,08^{(10)}$ & $8,80 \pm 0,08^{(8)}$ & $8,9 \pm 0,1^{(10)}$ \\
\hline & $\mathrm{AT}\left(\mathrm{mgCaCO}_{3} \cdot \mathrm{L}^{-1}\right)$ & $2312 \pm 192^{(13)}$ & $1999 \pm 135^{(8)}$ & $2200 \pm 43^{(10)}$ & $2125 \pm 195^{(8)}$ & $2201 \pm 52^{(10)}$ \\
\hline & $\mathrm{AB}\left(\mathrm{mgCaCO} 3 \cdot \mathrm{L}^{-1}\right)$ & $2140 \pm 189^{(13}$ & $1905 \pm 124^{(8)}$ & $2117 \pm 44^{(10)}$ & $2050 \pm 192^{(8)}$ & $2120 \pm 49^{(10)}$ \\
\hline & AVT (mgHAc. $\left.L^{-1}\right)$ & $242 \pm 95^{(13)}$ & $132 \pm 23^{(8)}$ & $117 \pm 36^{(10)}$ & $106 \pm 37^{(8)}$ & $115 \pm 50^{(10)}$ \\
\hline \multirow{4}{*}{ Efluente } & $\mathrm{pH}(\mathrm{u})$ & $7,7 \pm 0,3^{(12)}$ & $7,4 \pm 0,1^{(11)}$ & $7,5 \pm 0,2^{(10)}$ & $7,4 \pm 0,1^{(8)}$ & $7,8 \pm 0,2^{(10)}$ \\
\hline & $\mathrm{AT}\left(\mathrm{mgCaCO} 3 \cdot \mathrm{L}^{-1}\right)$ & $2384 \pm 213^{(12)}$ & $2006 \pm 164^{(11)}$ & $2220 \pm 115^{(10)}$ & $2110 \pm 143^{(8)}$ & $2149 \pm 61^{(10)}$ \\
\hline & $\mathrm{AB}\left(\mathrm{mgCaCO} 3 \cdot \mathrm{L}^{-1}\right)$ & $2196 \pm 300^{(12)}$ & $1776 \pm 204^{(11)}$ & $2144 \pm 107^{(10)}$ & $2016 \pm 151^{(8)}$ & $2048 \pm 69^{(10)}$ \\
\hline & $\operatorname{AVT}\left(\mathrm{mgHAc} . \mathrm{L}^{-1}\right)$ & $266 \pm 143^{(12)}$ & $325 \pm 137^{(11)}$ & $107 \pm 17^{(10)}$ & $131 \pm 36^{(8)}$ & $142 \pm 24^{(10)}$ \\
\hline \multirow{4}{*}{$\begin{array}{l}\text { Compostos } \\
\text { Intermediários } \\
\text { (molar) }\end{array}$} & Ácido Acético (\%) & 73,3 & 86,4 & 77,0 & 80,3 & 43,0 \\
\hline & Ácido Propiônico (\%) & 26,7 & 11,9 & 19,3 & 14,7 & 54,0 \\
\hline & Ácido Butírico (\%) & 0,0 & 1,7 & 3,7 & 5,0 & 3,0 \\
\hline & $\begin{array}{l}\text { Concentração total } \\
\left(\mathrm{mmol.L^{-1 } )}\right.\end{array}$ & 1,07 & 3,34 & 1,75 & 1,09 & 2,52 \\
\hline PrM & $\left(\mathrm{molCH}_{4} \cdot \mathrm{m}^{-3} \cdot \mathrm{d}^{-1}\right)$ & 93,7 & 101,8 & 94,2 & 78,2 & 78,7 \\
\hline PrME & $\left(\mathrm{molCH}_{4} \cdot \mathrm{kgSVT}^{-1} \cdot \mathrm{d}^{-1}\right)$ & 5,3 & 4,8 & 5,1 & 4,2 & 3,6 \\
\hline RMCA & $\left(\mathrm{molCH}_{4} \cdot \mathrm{kgDQO}^{-1}\right)$ & 12,6 & 13,3 & 12,0 & 10,1 & 10,0 \\
\hline RMSA & $\left(\mathrm{molCH}_{4} \mathrm{molSubstrato}^{-1}\right)$ & 6,0 & 5,7 & 4,9 & 3,6 & 2,8 \\
\hline \multirow{2}{*}{$\mathrm{Y}_{\mathrm{G}}$} & $(\%) \mathrm{CH}_{4}$ & 73,0 & 71,7 & 76,4 & 77,1 & 79,1 \\
\hline & $(\%) \mathrm{CO}_{2}$ & 27,0 & 28,3 & 23,6 & 22,9 & 20,9 \\
\hline
\end{tabular}


A Tabela 5.8 mostra uma comparação dos resultados deste trabalho com resultados da literatura em relação à digestão de soro e glicerina sozinhos, pois não foram encontrados outros trabalhos publicados que estudem essa. Nota-se que tanto a produtividade molar e o rendimento por carga orgânica aplicada encontrados neste trabalho foram superiores aos índices encontrados na maior parte dos artigos. Isso é um ótimo indicador de que a codigestão proposta é uma solução promissora para os dois resíduos, otimizando a relação entre remoção de matéria orgânica e produção de biogás. Cabe destacar a facilidade de armazenamento da glicerina com o efluente de uma indústria de laticínios, o que é um fator importante na escolha desse cosubstrato (Mata-Alvarez et al., 2014).

Tabela 5.8. Comparação entre os resultados obtidos neste trabalho na Fase I com resultados publicados na literatura que utilizaram soro ou glicerina para a produção de biometano.

\begin{tabular}{|c|c|c|c|c|}
\hline Substrato & Reator & $\begin{array}{c}\text { PrM } \\
\left(\mathrm{molCH}_{4} \cdot \mathrm{m}^{-3} \cdot \mathrm{d}^{-1}\right)\end{array}$ & $\begin{array}{c}\mathrm{RMCA}_{\left(\mathrm{molCH}_{4} \cdot \mathrm{kgDQO}^{-1}\right)} \\
\end{array}$ & Referência \\
\hline Glicerina & CSTR & 3,3 & 13,4 & Vlassis et al. (2013) \\
\hline Glicerina & PABR & 44,3 & 14,7 & Vlassis et al. (2013) \\
\hline Glicerina & Digestor & 30,0 & 6,7 & Baba et al. (2013) \\
\hline Glicerina & AnSBBR & 14,3 & 2,5 & Lovato et. al (2012) \\
\hline Glicerina & AnSBBR & 78,7 & 10,0 & Este trabalho \\
\hline Soro & ASBR & 24,3 & 5,1 & Mockaitis et al. (2006) \\
\hline Soro & AnSBBR & 16,3 & 1,35 & Bezerra et al. (2007) \\
\hline Soro & UASB & 499,7 & 64,3 & Yan et al. (1989) \\
\hline Soro & AnSBBR & 93,7 & 12,6 & Este trabalho \\
\hline Soro + Glicerina & AnSBBR & 101,8 & 13,3 & Este trabalho \\
\hline
\end{tabular}

É interessante mencionar que Yan et al. (1989) utilizando um reator UASB com carga orgânica aplicada próxima ao valor utilizado nesse trabalho $\left(7,77 \mathrm{kgDQO} \cdot \mathrm{m}^{-3} \cdot \mathrm{d}^{-1}\right)$, mas com superiores tempo de residência (2-3 dia) e concentração afluente (38,1 gDQO.L $\left.{ }^{-1}\right)$, encontraram uma produtividade molar cinco vezes maior, indicando a necessidade de realização de estudos com o reator AnSBBR para verificar a influência da relação entre concentração afluente e tempo de ciclo, mantendo a carga orgânica aplicada, no intuito de otimizar a produtividade de metano. 


\subsubsection{Modelagem Cinética para os Ensaios de 1 a 5.}

A Figura 5.47 mostra os valores obtidos experimentalmente (marcadores) e os valores obtidos pelo modelo cinético ajustado (linhas), ambos ao longo do ciclo, para as principais variáveis monitoradas e que estão relacionadas com o entendimento do metabolismo metanogênico na condição de substrato puro (soro ou glicerina) e na condição de codigestão (soro e glicerina em proporções diferentes).

Analisando essas figuras é possível notar que o modelo foi eficiente em predizer os dados experimentais em relação à concentração de substrato, ácido acético, ácido propiônico, ácido butírico e metano, validando a interpretação do comportamento dos parâmetros cinéticos nas diferentes condições experimentais implementadas.

Assim, pelos parâmetros cinéticos ajustados (Tabela 5.9), tem-se que a produção de metano nos Ensaios 1 (k6M 1,4 h ${ }^{-1}$ e $\left.\mathrm{k}_{7 \mathrm{M}} 36,6 \mathrm{~h}^{-1}\right), 2\left(\mathrm{k}_{6 \mathrm{M}} 0,8 \mathrm{~h}^{-1}\right.$ e $\left.\mathrm{k}_{7 \mathrm{M}} 24,4 \mathrm{~h}^{-1}\right), 3\left(\mathrm{k}_{6 \mathrm{M}} 1,3 \mathrm{~h}^{-1} \mathrm{e}\right.$ $\left.\mathrm{k}_{7 \mathrm{M}} 32,3 \mathrm{~h}^{-1}\right)$ e $4\left(\mathrm{k}_{6 \mathrm{M}} \quad 1,5 \mathrm{~h}^{-1}\right.$ e $\left.\mathrm{k}_{7 \mathrm{M}} 31,7 \mathrm{~h}^{-1}\right)$ acontece principalmente pela via hidrogenotrófica, pois os parâmetros cinéticos $\mathrm{k}_{7 \mathrm{M}}$, parâmetro associado à produção de metano pelo consumo de hidrogênio (Equação 4.39) são mais altos do que os parâmetros k6M, parâmetro associado à produção de metano pelo consumo de acetato (Equação 4.38). Enquanto no Ensaio $5\left(\mathrm{k}_{6 \mathrm{M}} 1,1 \mathrm{~h}^{-1}\right.$ e $\left.\mathrm{k}_{7 \mathrm{M}} 0,7 \mathrm{~h}^{-1}\right)$, a produção de metano acontece essencialmente pela via acetoclástica. De fato, o Ensaio 5 apresenta o menor valor de concentração de ácido acético dentre todos os ensaios, o que consolida os valores encontrados por modelagem.

Tabela 5.9. Parâmetros do modelo cinético para a Fase I.

\begin{tabular}{ccccccc}
\hline Fase & Parâmetro & 1 & 2 & 3 & 4 & 5 \\
\hline \multirow{2}{*}{ Hidrólise e } & $K^{\prime}{ }_{I S}\left(h^{-1}\right)$ & 21,8 & 15,8 & 26,7 & 38,8 & 0,4 \\
Acidogênese & $K_{\text {IHAC }}\left(h^{-1}\right)$ & 22,8 & 24,3 & 28,5 & 14,6 & 0,8 \\
& $K_{2 H P R}\left(h^{-1}\right)$ & 9,6 & 5,6 & 5,9 & 9,2 & 0,3 \\
\hline-5 & $K_{3 H B U}\left(h^{-1}\right)$ & 0,0 & 8,8 & 0,5 & 0,8 & 0,0 \\
& $K_{4 H P R}\left(h^{-1}\right)$ & 0,2 & 0,2 & 0,3 & 0,4 & 0,4 \\
Acetogênese & $K_{4 H A C}\left(h^{-1}\right)$ & 0,1 & 0,2 & 5,0 & 1,3 & 0,0 \\
& $K_{5 H B U}\left(h^{-1}\right)$ & 0,8 & 6,9 & 0,0 & 0,1 & 1,4 \\
& $K_{5 H P R}\left(h^{-1}\right)$ & 0,2 & 0,2 & 0,1 & 0,1 & 0,8 \\
\hline \multirow{3}{*}{ Metanogênese } & $K_{6 H A C}\left(h^{-1}\right)$ & 0,3 & 0,3 & 1,6 & 0,7 & 2,1 \\
& $K_{6 M}\left(h^{-1}\right)$ & 1,4 & 0,7 & 1,3 & 1,5 & 1,1 \\
& $K_{7 M}\left(h^{-1}\right)$ & 36,6 & 24,4 & 32,3 & 31,7 & 0,7 \\
\hline
\end{tabular}



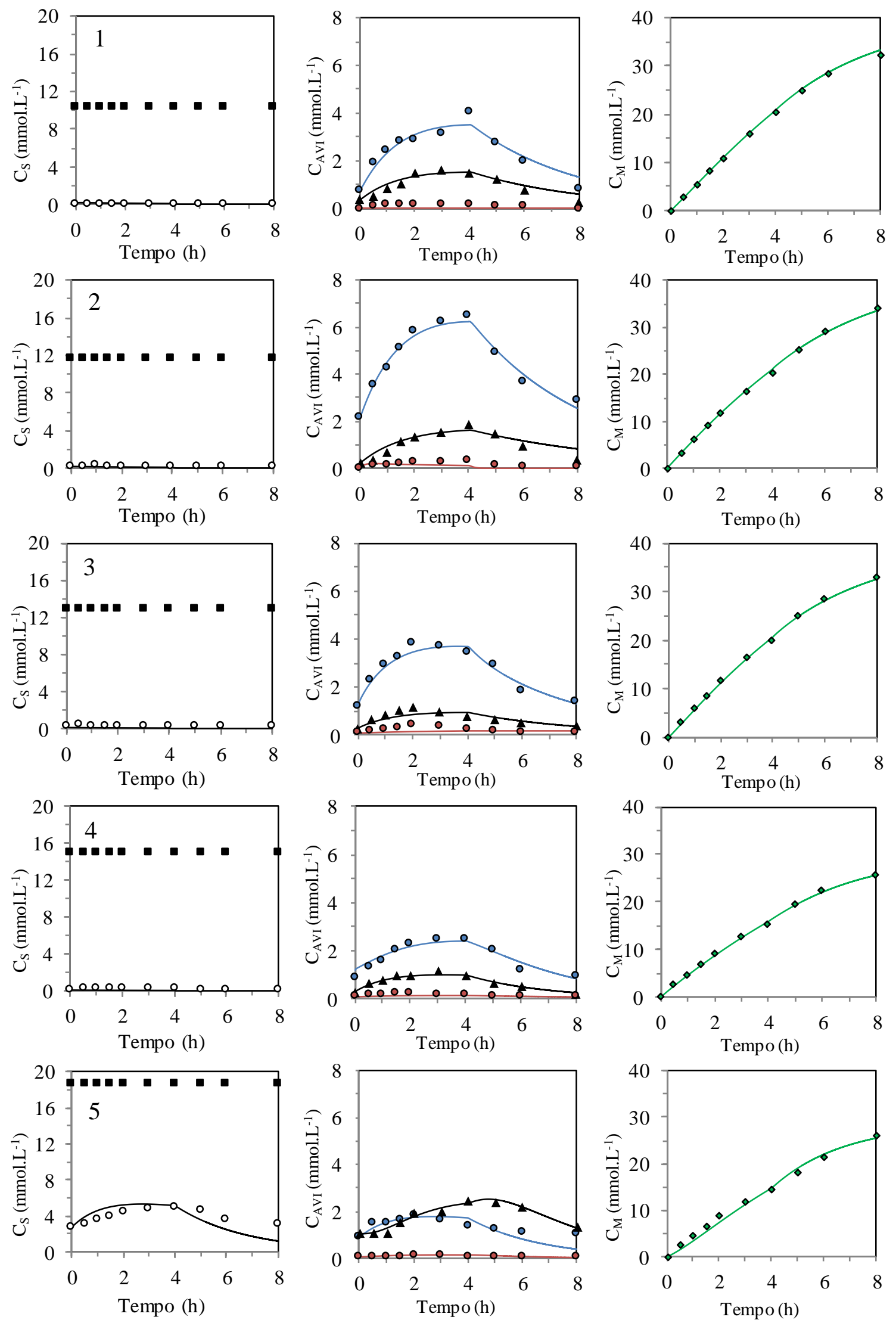

Figura 5.47. Perfis de concentração de substrato no afluente (®), efluente filtrado (०), ácido acético $(\bullet)$, ácido propiônico $(\boldsymbol{\Lambda})$, ácido butírico $(\bullet)$ e metano $(\diamond)$ (valores experimentais - marcadores e calculados pelo modelo cinético - linhas). 


\subsection{FASE II - PRODUÇÃO DE BIOHIDROGÊNIO - INFLUÊNCIA DA RAZÃO DE MISTURA}

A Fase II compreendeu os Ensaios de 6 a 10 e teve como objetivo encontrar a melhor razão de mistura entre o soro e a glicerina para a produção de hidrogênio. Todos os ensaios foram operados com concentração afluente de $5000 \mathrm{mgDQO}^{-1}$, tempo de ciclo igual a $3 \mathrm{~h}$ e tempo de alimentação igual a 1,5 h (COAV nominal de 17,1 gDQO.L $\left.\mathrm{L}^{-1} \cdot \mathrm{d}^{-1}\right)$, que foram as condições otimizadas encontradas no estudo de produção de biohidrogênio a partir do tratamento de glicerina encontrados em Lovato et al. (2015).

Como é característica para sistemas acidogênicos, o reator foi iniciado com a concentração desejada de $5000 \mathrm{mgDQO} . \mathrm{L}^{-1}$ (água residuária a base de soro) no intuito de começar a acidificação do sistema. Vale lembrar que o inóculo para esta Fase foi o mesmo inóculo utilizado na Fase I, mas com o tratamento térmico (HST) para minimizar o consórcio de bactérias metanogênicas.

\subsubsection{Ensaio 6 (100\% Soro - 5000 mgDQO.L $\left.{ }^{-1}-3 \mathrm{~h}-\mathrm{BA}\right)$}

O valor real da COAV para o Ensaio 6 foi de $16,1 \mathrm{gDQO} \cdot \mathrm{L}^{-1} \cdot \mathrm{d}^{-1}$ e a CORV atingida foi de 4,4 gDQO.L $\mathrm{L}^{-1} \cdot \mathrm{d}^{-1}$, o que representa uma baixa remoção. No entanto, este valor é coerente com os resultados esperados para um reator acidogênico, pois há a formação de ácidos que não são consumidos pelo processo e que são contabilizados na análise de DQO. Em relação aos carboidratos, a COAV foi de 12,6 gCarboidratos. $\mathrm{L}^{-1} \cdot \mathrm{d}^{-1}$ e a CORV 12,4 gCarboidratos. $\mathrm{L}^{-}$ ${ }^{1} . \mathrm{d}^{-1}$; representando um bom consumo de carboidratos como era esperado do sistema. A Tabela 5.10 apresenta a média dos parâmetros monitorados.

O monitoramento diário apresentou um baixo consumo de matéria orgânica na forma de DQO, com média de concentração afluente não filtrada de $4749 \mathrm{mgDQO} . \mathrm{L}^{-1}$, efluente não filtrada $3599 \mathrm{mgDQO} . \mathrm{L}^{-1}$ e de efluente filtrada de $3454 \mathrm{mgDQO} . \mathrm{L}^{-1}$, o que não é um bom rendimento em relação a esse parâmetro, mas o objetivo de um reator focado na produção de biohidrogênio não é a remoção de matéria orgânica devido às características desse sistema. A eficiência de remoção média para amostras não filtradas foi de $24 \%$ e para amostras filtradas de $27 \%$ (Figura 5.48).

Em relação ao monitoramento diário de carboidratos, o mesmo apresentou um

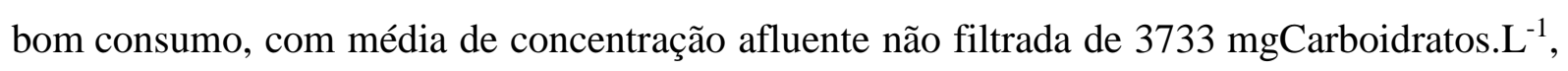

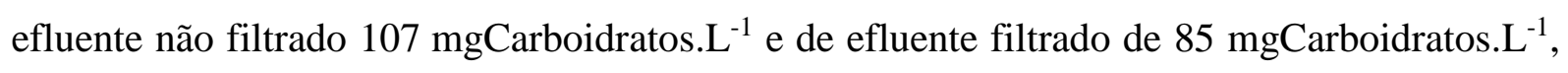


atingindo uma eficiência média de remoção para amostras não filtradas de $97 \%$ e para amostras filtradas de 98\% (Figura 5.49).

Tabela 5.10. Parâmetros médios monitorados no Ensaio 6.

\begin{tabular}{|c|c|c|c|c|c|c|c|c|c|c|c|c|c|}
\hline \multicolumn{2}{|r|}{ Parâmetro } & \multicolumn{6}{|c|}{ Afluente } & \multicolumn{6}{|c|}{ Efluente } \\
\hline $\mathrm{C}_{\text {MOT }}$ & $\left(\mathrm{mgDQO} \cdot \mathrm{L}^{-1}\right)$ & 4749 & \pm & 105 & & 13 & ) & 3599 & \pm 3 & 358 & ( & 12 & \\
\hline $\mathrm{C}_{\mathrm{MOF}}$ & $\left(\mathrm{mgDQO} \cdot \mathrm{L}^{-1}\right)$ & & & & & & & 3454 & \pm 3 & 327 & ( & 12 & \\
\hline$\varepsilon_{\text {MOT }}$ & $(\%)$ & & & - & & & & 24 & \pm & 8 & ( & 12 & \\
\hline$\varepsilon_{\mathrm{MOF}}$ & $(\%)$ & & & & & & & 27 & \pm & 8 & ( & 12 & ) \\
\hline $\mathrm{C}_{\mathrm{CT}}$ & (mgCarboidratos. $\left.\mathrm{L}^{-1}\right)$ & 3733 & \pm & 155 & ( & 13 & ) & 107 & \pm & 80 & ( & 8 & ) \\
\hline $\mathrm{C}_{\mathrm{CF}}$ & (mgCarboidratos. $\mathrm{L}^{-1}$ ) & & & & & & & 85 & \pm & & ( & 8 & \\
\hline$\varepsilon_{\mathrm{CT}}$ & $(\%)$ & & & & & & & 97 & \pm & 2 & ( & 8 & \\
\hline$\varepsilon_{\mathrm{CF}}$ & $(\%)$ & & & & & & & 98 & \pm & 2 & ( & 8 & ) \\
\hline $\mathrm{pH}$ & (u) & 7,2 & \pm & 0,1 & ( & 12 & ) & 4,5 & \pm 0 & 0,3 & ( & 11 & \\
\hline AVT & $\left(\operatorname{mgHAc} . \mathrm{L}^{-1}\right)$ & 147 & \pm & 9 & ( & 12 & ) & 1180 & \pm 3 & 357 & ( & 11 & \\
\hline $\mathrm{AT}$ & $\left(\mathrm{mgCaCO}_{3} \cdot \mathrm{L}^{-1}\right)$ & 242 & \pm & 30 & ( & 12 & ) & 75 & & 84 & ( & 11 & ) \\
\hline $\mathrm{AP}$ & $\left(\mathrm{mgCaCO}_{3} \cdot \mathrm{L}^{-1}\right)$ & 154 & \pm & 29 & ( & 12 & ) & 0 & \pm & 0 & ( & 11 & \\
\hline AI & $\left(\mathrm{mgCaCO}_{3} \cdot \mathrm{L}^{-1}\right)$ & 89 & \pm & 8 & ( & 12 & ) & 75 & $\pm \varepsilon$ & 84 & ( & 11 & \\
\hline $\mathrm{AB}$ & $\left(\mathrm{mgCaCO}_{3} \cdot \mathrm{L}^{-1}\right)$ & 138 & \pm & 26 & ( & 12 & ) & 0 & \pm & 0 & ( & 11 & ) \\
\hline $\mathrm{ST}$ & $\left(\mathrm{mg} . \mathrm{L}^{-1}\right)$ & 4309 & \pm & 189 & ( & 4 & ) & 2659 & \pm 6 & 657 & ( & 4 & \\
\hline SVT & $\left(\mathrm{mg} \cdot \mathrm{L}^{-1}\right)$ & 3855 & \pm & 186 & ( & 4 & ) & 2150 & \pm 6 & 664 & ( & 4 & ) \\
\hline SST & $\left(\mathrm{mg} \cdot \mathrm{L}^{-1}\right)$ & 84 & \pm & 22 & ( & 4 & ) & 152 & \pm & 64 & ( & 4 & ) \\
\hline SSV & $\left(\mathrm{mg} \cdot \mathrm{L}^{-1}\right)$ & 84 & \pm & 18 & ( & 4 & ) & 151 & \pm 5 & 58 & ( & 4 & \\
\hline $\mathrm{M}_{\mathrm{SVT}}$ & (g) & & & & & & & & 18,5 & & & & \\
\hline $\mathrm{Cx}$ & $\left(\mathrm{g} . \mathrm{L}^{-1}\right)$ & & 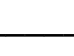 & & & & & & 5,3 & & & & \\
\hline $\mathrm{Cx}^{\prime}$ & $\left(\right.$ g.gsuporte $\left.{ }^{-1}\right)$ & & & & & & & & 0,012 & & & & \\
\hline $\mathrm{V}_{\mathrm{G}}$ & $\left(\mathrm{mL} . \mathrm{ciclo}^{-1}\right)$ & & & & & & & 870 & \pm 2 & 254 & ( & 9 & \\
\hline $\mathrm{V}_{\mathrm{H} 2}$ & $\left(\mathrm{~mL} \cdot \mathrm{ciclo}^{-1}\right)$ & & & & & & & 512 & \pm 1 & 153 & ( & 9 & \\
\hline $\mathrm{COAV}_{\mathrm{MO}}$ & $\left(\mathrm{gDQO} \cdot \mathrm{L}^{-1} \cdot \mathrm{d}^{-1}\right)$ & & 16,1 & & & & & & 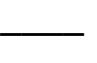 & & & & \\
\hline $\mathrm{CORV}_{\mathrm{MO}}$ & $\left(\mathrm{gDQO} \cdot \mathrm{L}^{-1} \cdot \mathrm{d}^{-1}\right)$ & & & & & & & & 4,4 & & & & \\
\hline $\mathrm{COAV}_{\mathrm{C}}$ & $\left(\right.$ gCarboidratos. $\left.\mathrm{L}^{-1} \cdot \mathrm{d}^{-1}\right)$ & & 12,6 & & & & & & 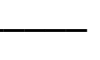 & & & & \\
\hline $\mathrm{CORV}_{\mathrm{C}}$ & (gCarboidratos. $\left.\mathrm{L}^{-1} \cdot \mathrm{d}^{-1}\right)$ & & & & & & & & 12,4 & & & & \\
\hline $\mathrm{COAE}_{\mathrm{MO}}$ & $\left(\right.$ gDQO.gSVT $\left.{ }^{-1} \cdot d^{-1}\right)$ & & 18,5 & & & & & & & & & & \\
\hline $\mathrm{CORE}_{\mathrm{MO}}$ & 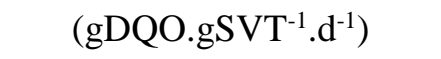 & & & & & & & & 3,0 & & & & \\
\hline $\mathrm{COAE}_{\mathrm{C}}$ & (gCarboidratos.gSVT ${ }^{-1} \cdot \mathrm{d}^{-1}$ ) & & 18,5 & & & & & & & & & & \\
\hline $\mathrm{CORE}_{\mathrm{C}}$ & (gCarboidratos.gSVT ${ }^{-1} \cdot \mathrm{d}^{-1}$ ) & & & & & & & & 2,4 & & & & \\
\hline $\mathrm{n}_{\mathrm{H} 2}$ & $\left(\mathrm{molH}_{2} \cdot \mathrm{d}^{-1}\right)$ & & & & & & & & 0,2 & & & & \\
\hline PrM & $\left(\mathrm{molH}_{2} \cdot \mathrm{m}^{-3} \cdot \mathrm{d}^{-1}\right)$ & & & & & & & & 52,7 & & & & \\
\hline PrME & $\left(\mathrm{molH}_{2} \cdot \mathrm{kgSVT}^{-1} \cdot \mathrm{d}^{-1}\right)$ & & 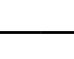 & & & & & & 9,9 & & & & \\
\hline RMCA & $\left(\mathrm{molH}_{2} \cdot \mathrm{kgDQO}^{-1}\right)$ & & 3,3 & & & & & & & & & & \\
\hline RMSA & $\left(\mathrm{molH}_{2} \cdot \mathrm{molSubstrato}^{-1}\right)$ & & 1,8 & & & & & & _ & & & & \\
\hline RMSR & $\left(\mathrm{molH}_{2} \cdot \mathrm{molSubstrato}^{-1}\right)$ & & & & & & & & 1,9 & & & & \\
\hline $\mathrm{V}_{\mathrm{A}}$ & (L) & 1,47 & \pm & 0,10 & & 12 & ) & & & & & & \\
\hline$V_{R}$ & $(\mathrm{~L})$ & & 3,5 & & & & & & & & & & \\
\hline
\end{tabular}

(*) Entre parênteses o número de amostras considerado no cálculo da média 

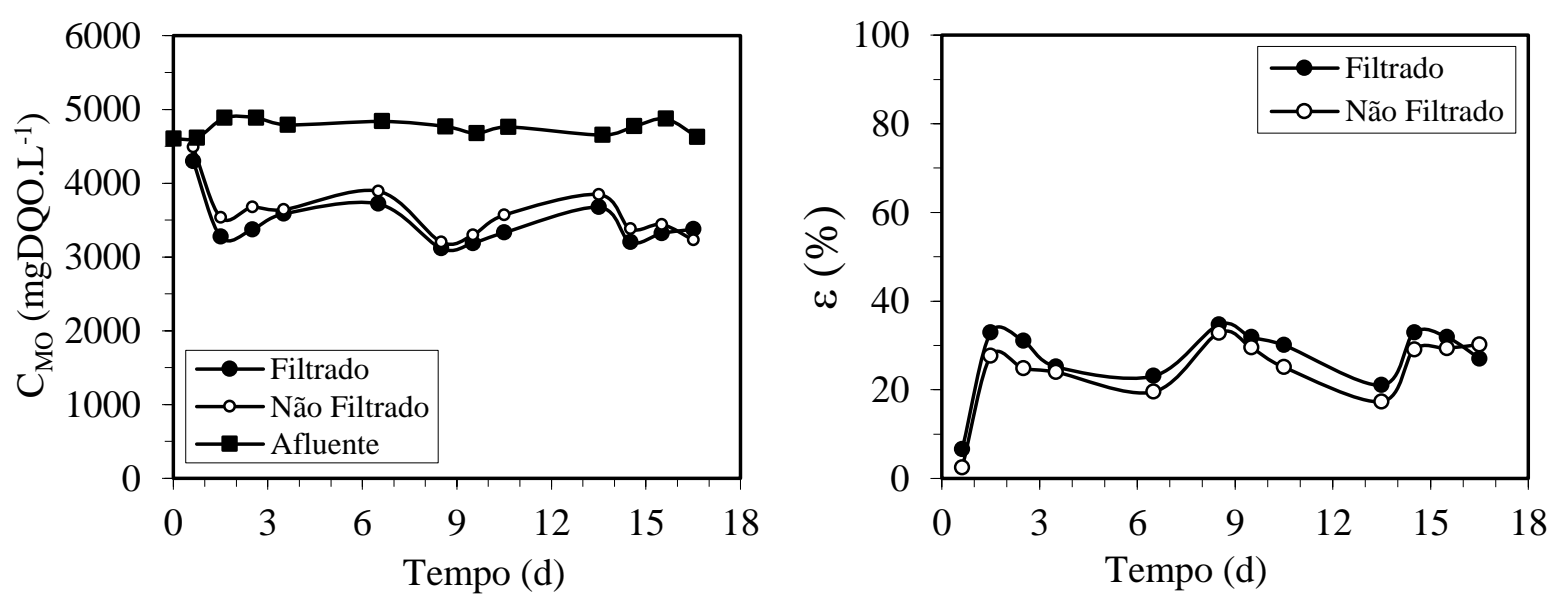

Figura 5.48. Concentração de matéria orgânica e eficiências de remoção na forma de DQO no Ensaio 6: - - afluente amostras não filtradas; • - efluente amostras não filtradas; $\bigcirc$ - efluente amostras filtradas.
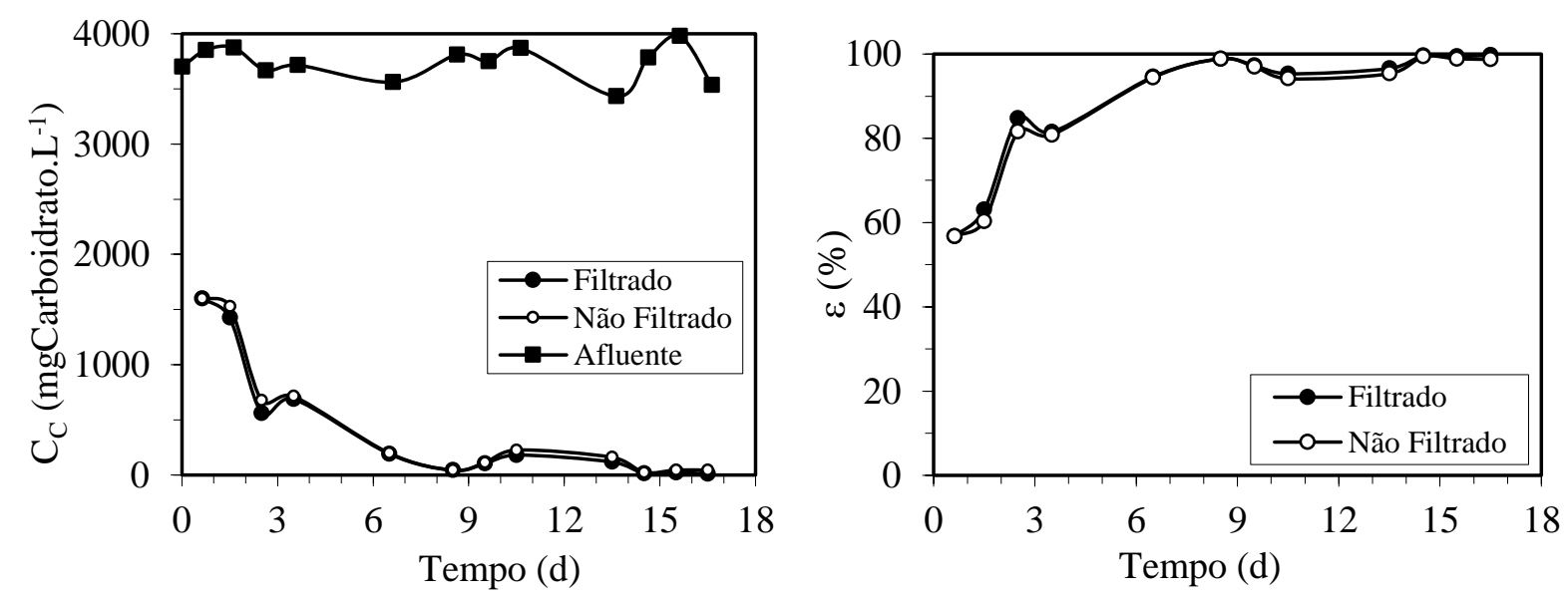

Figura 5.49. Concentração e eficiências de remoção de carboidratos no Ensaio 6: - afluente amostras não filtradas; • - efluente amostras não filtradas; ○ - efluente amostras filtradas.

A média do $\mathrm{pH}$ afluente foi de 7,2 e do efluente de 4,5. A alcalinidade total do afluente teve média de $242 \mathrm{mgCaCO}_{3} . \mathrm{L}^{-1}$ sendo consumida pelo processo e resultando em uma média de $75 \mathrm{mgCaCO}_{3} . \mathrm{L}^{-1}$ no efluente. A média de AVT do afluente foi de $147 \mathrm{mgHAc}^{-1}$ e a média de AVT do efluente de 1180 mgHAc. $\mathrm{L}^{-1}$, o que mostra uma alta acidificação no meio, como era esperado em um reator acidogênico.

A produção de biogás, em aspecto quantitativo, e a distribuição dos gases que compõem o biogás no final do ciclo podem ser observadas pela Figura 5.50, com média de $870 \mathrm{~mL}$ de biogás e $512 \mathrm{~mL}$ de hidrogênio, sendo que a porcentagem média de hidrogênio foi igual a $59 \%$. Nesta condição, não foram detectados traços de metano.

Após a estabilização dos parâmetros monitorados, foram realizados perfis ao longo do ciclo para que fosse feita uma análise de comportamento durante o consumo do substrato. A Figura 5.51 apresenta o perfil de DQO e de Carboidratos; nota-se que há variações na medida 
de DQO durante o ciclo, mas não é possível tirar conclusões a respeito de consumo de matéria orgânica devido à grande produção de ácidos que ocorre no sistema. Em relação aos carboidratos, há uma baixa variação, indicando que o consumo do mesmo ocorre rapidamente assim que o afluente entra no sistema, com seu ponto máximo sendo atingido em 1,5 h (que é quando a alimentação do afluente termina) e no restante do ciclo há apenas o consumo dos mesmos, como era esperado.
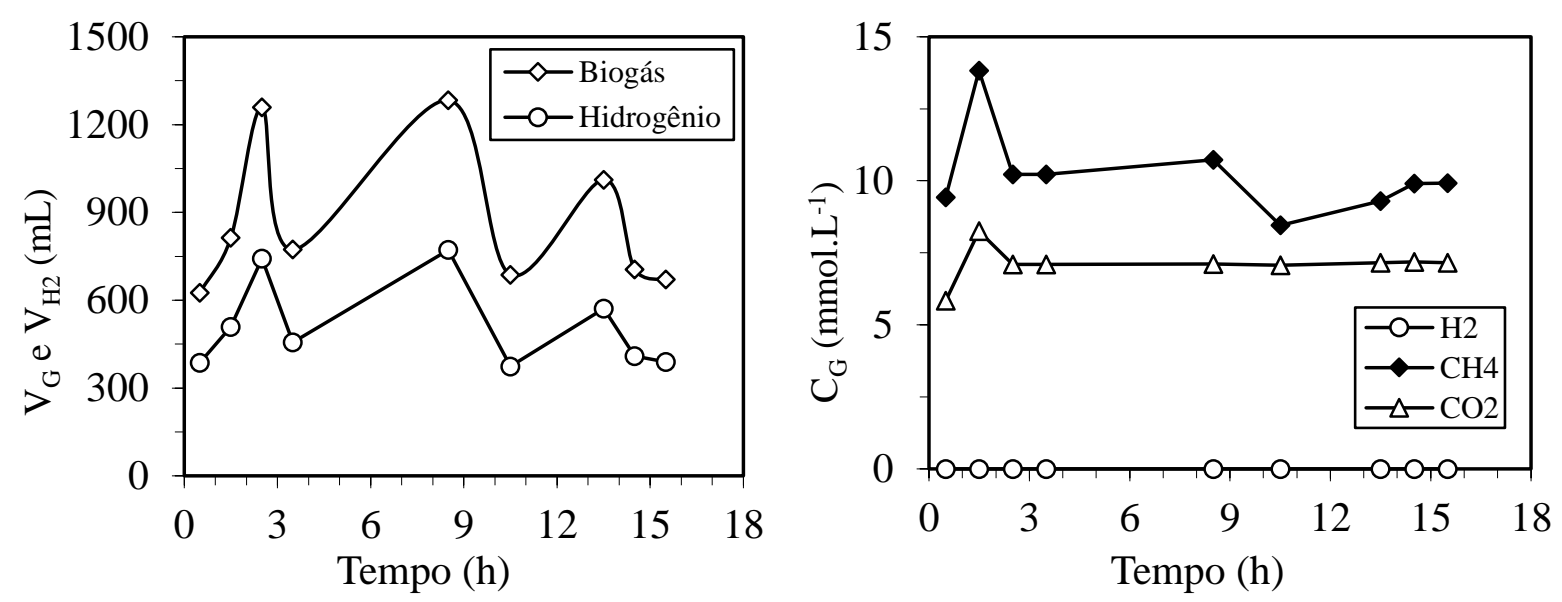

Figura 5.50. Volume de biogás $\left(\mathrm{V}_{\mathrm{G}}\right)$ e de hidrogênio $\left(\mathrm{V}_{\mathrm{H} 2}\right)$ nas $\mathrm{CNTP}$ e concentrações dos componentes do biogás no final do ciclo $\left(\mathrm{C}_{\mathrm{G}}\right)$ no Ensaio 6: $\diamond$-Biogás; - Metano; $\bigcirc-$-Hidrogênio; $\Delta-$ Dióxido de Carbono.
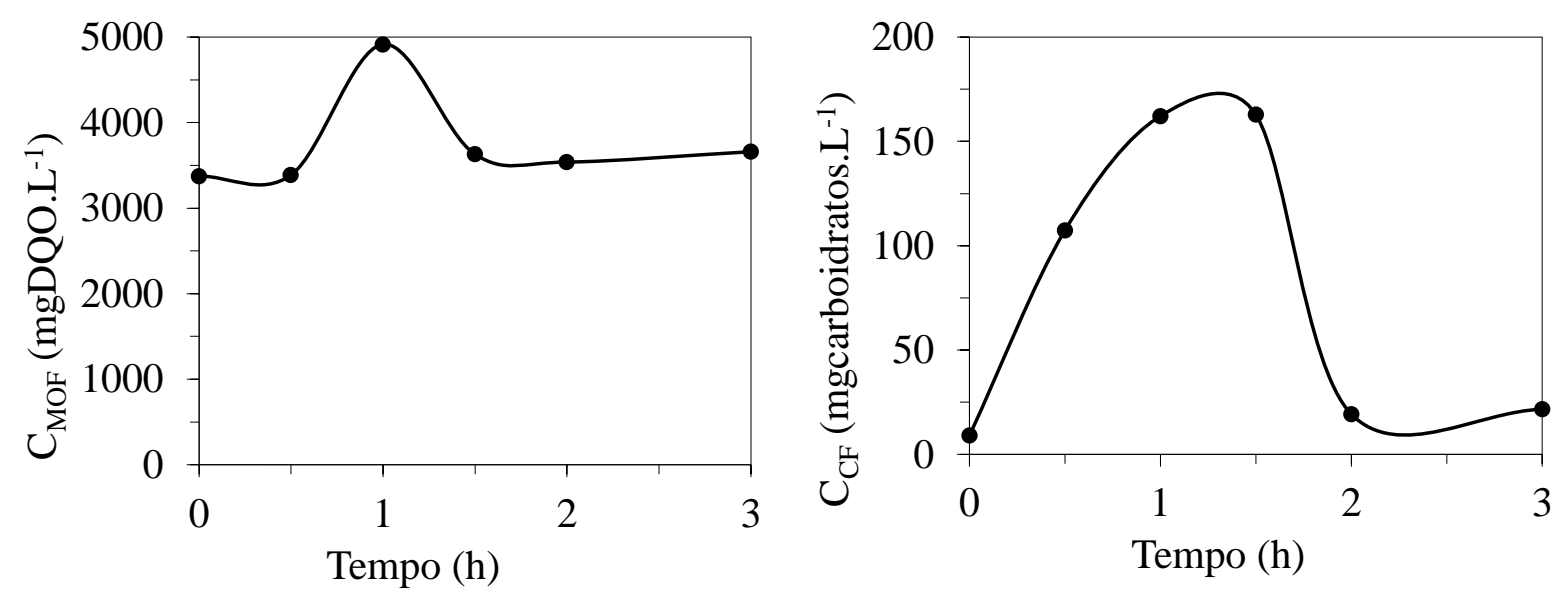

Figura 5.51. Concentração de matéria orgânica e de carboidratos durante o ciclo no Ensaio 6.

A Figura 5.52 apresenta os perfis de $\mathrm{pH}$, alcalinidade total e ácidos voláteis totais ao longo do ciclo. $\mathrm{O}$ pH permanece constante ao longo do ciclo por volta de 4,2, devido à presença da alcalinidade que é fornecida gradualmente pelo afluente e é completamente consumida no processo. Os ácidos voláteis totais apresentam baixa variação ao longo do ciclo, se estabilizando por volta de $1,0 \mathrm{~h}$ em $1700 \mathrm{mgHAc} . \mathrm{L}^{-1}$. 

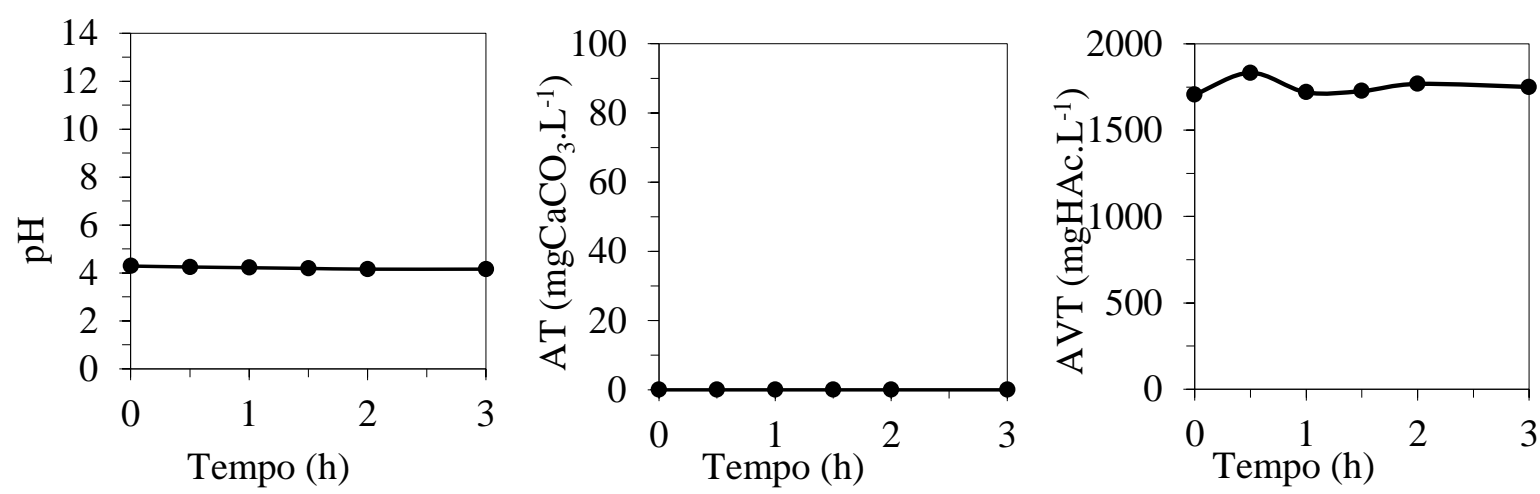

Figura 5.52. Valores de pH, alcalinidade total (AT) e ácidos voláteis totais (AVT) no Ensaio 6.

O perfil dos compostos intermediários do metabolismo é apresentado na Figura 5.53. É possível verificar que há a produção dos mesmos enquanto o afluente é alimentado $(1,5 \mathrm{~h}$ do início do ciclo) e, depois do término da alimentação, há o consumo desses compostos. Os ácidos voláteis intermediários com maiores concentrações molares foram o ácido acético e o ácido butírico. É interessante notar o aumento da concentração dos AVI em relação ao Ensaio 1 (concentração máxima por volta de $5 \mathrm{mmol} \cdot \mathrm{L}^{-1}$ ).

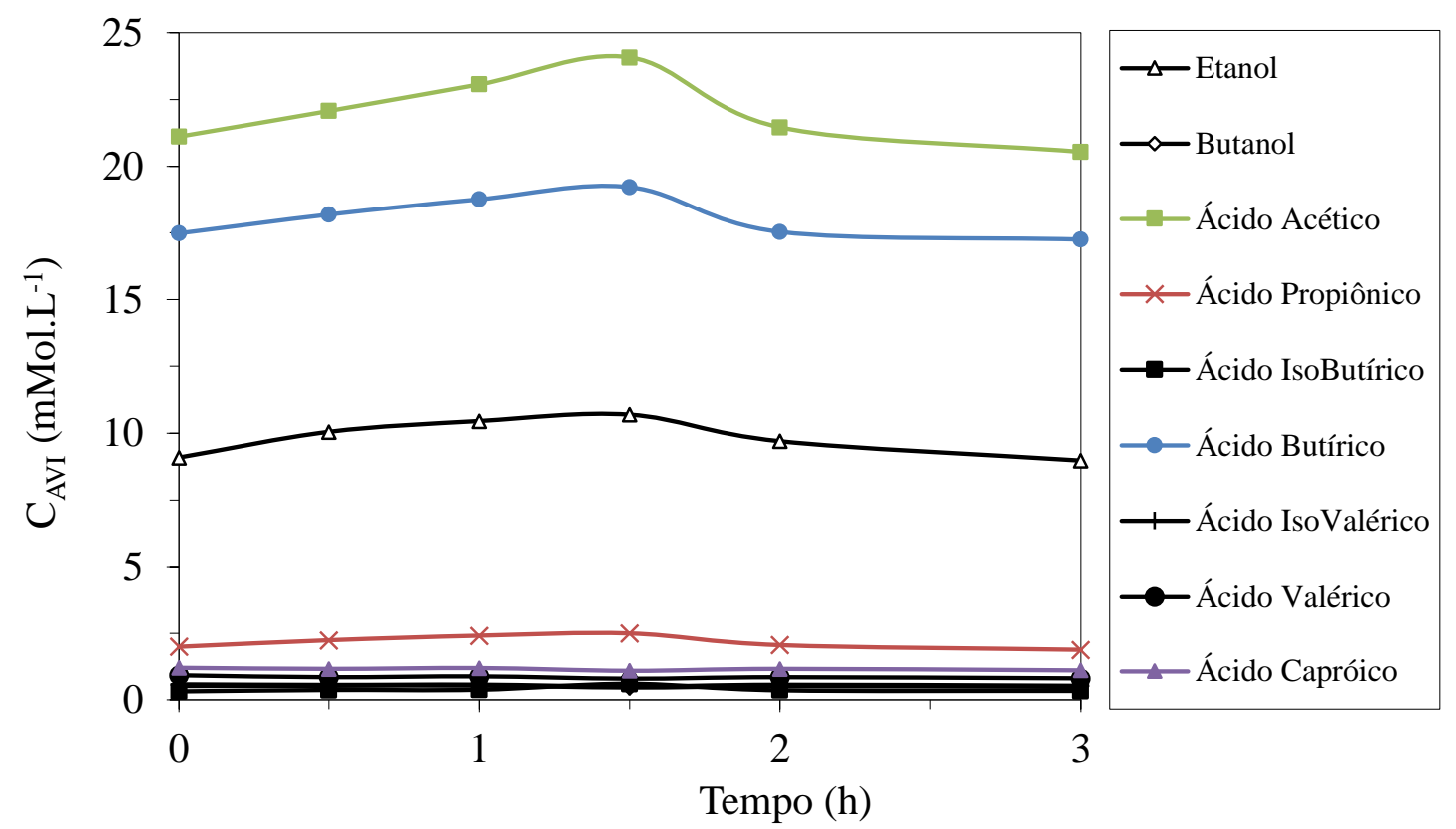

Figura 5.53. Concentração dos compostos intermediários ao longo do ciclo no Ensaio 6: $\Delta$ - etanol; $\diamond$ butanol; $\square$ - ácido acético; -X- ácido propiônico; - ácido isobutírico; • - ácido butírico; + ácido isovalérico $\bullet$ - ácido valérico; $\boldsymbol{\Delta}$ - ácido capróico.

A produção volumétrica acumulada de biogás e os desvios padrões de cada um dos pontos podem ser observados na Figura 5.54 e o perfil das concentrações de cada um dos 
gases e suas respectivas porcentagens podem ser observados na Figura 5.55. Houve grande variação no volume de gás recolhido diariamente em relação à média desse parâmetro e, ao final do ensaio, tinha-se $42 \%$ de $\mathrm{CO}_{2}$ e $58 \%$ de $\mathrm{H}_{2}$, o que representa uma qualidade de gás inferior quando comparada ao Ensaio 1 (27\% de $\mathrm{CO}_{2}$ e $73 \%$ de $\left.\mathrm{CH}_{4}\right)$.

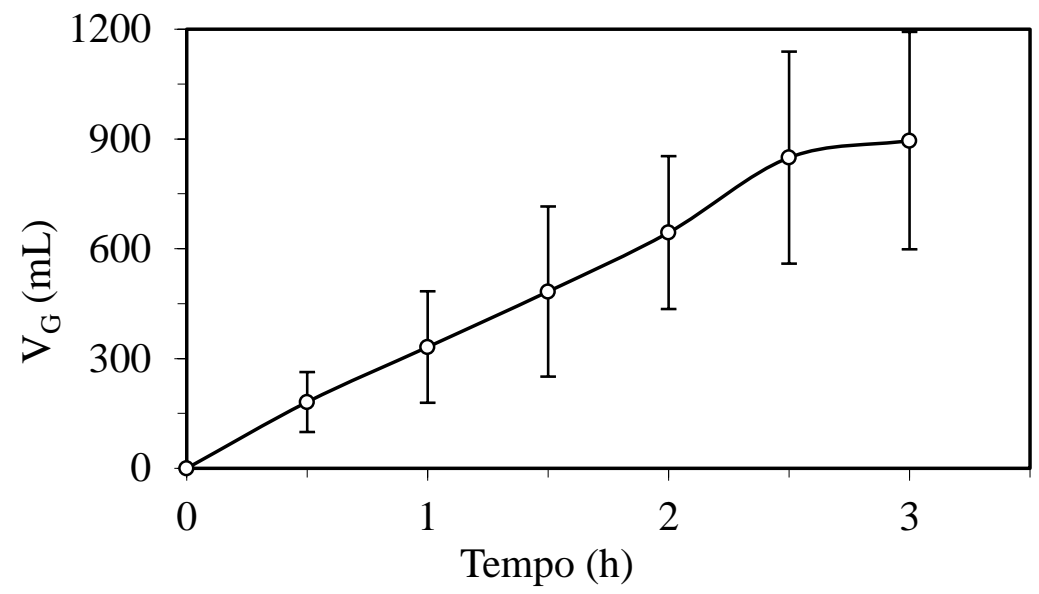

Figura 5.54. Produção volumétrica média acumulada do biogás durante o ciclo no Ensaio 6.
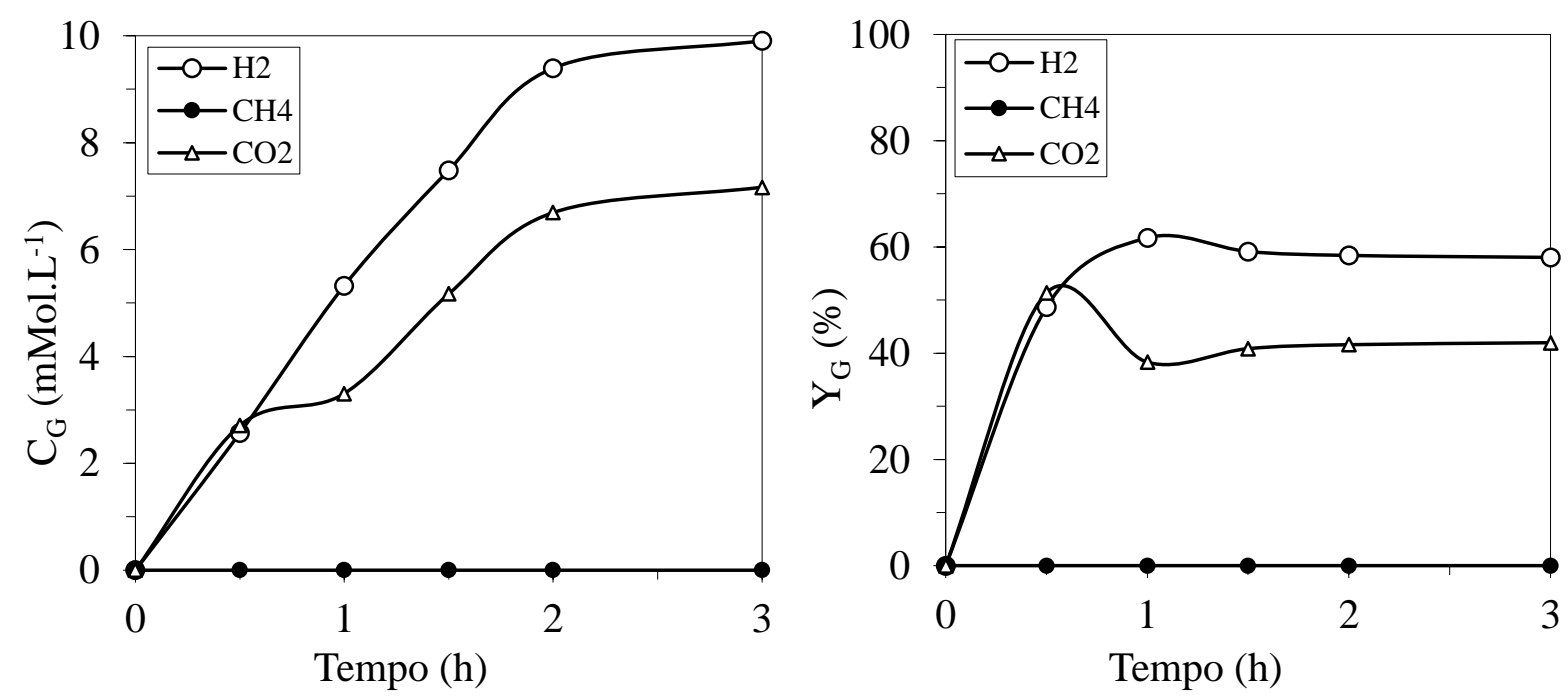

Figura 5.55. Concentração dos compostos do biogás durante o ciclo e suas respectivas porcentagens no Ensaio 6: $\circ-\mathrm{H}_{2} ; \bullet-\mathrm{CH}_{4} ; \Delta-\mathrm{CO}_{2}$.

\subsubsection{Ensaio 7 (75\% Soro e 25\% Glicerina - $\left.5000 \mathrm{mgDQO} . \mathrm{L}^{-1}-3 \mathrm{~h}-\mathrm{BA}\right)$}

O Ensaio 7 representa a primeira condição realizada com codigestão para a produção de hidrogênio. Neste ensaio, o afluente foi feito contendo $75 \%$, em base de DQO, de soro e $25 \%$ de glicerina. A Tabela 5.11 mostra os parâmetros médios monitorados no Ensaio 7. 
Tabela 5.11. Parâmetros médios monitorados no Ensaio 7.

\begin{tabular}{|c|c|c|c|c|c|c|c|c|c|c|}
\hline \multicolumn{2}{|r|}{ Parâmetro } & \multicolumn{5}{|c|}{ Afluente } & \multicolumn{4}{|c|}{ Efluente } \\
\hline $\mathrm{C}_{\text {MOT }}$ & $\left(\mathrm{mgDQO} \cdot \mathrm{L}^{-1}\right)$ & 4992 & \pm 157 & & 13 & & 3702 & \pm 211 & $(11$ & $1 \quad$ \\
\hline $\mathrm{C}_{\mathrm{MOF}}$ & $\left(\mathrm{mgDQO} \cdot \mathrm{L}^{-1}\right)$ & & & & & & 3650 & \pm 208 & ( 11 & $1 \quad)$ \\
\hline$\varepsilon_{\text {MOT }}$ & $(\%)$ & & & & & & 26 & \pm 3 & ( 11 & $1 \quad$ \\
\hline$\varepsilon_{\mathrm{MOF}}$ & $(\%)$ & & & & & & 27 & \pm 3 & ( 11 & $1 \quad)$ \\
\hline $\mathrm{C}_{\mathrm{CT}}$ & $\left(\right.$ mgCarboidratos. $\left.\mathrm{L}^{-1}\right)$ & 2858 & \pm 316 & $(1$ & 13 & ) & 48 & \pm 18 & $(8$ & $8 \quad)$ \\
\hline $\mathrm{C}_{\mathrm{CF}}$ & $\left(\right.$ mgCarboidratos. $\left.\mathrm{L}^{-1}\right)$ & & & & & & 33 & \pm 14 & ( 8 & $8 \quad$ \\
\hline$\varepsilon_{\mathrm{CT}}$ & $(\%)$ & & & & & & 98 & \pm 5 & ( 8 & $8 \quad$ \\
\hline$\varepsilon_{\mathrm{CF}}$ & $(\%)$ & & & & & & 98,9 & $\pm 0,4$ & ( 8 & $8 \quad$ \\
\hline $\mathrm{C}_{\mathrm{GT}}$ & $\left(\right.$ mgGlicerina. $\left.\mathrm{L}^{-1}\right)$ & 998 & \pm 40 & $(1$ & 13 & ) & 31 & \pm 39 & ( 8 & $8 \quad$ \\
\hline $\mathrm{C}_{\mathrm{GF}}$ & (mgGlicerina. $\left.\mathrm{L}^{-1}\right)$ & & & & & & 29 & \pm 37 & ( 8 & $8 \quad$ \\
\hline$\varepsilon_{\mathrm{GT}}$ & $(\%)$ & & & & & & 97 & \pm 4 & ( 8 & $8 \quad$ \\
\hline$\varepsilon_{\mathrm{GF}}$ & $(\%)$ & & 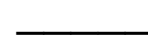 & & & & 97 & \pm 4 & ( 8 & $8 \quad$ \\
\hline $\mathrm{pH}$ & (u) & 7,39 & $\pm 0,07$ & $(1$ & 11 & ) & 4,42 & $\pm 0,09$ & ( 11 & $1 \quad)$ \\
\hline AVT & $\left(\mathrm{mgHAc} . \mathrm{L}^{-1}\right)$ & 128 & \pm 12 & $(1$ & 11 & ) & 1006 & \pm 102 & ( 11 & $1 \quad$ \\
\hline $\mathrm{AT}$ & $\left(\mathrm{mgCaCO}_{3} \cdot \mathrm{L}^{-1}\right)$ & 242 & \pm 18 & $(1$ & 11 & ) & 50 & \pm 33 & ( 11 & $1)$ \\
\hline $\mathrm{AP}$ & $\left(\mathrm{mgCaCO}_{3} \cdot \mathrm{L}^{-1}\right)$ & 171 & \pm 13 & $(1$ & 11 & ) & 0 & \pm 0 & ( 11 & $1 \quad$ \\
\hline AI & $\left(\mathrm{mgCaCO}_{3} \cdot \mathrm{L}^{-1}\right)$ & 71 & \pm & $(1$ & 11 & ) & 50 & \pm 33 & ( 11 & $1 \quad$ \\
\hline $\mathrm{AB}$ & $\left(\mathrm{mgCaCO}_{3} \cdot \mathrm{L}^{-1}\right)$ & 150 & $\pm \quad 19$ & $(1$ & 11 & ) & 0 & \pm 0 & ( 11 & $1 \quad$ \\
\hline ST & $\left(\mathrm{mg} \cdot \mathrm{L}^{-1}\right)$ & 3232 & $\pm \quad 98$ & ( & 6 & ) & 1786 & \pm 171 & ( 6 & $6 \quad$ \\
\hline SVT & $\left(\mathrm{mg} \cdot \mathrm{L}^{-1}\right)$ & 2688 & \pm 93 & ( & 6 & ) & 1295 & \pm 150 & ( 6 & $6 \quad$ \\
\hline SST & $\left(\mathrm{mg} \cdot \mathrm{L}^{-1}\right)$ & 62 & $\pm \quad 14$ & ( & 6 & ) & 98 & \pm 55 & ( 6 & $6 \quad)$ \\
\hline SSV & $\left(\mathrm{mg} \cdot \mathrm{L}^{-1}\right)$ & 56 & \pm 16 & ( & 6 & ) & 91 & \pm 44 & ( 6 & $6 \quad$ \\
\hline $\mathrm{M}_{\mathrm{SVT}}$ & (g) & & & & & & & 0,5 & & \\
\hline $\mathrm{Cx}$ & $\left(\mathrm{g} \cdot \mathrm{L}^{-1}\right)$ & & - & & & & & 3,0 & & \\
\hline $\mathrm{Cx}^{\prime}$ & $\left(\right.$ g.gsuporte $\left.{ }^{-1}\right)$ & & 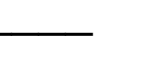 & & & & & 006 & & \\
\hline $\mathrm{V}_{\mathrm{G}}$ & $\left(\mathrm{mL} . \mathrm{ciclo}^{-1}\right)$ & & 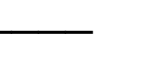 & & & & 1360 & \pm 274 & ( 12 & $2)$ \\
\hline $\mathrm{V}_{\mathrm{H} 2}$ & $\left(\mathrm{~mL} \cdot \mathrm{ciclo}^{-1}\right)$ & & 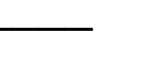 & & & & 900 & \pm 174 & ( 12 & $2)$ \\
\hline COAV $_{\text {мот }}$ & $\left(\right.$ gDQO.L $\left.\mathrm{L}^{-1} \cdot \mathrm{d}^{-1}\right)$ & & 17,2 & & & & & - & & \\
\hline $\mathrm{CORV}_{\mathrm{MOF}}$ & $\left(\mathrm{gDQO} \cdot \mathrm{L}^{-1} \cdot \mathrm{d}^{-1}\right)$ & & & & & & & 4,6 & & \\
\hline $\mathrm{COAV}_{\mathrm{CT}}$ & (gCarboidratos. $\mathrm{L}^{-1} \cdot \mathrm{d}^{-1}$ ) & & 9,9 & & & & & & & \\
\hline $\mathrm{CORV}_{\mathrm{CF}}$ & $\left(\right.$ gCarboidratos. $\left.\mathrm{L}^{-1} \cdot \mathrm{d}^{-1}\right)$ & & & & & & & 9,8 & & \\
\hline $\mathrm{COAV}_{\mathrm{GT}}$ & (gGlicerina. $L^{-1} \cdot d^{-1}$ ) & & 3,4 & & & & & & & \\
\hline $\mathrm{CORV}_{\mathrm{GF}}$ & (gGlicerina. $\mathrm{L}^{-1} \cdot \mathrm{d}^{-1}$ ) & & & & & & & 3,3 & & \\
\hline $\mathrm{COAE}_{\mathrm{MOT}}$ & $\left(\right.$ gDQO.gSVT $\left.{ }^{-1} \cdot d^{-1}\right)$ & & 10,5 & & & & & & & \\
\hline $\mathrm{CORE}_{\mathrm{MOF}}$ & $\left(\mathrm{gDQO}_{\mathrm{gSVT}} \mathrm{gS}^{-1} \mathrm{~d}^{-1}\right)$ & & & & & & & 5,8 & & \\
\hline $\mathrm{COAE}_{\mathrm{CT}}$ & (gCarboidratos.gSVT ${ }^{-1} \cdot \mathrm{d}^{-1}$ ) & & 10,5 & & & & & & & \\
\hline $\mathrm{CORE}_{\mathrm{CF}}$ & (gCarboidratos.gSVT ${ }^{-1} \cdot \mathrm{d}^{-1}$ ) & & & & & & & 3,3 & & \\
\hline $\mathrm{COAE}_{\mathrm{GT}}$ & (gGlicerina.gSVT ${ }^{-1} \cdot \mathrm{d}^{-1}$ ) & & 10,5 & & & & & & & \\
\hline $\mathrm{CORE}_{\mathrm{GF}}$ & (gGlicerina.gSVT ${ }^{-1} \cdot \mathrm{d}^{-1}$ ) & & & & & & & 1,2 & & \\
\hline $\mathrm{n}_{\mathrm{H} 2}$ & $\left(\mathrm{molH}_{2} \cdot \mathrm{d}^{-1}\right)$ & & & & & & & 0,3 & & \\
\hline PrM & $\left(\mathrm{molH}_{2} \cdot \mathrm{m}^{-3} \cdot \mathrm{d}^{-1}\right)$ & & & & & & & 91,3 & & \\
\hline PrME & $\left(\mathrm{molH}_{2} \cdot \mathrm{kgSVT}^{-1} \cdot \mathrm{d}^{-1}\right)$ & & & & & & & 30,7 & & \\
\hline RMCA & $\left(\mathrm{molH}_{2} \cdot \mathrm{kgDQO}^{-1}\right)$ & & 5,3 & & & & & & & \\
\hline RMSA & $\left(\mathrm{molH}_{2} \cdot \mathrm{molSubstrato}^{-1}\right)$ & & 1,5 & & & & & & & \\
\hline RMSR & $\left(\mathrm{molH}_{2} \cdot \mathrm{molSubstrato}^{-1}\right)$ & & & & & & & 1,6 & & \\
\hline $\mathrm{V}_{\mathrm{A}}$ & $(\mathrm{L})$ & 1,52 & $\pm 0,05$ & ( & 12 & & & & & \\
\hline $\mathrm{V}_{\mathrm{R}}$ & $(\mathrm{L})$ & & 3,5 & & & & & & & \\
\hline
\end{tabular}

(*) Entre parênteses o número de amostras considerado no cálculo da média 
O valor real da COAV foi de $17,2 \mathrm{gDQO} \cdot \mathrm{L}^{-1} \cdot \mathrm{d}^{-1}$ e a CORV atingida foi de $4,6 \mathrm{gDQO} . \mathrm{L}^{-}$ ${ }^{1} \cdot \mathrm{d}^{-1}$, novamente, o sistema apresentou uma baixa remoção de matéria orgânica. Adicionar $75 \%$ da DQO total em soro, significou que o afluente teve, em média, 2858 mgCarboidratos. $\mathrm{L}^{-1}$ (COAV foi de 9,9 gCarboidratos. $\mathrm{L}^{-1} \cdot \mathrm{d}^{-1}$ e a CORV atingida foi de 9,8 gCarboidratos. $\mathrm{L}^{-1} \cdot \mathrm{d}^{-1}$ ) e $998 \mathrm{mgGlicerina} . \mathrm{L}^{-1}$ (COAV foi de 3,4 gGlicerina. $\mathrm{L}^{-1} \cdot \mathrm{d}^{-1}$ e a CORV atingida foi de 3,3 gGlicerina. $\left.\mathrm{L}^{-1} \cdot \mathrm{d}^{-1}\right)$. Lembrando que a glicerina utilizada nos ensaios focados na produção de biohidrogênio foi obtida de uma usina de produção de biodiesel bidestilada.

O monitoramento diário apresentou um baixo consumo de matéria orgânica na forma de DQO, com média de concentração afluente não filtrada de $4992 \mathrm{mgDQO}$. $^{-1}$, efluente não filtrada $3702 \mathrm{mgDQO} . \mathrm{L}^{-1}$ e de efluente filtrada de $3650 \mathrm{mgDQO} . \mathrm{L}^{-1}$, o que representa uma remoção média para amostras não filtradas de $26 \%$ e para amostras filtradas de $27 \%$ (Figura 5.56) - valores próximos aos obtidos no Ensaio 6.
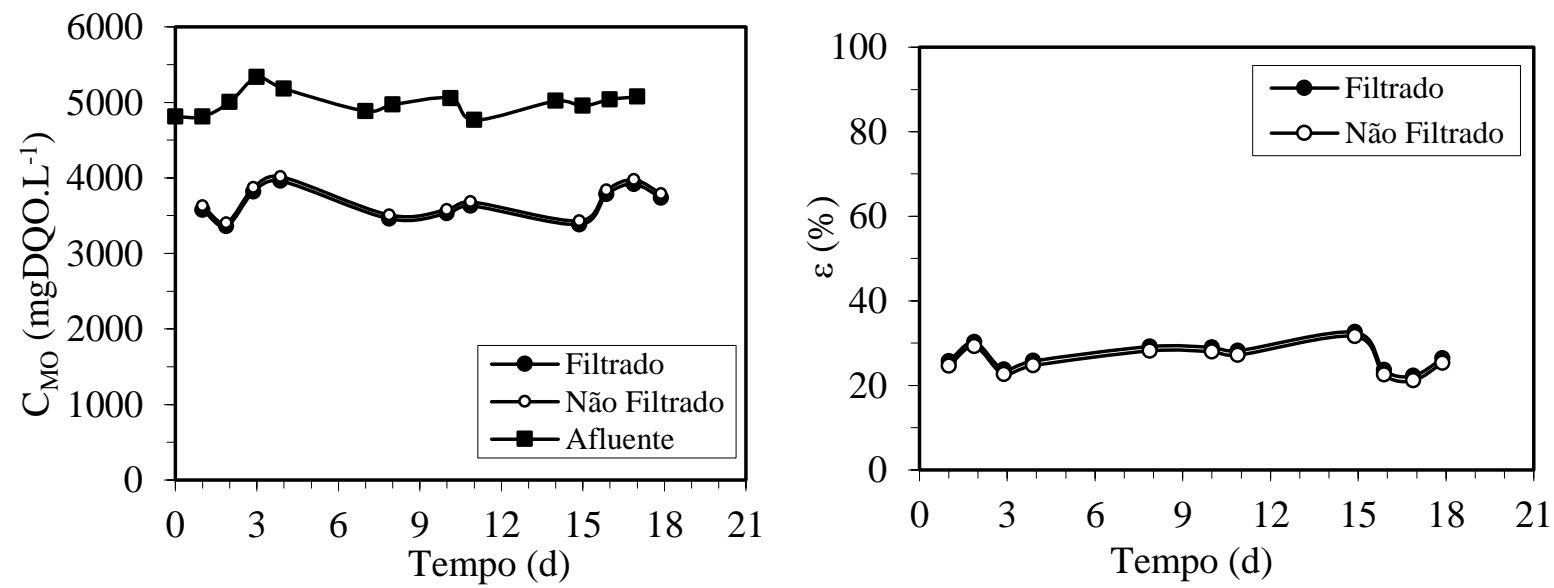

Figura 5.56. Concentração e eficiência de remoção de matéria orgânica na forma de DQO no Ensaio 7: - - afluente amostras não filtradas; • - efluente amostras não filtradas; ○ - efluente amostras filtradas.

Em relação ao monitoramento diário de carboidratos, o mesmo novamente apresentou um ótimo consumo, com média de concentração afluente não filtrada de $2858 \mathrm{mgCarboidratos.} \mathrm{L}^{-1}$, efluente não filtrado $48 \mathrm{mgCarboidratos. \textrm {L } ^ { - 1 }} \mathrm{e}$ de efluente filtrado

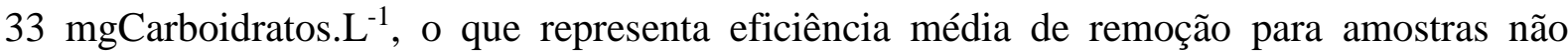
filtradas de $98 \%$ e para amostras filtradas de $99 \%$ (Figura 5.57). 

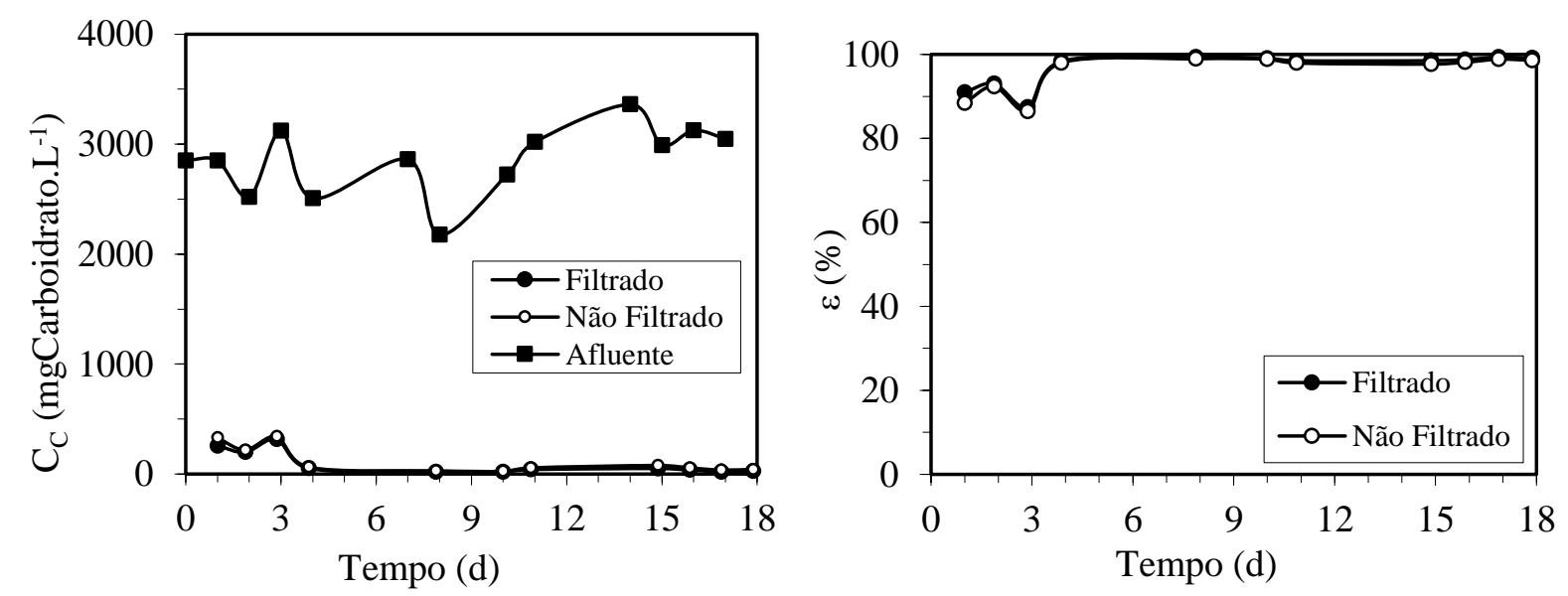

Figura 5.57. Concentração e eficiência de remoção na forma de carboidratos no Ensaio 7: - - afluente amostras não filtradas; • - efluente amostras não filtradas; $\bigcirc$ - efluente amostras filtradas.

Neste ensaio houve também o monitoramento diário de glicerina, que apresentou média de concentração afluente não filtrada de $998 \mathrm{mgGlicerina} . \mathrm{L}^{-1}$, efluente não filtrado 31 mgGlicerina. $L^{-1}$ e de efluente filtrado de $29 \operatorname{mgGlicerina} . \mathrm{L}^{-1}$, o que representa uma eficiência média de remoção para amostras não filtradas de $97 \%$ e para amostras filtradas de 97\% (Figura 5.58).
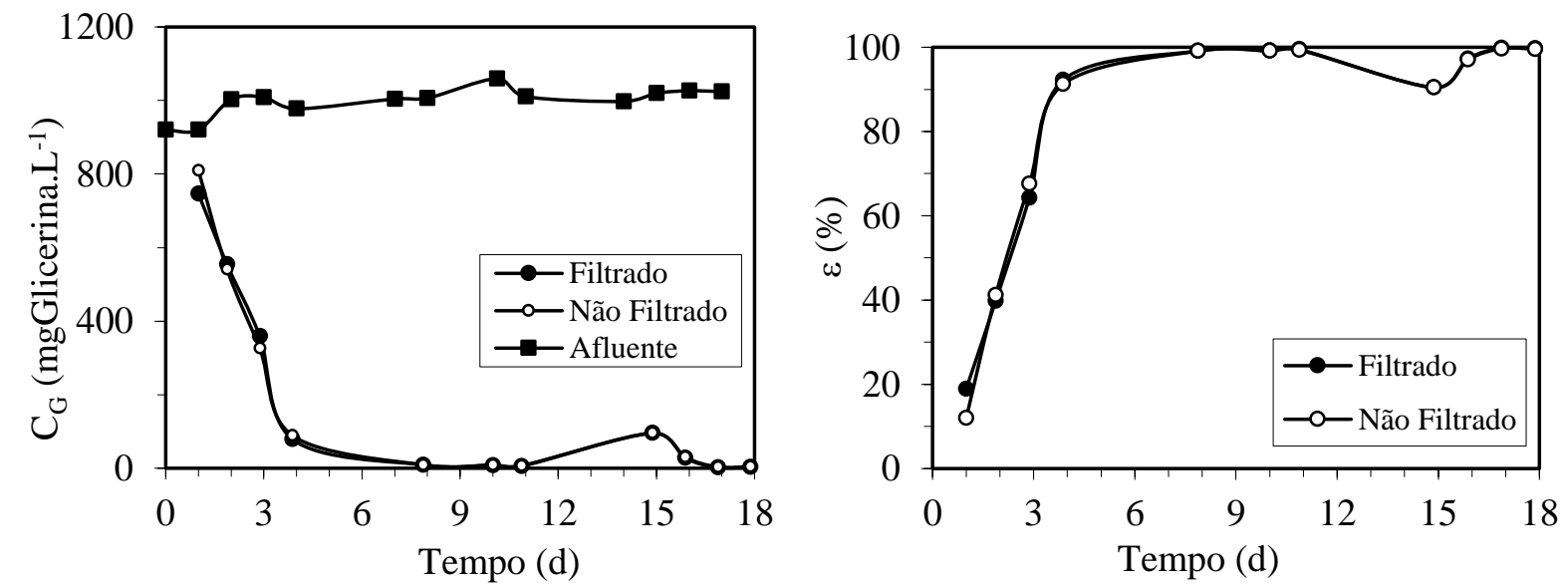

Figura 5.58. Concentração e eficiência de remoção na forma de glicerina no Ensaio 7: - - afluente amostras não filtradas; • - efluente amostras não filtradas; $\bigcirc-$ efluente amostras filtradas

A média do pH afluente foi de 7,4 e do efluente de 4,4. A alcalinidade total no afluente teve média de $242 \mathrm{mgCaCO}_{3} . \mathrm{L}^{-1}$ sendo que a mesma foi consumida até uma média de $50 \mathrm{mgCaCO} 3 . \mathrm{L}^{-1}$. A média de AVT no afluente foi de $128 \mathrm{mgHAc} . \mathrm{L}^{-1}$ e a média de AVT no efluente de 1006 mgHAc. $\mathrm{L}^{-1}$. Devido à adição de glicerina, os ácidos voláteis totais foram ligeiramente menores do que no Ensaio 6.

A produção de biogás, em aspecto quantitativo, e a distribuição dos gases que compõem o biogás no final do ciclo podem ser observadas pela Figura 5.59, com média de $1360 \mathrm{~mL}$ de 
biogás e $900 \mathrm{~mL}$ de hidrogênio, sendo que a porcentagem média de hidrogênio foi igual a $66 \%$. Este ensaio obteve qualidade e quantidade de biogás melhores do que as obtidas no Ensaio 6, o que demonstra que o codigestão foi benéfica para o sistema de produção de hidrogênio assim como para a produção de metano. A produtividade molar de hidrogênio foi igual a 91,3 $\mathrm{molH}_{2} \cdot \mathrm{m}^{-3} \cdot \mathrm{d}^{-1}$ - um aumento de $73,2 \%$ em relação a produtividade atingida com água residuária composta unicamente por soro.
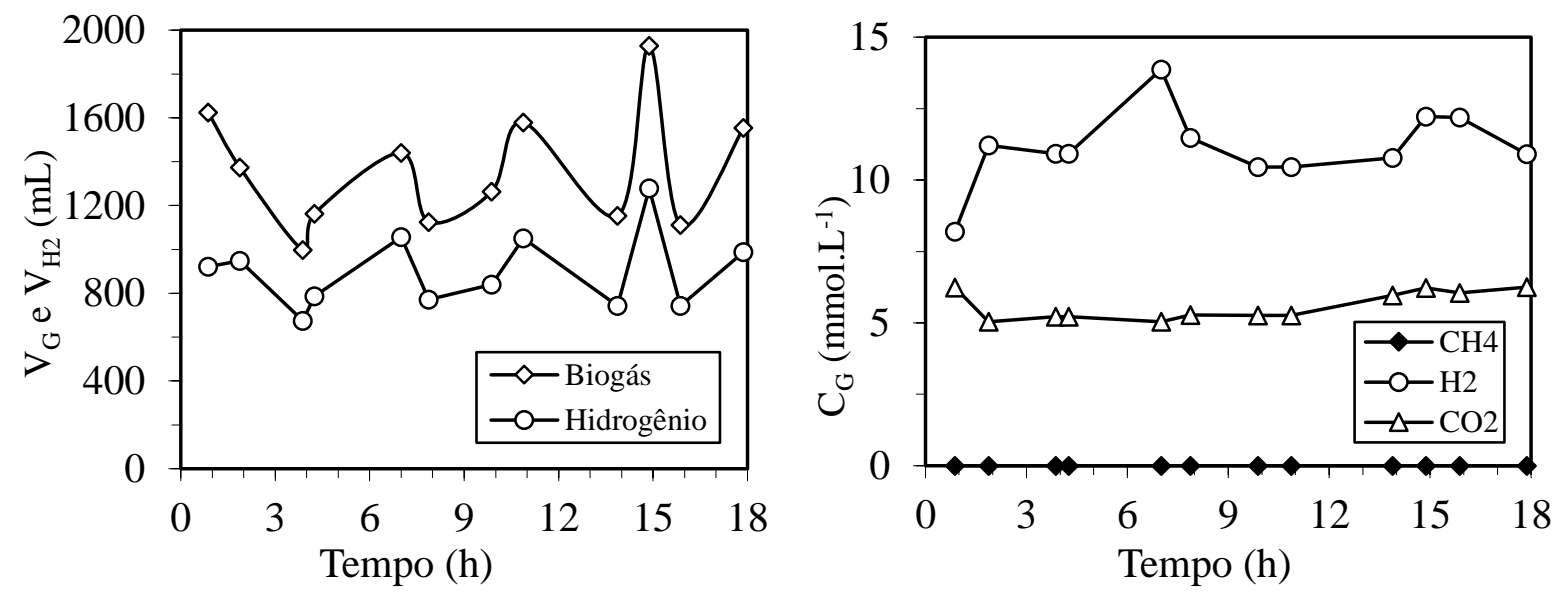

Figura 5.59. Volume de biogás $\left(\mathrm{V}_{\mathrm{G}}\right)$ e de hidrogênio $\left(\mathrm{V}_{\mathrm{H} 2}\right)$ nas CNTP e concentrações dos componentes do

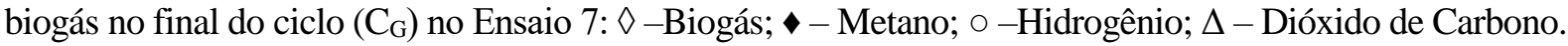

A Figura 5.60 apresenta o perfil de DQO, de Carboidratos e de Glicerina, nota-se que há uma baixa variação na medida de DQO durante o ciclo, enquanto os perfis de carboidrato e de glicerina mostram grandes variações. Nestes últimos dois, é possível observar um ponto de máxima concentração em $1,5 \mathrm{~h}$ (que representa o final da alimentação do afluente) e o consumo desses dois substratos até o final do ciclo.

A Figura 5.61 apresenta os perfis de $\mathrm{pH}$, alcalinidade total e ácidos voláteis totais ao longo do ciclo. $\mathrm{O}$ pH permanece constante ao longo do ciclo por volta de 4,3, bem como os ácidos voláteis totais por volta de $988 \mathrm{mgHAc} . \mathrm{L}^{-1}$. A alcalinidade fornecida pelo afluente é completamente consumida ao longo do processo.

O perfil dos compostos intermediários do metabolismo é apresentado na Figura 5.62. Neste ensaio, é possível verificar que há a predominância de ácido acético e de ácido butírico, mas com um perfil diferente do que o encontrado no Ensaio 6, pois o ponto de mínima concentração acontece em 1,5 h. 

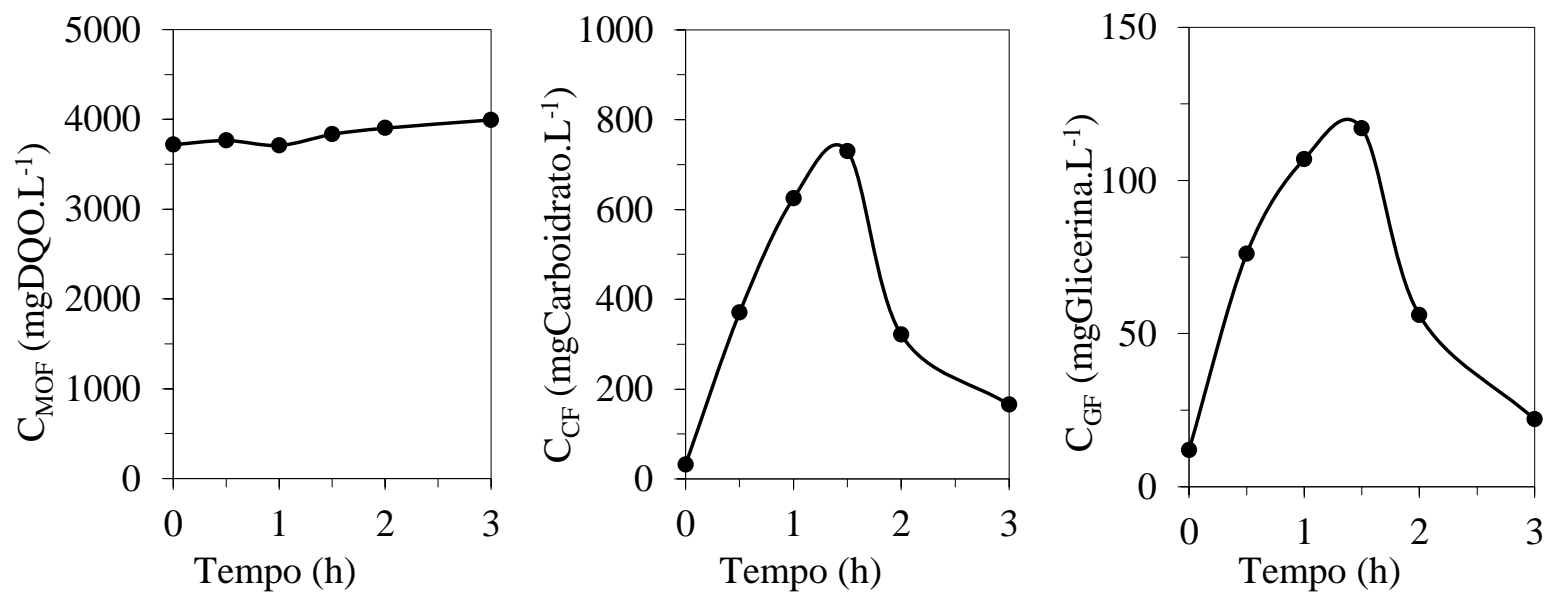

Figura 5.60. Concentração de matéria orgânica, carboidratos e de glicerina durante o ciclo no Ensaio 7.
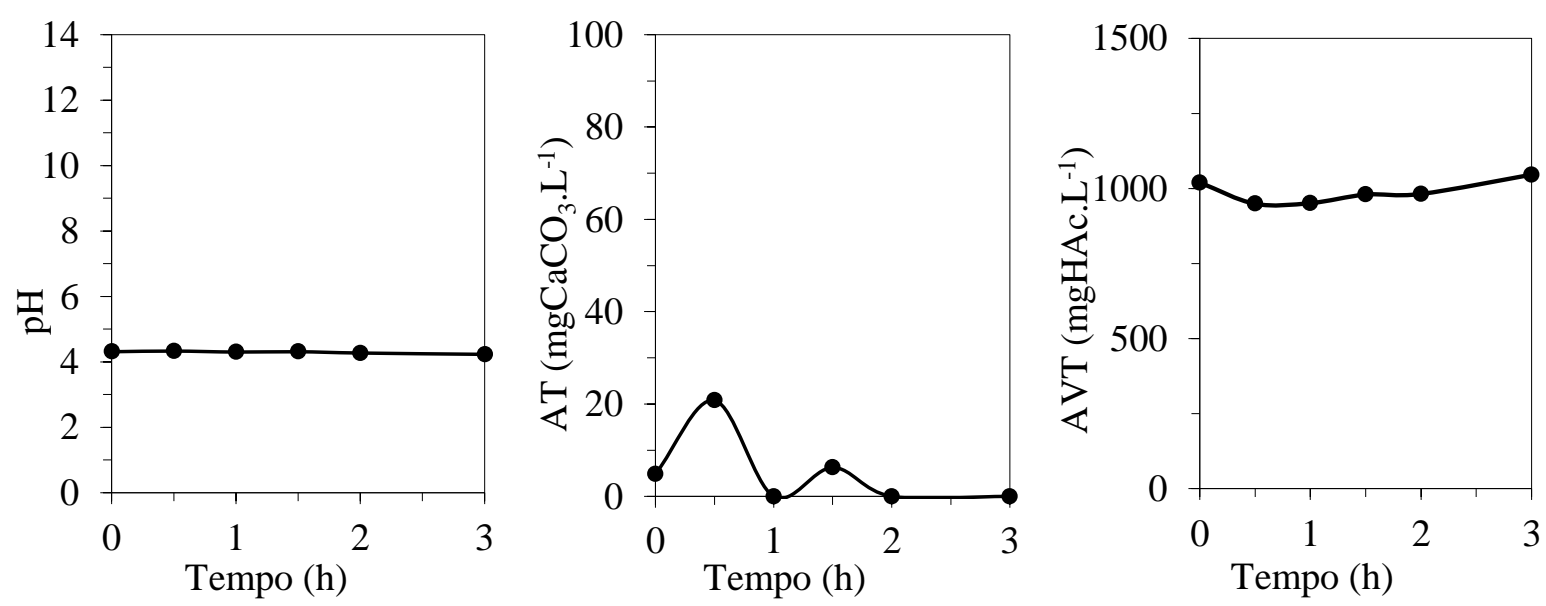

Figura 5.61. Valores de pH, alcalinidade total(AT) e ácidos voláteis totais (AVT) no Ensaio 7.
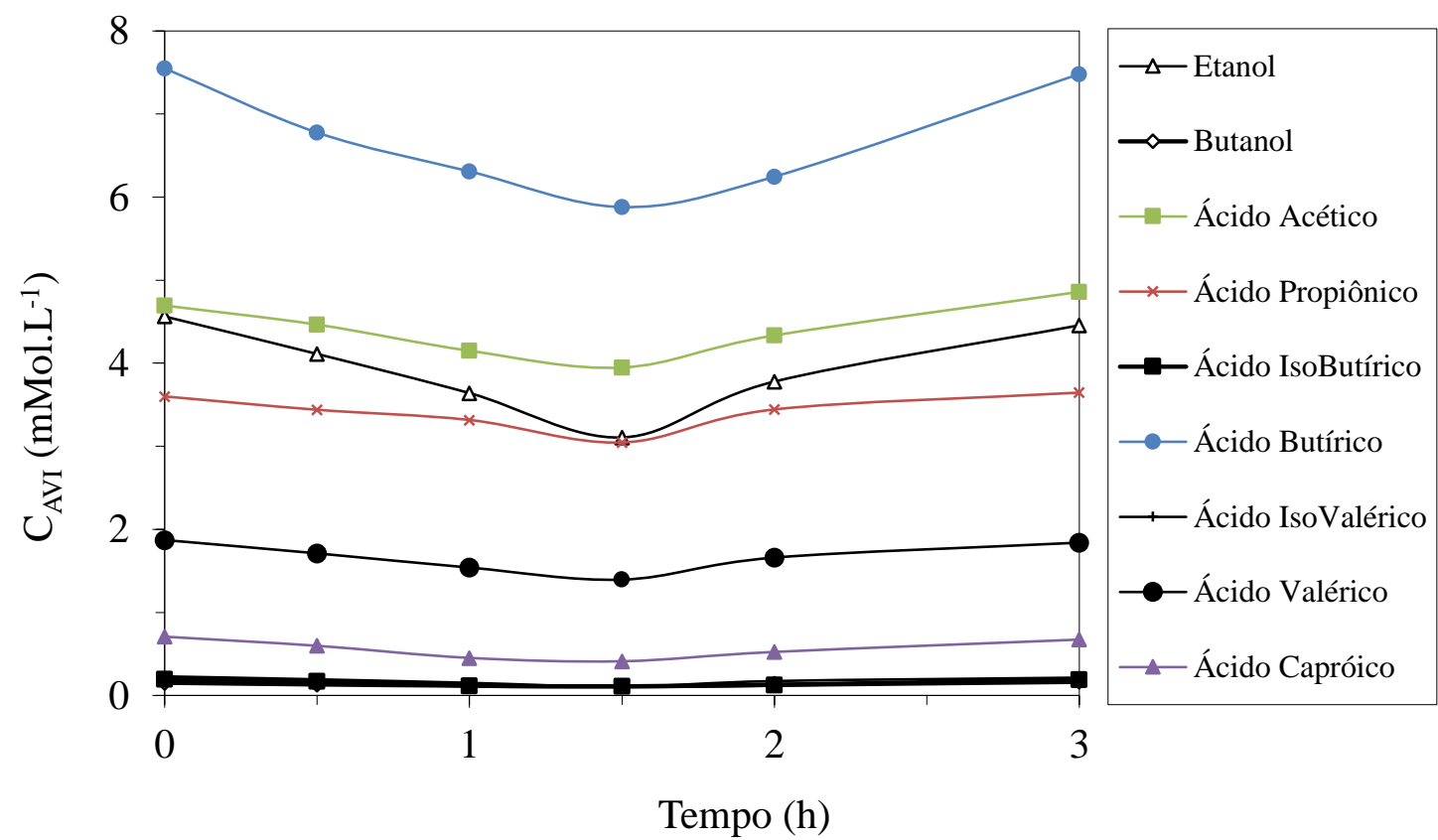

Figura 5.62. Concentração dos compostos intermediários ao longo do ciclo no Ensaio 7: $\Delta$ - etanol; $\diamond$ butanol; $\square$ - ácido acético; -X- ácido propiônico; - ácido isobutírico; $\bullet$ - ácido butírico; + ácido isovalérico $\bullet$ - ácido valérico; $\boldsymbol{\Delta}$ - ácido capróico. 
A produção volumétrica acumulada de biogás e os desvios padrões de cada um dos pontos podem ser observados na Figura 5.63 e o perfil das concentrações de cada um dos gases e suas respectivas porcentagens podem ser observados na Figura 5.64. Houve baixa variação no volume de gás recolhido diariamente, o que é uma melhora em relação ao resultado obtido no Ensaio 6, e que se manteve estável ao longo do tempo. Ao final do perfil, tinha-se $33 \%$ de $\mathrm{CO}_{2}$ e $67 \%$ de $\mathrm{H}_{2}$.

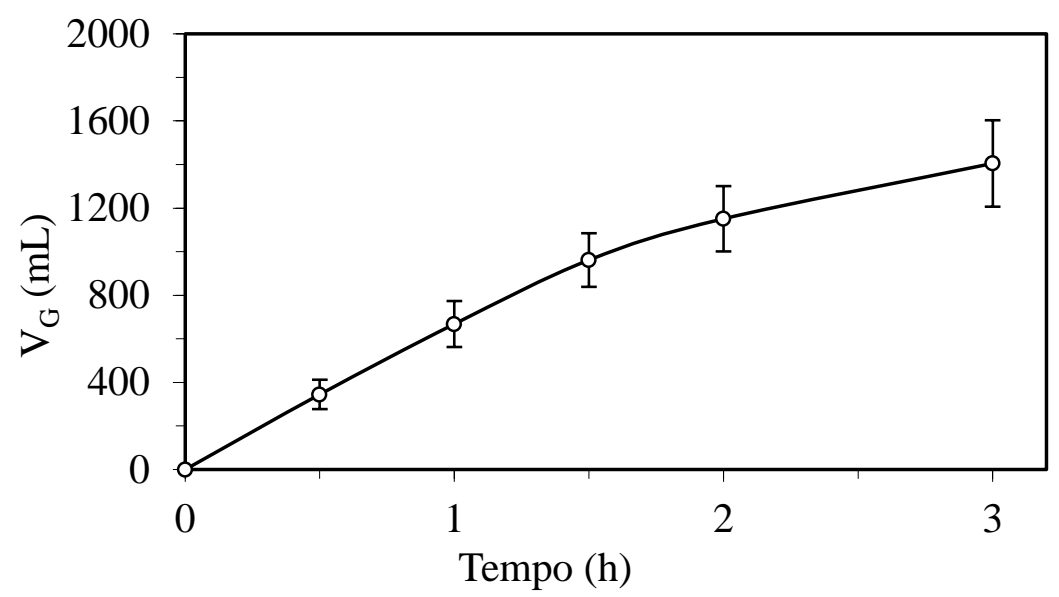

Figura 5.63. Produção volumétrica média acumulada do biogás durante o ciclo no Ensaio 7.
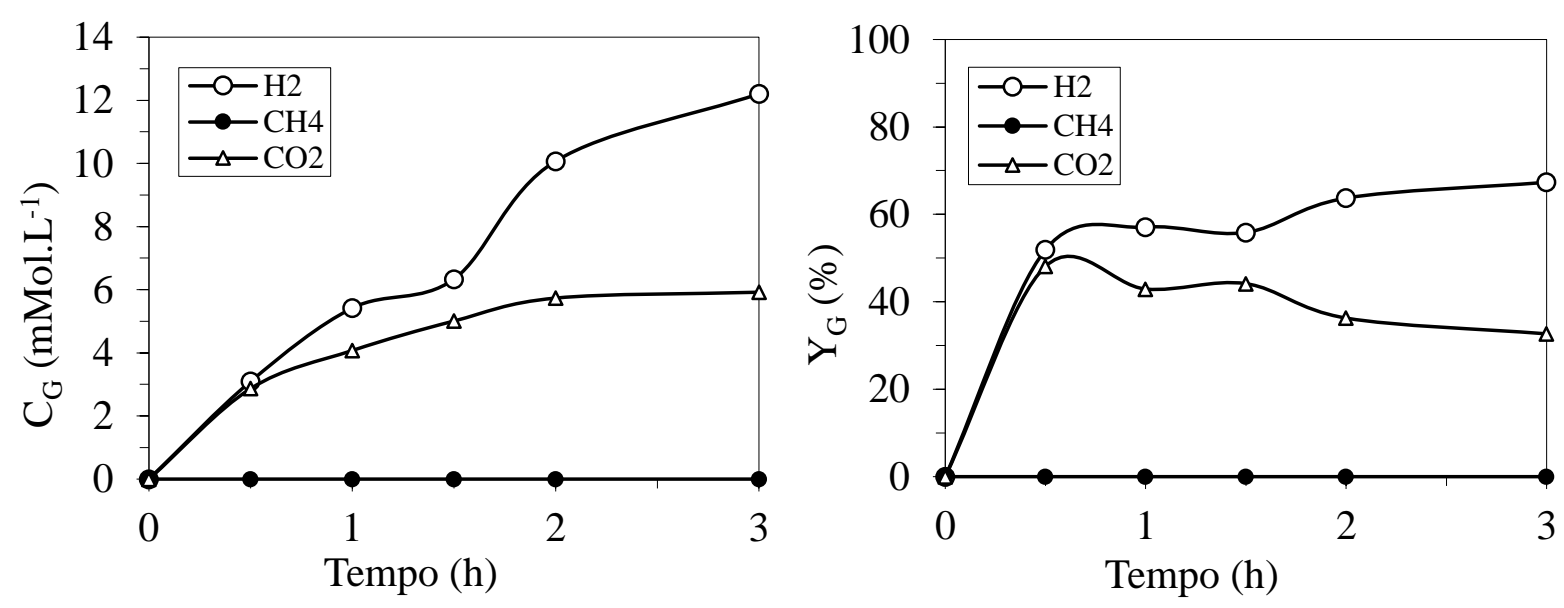

Figura 5.64. Concentração dos compostos do biogás durante o ciclo e suas respectivas porcentagens no Ensaio 7: ० $-\mathrm{H}_{2} ; \bullet-\mathrm{CH}_{4} ; \Delta-\mathrm{CO}_{2}$.

\subsubsection{Ensaio 8 (50\% Soro e 50\% Glicerina - 5000 mgDQO.L $\left.{ }^{-1}-3 \mathrm{~h}-\mathrm{BA}\right)$}

O Ensaio 8 foi feito com uma proporção de 1:1 de soro e glicerina (base DQO). A Tabela 5.12 apresenta a média dos parâmetros monitorados. 
Tabela 5.12. Parâmetros médios monitorados no Ensaio 8.

\begin{tabular}{|c|c|c|c|c|c|c|c|c|c|c|c|}
\hline \multicolumn{2}{|r|}{ Parâmetro } & \multicolumn{5}{|c|}{ Afluente } & \multicolumn{5}{|c|}{ Efluente } \\
\hline $\mathrm{C}_{\text {МOT }}$ & $\left(\mathrm{mgDQO} \cdot \mathrm{L}^{-1}\right)$ & 5119 & \pm 176 & & 12 & & 4064 & \pm 2 & 267 & $(1$ & $\begin{array}{ll}12) \\
\end{array}$ \\
\hline $\mathrm{C}_{\mathrm{MOF}}$ & (mgDQO.L-1) & & & & & & 3880 & \pm 2 & 231 & $(1$ & 12 \\
\hline$\varepsilon_{\mathrm{MOT}}$ & $(\%)$ & & & & & & 21 & \pm & 5 & $(1$ & $12)$ \\
\hline$\varepsilon_{\mathrm{MOF}}$ & $(\%)$ & & & & & & 24 & \pm & 4 & $(1$ & $12)$ \\
\hline $\mathrm{C}_{\mathrm{CT}}$ & (mgCarboidratos. $\mathrm{L}^{-1}$ ) & 2435 & $\pm \quad 77$ & ( & 12 & ) & 38 & \pm & 10 & $(1$ & 12 \\
\hline $\mathrm{C}_{\mathrm{CF}}$ & (mgCarboidratos. $\mathrm{L}^{-1}$ ) & & & & & & 26 & \pm & 7 & $(1$ & $12)$ \\
\hline$\varepsilon_{\mathrm{CT}}$ & $(\%)$ & & 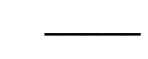 & & & & 98,4 & \pm 0 & 0,4 & $(1$ & $12)$ \\
\hline$\varepsilon_{\mathrm{CF}}$ & $(\%)$ & & & & & & 98,9 & \pm 0 & 0,3 & $(1$ & $12)$ \\
\hline $\mathrm{C}_{\mathrm{GT}}$ & (mgGlicerina. $\mathrm{L}^{-1}$ ) & 2061 & \pm 123 & ( & 12 & ) & 353 & \pm 3 & 316 & $(1$ & $12)$ \\
\hline $\mathrm{C}_{\mathrm{GF}}$ & (mgGlicerina. $\mathrm{L}^{-1}$ ) & & & & & & 314 & \pm 2 & 288 & $(1$ & $12)$ \\
\hline$\varepsilon_{\mathrm{GT}}$ & $(\%)$ & & & & & & 83 & \pm & 16 & $(1$ & $12)$ \\
\hline$\varepsilon_{\mathrm{GF}}$ & $(\%)$ & & - & & & & 85 & \pm & & $(1$ & $12)$ \\
\hline $\mathrm{pH}$ & (u) & 7,56 & $\pm 0,08$ & ( & 11 & ) & 4,55 & \pm 0 & 0,09 & $(1$ & $12)$ \\
\hline AVT & $\left(\mathrm{mgHAc} . \mathrm{L}^{-1}\right)$ & 98 & \pm 11 & ( & 11 & ) & 952 & \pm 1 & 157 & $(1$ & $12)$ \\
\hline $\mathrm{AT}$ & $\left(\mathrm{mgCaCO}_{3} \cdot \mathrm{L}^{-1}\right)$ & 245 & \pm 17 & ( & 11 & ) & 89 & \pm & 25 & $(1$ & $12)$ \\
\hline $\mathrm{AP}$ & $\left(\mathrm{mgCaCO}_{3} \cdot \mathrm{L}^{-1}\right)$ & 171 & $\pm \quad 14$ & ( & 11 & ) & 0 & \pm & 0 & $(1$ & $12)$ \\
\hline AI & $\left(\mathrm{mgCaCO}_{3} \cdot \mathrm{L}^{-1}\right)$ & 74 & \pm & ( & 11 & ) & 89 & \pm & 25 & $(1$ & $12)$ \\
\hline $\mathrm{AB}$ & $\left(\mathrm{mgCaCO}_{3} \cdot \mathrm{L}^{-1}\right)$ & 176 & $\pm \quad 19$ & ( & 11 & ) & 0 & \pm & 0 & $(1$ & $12)$ \\
\hline ST & $\left(\mathrm{mg} . \mathrm{L}^{-1}\right)$ & 2473 & \pm 58 & ( & 5 & ) & 1910 & \pm 3 & 375 & ( & $5 \quad)$ \\
\hline SVT & $\left(\mathrm{mg} \cdot \mathrm{L}^{-1}\right)$ & 1880 & \pm 59 & ( & 5 & ) & 1360 & \pm 3 & 353 & ( & 5 \\
\hline SST & $\left(\mathrm{mg} \cdot \mathrm{L}^{-1}\right)$ & 41 & \pm 15 & ( & 5 & ) & 90 & \pm & 37 & ( & $5)$ \\
\hline SSV & $\left(\mathrm{mg} \cdot \mathrm{L}^{-1}\right)$ & 37 & \pm 10 & ( & 5 & ) & 87 & \pm & 37 & ( & $5 \quad)$ \\
\hline $\mathrm{M}_{\mathrm{SVT}}$ & (g) & & 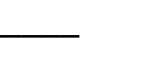 & & & & & 19,1 & & & \\
\hline $\mathrm{Cx}$ & $\left(\mathrm{g} . \mathrm{L}^{-1}\right)$ & & 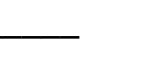 & & & & & 4,1 & & & \\
\hline $\mathrm{Cx}^{\prime}$ & (g.gsuporte $\left.{ }^{-1}\right)$ & & 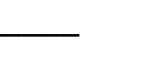 & & & & &, 006 & & & \\
\hline $\mathrm{V}_{\mathrm{G}}$ & $\left(\mathrm{mL} . \mathrm{ciclo}^{-1}\right)$ & & 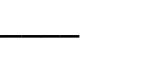 & & & & 1076 & \pm 1 & 193 & $(1$ & $11)$ \\
\hline $\mathrm{V}_{\mathrm{H} 2}$ & $\left(\mathrm{~mL}\right.$. ciclo $\left.^{-1}\right)$ & & 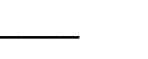 & & & & 513 & \pm 2 & 202 & $(1$ & 11 \\
\hline $\mathrm{COAV}_{\text {мот }}$ & $\left(\mathrm{gDQO} \cdot \mathrm{L}^{-1} \cdot \mathrm{d}^{-1}\right)$ & & 17,7 & & & & & & & & \\
\hline $\mathrm{CORV}_{\mathrm{MOF}}$ & $\left(\right.$ gDQO.L $\left.L^{-1} \cdot d^{-1}\right)$ & & & & & & & 4,3 & & & \\
\hline $\mathrm{COAV}_{\mathrm{CT}}$ & (gCarboidratos. $\mathrm{L}^{-1} \cdot \mathrm{d}^{-1}$ ) & & 3,2 & & & & & & & & \\
\hline $\mathrm{CORV}_{\mathrm{CF}}$ & (gCarboidratos. $\mathrm{L}^{-1} \cdot \mathrm{d}^{-1}$ ) & & & & & & & 3,1 & & & \\
\hline $\mathrm{COAV}_{\mathrm{GT}}$ & (gGlicerina. $L^{-1} \cdot d^{-1}$ ) & & 2,7 & & & & & 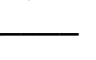 & & & \\
\hline $\mathrm{CORV}_{\mathrm{GF}}$ & (gGlicerina. $\mathrm{L}^{-1} \cdot \mathrm{d}^{-1}$ ) & & & & & & & 2,3 & & & \\
\hline $\mathrm{COAE}_{\mathrm{MOT}}$ & $\left(\right.$ gDQO.gSVT $\left.{ }^{-1} \cdot \mathrm{d}^{-1}\right)$ & & 14,6 & & & & & & & & \\
\hline $\mathrm{CORE}_{\mathrm{MOF}}$ & $\left(\right.$ gDQO.gSVT $\left.{ }^{-1} \cdot \mathrm{d}^{-1}\right)$ & & 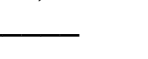 & & & & & 4,3 & & & \\
\hline $\mathrm{COAE}_{\mathrm{CT}}$ & (gCarboidratos.gSVT ${ }^{-1} \cdot \mathrm{d}^{-1}$ ) & & 14,6 & & & & & & & & \\
\hline $\mathrm{CORE}_{\mathrm{CF}}$ & (gCarboidratos.gSVT ${ }^{-1} \cdot \mathrm{d}^{-1}$ ) & & & & & & & 0,8 & & & \\
\hline $\mathrm{COAE}_{\mathrm{GT}}$ & (gGlicerina.gSVT ${ }^{-1} \cdot \mathrm{d}^{-1}$ ) & & 14,6 & & & & & & & & \\
\hline $\mathrm{CORE}_{\mathrm{GF}}$ & (gGlicerina.gSVT ${ }^{-1} \cdot \mathrm{d}^{-1}$ ) & & & & & & & 0,6 & & & \\
\hline $\mathrm{n}_{\mathrm{H} 2}$ & $\left(\mathrm{molH}_{2} \cdot \mathrm{d}^{-1}\right)$ & & & & & & & 0,2 & & & \\
\hline PrM & $\left(\mathrm{molH}_{2} \cdot \mathrm{m}^{-3} \cdot \mathrm{d}^{-1}\right)$ & & 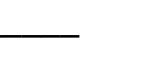 & & & & & 51,9 & & & \\
\hline PrME & $\left(\mathrm{molH}_{2} \cdot \mathrm{kgSVT}^{-1} \cdot \mathrm{d}^{-1}\right)$ & & 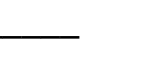 & & & & & 12,6 & & & \\
\hline RMCA & $\left(\mathrm{molH}_{2} \cdot \mathrm{kgDQO}^{-1}\right)$ & & 2,9 & & & & & & & & \\
\hline RMSA & $\left(\mathrm{molH}_{2} \cdot \mathrm{molSubstrato}^{-1}\right)$ & & 0,5 & & & & & 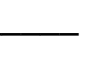 & & & \\
\hline RMSR & $\left(\mathrm{molH}_{2} \cdot \mathrm{molSubstrato}^{-1}\right)$ & & & & & & & 0,6 & & & \\
\hline $\mathrm{V}_{\mathrm{A}}$ & $(\mathrm{L})$ & 1,53 & $\pm 0,05$ & ( & 12 & ) & & & & & \\
\hline$V_{R}$ & (L) & & 3,5 & & & & & - & & & \\
\hline
\end{tabular}

(*) Entre parênteses o número de amostras considerado no cálculo da média 
O valor real da COAV foi de $17,7 \mathrm{gDQO} \cdot \mathrm{L}^{-1} \cdot \mathrm{d}^{-1} \mathrm{e}$ a CORV atingida foi de $4,3 \mathrm{gDQO}$. $\mathrm{L}^{-}$ ${ }^{1} . \mathrm{d}^{-1}$. Com $50 \%$ da DQO total composta por soro, o afluente teve, em média, 2435 mgCarboidratos. $\mathrm{L}^{-1}$ (COAV foi de 3,2 gCarboidratos. $\mathrm{L}^{-1} \cdot \mathrm{d}^{-1}$ e a CORV atingida foi de 3,1 gCarboidratos. $\mathrm{L}^{-1} \cdot \mathrm{d}^{-1}$ ) e $2061 \mathrm{mgGlicerina} . \mathrm{L}^{-1}$ (COAV foi de 2,7 gGlicerina. $\mathrm{L}^{-1} \cdot \mathrm{d}^{-1}$ e a CORV atingida foi de $\left.2,3 \mathrm{gGlicerina} \cdot \mathrm{L}^{-1} \cdot \mathrm{d}^{-1}\right)$.

O monitoramento diário apresentou um baixo consumo de matéria orgânica na forma de DQO, com média de concentração afluente não filtrada de $5119 \mathrm{mgDQO} . \mathrm{L}^{-1}$, efluente não filtrada $4064 \mathrm{mgDQO} . \mathrm{L}^{-1}$ e de efluente filtrada de $3880 \mathrm{mgDQO} . \mathrm{L}^{-1}$, o que representa uma remoção média para amostras não filtradas de $21 \%$ e para amostras filtradas de $24 \%$ (Figura 5.65), o que representam eficiências ligeiramente menores do que as obtidas no Ensaio 7.
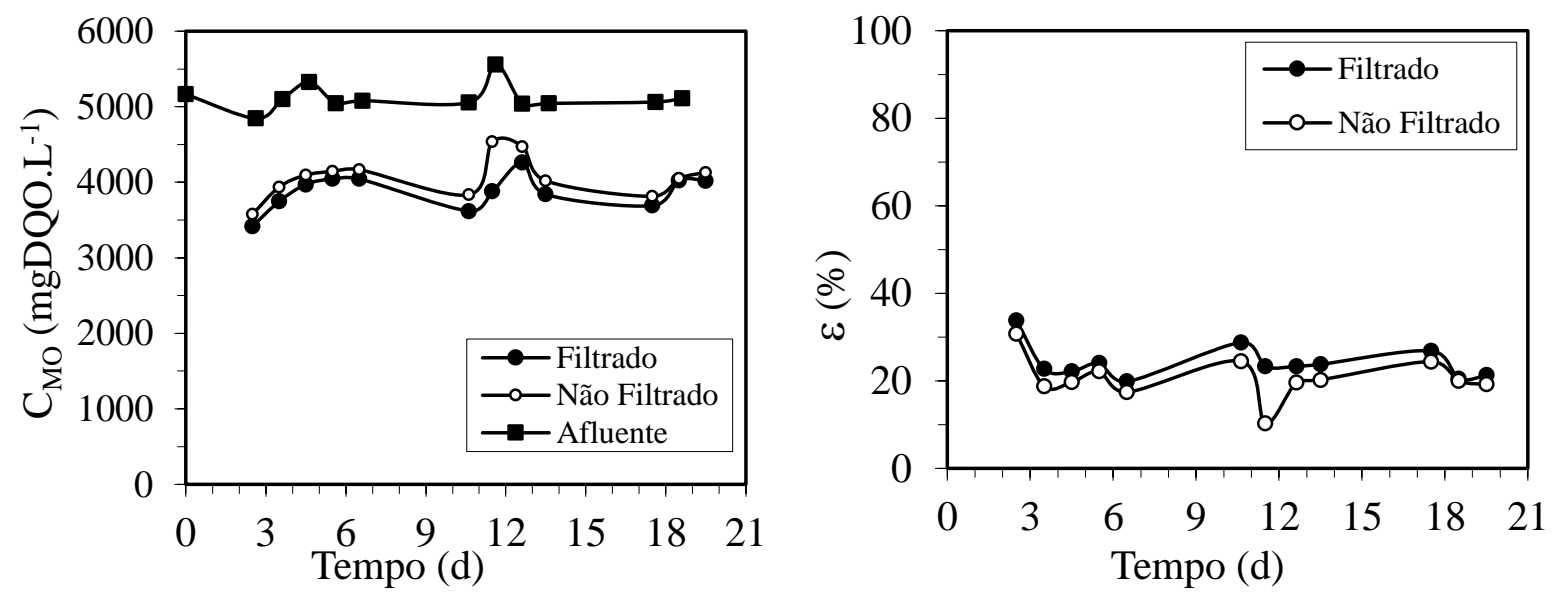

Figura 5.65. Concentração e eficiência de remoção de matéria orgânica na forma de DQO no Ensaio 8: - - afluente amostras não filtradas; • - efluente amostras não filtradas; ○ - efluente amostras filtradas.

O monitoramento diário de carboidratos apresentou um excelente consumo, com média

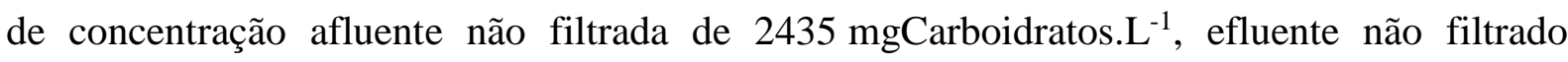
$38 \mathrm{mgCarboidratos} . \mathrm{L}^{-1}$ e de efluente filtrado $26 \mathrm{mgCarboidratos} . \mathrm{L}^{-1}$, o que representa eficiência média de remoção para amostras não filtradas de $98,4 \%$ e para amostras filtradas de 98,9\% (Figura 5.66).

Em relação ao monitoramento diário de glicerina, a concentração afluente não filtrada foi de $2061 \mathrm{mgGlicerina} . \mathrm{L}^{-1}$, efluente não filtrado $353 \mathrm{mgGlicerina} . \mathrm{L}^{-1}$ e de efluente filtrado 314 mgGlicerina. $L^{-1}$, o que representa uma eficiência média de remoção para amostras não filtradas de $83 \%$ e para amostras filtradas de $85 \%$ (Figura 5.67), o que representa um bom consumo desse substrato. 

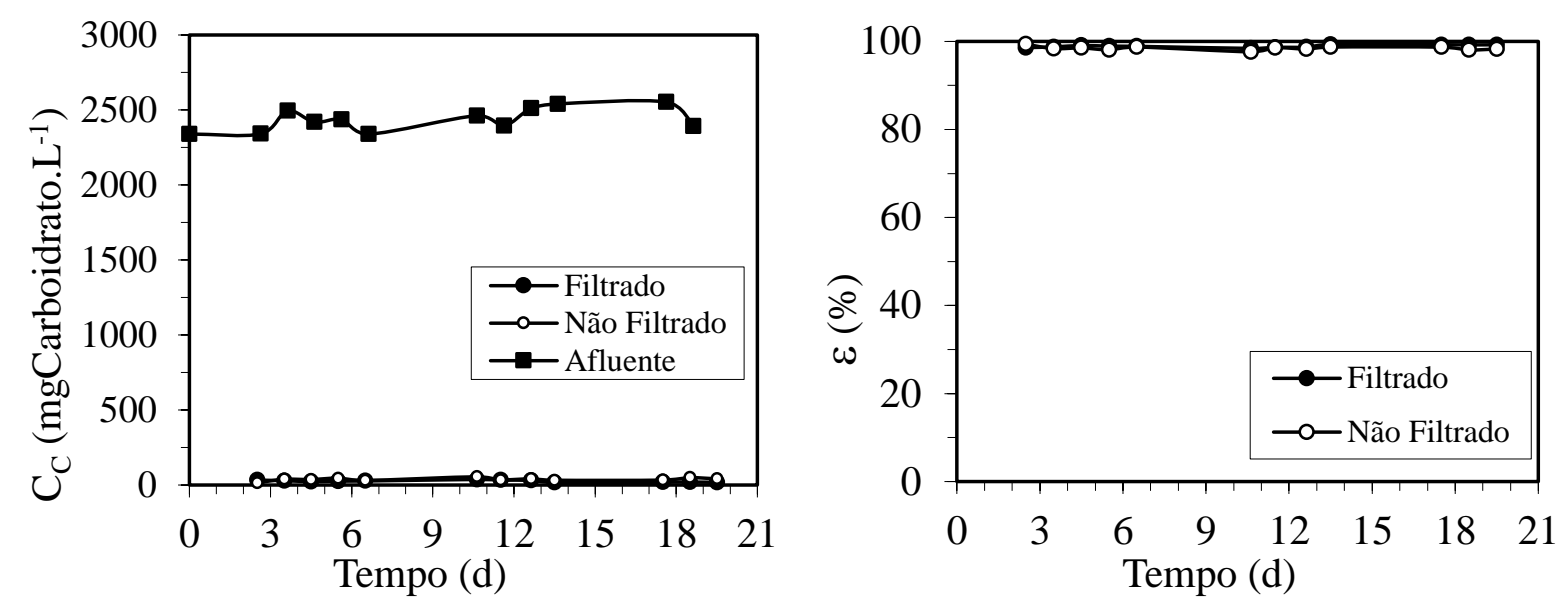

Figura 5.66. Concentração e eficiência de remoção na forma de carboidratos no Ensaio 8: - - afluente amostras não filtradas; • - efluente amostras não filtradas; $\bigcirc$ - efluente amostras filtradas.
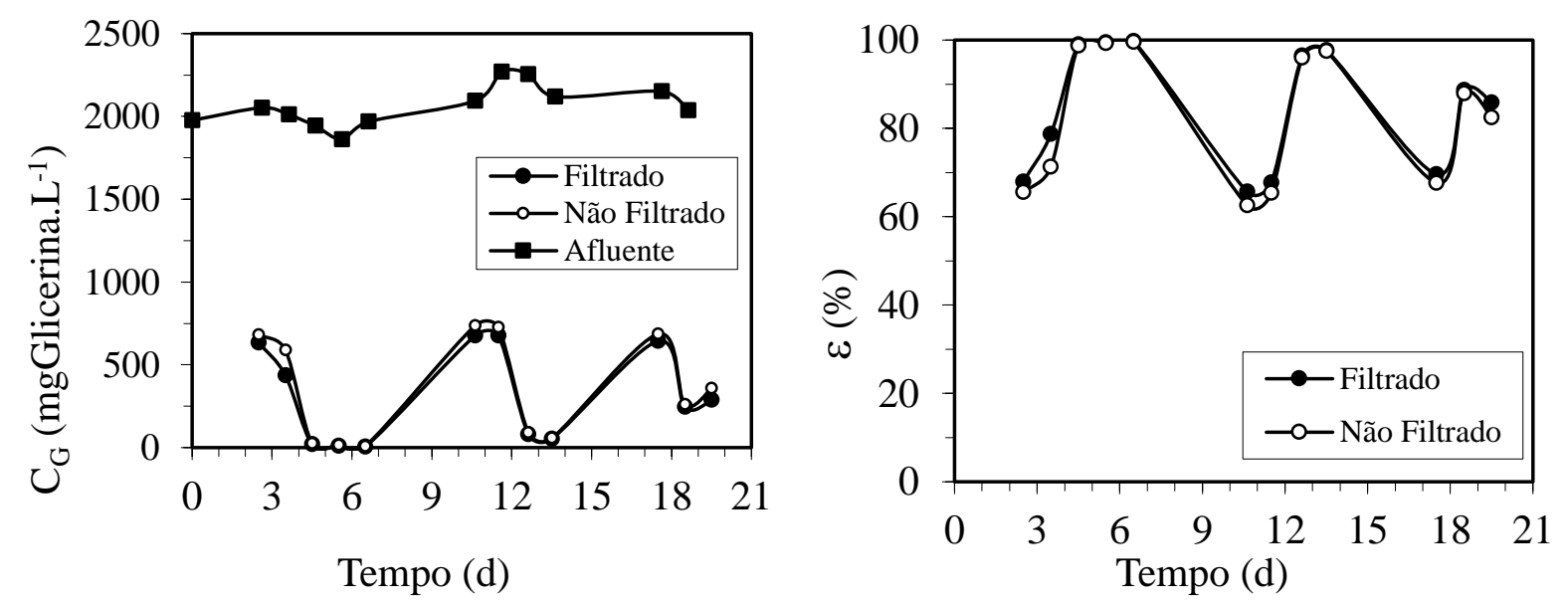

Figura 5.67. Concentração e eficiência de remoção na forma de glicerina no Ensaio 8: - - afluente amostras não filtradas; • - efluente amostras não filtradas; $\bigcirc$ - efluente amostras filtradas.

A média do pH afluente foi de 7,6 e do efluente de 4,6. A alcalinidade total no afluente teve média de $245 \mathrm{mgCaCO} 3 . \mathrm{L}^{-1}$ sendo que a mesma foi consumida até uma média de $89 \mathrm{mgCaCO}_{3} \cdot \mathrm{L}^{-1}$. A média de AVT no afluente foi de $98 \mathrm{mgHAc} . \mathrm{L}^{-1}$ e a média de AVT no efluente de 952 mgHAc. $\mathrm{L}^{-1}$.

A produção de biogás, em aspecto quantitativo, e a distribuição dos gases que compõem o biogás no final do ciclo podem ser observadas pela Figura 5.68, com média de $1076 \mathrm{~mL}$ de biogás e $513 \mathrm{~mL}$ de hidrogênio, sendo que a porcentagem média de hidrogênio foi igual a $47 \%$. A produtividade molar de hidrogênio foi igual a $51,9 \mathrm{molH}_{2} \cdot \mathrm{m}^{-3} \cdot \mathrm{d}^{-1}$, o que representa uma queda em relação ao Ensaio $7\left(91,3 \mathrm{molH}_{2} \cdot \mathrm{m}^{-3} \cdot \mathrm{d}^{-1}\right)$ e ao Ensaio $6\left(52,7 \mathrm{molH} 2 \cdot \mathrm{m}^{-3} \cdot \mathrm{d}^{-1}\right)$. 

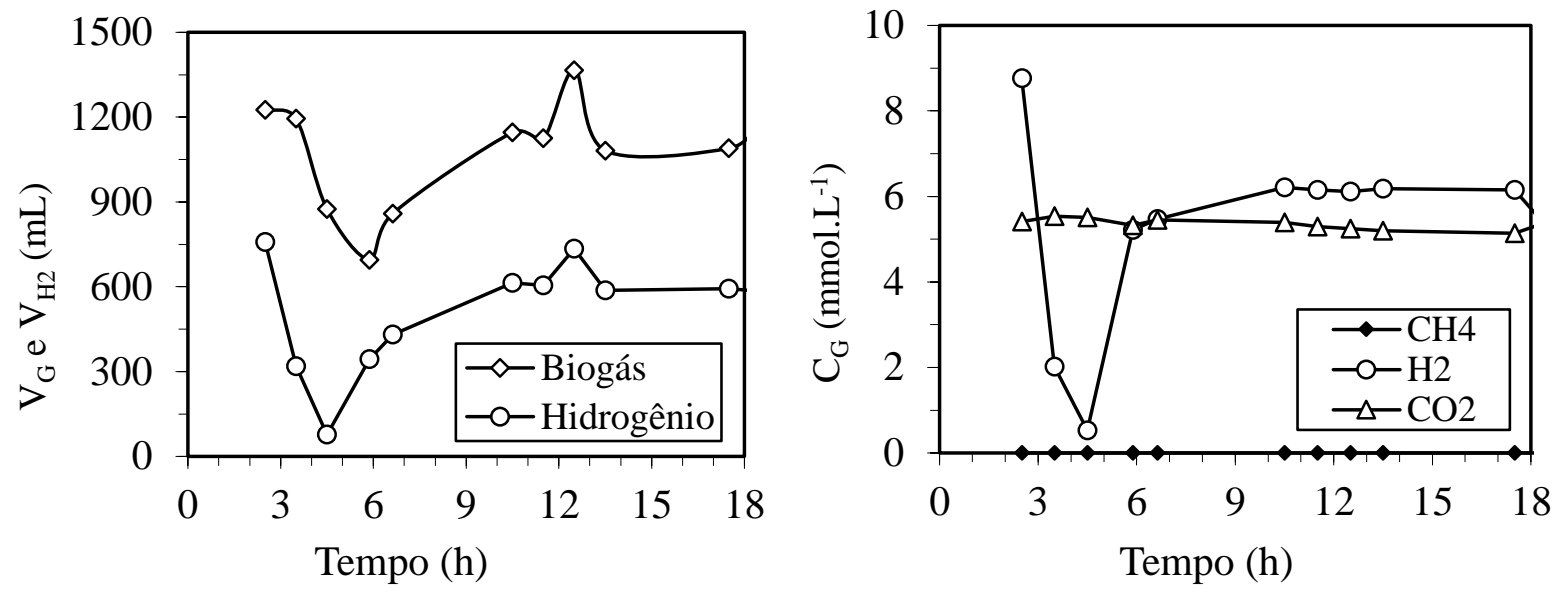

Figura 5.68. Volume de biogás $\left(\mathrm{V}_{\mathrm{G}}\right)$ e de hidrogênio $\left(\mathrm{V}_{\mathrm{H} 2}\right)$ nas $\mathrm{CNTP}$ e concentrações dos componentes do biogás no final do ciclo $\left(\mathrm{C}_{\mathrm{G}}\right)$ no Ensaio 8: $\diamond$ - Biogás; - Metano; $\bigcirc$-Hidrogênio; $\Delta$ - Dióxido de Carbono.

A Figura 5.60 apresenta o perfil de DQO, de Carboidratos e de Glicerina. Nota-se que há uma baixa variação na medida de DQO durante o ciclo, enquanto os perfis de carboidrato e de glicerina mostram grandes variações. Nestes últimos dois, é possível observar um ponto de máxima concentração em $1,5 \mathrm{~h}$ (que representa o final da alimentação do afluente) e o consumo desses dois substratos até o final do ciclo, assim como aconteceu no Ensaio 7.
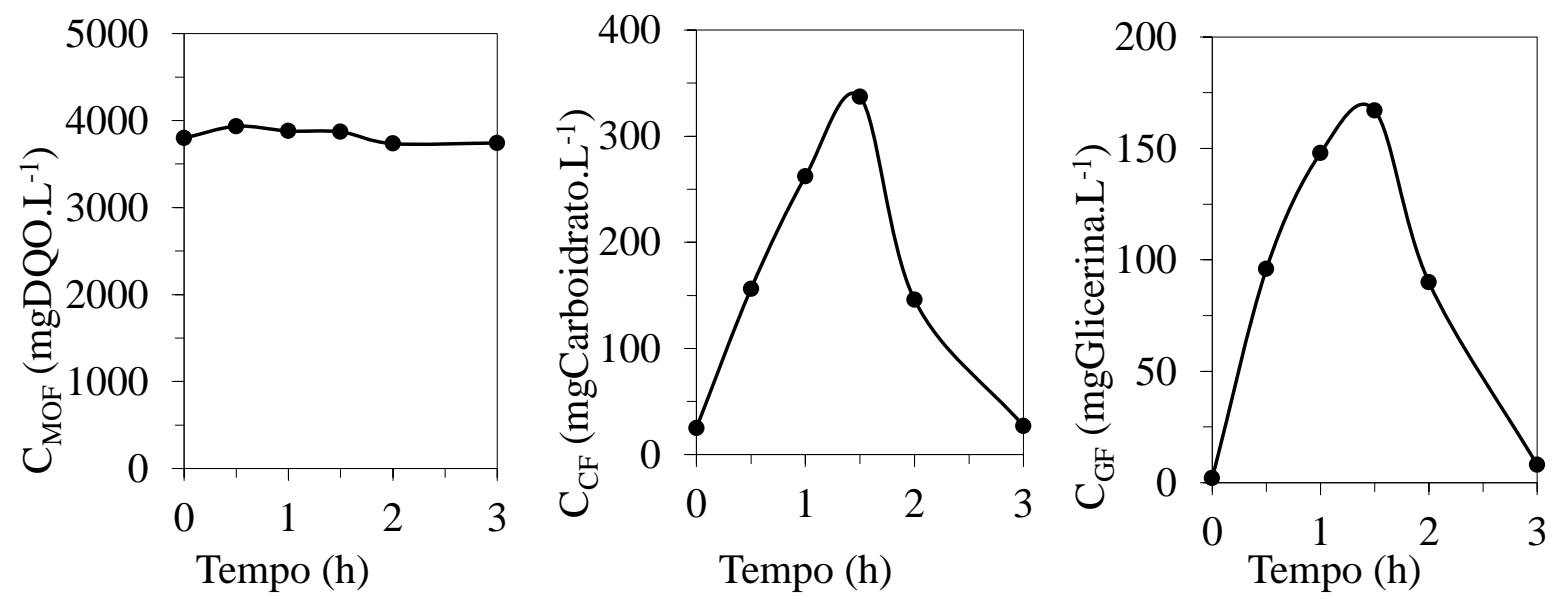

Figura 5.69. Concentração de matéria orgânica, carboidratos e de glicerina durante o ciclo no Ensaio 8.

A Figura 5.70 apresenta os perfis de $\mathrm{pH}$, alcalinidade total e ácidos voláteis totais ao longo do ciclo. $\mathrm{O}$ pH permanece constante ao longo do ciclo por volta de 4,5, bem como os ácidos voláteis totais por volta de $917 \mathrm{mgHAc} . \mathrm{L}^{-1}$. A alcalinidade fornecida pelo afluente é consumida ao longo do ciclo, saindo em $52 \mathrm{mgCaCO} 3 \cdot \mathrm{L}^{-1}$. 

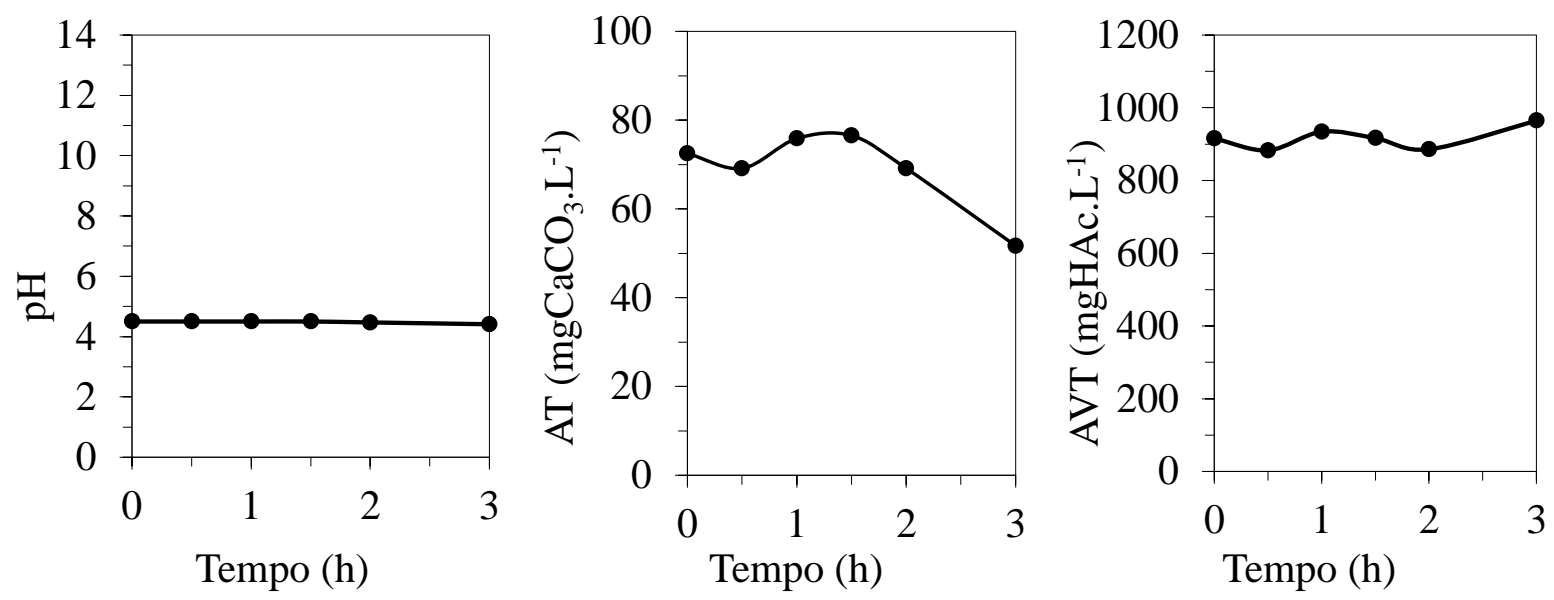

Figura 5.70. Valores de pH, alcalinidade total(AT) e ácidos voláteis totais (AVT) no Ensaio 8.

O perfil dos compostos intermediários do metabolismo é apresentado na Figura 5.71. Neste ensaio, é possível verificar que há a predominância de ácido propiônico e de ácido acético, o que ajuda a explicar a queda de produtividade obtida neste ensaio, pois a produção de ácido propiônico a partir de substratos consome o hidrogênio disponível no ambiente, como é mostrado na Equação 4.52 da modelagem de hidrogênio.

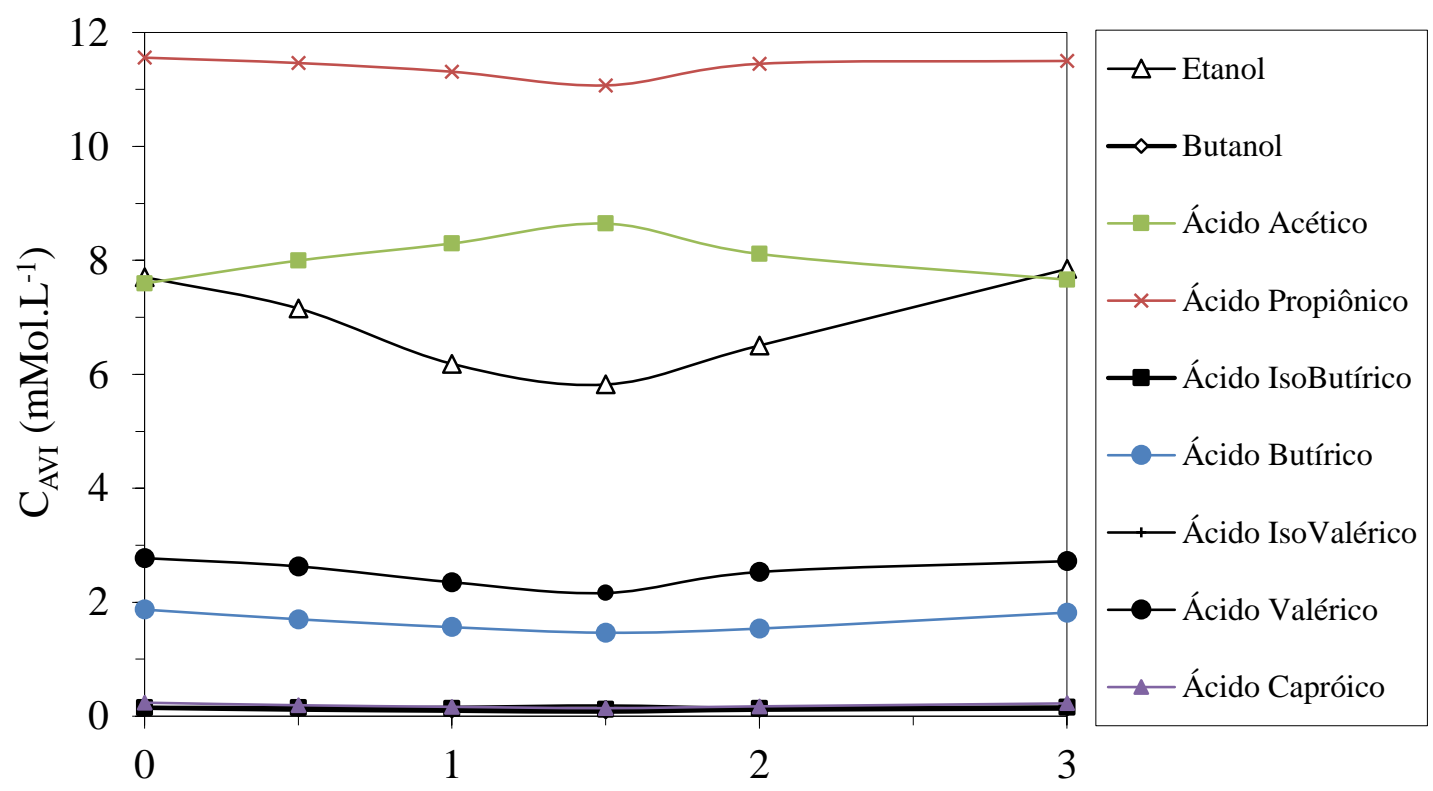

Tempo (h)

Figura 5.71. Concentração dos compostos intermediários ao longo do ciclo no Ensaio 8: $\Delta$ - etanol; $\diamond$ butanol; $\square$ - ácido acético; -X- ácido propiônico; - ácido isobutírico; • - ácido butírico; + ácido isovalérico $\bullet$ - ácido valérico; $\boldsymbol{\Delta}$ - ácido capróico.

A produção volumétrica acumulada de biogás e os desvios padrões de cada um dos pontos podem ser observados na Figura 5.72 e o perfil das concentrações de cada um dos gases e suas respectivas porcentagens podem ser observados na Figura 5.73. Houve baixa 
variação no volume de gás recolhido diariamente, atingindo a estabilidade ao longo do tempo; ao final do perfil, tinha-se $46 \%$ de $\mathrm{H}_{2}$ e $54 \%$ de $\mathrm{CO}_{2}$.

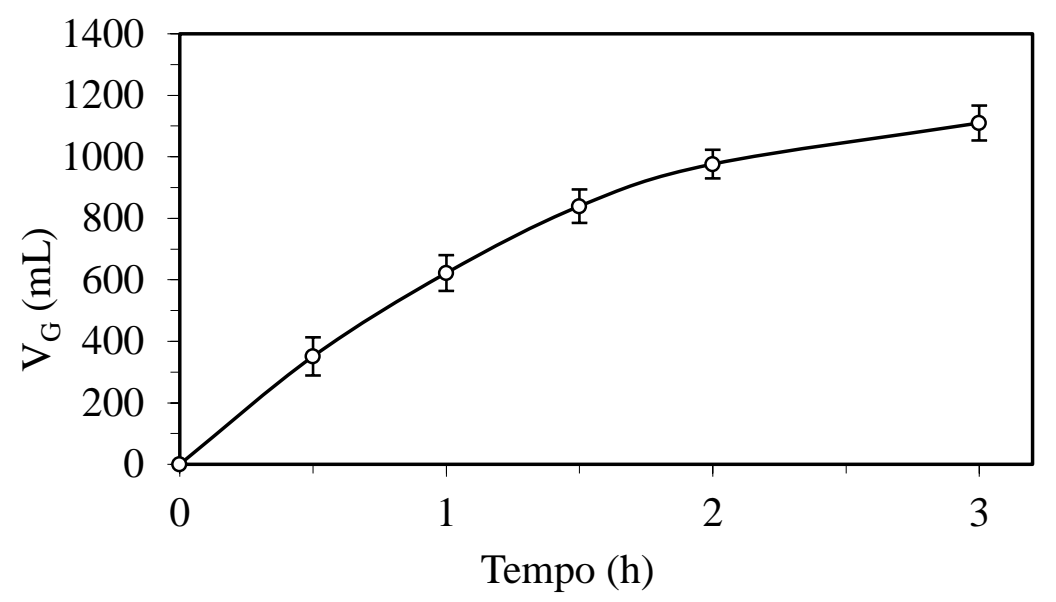

Figura 5.72. Produção volumétrica média acumulada do biogás durante o ciclo no Ensaio 8.
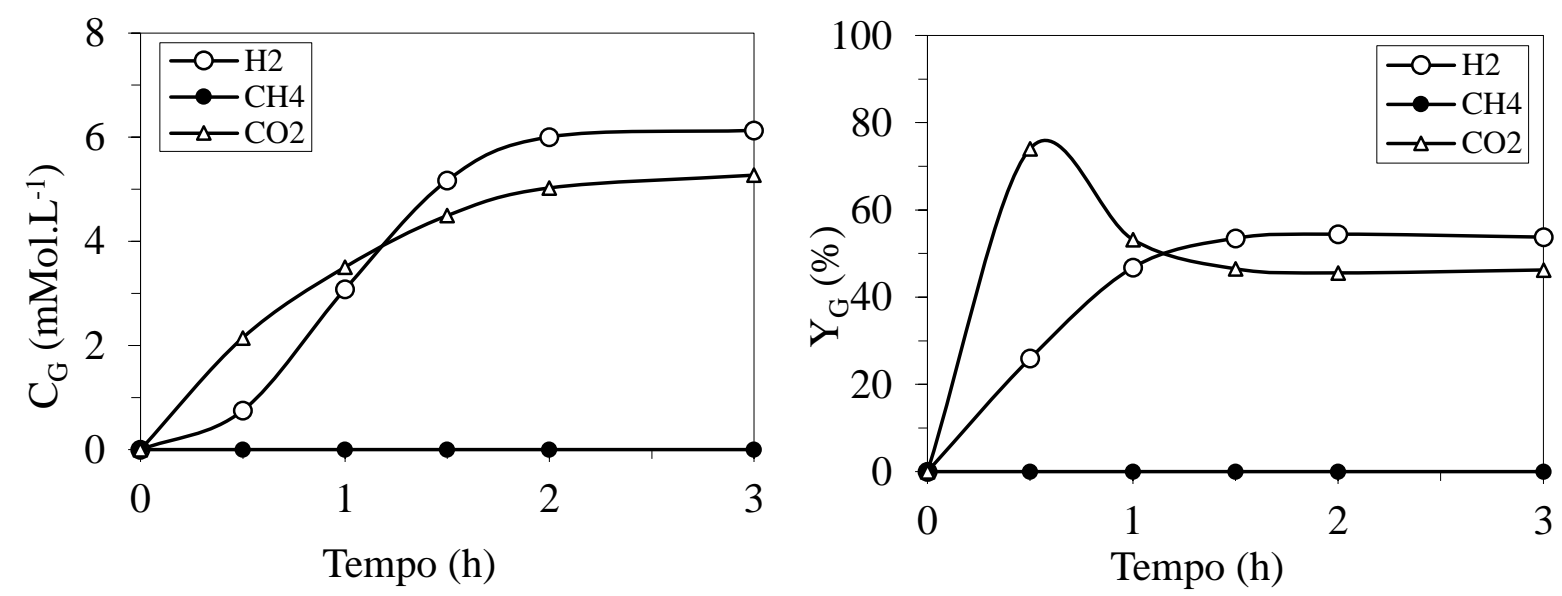

Figura 5.73. Concentração dos compostos do biogás durante o ciclo e suas respectivas porcentagens no Ensaio 8: $\circ-\mathrm{H}_{2} ; \bullet-\mathrm{CH}_{4} ; \Delta-\mathrm{CO}_{2}$.

\subsubsection{Ensaio 9 (25\% Soro e $75 \%$ Glicerina $\left.-5000 \mathrm{mgDQO} . \mathrm{L}^{-1}-3 \mathrm{~h}-\mathrm{BA}\right)$}

O Ensaio 9 representa a última condição que avalia a codigestão entre soro e glicerina com foco na produção de biohidrogênio.

O valor real da COAV foi de $17,1 \mathrm{gDQO} \cdot \mathrm{L}^{-1} \cdot \mathrm{d}^{-1}$ e a CORV atingida foi de 43,2 gDQO. $\mathrm{L}^{-1} \cdot \mathrm{d}^{-1}$. Com apenas $25 \%$ da DQO total composta por soro, o afluente teve, em

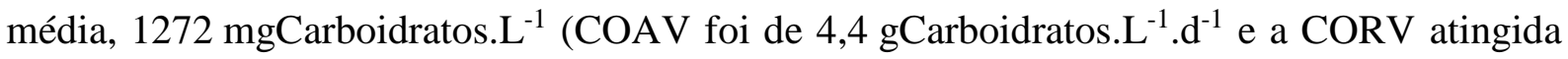
foi de 4,3 gCarboidratos. $\mathrm{L}^{-1} \cdot \mathrm{d}^{-1}$ ) e $3015 \mathrm{mgGlicerina} . \mathrm{L}^{-1}$ (COAV foi de 2,0 gGlicerina. $\mathrm{L}^{-1} \cdot \mathrm{d}^{-1} \mathrm{e}$ a CORV atingida foi de $\left.1,7 \mathrm{gGlicerina} \cdot \mathrm{L}^{-1} \cdot \mathrm{d}^{-1}\right)$.

A Tabela 5.13 apresenta a média dos parâmetros monitorados. 
Tabela 5.13. Parâmetros médios monitorados no Ensaio 9.

\begin{tabular}{|c|c|c|c|c|c|c|c|c|c|c|c|c|c|}
\hline \multicolumn{2}{|r|}{ Parâmetro } & \multicolumn{6}{|c|}{ Afluente } & \multicolumn{6}{|c|}{ Efluente } \\
\hline $\mathrm{C}_{\mathrm{MOT}}$ & $\left(\mathrm{mgDQO} \cdot \mathrm{L}^{-1}\right)$ & 4917 & \pm & 162 & & 11 & ) & 4152 & \pm & 129 & $(1$ & 11 & ) \\
\hline $\mathrm{C}_{\mathrm{MOF}}$ & $\left(\mathrm{mgDQO} \cdot \mathrm{L}^{-1}\right)$ & & & & & & & 3985 & \pm & 123 & $(1$ & 11 & ) \\
\hline$\varepsilon_{\text {MOT }}$ & $(\%)$ & & & & & & & 16 & \pm & 3 & $(1$ & 11 & ) \\
\hline$\varepsilon_{\mathrm{MOF}}$ & $(\%)$ & & & & & & & 19 & \pm & 4 & & $11)$ & ) \\
\hline $\mathrm{C}_{\mathrm{CT}}$ & $\left(\right.$ mgCarboidratos. $\left.\mathrm{L}^{-1}\right)$ & 1272 & \pm & 221 & ( & 11 & ) & 61 & \pm & 65 & $(1$ & 11 & ) \\
\hline $\mathrm{C}_{\mathrm{CF}}$ & $\left(\right.$ mgCarboidratos. $\left.\mathrm{L}^{-1}\right)$ & & & & & & & 45 & \pm & 54 & $(1$ & 11 & ) \\
\hline$\varepsilon_{\mathrm{CT}}$ & $(\%)$ & & & & & & & 95 & \pm & 5 & & 11 & ) \\
\hline$\varepsilon_{\mathrm{CF}}$ & $(\%)$ & & & & & & & 97 & \pm & 4 & ( 1 & 11 & ) \\
\hline $\mathrm{C}_{\mathrm{GT}}$ & (mgGlicerina. $\left.\mathrm{L}^{-1}\right)$ & 3015 & \pm & 111 & ( & 11 & ) & 389 & \pm & 238 & $(1$ & 11 & ) \\
\hline $\mathrm{C}_{\mathrm{GF}}$ & (mgGlicerina. $\mathrm{L}^{-1}$ ) & & & & & & & 394 & \pm & 232 & & 11 & ) \\
\hline$\varepsilon_{\mathrm{GT}}$ & $(\%)$ & & - & & & & & 87 & \pm & 8 & & 11 & ) \\
\hline$\varepsilon_{\mathrm{GF}}$ & $(\%)$ & & 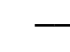 & - & & & & 87 & \pm & 8 & & 11 & ) \\
\hline $\mathrm{pH}$ & (u) & 7,7 & \pm & 0,1 & ( & 10 & ) & 4,5 & \pm & 0,2 & & 11 & ) \\
\hline AVT & $\left(\right.$ mgHAc. $\left.L^{-1}\right)$ & 75 & \pm & 8 & ( & 10 & ) & 1025 & \pm & 363 & ( 1 & 11 & ) \\
\hline AT & $\left(\mathrm{mgCaCO}_{3} \cdot \mathrm{L}^{-1}\right)$ & 224 & \pm & 19 & ( & 10 & ) & 69 & \pm & 40 & & 11 & ) \\
\hline $\mathrm{AP}$ & $\left(\mathrm{mgCaCO}_{3} \cdot \mathrm{L}^{-1}\right)$ & 165 & \pm & 14 & ( & 10 & ) & 0 & \pm & 0 & & 11 & ) \\
\hline AI & $\left(\mathrm{mgCaCO}_{3} \cdot \mathrm{L}^{-1}\right)$ & 59 & \pm & 8 & ( & 10 & ) & 69 & \pm & 40 & $(1$ & 11 & ) \\
\hline $\mathrm{AB}$ & $\left(\mathrm{mgCaCO}_{3} \cdot \mathrm{L}^{-1}\right)$ & 171 & \pm & 19 & ( & 10 & ) & 0 & \pm & 0 & & 11 & ) \\
\hline ST & $\left(\mathrm{mg} \cdot \mathrm{L}^{-1}\right)$ & 2114 & \pm & 271 & ( & 5 & ) & 1660 & \pm & 232 & & 5 & ) \\
\hline SVT & $\left(\mathrm{mg} \cdot \mathrm{L}^{-1}\right)$ & 1477 & \pm & 197 & ( & 5 & ) & 1054 & \pm & 228 & & 5 & ) \\
\hline SST & $\left(\mathrm{mg} \cdot \mathrm{L}^{-1}\right)$ & 24 & \pm & 15 & ( & 5 & ) & 77 & \pm & 30 & & 5 & ) \\
\hline SSV & $\left(\mathrm{mg} \cdot \mathrm{L}^{-1}\right)$ & 18 & \pm & 17 & ( & 5 & ) & 66 & \pm & 19 & & 5 & ) \\
\hline $\mathrm{M}_{\mathrm{SVT}}$ & (g) & & - & & & & & & 5,3 & & & & \\
\hline $\mathrm{Cx}$ & $\left(\mathrm{g} . \mathrm{L}^{-1}\right)$ & & - & & & & & & 1,4 & & & & \\
\hline $\mathrm{Cx}^{\prime}$ & (g.gsuporte ${ }^{-1}$ ) & & - & & & & & &, 003 & & & & \\
\hline $\mathrm{V}_{\mathrm{G}}$ & $\left(\mathrm{mL} . \mathrm{ciclo}^{-1}\right)$ & & - & & & & & 1052 & \pm & 190 & $(1$ & 13 & ) \\
\hline $\mathrm{V}_{\mathrm{H} 2}$ & $\left(\mathrm{~mL} \cdot \mathrm{ciclo}^{-1}\right)$ & & 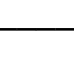 & & & & & 559 & \pm & 162 & & 13 & ) \\
\hline $\mathrm{COAV}_{\text {MOT }}$ & $\left(\mathrm{gDQO} \cdot \mathrm{L}^{-1} \cdot \mathrm{d}^{-1}\right)$ & & 17,1 & & & & & & - & & & & \\
\hline $\mathrm{CORV}_{\mathrm{MOF}}$ & $\left(\mathrm{gDQO} \cdot \mathrm{L}^{-1} \cdot \mathrm{d}^{-1}\right)$ & & & & & & & & 3,2 & & & & \\
\hline $\mathrm{COAV}_{\mathrm{CT}}$ & (gCarboidratos. $\left.\mathrm{L}^{-1} \cdot \mathrm{d}^{-1}\right)$ & & 4,4 & & & & & & . & & & & \\
\hline $\mathrm{CORV}_{\mathrm{CF}}$ & (gCarboidratos. $\mathrm{L}^{-1} \cdot \mathrm{d}^{-1}$ ) & & & & & & & & 4,3 & & & & \\
\hline $\mathrm{COAV}_{\mathrm{GT}}$ & (gGlicerina. $\mathrm{L}^{-1} \cdot \mathrm{d}^{-1}$ ) & & 2,0 & & & & & & & & & & \\
\hline $\mathrm{CORV}_{\mathrm{GF}}$ & (gGlicerina. $L^{-1} \cdot \mathrm{d}^{-1}$ ) & & 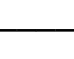 & & & & & & 1,7 & & & & \\
\hline COAE $_{\text {MOT }}$ & $\left(\right.$ gDQO.gSVT $\left.{ }^{-1} \cdot d^{-1}\right)$ & & 4,9 & & & & & & 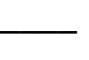 & & & & \\
\hline $\mathrm{CORE}_{\mathrm{MOF}}$ & $\left(\right.$ gDQO.gSVT $\left.{ }^{-1} \cdot d^{-1}\right)$ & & 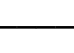 & & & & & & 12,3 & & & & \\
\hline $\mathrm{COAE}_{\mathrm{CT}}$ & $\left(\right.$ gCarboidratos.gSVT $\left.^{-1} \cdot \mathrm{d}^{-1}\right)$ & & 4,9 & & & & & & & & & & \\
\hline $\mathrm{CORE}_{\mathrm{CF}}$ & $\left(\right.$ gCarboidratos.gSVT $\left.{ }^{-1} \cdot \mathrm{d}^{-1}\right)$ & & 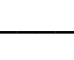 & & & & & & 3,2 & & & & \\
\hline $\mathrm{COAE}_{\mathrm{GT}}$ & (gGlicerina.gSVT ${ }^{-1} \cdot \mathrm{d}^{-1}$ ) & & 4,9 & & & & & & & & & & \\
\hline $\mathrm{CORE}_{\mathrm{GF}}$ & (gGlicerina.gSVT ${ }^{-1} \cdot \mathrm{d}^{-1}$ ) & & & & & & & & 1,4 & & & & \\
\hline $\mathrm{n}_{\mathrm{H} 2}$ & $\left(\mathrm{molH}_{2} \cdot \mathrm{d}^{-1}\right)$ & & 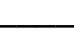 & & & & & & 0,2 & & & & \\
\hline PrM & $\left(\mathrm{molH}_{2} \cdot \mathrm{m}^{-3} \cdot \mathrm{d}^{-1}\right)$ & & 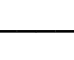 & & & & & & 56,3 & & & & \\
\hline PrME & $\left(\mathrm{molH}_{2} \cdot \mathrm{kgSVT}^{-1} \cdot \mathrm{d}^{-1}\right)$ & & 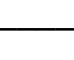 & & & & & & 40,4 & & & & \\
\hline RMCA & $\left(\mathrm{molH}_{2} \cdot \mathrm{kgDQO}^{-1}\right)$ & & 3,3 & & & & & & & & & & \\
\hline RMSA & $\left(\mathrm{molH}_{2} \cdot \mathrm{molSubstrato}^{-1}\right)$ & & 0,5 & & & & & & - & & & & \\
\hline RMSR & $\left(\mathrm{molH}_{2} \cdot \mathrm{molSubstrato}^{-1}\right)$ & & 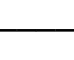 & & & & & & 0,5 & & & & \\
\hline $\mathrm{V}_{\mathrm{A}}$ & $(\mathrm{L})$ & 1,54 & \pm & 0,02 & ( & 10 & ) & & & & & & \\
\hline $\mathrm{V}_{\mathrm{R}}$ & $(\mathrm{L})$ & & 3,5 & & & & & & & & & & \\
\hline
\end{tabular}

(*) Entre parênteses o número de amostras considerado no cálculo da média 
O monitoramento diário apresentou, novamente, um baixo consumo de matéria orgânica na forma de DQO, com média de concentração afluente não filtrada de 4917 mgDQO.L ${ }^{-1}$, efluente não filtrada $4152 \mathrm{mgDQO} . \mathrm{L}^{-1}$ e de efluente filtrada de $3985 \mathrm{mgDQO} . \mathrm{L}^{-1}$, o que representa uma remoção média para amostras não filtradas de $16 \%$ e para amostras filtradas de $19 \%$ (Figura 5.74).
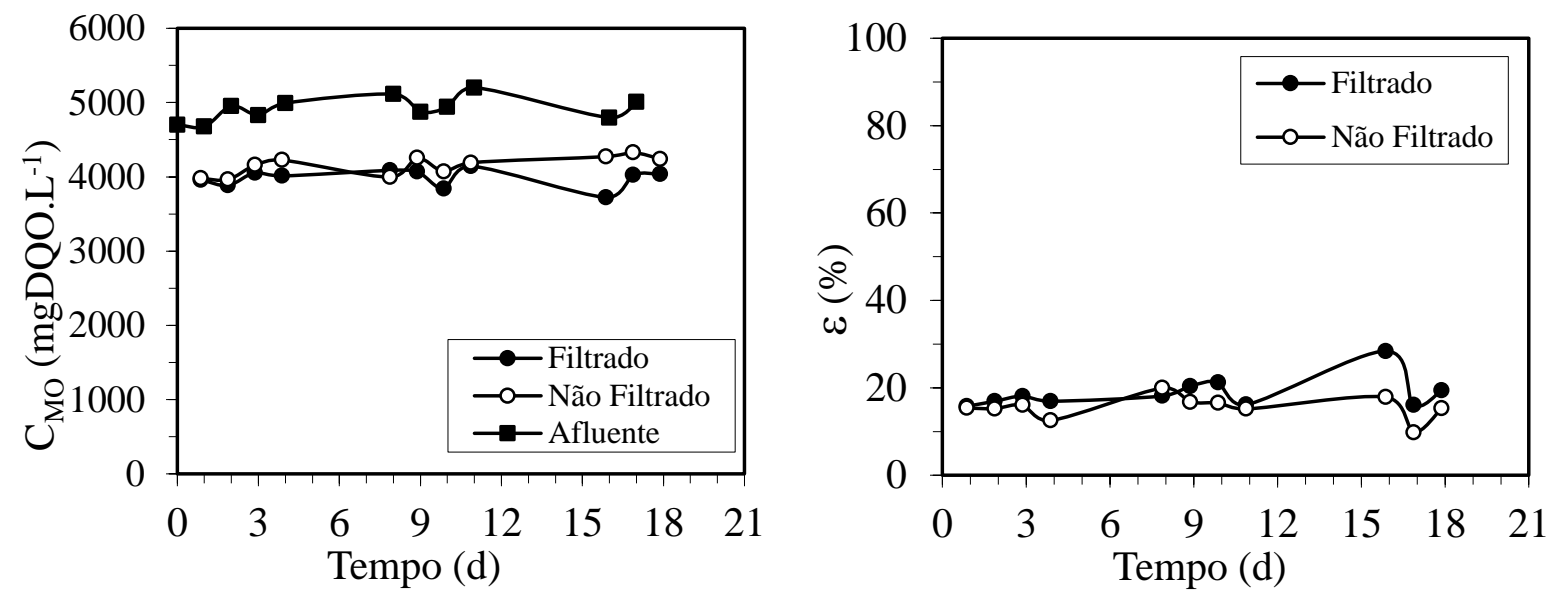

Figura 5.74. Concentração e eficiência de remoção de matéria orgânica na forma de DQO no Ensaio 9: - - afluente amostras não filtradas; - - efluente amostras não filtradas; o - efluente amostras filtradas.

O monitoramento diário de carboidratos apresentou um ótimo consumo, com média de concentração afluente não filtrada de $1272 \mathrm{mgCarboidratos} . \mathrm{L}^{-1}$, efluente não filtrado $61 \mathrm{mgCarboidratos} . \mathrm{L}^{-1}$ e de efluente filtrado $45 \mathrm{mgCarboidratos} . \mathrm{L}^{-1}$, o que representa eficiência média de remoção para amostras não filtradas de $95 \%$ e para amostras filtradas de 97\% (Figura 5.75).
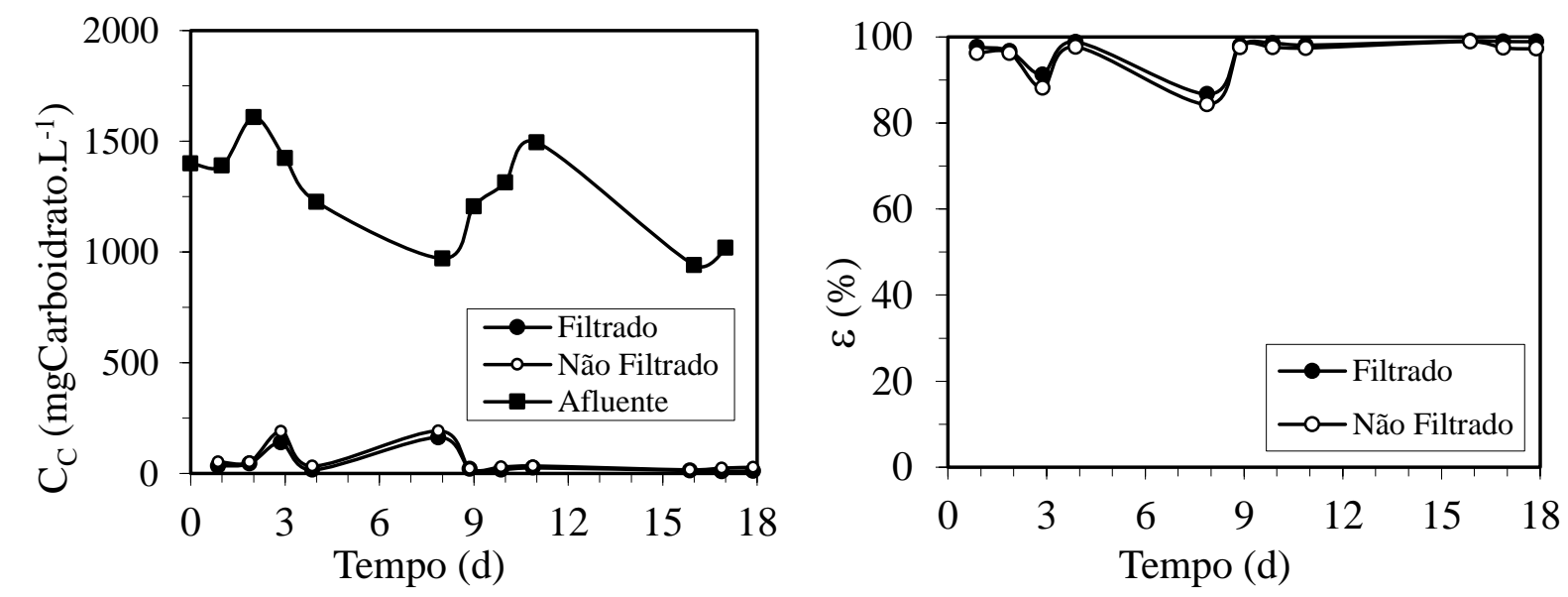

Figura 5.75. Concentração e eficiência de remoção na forma de carboidratos no Ensaio 9: - - afluente amostras não filtradas; • - efluente amostras não filtradas; ○ - efluente amostras filtradas. 
Em relação ao monitoramento diário de glicerina, a concentração afluente não filtrada foi de $3015 \mathrm{mgGlicerina} . \mathrm{L}^{-1}$, efluente não filtrado $389 \mathrm{mgGlicerina} . \mathrm{L}^{-1}$ e de efluente filtrado 394 mgGlicerina. $L^{-1}$, o que representa uma eficiência média de remoção para amostras não filtradas de $87 \%$ e para amostras filtradas de $87 \%$ (Figura 5.76), o que representa também um ótimo consumo desse substrato.
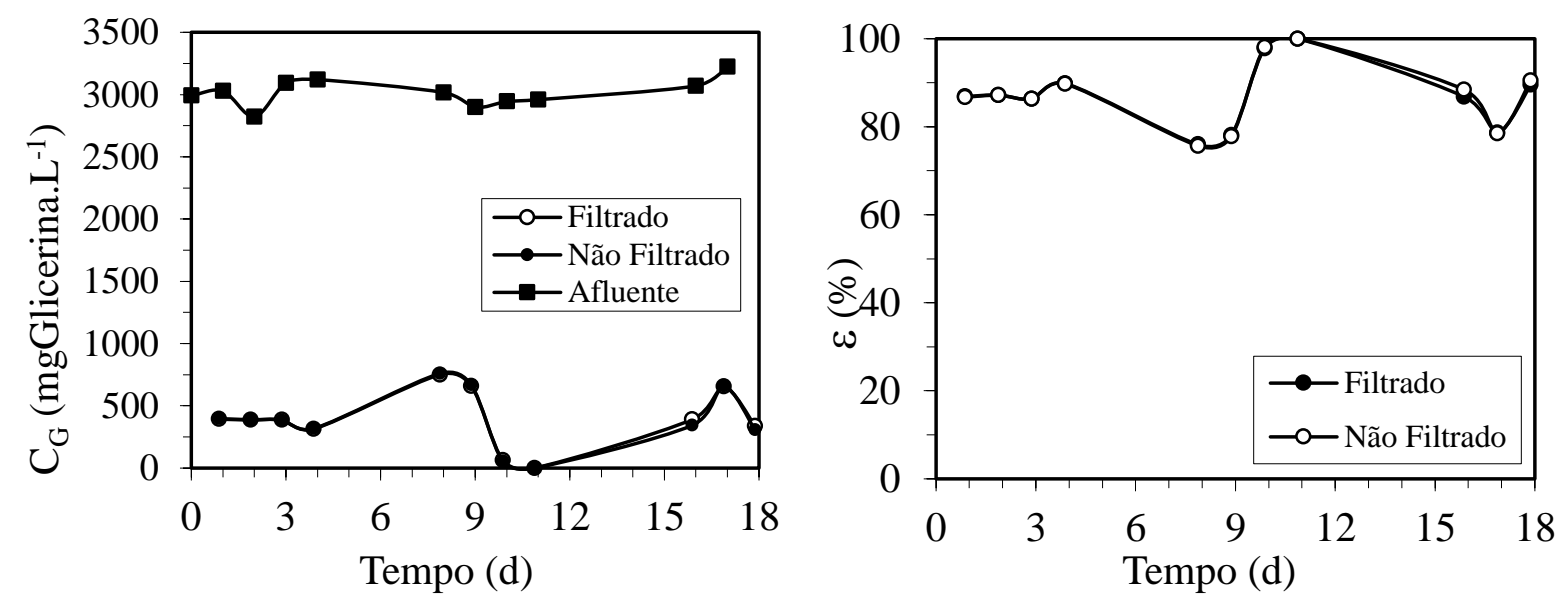

Figura 5.76. Concentração e eficiência de remoção na forma de glicerina no Ensaio 9: - - afluente amostras não filtradas; • - efluente amostras não filtradas; $\bigcirc$ - efluente amostras filtradas.

A média do pH afluente foi de 7,7 e do efluente de 4,5. A alcalinidade total no afluente teve média de $224 \mathrm{mgCaCO} 3 \cdot \mathrm{L}^{-1}$ sendo consumida até uma média de $69 \mathrm{mgCaCO}_{3} \cdot \mathrm{L}^{-1}$. A média de AVT no afluente foi de 75 mgHAc. $\mathrm{L}^{-1}$ e a média de AVT no efluente de 1025 mgHAc. $L^{-1}$.

A produção de biogás, em aspecto quantitativo, e a distribuição dos gases que compõem o biogás no final do ciclo podem ser observadas pela Figura 5.77, com média de $1052 \mathrm{~mL}$ de biogás e $559 \mathrm{~mL}$ de hidrogênio, sendo que a porcentagem média de hidrogênio foi igual a $52 \%$. A produtividade molar de hidrogênio foi igual a $56,3 \mathrm{molH}_{2} \cdot \mathrm{m}^{-3} \cdot \mathrm{d}^{-1}$, o que é um resultado melhor do que os obtidos nos Ensaios 6 e 8, mas ainda assim muito abaixo da produtividade obtida no Ensaio 7. 

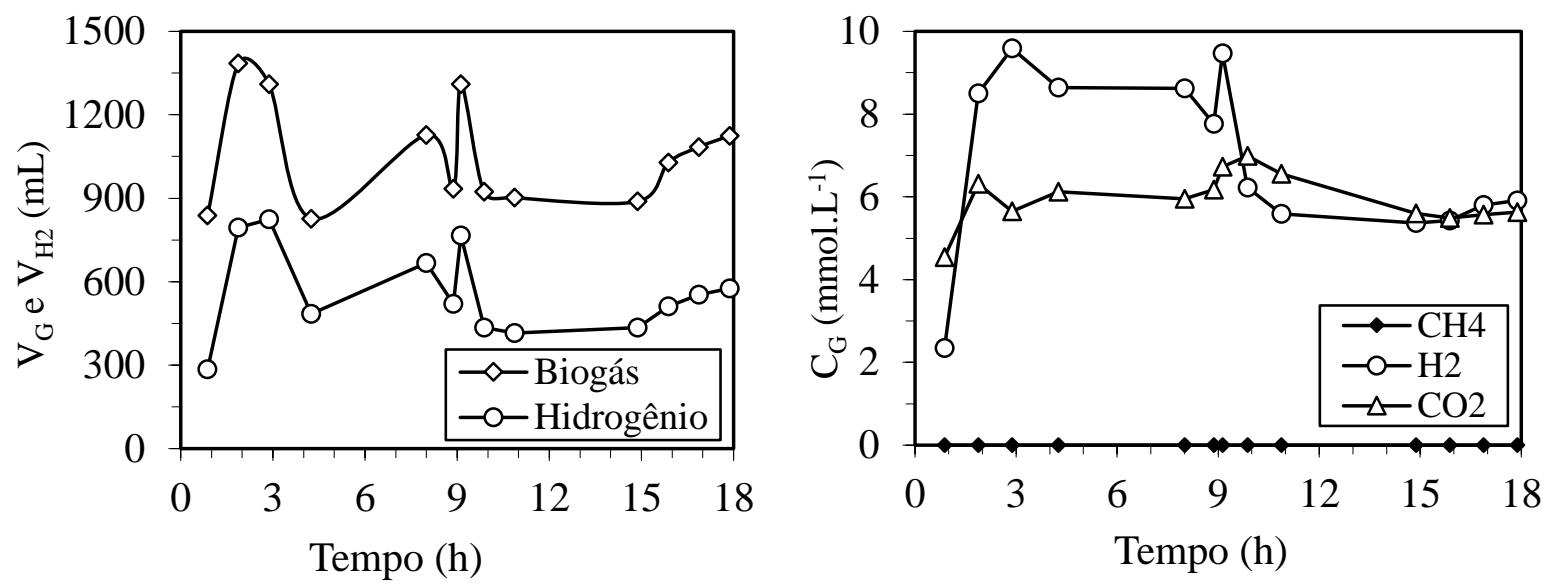

Figura 5.77. Volume de biogás $\left(\mathrm{V}_{\mathrm{G}}\right)$ e de hidrogênio $\left(\mathrm{V}_{\mathrm{H} 2}\right)$ nas $\mathrm{CNTP}$ e concentrações dos componentes do biogás no final do ciclo $\left(\mathrm{C}_{\mathrm{G}}\right)$ no Ensaio 9: $\diamond$ - Biogás; - Metano; $\bigcirc$-Hidrogênio; $\Delta$ - Dióxido de Carbono.

A Figura 5.78 apresenta o perfil de DQO, de Carboidratos e de Glicerina. Os três perfis apresentam a mesma tendência observada nos Ensaios 7 e 8.
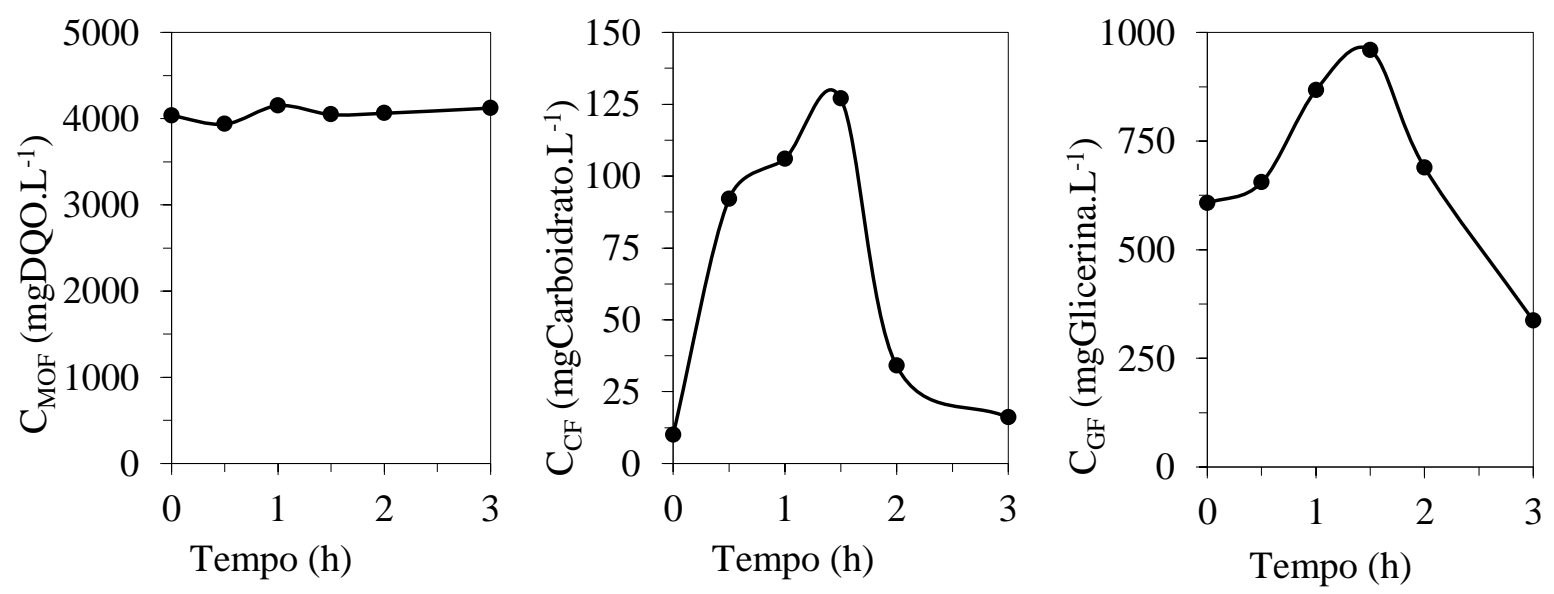

Figura 5.78. Concentração de matéria orgânica, carboidratos e de glicerina durante o ciclo no Ensaio 9.

A Figura 5.79 apresenta os perfis de $\mathrm{pH}$, alcalinidade total e ácidos voláteis totais ao longo do ciclo. O pH permanece constante ao longo do ciclo por volta de 4, bem como os ácidos voláteis totais por volta de $1150 \mathrm{mgHAc} . \mathrm{L}^{-1}$. A alcalinidade é consumida ao longo do ciclo e sai por volta de $30 \mathrm{mgCaCO} 3 \cdot \mathrm{L}^{-1}$.

O perfil dos compostos intermediários do metabolismo é apresentado na Figura 5.80. Neste ensaio, é possível verificar que há a predominância de etanol e de ácido butírico. Vale lembrar que não é benéfico para a produção de hidrogênio ter altas concentrações de etanol no meio, pois ocorre o consumo do substrato e não há formação de $\mathrm{H}_{2}$. 

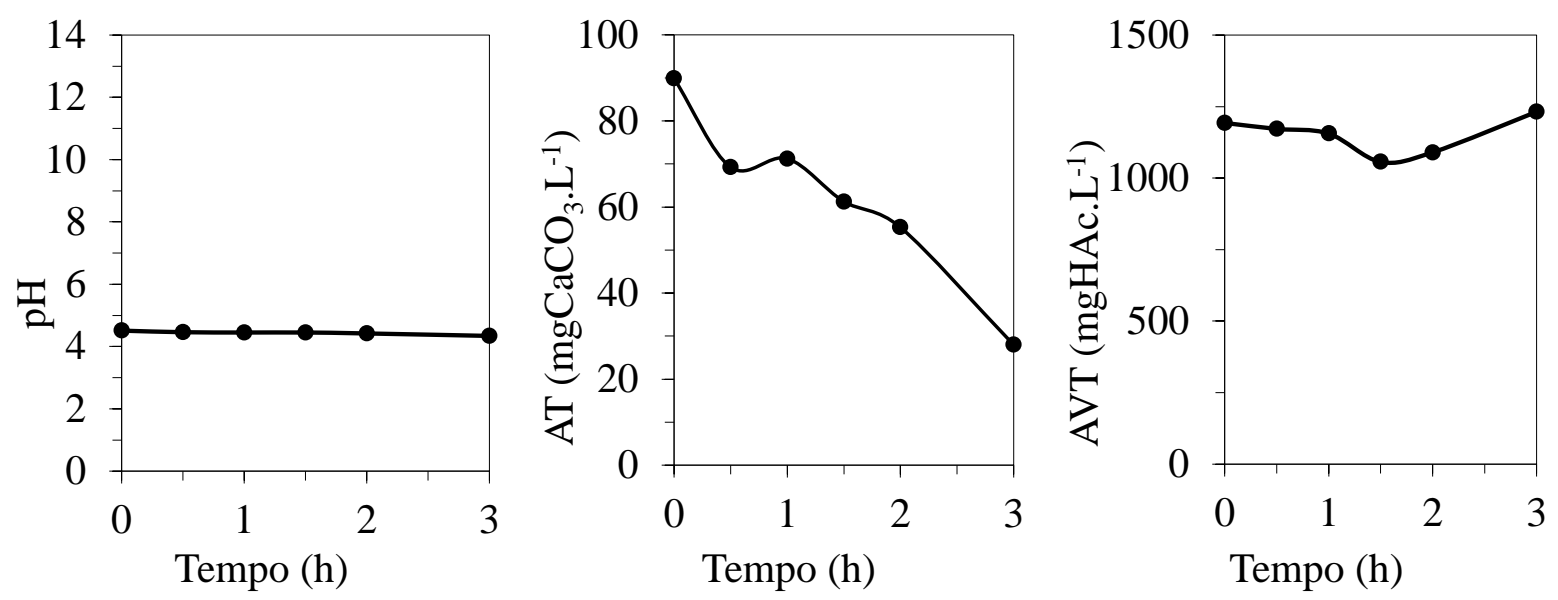

Figura 5.79. Valores de pH, alcalinidade total(AT) e ácidos voláteis totais (AVT) no Ensaio 9.

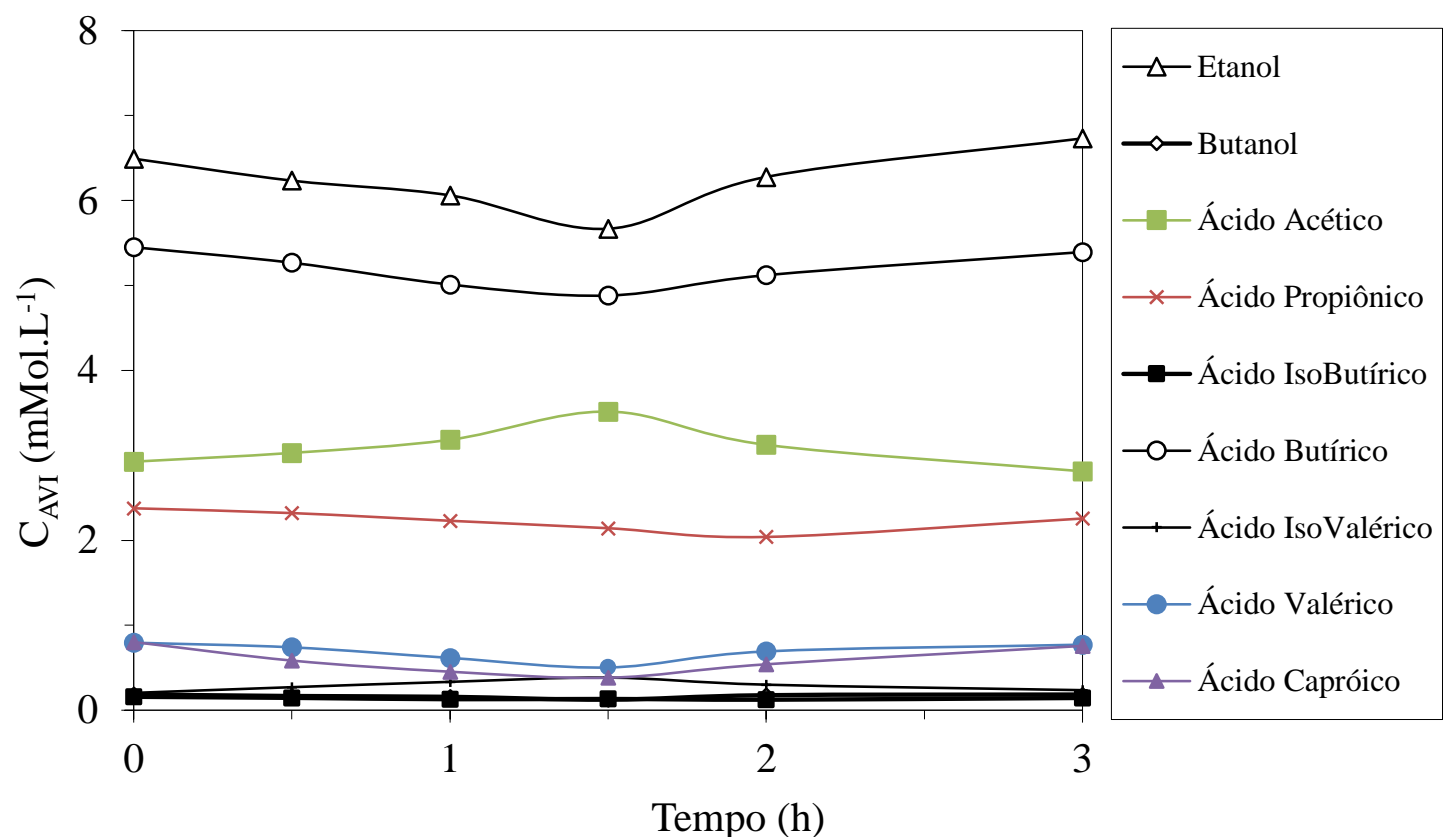

Figura 5.80. Concentração dos compostos intermediários ao longo do ciclo no Ensaio 9: $\Delta$ - etanol; $\diamond$ butanol; - - ácido acético ; -X- ácido propiônico; - - ácido isobutírico; - - ácido butírico; + ácido isovalérico $\bullet$ - ácido valérico; $\boldsymbol{\Delta}$ - ácido capróico.

A produção volumétrica acumulada de biogás e os desvios padrões de cada um dos pontos podem ser observados na Figura 5.81 e o perfil das concentrações de cada um dos gases e suas respectivas porcentagens podem ser observados na Figura 5.82. Houve uma variação considerável no volume de gás recolhido diariamente, mas o sistema caminhou para a estabilidade ao longo tempo e, ao final do perfil, tinha-se $51 \%$ de $\mathrm{CO}_{2}$ e $49 \%$ de $\mathrm{H}_{2}$. 


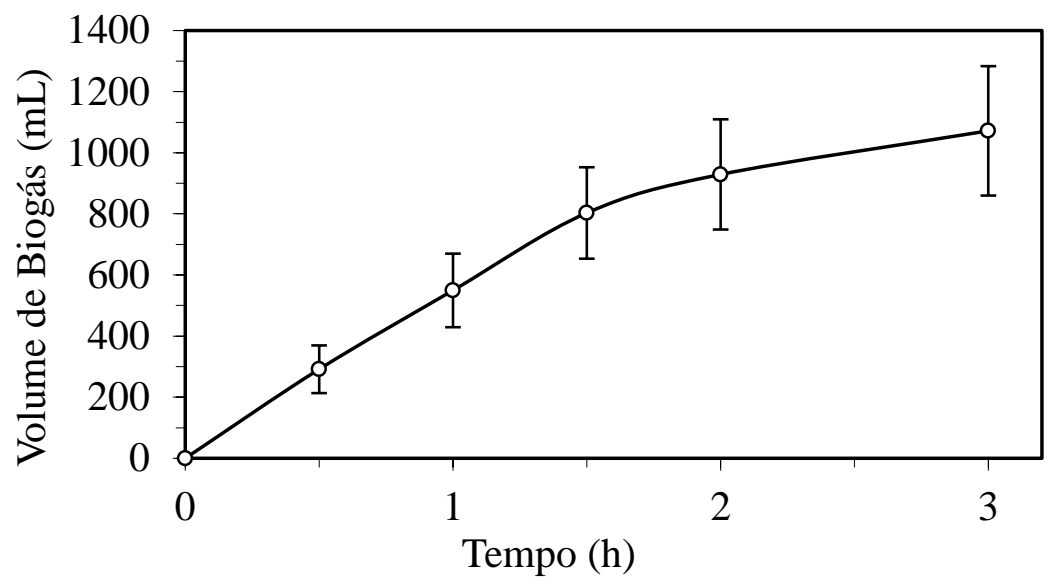

Figura 5.81. Produção volumétrica média acumulada do biogás durante o ciclo no Ensaio 9.
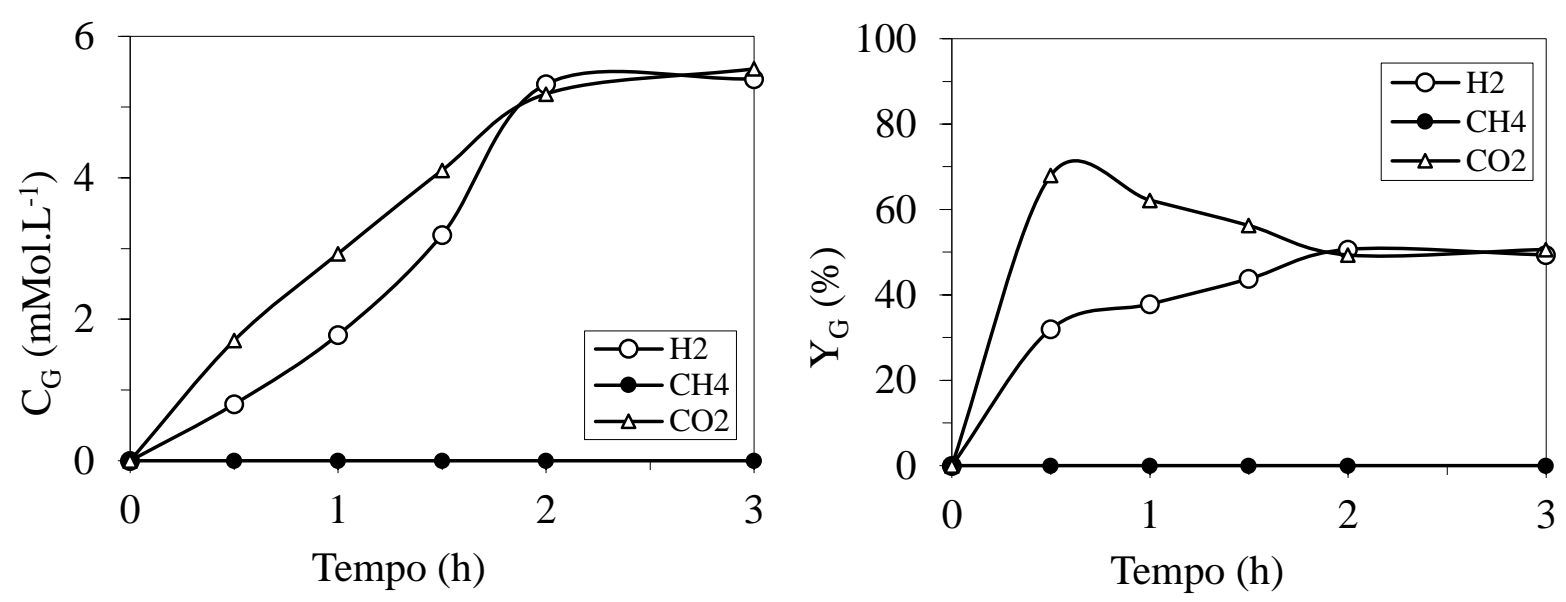

Figura 5.82. Concentração dos compostos do biogás durante o ciclo e suas respectivas porcentagens no Ensaio 9: $\circ-\mathrm{H}_{2} ; \bullet-\mathrm{CH}_{4} ; \Delta-\mathrm{CO}_{2}$.

\subsubsection{Ensaio $10\left(100 \%\right.$ Glicerina $\left.-5000 \mathrm{mgDQO} . \mathrm{L}^{-1}-3 \mathrm{~h}-\mathrm{BA}\right)$}

O Ensaio 10 foi a última condição da Fase II, sendo realizado com afluente $100 \%$ de glicerina (em média 4268 mgGlicerina. $\mathrm{L}^{-1}$ ) e ele teve como objetivo servir como comparação para os ensaios onde houve codigestão, assim como o Ensaio 6 (100\% soro).

O valor real da COAV foi de $17,7 \mathrm{gDQO} . \mathrm{L}^{-1} \cdot \mathrm{d}^{-1}$ e a CORV atingida foi de $2,8 \mathrm{gDQO} . \mathrm{L}^{-}$ ${ }^{1} . \mathrm{d}^{-1}$. A Tabela 5.14 apresenta a média dos parâmetros monitorados.

O monitoramento diário apresentou, novamente, um baixo consumo de matéria orgânica na forma de DQO, com média de concentração afluente não filtrada de $5023 \mathrm{mgDQO} . \mathrm{L}^{-1}$, efluente não filtrada $4239 \mathrm{mgDQO} . \mathrm{L}^{-1}$ e de efluente filtrada de $4217 \mathrm{mgDQO} . \mathrm{L}^{-1}$, o que representa uma eficiência de remoção média de $16 \%$ para amostras não filtradas e filtradas (Figura 5.83). 
Tabela 5.14. Parâmetros médios monitorados no Ensaio 10.

\begin{tabular}{|c|c|c|c|c|c|c|c|c|c|c|c|c|}
\hline \multicolumn{2}{|r|}{ Parâmetro } & \multicolumn{6}{|c|}{ Afluente } & \multicolumn{5}{|c|}{ Efluente } \\
\hline $\mathrm{C}_{\mathrm{MOT}}$ & $\left(\mathrm{mgDQO} . \mathrm{L}^{-1}\right)$ & 5023 & \pm & 125 & & 11 & ) & 4234 & \pm 2 & 239 & ( & $11)$ \\
\hline $\mathrm{C}_{\mathrm{MOF}}$ & $\left(\mathrm{mgDQO} . \mathrm{L}^{-1}\right)$ & & & & & & & 4217 & \pm 2 & 222 & ( & $11)$ \\
\hline$\varepsilon_{\mathrm{MOT}}$ & $(\%)$ & & - & & & & & 16 & \pm & 5 & ( & $11)$ \\
\hline$\varepsilon_{\mathrm{MOF}}$ & $(\%)$ & & & - & & & & 16 & \pm & 5 & ( & $11)$ \\
\hline $\mathrm{C}_{\mathrm{GT}}$ & (mgGlicerina.L $\mathrm{L}^{-1}$ ) & 4268 & \pm & 118 & ( & 11 & ) & 524 & \pm 3 & 319 & ( & $9 \quad)$ \\
\hline $\mathrm{C}_{\mathrm{GF}}$ & (mgGlicerina.L $\mathrm{L}^{-1}$ ) & & & & & & & 455 & \pm 2 & 246 & ( & $9 \quad$ \\
\hline$\varepsilon_{\mathrm{GT}}$ & $(\%)$ & & - & & & & & 88 & \pm & 7 & ( & $9 \quad$ \\
\hline$\varepsilon_{\mathrm{GF}}$ & $(\%)$ & & - & - & & & & 89 & \pm & 7 & ( & $9 \quad)$ \\
\hline $\mathrm{pH}$ & (u) & 7,6 & \pm & 0,1 & ( & 10 & ) & 4,4 & \pm & 0,3 & ( & $11)$ \\
\hline AVT & $\left(\mathrm{mgHAc} . \mathrm{L}^{-1}\right)$ & 41 & \pm & 4 & ( & 10 & ) & 638 & \pm 2 & 205 & ( & $11)$ \\
\hline AT & $\left(\mathrm{mgCaCO}_{3} \cdot \mathrm{L}^{-1}\right)$ & 143 & \pm & 14 & ( & 10 & ) & 24 & \pm & 36 & ( & $11)$ \\
\hline $\mathrm{AP}$ & $\left(\mathrm{mgCaCO}_{3} \cdot \mathrm{L}^{-1}\right)$ & 107 & \pm & 11 & ( & 10 & ) & 0 & \pm & 0 & ( & $11)$ \\
\hline AI & $\left(\mathrm{mgCaCO}_{3} \cdot \mathrm{L}^{-1}\right)$ & 36 & \pm & 4 & ( & 10 & ) & 24 & \pm & 36 & ( & $11 \quad)$ \\
\hline $\mathrm{AB}$ & $\left(\mathrm{mgCaCO}_{3} \cdot \mathrm{L}^{-1}\right)$ & 114 & \pm & 14 & ( & 10 & ) & 0 & & 0 & ( & $11 \quad$ \\
\hline ST & $\left(\mathrm{mg} . \mathrm{L}^{-1}\right)$ & 1131 & \pm & 410 & ( & 5 & ) & 1243 & \pm 1 & 198 & ( & $5 \quad)$ \\
\hline SVT & $\left(\mathrm{mg} \cdot \mathrm{L}^{-1}\right)$ & 608 & \pm & 441 & ( & 5 & ) & 746 & \pm 1 & 177 & ( & $5 \quad)$ \\
\hline SST & $\left(\mathrm{mg} \cdot \mathrm{L}^{-1}\right)$ & 21 & \pm & 10 & ( & 5 & ) & 29 & \pm & 18 & ( & $5 \quad)$ \\
\hline SSV & $\left(\mathrm{mg} \cdot \mathrm{L}^{-1}\right)$ & 20 & \pm & 11 & ( & 5 & ) & 27 & \pm & 18 & ( & $5)$ \\
\hline $\mathrm{M}_{\mathrm{SVT}}$ & (g) & & 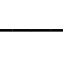 & & & & & & 7,5 & & & \\
\hline $\mathrm{Cx}$ & $\left(\mathrm{g} \cdot \mathrm{L}^{-1}\right)$ & & 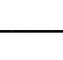 & & & & & & 2,1 & & & \\
\hline $\mathrm{Cx}^{\prime}$ & $\left(\right.$ g.gsuporte $\left.{ }^{-1}\right)$ & & 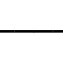 & & & & & &, 005 & & & \\
\hline $\mathrm{V}_{\mathrm{G}}$ & $\left(\mathrm{mL} \cdot \mathrm{ciclo}^{-1}\right)$ & & 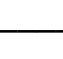 & & & & & 1339 & \pm 1 & 158 & ( & $12)$ \\
\hline $\mathrm{V}_{\mathrm{H} 2}$ & $\left(\mathrm{~mL} \cdot \mathrm{ciclo}^{-1}\right)$ & & 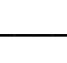 & & & & & 1019 & \pm 1 & 155 & ( & $12)$ \\
\hline $\mathrm{COAV}_{\text {мот }}$ & $\left(\mathrm{gDQO} \cdot \mathrm{L}^{-1} \cdot \mathrm{d}^{-1}\right)$ & & 17,7 & & & & & & - & & & \\
\hline $\mathrm{CORV}_{\mathrm{MOF}}$ & $\left(\mathrm{gDQO} \cdot \mathrm{L}^{-1} \cdot \mathrm{d}^{-1}\right)$ & & 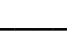 & & & & & & 2,8 & & & \\
\hline $\mathrm{COAV}_{\mathrm{GT}}$ & (gGlicerina. $\mathrm{L}^{-1} \cdot \mathrm{d}^{-1}$ ) & & 15,0 & & & & & & - & & & \\
\hline $\mathrm{CORV}_{\mathrm{GF}}$ & (gGlicerina. $\left.L^{-1} \cdot \mathrm{d}^{-1}\right)$ & & 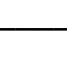 & & & & & & 13,4 & & & \\
\hline COAЕ $_{\text {MOT }}$ & $\left(\right.$ gDQO.gSVT $\left.{ }^{-1} \cdot d^{-1}\right)$ & & 7,5 & & & & & & 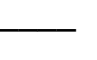 & & & \\
\hline $\mathrm{CORE}_{\mathrm{MOF}}$ & $\left(\right.$ gDQO.gSVT $\left.{ }^{-1} \cdot d^{-1}\right)$ & & 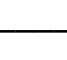 & & & & & & 8,5 & & & \\
\hline $\mathrm{COAE}_{\mathrm{GT}}$ & (gGlicerina.gSVT ${ }^{-1} \cdot \mathrm{d}^{-1}$ ) & & 7,5 & & & & & & - & & & \\
\hline $\mathrm{CORE}_{\mathrm{GF}}$ & (gGlicerina.gSVT ${ }^{-1} \cdot \mathrm{d}^{-1}$ ) & & & & & & & & 7,2 & & & \\
\hline $\mathrm{n}_{\mathrm{H} 2}$ & $\left(\mathrm{molH}_{2} \cdot \mathrm{d}^{-1}\right)$ & & 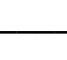 & & & & & & 0,4 & & & \\
\hline PrM & $\left(\mathrm{molH}_{2} \cdot \mathrm{m}^{-3} \cdot \mathrm{d}^{-1}\right)$ & & - & & & & & & 01,8 & & & \\
\hline PrME & $\left(\mathrm{molH}_{2} \cdot \mathrm{kgSVT}^{-1} \cdot \mathrm{d}^{-1}\right)$ & & 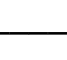 & & & & & & 48,8 & & & \\
\hline RMCA & $\left(\mathrm{molH}_{2} \cdot \mathrm{kgDQO}^{-1}\right)$ & & 5,8 & & & & & & & & & \\
\hline RMSA & $\left(\mathrm{molH}_{2} \cdot \mathrm{molSubstrato}^{-1}\right)$ & & 0,6 & & & & & & 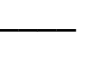 & & & \\
\hline RMSR & $\left(\mathrm{molH}_{2} \cdot \mathrm{molSubstrato}^{-1}\right)$ & & 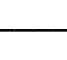 & & & & & & 0,7 & & & \\
\hline $\mathrm{V}_{\mathrm{A}}$ & (L) & 1,57 & \pm & 0,12 & ( & 11 & ) & & $\ldots$ & & & \\
\hline $\mathrm{V}_{\mathrm{R}}$ & $(\mathrm{L})$ & & 3,6 & & & & & & 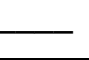 & & & \\
\hline
\end{tabular}

(*) Entre parênteses o número de amostras considerado no cálculo da média 

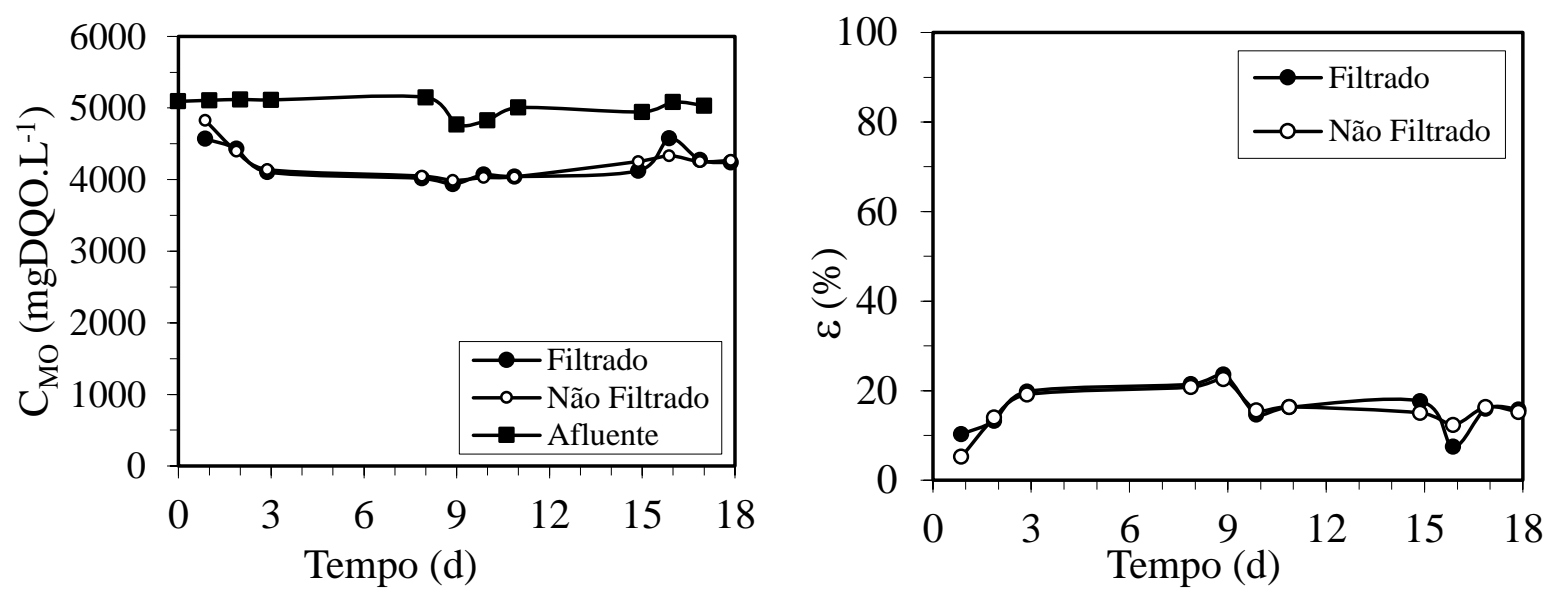

Figura 5.83. Concentração e eficiência de remoção de matéria orgânica na forma de DQO no Ensaio 10: - - afluente amostras não filtradas; - - efluente amostras não filtradas; $\circ-$ efluente amostras filtradas.

Em relação ao monitoramento diário de glicerina, a concentração afluente não filtrada foi de $4268 \mathrm{mgGlicerina} . \mathrm{L}^{-1}$, efluente não filtrado $524 \mathrm{mgGlicerina} . \mathrm{L}^{-1}$ e de efluente filtrado 455 mgGlicerina. $L^{-1}$, o que representa uma eficiência média de remoção para amostras não filtradas de $88 \%$ e para amostras filtradas de $89 \%$ (Figura 5.84).
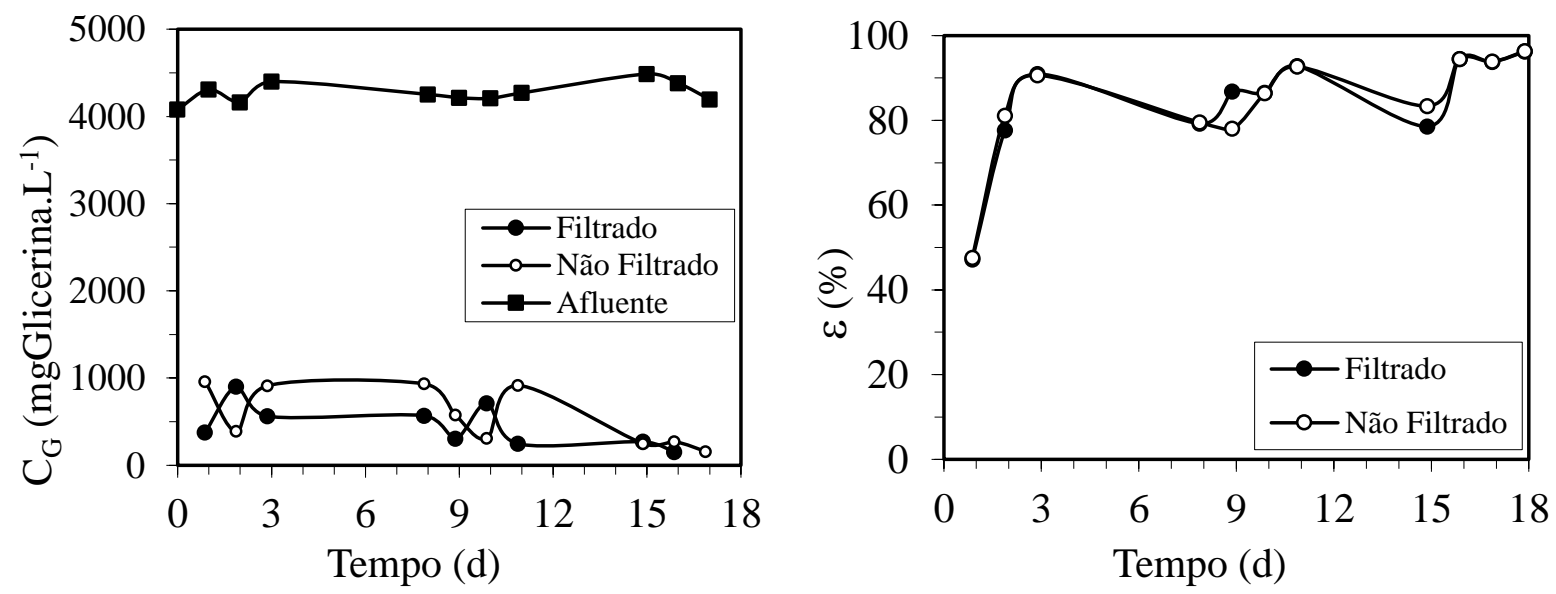

Figura 5.84. Concentração e eficiência de remoção na forma de glicerina no Ensaio 10: - - afluente amostras não filtradas; • - efluente amostras não filtradas; ○ - efluente amostras filtradas.

A média do $\mathrm{pH}$ afluente foi de 7,6 e do efluente de 4,4. A alcalinidade total no afluente teve média de $143 \mathrm{mgCaCO}_{3} \cdot \mathrm{L}^{-1}$ sendo consumida até uma média de $24 \mathrm{mgCaCO} 3 . \mathrm{L}^{-1}$. A média de AVT no afluente foi de 41 mgHAc.L-1 e a média de AVT no efluente de 638 mgHAc. $\mathrm{L}^{-1}$, sendo este o menor valor de AVT dentre todos os ensaios da Fase II.

A produção de biogás, em aspecto quantitativo, e a distribuição dos gases que compõem o biogás no final do ciclo podem ser observadas pela Figura 5.85, com média de $1339 \mathrm{~mL}$ de 
biogás e $1019 \mathrm{~mL}$ de hidrogênio, sendo que a porcentagem média de hidrogênio foi igual a $76 \%$. A produtividade molar de hidrogênio foi igual a $101,8 \mathrm{molH}_{2} \cdot \mathrm{m}^{-3} \cdot \mathrm{d}^{-1}$, o que é o melhor resultado dentre todos os ensaios da Fase II; este foi um resultado surpreendente considerando os resultados obtidos por Lovato et al. (2015).

O melhor rendimento conseguido por Lovato et al. (2015) com glicerina industrial foi $9,7 \mathrm{molH} 2 \cdot \mathrm{m}^{-3} \cdot \mathrm{d}^{-1}$, enquanto que, com glicerol puro, a produtividade foi igual a $100,9 \mathrm{molH}_{2} \cdot \mathrm{m}^{-3} \cdot \mathrm{d}^{-1} \mathrm{com}$ condições similares às condições de operação deste Ensaio 10 (5000 mgDQO.L $\mathrm{L}^{-1}, 3 \mathrm{~h}$ de tempo de ciclo e 1,5 h de tempo de enchimento). Isso mostra que os resultados alcançados com glicerina bidestilada se assemelham aos resultados obtidos com glicerol puro, o que traz a produção de biohidrogênio a partir deste resíduo um passo mais próximo à viabilidade industrial, mas ainda é necessária uma análise econômica deste processo.
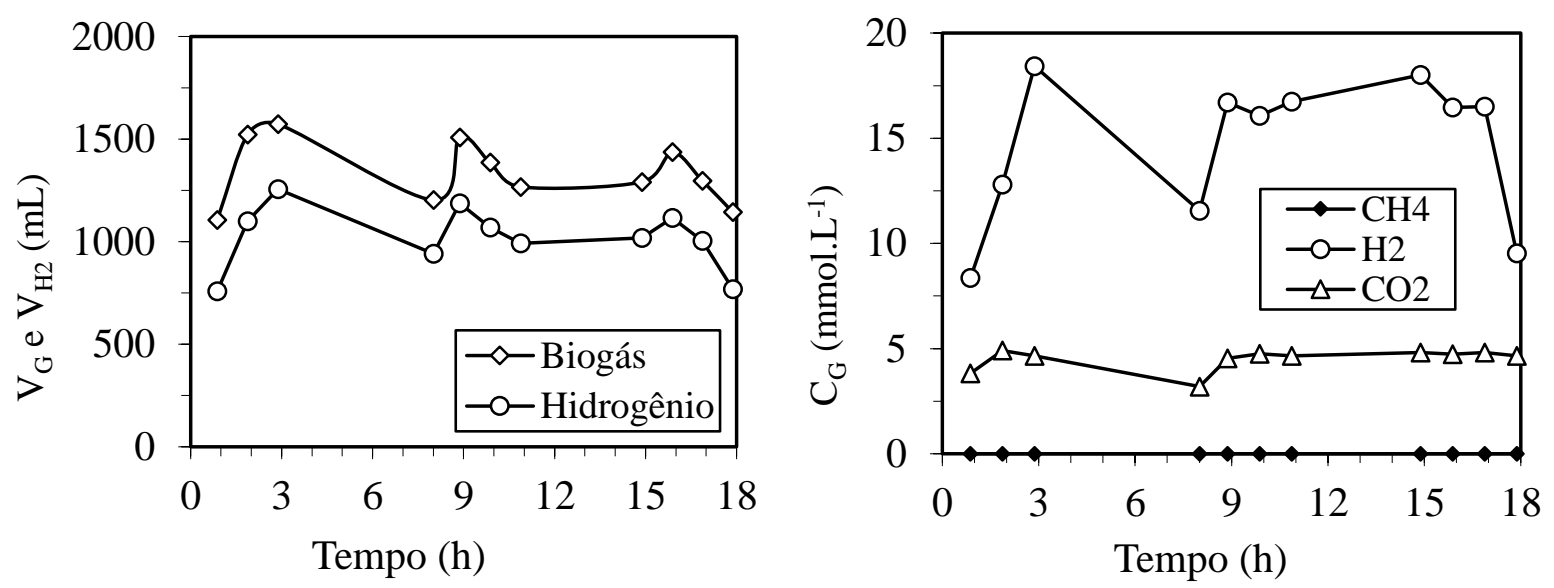

Figura 5.85. Volume de biogás $\left(\mathrm{V}_{\mathrm{G}}\right)$ e de hidrogênio $\left(\mathrm{V}_{\mathrm{H} 2}\right)$ nas $\mathrm{CNTP}$ e concentrações dos componentes do biogás no final do ciclo $\left(\mathrm{C}_{\mathrm{G}}\right)$ no Ensaio 9: $\diamond$ - Biogás; - Metano; $\bigcirc-$ Hidrogênio; $\Delta$ - Dióxido de Carbono.

A Figura 5.86 apresenta o perfil de DQO e de Glicerina. Esses dois perfis apresentam a mesma tendência observada anteriormente: perfil de DQO sem grandes variações ao longo do ciclo e perfil de glicerina com grandes variações, sendo que a concentração de glicerina aumenta enquanto o afluente é alimentado (1,5 h) e depois há o consumo desse substrato. 

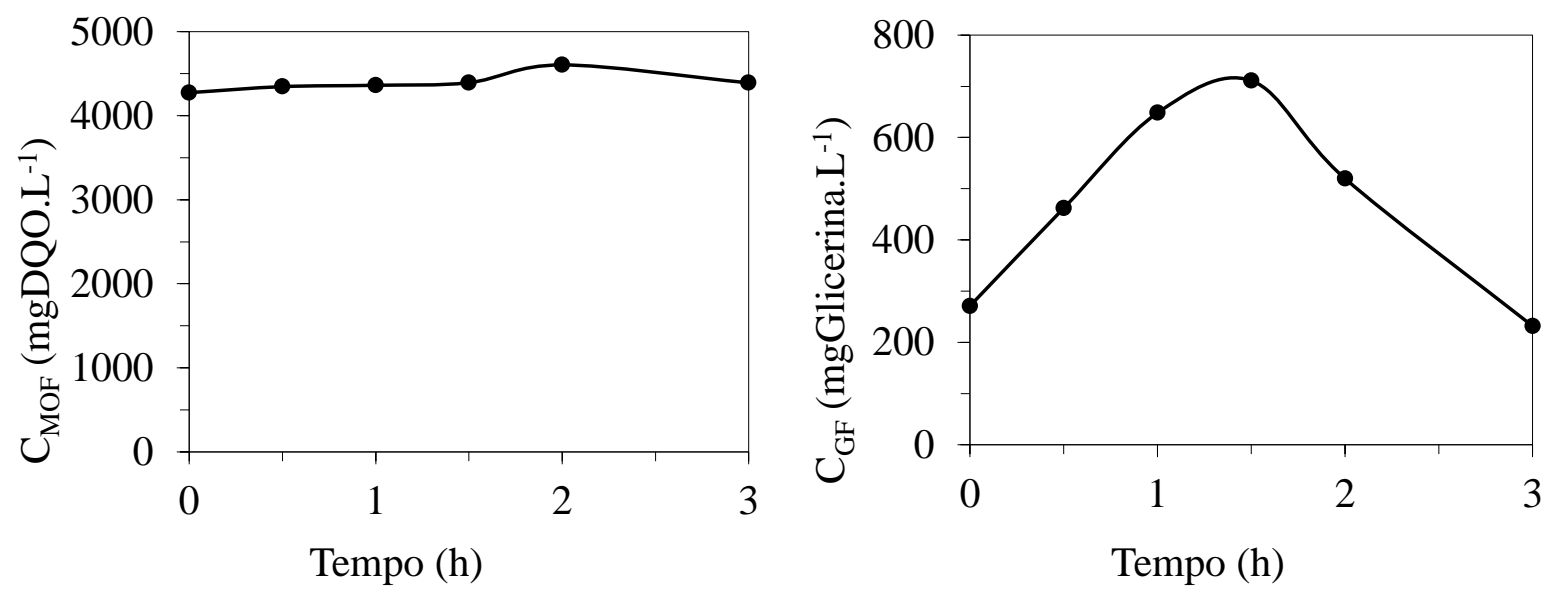

Figura 5.86. Concentração de matéria orgânica, carboidratos e de glicerina durante o ciclo no Ensaio 10.

A Figura 5.87 apresenta os perfis de $\mathrm{pH}$, alcalinidade total e ácidos voláteis totais ao longo do ciclo. $\mathrm{O}$ pH permanece constante ao longo do ciclo por volta de 4,2 e toda a alcalinidade é completamente consumida. Os ácidos voláteis totais apresentam uma tendência de queda até as $2 \mathrm{~h}$ de tempo de ciclo e depois há uma pequena formação de ácidos; o que provavelmente se deve à degradação dos ácidos voláteis de cadeias maiores (butírico, valérico e capróico) em ácidos de cadeia menor.
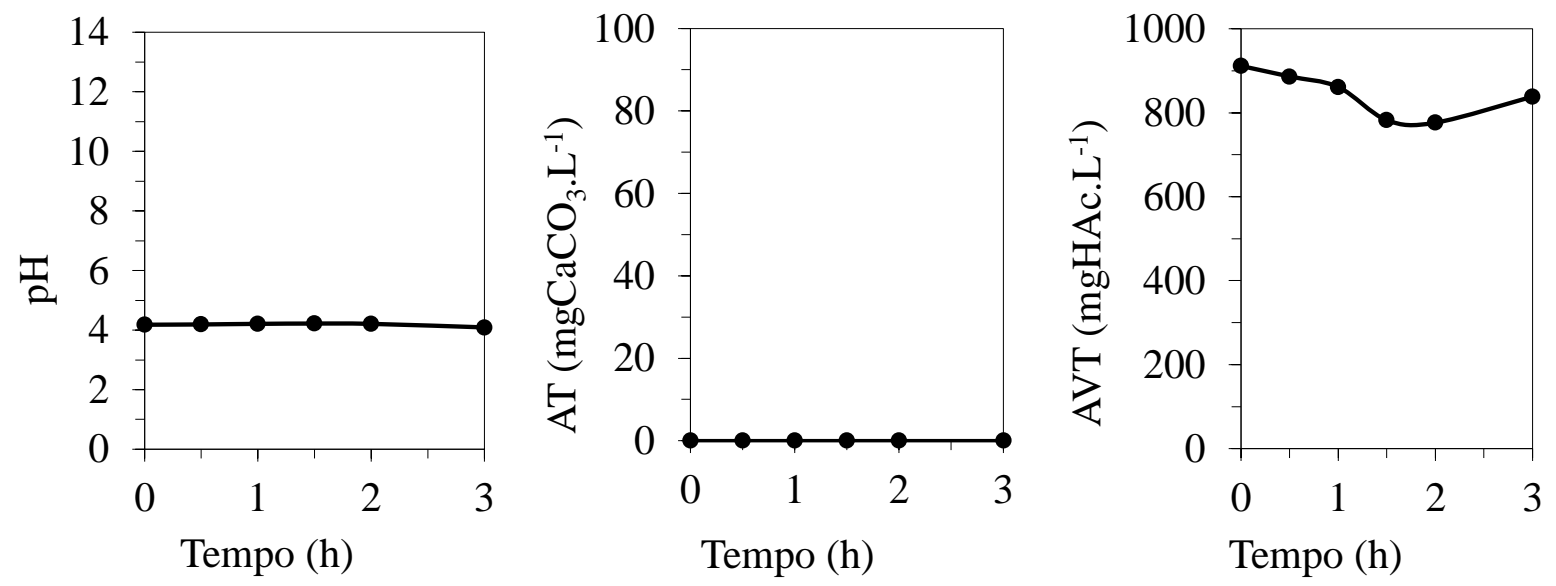

Figura 5.87. Valores de pH, alcalinidade total(AT) e ácidos voláteis totais (AVT) no Ensaio 10.

O perfil dos compostos intermediários do metabolismo é apresentado na Figura 5.88. Neste ensaio, é possível verificar que há a predominância de ácido butírico e de ácido propiônico, com a mesma tendência observada no perfil de AVT: consumo desses dois ácidos até o meio do ciclo com formação na $1,5 \mathrm{~h}$ final, o que pode ser devido à degradação dos ácidos valérico e capróico. 


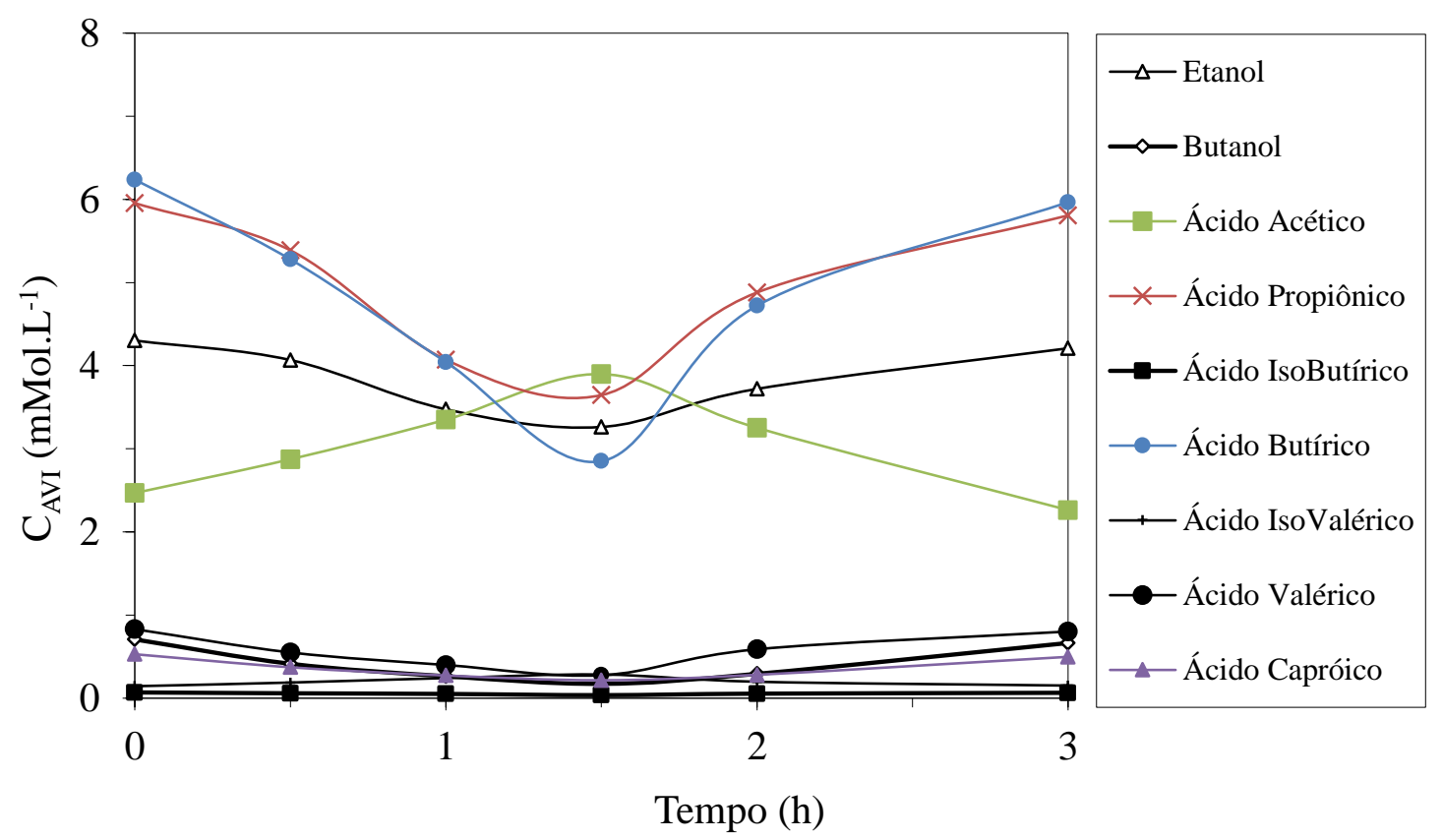

Figura 5.88. Concentração dos compostos intermediários ao longo do ciclo no Ensaio 10: $\Delta$ - etanol; $\diamond$ butanol; $\square$ - ácido acético ; -X- ácido propiônico; - - ácido isobutírico; • - ácido butírico; + ácido isovalérico $\bullet$ - ácido valérico; $\Delta$ - ácido capróico.

A produção volumétrica acumulada de biogás e os desvios padrões de cada um dos pontos podem ser observados na Figura 5.89 e o perfil das concentrações de cada um dos gases e suas respectivas porcentagens podem ser observados na Figura 5.90. Houve uma variação considerável no volume de gás recolhido diariamente, mas o sistema caminhou para a estabilidade ao longo tempo e, ao final do perfil, tinha-se $22 \%$ de $\mathrm{CO}_{2}$ e $78 \%$ de $\mathrm{H}_{2}$, o que é uma excelente qualidade de biogás.

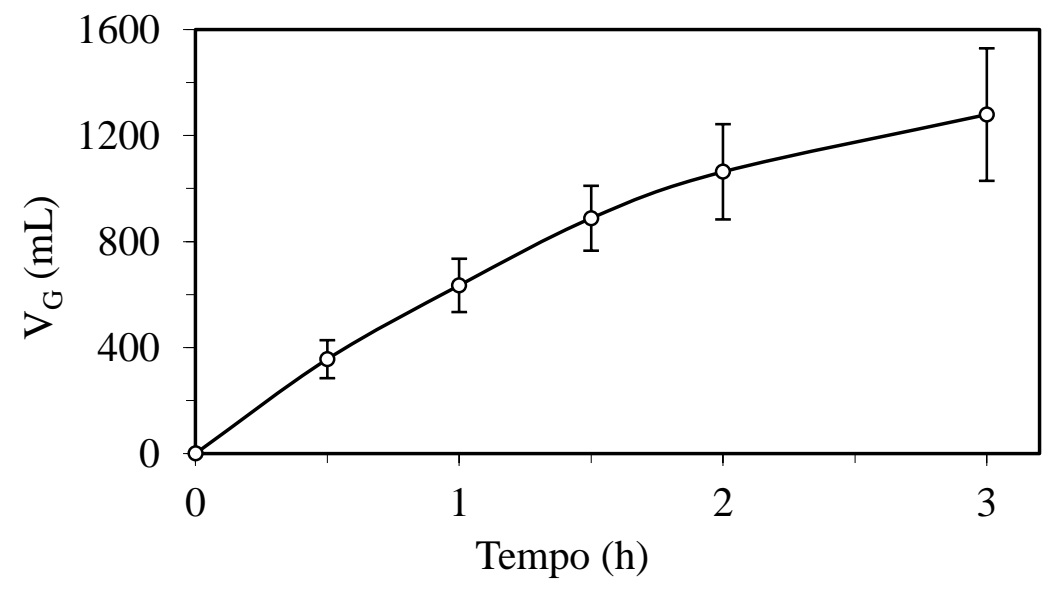

Figura 5.89. Produção volumétrica média acumulada do biogás durante o ciclo no Ensaio 10. 

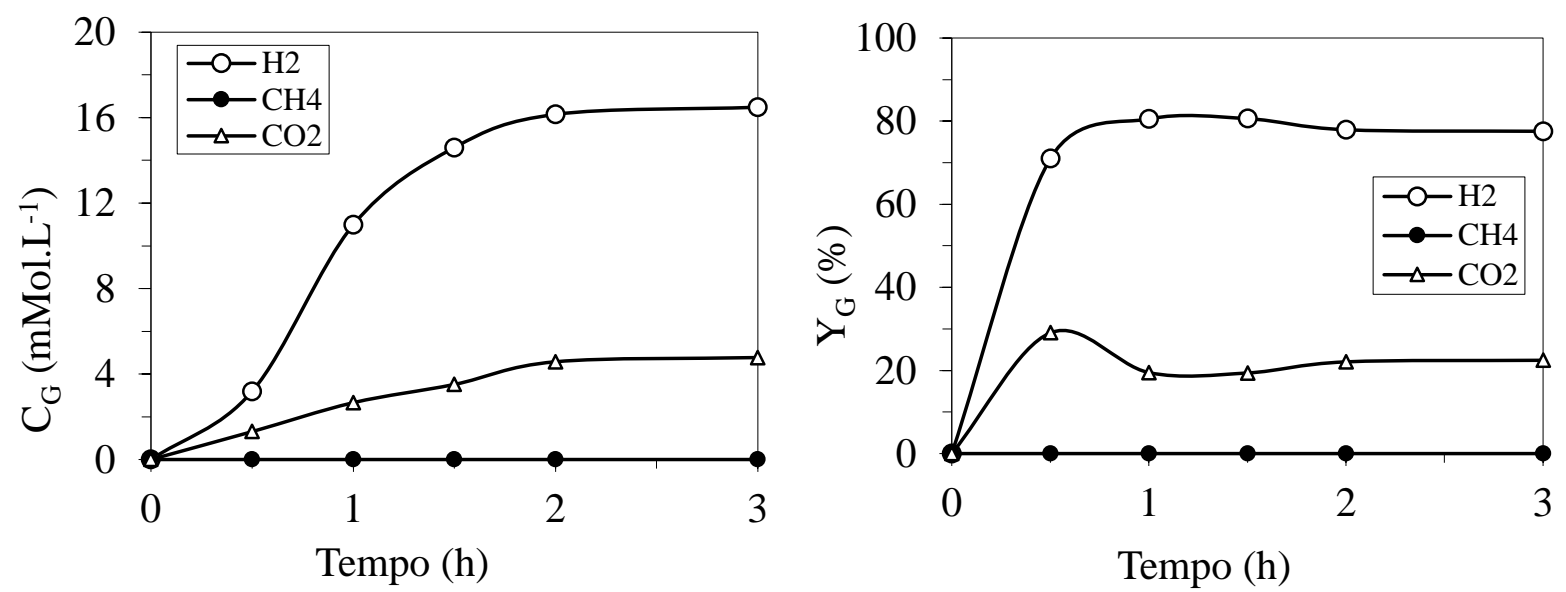

Figura 5.90. Concentração dos compostos do biogás durante o ciclo e suas respectivas porcentagens no Ensaio 10: $\circ-\mathrm{H}_{2} ; \bullet-\mathrm{CH}_{4} ; \Delta-\mathrm{CO}_{2}$.

\subsubsection{Análise comparativa entre os Ensaios de 6 a 10 (Fase II)}

O objetivo desta seção é comparar os Ensaios de 6 a 10 para verificar quais parâmetros foram favorecidos em cada ensaio. Os parâmetros comparados serão a matéria orgânica, carboidratos, glicerina (englobando carga aplicada e removida), $\mathrm{pH}$, alcalinidade e ácidos (AVT e AVI), sólidos e, por último, parâmetros relativos a produção de biohidrogênio.

A Figura 5.91 e Figura 5.92 mostram os dados experimentais dos Ensaios de 6 a 10. Os dados são mostrados continuamente para observar as mudanças entre uma condição e outra, sendo importante ressaltar que todos os ensaios foram realizados de modo independente, ou seja, partiram da mesma condição experimental a partir da inoculação do reator.

Em relação à remoção de matéria orgânica na forma de DQO, a Figura 5.91 mostra a diferença entre as concentrações do afluente e efluente, indicando que houve baixa remoção de matéria orgânica em todos os ensaios, sendo a eficiência mínima de remoção de DQO atingida no Ensaio 10 (16\%) e a máxima, no Ensaio 7 (27\%). Contudo, este é um resultado adequado quando se trata de um reator acidogênico, pois há o consumo dos substratos e a formação de ácidos que não são consumidos pelo processo e geram uma demanda química de oxigênio, além disso, na Figura, também é possível notar a estabilidade do reator em relação a esse parâmetro.

Em relação ao soro, todos os ensaios atingiram ótimas eficiências de remoção, sendo a eficiência mínima atingida no Ensaio 9 (97\%) e a máxima, nos Ensaio 7 e 8 (98,9\%). Com relação à glicerina, resultados um pouco inferiores foram obtidos, mas ainda bons: a eficiência mínima foi atingida no Ensaio 8 (85\%) e a máxima, no Ensaio 7 (97\%), essa diferença entre o soro e a glicerina se deve a facilidade de degradação dos carboidratos presentes no soro. 

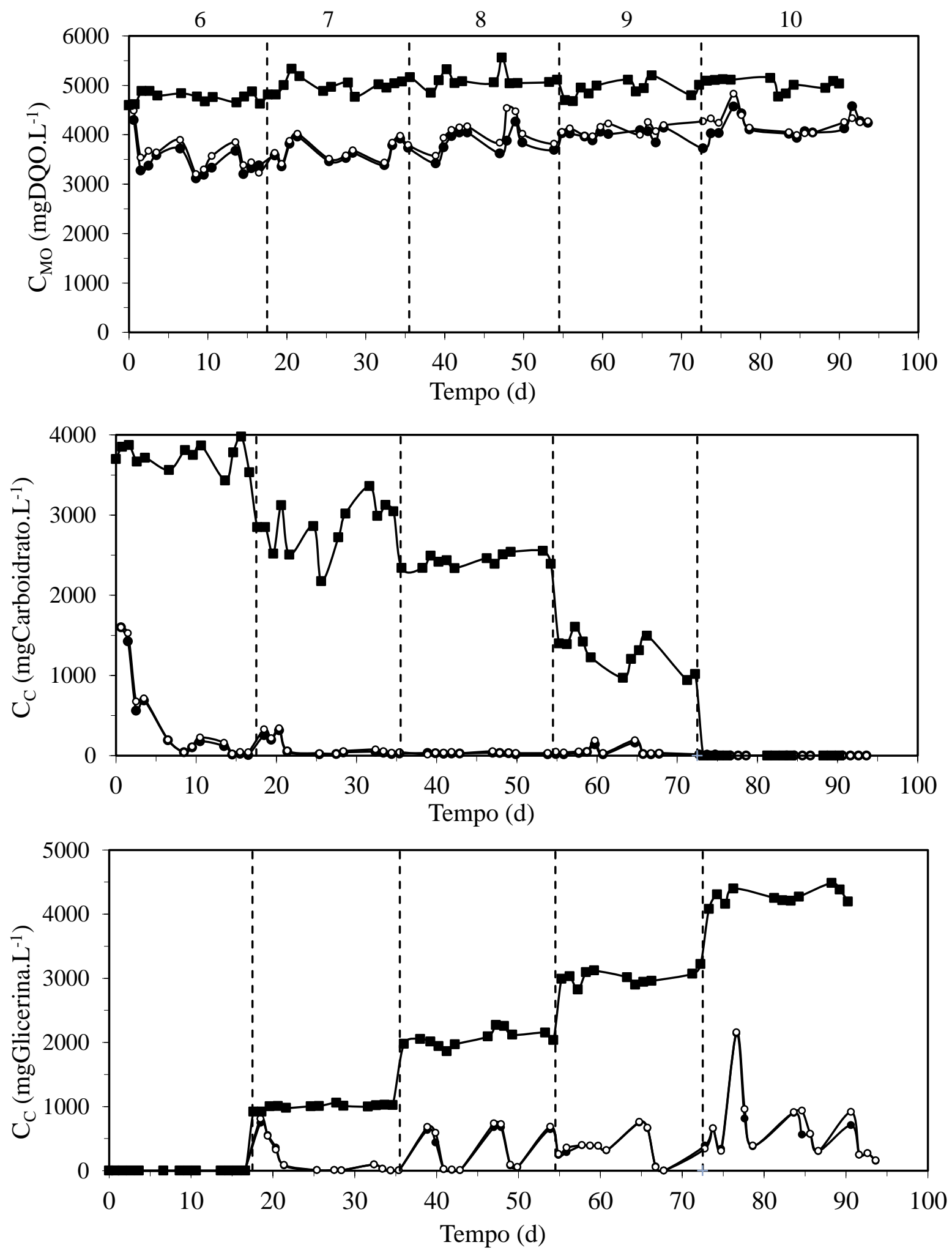

Figura 5.91. Monitoramento da DQO, dos carboidratos e da glicerina nos Ensaios 6 a 10: $\mathbf{-}$ - afluente amostras não filtradas; $\bigcirc$ - efluente amostras não filtradas; • - efluente amostras filtradas. 

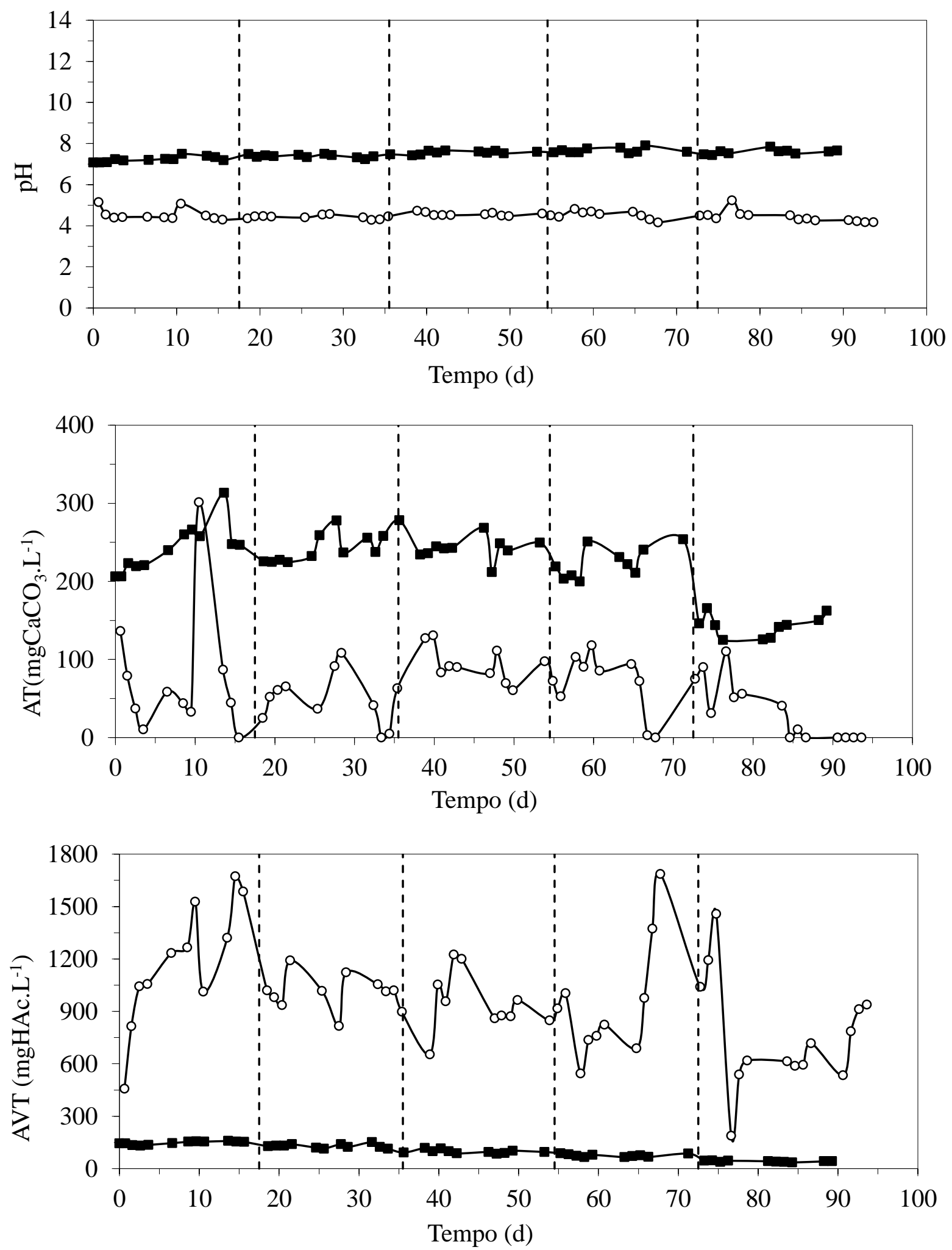

Figura 5.92. Monitoramento do pH, da AT e dos AVT nos Ensaios 6 a 10: - - afluente amostras não filtradas; $\bigcirc$ - efluente amostras não filtradas. 
Quanto ao pH, observa-se pela Figura 5.92 um comportamento estável nos ensaios. O afluente apresentou um valor mínimo de 7,2 no Ensaio 6 (100\% soro) e um valor máximo de 7,7 para o Ensaio 9 (75\% glicerina). O efluente apresentou um valor de mínimo de $\mathrm{pH}$ de 4,4 no Ensaio 10 (100\% glicerina) e um valor máximo de 4,6 no Ensaio 8 (50\% soro), o que representa uma reduzida variação.

Para este trabalho, o pH do efluente por volta de 4,5 foi adequado para a produção de hidrogênio, sendo que a mesma foi elevada e não houve traços de metano em nenhum dos ensaios.

A alcalinidade total do afluente se manteve próxima em todos os ensaios (143$\left.244 \mathrm{mgCaCO}_{3} \cdot \mathrm{L}^{-1}\right)$, sendo consumida pelo processo (24-89 $\mathrm{mgCaCO}_{3} \cdot \mathrm{L}^{-1}$ ) (Tabela 5.16), corroborando para o comportamento estável do processo, sendo também observado tal comportamento com relação aos ácidos voláteis totais no afluente (41-147 mgHAc. $\mathrm{L}^{-1}$ ) e efluente (952-1180 mgHAc. $\left.\mathrm{L}^{-1}\right)$, com exceção do Ensaio 10 que atingiu apenas 638 mgHAc. $\mathrm{L}^{-1}$, comportamento coerente com a hipótese de que a glicerina contém traços de álcalis derivados do processo de produção de biodiesel.

Analisando a série de sólidos e a quantidade de biomassa presente no reator em cada ensaio (Tabela 5.15) nota-se que não houve perda de sólidos significativa em nenhuma das condições estudadas, principalmente quando se trata de sólidos voláteis totais e sólidos totais (os sólidos do afluente são maiores do que os sólidos do efluente), ou seja, o sistema não foi submetido a nenhuma condição crítica o suficiente para que houvesse o desprendimento da biomassa do suporte inerte.

Observando a quantidade de biomassa dentro do reator (MSvT), é possível dizer que não há uma correlação direta entre essa quantidade e a produtividade de biogás atingida. Mas mais importante do que esse parâmetro é notar que, para obter um bom funcionamento do sistema de produção de hidrogênio, é necessário controlar a massa específica do reator com lavagens periódicas, o que representa um grande empecilho em um possível aumento de escala, pois seria necessário um sistema de recirculação de água em regime altamente turbulento para promover a remoção dessa quantidade de biomassa (é possível observar que pelo menos $59,7 \%$ da biomassa foi removida nessas lavagens). 
Tabela 5.15. Comparação entre os valores médios da série de sólidos entre os Ensaios da Fase II.

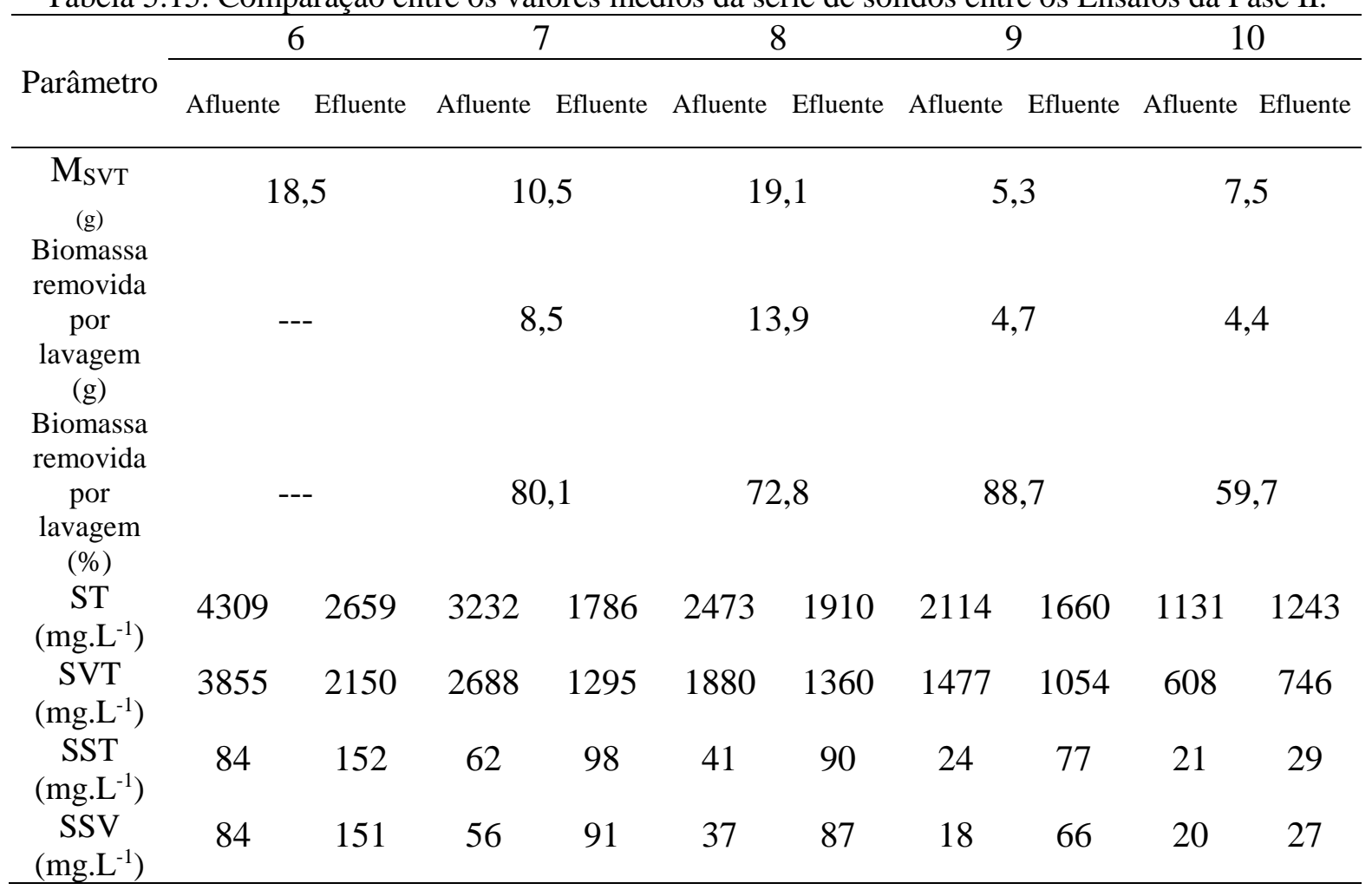

O desempenho do reator quanto à produção de biogás é mostrado na Figura 5.93 e na Tabela 5.16, as quais indicam um comportamento estável em todos os ensaios, obtendo-se valores de produtividade de 51,9-101,8 $\mathrm{molH}_{2} \cdot \mathrm{m}^{-3} \cdot \mathrm{d}^{-1}$ com composição de hidrogênio entre 46,7-75,9\%, cujo valor máximo foi obtido no Ensaio 10 (100\% glicerina, 1339 mLbiogás.ciclo ${ }^{-1}, 101,8 \mathrm{molH}_{2} \cdot \mathrm{m}^{-3} \cdot \mathrm{d}^{-1}$ e $75,9 \%$ de hidrogênio). Foi um resultado surpreendente alcançar a maior produtividade em um ensaio que contém apenas glicerina, pois este é um substrato de difícil degradação; isso se deve ao uso da glicerina bidestilada que tem um comportamento semelhante ao do glicerol puro. No entanto, como o objetivo do trabalho é utilizar a codigestão, nos ensaios daqui por diante foi utilizada a razão de $75 \%$ soro e $25 \%$ glicerina que obteve os seguintes resultados: $1360 \mathrm{mLbiogás.ciclo}{ }^{-1}, 91,3 \mathrm{molH}_{2} \cdot \mathrm{m}^{-3} \cdot \mathrm{d}^{-}$ ${ }^{1}$ e $66,4 \%$ de hidrogênio; o que representa a melhor condição de codigestão e um aumento de $73,2 \%$ de produtividade em relação ao ensaio com 100\% soro. Logo, a codigestão se provou eficaz em melhorar a monodigestão do soro, provavelmente devido à capacidade tamponante da glicerina. 


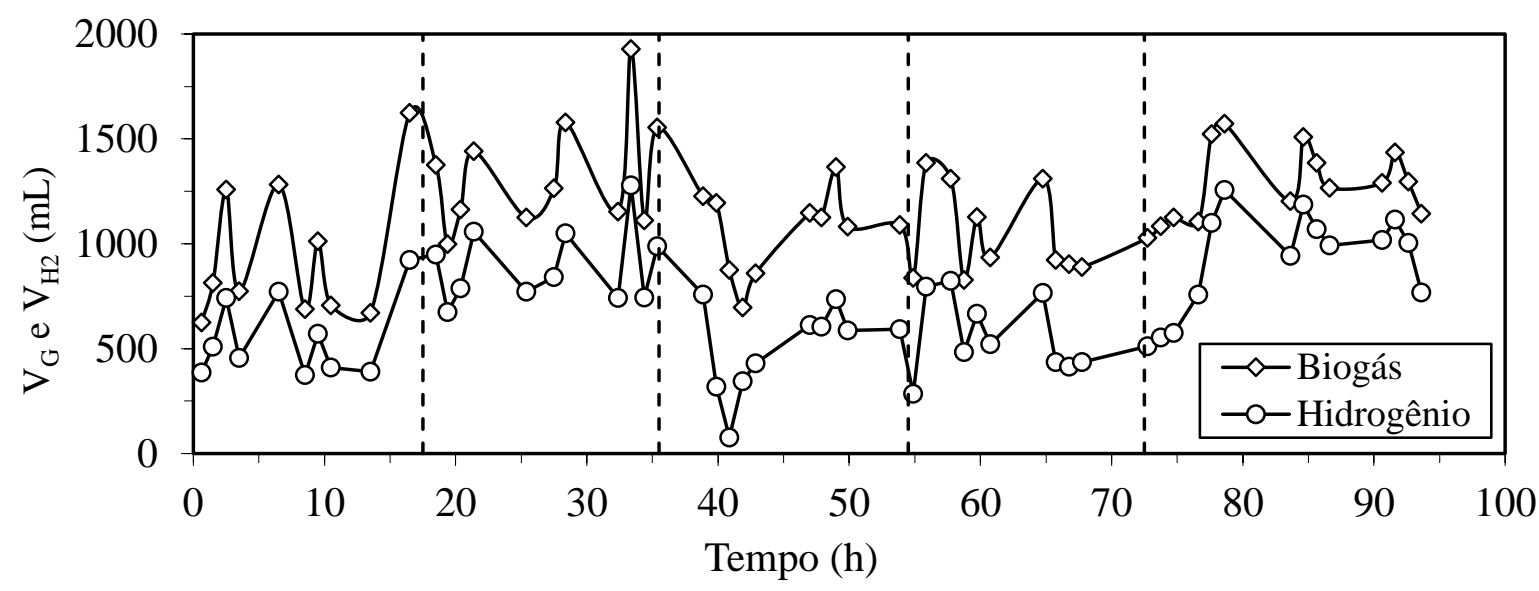

Figura 5.93. Produção volumétrica por ciclo de Biogás $(\diamond)$ e Hidrogênio (०).

Analisando os rendimentos em relação ao substrato aplicado (Tabela 5.16), o Ensaio 1 foi o que obteve o melhor parâmetro com $1,8 \mathrm{molH}_{2} \cdot \mathrm{molSubstrato}^{-1}$, sendo que o rendimento máximo teórico da lactose é de 4,0 $\mathrm{molH}_{2}$. molLactose ${ }^{-1}$. Nota-se também uma diminuição do rendimento conforme se adiciona glicerina ao afluente, pois o rendimento máximo teórico da glicerina $\left(3,0 \mathrm{molH}_{2} \cdot \mathrm{molGlicerina}^{-1}\right)$ é menor do que o do soro, situação praticamente igual a encontrada na Fase I.

Em relação aos compostos intermediários mostrados na Tabela 5.16, houve variada produção de ácidos e álcoois ao longo dos Ensaios. Vale destacar que para o reator acidogênico foram encontradas quantidades significativas de Etanol, Ácido Valérico e Ácido Capróico na maior parte dos Ensaios, o que não aconteceu no reator metanogênico. 
Tabela 5.16. Estabilidade e desempenho nas variáveis monitoradas nos ensaios de 6 a 10 .

\begin{tabular}{|c|c|c|c|c|c|c|}
\hline & Parâmetro & 6 & 7 & 8 & 9 & 10 \\
\hline$\varepsilon_{\mathrm{MO}, \mathrm{F}}$ & $(\%)$ & $27 \pm 8^{(12)}$ & $27 \pm 3^{(11)}$ & $24 \pm 4^{(12)}$ & $19 \pm 4^{(11)}$ & $16 \pm 5^{(10)}$ \\
\hline$\varepsilon_{\mathrm{C}, \mathrm{F}}$ & $(\%)$ & $98 \pm 2^{(8)}$ & $98,9 \pm 0,4^{(8)}$ & $98,9 \pm 0,3^{(12)}$ & $97 \pm 4^{(10)}$ & - \\
\hline$\varepsilon_{\mathrm{G}, \mathrm{F}}$ & $(\%)$ & - & $97 \pm 4^{(8)}$ & $85 \pm 14^{(12)}$ & $87 \pm 8^{(10)}$ & $89 \pm 7^{(10)}$ \\
\hline $\mathrm{M}_{\mathrm{SVT}}$ & (g) & 18,5 & 10,5 & 19,1 & 5,3 & 7,5 \\
\hline COAV & $\left(\operatorname{kgDQO} \cdot \mathrm{m}^{-3} \cdot \mathrm{d}^{-1}\right)$ & 16,1 & 17,2 & 17,7 & 17,1 & 17,7 \\
\hline CORV & $\left(\mathrm{kgDQO} \cdot \mathrm{m}^{-3} \cdot \mathrm{d}^{-1}\right)$ & 4,4 & 4,6 & 4,3 & 3,2 & 2,8 \\
\hline \multirow{3}{*}{ Afluente } & $\mathrm{pH}(\mathrm{u})$ & $7,2 \pm 0,1^{(12)}$ & $7,39 \pm 0,07^{(11)}$ & $7,56 \pm 0,08^{(12)}$ & $7,7 \pm 0,1^{(10)}$ & $7,6 \pm 0,1^{(10)}$ \\
\hline & $\mathrm{AT}\left(\mathrm{mgCaCO}_{3} \cdot \mathrm{L}^{-1}\right)$ & $242 \pm 30^{(12)}$ & $242 \pm 18^{(11)}$ & $245 \pm 17^{(12)}$ & $224 \pm 19^{(10)}$ & $143 \pm 14^{(10)}$ \\
\hline & $\operatorname{AVT}\left(m g H A c . L^{-1}\right)$ & $147 \pm 9^{(12)}$ & $128 \pm 12^{(11)}$ & $98 \pm 11^{(12)}$ & $75 \pm 8^{(10)}$ & $41 \pm 4^{(10)}$ \\
\hline \multirow{3}{*}{ Efluente } & $\mathrm{pH}(\mathrm{u})$ & $4,5 \pm 0,3^{(11)}$ & $4,42 \pm 0,09^{(11)}$ & $4,55 \pm 0,09^{(12)}$ & $4,5 \pm 0,2^{(11)}$ & $4,4 \pm 0,3^{(11)}$ \\
\hline & $\mathrm{AT}\left(\mathrm{mgCaCO}_{3} \cdot \mathrm{L}^{-1}\right)$ & $75 \pm 84^{(11)}$ & $50 \pm 33^{(11)}$ & $89 \pm 25^{(12)}$ & $69 \pm 40^{(11)}$ & $24 \pm 36^{(11)}$ \\
\hline & $\operatorname{AVT}\left(\right.$ mgHAc. $\left.L^{-1}\right)$ & $1180 \pm 357^{(11)}$ & $1006 \pm 102^{(11)}$ & $952 \pm 157^{(12)}$ & $1025 \pm 363^{(11)}$ & $638 \pm 205^{(11)}$ \\
\hline \multirow{8}{*}{$\begin{array}{l}\text { Compostos } \\
\text { Intermediários } \\
\text { (molar) }\end{array}$} & Etanol (\%) & 17,3 & 18,9 & 24,4 & 34,9 & 20,6 \\
\hline & Butanol (\%) & 0,9 & 0,7 & 0,4 & 1,0 & 3,2 \\
\hline & Ácido Acético (\%) & 39,6 & 20,7 & 23,8 & 14,6 & 11,1 \\
\hline & Ácido Propiônico (\%) & 3,6 & 15,5 & 35,7 & 11,7 & 28,4 \\
\hline & Ácido Butírico (\%) & 33,9 & 32,6 & 6,1 & 28,7 & 29,5 \\
\hline & Ácido Valérico (\%) & 2,6 & 8,7 & 8,9 & 5,2 & 4,7 \\
\hline & Ácido Capróico (\%) & 2,1 & 2,9 & 0,7 & 3,9 & 2,4 \\
\hline & $\begin{array}{l}\text { Concentração total } \\
\left(\text { mmol. } \mathrm{L}^{-1}\right)\end{array}$ & 51,9 & 23,5 & 32,2 & 19,3 & 20,4 \\
\hline PrM & $\left(\mathrm{molH}_{2} \cdot \mathrm{m}^{-3} \cdot \mathrm{d}^{-1}\right)$ & 52,7 & 91,3 & 51,9 & 56,3 & 101,8 \\
\hline PrME & $\left(\mathrm{molH}_{2} \cdot \mathrm{kgSVT}^{-1} \cdot \mathrm{d}^{-1}\right)$ & 9,9 & 30,7 & 12,6 & 40,4 & 48,8 \\
\hline RMCA & $\left(\mathrm{molH}_{2} \cdot \mathrm{kgDQO}^{-1}\right)$ & 3,3 & 5,3 & 2,9 & 3,3 & 5,8 \\
\hline RMSA & $\left(\mathrm{molH}_{2}\right.$ molSubstrato $\left.^{-1}\right)$ & 1,8 & 1,5 & 0,5 & 0,5 & 0,6 \\
\hline \multirow{2}{*}{$\mathrm{Y}_{\mathrm{G}}$} & (\%) $\mathrm{H}_{2}$ & 58,8 & 66,4 & 46,7 & 52,3 & 75,9 \\
\hline & $(\%) \mathrm{CO}_{2}$ & 41,2 & 33,6 & 53,3 & 47,7 & 24,1 \\
\hline
\end{tabular}


A maior concentração de ácido acético (11,1-39,6\%) ocorreu no Ensaio 6, o que teoricamente seria melhor para a produção de hidrogênio, pois uma razão HAc/HBu alta é um bom indicativo de produção de hidrogênio em sistemas acidogênicos (Das e Veziroglu, 2001). No entanto, nos Ensaios 7 e 510(maiores produção de $\mathrm{H}_{2}$ ) ocorreu predominância de ácido butírico $(6,1-33,9 \%)$, indicando que a adição da glicerina muda a rota metabólica ótima de produção desse biogás, como é mostrado nas Equações 4.51 e 4.53.

Em relação à produção de álcoois, nos Ensaios 8 e 9 houve grande concentração de etanol (17,3-20,6\%) coincidindo com menores produtividades de hidrogênio; o que faz sentido considerando que a produção de álcoois consome o substrato e não libera hidrogênio.

A Tabela 5.17 mostra uma comparação dos resultados deste trabalho com resultados da literatura em relação à digestão de soro e glicerina sozinhos, pois não foram encontrados outros trabalhos publicados que estudem a codigestão entre soro e glicerina com foco da produção de biohidrogênio.

Tabela 5.17. Comparação entre os resultados obtidos neste trabalho na Fase II com resultados publicados na literatura que utilizaram soro ou glicerina para a produção de biohidrogênio.

\begin{tabular}{|c|c|c|c|c|}
\hline Substrato & Reator & $\begin{array}{c}\operatorname{PrM} \\
\left(\mathrm{molH}_{2} \cdot \mathrm{m}^{-3} \cdot \mathrm{d}^{-1}\right)\end{array}$ & $\begin{array}{c}\text { RMSA } \\
\left(\mathrm{molH}_{2} \cdot \mathrm{molSubstrato}^{-1}\right)\end{array}$ & Referência \\
\hline Glicerol & PBR & - & 1,05 & Ito et al. (2005) \\
\hline Glicerina & PBR & - & 1,12 & Ito et al. (2005) \\
\hline Glicerina & CSTR & - & 0,05 & $\begin{array}{l}\text { Termudo et al. } \\
\quad \text { (2008) }\end{array}$ \\
\hline Glicerol & AnSBBR & 100,9 & 1,19 & $\begin{array}{l}\text { Lovato et. al } \\
\quad(2015)\end{array}$ \\
\hline Glicerina & AnSBBR & 9,7 & 0,10 & $\begin{array}{l}\text { Lovato et. al } \\
\quad(2015)\end{array}$ \\
\hline Glicerina & AnSBBR & 101,8 & 0,60 & Este trabalho \\
\hline Soro & AnSBBR & 48,4 & 1,04 & $\begin{array}{l}\text { Lima et al. } \\
\quad(2015)\end{array}$ \\
\hline Soro & $\begin{array}{c}\text { Reator } \\
\text { anaeróbio de } \\
\text { leito fixo e fluxo } \\
\text { ascendente }\end{array}$ & 44,6 & 1,10 & $\begin{array}{l}\text { Perna } \text { et al., } \\
\quad \text { (2013) }\end{array}$ \\
\hline Soro & $\begin{array}{c}\text { Reator } \\
\text { anaeróbio de } \\
\text { leito fluidizado }\end{array}$ & 128,5 & 1,27 & $\begin{array}{c}\text { Rosa et al. } \\
\text { (2014) }\end{array}$ \\
\hline Soro & $\begin{array}{l}\text { Reator tubular } \\
\text { de leito fixo }\end{array}$ & 13,9 & 0,50 & $\begin{array}{l}\text { Fernández et al } \\
\text { (2014) }\end{array}$ \\
\hline Soro & AnSBBR & 52,7 & 1,81 & Este trabalho \\
\hline Soro + Glicerina & AnSBBR & 91,3 & 1,52 & Este trabalho \\
\hline
\end{tabular}

É possível observar que tanto a produtividade molar quanto o rendimento molar neste trabalho foram muito bons quando comparados aos outros artigos, sendo que o rendimento 
encontrado na condição de codigestão foi superior ao de todos os trabalhos utilizados na comparação. Vale destacar ainda a estabilidade atingida pelo AnSBBR e a qualidade do biogás produzido, com altas concentrações de hidrogênio e sem traços de metano.

\subsubsection{Modelagem Cinética para os Ensaios de 6 a 10.}

A Figura 5.94 mostra os valores obtidos experimentalmente (marcadores) e os valores obtidos pelo modelo cinético ajustado (linhas), ambos ao longo do ciclo, para as principais variáveis monitoradas e que estão relacionadas com o entendimento do metabolismo acidogênico na condição de substrato puro (soro ou glicerina) e na condição de codigestão (soro e glicerina em proporções diferentes).

Analisando essas figuras é possível notar que o modelo foi eficiente em predizer os dados experimentais em relação à concentração de substrato, ácidos acético, propiônico, butírico, valérico e hidrogênio, validando a interpretação do comportamento dos parâmetros cinéticos nas diferentes condições experimentais implementadas.

Analisando, primeiramente, a influência da adição de glicerina nas rotas metabólicas, nota-se que a produção de hidrogênio no Ensaio $6\left(\mathrm{k}_{1 \mathrm{HAc}}=705,3 \mathrm{~h}^{-1}, \mathrm{k}_{1 \mathrm{H}}=12,6 \mathrm{~h}^{-1}, \mathrm{k}_{3 \mathrm{HBu}}=\right.$ $157,6 \mathrm{~h}^{-1}, \mathrm{k}_{3 \mathrm{H}}=10,6 \mathrm{~h}^{-1}$ ) vem predominante da conversão de substrato em ácido acético (Equação 1) como é recomendado por Das and Veziroglu (2001). No entanto, assim que 25\% de glicerina são adicionados ao meio, observa-se que a produção de hidrogênio pela conversão de substrato em ácido acético e em ácido butírico fica aproximadamente equivalente e essa tendência se mantém ao longo dos Ensaios 7, 8 e $9\left(\mathrm{k}_{1 \mathrm{HAc}}=0,2-2,4 \mathrm{~h}^{-1}\right.$, $\mathrm{k}_{1 \mathrm{H}}=0,1-0,8 \mathrm{~h}^{-1}, \mathrm{k}_{3 \mathrm{HBu}}=0,0-0,2 \mathrm{~h}^{-1}, \mathrm{k}_{3 \mathrm{H}}=0,2-0,8 \mathrm{~h}^{-1}$ ); como foi notado nos dados obtidos

experimentalmente. É possível notar também que não há grande relevância no hidrogênio produzido a partir do ácido valérico $\left(\mathrm{k}_{4 \mathrm{H}}=0,0-0,1 \mathrm{~h}^{-1}\right)$, como era esperado, pois a concentração de ácido valérico foi de, no máximo, 8,9\%.

Verificando agora as reações prejudicais a produção de hidrogênio (Equações 4.52 e 4.55), é possível inferir que a adição de glicerina diminui a influência tanto da produção de ácido propiônico quanto da produção de etanol (Ensaio 6: $\mathrm{k}_{2 \mathrm{HPr}}=23,2 \mathrm{~h}^{-1}$ e $\mathrm{k}_{5 \mathrm{ETOH}}=71,0 \mathrm{~h}^{-1}$; Ensaios 7 a 9: $\mathrm{k}_{2 \mathrm{HPr}}=0,0-1,9 \mathrm{~h}^{-1}$ e $\left.\mathrm{k}_{5 \mathrm{ETOH}}=0,1-0,6 \mathrm{~h}^{-1}\right)$, o que é corroborado pelos dados experimentais, pois a adição de glicerina melhorou a produtividade de hidrogênio em relação ao ensaio com monodigestão do soro.

A acetogênese (Equações 4.56, 4.57 e 4.58) tem um papel muito menor na produção de hidrogênio quando comparada com a acidogênese, o que está de acordo com a teoria de digestão anaeróbia, como é possível ver pelos parâmetros $\mathrm{k}_{6 \mathrm{H}}, \mathrm{k}_{7 \mathrm{H}}, \mathrm{k}_{8 \mathrm{H}}$ de todos os ensaios. 
168

Entretanto, é possível notar que a adição de glicerina deixa a acetogênese ligeiramente menos acentuada (enquanto os parâmetros k7H e k8H são nulos para os Ensaios 8, 9 e 10, os mesmos têm valores baixos para os Ensaios 6 e 7).

A respeito da metanogênese, a mesma foi completamente inibida em todos os ensaios, daí são justificados os valores de $\mathrm{k}_{9 \mathrm{HAc}}, \mathrm{k}_{9 \mathrm{M}}, \mathrm{k}_{10 \mathrm{H}}, \mathrm{k}_{10 \mathrm{M}}$ iguais a $0 \mathrm{~h}^{-1} \mathrm{em}$ todas as condições.

Finalmente, em relação ao consumo de substrato por microrganismos do gênero Megasphaera, é possível observar que ele é aumentado nos Ensaio 6 e $9\left(\mathrm{k}_{11 \mathrm{HAc}}=15,6 \mathrm{e}\right.$

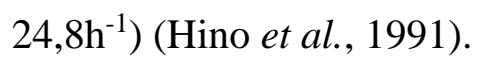

Tabela 5.18. Parâmetros do modelo cinético para a Fase II.

\begin{tabular}{|c|c|c|c|c|c|c|}
\hline Fase & Parâmetro & 6 & 7 & 8 & 9 & 10 \\
\hline \multirow{7}{*}{$\begin{array}{l}\text { Hidrólise e } \\
\text { Acidogênese } \\
\text { (positivo para } \\
\text { produção } \mathrm{H}_{2} \text { ) }\end{array}$} & $\mathrm{k}_{1 \mathrm{~S}}^{\prime}\left(\mathrm{h}^{-1}\right)$ & 68,7 & 1,7 & 3,0 & 0,7 & 2,0 \\
\hline & $\mathrm{k}_{1 \mathrm{HAc}}\left(\mathrm{h}^{-1}\right)$ & 705,3 & 0,2 & 2,2 & 2,4 & 0,7 \\
\hline & $\mathrm{k}_{1 \mathrm{H}}\left(\mathrm{h}^{-1}\right)$ & 12,6 & 0,7 & 0,8 & 0,1 & 0,6 \\
\hline & $\mathrm{k}_{3 \mathrm{HBu}}\left(\mathrm{h}^{-1}\right)$ & 157,6 & 0,0 & 0,1 & 0,2 & 0,0 \\
\hline & $\mathrm{k}_{3 \mathrm{H}}\left(\mathrm{h}^{-1}\right)$ & 10,6 & 0,7 & 0,8 & 0,2 & 0,6 \\
\hline & $\mathrm{k}_{4 \mathrm{HVa}}\left(\mathrm{h}^{-1}\right)$ & 0,2 & 0,1 & 0,3 & 0,0 & 0,1 \\
\hline & $\mathrm{k}_{4 \mathrm{H}}\left(\mathrm{h}^{-1}\right)$ & 0,0 & 0,1 & 0,1 & 0,0 & 0,0 \\
\hline \multirow{3}{*}{$\begin{array}{c}\text { Hidrólise e } \\
\text { Acidogênese } \\
\text { (negativo para } \\
\text { produção } \mathrm{H}_{2} \text { ) }\end{array}$} & $\mathrm{k}_{2 \mathrm{HPr}}\left(\mathrm{h}^{-1}\right)$ & 23,2 & 0,4 & 1,9 & 0,3 & 0,0 \\
\hline & $\mathrm{k}_{2 \mathrm{H}}\left(\mathrm{h}^{-1}\right)$ & 0,0 & 0,0 & 0,0 & 0,0 & 0,1 \\
\hline & $\mathrm{k}_{5 \mathrm{ETOH}}\left(\mathrm{h}^{-1}\right)$ & 71,0 & 0,3 & 0,6 & 0,2 & 0,1 \\
\hline \multirow{9}{*}{$\begin{array}{c}\text { Acetogênese } \\
\text { (positivo para } \\
\text { produção de } H_{2} \text { ) }\end{array}$} & $\mathrm{k}_{6 \mathrm{HPr}}\left(\mathrm{h}^{-1}\right)$ & 0,1 & 3,3 & 2,4 & 4,9 & 2,9 \\
\hline & $\mathrm{k}_{6 \mathrm{HAc}}\left(\mathrm{h}^{-1}\right)$ & 137,7 & 2,0 & 2,6 & 26,8 & 0,4 \\
\hline & $\mathrm{k}_{6 \mathrm{H}}\left(\mathrm{h}^{-1}\right)$ & 0,0 & 0,0 & 0,0 & 0,0 & 0,0 \\
\hline & $\mathrm{k}_{7 \mathrm{HPr}}\left(\mathrm{h}^{-1}\right)$ & 0,0 & 1,6 & 14,8 & 1,7 & 3,1 \\
\hline & $\mathrm{k}_{7 \mathrm{HBu}}\left(\mathrm{h}^{-1}\right)$ & 0,1 & 0,0 & 0,0 & 1,1 & 1,0 \\
\hline & $\mathrm{k}_{7 \mathrm{H}}\left(\mathrm{h}^{-1}\right)$ & 0,1 & 0,3 & 0,0 & 0,0 & 0,0 \\
\hline & $\mathrm{k}_{8 \mathrm{HBu}}\left(\mathrm{h}^{-1}\right)$ & 0,0 & 0,6 & 0,1 & 6,5 & 5,0 \\
\hline & $\mathrm{k}_{8 \mathrm{HVa}}\left(\mathrm{h}^{-1}\right)$ & 0,0 & 0,0 & 0,0 & 0,0 & 0,0 \\
\hline & $\mathrm{k}_{8 \mathrm{H}}\left(\mathrm{h}^{-1}\right)$ & 0,0 & 0,0 & 0,0 & 0,0 & 0,0 \\
\hline \multirow{4}{*}{$\begin{array}{c}\text { Metanogênese } \\
\text { (negativo para } \\
\text { produção de } \mathrm{H}_{2} \text { ) }\end{array}$} & $\mathrm{k}_{9 \mathrm{HAc}}\left(\mathrm{h}^{-1}\right)$ & 0.0 & 0.0 & 0.0 & 0.0 & 0.0 \\
\hline & $\mathrm{k}_{9 \mathrm{M}}\left(\mathrm{h}^{-1}\right)$ & 0.0 & 0.0 & 0.0 & 0.0 & 0.0 \\
\hline & $\mathrm{k}_{10 \mathrm{H}}\left(\mathrm{h}^{-1}\right)$ & 0.0 & 0.0 & 0.0 & 0.0 & 0.0 \\
\hline & $\mathrm{k}_{10 \mathrm{M}}\left(\mathrm{h}^{-1}\right)$ & 0.0 & 0.0 & 0.0 & 0.0 & 0.0 \\
\hline $\begin{array}{l}\text { Crescimento } \\
\text { celular }\end{array}$ & $\mathrm{k}_{11 \mathrm{HAc}}\left(\mathrm{h}^{-1}\right)$ & 15,6 & 1,4 & 4,0 & 24,8 & 1,5 \\
\hline
\end{tabular}



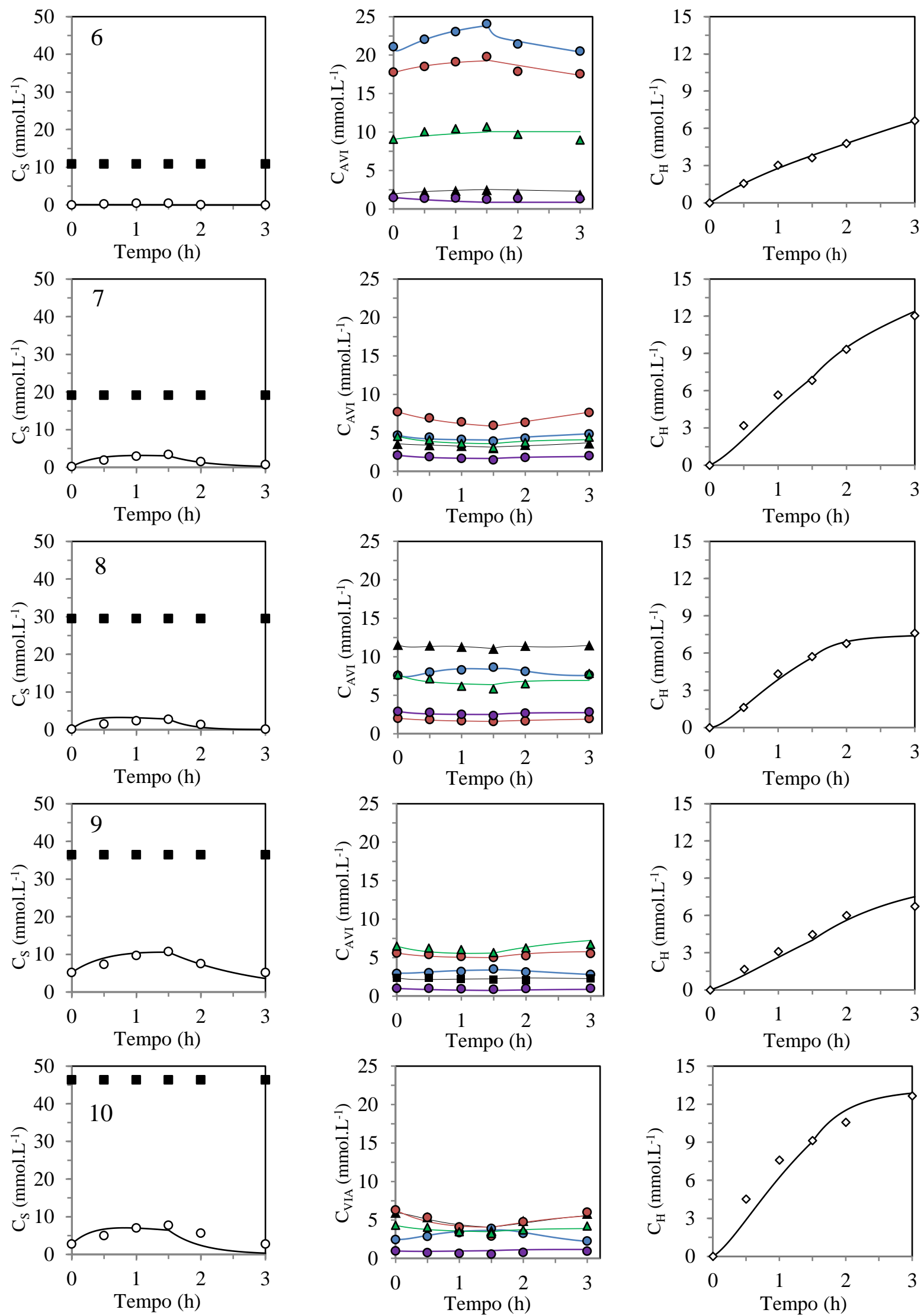

Figura 5.94. Perfis de substrato $(\bullet)$, efluente filtrado $(\circ)$, ácido acético $(\bullet)$, ácido propiônico $(\boldsymbol{\Delta})$, ácido butírico $(\bullet)$, etanol $(\Delta)$, ácido valérico $(\bullet)$ e hidrogênio $(\diamond)$ (valores experimentais e calculados pelo modelo). 


\subsection{FASE III - PRODUÇÃO DE BIOHIDROGÊNIO - INFLUÊNCIA DA CONCENTRAÇÃO DO AFLUENTE}

A Fase III compreendeu os Ensaios 11 e 12 e teve como objetivo encontrar a melhor concentração do afluente utilizando a melhor razão de mistura entre glicerina e soro que foi encontrada na Fase II (75\% soro e $25 \%$ glicerina). Ambos os ensaios foram operados com tempo de ciclo de $3 \mathrm{~h}$ em modo batelada alimentada. O Ensaio 11 teve concentração do afluente reduzida para $3000 \mathrm{mgDQO} . \mathrm{L}^{-1}$ e o Ensaio 12, aumentada para $7000 \mathrm{mgDQO} . \mathrm{L}^{-1}$.

\subsubsection{Ensaio 11 (75\% Soro e 25\% Glicerina - 3000 mgDQO.L $\left.{ }^{-1}-3 \mathrm{~h}-\mathrm{BA}\right)$}

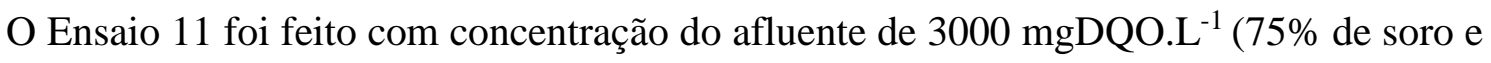
$25 \%$ de glicerina), tempo de ciclo de $3 \mathrm{~h}$ e tempo de alimentação de $1,5 \mathrm{~h}$.

O valor real da COAV foi de 10,1 gDQO.L $\mathrm{L}^{-1} \cdot \mathrm{d}^{-1}$ e a CORV atingida foi de 3,0 gDQO.L ${ }^{1} \cdot \mathrm{d}^{-1}$, novamente, o sistema apresentou uma baixa remoção de matéria orgânica. O afluente teve, em média, $1731 \mathrm{mgCarboidratos.L^{-1 }}$ (COAV foi de 5,9 gCarboidratos. $\mathrm{L}^{-1} \cdot \mathrm{d}^{-1}$ e a CORV atingida foi de 5,8 gCarboidratos. $\mathrm{L}^{-1} \cdot \mathrm{d}^{-1}$ ) e $609 \mathrm{mgGlicerina} . \mathrm{L}^{-1}$ (COAV foi de 2,1 gGlicerina. $\mathrm{L}^{-1} \cdot \mathrm{d}^{-1}$ e a CORV atingida foi de 2,0 gGlicerina. $\left.\mathrm{L}^{-1} \cdot \mathrm{d}^{-1}\right)$, de acordo com a Tabela 5.19.

O monitoramento diário apresentou um baixo consumo de matéria orgânica na forma de DQO, com média de concentração afluente não filtrada de $2989 \mathrm{mgDQO}$. $^{-1}$, efluente não filtrada $2250 \mathrm{mgDQO} . \mathrm{L}^{-1}$ e de efluente filtrada de $2110 \mathrm{mgDQO} . \mathrm{L}^{-1}$, o que representa uma remoção média para amostras não filtradas de 25\% e para amostras filtradas de $29 \%$ (Figura 5.95) - valores próximos aos obtidos nos ensaios da Fase II.

Em relação ao monitoramento diário de carboidratos, o mesmo novamente apresentou um ótimo consumo, com média de concentração afluente não filtrada de $1731 \mathrm{mgCarboidratos.} \mathrm{L}^{-1}$, efluente não filtrado $22 \mathrm{mgCarboidratos.} \mathrm{L}^{-1}$ e de efluente filtrado $15 \mathrm{mgCarboidratos.} \mathrm{L}^{-1}$, o que representa eficiência média de remoção para amostras não filtradas de 98,7\% e para amostras filtradas de 99,1\% (Figura 5.96).

O monitoramento diário de glicerina apresentou média de concentração afluente não filtrada de $609 \mathrm{mgGlicerina} . \mathrm{L}^{-1}$, efluente não filtrado $23 \mathrm{mgGlicerina} . \mathrm{L}^{-1}$ e de efluente filtrado

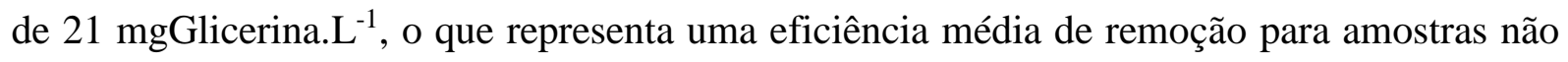
filtradas de 96 e filtradas de 97\% (Figura 5.97). 
Tabela 5.19. Parâmetros médios monitorados no Ensaio 11.

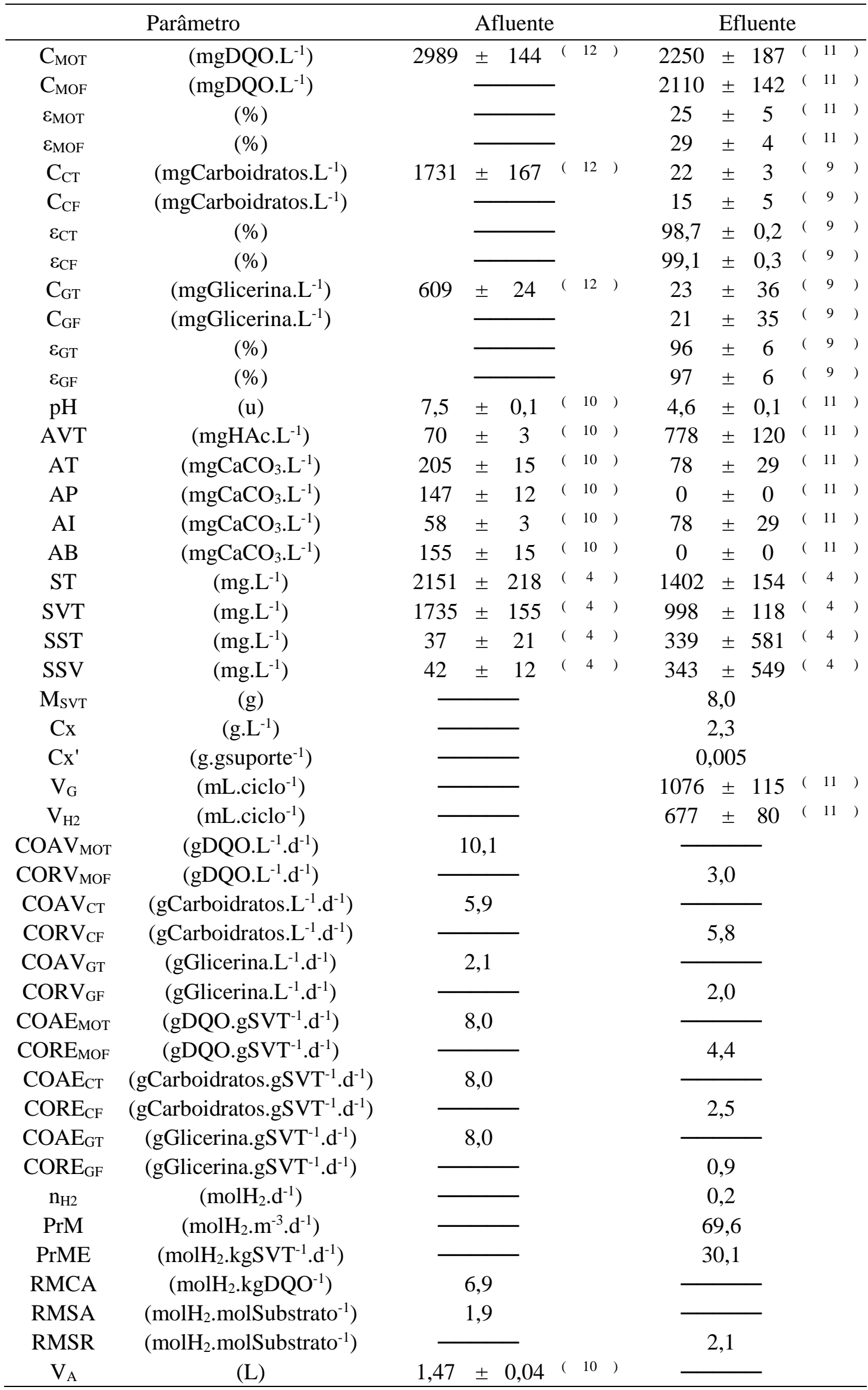

(*) Entre parênteses o número de amostras considerado no cálculo da média 

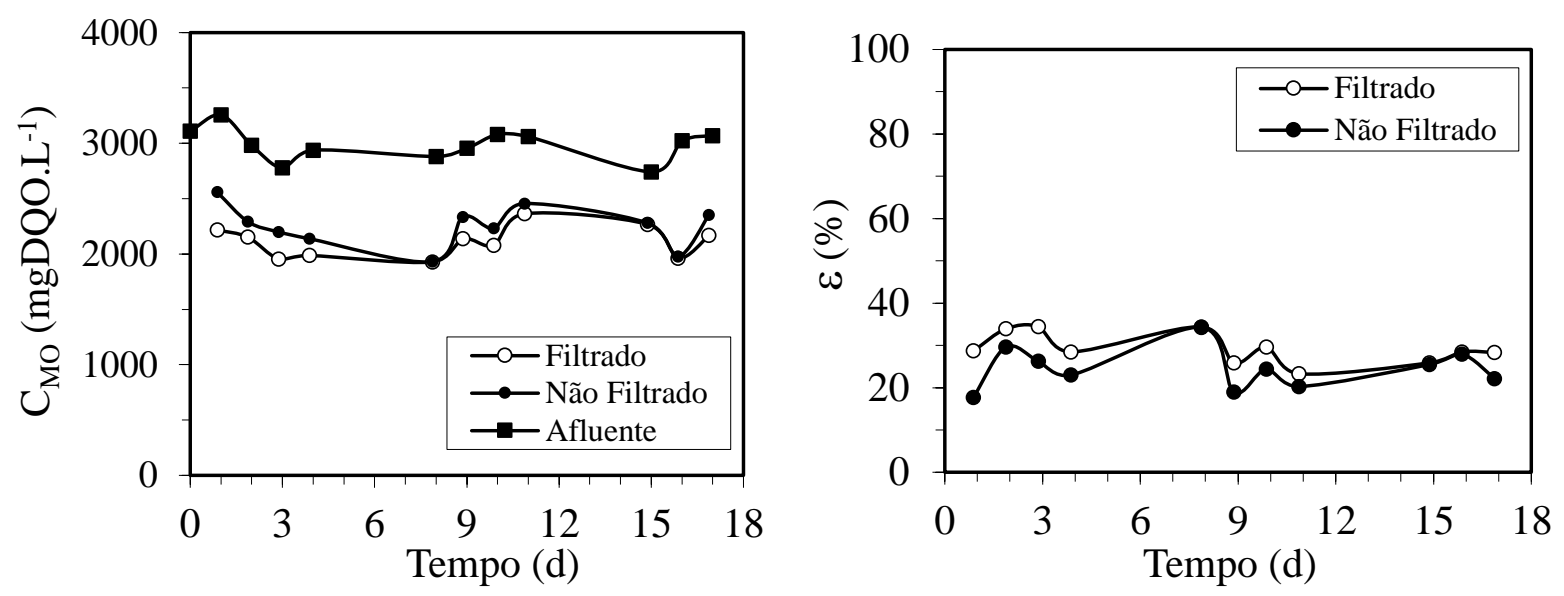

Figura 5.95. Concentração e eficiência de remoção de matéria orgânica na forma de DQO no Ensaio 11: - - afluente amostras não filtradas; • - efluente amostras não filtradas; $\bigcirc$ - efluente amostras filtradas.
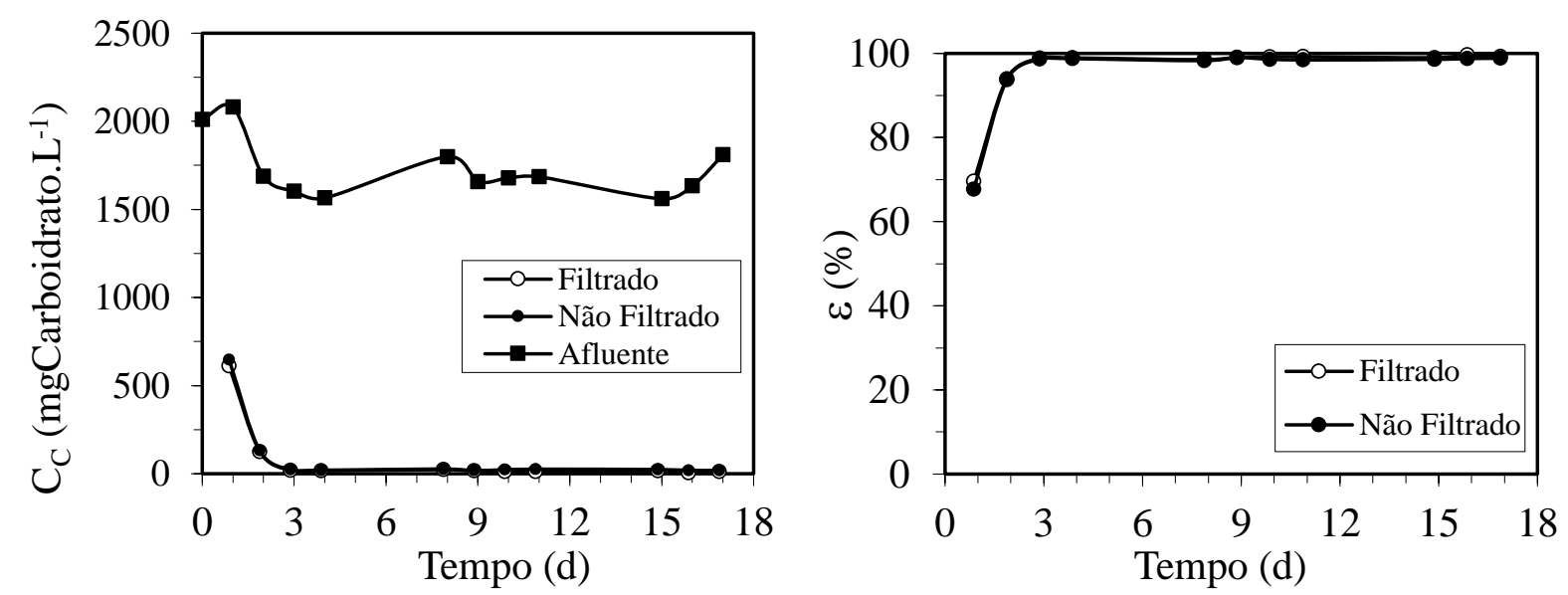

Figura 5.96. Concentração e eficiência de remoção na forma de carboidratos no Ensaio 11: - - afluente amostras não filtradas; • - efluente amostras não filtradas; ○ - efluente amostras filtradas.
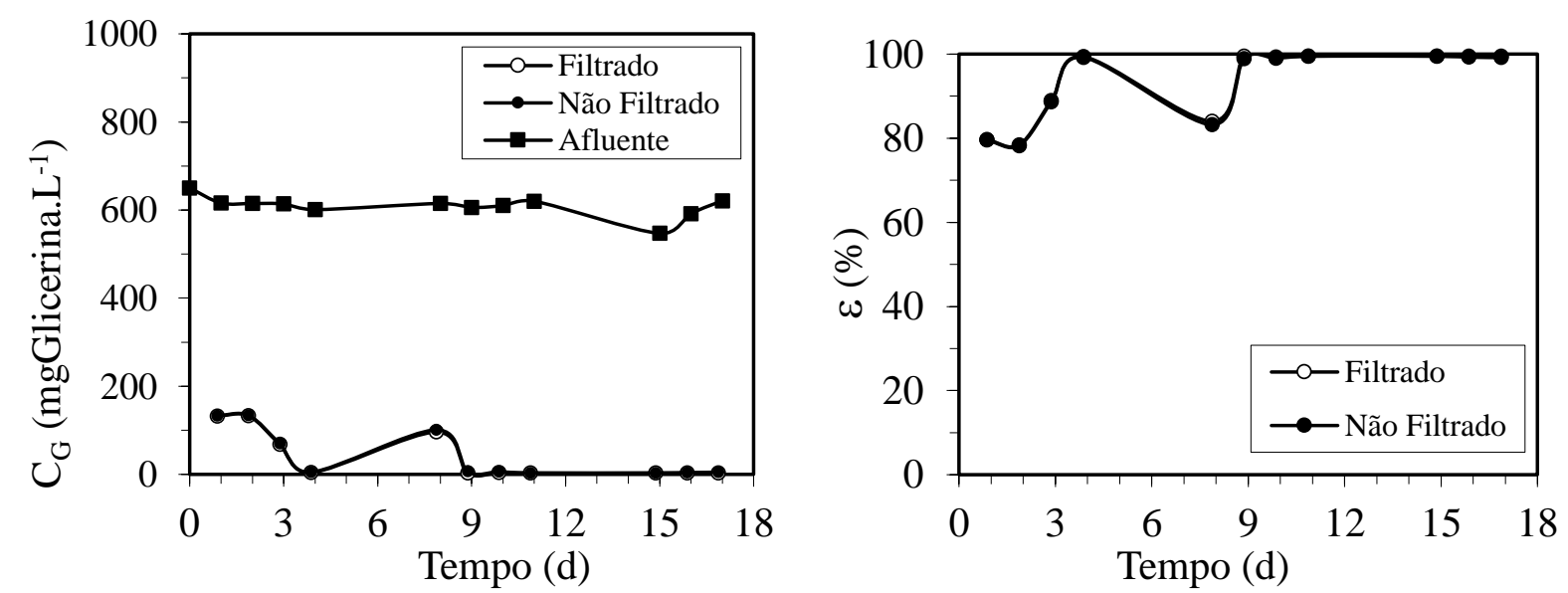

Figura 5.97. Concentração e eficiência de remoção na forma de glicerina no Ensaio 11: - - afluente amostras não filtradas; • - efluente amostras não filtradas; ○ - efluente amostras filtradas

A média do pH afluente foi de 7,5 e do efluente de 4,6. A alcalinidade total no afluente teve média de $205 \mathrm{mgCaCO} 3 . \mathrm{L}^{-1}$ sendo que a mesma foi consumida até uma média de 
$78 \mathrm{mgCaCO}_{3} \cdot \mathrm{L}^{-1}$. A média de AVT no afluente foi de $70 \mathrm{mgHAc} . \mathrm{L}^{-1}$ e a média de AVT no efluente de 778 mgHAc. $\mathrm{L}^{-1}$, o que representa uma concentração menor de AVT em relação ao Ensaio 7, ou seja, a mesma é influenciada pela concentração do afluente.

A produção de biogás, em aspecto quantitativo, e a distribuição dos gases que compõem o biogás no final do ciclo podem ser observadas pela Figura 5.98, com média de $1076 \mathrm{~mL}$ de biogás e $677 \mathrm{~mL}$ de hidrogênio, sendo que a porcentagem média de hidrogênio foi igual a $63 \%$. Este ensaio obteve qualidade e quantidade de biogás piores do que as obtidas no Ensaio 7, o que demonstra que a limitação de substrato influenciou diretamente (e negativamente) na produção de biogás. A produtividade molar de hidrogênio foi igual a $69,6 \mathrm{molH}_{2} \cdot \mathrm{m}^{-3} \cdot \mathrm{d}^{-1}$ contra $91,3 \mathrm{molH}_{2} \cdot \mathrm{m}^{-3} \cdot \mathrm{d}^{-1}$ do Ensaio 7 , uma redução de quase $24 \%$.
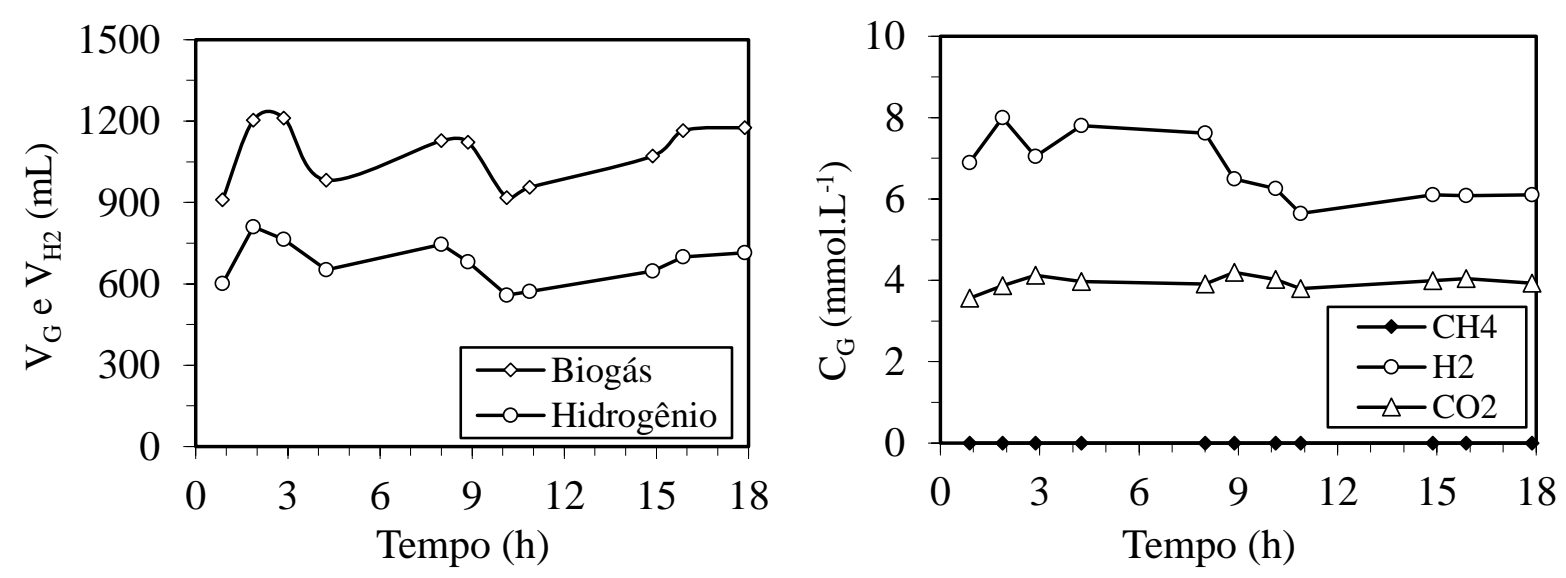

Figura 5.98. Volume de biogás $\left(\mathrm{V}_{\mathrm{G}}\right)$ e de hidrogênio $\left(\mathrm{V}_{\mathrm{H} 2}\right)$ nas $\mathrm{CNTP}$ e concentrações dos componentes do biogás no final do ciclo $\left(\mathrm{C}_{\mathrm{G}}\right)$ no Ensaio 11: $\diamond$ - Biogás; - Metano; $\bigcirc-$ Hidrogênio; $\Delta$ - Dióxido de Carbono.

A Figura 5.99 apresenta o perfil de DQO, de Carboidratos e de Glicerina, nota-se que há uma baixa variação na medida de DQO durante o ciclo, enquanto os perfis de carboidrato e de glicerina mostram variações maiores. Nestes últimos dois, é possível observar um ponto de máxima concentração em $1,5 \mathrm{~h}$ (que representa o final da alimentação do afluente) e o consumo desses dois substratos até o final do ciclo.

A Figura 5.100 apresenta os perfis de $\mathrm{pH}$, alcalinidade total e ácidos voláteis totais ao longo do ciclo. $\mathrm{O} \mathrm{pH}$ permanece constante ao longo do ciclo por volta de 4,5, bem como os ácidos voláteis totais por volta de $959 \mathrm{mgHAc} . \mathrm{L}^{-1}$. A alcalinidade fornecida pelo afluente não chega a ser totalmente consumida pelo processo. No geral, perfis bem próximos aos encontrados no Ensaio 7. 

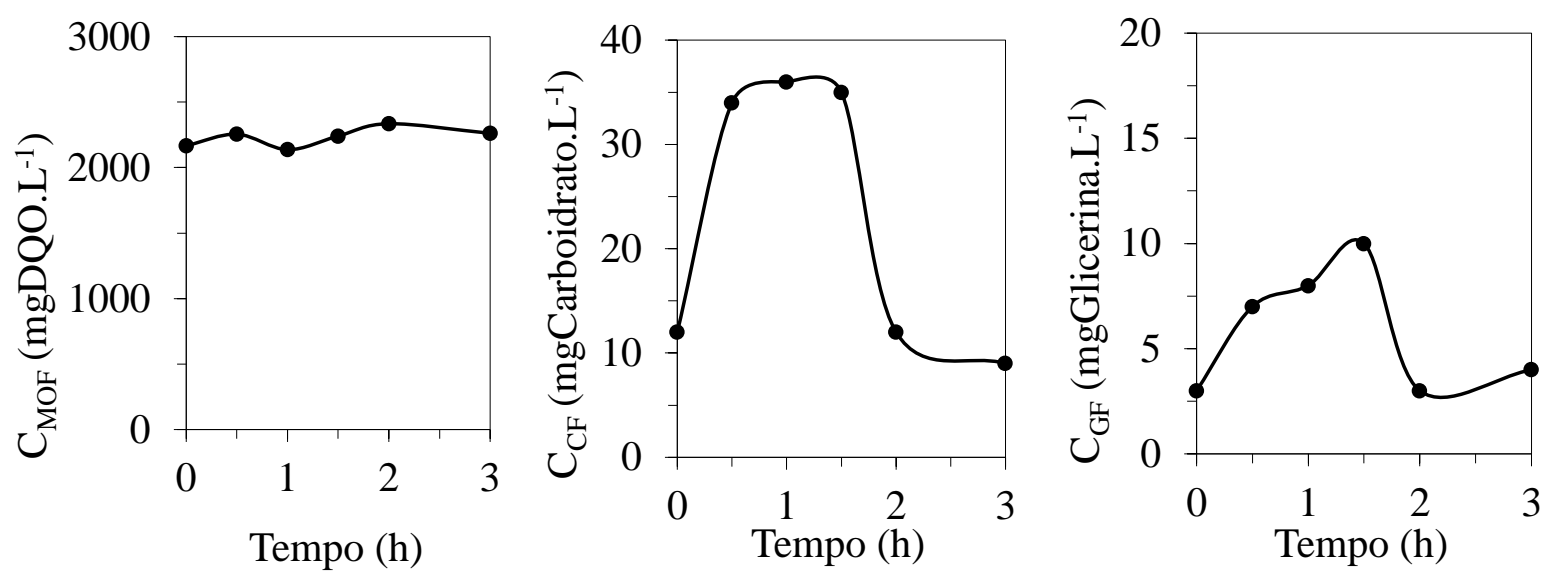

Figura 5.99. Concentração de matéria orgânica, carboidratos e de glicerina durante o ciclo no Ensaio 11.
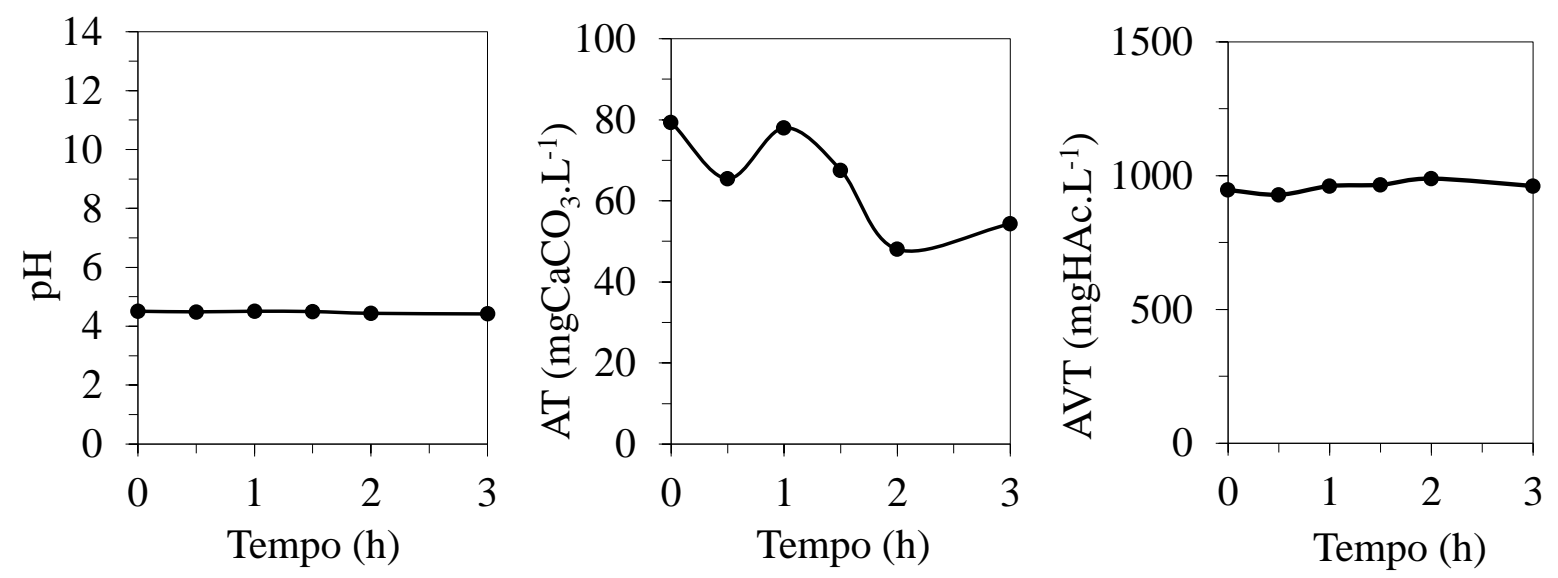

Figura 5.100. Valores de $\mathrm{pH}$, alcalinidade total (AT) e ácidos voláteis totais (AVT) no Ensaio 11.

O perfil dos compostos intermediários do metabolismo é apresentado na Figura 5.101. Neste ensaio, é possível verificar que há a predominância de ácido acético e de etanol, mas com o ponto de mínima concentração que acontece em 1,5 h, assim como no Ensaio 7.

A produção volumétrica acumulada de biogás e os desvios padrões de cada um dos pontos podem ser observados na Figura 5.102 e o perfil das concentrações de cada um dos gases e suas respectivas porcentagens podem ser observados na Figura 5.103. Houve baixa variação no volume de gás recolhido diariamente e o mesmo manteve-se estável ao longo do tempo; ao final do perfil, tinha-se $40 \%$ de $\mathrm{CO}_{2}$ e $60 \%$ de $\mathrm{H}_{2}$. 


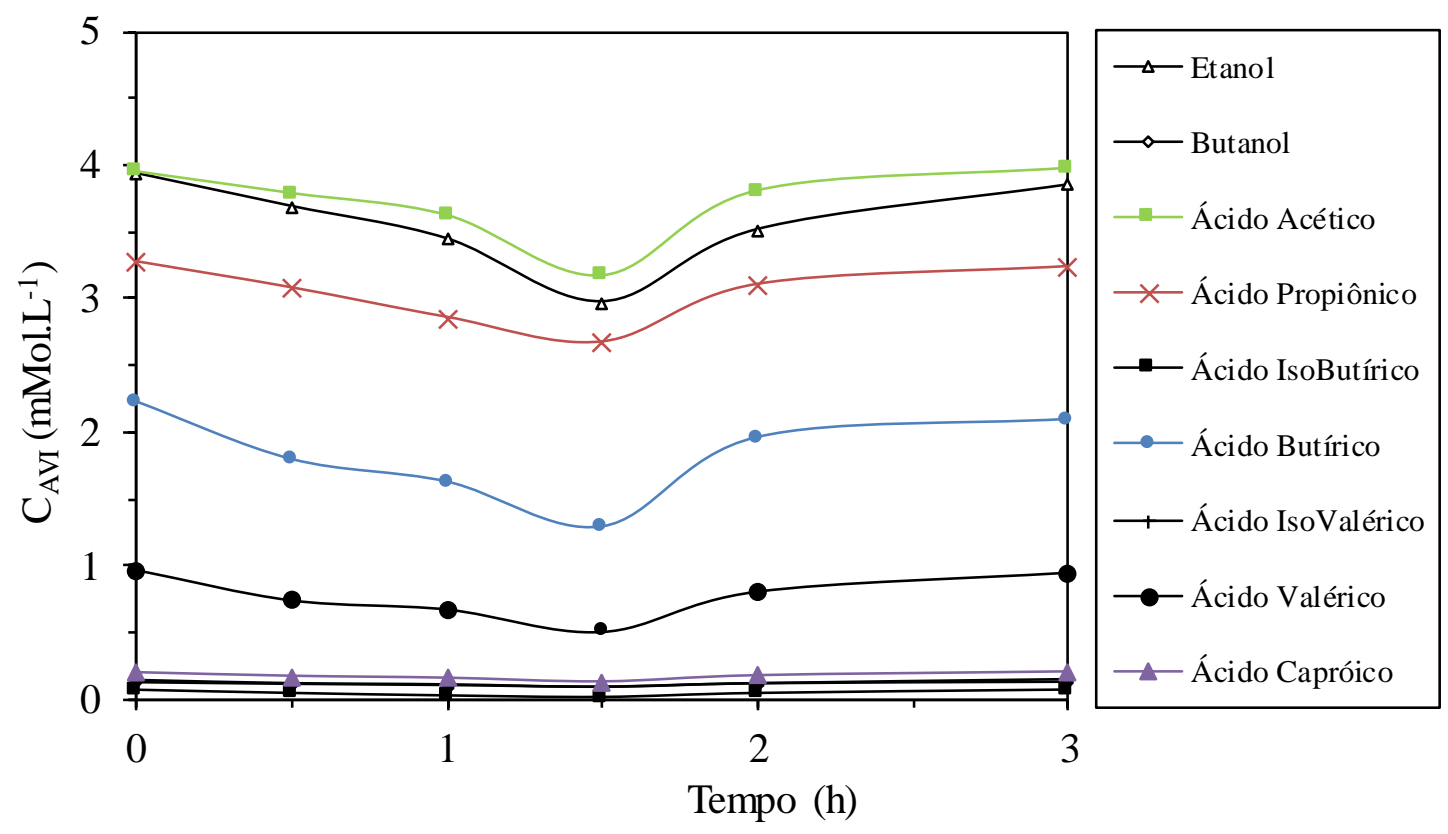

Figura 5.101. Concentração dos compostos intermediários ao longo do ciclo no Ensaio 11: $\Delta$ etanol; $\diamond$ butanol; $\square$ - ácido acético; -X- ácido propiônico; - - ácido isobutírico; $\bullet$ - ácido butírico; + ácido isovalérico $\bullet$ - ácido valérico; $\boldsymbol{\Delta}$ - ácido capróico.

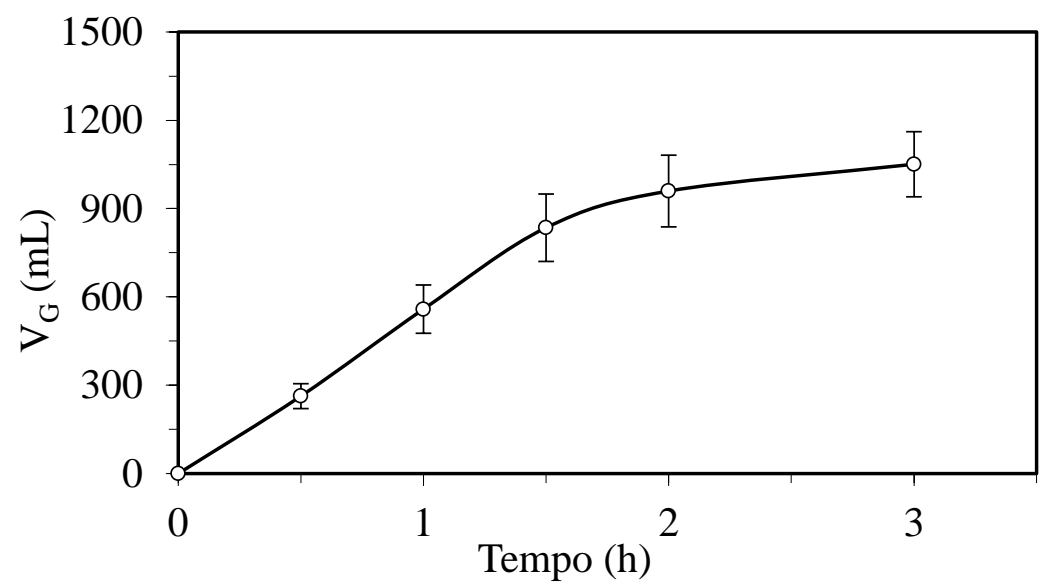

Figura 5.102. Produção volumétrica média acumulada do biogás durante o ciclo no Ensaio 11.
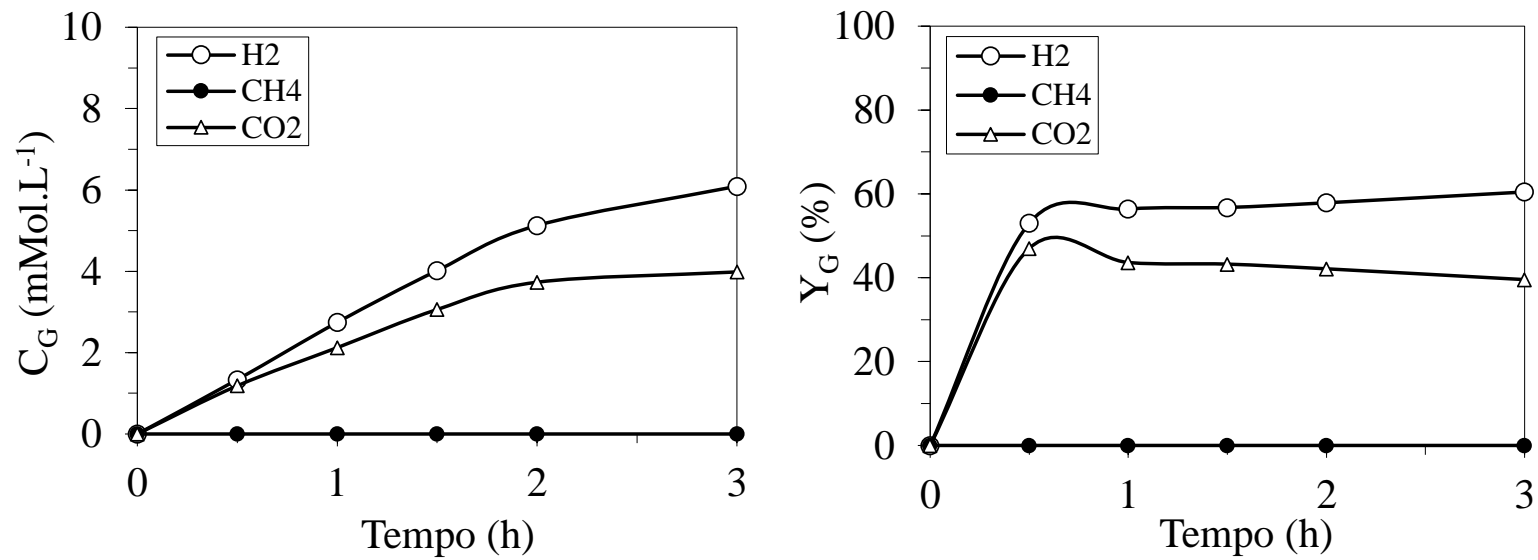

Figura 5.103. Concentração dos compostos do biogás durante o ciclo e suas respectivas porcentagens no Ensaio 11: $\odot-\mathrm{H}_{2} ; \bullet-\mathrm{CH}_{4} ; \Delta-\mathrm{CO}_{2}$ 


\subsubsection{Ensaio 12 (75\% Soro e 25\% Glicerina - 7000 mgDQO.L $\left.{ }^{-1}-3 \mathrm{~h}-\mathrm{BA}\right)$}

O Ensaio 12 foi feito com concentração do afluente de $7000 \mathrm{mgDQO} . \mathrm{L}^{-1}$ (75\% de soro e $25 \%$ de glicerina), tempo de ciclo de 3 h e tempo de alimentação de $2 \mathrm{~h}$. A Tabela 5.20 mostra os parâmetros médios monitorados neste ensaio.O valor real da COAV foi de 23,9 gDQO.L' ${ }^{1} . \mathrm{d}^{-1}$ e a CORV atingida foi de $4,7 \mathrm{gDQO} \cdot \mathrm{L}^{-1} \cdot \mathrm{d}^{-1}$, como era esperado. O afluente teve, em média, 4485 mgCarboidratos. $\mathrm{L}^{-1}$ (COAV foi de 15,4 gCarboidratos. $\mathrm{L}^{-1} \cdot \mathrm{d}^{-1}$ e a CORV atingida foi de 15,2 gCarboidratos. $\mathrm{L}^{-1} \cdot \mathrm{d}^{-1}$ ) e $1480 \mathrm{mgGlicerina} . \mathrm{L}^{-1}$ (COAV foi de $5,1 \mathrm{gGlicerina} . \mathrm{L}^{-1} \cdot \mathrm{d}^{-1}$ e a CORV atingida foi de $\left.4,9 \mathrm{gGlicerina} \cdot \mathrm{L}^{-1} \cdot \mathrm{d}^{-1}\right)$.

O monitoramento diário apresentou um baixo consumo de matéria orgânica na forma de DQO, com média de concentração afluente não filtrada de $6955 \mathrm{mgDQO} . \mathrm{L}^{-1}$, efluente não filtrada $5774 \mathrm{mgDQO} . \mathrm{L}^{-1}$ e de efluente filtrada de $5586 \mathrm{mgDQO} . \mathrm{L}^{-1}$, o que representa uma remoção média para amostras não filtradas de 16\% e para amostras filtradas de 19\% (Figura 5.104) - valores ainda mais baixos do que os encontrados até agora.

O monitoramento diário de carboidratos apresentou um excelente consumo, com média de concentração afluente não filtrada de $4485 \mathrm{mgCarboidratos.} \mathrm{L}^{-1}$, efluente não filtrado

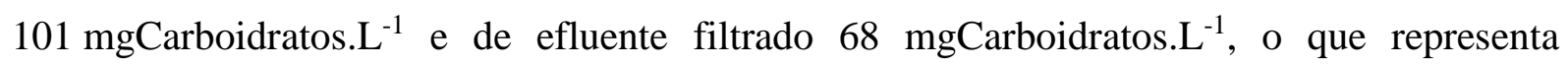
eficiência média de remoção para amostras não filtradas de $98 \%$ e para amostras filtradas de 98\% (Figura 5.105).

Em relação ao monitoramento da glicerina, a média de concentração afluente não

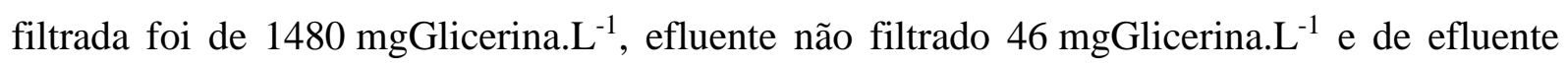
filtrado de 45 mgGlicerina. $\mathrm{L}^{-1}$, o que representa uma eficiência média de remoção para amostras não filtradas e filtradas de $97 \%$ (Figura 5.106).

A média do $\mathrm{pH}$ afluente foi de 7,7 e do efluente de 4,3. A alcalinidade total no afluente teve média de $522 \mathrm{mgCaCO} 3 . \mathrm{L}^{-1}$ sendo que a mesma foi consumida até uma média de $126 \mathrm{mgCaCO}_{3} \cdot \mathrm{L}^{-1}$. A média de AVT no afluente foi de $137 \mathrm{mgHAc} . \mathrm{L}^{-1}$ e a média de AVT no efluente de 1461 mgHAc. $\mathrm{L}^{-1}$. Neste ensaio, houve grande dificuldade em controlar o $\mathrm{pH}$ do efluente: o pH inicial era de 4,2 e houve uma queda contínua até 3,8 mesmo aumentando o bicarbonato de sódio que era adicionado ao meio, sendo observado que na faixa de $\mathrm{pH}$ entre 3,8 e 4,3 houve uma significativa redução na produção de hidrogênio. Assim que o pH do efluente retornou a 4,5 (pelo aumento da suplementação de bicarbonato no afluente para $1.4 \mathrm{gNaHCO}$. $\mathrm{gCOD}^{-1}$ ), a produção de hidrogênio aumentou e atingiu o maior valor dentre todos os ensaios $\left(129 \mathrm{molH}_{2} \cdot \mathrm{m}^{-3} \cdot \mathrm{d}^{-1}\right)$, como se vê na Figura 5.107 . 
Tabela 5.20. Parâmetros médios monitorados no Ensaio 12.

\begin{tabular}{|c|c|c|c|c|c|c|c|c|c|}
\hline \multicolumn{2}{|r|}{ Parâmetro } & \multicolumn{5}{|c|}{ Afluente } & \multicolumn{3}{|c|}{ Efluente } \\
\hline $\mathrm{C}_{\text {MOT }}$ & $\left(\mathrm{mgDQO} . \mathrm{L}^{-1}\right)$ & 6955 & \pm 249 & $(1$ & $11 \quad$ & ) & $5774 \pm 332$ & ( & 11 \\
\hline $\mathrm{C}_{\mathrm{MOF}}$ & $\left(\mathrm{mgDQO} \cdot \mathrm{L}^{-1}\right)$ & & & & & & $5586 \pm 383$ & ( & $11)$ \\
\hline$\varepsilon_{\mathrm{MOT}}$ & $(\%)$ & & & & & & $16 \pm 4$ & ( & $11)$ \\
\hline$\varepsilon_{\mathrm{MOF}}$ & $(\%)$ & & 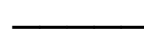 & & & & \pm 6 & ( & $11)$ \\
\hline $\mathrm{C}_{\mathrm{CT}}$ & (mgCarboidratos. $\mathrm{L}^{-1}$ ) & 4485 & \pm 182 & $(1$ & $11)$ & & $101 \pm 96$ & ( & 5 \\
\hline $\mathrm{C}_{\mathrm{CF}}$ & (mgCarboidratos. $\mathrm{L}^{-1}$ ) & & & & & & $68 \pm 87$ & ( & 5 \\
\hline$\varepsilon_{\mathrm{CT}}$ & $(\%)$ & & & & & & \pm 2 & ( & 5 \\
\hline$\varepsilon_{\mathrm{CF}}$ & $(\%)$ & & & & & & \pm 2 & ( & 5 \\
\hline $\mathrm{C}_{\mathrm{GT}}$ & $\left(\right.$ mgGlicerina. $\left.L^{-1}\right)$ & 1480 & \pm 75 & $(1$ & $11)$ & & \pm 58 & ( & 5 \\
\hline $\mathrm{C}_{\mathrm{GF}}$ & (mgGlicerina. $\mathrm{L}^{-1}$ ) & & & & & & $45 \pm 58$ & ( & 5 \\
\hline$\varepsilon_{\mathrm{GT}}$ & $(\%)$ & & & & & & $97 \pm 4$ & ( & 5 \\
\hline$\varepsilon_{\mathrm{GF}}$ & $(\%)$ & & & & & & $97 \pm 4$ & ( & 5 \\
\hline $\mathrm{pH}$ & (u) & 7,7 & $\pm 0,2$ & $(1$ & $11)$ & ) & $4,3 \pm 0,4$ & ( & $11)$ \\
\hline AVT & $\left(\mathrm{mgHAc} . \mathrm{L}^{-1}\right)$ & 137 & \pm 16 & $(1$ & $11)$ & ) & $1461 \pm 561$ & ( & 11 \\
\hline AT & $\left(\mathrm{mgCaCO}_{3} \cdot \mathrm{L}^{-1}\right)$ & 522 & \pm 200 & $(1$ & $11)$ & ) & $196 \pm 283$ & ( & 11 \\
\hline $\mathrm{AP}$ & $\left(\mathrm{mgCaCO}_{3} \cdot \mathrm{L}^{-1}\right)$ & 370 & \pm 155 & $(1$ & $11)$ & ) & $0 \pm 0$ & ( & 11 \\
\hline AI & $\left(\mathrm{mgCaCO}_{3} \cdot \mathrm{L}^{-1}\right)$ & 152 & $\pm \quad 45$ & $(1$ & $11)$ & ) & $196 \pm 283$ & ( & 11 \\
\hline $\mathrm{AB}$ & $\left(\mathrm{mgCaCO}_{3} \cdot \mathrm{L}^{-1}\right)$ & 424 & \pm 196 & $(1$ & $11)$ & ) & \pm 0 & ( & 11 \\
\hline ST & $\left(\mathrm{mg} . \mathrm{L}^{-1}\right)$ & 5086 & \pm 354 & ( & $4 \quad)$ & ) & $3879 \pm 736$ & ( & $4)$ \\
\hline SVT & $\left(\mathrm{mg} \cdot \mathrm{L}^{-1}\right)$ & 3977 & \pm 252 & ( & $4 \quad)$ & ) & $2854 \pm 864$ & ( & 4 \\
\hline SST & $\left(\mathrm{mg} \cdot \mathrm{L}^{-1}\right)$ & 62 & \pm 15 & ( & $4 \quad)$ & ) & $91 \pm 57$ & ( & 4 \\
\hline SSV & $\left(\mathrm{mg} \cdot \mathrm{L}^{-1}\right)$ & 44 & \pm 17 & ( & $4 \quad)$ & ) & \pm 57 & ( & $4)$ \\
\hline $\mathrm{M}_{\mathrm{SVT}}$ & $(\mathrm{g})$ & & & & & & 18,4 & & \\
\hline $\mathrm{Cx}$ & $\left(\mathrm{g} \cdot \mathrm{L}^{-1}\right)$ & & 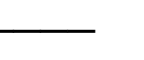 & & & & 5,3 & & \\
\hline $\mathrm{Cx}^{\prime}$ & $\left(\right.$ g.gsuporte $\left.{ }^{-1}\right)$ & & & & & & 0,012 & & \\
\hline $\mathrm{V}_{\mathrm{G}}$ & $\left(\mathrm{mL}\right.$. ciclo $\left.^{-1}\right)$ & & 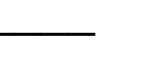 & & & & $2034 \pm 146$ & ( & 5 \\
\hline $\mathrm{V}_{\mathrm{H} 2}$ & $\left(\mathrm{~mL} \cdot \mathrm{ciclo}^{-1}\right)$ & & & & & & $1267 \pm 77$ & ( & 5 \\
\hline $\mathrm{COAV}_{\text {мот }}$ & $\left(\right.$ gDQO.L $\left.L^{-1} \cdot d^{-1}\right)$ & & 23,9 & & & & - & & \\
\hline $\mathrm{CORV}_{\mathrm{MOF}}$ & $\left(\mathrm{gDQO} \cdot \mathrm{L}^{-1} \cdot \mathrm{d}^{-1}\right)$ & & & & & & 4,7 & & \\
\hline $\mathrm{COAV}_{\mathrm{CT}}$ & (gCarboidratos. $\left.\mathrm{L}^{-1} \cdot \mathrm{d}^{-1}\right)$ & & 15,4 & & & & & & \\
\hline $\mathrm{CORV}_{\mathrm{CF}}$ & (gCarboidratos. $\mathrm{L}^{-1} \cdot \mathrm{d}^{-1}$ ) & & & & & & 15,2 & & \\
\hline $\mathrm{COAV}_{\mathrm{GT}}$ & (gGlicerina. $\mathrm{L}^{-1} \cdot \mathrm{d}^{-1}$ ) & & 5,1 & & & & & & \\
\hline $\mathrm{CORV}_{\mathrm{GF}}$ & (gGlicerina. $L^{-1} \cdot d^{-1}$ ) & & & & & & 4,9 & & \\
\hline $\mathrm{COAE}_{\mathrm{MOT}}$ & $\left(\right.$ gDQO.gSVT $\left.{ }^{-1} \cdot \mathrm{d}^{-1}\right)$ & & 15,3 & & & & & & \\
\hline $\mathrm{CORE}_{\mathrm{MOF}}$ & $\left(\right.$ gDQO.gSVT $\left.{ }^{-1} \cdot \mathrm{d}^{-1}\right)$ & & & & & & 5,5 & & \\
\hline $\mathrm{COAE}_{\mathrm{CT}}$ & $\left(\right.$ gCarboidratos.gSVT $\left.{ }^{-1} \cdot \mathrm{d}^{-1}\right)$ & & 15,3 & & & & & & \\
\hline $\mathrm{CORE}_{\mathrm{CF}}$ & $\left(\right.$ gCarboidratos.gSVT $\left.{ }^{-1} \cdot \mathrm{d}^{-1}\right)$ & & & & & & 3,5 & & \\
\hline $\mathrm{COAE}_{\mathrm{GT}}$ & (gGlicerina.gSVT ${ }^{-1} \cdot \mathrm{d}^{-1}$ ) & & 15,3 & & & & & & \\
\hline $\mathrm{CORE}_{\mathrm{GF}}$ & (gGlicerina.gSVT ${ }^{-1} \cdot \mathrm{d}^{-1}$ ) & & & & & & 1,2 & & \\
\hline $\mathrm{n}_{\mathrm{H} 2}$ & $\left(\mathrm{molH}_{2} \cdot \mathrm{d}^{-1}\right)$ & & & & & & 0,5 & & \\
\hline PrM & $\left(\mathrm{molH}_{2} \cdot \mathrm{m}^{-3} \cdot \mathrm{d}^{-1}\right)$ & & & & & & 129,0 & & \\
\hline PrME & $\left(\mathrm{molH}_{2} \cdot \mathrm{kgSVT}^{-1} \cdot \mathrm{d}^{-1}\right)$ & & $\bar{x}$ & & & & 29,5 & & \\
\hline RMCA & $\left(\mathrm{molH}_{2} \cdot \mathrm{kgDQO}^{-1}\right)$ & & 5,4 & & & & & & \\
\hline RMSA & $\left(\mathrm{molH}_{2} \cdot \mathrm{molSubstrato}^{-1}\right)$ & & 1,4 & & & & & & \\
\hline RMSR & $\left(\mathrm{molH}_{2} \cdot \mathrm{molSubstrato}^{-1}\right)$ & & & & & & 1,5 & & \\
\hline $\mathrm{V}_{\mathrm{A}}$ & $(\mathrm{L})$ & 1,51 & $\pm 0,03$ & $(1$ & $11)$ & 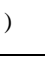 & & & \\
\hline
\end{tabular}

(*) Entre parênteses o número de amostras considerado no cálculo da média 

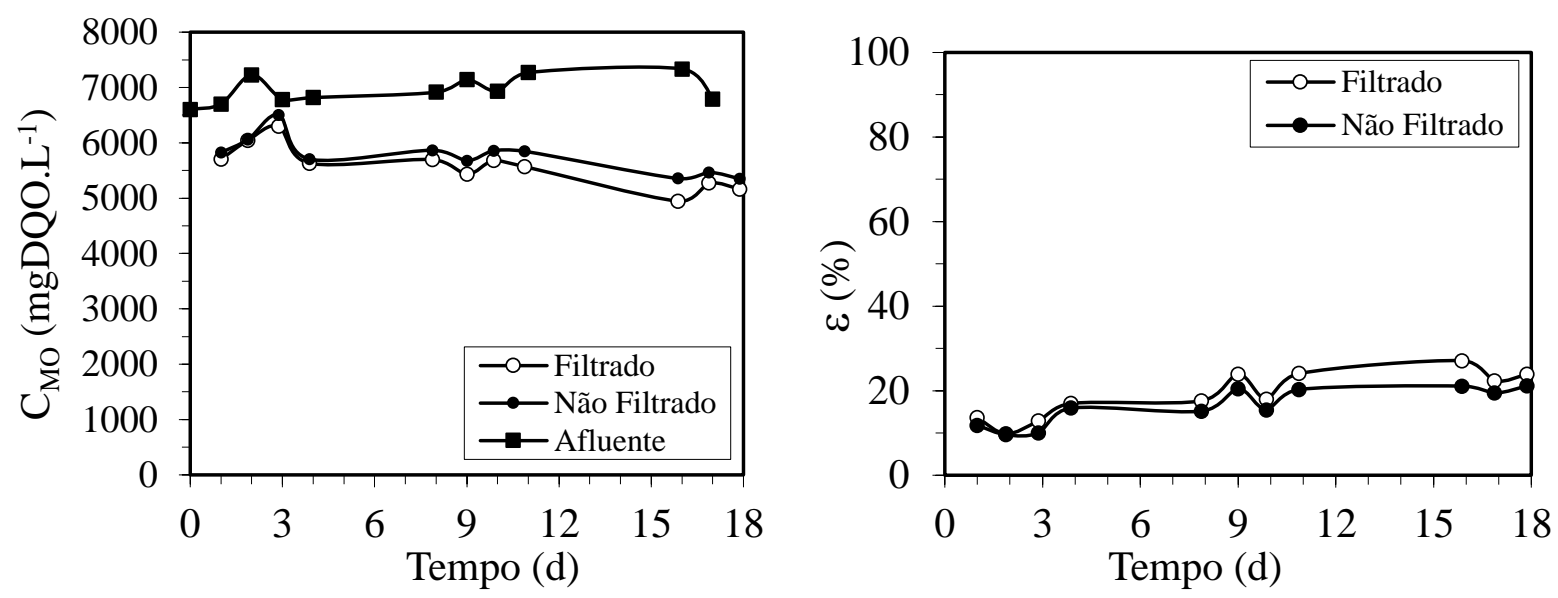

Figura 5.104. Concentração e eficiência de remoção de matéria orgânica na forma de DQO no Ensaio 12: - - afluente amostras não filtradas; • - efluente amostras não filtradas; ○ - efluente amostras filtradas.
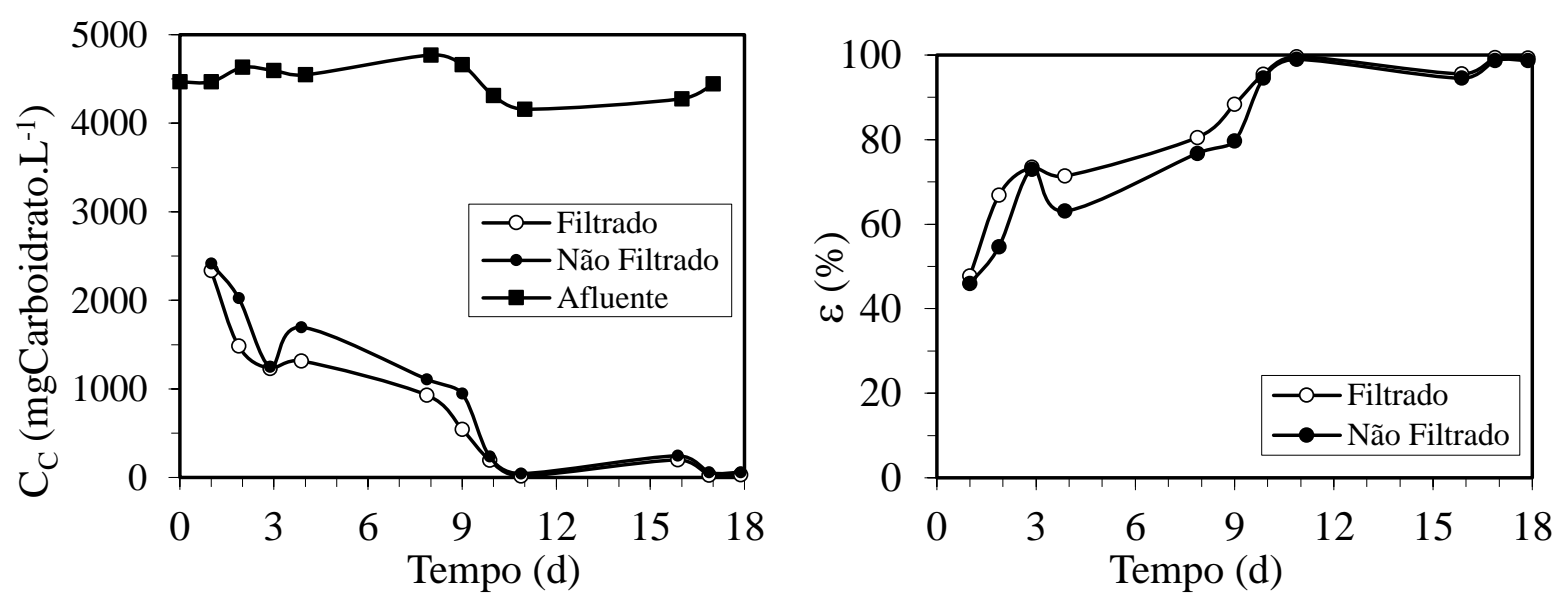

Figura 5.105. Concentração e eficiência de remoção na forma de carboidratos no Ensaio 12: - - afluente amostras não filtradas; • - efluente amostras não filtradas; $\bigcirc$ - efluente amostras filtradas.
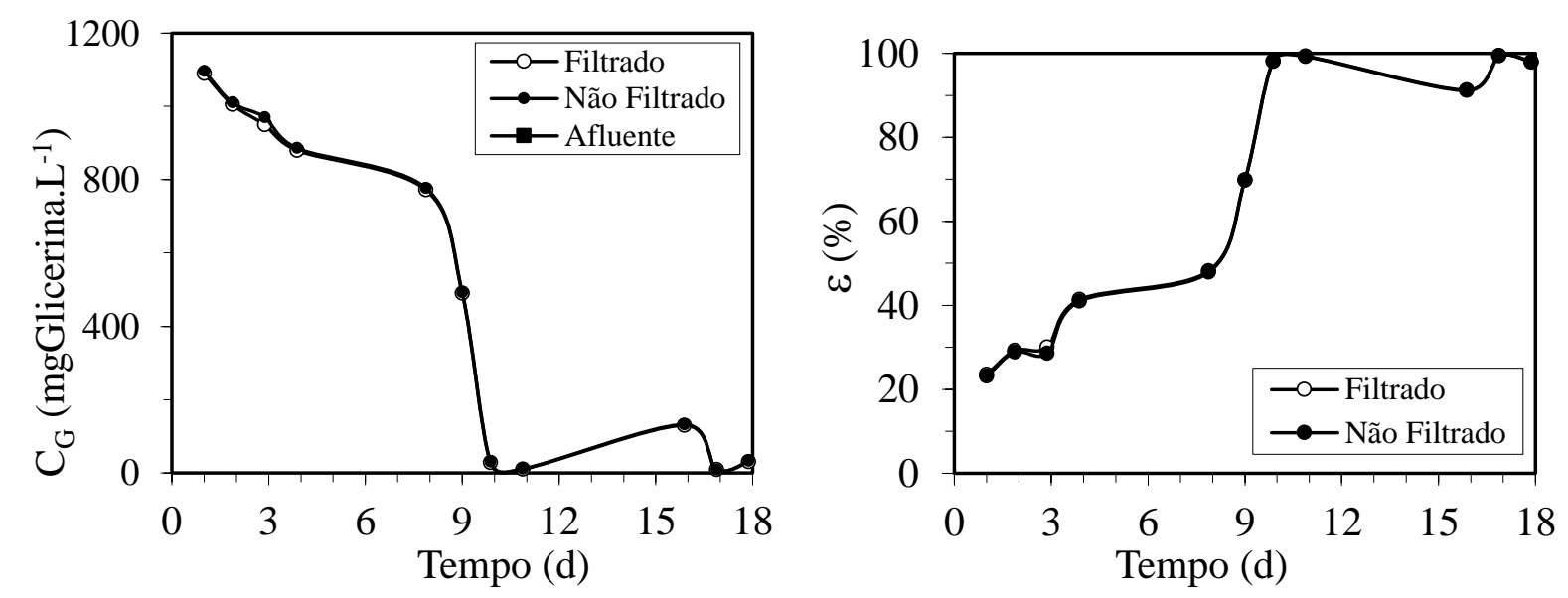

Figura 5.106. Concentração e eficiência de remoção na forma de glicerina no Ensaio 12: - - afluente amostras não filtradas; • - efluente amostras não filtradas; ○ - efluente amostras filtradas 


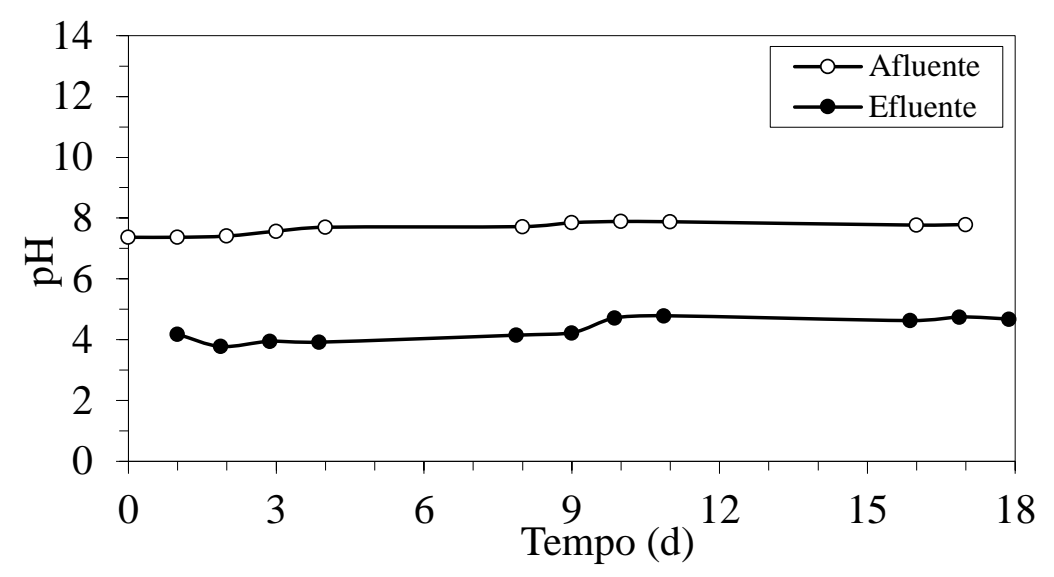

Figura 5.107. Medidas de pH no afluente e efluente no Ensaio 12: • - Efluente; ○ - Afluente.

A produção de biogás, em aspecto quantitativo, e a distribuição dos gases que compõem o biogás no final do ciclo podem ser observadas pela Figura 5.108, com média de $2034 \mathrm{~mL}$ de biogás e $1267 \mathrm{~mL}$ de hidrogênio depois que o pH foi estabilizado acima de 4,5, sendo que a porcentagem média de hidrogênio foi igual a $62 \%$. Assim que o $\mathrm{pH}$ foi estabilizado acima de 4,5 , este ensaio representa a maior quantidade de biogás atingida pelo sistema, sendo sua produtividade igual a $129,0 \mathrm{molH}_{2} \cdot \mathrm{m}^{-3} \cdot \mathrm{d}^{-1}$.
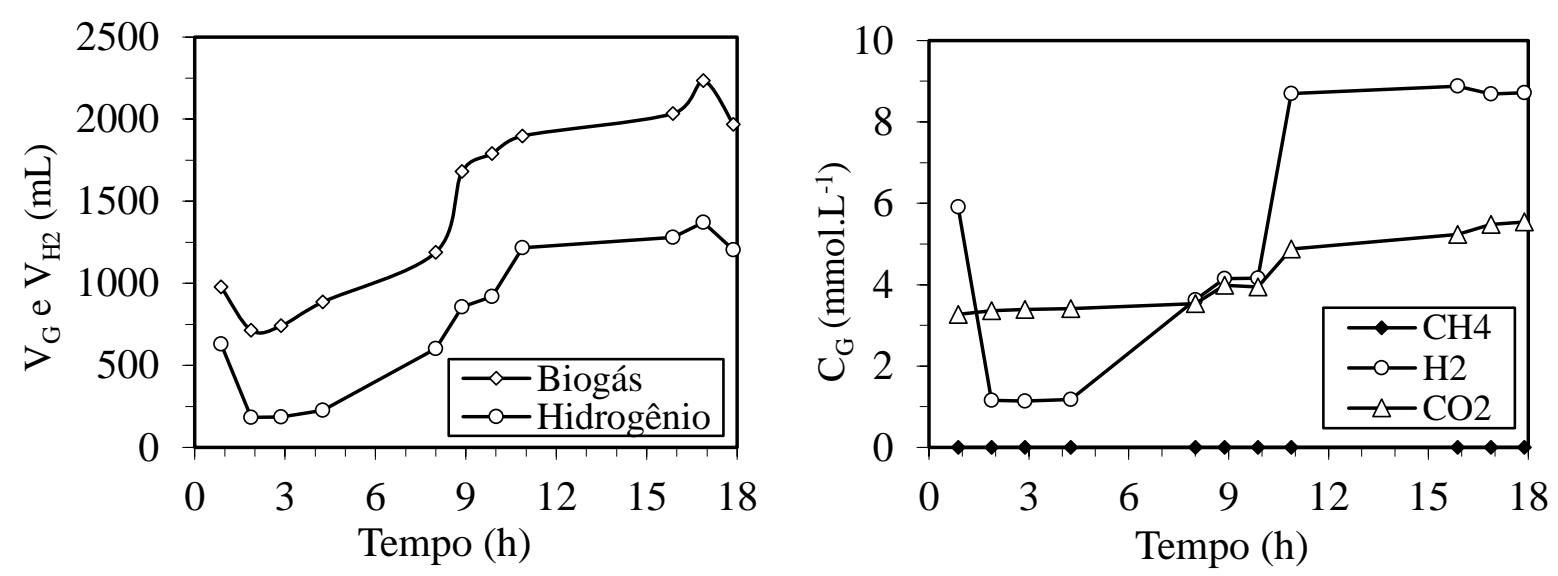

Figura 5.108. Volume de biogás $\left(\mathrm{V}_{\mathrm{G}}\right)$ e de hidrogênio $\left(\mathrm{V}_{\mathrm{H} 2}\right)$ nas $\mathrm{CNTP}$ e concentrações dos componentes do biogás no final do ciclo $\left(\mathrm{C}_{\mathrm{G}}\right)$ no Ensaio 12: $\diamond$ - Biogás; - Metano; $\odot-$ Hidrogênio; $\Delta$ - Dióxido de Carbono

A Figura 5.109 apresenta o perfil de DQO, de Carboidratos e de Glicerina, onde é possível observar o mesmo comportamento observado no Ensaio 11.

A Figura 5.110 apresenta os perfis de $\mathrm{pH}$, alcalinidade total e ácidos voláteis totais ao longo do ciclo. $\mathrm{O}$ pH permanece constante ao longo do ciclo por volta de 4,3, bem como os ácidos voláteis totais por volta de $1642 \mathrm{mgHAc} . \mathrm{L}^{-1}$. A alcalinidade fornecida pelo afluente não chega a ser totalmente consumida pelo processo, assim como no Ensaio 11. 

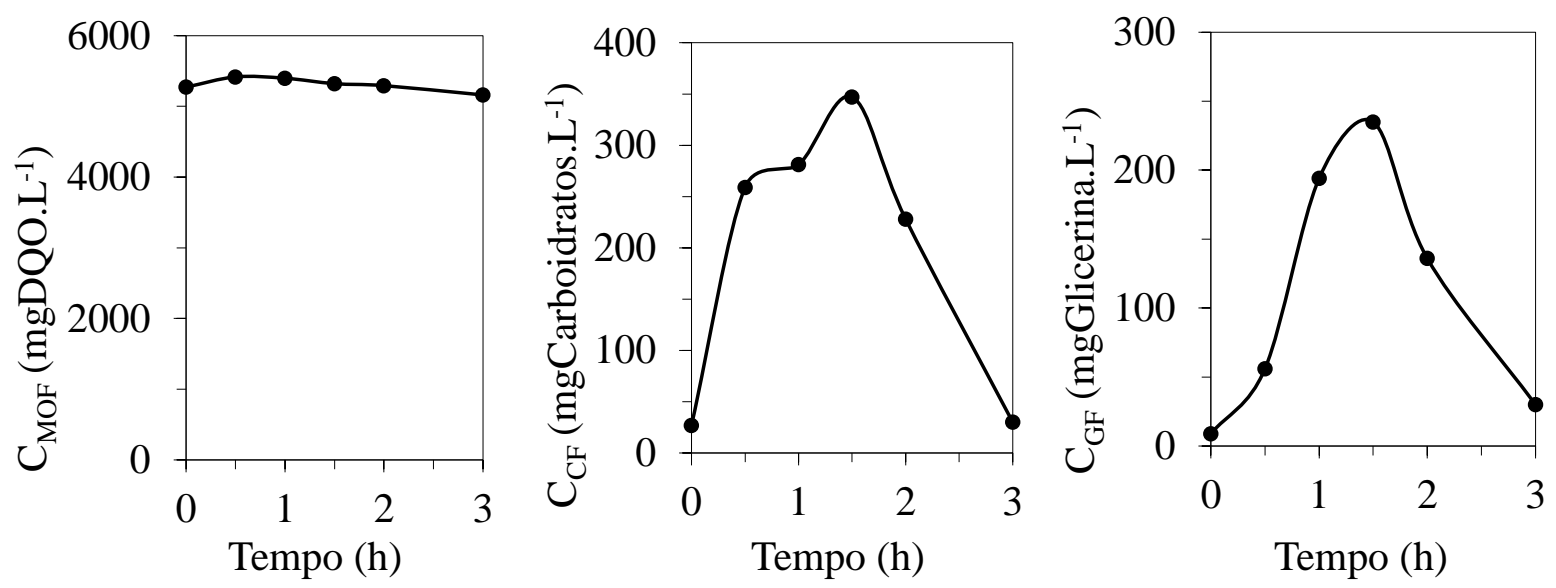

Figura 5.109. Concentração de matéria orgânica, carboidratos e de glicerina durante o ciclo no Ensaio 12.
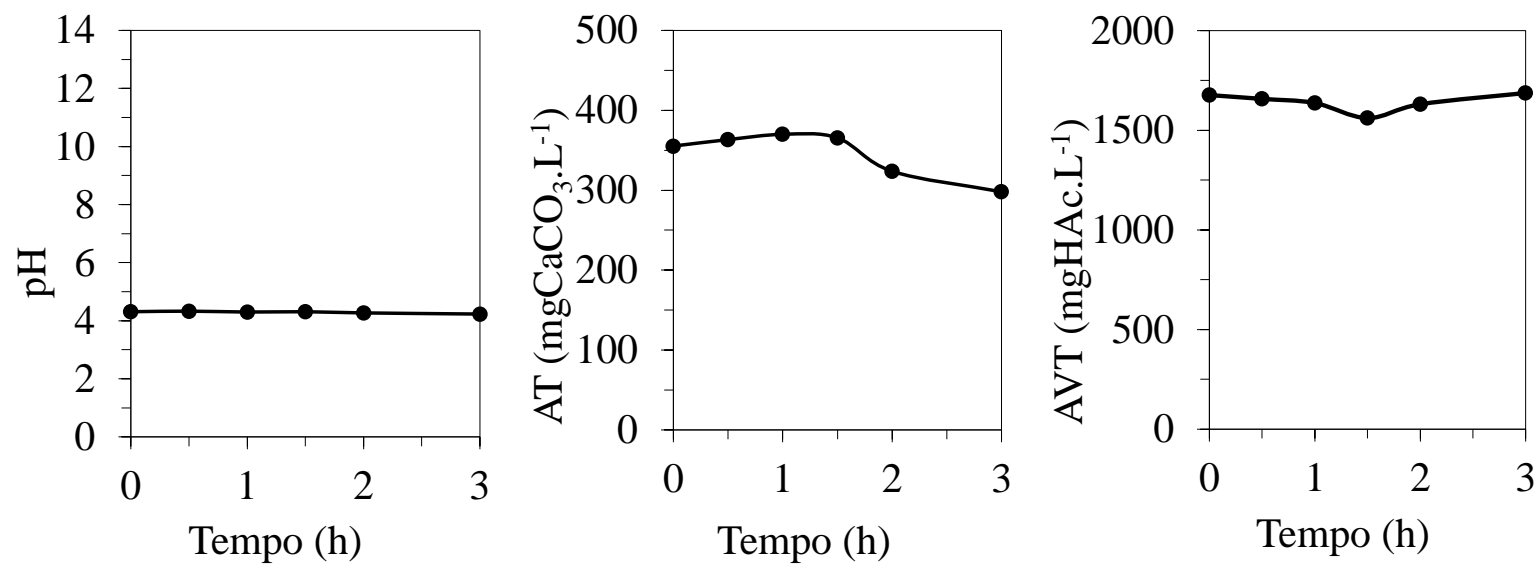

Figura 5.110. Valores de pH, alcalinidade total(AT) e ácidos voláteis totais (AVT) no Ensaio 12.

O perfil dos compostos intermediários do metabolismo é apresentado na Figura 5.111. Neste ensaio, é possível verificar que há a predominância de ácido acético e de etanol, com o ponto de mínima concentração que acontece em 1,5 h, assim como nos Ensaios 7 e 11.

A produção volumétrica acumulada de biogás e os desvios padrões de cada um dos pontos podem ser observados na Figura 5.112 e o perfil das concentrações de cada um dos gases e suas respectivas porcentagens podem ser observados na Figura 5.113. Houve uma variação muito baixa no volume de gás recolhido diariamente depois da estabilização do $\mathrm{pH}$; ao final do perfil, tinha-se $39 \%$ de $\mathrm{CO}_{2}$ e $61 \%$ de $\mathrm{H}_{2}$. 


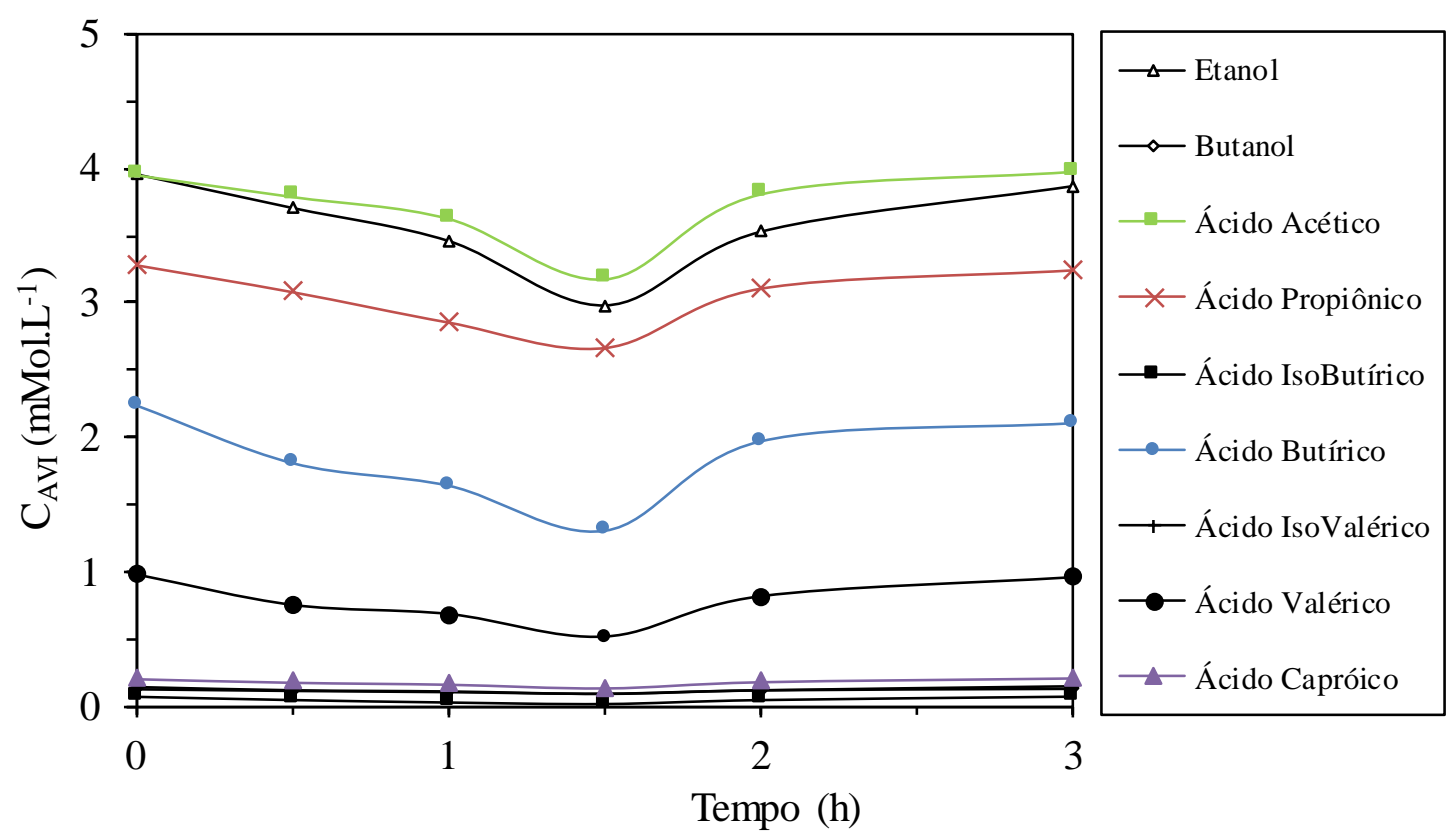

Figura 5.111. Concentração dos compostos intermediários ao longo do ciclo no Ensaio 12: $\Delta$ - etanol; $\diamond$ butanol; $\square$ - ácido acético; -x- ácido propiônico; - ácido isobutírico; • - ácido butírico; + ácido isovalérico $\bullet$ - ácido valérico; $\boldsymbol{\Delta}$-ácido capróico.

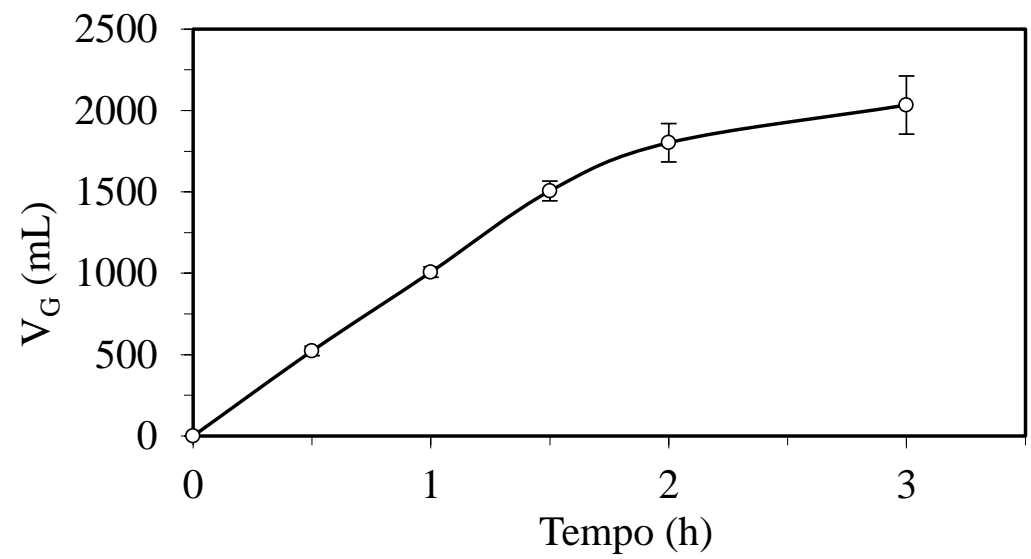

Figura 5.112. Produção volumétrica média acumulada do biogás durante o ciclo no Ensaio 12.
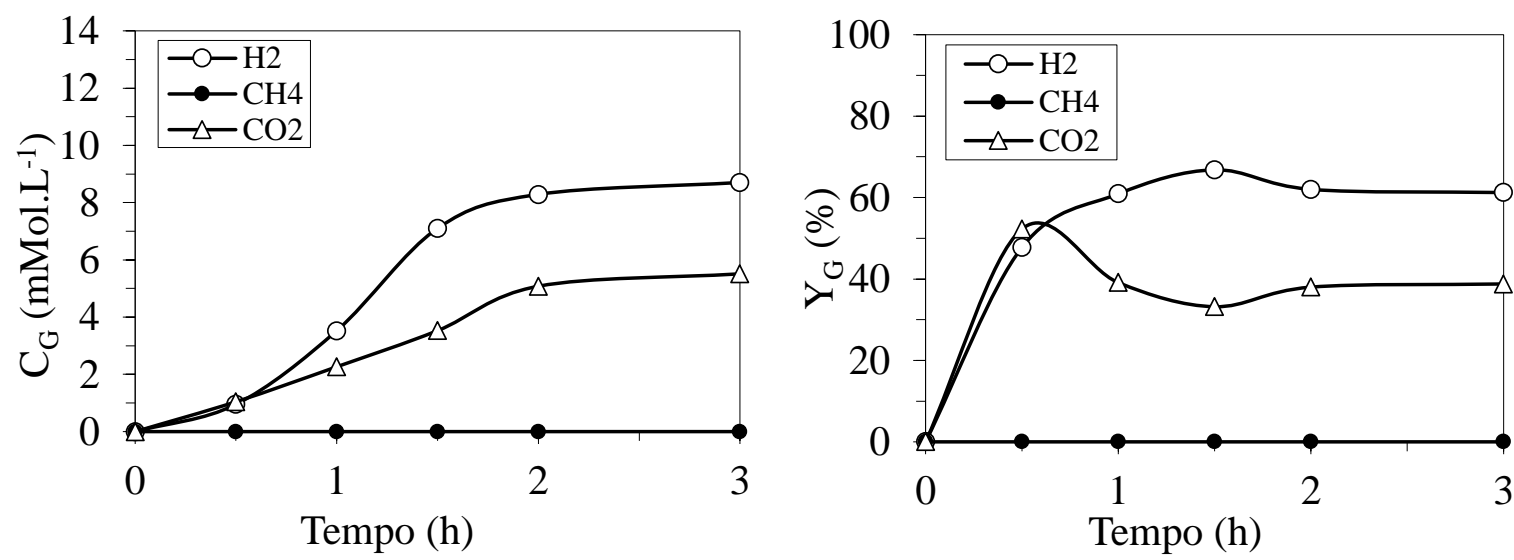

Figura 5.113. Concentração dos compostos do biogás durante o ciclo e suas respectivas porcentagens no Ensaio 12: $\circ-\mathrm{H}_{2} ; \bullet-\mathrm{CH}_{4} ; \Delta-\mathrm{CO}_{2}$ 


\subsubsection{Análise comparativa entre os Ensaios 11 e 12 (Fase III)}

Nesta seção, a influência da variação da concentração do afluente será analisada tendo como comparação o Ensaio 7 que foi a melhor condição de codigestão (5000 mgDQO.L ${ }^{-1}$ e AVOL 17,2 kgDQO. $\mathrm{m}^{-3} \cdot \mathrm{d}^{-1}-75 \%$ soro): o Ensaio 11 teve a concentração do afluente reduzida para $3000 \mathrm{mgDQO} . \mathrm{L}^{-1}$ (AVOL 10,1 kgDQO. $\mathrm{m}^{-3} \cdot \mathrm{d}^{-1}$ ) e o Ensaio 12 teve a concentração do afluente aumentada para $7000 \mathrm{mgDQO} \cdot \mathrm{L}^{-1}$ (AVOL 23,9 kgDQO. $\mathrm{m}^{-3} \cdot \mathrm{d}^{-1}$ ).

Os parâmetros comparados serão a matéria orgânica, carboidratos, glicerina (englobando carga aplicada e removida), pH, alcalinidade e ácidos (AVT e AVI), sólidos e, por último, parâmetros relativos a produção de biohidrogênio, de acordo com a Tabela 5.21.

Analisando as eficiências de remoção de matéria orgânica (29-19\%), de remoção de carboidratos (98-99,1\%) e de glicerina (97\%) dos ensaios, é possível notar que a diminuição da concentração do afluente aumenta ligeiramente a remoção de matéria orgânica e substratos, de acordo com a Figura 5.114.

Em relação ao $\mathrm{pH}$, nota-se que o efluente fica mais ácido conforme aumenta-se a carga orgânica. Os Ensaios 11 e 7 não apresentaram interferência ( $\mathrm{pH}$ médio de 4,6 e 4,4, respectivamente), mas o Ensaio 12 apresentou $\mathrm{pH}$ inicial do efluente de 4,2 com queda contínua até 3,8 mesmo aumentando o bicarbonato de sódio que era adicionado ao meio (Figura 5.115), sendo observado que na faixa de $\mathrm{pH}$ entre 3,8 e 4,3 houve uma significativa redução na produção de hidrogênio, como nota-se na Figura 5.116. A influência do pH na produção de hidrogênio é bastante controversa na literatura, sendo que Lay et al. (1999) destacam que um pH muito abaixo de 4,5 é desfavorável para a produção de hidrogênio, pela possível redução da atividade da hidrogenase e de outras enzimas, com consequente alteração das rotas metabólicas envolvidas no processo. Tal fato pode justificar o que foi verificado neste estudo, pois assim que o pH do efluente retornou a 4,5 (pelo aumento da suplementação de bicarbonato no afluente para $\left.1.4 \mathrm{gNaHCO}_{3} \cdot \mathrm{gCOD}^{-1}\right)$, a produção de hidrogênio aumentou e atingiu o maior valor dentre todos as condições $\left(129 \mathrm{molH} 2 \cdot \mathrm{m}^{-3} \cdot \mathrm{d}^{-1}\right)$.

Observando a biomassa no reator, nota-se que há um aumento concomitante com o aumento da concentração do afluente, assim com a série de sólidos. Novamente, destaca-se que as lavagens periódicas realizadas no reator ao longo de cada ensaio se mostraram necessárias para o bom funcionamento do sistema (por volta de $76 \%$ da biomassa era removida em cada lavagem), de acordo com a Tabela 5.22. 
Tabela 5.21. Estabilidade e desempenho nas variáveis monitoradas nos Ensaios 11, 7 e 12.

\begin{tabular}{|c|c|c|c|c|}
\hline Parâmetro & & 11 & 7 & 12 \\
\hline Soro:Glicerina & $(\%)$ & $75: 25$ & $75: 25$ & $75: 25$ \\
\hline$\varepsilon_{\mathrm{MO}, \mathrm{F}}$ & $(\%)$ & $29 \pm 4^{(11)}$ & $27 \pm 3^{(11)}$ & $19 \pm 6^{(11)}$ \\
\hline$\varepsilon_{\mathrm{C}, \mathrm{F}}$ & $(\%)$ & $99,1 \pm 0,3^{(9)}$ & $98,4 \pm 0,4^{(11)}$ & $98 \pm 2^{(11)}$ \\
\hline$\varepsilon_{\mathrm{G}, \mathrm{F}}$ & $(\%)$ & $97 \pm 6^{(9)}$ & $97 \pm 4^{(11)}$ & $97 \pm 4^{(11)}$ \\
\hline $\mathrm{M}_{\mathrm{SVT}}$ & (g) & 8,0 & 10,5 & 18,4 \\
\hline COAV & $\left(\mathrm{kgDQO} \cdot \mathrm{m}^{-3} \cdot \mathrm{d}^{-1}\right)$ & 10,1 & 17,2 & 23,9 \\
\hline CORV & $\left(\mathrm{kgDQO} \cdot \mathrm{m}^{-3} \cdot \mathrm{d}^{-1}\right)$ & 3,0 & 4,6 & 4,7 \\
\hline \multirow{3}{*}{ Afluente } & $\mathrm{pH}(\mathrm{u})$ & $7,5 \pm 0,1$ & $7,4 \pm 0,1^{(11)}$ & $7,7 \pm 0,2^{(11)}$ \\
\hline & $\mathrm{AT}\left(\mathrm{mgCaCO}_{3} \cdot \mathrm{L}^{-1}\right)$ & $205 \pm 15^{(11)}$ & $242 \pm 18^{(11)}$ & $522 \pm 200^{(11)}$ \\
\hline & AVT (mgHAc. L $\left.^{-1}\right)$ & $70 \pm 3^{(11)}$ & $128 \pm 12^{(11)}$ & $137 \pm 16^{(11)}$ \\
\hline \multirow{3}{*}{ Efluente } & $\mathrm{pH}(\mathrm{u})$ & $4,6 \pm 0,1^{(11)}$ & $4,4 \pm 0,1^{(11)}$ & $4,3 \pm 0,4^{(11)}$ \\
\hline & $\mathrm{AT}\left(\mathrm{mgCaCO} \mathrm{Cl}_{3} \cdot \mathrm{L}^{-1}\right)$ & $78 \pm 29^{(11)}$ & $50 \pm 33^{(11)}$ & $196 \pm 283^{(11)}$ \\
\hline & AVT (mgHAc. L $\left.^{-1}\right)$ & $778 \pm 120^{(11)}$ & $1006 \pm 102^{(11)}$ & $1461 \pm 561^{(11)}$ \\
\hline \multirow{8}{*}{$\begin{array}{c}\text { Compostos } \\
\text { intermediários } \\
\text { (molar) }\end{array}$} & Etanol $(\%)$ & 26,3 & 18,9 & 38,3 \\
\hline & Butanol (\%) & 0,9 & 0,7 & 0,3 \\
\hline & Ácido Acético (\%) & 27,1 & 20,7 & 30,1 \\
\hline & Ácido Propiônico (\%) & 22,0 & 15,5 & 13,2 \\
\hline & Ácido Butírico (\%) & 14,7 & 32,6 & 10,7 \\
\hline & Ácido Valérico (\%) & 7,5 & 8,7 & 6,8 \\
\hline & Ácido Capróico (\%) & 1,4 & 2,9 & 0,7 \\
\hline & $\begin{array}{c}\text { Concentração total } \\
\left(m m o l . L^{-1}\right)\end{array}$ & 14,7 & 23,5 & 42,6 \\
\hline PrM & $\left(\mathrm{molH}_{2} \cdot \mathrm{m}^{-3} \cdot \mathrm{d}^{-1}\right)$ & 69,6 & 91,3 & 129,0 \\
\hline PrME & $\left(\mathrm{molH}_{2} \cdot \mathrm{kgSVT}^{-1} \cdot \mathrm{d}^{-1}\right)$ & 30,1 & 30,7 & 29,5 \\
\hline RMCA & $\left(\mathrm{molH}_{2} \cdot \mathrm{kgDQO}^{-1}\right)$ & 6,9 & 5,3 & 5,4 \\
\hline RMSA & $\left(\mathrm{molH}_{2} \mathrm{molSubstrato}^{-1}\right)$ & 1,9 & 1,5 & 1,4 \\
\hline \multirow{2}{*}{$\mathrm{Y}_{\mathrm{G}}$} & (\%) $\mathrm{H}_{2}$ & 62,9 & 66,4 & 62,3 \\
\hline & $(\%) \mathrm{CO}_{2}$ & 37,1 & 33,6 & 37,7 \\
\hline
\end{tabular}

Tabela 5.22. Comparação entre os valores médios da série de sólidos entre os Ensaios 11, 7 e 12.

Parâmetro

$\begin{array}{lll}11 & 7 & 12\end{array}$

Afluente Efluente Afluente Efluente Afluente Efluente

\begin{tabular}{|c|c|c|c|c|c|c|c|}
\hline $\mathrm{M}_{\mathrm{SVT}}$ & (g) & \multicolumn{2}{|c|}{8,0} & \multicolumn{2}{|c|}{10,5} & \multicolumn{2}{|c|}{18,4} \\
\hline Biomassa removida & (g) & \multicolumn{2}{|c|}{6,0} & \multicolumn{2}{|c|}{8,5} & \multicolumn{2}{|c|}{14,4} \\
\hline por lavagem & $(\%)$ & \multicolumn{2}{|c|}{74,9} & \multicolumn{2}{|c|}{80,1} & \multicolumn{2}{|c|}{74,7} \\
\hline ST & $\left(\mathrm{mg} . \mathrm{L}^{-1}\right)$ & 2151 & 1402 & 3232 & 1786 & 5086 & 3879 \\
\hline SVT & $\left(\mathrm{mg} \cdot \mathrm{L}^{-1}\right)$ & 1735 & 998 & 2688 & 1295 & 3977 & 2854 \\
\hline SST & $\left(\mathrm{mg} \cdot \mathrm{L}^{-1}\right)$ & 37 & 339 & 62 & 98 & 62 & 91 \\
\hline SSV & $\left(\mathrm{mg} \cdot \mathrm{L}^{-1}\right)$ & 42 & 343 & 56 & 91 & 44 & 82 \\
\hline
\end{tabular}



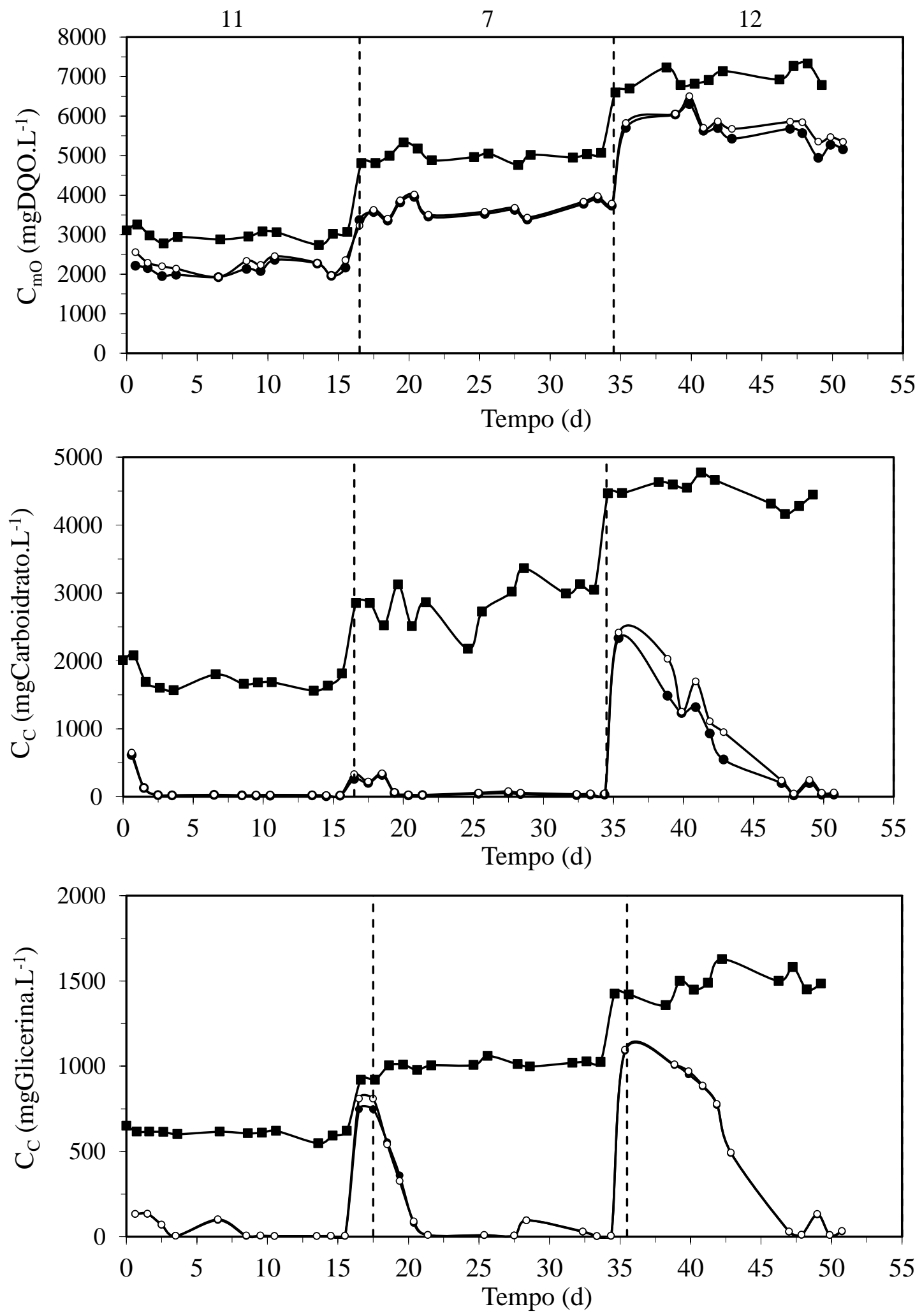

Figura 5.114. Monitoramento da DQO, dos carboidratos e da glicerina nos Ensaios 11, 7 e 12: - - afluente amostras não filtradas; $\bigcirc$ - efluente amostras não filtradas; • - efluente amostras filtradas. 

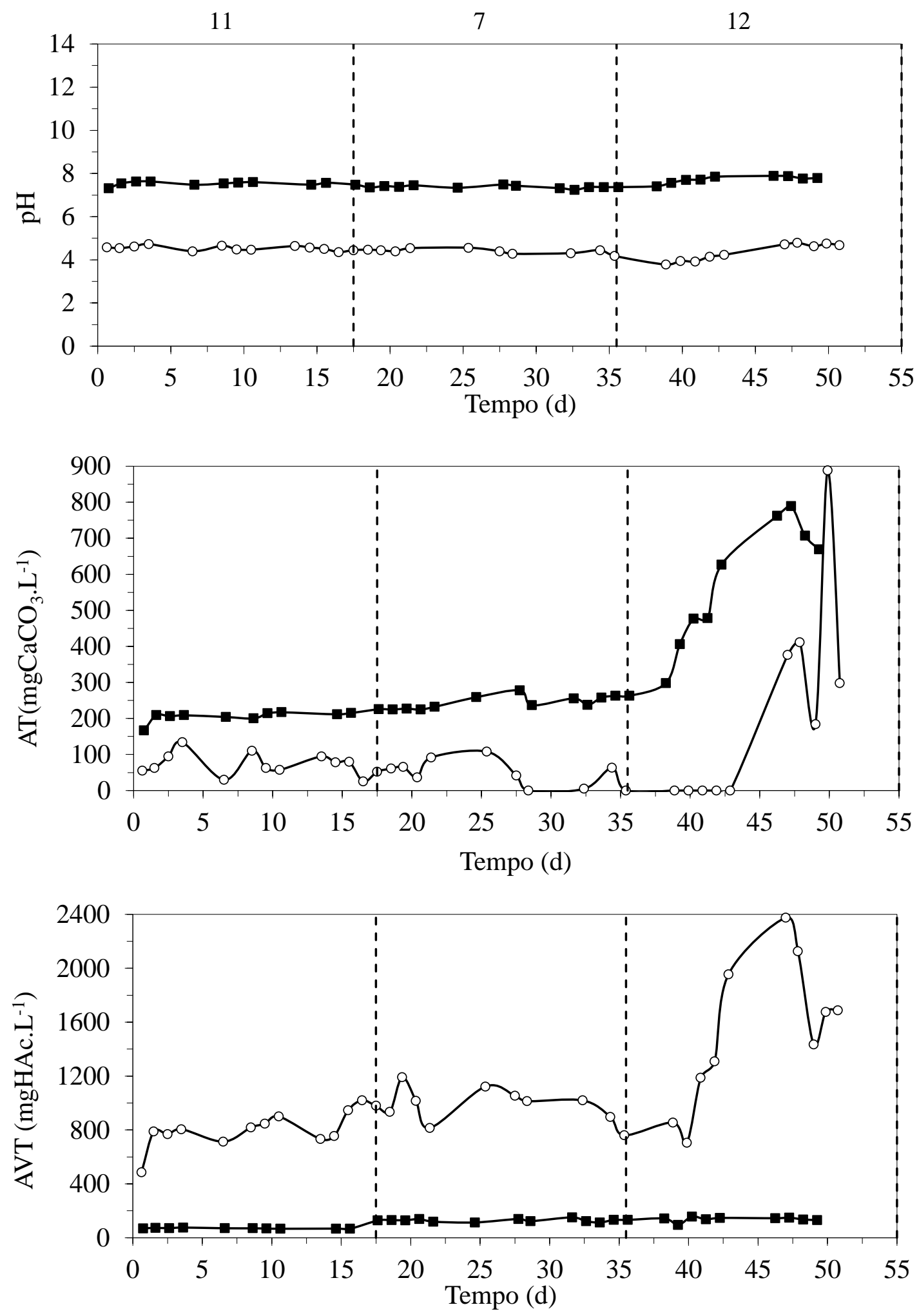

Figura 5.115. Monitoramento do $\mathrm{pH}$, da AT e dos AVT nos Ensaios 11, 7 e 12: - - afluente amostras não filtradas; ○ - efluente amostras não filtradas. 
O desempenho do reator quanto à produção de biogás foi significativamente melhor no Ensaio 12 (depois que o pH foi estabilizado acima de 4,5) e reduzido no Ensaio 11. O Ensaio 12 produziu 2034 mLbiogás.ciclo $^{-1}$ com 62,3\% de hidrogênio, o que representa 129,0 $\mathrm{molH}_{2} \cdot \mathrm{m}^{-3} \cdot \mathrm{d}^{-1} \mathrm{e}$ o torna a melhor condição operacional. Realizando uma comparação com os outros ensaios, esta condição obteve uma produtividade $145 \%$ maior do que a do Ensaio 6 (100\% soro) e $27 \%$ maior do que a do Ensaio 10 (100\% glicerina). É possível notar, no entanto, que a redução na carga orgânica no Ensaio 11 aumentou o rendimento $\left(1,9 \mathrm{molH}_{2} \cdot \mathrm{molSubstrato}^{-1}\right)$, mas não atingiu uma produtividade significativa de biogás $\left(69,6 \mathrm{molH} 2 \cdot \mathrm{m}^{-3} \cdot \mathrm{d}^{-1}\right)$, como ilustrado na Figura 5.116.

No geral, nota-se que quanto maior a concentração do afluente, maior a produtividade de biogás, mas deve-se prestar atenção ao controle do pH. Dentro destes ensaios, não foi observada uma carga orgânica máxima para a operação do sistema.

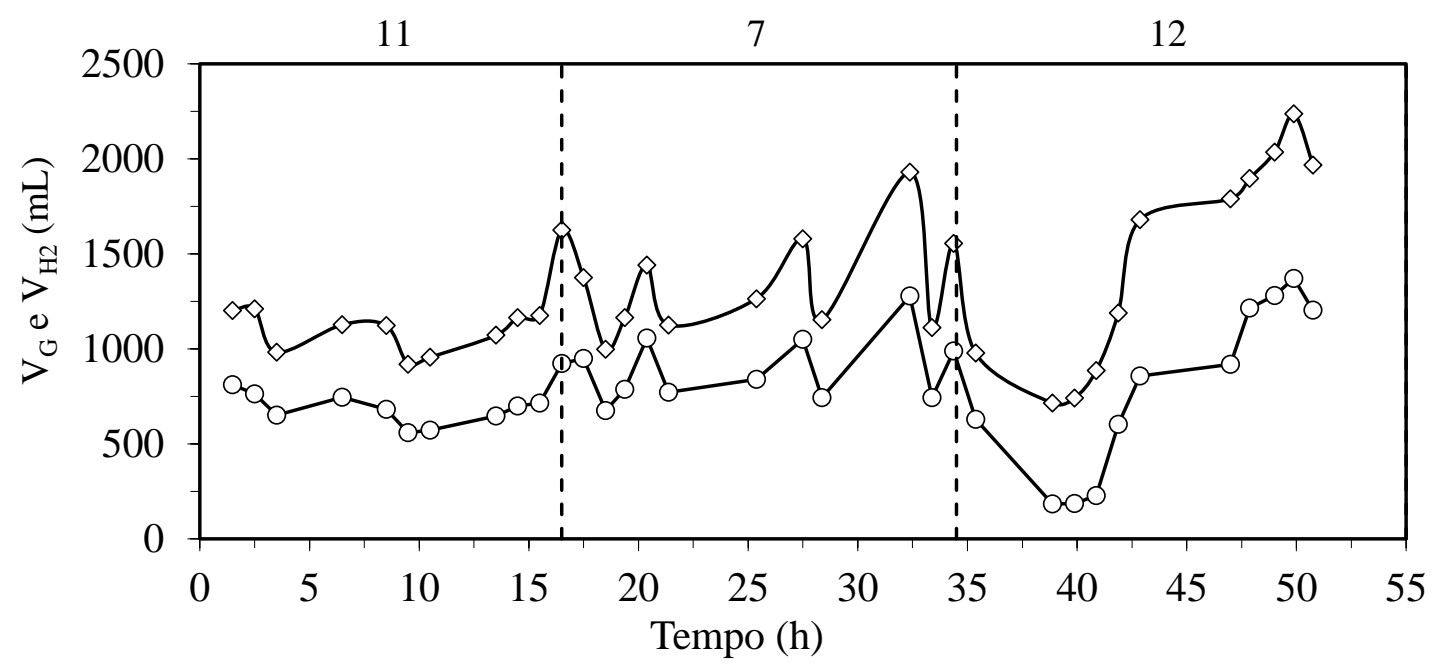

Figura 5.116. Produção volumétrica por ciclo de Biogás $(\diamond)$ e Hidrogênio (○) nos Ensaios 11, 7 e 12.

Finalmente, analisando os compostos intermediários, nota-se que o Ensaio 12 apresenta predominância de etanol dentre os compostos $(38,3 \%)$, indicando que é uma condição que pode ser melhorada se a redução da produção de etanol for atingida. Em seguida à produção de etanol, seguem a produção de ácido acético (20,7-30,1\%) e de ácido butírico (10,7-32,6\%), semelhante ao encontrado nos ensaios da Fase II. A distribuição dos compostos intermediários destes ensaios indica que é difícil deduzir sobre a produção de hidrogênio apenas observando os AVI, pois a melhor condição operacional apresentou predominância de etanol (que é nocivo para a produção de $\mathrm{H}_{2}$ ) e a razão HAc/HBu não apresenta linearidade em relação às produtividades encontradas. 
5.3.4 Modelagem Cinética para os Ensaios 11 e 12.

A Figura 5.117 mostra os valores obtidos experimentalmente (marcadores) e os valores obtidos pelo modelo cinético ajustado (linhas), ambos ao longo do ciclo, para as principais variáveis monitoradas e que estão relacionadas com o entendimento do metabolismo acidogênico para os Ensaios 11 e 12. A Tabela 5.23 mostra os parâmetros cinéticos ajustados.

Analisando essas figuras é possível notar, novamente, que o modelo foi eficiente em predizer os dados experimentais em relação à concentração de substrato, ácidos acético, propiônico, butírico, valérico e hidrogênio, validando a interpretação do comportamento dos parâmetros cinéticos nas diferentes condições experimentais implementadas.
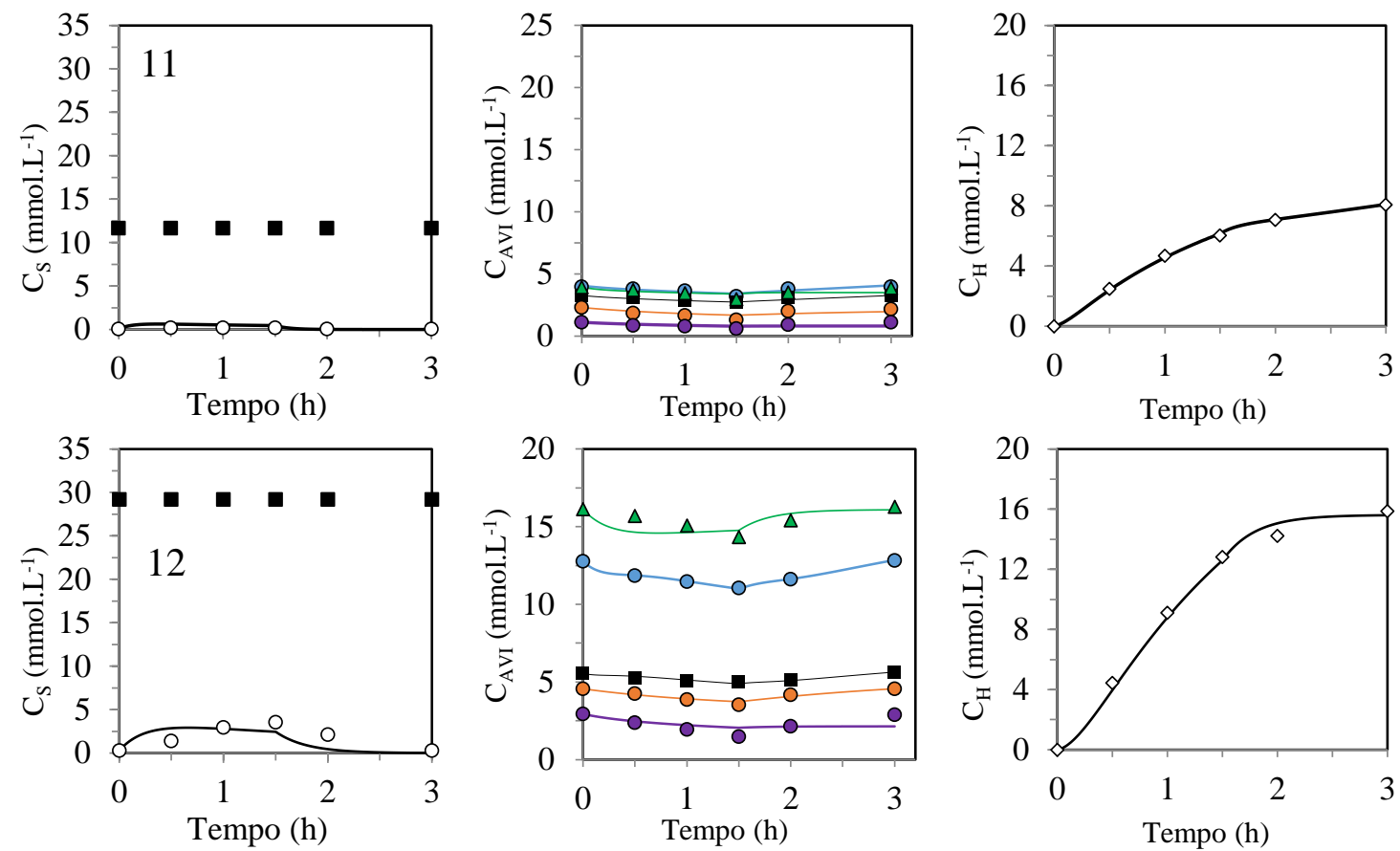

Figura 5.117. Perfis de substrato ( $\bullet$ ), efluente filtrado (०), ácido acético $(\bullet)$, ácido propiônico $(\mathbf{\Delta})$, ácido butírico $(\bullet)$, etanol $(\boldsymbol{\Delta})$, ácido valérico $(\bullet)$ e hidrogênio $(\diamond)$ (valores experimentais $\mathrm{e}$ calculados pelo modelo).

É possível conferir que o aumento da concentração do afluente equilibra as rotas de produção de $\mathrm{H}_{2}$. Enquanto o Ensaio 11 produz $\mathrm{H}_{2}$ preferencialmente pela conversão de substrato em ácido acético e butírico $\left(\mathrm{k}_{1 \mathrm{H}}=3,8 \mathrm{~h}^{-1}, \mathrm{k}_{3 \mathrm{H}}=4,4 \mathrm{~h}^{-1}, \mathrm{k}_{4 \mathrm{H}}=0,0 \mathrm{~h}^{-1}\right)$, o Ensaio 12 produz hidrogênio similarmente pela conversão de substrato em ácidos acético, butírico e valérico $\left(\mathrm{k}_{1 \mathrm{H}}=1,4 \mathrm{~h}^{-1}, \mathrm{k}_{3 \mathrm{H}}=1,4 \mathrm{~h}^{-1}, \mathrm{k}_{4 \mathrm{H}}=1,4 \mathrm{~h}^{-1}\right)$.

Verificando agora as reações prejudicais a produção de hidrogênio (Equações 4.52 e 4.55), é possível observar que, a concentração do afluente não tem grande influência nessas $\operatorname{rotas}\left(\mathrm{k}_{2 \mathrm{HPr}}=0,4-0,9 \mathrm{~h}^{-1}\right.$ e $\left.\mathrm{k}_{5 \mathrm{ETOH}}=0,3-1,8 \mathrm{~h}^{-1}\right)$. 
Em relação a metanogênese, novamente a mesma foi completamente inibida em todos os ensaios, daí são justificados os valores de $\mathrm{k}_{9 \mathrm{HAc}}, \mathrm{k}_{9 \mathrm{M}}, \mathrm{k}_{10 \mathrm{H}}, \mathrm{k}_{10 \mathrm{M}}$ iguais a $0 \mathrm{~h}^{-1} \mathrm{em}$ todas as condições.

Enfim, em relação ao consumo de substrato por microrganismos do gênero Megasphaera, é possível observar que ele é aumentado no Ensaio 11 - $3000 \mathrm{mgDQO} . \mathrm{L}^{-1}$ $\left(\mathrm{k}_{11 \mathrm{HAc}}=30,7 \mathrm{~h}^{-1}\right)$, o que pode estar ligado a uma inibição desse microrganismo em concentrações mais altas de substrato.

Tabela 5.23. Parâmetros do modelo cinético para a Fase III.

\begin{tabular}{|c|c|c|c|c|}
\hline Fase & Parâmetro & 11 & 7 & 12 \\
\hline \multirow{7}{*}{$\begin{array}{c}\text { Hidrólise e } \\
\text { Acidogênese } \\
\text { (positivo para } \\
\text { produção } \mathrm{H}_{2} \text { ) }\end{array}$} & $\mathrm{k}_{1 \mathrm{~S}}^{\prime}\left(\mathrm{h}^{-1}\right)$ & 7,4 & 1,7 & 3,4 \\
\hline & $\mathrm{k}_{1 \mathrm{HAc}}\left(\mathrm{h}^{-1}\right)$ & 0,0 & 0,2 & 0,0 \\
\hline & $\mathrm{k}_{1 \mathrm{H}}\left(\mathrm{h}^{-1}\right)$ & 3,8 & 0,7 & 1,4 \\
\hline & $\mathrm{k}_{3 \mathrm{HBu}}\left(\mathrm{h}^{-1}\right)$ & 0,0 & 0,0 & 0,0 \\
\hline & $\mathrm{k}_{3 \mathrm{H}}\left(\mathrm{h}^{-1}\right)$ & 4,4 & 0,7 & 1,4 \\
\hline & $\mathrm{k}_{4 \mathrm{HVa}}\left(\mathrm{h}^{-1}\right)$ & 0,2 & 0,1 & 0,1 \\
\hline & $\mathrm{k}_{4 \mathrm{H}}\left(\mathrm{h}^{-1}\right)$ & 0,0 & 0,1 & 1,4 \\
\hline \multirow{3}{*}{$\begin{array}{c}\text { Hidrólise e } \\
\text { Acidogênese } \\
\text { (negativo para } \\
\text { producão } \mathrm{H}_{2} \text { ) }\end{array}$} & $\mathrm{k}_{2 \mathrm{HPr}}\left(\mathrm{h}^{-1}\right)$ & 0,6 & 0,4 & 0,9 \\
\hline & $\mathrm{k}_{2 \mathrm{H}}\left(\mathrm{h}^{-1}\right)$ & 0,1 & 0,0 & 0,1 \\
\hline & $\mathrm{k}_{\text {SETOH }}\left(\mathrm{h}^{-1}\right)$ & 1,8 & 0,3 & 1,8 \\
\hline \multirow{9}{*}{$\begin{array}{c}\text { Acetogênese } \\
\text { (positivo para } \\
\text { produção de } \mathrm{H}_{2} \text { ) }\end{array}$} & $\mathrm{k}_{6 \mathrm{HPr}}\left(\mathrm{h}^{-1}\right)$ & 0,5 & 3,3 & 6,0 \\
\hline & $\mathrm{k}_{6 \mathrm{HAc}}\left(\mathrm{h}^{-1}\right)$ & 38,5 & 2,0 & 19,7 \\
\hline & $\mathrm{k}_{6 \mathrm{H}}\left(\mathrm{h}^{-1}\right)$ & 0,3 & 0,0 & 0,0 \\
\hline & $\mathrm{k}_{7 \mathrm{HPr}}\left(\mathrm{h}^{-1}\right)$ & 0,9 & 1,6 & 7,5 \\
\hline & $\mathrm{k}_{7 \mathrm{HBu}}\left(\mathrm{h}^{-1}\right)$ & 0,6 & 0,0 & 0,5 \\
\hline & $\mathrm{k}_{7 \mathrm{H}}\left(\mathrm{h}^{-1}\right)$ & 0,0 & 0,3 & 0,0 \\
\hline & $\mathrm{k}_{8 \mathrm{HBu}}\left(\mathrm{h}^{-1}\right)$ & 1,5 & 0,6 & 1,2 \\
\hline & $\mathrm{k}_{8 \mathrm{HVa}}\left(\mathrm{h}^{-1}\right)$ & 0,0 & 0,0 & 0,0 \\
\hline & $\mathrm{k}_{8 \mathrm{H}}\left(\mathrm{h}^{-1}\right)$ & 0,0 & 0,0 & 0,0 \\
\hline \multirow{4}{*}{$\begin{array}{c}\text { Metanogênese } \\
\text { (negativo para } \\
\text { produção de } \mathrm{H}_{2} \text { ) }\end{array}$} & $\mathrm{K}_{9 \mathrm{HAc}}\left(\mathrm{h}^{-1}\right)$ & 0,0 & 0,0 & 0,0 \\
\hline & $\mathrm{k}_{9 \mathrm{M}}\left(\mathrm{h}^{-1}\right)$ & 0,0 & 0,0 & 0,0 \\
\hline & $\mathrm{k}_{10 \mathrm{H}}\left(\mathrm{h}^{-1}\right)$ & 0,0 & 0,0 & 0,0 \\
\hline & $\mathrm{k}_{10 \mathrm{M}}\left(\mathrm{h}^{-1}\right)$ & 0,0 & 0,0 & 0,0 \\
\hline $\begin{array}{l}\text { Crescimento } \\
\text { celular }\end{array}$ & $\mathrm{k}_{11 \mathrm{HAc}}\left(\mathrm{h}^{-1}\right)$ & 30,7 & 1,4 & 8,5 \\
\hline
\end{tabular}




\subsection{FASE IV - PRODUÇÃO DE BIOHIDROGÊNIO - INFLUÊNCIA DO TEMPO DE CICLO}

A Fase IV compreendeu os Ensaios 13, 14 e 15 e teve como objetivo encontrar o melhor tempo de ciclo e tempo de enchimento para o sistema, sendo que todos os ensaios foram conduzidos com a razão ótima de mistura entre soro e glicerina (75:25) - e com a concentração ótima de afluente (7000 mgDQO.L $\left.\mathrm{L}^{-1}\right)$ encontradas nas Fases II e III.

O Ensaio 13 teve o tempo de ciclo aumentado para $4 \mathrm{~h}$ com tempo de alimentação de $2 \mathrm{~h}$, o Ensaio 14 teve o tempo de ciclo reduzido para $2 \mathrm{~h}$ com tempo de enchimento de $1 \mathrm{~h}$ e o Ensaio 15 trabalhou com $3 \mathrm{~h}$ de tempo de ciclo, mas com tempo de enchimento de 10 minutos, caracterizando o modo batelada.

\subsubsection{Ensaio $13\left(75 \%\right.$ Soro e $25 \%$ Glicerina $\left.-7000 \mathrm{mgDQO} . \mathrm{L}^{-1}-4 \mathrm{~h}-\mathrm{BA}\right)$}

O Ensaio 13 foi feito com concentração do afluente de $7000 \mathrm{mgDQO} . \mathrm{L}^{-1}$ (75\% de soro e $25 \%$ de glicerina), tempo de ciclo de 4 h e tempo de alimentação de $2 \mathrm{~h}$. Os parâmetros médios deste ensaio se encontram na Tabela 5.24.

O valor real da COAV foi de 17,9 gDQO.L $\mathrm{L}^{-1} \cdot \mathrm{d}^{-1}$ e a CORV atingida foi de 4,5 gDQO.L $\mathrm{L}^{-}$ ${ }^{1} \cdot \mathrm{d}^{-1}$, uma baixa remoção de matéria orgânica, como era esperado. $\mathrm{O}$ afluente teve, em média, $4201 \mathrm{mgCarboidratos} . \mathrm{L}^{-1}$ (COAV foi de 10,8 gCarboidratos. $\mathrm{L}^{-1} \cdot \mathrm{d}^{-1}$ e a CORV atingida foi de 10,7 gCarboidratos. $\mathrm{L}^{-1} \cdot \mathrm{d}^{-1}$ ) e $1440 \mathrm{mgGlicerina} . \mathrm{L}^{-1}$ (COAV foi de $3,7 \mathrm{gGlicerina} . \mathrm{L}^{-1} \cdot \mathrm{d}^{-1}$ e a CORV atingida foi de 3,6 gGlicerina. $\left.\mathrm{L}^{-1} \cdot \mathrm{d}^{-1}\right)$.

O monitoramento diário apresentou baixo consumo de matéria orgânica na forma de DQO, com média de concentração afluente não filtrada de $6977 \mathrm{mgDQO} . \mathrm{L}^{-1}$, efluente não filtrada $5402 \mathrm{mgDQO} . \mathrm{L}^{-1}$ e de efluente filtrada de $5225 \mathrm{mgDQO} . \mathrm{L}^{-1}$, o que representa uma remoção média para amostras não filtradas de $23 \%$ e de $25 \%$ para as filtradas (Figura 5.118).

Em relação ao monitoramento diário de carboidratos, o mesmo novamente apresentou um bom consumo, com média de concentração afluente não filtrada de

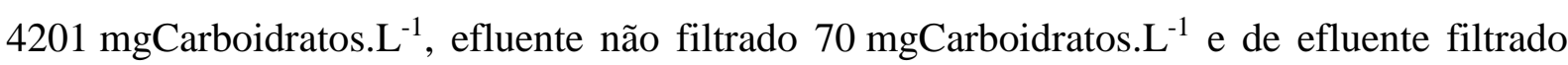
$45 \mathrm{mgCarboidratos.} \mathrm{L}^{-1}$, o que representa eficiência média de remoção para amostras não filtradas de $98 \%$ e para amostras filtradas de 99\% (Figura 5.119).

O monitoramento diário de glicerina apresentou média de concentração afluente não filtrada de $1440 \mathrm{mgGlicerina} . \mathrm{L}^{-1}$, efluente não filtrado $39 \mathrm{mgGlicerina} . \mathrm{L}^{-1}$ e de efluente filtrado de 37 mgGlicerina. $\mathrm{L}^{-1}$, o que representa uma eficiência média de remoção para amostras não filtradas e filtradas de 97\% (Figura 5.120). 
Tabela 5.24. Parâmetros médios monitorados no Ensaio 13.

\begin{tabular}{|c|c|c|c|c|c|c|c|c|c|}
\hline \multicolumn{2}{|r|}{ Parâmetro } & \multicolumn{5}{|c|}{ Afluente } & \multicolumn{3}{|c|}{ Efluente } \\
\hline $\mathrm{C}_{\text {мот }}$ & $\left(\mathrm{mgDQO} \cdot \mathrm{L}^{-1}\right)$ & 6977 & \pm 239 & & 14 & & $5402 \pm 447$ & ( 13 & 3 \\
\hline $\mathrm{C}_{\mathrm{MOF}}$ & $\left(\mathrm{mgDQO} \cdot \mathrm{L}^{-1}\right)$ & & & & & & $5225 \pm 424$ & $(13$ & 3 \\
\hline$\varepsilon_{\mathrm{MOT}}$ & $(\%)$ & & & & & & $23 \pm 6$ & ( 13 & $3)$ \\
\hline$\varepsilon_{\mathrm{MOF}}$ & $(\%)$ & & & & & & \pm 6 & ( 13 & $3)$ \\
\hline $\mathrm{C}_{\mathrm{CT}}$ & (mgCarboidratos. $\left.\mathrm{L}^{-1}\right)$ & 4201 & \pm 268 & & 14 & ) & \pm 56 & ( 10 & $0 \quad)$ \\
\hline $\mathrm{C}_{\mathrm{CF}}$ & (mgCarboidratos. $\left.\mathrm{L}^{-1}\right)$ & & & & & & \pm 42 & $(10$ & 0 \\
\hline$\varepsilon_{\mathrm{CT}}$ & $(\%)$ & & & & & & $98 \pm 1$ & $(10$ & $0 \quad)$ \\
\hline$\varepsilon_{\mathrm{CF}}$ & $(\%)$ & & & & & & $99 \pm 1$ & $(10$ & $0 \quad)$ \\
\hline $\mathrm{C}_{\mathrm{GT}}$ & (mgGlicerina. $\left.L^{-1}\right)$ & 1440 & $\pm \quad 37$ & ( & 14 & ) & \pm 37 & ( 10 & 0 \\
\hline $\mathrm{C}_{\mathrm{GF}}$ & (mgGlicerina. $\mathrm{L}^{-1}$ ) & & & & & & $37 \pm 37$ & ( 10 & 0 \\
\hline$\varepsilon_{\mathrm{GT}}$ & $(\%)$ & & & & & & $97 \pm 3$ & ( 10 & 0 \\
\hline$\varepsilon_{\mathrm{GF}}$ & $(\%)$ & & & & & & $97 \pm 3$ & ( 10 & 0 \\
\hline $\mathrm{pH}$ & (u) & 7,8 & $\pm 0,1$ & ( & 11 & ) & $4,6 \pm 0,3$ & ( 11 & $1)$ \\
\hline AVT & $\left(\operatorname{mgHAc} . \mathrm{L}^{-1}\right)$ & 169 & \pm 14 & ( & 11 & ) & $2123 \pm 783$ & ( 11 & $1)$ \\
\hline AT & $\left(\mathrm{mgCaCO} 3 \cdot \mathrm{L}^{-1}\right)$ & 612 & \pm 77 & ( & 11 & ) & $252 \pm 169$ & ( 11 & $1)$ \\
\hline AP & $\left(\mathrm{mgCaCO}_{3} \cdot \mathrm{L}^{-1}\right)$ & 458 & \pm 62 & ( & 11 & ) & $0 \pm 0$ & ( 11 & $1)$ \\
\hline AI & $\left(\mathrm{mgCaCO}_{3} \cdot \mathrm{L}^{-1}\right)$ & 153 & \pm 25 & ( & 11 & ) & $252 \pm 169$ & ( 11 & $1 \quad)$ \\
\hline $\mathrm{AB}$ & $\left(\mathrm{mgCaCO}_{3} \cdot \mathrm{L}^{-1}\right)$ & 492 & \pm 75 & ( & 11 & ) & $0 \pm 0$ & ( 11 & $1)$ \\
\hline ST & $\left(\mathrm{mg} \cdot \mathrm{L}^{-1}\right)$ & 2151 & \pm 218 & ( & 4 & ) & $1402 \pm 154$ & ( 4 & $4 \quad)$ \\
\hline SVT & $\left(\mathrm{mg} \cdot \mathrm{L}^{-1}\right)$ & 1735 & \pm 155 & ( & 4 & ) & $998 \pm 118$ & ( 4 & $4 \quad)$ \\
\hline SST & $\left(\mathrm{mg} \cdot \mathrm{L}^{-1}\right)$ & 37 & \pm 21 & ( & 4 & ) & $339 \pm 581$ & ( 4 & $4 \quad)$ \\
\hline SSV & $\left(\mathrm{mg} \cdot \mathrm{L}^{-1}\right)$ & 42 & \pm 12 & ( & 4 & ) & $343 \pm 549$ & ( 4 & $4 \quad)$ \\
\hline $\mathrm{M}_{\mathrm{SVT}}$ & (g) & & - & & & & 8,0 & & \\
\hline $\mathrm{Cx}$ & $\left(\right.$ g. $\left.\mathrm{L}^{-1}\right)$ & & & & & & 2,3 & & \\
\hline $\mathrm{Cx}^{\prime}$ & (g.gsuporte ${ }^{-1}$ ) & & & & & & 0,005 & & \\
\hline $\mathrm{V}_{\mathrm{G}}$ & $\left(\mathrm{mL} \cdot\right.$ ciclo $\left.^{-1}\right)$ & & & & & & $1502 \pm 388$ & ( 12 & 2 \\
\hline $\mathrm{V}_{\mathrm{H} 2}$ & $\left(\mathrm{~mL} \cdot \mathrm{ciclo}^{-1}\right)$ & & & & & & $811 \pm 229$ & ( 12 & 2 \\
\hline $\mathrm{COAV}_{\text {мот }}$ & $\left(\right.$ gDQO.L $\left.L^{-1} \cdot \mathrm{d}^{-1}\right)$ & & 17,9 & & & & 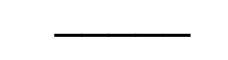 & & \\
\hline $\mathrm{CORV}_{\mathrm{MOF}}$ & $\left(\right.$ gDQO.L $\left.L^{-1} \cdot \mathrm{d}^{-1}\right)$ & & & & & & 4,5 & & \\
\hline $\mathrm{COAV}_{\mathrm{CT}}$ & (gCarboidratos. $\mathrm{L}^{-1} \cdot \mathrm{d}^{-1}$ ) & & 10,8 & & & & & & \\
\hline $\mathrm{CORV}_{\mathrm{CF}}$ & (gCarboidratos. $\mathrm{L}^{-1} \cdot \mathrm{d}^{-1}$ ) & & & & & & 10,7 & & \\
\hline $\mathrm{COAV}_{\mathrm{GT}}$ & (gGlicerina. $\mathrm{L}^{-1} \cdot \mathrm{d}^{-1}$ ) & & 3,7 & & & & & & \\
\hline $\mathrm{CORV}_{\mathrm{GF}}$ & (gGlicerina. $\left.\mathrm{L}^{-1} \cdot \mathrm{d}^{-1}\right)$ & & & & & & 3,6 & & \\
\hline $\mathrm{COAE}_{\text {MOT }}$ & $\left(\right.$ gDQO.gSVT $\left.{ }^{-1} \cdot d^{-1}\right)$ & & 8,0 & & & & & & \\
\hline $\mathrm{CORE}_{\mathrm{MOF}}$ & $\left(\right.$ gDQO.gSVT $\left.{ }^{-1} \cdot \mathrm{d}^{-1}\right)$ & & & & & & 7,8 & & \\
\hline COAE $_{\mathrm{CT}}$ & (gCarboidratos.gSVT ${ }^{-1} \cdot \mathrm{d}^{-1}$ ) & & 8,0 & & & & & & \\
\hline $\mathrm{CORE}_{\mathrm{CF}}$ & (gCarboidratos.gSVT ${ }^{-1} \cdot \mathrm{d}^{-1}$ ) & & & & & & 4,7 & & \\
\hline $\mathrm{COAE}_{\mathrm{GT}}$ & (gGlicerina.gSVT ${ }^{-1} \cdot \mathrm{d}^{-1}$ ) & & 8,0 & & & & & & \\
\hline $\mathrm{CORE}_{\mathrm{GF}}$ & (gGlicerina.gSVT ${ }^{-1} \cdot \mathrm{d}^{-1}$ ) & & & & & & 1,6 & & \\
\hline $\mathrm{n}_{\mathrm{H} 2}$ & $\left(\mathrm{molH}_{2} \cdot \mathrm{d}^{-1}\right)$ & & & & & & 0,2 & & \\
\hline PrM & $\left(\mathrm{molH}_{2} \cdot \mathrm{m}^{-3} \cdot \mathrm{d}^{-1}\right)$ & & & & & & 62,2 & & \\
\hline PrME & $\left(\mathrm{molH}_{2} \cdot \mathrm{kgSVT}^{-1} \cdot \mathrm{d}^{-1}\right)$ & & & & & & 27,0 & & \\
\hline RMCA & $\left(\mathrm{molH}_{2} \cdot \mathrm{kgDQO}^{-1}\right)$ & & 3,5 & & & & & & \\
\hline RMSA & $\left(\mathrm{molH}_{2} \cdot \mathrm{molSubstrato}^{-1}\right)$ & & 1,0 & & & & 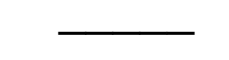 & & \\
\hline RMSR & $\left(\mathrm{molH}_{2} \cdot \mathrm{molSubstrato}^{-1}\right)$ & & & & & & 1,1 & & \\
\hline $\mathrm{V}_{\mathrm{A}}$ & $(\mathrm{L})$ & 1,49 & $\pm 0,08$ & $(1$ & 12 & ) & & & \\
\hline
\end{tabular}

(*) Entre parênteses o número de amostras considerado no cálculo da média 

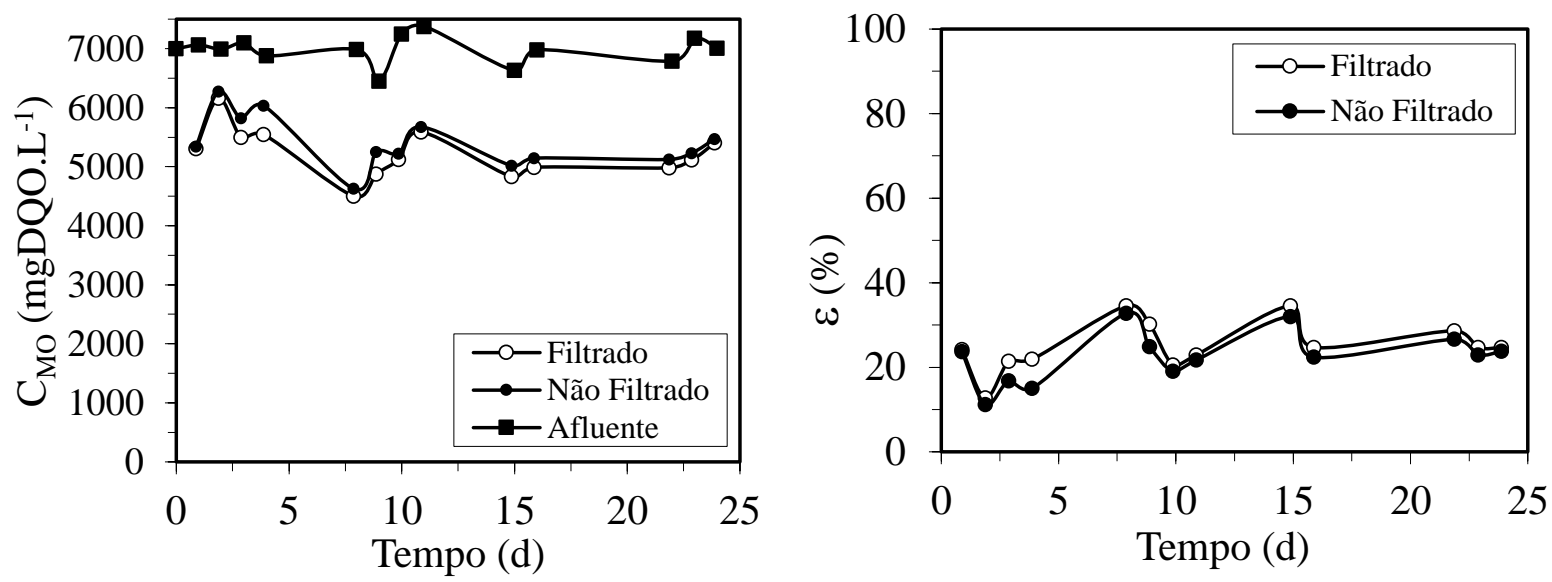

Figura 5.118. Concentração e eficiência de remoção de matéria orgânica na forma de DQO no Ensaio 13: - - afluente amostras não filtradas; • - efluente amostras não filtradas; $\bigcirc$ - efluente amostras filtradas.
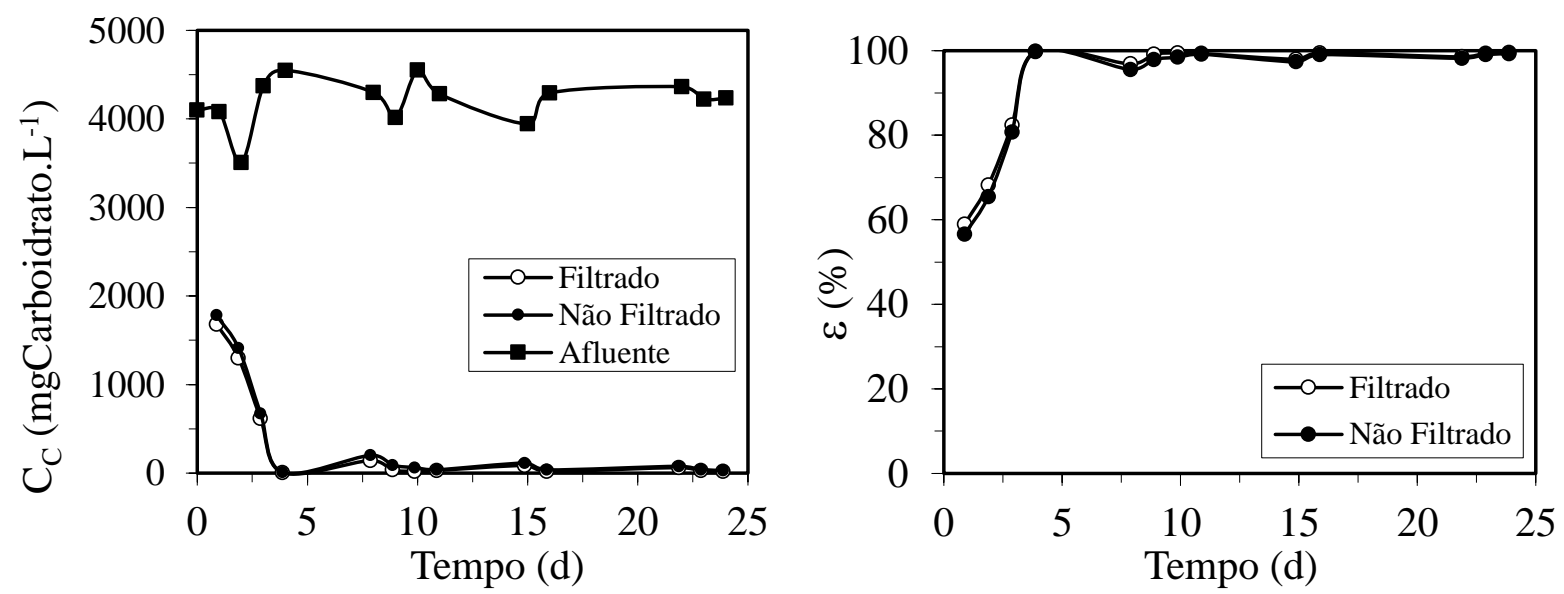

Figura 5.119. Concentração e eficiência de remoção na forma de carboidratos no Ensaio 13: - - afluente amostras não filtradas; • - efluente amostras não filtradas; ○ - efluente amostras filtradas.
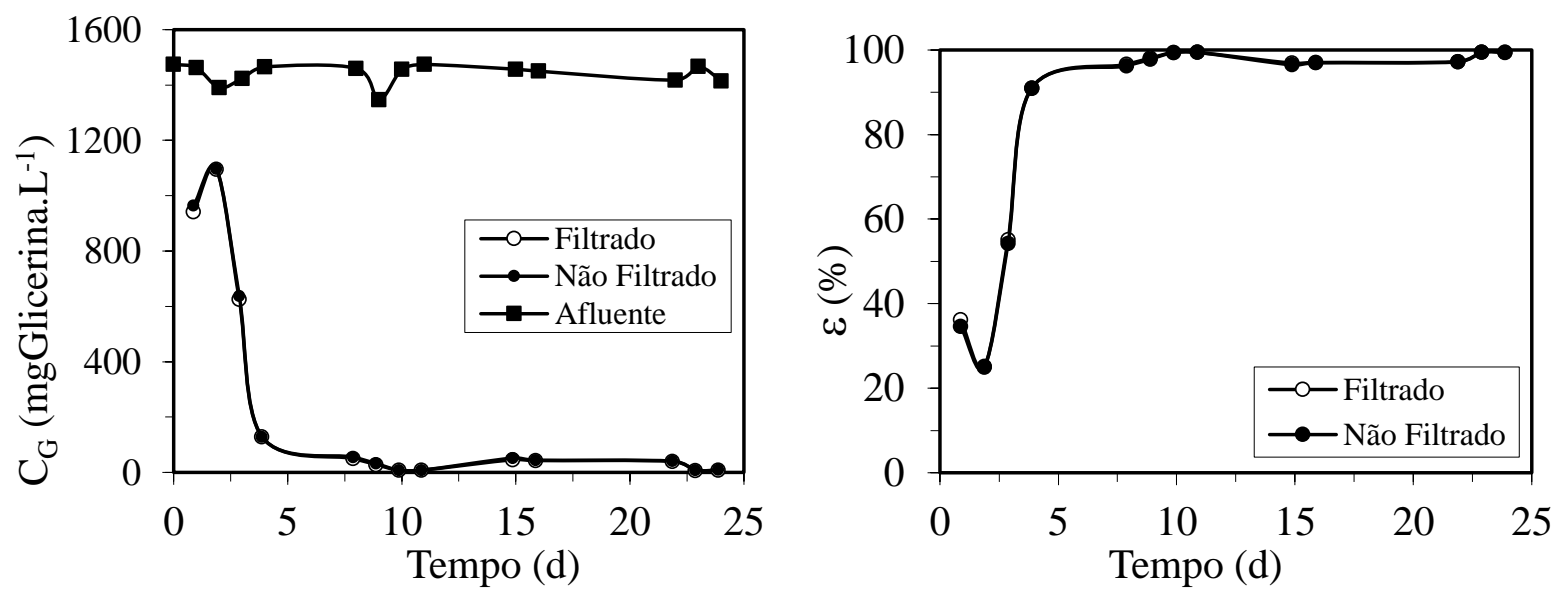

Figura 5.120. Concentração e eficiência de remoção na forma de glicerina no Ensaio 13: - - afluente amostras não filtradas; • - efluente amostras não filtradas; $\bigcirc$ - efluente amostras filtradas

A média do $\mathrm{pH}$ afluente foi de 7,8 e do efluente de 4,6. A alcalinidade total no afluente teve média de $612 \mathrm{mgCaCO} 3 \cdot \mathrm{L}^{-1}$ sendo que a mesma foi consumida até uma média de 
$252 \mathrm{mgCaCO}_{3} \cdot \mathrm{L}^{-1}$. A média de AVT no afluente foi de $169 \mathrm{mgHAc} . \mathrm{L}^{-1}$ e a média de AVT no efluente de $2123 \mathrm{mgHAc} . \mathrm{L}^{-1}$.

A produção de biogás, em aspecto quantitativo, e a distribuição dos gases que compõem o biogás no final do ciclo podem ser observadas pela Figura 5.121, com média de $1502 \mathrm{~mL}$ de biogás e $811 \mathrm{~mL}$ de hidrogênio, sendo que a porcentagem média de hidrogênio foi igual a $54 \%$. Este ensaio obteve qualidade e quantidade de biogás ainda piores do que as obtidas no Ensaio 12, o que demonstra que o aumento do tempo de ciclo não foi benéfico para a produção de hidrogênio e ainda acarretou na diminuição da produtividade, que foi de $62,2 \mathrm{molH}_{2} \cdot \mathrm{m}^{-3} \cdot \mathrm{d}^{-1}$ - quase $52 \%$ pior que os $129,0 \mathrm{molH} 2 \cdot \mathrm{m}^{-3} \cdot \mathrm{d}^{-1}$ do Ensaio 12.
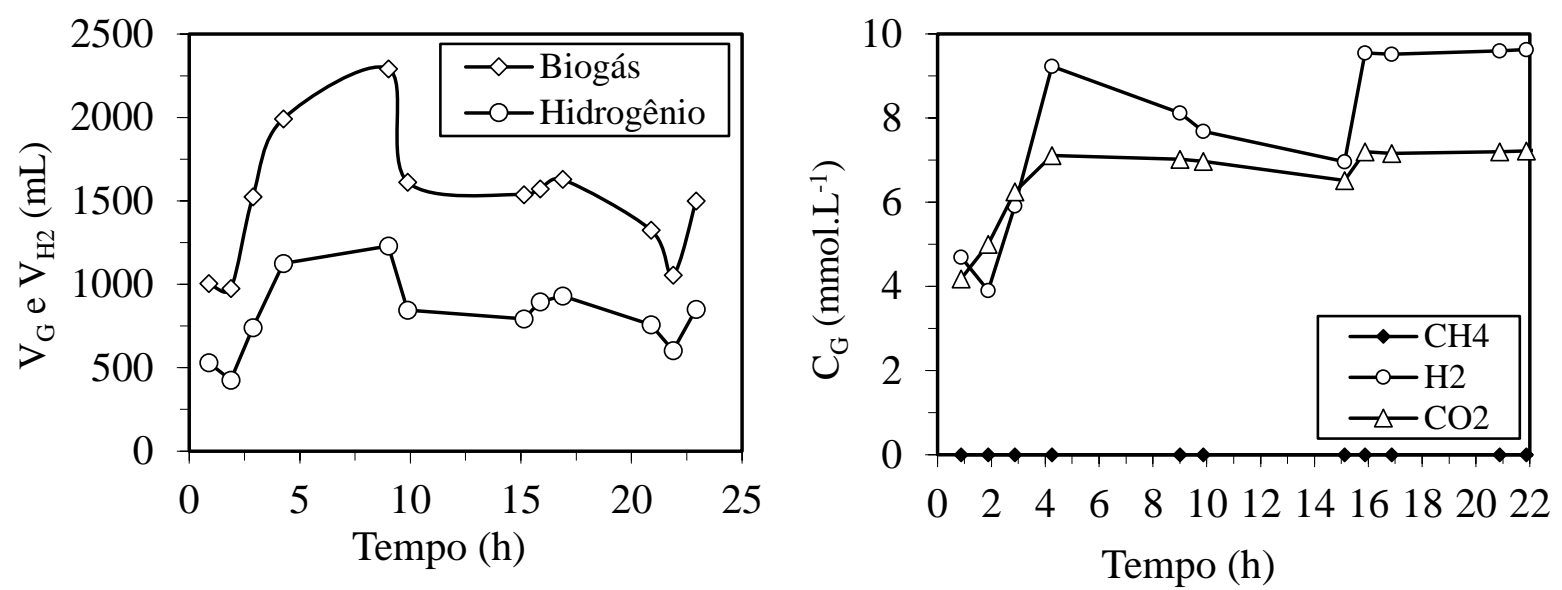

Figura 5.121. Volume de biogás $\left(\mathrm{V}_{\mathrm{G}}\right)$ e de hidrogênio $\left(\mathrm{V}_{\mathrm{H} 2}\right)$ nas $\mathrm{CNTP}$ e concentrações dos componentes do biogás no final do ciclo $\left(\mathrm{C}_{\mathrm{G}}\right)$ no Ensaio 13: $\diamond$ - Biogás; - Metano; $\bigcirc-$ Hidrogênio; $\Delta$ - Dióxido de Carbono.

A Figura 5.122 apresenta o perfil de DQO, de Carboidratos e de Glicerina, nota-se que há uma baixa variação na medida de DQO durante o ciclo, assim como nos perfis anteriores, enquanto os perfis de carboidrato e de glicerina mostram variações maiores. No perfil de carboidratos, nota-se que a velocidade de consumo de substrato é alta, com ponto de máximo em $0,5 \mathrm{~h}$ ao invés de 2,0 h (final da alimentação do afluente). Em relação ao perfil de glicerina, nota-se o típico padrão da batelada alimentada com ponto de máximo de 2,0 h.

A Figura 5.123 apresenta os perfis de $\mathrm{pH}$, alcalinidade total e ácidos voláteis totais ao longo do ciclo. O pH permanece constante ao longo do ciclo por volta de 4,6, bem como os ácidos voláteis totais por volta de $2545 \mathrm{mgHAc} . \mathrm{L}^{-1}$, como nos perfis anteriores. A alcalinidade fornecida pelo afluente não chega a ser totalmente consumida pelo processo e é gerada no final de ciclo. 

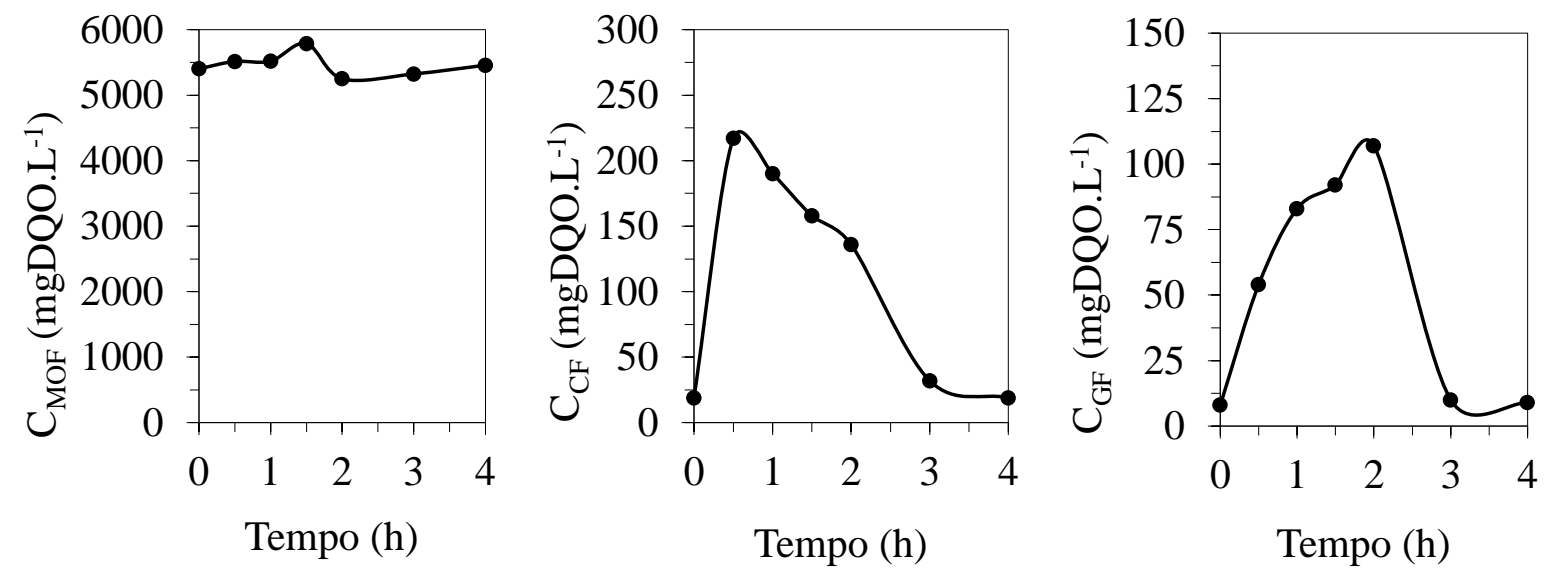

Figura 5.122. Concentração de matéria orgânica, carboidratos e de glicerina durante o ciclo no Ensaio 13.
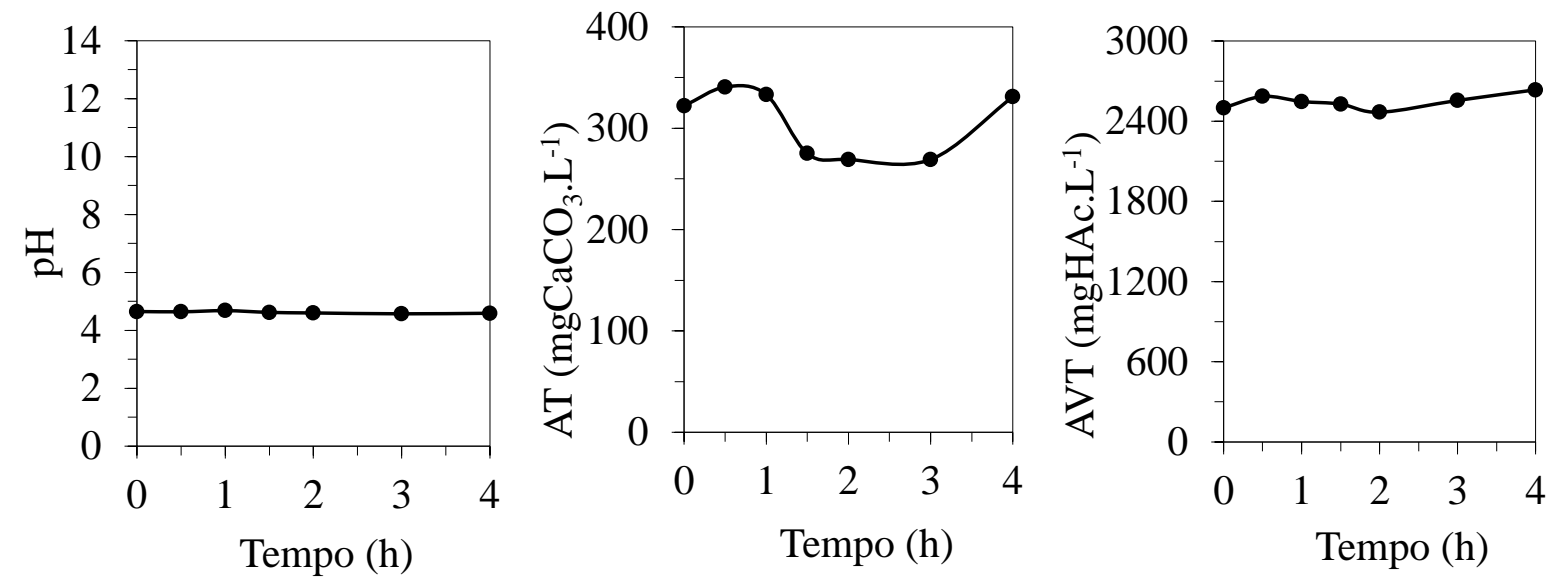

Figura 5.123. Valores de pH, alcalinidade total (AT) e ácidos voláteis totais (AVT) no Ensaio 13.

O perfil dos compostos intermediários do metabolismo é apresentado na Figura 5.124, sendo possível verificar predominância de ácido acético e etanol, com ponto de mínima concentração em 2 h, mesmo padrão dos ensaios da Fase III.

A produção volumétrica acumulada de biogás e os desvios padrões de cada um dos pontos podem ser observados na Figura 5.125 e o perfil das concentrações de cada um dos gases e suas respectivas porcentagens podem ser observados na Figura 5.126. Nota-se que a produção volumétrica de biogás é maior do que a produção atingida no Ensaio 11, mas, devido ao tempo de ciclo maior, a produtividade é mais baixa, evidenciando a importância de trabalhar-se com parâmetros intrínsecos ao processo. Houve baixa variação no volume de gás recolhido diariamente e o mesmo manteve-se estável ao longo do tempo; ao final do perfil, tinha-se $43 \%$ de $\mathrm{CO}_{2}$ e $57 \%$ de $\mathrm{H}_{2}$. 


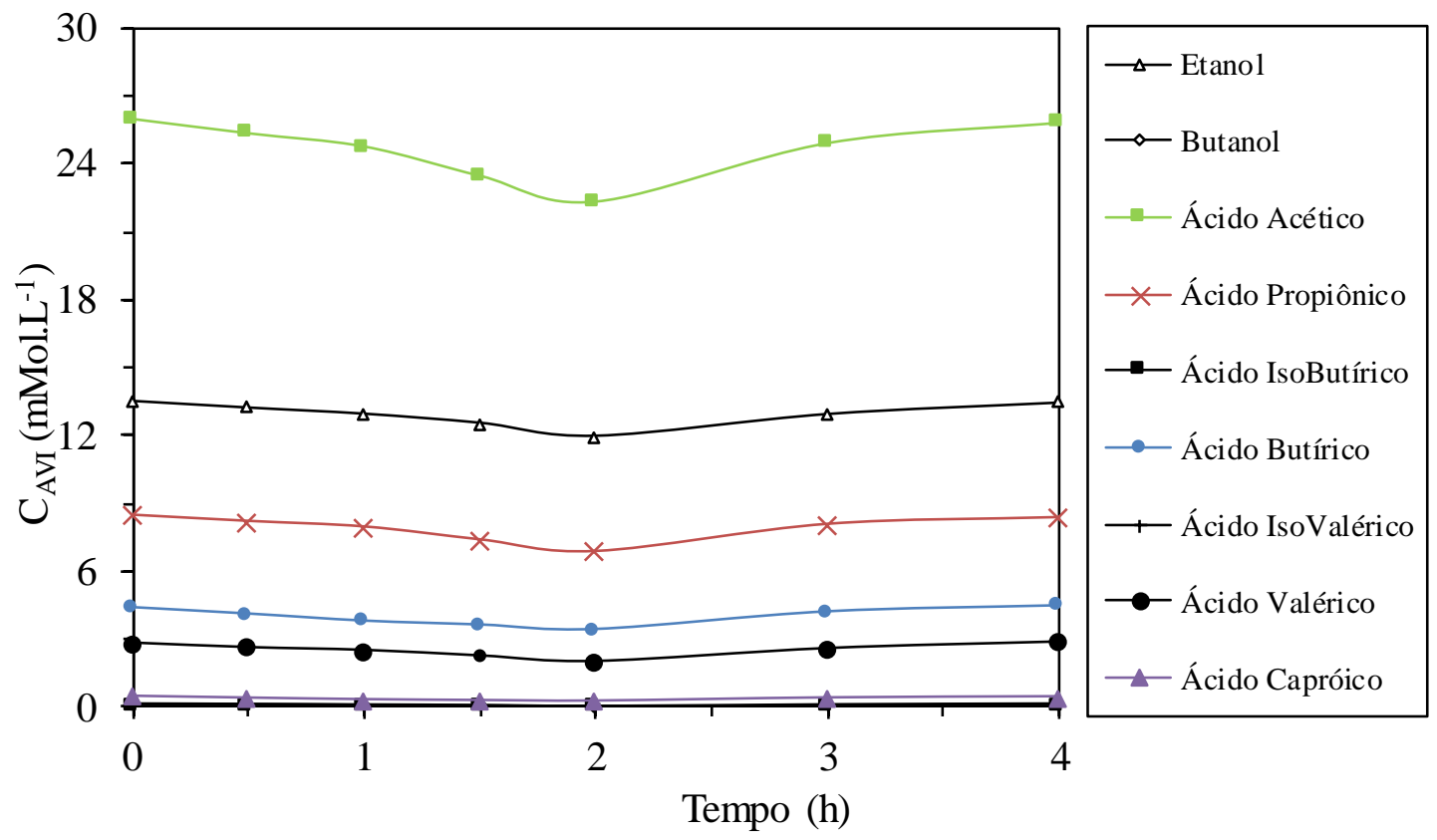

Figura 5.124. Concentração dos compostos intermediários ao longo do ciclo no Ensaio 13: $\Delta$ - etanol; $\diamond$ butanol; $\square$ - ácido acético; -X- ácido propiônico; - ácido isobutírico; • - ácido butírico; + ácido isovalérico $\bullet$ - ácido valérico; $\boldsymbol{\Delta}$ - ácido capróico.

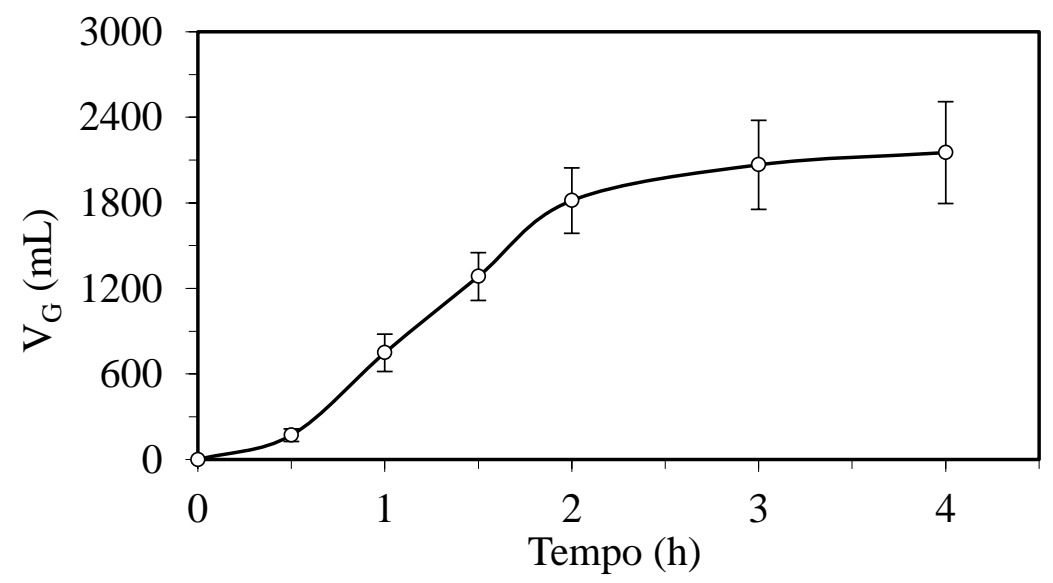

Figura 5.125. Produção volumétrica média acumulada do biogás durante o ciclo no Ensaio 13.
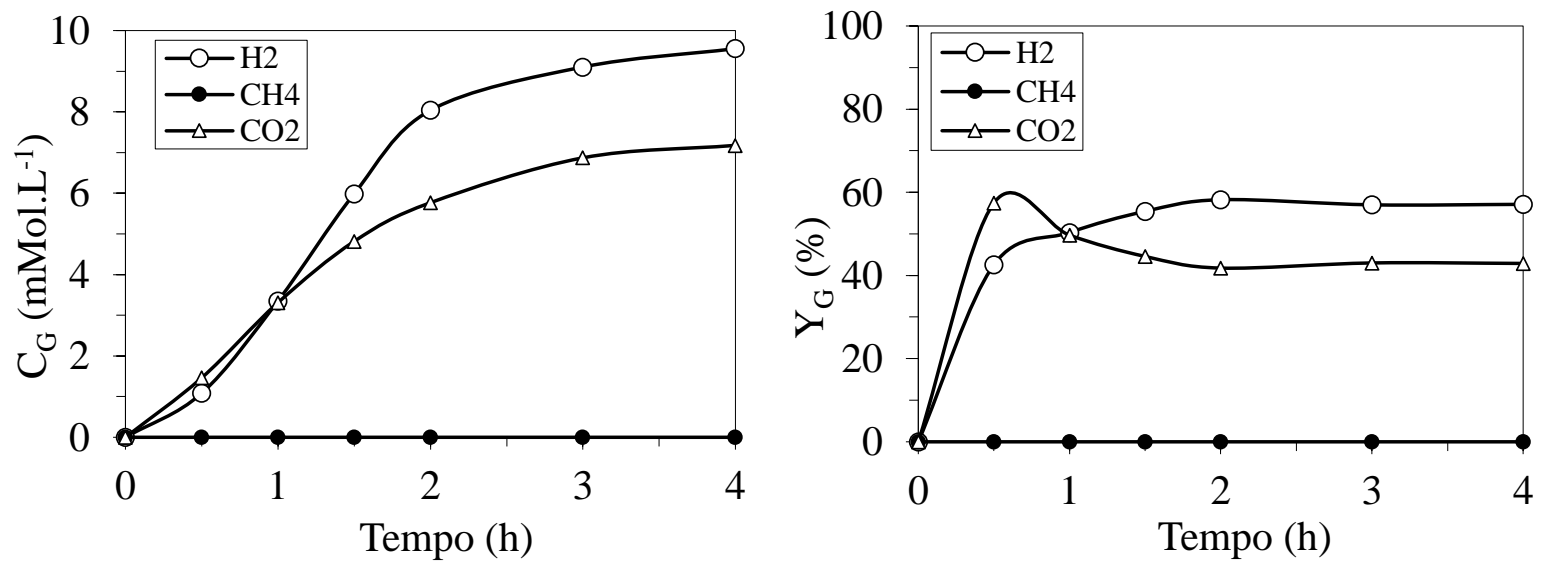

Figura 5.126. Concentração dos compostos do biogás durante o ciclo e suas respectivas porcentagens no Ensaio 13: $\circ-\mathrm{H}_{2} ; \bullet-\mathrm{CH}_{4} ; \Delta-\mathrm{CO}_{2}$. 
5.4.2 Ensaio 14 (75\% Soro e $25 \%$ Glicerina - $\left.7000 \mathrm{mgDQO} . \mathrm{L}^{-1}-2 \mathrm{~h}-\mathrm{BA}\right)$

O Ensaio 14 foi feito com concentração do afluente de $7000 \mathrm{mgDQO} \cdot \mathrm{L}^{-1}$ (75\% de soro e $25 \%$ de glicerina), tempo de ciclo de $2 \mathrm{~h}$ e tempo de alimentação de 1 h. Os parâmetros médios deste ensaio se encontram na Tabela 5.25.

O valor real da COAV foi de $36,4 \mathrm{gDQO} \cdot \mathrm{L}^{-1} \cdot \mathrm{d}^{-1}$ e a CORV atingida foi de 7,6 gDQO.L ${ }^{1} . \mathrm{d}^{-1}$. O afluente teve, em média, $4258 \mathrm{mgCarboidratos} . \mathrm{L}^{-1}$ (COAV foi de 22,0 gCarboidratos. $\mathrm{L}^{-1} \cdot \mathrm{d}^{-1}$ e a CORV atingida foi de 20,9 gCarboidratos. $\mathrm{L}^{-1} \cdot \mathrm{d}^{-1}$ ) e 1440 mgGlicerina. $\mathrm{L}^{-1}$ (COAV foi de 7,5 gGlicerina. $\mathrm{L}^{-1} \cdot \mathrm{d}^{-1}$ e a CORV atingida foi de 6,5 gGlicerina. $\left.\mathrm{L}^{-1} \cdot \mathrm{d}^{-1}\right)$.

O monitoramento diário apresentou o mais baixo consumo de matéria orgânica na forma de DQO até o momento, com média de concentração afluente não filtrada de $7032 \mathrm{mgDQO}$. $^{-}$ ${ }^{1}$, efluente não filtrada $5733 \mathrm{mgDQO} . \mathrm{L}^{-1}$ e de efluente filtrada de $5561 \mathrm{mgDQO} . \mathrm{L}^{-1}$, o que representa uma remoção média para amostras não filtradas de $18 \%$ e para amostras filtradas de $21 \%$ (Figura 5.127).

Em relação ao monitoramento diário de carboidratos, a média de concentração afluente

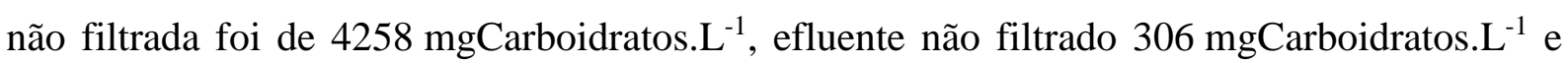
de efluente filtrado $223 \mathrm{mgCarboidratos.} \mathrm{L}^{-1}$, o que representa eficiência média de remoção para amostras não filtradas de 93\% e para amostras filtradas de 95\% (Figura 5.128).

O monitoramento diário de glicerina apresentou média de concentração afluente não

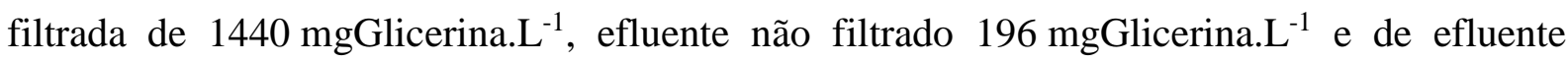
filtrado de 189 mgGlicerina. $L^{-1}$, o que representa uma eficiência média de remoção para amostras não filtradas de $86 \%$ e filtradas de $87 \%$ (Figura 5.129).

A média do $\mathrm{pH}$ afluente foi de 8,0 e do efluente de 4,7. A alcalinidade total no afluente teve média de $681 \mathrm{mgCaCO} 3 . \mathrm{L}^{-1}$ sendo que a mesma foi consumida até uma média de $245 \mathrm{mgCaCO} 3 . \mathrm{L}^{-1}$. A média de AVT no afluente foi de $193 \mathrm{mgHAc} . \mathrm{L}^{-1}$ e a média de AVT no efluente de 2228 mgHAc. $\mathrm{L}^{-1}$. 
Tabela 5.25. Parâmetros médios monitorados no Ensaio 14.

\begin{tabular}{|c|c|c|c|c|c|c|c|c|c|}
\hline \multicolumn{2}{|r|}{ Parâmetro } & \multicolumn{4}{|c|}{ Afluente } & \multicolumn{4}{|c|}{ Efluente } \\
\hline $\mathrm{C}_{\text {мот }}$ & $\left(\mathrm{mgDQO} \cdot \mathrm{L}^{-1}\right)$ & 7032 & \pm 106 & & $12)$ & 5733 & \pm 275 & $(1$ & $12 \quad$ \\
\hline $\mathrm{C}_{\mathrm{MOF}}$ & $\left(\mathrm{mgDQO} \cdot \mathrm{L}^{-1}\right)$ & & & & & 5561 & \pm 300 & $(1$ & $12)$ \\
\hline$\varepsilon_{\mathrm{MOT}}$ & $(\%)$ & & & & & 18 & \pm 4 & $(1$ & $12)$ \\
\hline$\varepsilon_{\mathrm{MOF}}$ & $(\%)$ & & & & & 21 & \pm 4 & $(1$ & $12)$ \\
\hline $\mathrm{C}_{\mathrm{CT}}$ & (mgCarboidratos. $\mathrm{L}^{-1}$ ) & 4258 & \pm 235 & & $12)$ & 306 & \pm 307 & $(1$ & $11)$ \\
\hline $\mathrm{C}_{\mathrm{CF}}$ & (mgCarboidratos. $\mathrm{L}^{-1}$ ) & & & & & 223 & \pm 232 & $(1$ & $11 \quad)$ \\
\hline$\varepsilon_{\mathrm{CT}}$ & $(\%)$ & & & & & 93 & \pm 8 & $(1$ & $11 \quad)$ \\
\hline$\varepsilon_{\mathrm{CF}}$ & $(\%)$ & & & & & 95 & \pm 6 & $(1$ & $11)$ \\
\hline $\mathrm{C}_{\mathrm{GT}}$ & (mgGlicerina. $\mathrm{L}^{-1}$ ) & 1440 & \pm 26 & $(1)$ & $12)$ & 196 & \pm 180 & $(1$ & $11)$ \\
\hline $\mathrm{C}_{\mathrm{GF}}$ & (mgGlicerina. $\mathrm{L}^{-1}$ ) & & & & & 189 & \pm 170 & $(1$ & $11 \quad)$ \\
\hline$\varepsilon_{\mathrm{GT}}$ & $(\%)$ & & & & & 86 & \pm 13 & $(1$ & $11)$ \\
\hline$\varepsilon_{\mathrm{GF}}$ & $(\%)$ & & & & & 87 & \pm 12 & $(1$ & $11)$ \\
\hline $\mathrm{pH}$ & (u) & 8,0 & $\pm \quad 0,1$ & $(1$ & $11 \quad$ & 4,7 & $\pm 0,4$ & $(1$ & $11)$ \\
\hline AVT & $\left(\mathrm{mgHAc} . \mathrm{L}^{-1}\right)$ & 193 & $\pm \quad 53$ & $(1$ & $11 \quad)$ & 2228 & \pm 726 & $(1$ & $11 \quad)$ \\
\hline AT & $\left(\mathrm{mgCaCO}_{3} \cdot \mathrm{L}^{-1}\right)$ & 681 & $\pm \quad 70$ & $(1$ & $11 \quad$ & 245 & \pm 176 & $(1$ & $11 \quad)$ \\
\hline $\mathrm{AP}$ & $\left(\mathrm{mgCaCO}_{3} \cdot \mathrm{L}^{-1}\right)$ & 517 & $\pm \quad 42$ & $(1$ & $11)$ & 0 & \pm 0 & $(1$ & $11 \quad)$ \\
\hline AI & $\left(\mathrm{mgCaCO}_{3} \cdot \mathrm{L}^{-1}\right)$ & 164 & $\pm \quad 30$ & $(1$ & $11 \quad)$ & 245 & \pm 176 & $(1$ & $11 \quad)$ \\
\hline $\mathrm{AB}$ & $\left(\mathrm{mgCaCO}_{3} \cdot \mathrm{L}^{-1}\right)$ & 544 & $\pm \quad 57$ & $(1$ & $11 \quad)$ & 0 & \pm 0 & $(1$ & $11 \quad)$ \\
\hline ST & $\left(\mathrm{mg} \cdot \mathrm{L}^{-1}\right)$ & 3008 & \pm 1640 & $(4$ & $4 \quad)$ & 2121 & \pm 692 & ( & 4 \\
\hline SVT & $\left(\mathrm{mg} \cdot \mathrm{L}^{-1}\right)$ & 2363 & \pm 1191 & $(4$ & $4 \quad)$ & 1439 & \pm 431 & ( & $4 \quad)$ \\
\hline SST & $\left(\mathrm{mg} \cdot \mathrm{L}^{-1}\right)$ & 48 & \pm 18 & $(4$ & $4 \quad)$ & 121 & \pm 90 & ( & $4 \quad)$ \\
\hline SSV & $\left(\mathrm{mg} \cdot \mathrm{L}^{-1}\right)$ & 32 & \pm 18 & $(4$ & $4 \quad)$ & 70 & \pm 18 & ( & $4 \quad)$ \\
\hline $\mathrm{M}_{\mathrm{SVT}}$ & (g) & & & & & & 26,6 & & \\
\hline $\mathrm{Cx}$ & $\left(\right.$ g. $\left.\mathrm{L}^{-1}\right)$ & & & & & & 3,8 & & \\
\hline $\mathrm{Cx}^{\prime}$ & (g.gsuporte ${ }^{-1}$ ) & & & & & & 008 & & \\
\hline $\mathrm{V}_{\mathrm{G}}$ & $\left(\mathrm{mL} . \mathrm{ciclo}^{-1}\right)$ & & & & & 1053 & \pm 241 & $(1$ & 12 \\
\hline $\mathrm{V}_{\mathrm{H} 2}$ & $\left(\mathrm{~mL} \cdot \mathrm{ciclo}^{-1}\right)$ & & & & & 605 & \pm 220 & $(1$ & 12 \\
\hline $\mathrm{COAV}_{\text {мот }}$ & $\left(\mathrm{gDQO} \cdot \mathrm{L}^{-1} \cdot \mathrm{d}^{-1}\right)$ & & 36,4 & & & & & & \\
\hline $\mathrm{CORV}_{\mathrm{MOF}}$ & $\left(\mathrm{gDQO} \cdot \mathrm{L}^{-1} \cdot \mathrm{d}^{-1}\right)$ & & & & & & 7,6 & & \\
\hline $\mathrm{COAV}_{\mathrm{CT}}$ & (gCarboidratos. $\left.\mathrm{L}^{-1} \cdot \mathrm{d}^{-1}\right)$ & & 22,0 & & & & & & \\
\hline $\mathrm{CORV}_{\mathrm{CF}}$ & (gCarboidratos. $\mathrm{L}^{-1} \cdot \mathrm{d}^{-1}$ ) & & & & & & 20,9 & & \\
\hline $\mathrm{COAV}_{\mathrm{GT}}$ & (gGlicerina. $\mathrm{L}^{-1} \cdot \mathrm{d}^{-1}$ ) & & 7,5 & & & & & & \\
\hline $\mathrm{CORV}_{\mathrm{GF}}$ & (gGlicerina. $\mathrm{L}^{-1} \cdot \mathrm{d}^{-1}$ ) & & & & & & 6,5 & & \\
\hline $\mathrm{COAE}_{\text {MOT }}$ & $\left(\right.$ gDQO.gSVT $\left.{ }^{-1} \cdot \mathrm{d}^{-1}\right)$ & & 13,3 & & & & & & \\
\hline $\mathrm{CORE}_{\mathrm{MOF}}$ & $\left(\right.$ gDQO.gSVT $\left.{ }^{-1} \cdot \mathrm{d}^{-1}\right)$ & & & & & & 9,6 & & \\
\hline $\mathrm{COAE}_{\mathrm{CT}}$ & (gCarboidratos.gSVT ${ }^{-1} \cdot \mathrm{d}^{-1}$ ) & & 13,3 & & & & & & \\
\hline $\mathrm{CORE}_{\mathrm{CF}}$ & (gCarboidratos.gSVT ${ }^{-1} \cdot \mathrm{d}^{-1}$ ) & & & & & & 5,8 & & \\
\hline $\mathrm{COAE}_{\mathrm{GT}}$ & (gGlicerina.gSVT ${ }^{-1} \cdot \mathrm{d}^{-1}$ ) & & 13,3 & & & & & & \\
\hline $\mathrm{CORE}_{\mathrm{GF}}$ & (gGlicerina.gSVT ${ }^{-1} \cdot \mathrm{d}^{-1}$ ) & & & & & & 2,0 & & \\
\hline $\mathrm{n}_{\mathrm{H} 2}$ & $\left(\mathrm{molH}_{2} \cdot \mathrm{d}^{-1}\right)$ & & & & & & 0,3 & & \\
\hline PrM & $\left(\mathrm{molH}_{2} \cdot \mathrm{m}^{-3} \cdot \mathrm{d}^{-1}\right)$ & & & & & & 92,1 & & \\
\hline PrME & $\left(\mathrm{molH}_{2} \cdot \mathrm{kgSVT}^{-1} \cdot \mathrm{d}^{-1}\right)$ & & & & & & 24,4 & & \\
\hline RMCA & $\left(\mathrm{molH}_{2} \cdot \mathrm{kgDQO}^{-1}\right)$ & & 2,5 & & & & & & \\
\hline RMSA & $\left(\mathrm{molH}_{2} \cdot \mathrm{molSubstrato}^{-1}\right)$ & & 0,7 & & & & - & & \\
\hline RMSR & $\left(\mathrm{molH}_{2} \cdot \mathrm{molSubstrato}^{-1}\right)$ & & & & & & 0,8 & & \\
\hline $\mathrm{V}_{\mathrm{A}}$ & $(\mathrm{L})$ & 1,52 & $\pm 0,07$ & $(1$ & $11)$ & & & & \\
\hline
\end{tabular}

(*) Entre parênteses o número de amostras considerado no cálculo da média 

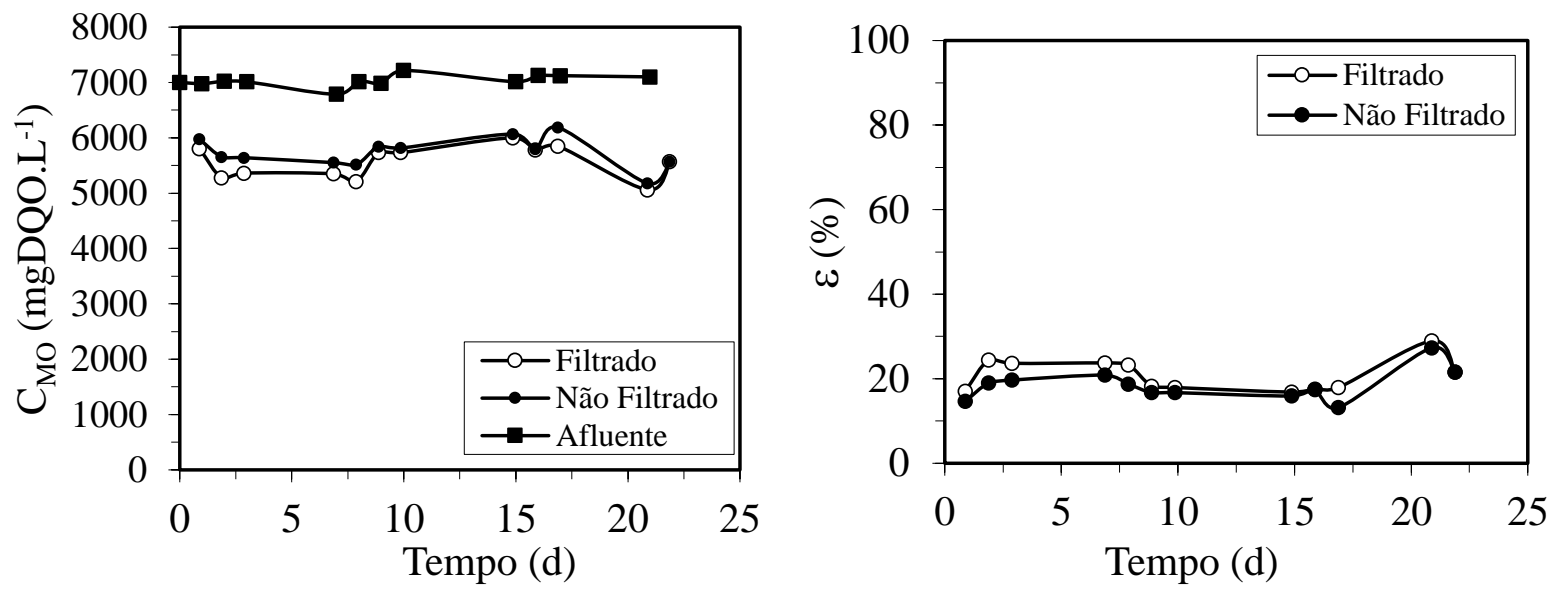

Figura 5.127. Concentração e eficiência de remoção de matéria orgânica na forma de DQO no Ensaio 14: - - afluente amostras não filtradas; • - efluente amostras não filtradas; $\bigcirc$ - efluente amostras filtradas.
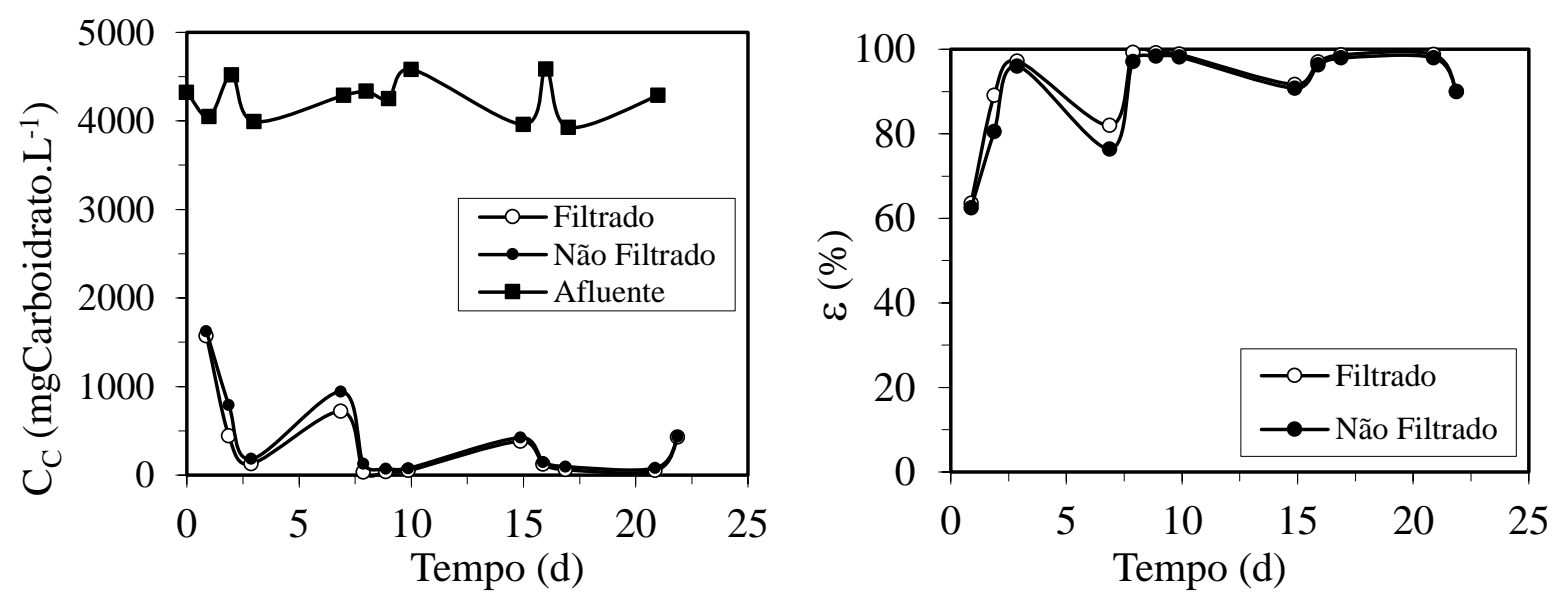

Figura 5.128. Concentração e eficiência de remoção na forma de carboidratos no Ensaio 14: - - afluente amostras não filtradas; • - efluente amostras não filtradas; ○ - efluente amostras filtradas.
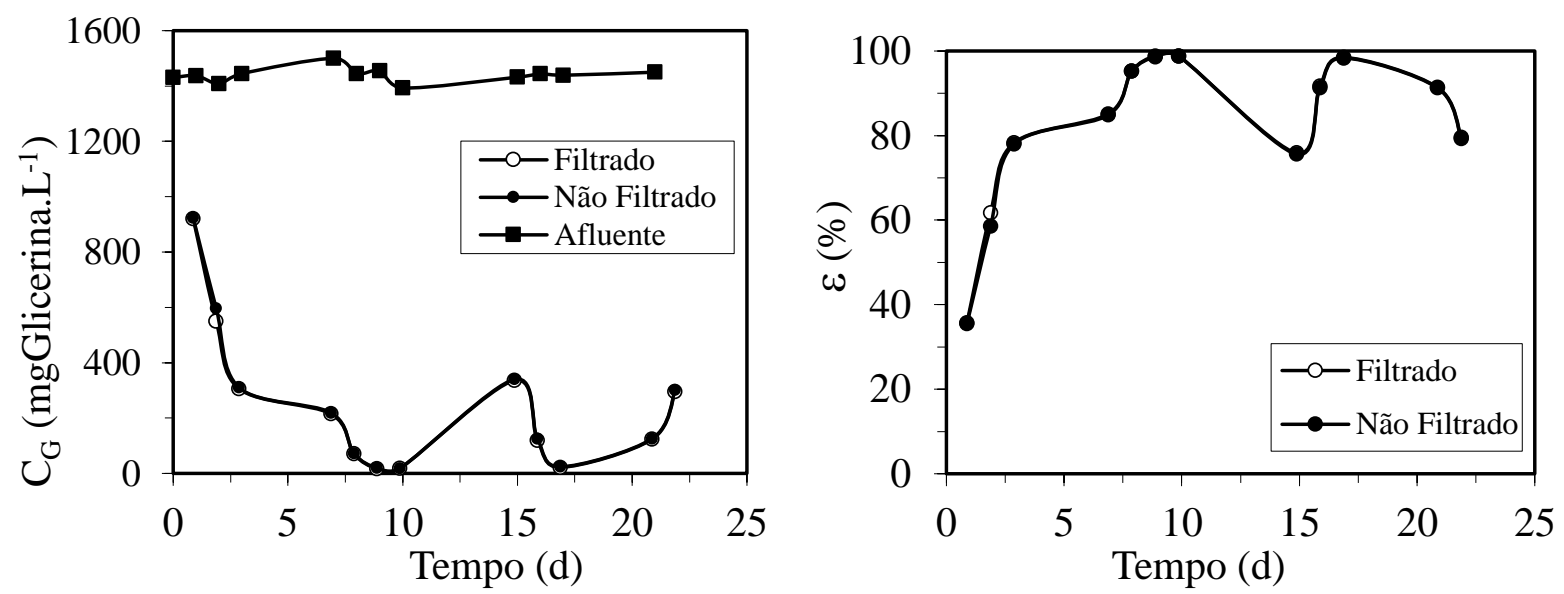

Figura 5.129. Concentração e eficiência de remoção na forma de glicerina no Ensaio 14: - - afluente amostras não filtradas; • - efluente amostras não filtradas; $\bigcirc$ - efluente amostras filtradas

A produção de biogás, em aspecto quantitativo, e a distribuição dos gases que compõem o biogás no final do ciclo podem ser observadas pela Figura 5.130, com média de $1553 \mathrm{~mL}$ de 
biogás e $605 \mathrm{~mL}$ de hidrogênio, sendo que a porcentagem média de hidrogênio foi igual a $56 \%$. Este ensaio obteve qualidade e quantidade de biogás semelhantes às do Ensaio 13, mas, devido a diminuição do tempo de ciclo, a produtividade atingiu um valor muito superior: $92,1 \mathrm{molH}_{2} \cdot \mathrm{m}^{-3} \cdot \mathrm{d}^{-1}$.
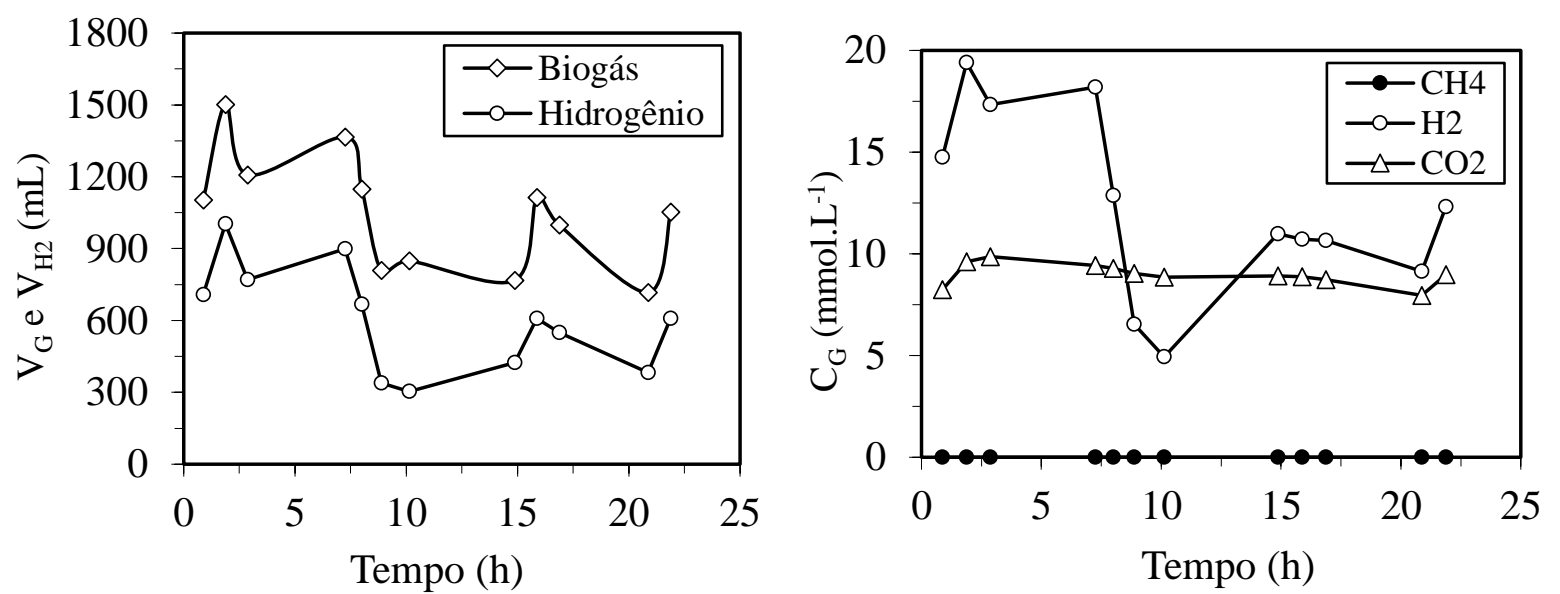

Figura 5.130. Volume de biogás $\left(\mathrm{V}_{\mathrm{G}}\right)$ e de hidrogênio $\left(\mathrm{V}_{\mathrm{H} 2}\right)$ nas CNTP e concentrações dos componentes do biogás no final do ciclo $\left(\mathrm{C}_{\mathrm{G}}\right)$ no Ensaio 14: $\diamond$ - Biogás; $\bullet$ - Metano; $\bigcirc-$ Hidrogênio; $\Delta$ - Dióxido de Carbono.

A Figura 5.131 apresenta o perfil de DQO, de Carboidratos e de Glicerina. Nota-se que há uma baixa variação na medida de DQO durante o ciclo, assim como nos perfis anteriores, enquanto os perfis de carboidrato e de glicerina mostram variações maiores. Tanto no perfil de carboidratos quanto no de glicerina, nota-se o ponto de máximo em 1,0 h (final da alimentação do afluente), típico padrão da batelada alimentada.

A Figura 5.132 apresenta os perfis de $\mathrm{pH}$, alcalinidade total e ácidos voláteis totais ao longo do ciclo. $\mathrm{O}$ pH permanece constante ao longo do ciclo por volta de 4,5. Nota-se um ponto suave de mínima concentração em 1,0 no perfil dos ácidos voláteis, sendo que a média foi de $2355 \mathrm{mgHAc} . \mathrm{L}^{-1}$. A alcalinidade fornecida pelo afluente não chega a ser totalmente consumida pelo processo e termina o perfil em $110 \mathrm{mgCaCO} 3 \cdot \mathrm{L}^{-1}$. 

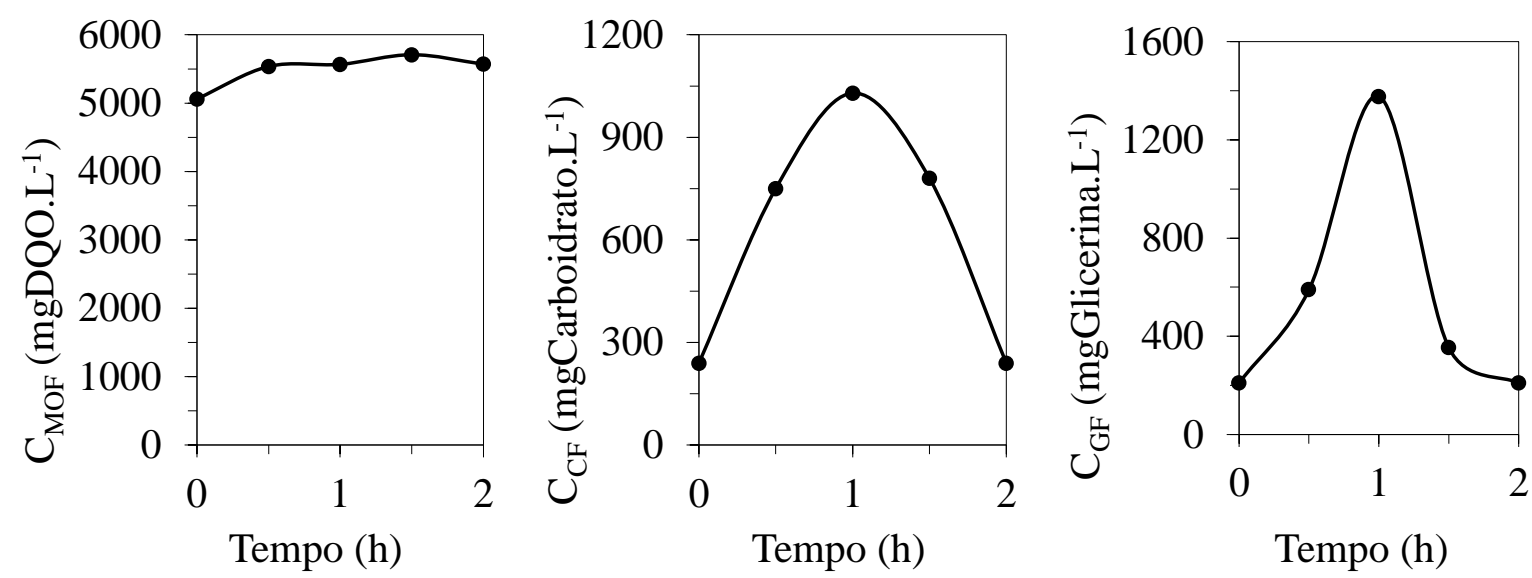

Figura 5.131. Concentração de matéria orgânica, carboidratos e de glicerina durante o ciclo no Ensaio 14.
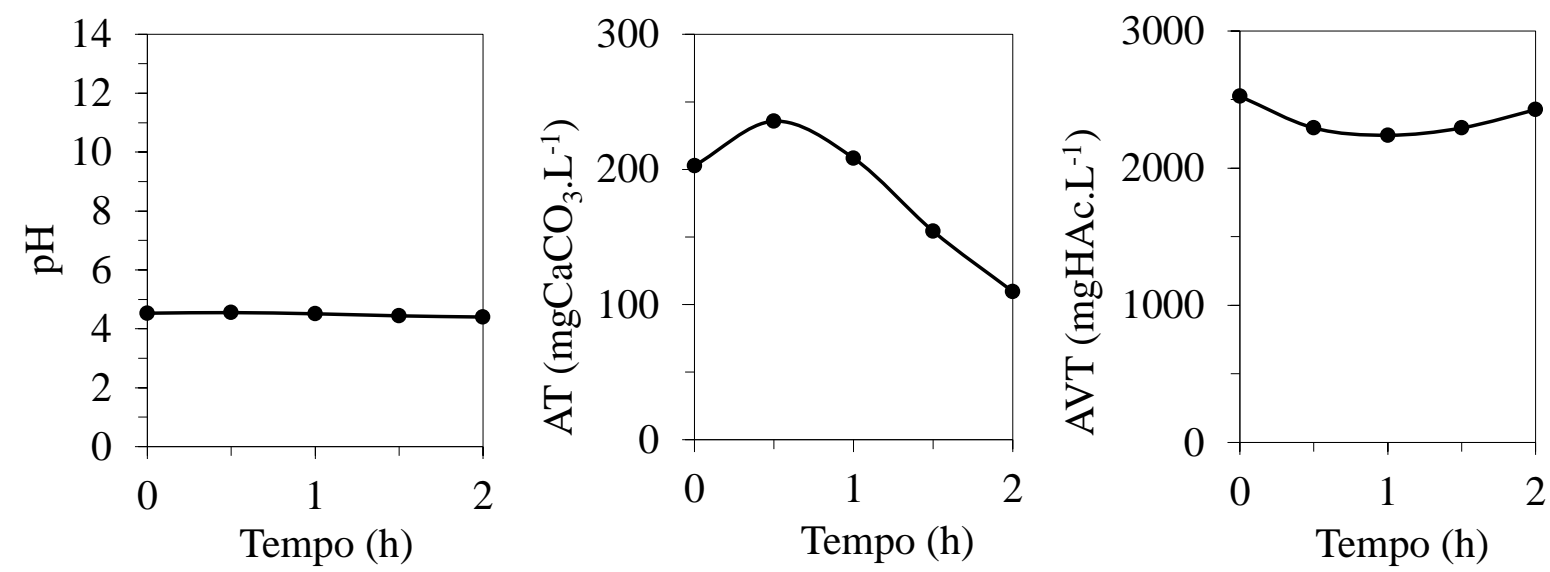

Figura 5.132. Valores de pH, alcalinidade total (AT) e ácidos voláteis totais (AVT) no Ensaio 14.

O perfil dos compostos intermediários do metabolismo é apresentado na Figura 5.133, sendo possível verificar predominância de ácido acético e ácido propiônico, com ponto de mínima concentração em 1 h (para o ácido acético).

A produção volumétrica acumulada de biogás e os desvios padrões de cada um dos pontos podem ser observados na Figura 5.134 e o perfil das concentrações de cada um dos gases e suas respectivas porcentagens podem ser observados na Figura 5.135. Nota-se que a produção volumétrica de biogás é semelhante a produção atingida no Ensaio 13, mas, devido ao tempo de ciclo menor, a produtividade é mais alta. Houve baixa variação no volume de gás recolhido diariamente e o mesmo manteve-se estável ao longo do tempo; ao final do perfil, tinha-se $42 \%$ de $\mathrm{CO}_{2}$ e $58 \%$ de $\mathrm{H}_{2}$. 


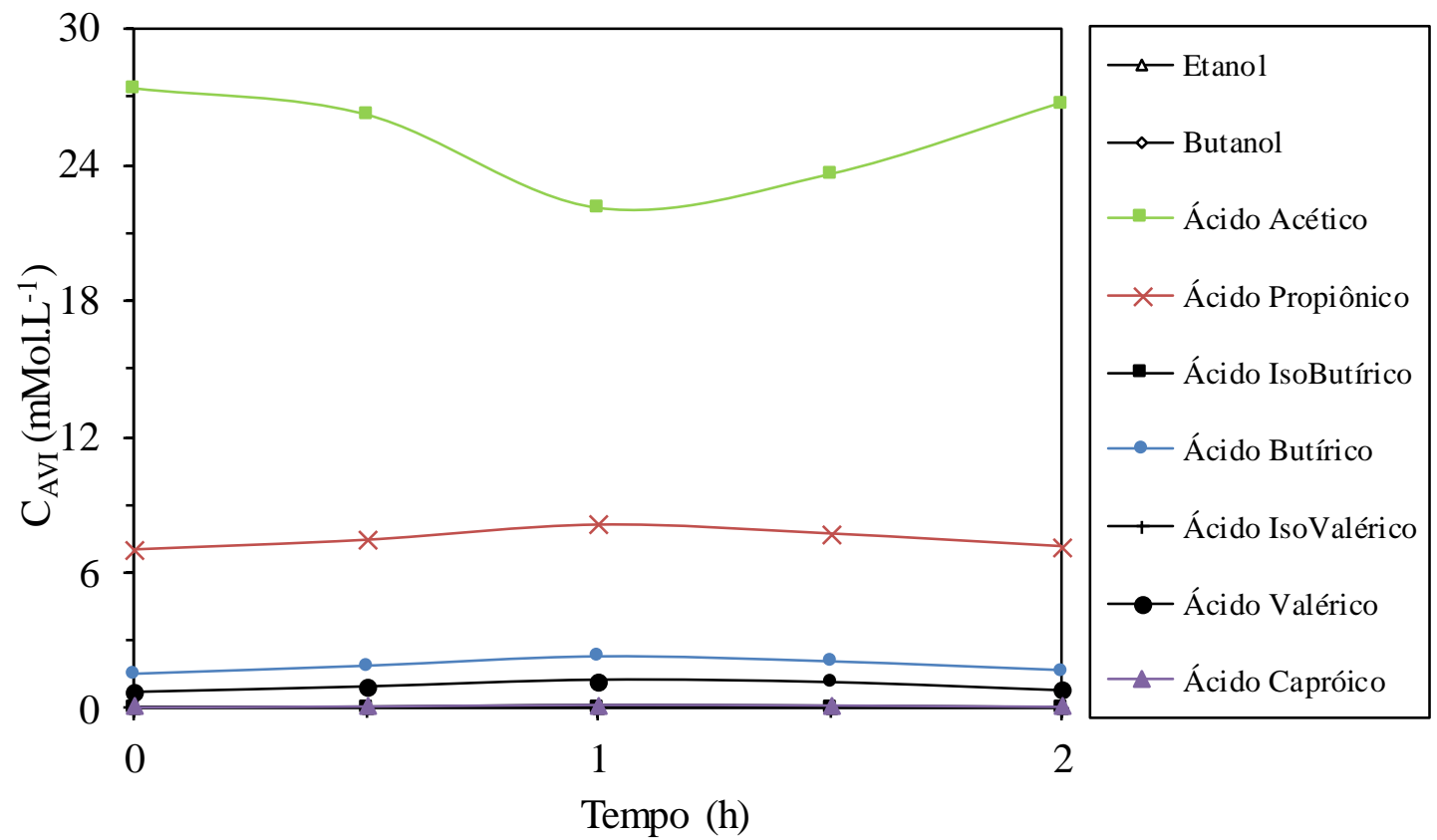

Figura 5.133. Concentração dos compostos intermediários ao longo do ciclo no Ensaio 14: $\Delta$ - etanol; $\diamond$ butanol; - - ácido acético; -X- ácido propiônico; - ácido isobutírico; • - ácido butírico; + ácido isovalérico $\bullet$ - ácido valérico; $\Delta$ - ácido capróico.

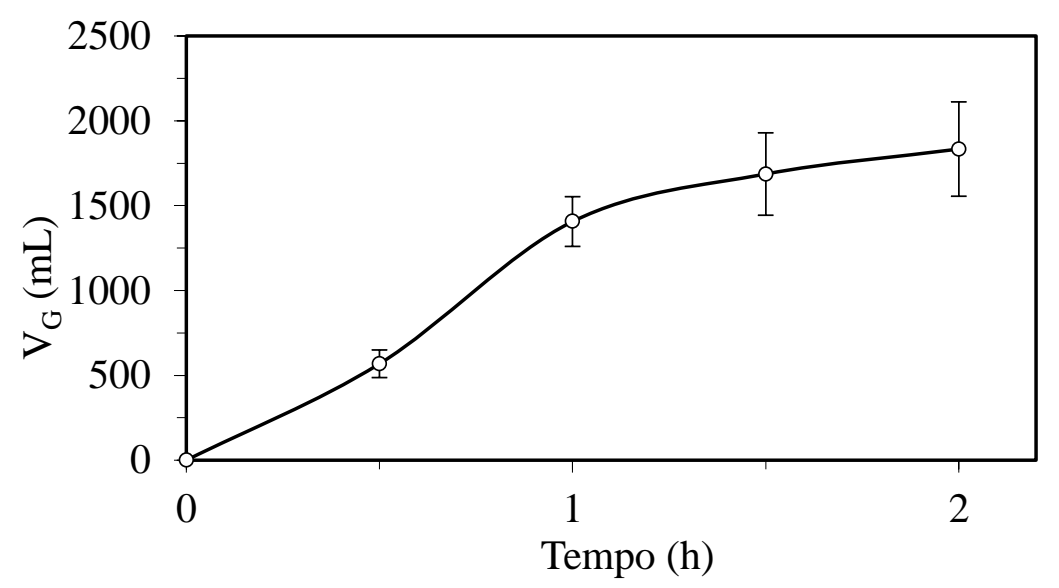

Figura 5.134. Produção volumétrica média acumulada do biogás durante o ciclo no Ensaio 14.
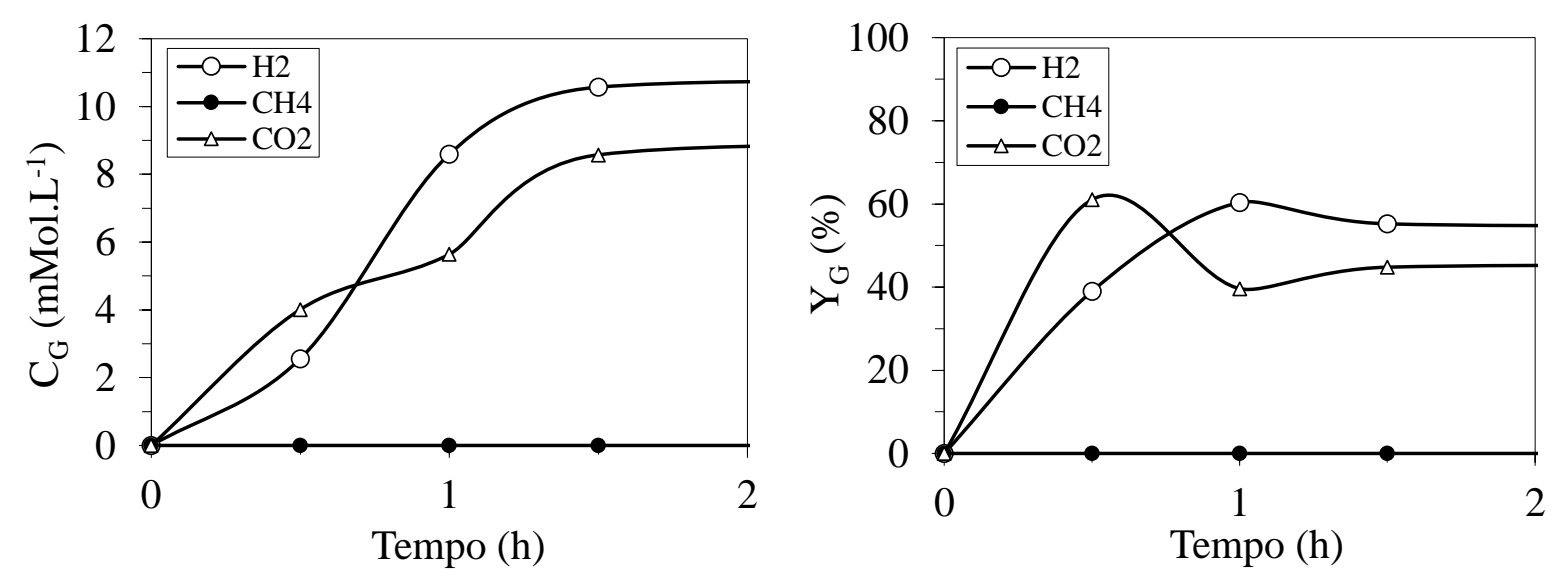

Figura 5.135. Concentração dos compostos do biogás durante o ciclo e suas respectivas porcentagens no Ensaio 14: $\odot-\mathrm{H}_{2} ; \bullet-\mathrm{CH}_{4} ; \Delta-\mathrm{CO}_{2}$. 
5.4.3 Ensaio 15 (75\% Soro e 25\% Glicerina - $\left.7000 \mathrm{mgDQO} . \mathrm{L}^{-1}-3 \mathrm{~h}-\mathrm{B}\right)$

O Ensaio 15 foi feito com concentração do afluente de $7000 \mathrm{mgDQO} . \mathrm{L}^{-1}$ (75\% de soro e $25 \%$ de glicerina), tempo de ciclo de $3 \mathrm{~h}$ e tempo de alimentação de 10 minutos, o que caracteriza este ensaio como uma batelada e não como uma batelada alimentada como foram os Ensaios de 1 a 14. Os parâmetros médios deste ensaio se encontram na Tabela 5.26.

O valor real da COAV foi de 23,3 gDQO.L $\mathrm{L}^{-1} \cdot \mathrm{d}^{-1}$ e a CORV atingida foi de 4,9 gDQO.L ${ }^{-}$ ${ }^{1} . \mathrm{d}^{-1}$. O afluente teve, em média, $4776 \mathrm{mgCarboidratos} . \mathrm{L}^{-1} \quad(\mathrm{COAV}$ foi de 12,0 gCarboidratos. $\mathrm{L}^{-1} \cdot \mathrm{d}^{-1}$ e a CORV atingida foi de 11,4 gCarboidratos. $\left.\mathrm{L}^{-1} \cdot \mathrm{d}^{-1}\right)$ e $1450 \mathrm{mgGlicerina} . \mathrm{L}^{-1}$ (COAV foi de $3,6 \mathrm{gGlicerina} . \mathrm{L}^{-1} \cdot \mathrm{d}^{-1}$ e a CORV atingida foi de 3,5 gGlicerina. $\left.\mathrm{L}^{-1} \cdot \mathrm{d}^{-1}\right)$.

O monitoramento diário apresentou um baixo consumo de matéria orgânica na forma de DQO, mas semelhante ao encontrado nos outros ensaios, com média de concentração afluente não filtrada de $6977 \mathrm{mgDQO} . \mathrm{L}^{-1}$, efluente não filtrada $5739 \mathrm{mgDQO} . \mathrm{L}^{-1}$ e de efluente filtrada de $5497 \mathrm{mgDQO} . \mathrm{L}^{-1}$, o que representa uma remoção média para amostras não filtradas de $18 \%$ e para amostras filtradas de $21 \%$ (Figura 5.136).

Em relação ao monitoramento diário de carboidratos, a média de concentração afluente

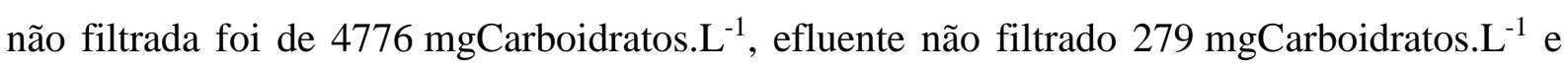
de efluente filtrado $242 \mathrm{mgCarboidratos} . \mathrm{L}^{-1}$, o que representa eficiência média de remoção para amostras não filtradas de 94\% e filtradas de 95\% (Figura 5.137).

O monitoramento diário de glicerina apresentou média de concentração afluente não filtrada de $1450 \mathrm{mgGlicerina.} \mathrm{L}^{-1}$, efluente não filtrado $35 \mathrm{mgGlicerina} . \mathrm{L}^{-1}$ e de efluente filtrado de 33 mgGlicerina. $L^{-1}$, o que representa uma eficiência média de remoção para amostras não filtradas e filtradas de $97 \%$ (Figura 5.138). As eficiências de remoção tanto de glicerina quanto de carboidratos são inferiores às encontradas no Ensaio 12 (mesmas condições deste ensaio, só que em BA), isso provavelmente se deve a liberação gradual de substrato na batelada alimentada e, por conseguinte, uma melhor assimilação do mesmo pelo consórcio microbiano.

A média do $\mathrm{pH}$ afluente foi de 7,9 e do efluente de 4,7. A alcalinidade total no afluente teve média de $688 \mathrm{mgCaCO}_{3} \cdot \mathrm{L}^{-1}$ sendo que a mesma foi consumida até uma média de $253 \mathrm{mgCaCO}_{3} \cdot \mathrm{L}^{-1}$. A média de AVT no afluente foi de $187 \mathrm{mgHAc} . \mathrm{L}^{-1}$ e a média de AVT no efluente de 2198 mgHAc. $\mathrm{L}^{-1}$, o que são resultados equivalentes aos encontrados nos ensaios em batelada alimentada. 
Tabela 5.26. Parâmetros médios monitorados no Ensaio 15.

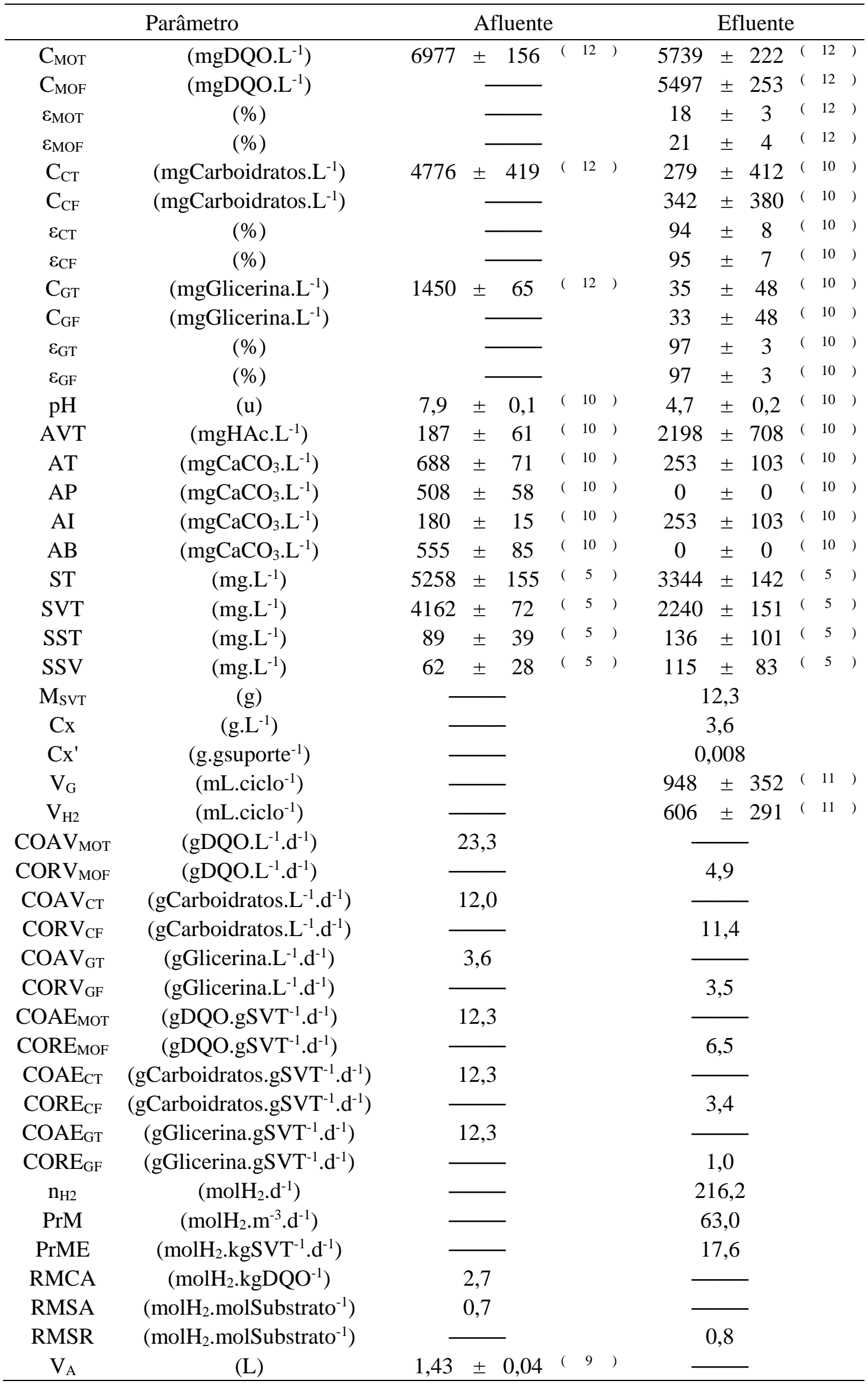

(*) Entre parênteses o número de amostras considerado no cálculo da média 

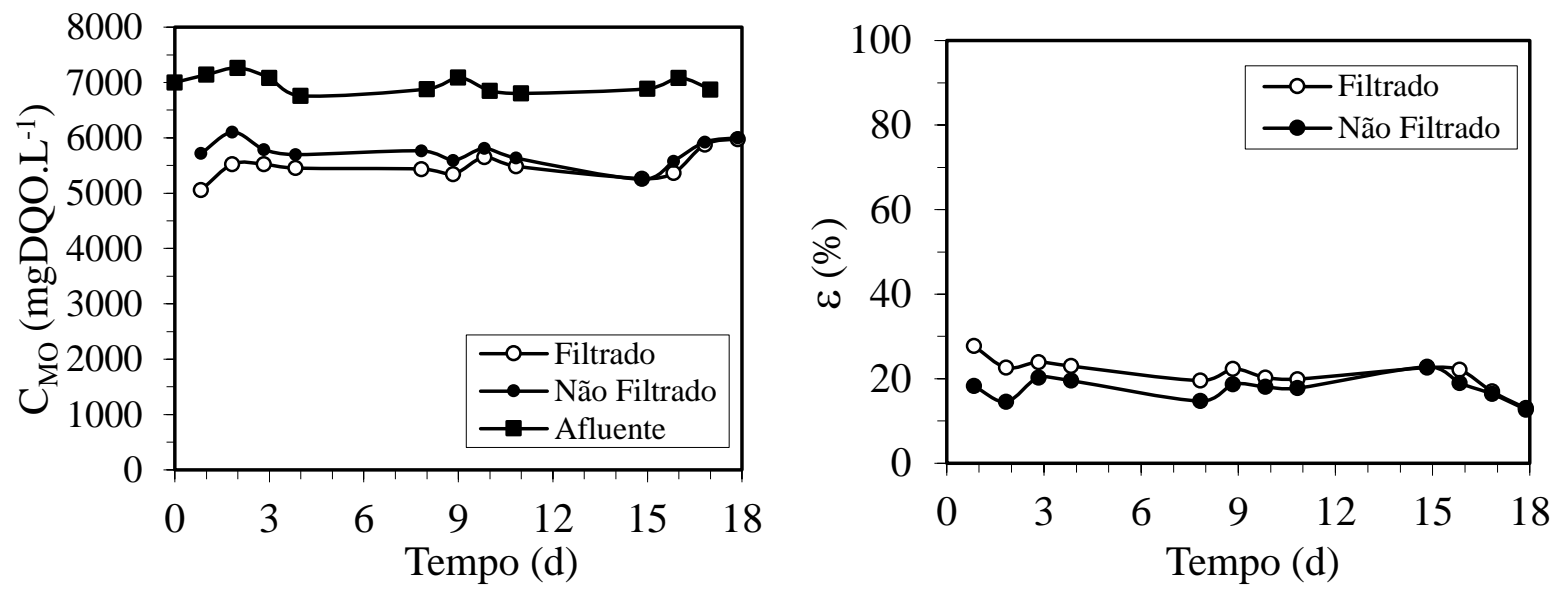

Figura 5.136. Concentração e eficiência de remoção de matéria orgânica na forma de DQO no Ensaio 15: - - afluente amostras não filtradas; • - efluente amostras não filtradas; $\bigcirc$ - efluente amostras filtradas.
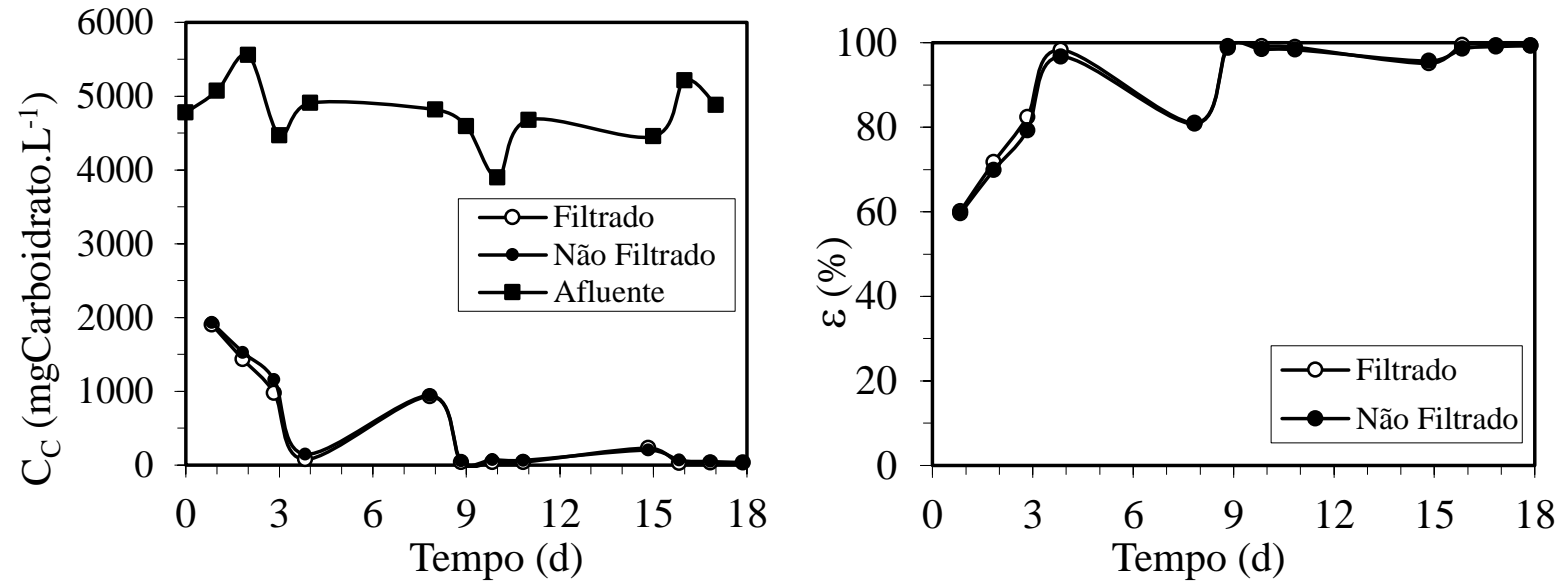

Figura 5.137. Concentração e eficiência de remoção na forma de carboidratos no Ensaio 15: - - afluente amostras não filtradas; • - efluente amostras não filtradas; ○ - efluente amostras filtradas.
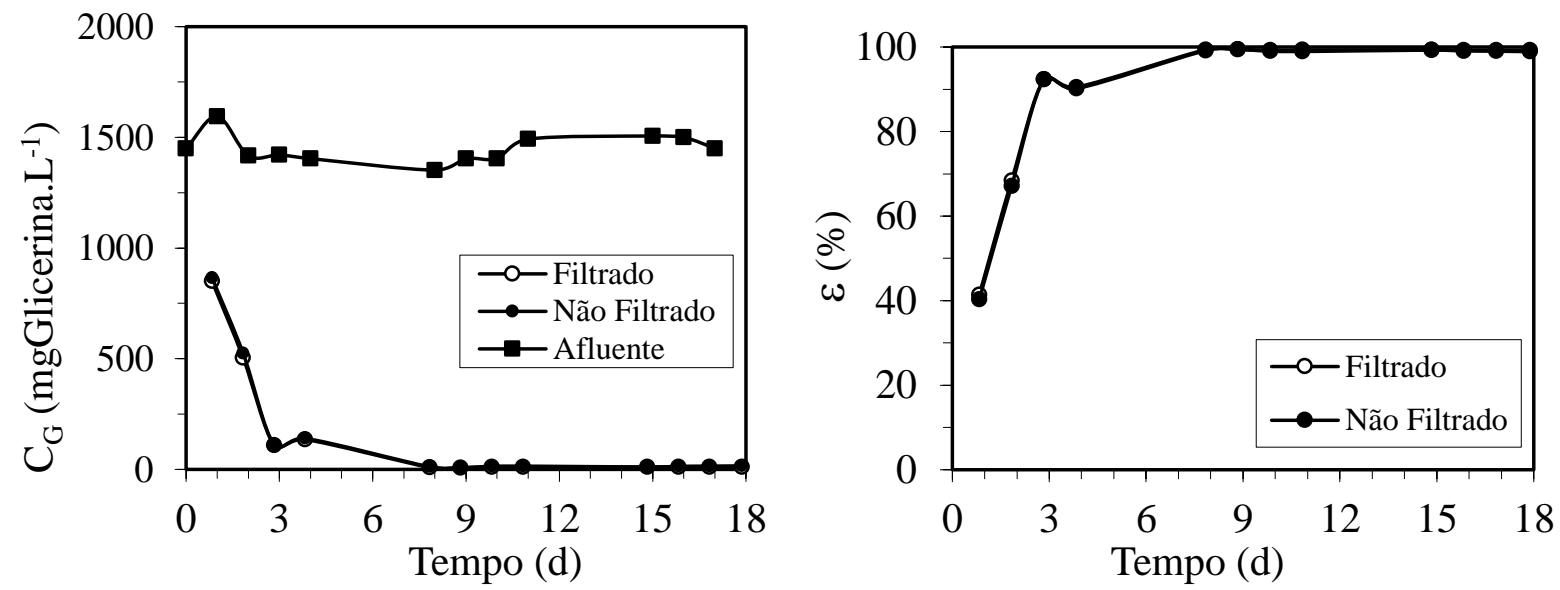

Figura 5.138. Concentração e eficiência de remoção na forma de glicerina no Ensaio 15: - - afluente amostras não filtradas; • - efluente amostras não filtradas; $\bigcirc-$ efluente amostras filtradas 
A produção de biogás, em aspecto quantitativo, e a distribuição dos gases que compõem o biogás no final do ciclo podem ser observadas pela Figura 5.139, com média de $948 \mathrm{~mL}$ de biogás e $606 \mathrm{~mL}$ de hidrogênio, sendo que a porcentagem média de hidrogênio foi igual a $62 \%$. Este ensaio obteve qualidade de biogás semelhantes a do Ensaio 12, mas a quantidade de biogás produzido foi significativamente menor, com produtividade de $63,0 \mathrm{molH}_{2} \cdot \mathrm{m}^{-3} \cdot \mathrm{d}^{-1}$.
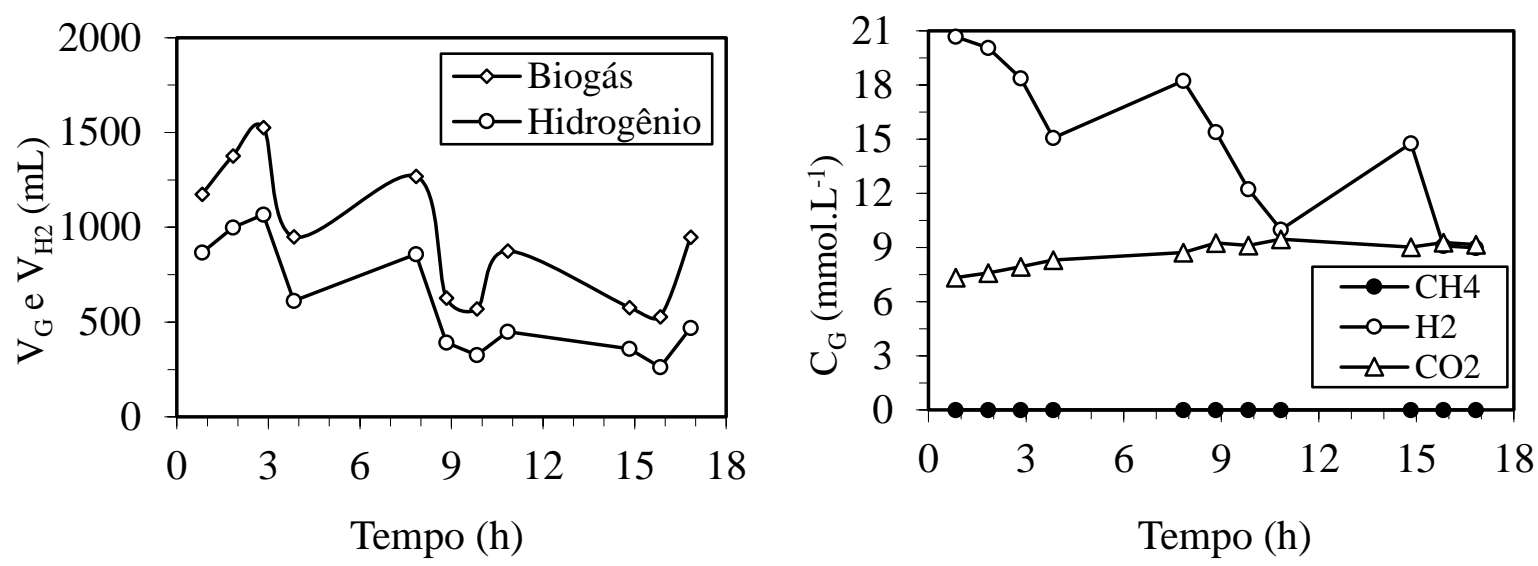

Figura 5.139. Volume de biogás $\left(\mathrm{V}_{\mathrm{G}}\right)$ e de hidrogênio $\left(\mathrm{V}_{\mathrm{H} 2}\right)$ nas CNTP e concentrações dos componentes do biogás no final do ciclo $\left(\mathrm{C}_{\mathrm{G}}\right)$ no Ensaio 15: $\diamond$ - Biogás; $\bullet$ - Metano; ○ - Hidrogênio; $\Delta$ - Dióxido de Carbono.

A Figura 5.140 apresenta o perfil de DQO, de Carboidratos e de Glicerina. Observa-se uma baixa variação na medida de DQO ao longo do ciclo, assim como nos ensaios em batelada alimentada, mas os perfis de substrato (carboidratos e glicerina) mostram o perfil característico da batelada: alta concentração de substrato no início do ciclo, logo após a finalização da alimentação, seguida de gradual diminuição ao longo do ciclo devido ao consumo.

A Figura 5.141 apresenta os perfis de $\mathrm{pH}$, alcalinidade total e ácidos voláteis totais ao longo do ciclo. $\mathrm{O} \mathrm{pH}$ permanece constante ao longo do ciclo por volta de 4,4, mas tanto o perfil de AT quanto o de AVT variam ao longo do ciclo. No início do ciclo, devido ao término da alimentação, a alcalinidade total é alta e os ácidos voláteis totais, baixos. Ao longo do ciclo, a alcalinidade é consumida e os ácidos são gerados. 

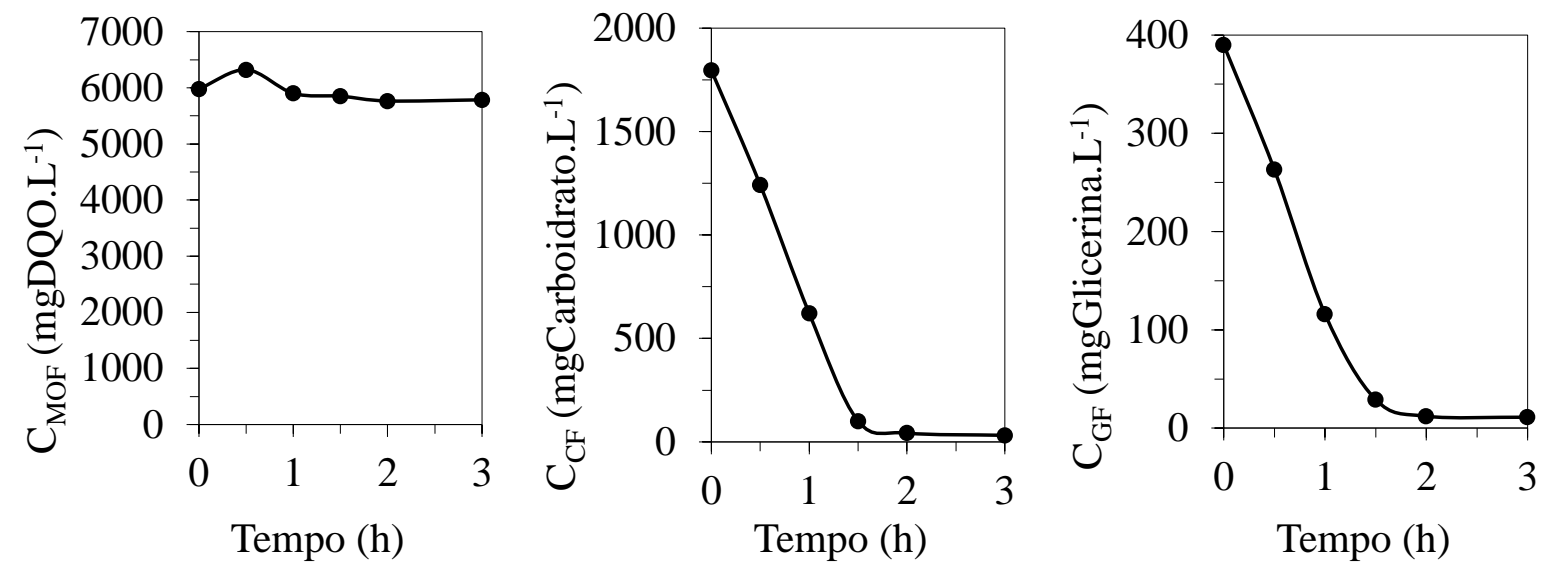

Figura 5.140. Concentração de matéria orgânica, carboidratos e de glicerina durante o ciclo no Ensaio 15 .
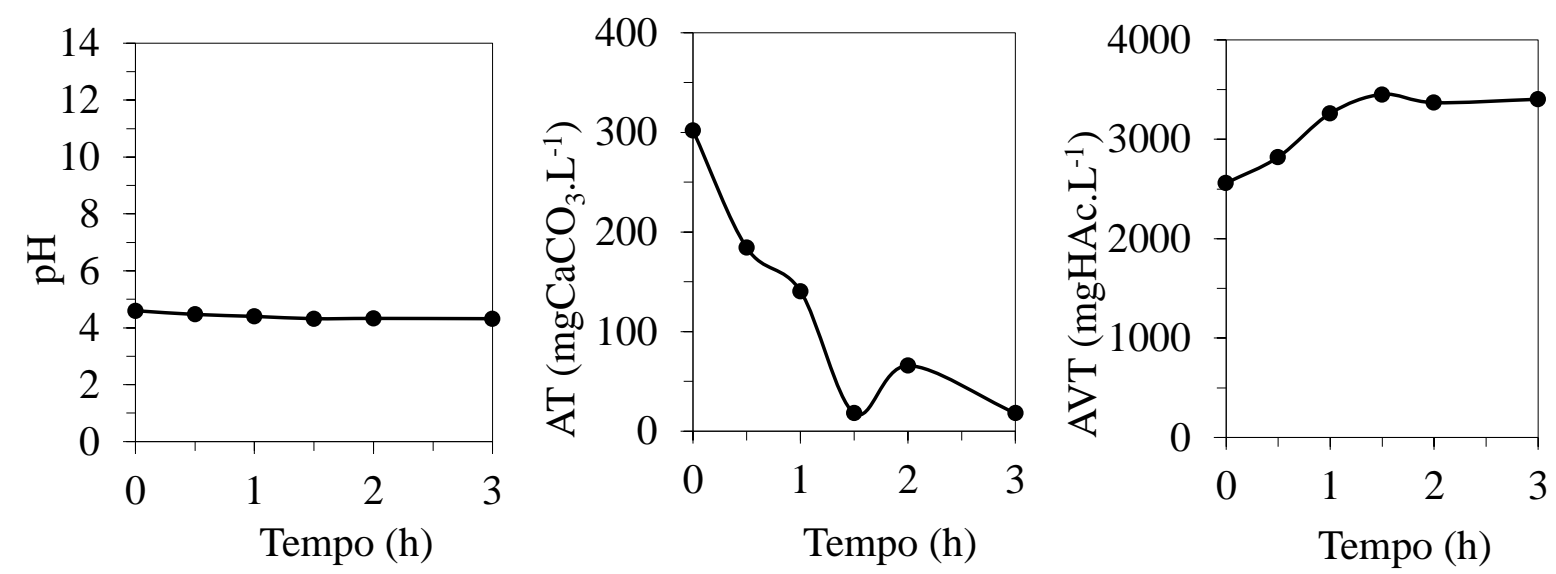

Figura 5.141. Valores de pH, alcalinidade total (AT) e ácidos voláteis totais (AVT) no Ensaio 15.

O perfil dos compostos intermediários do metabolismo é apresentado na Figura 5.142, seguindo a mesma tendência verificada no perfil de AVT. É possível verificar que há predominância de ácido acético e de ácido propiônico.

A produção volumétrica acumulada de biogás e os desvios padrões de cada um dos pontos podem ser observados na Figura 5.143 e o perfil das concentrações de cada um dos gases e suas respectivas porcentagens podem ser observados na Figura 5.144. Nota-se que a produção volumétrica de biogás é menor do que a atingida no Ensaio 12, mas é importante ressaltar a grande variação do volume de biogás recolhido diariamente; o que mostra que a batelada alimentada gera um sistema mais estável que a batelada no que concerne a produção de biogás. Ao final do perfil de biogás, tinha-se $51 \%$ de $\mathrm{CO}_{2}$ e $49 \%$ de $\mathrm{H}_{2}$. 


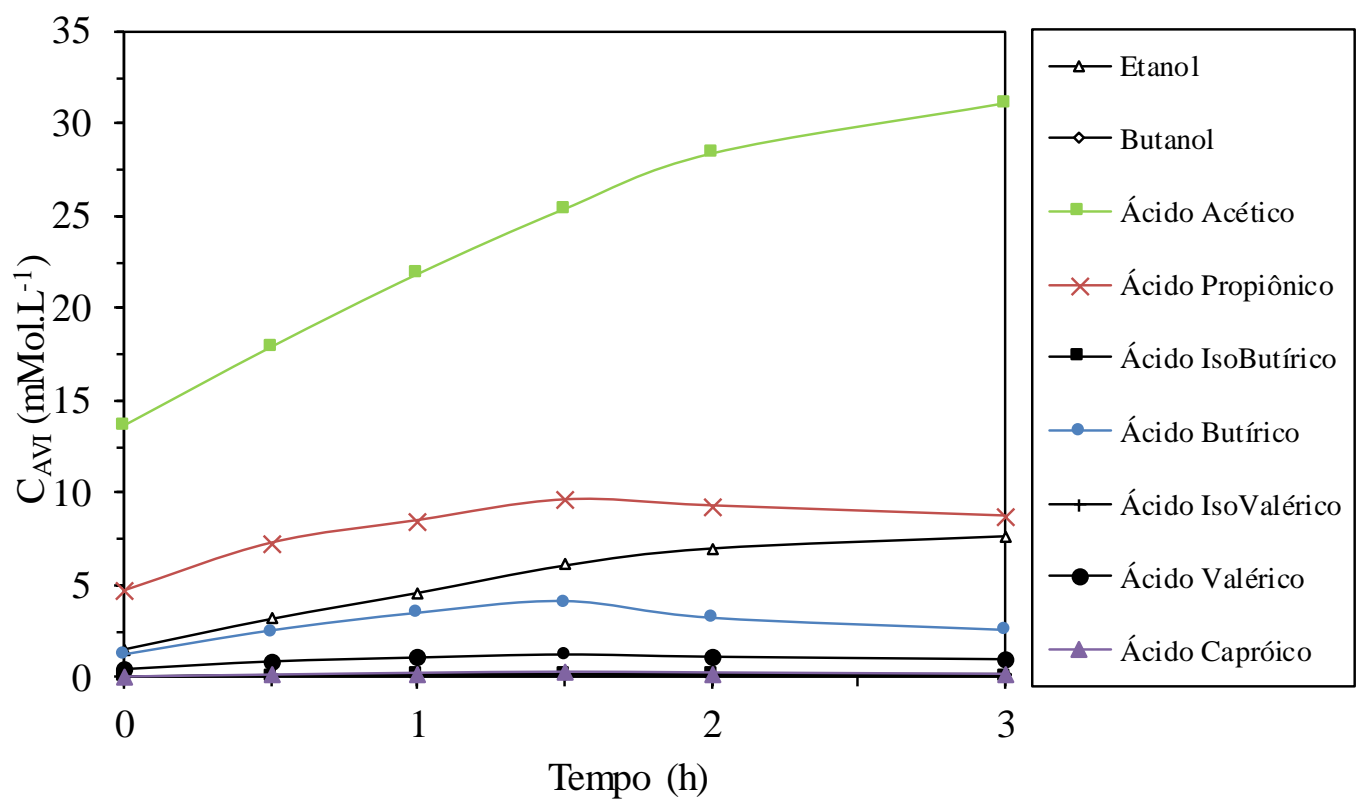

Figura 5.142. Concentração dos compostos intermediários ao longo do ciclo no Ensaio 15: $\Delta$ - etanol; $\diamond$ butanol; $\square$ - ácido acético; -X-ácido propiônico; - ácido isobutírico; $\bullet$ - ácido butírico; + ácido isovalérico $\bullet$ - ácido valérico; $\Delta$ - ácido capróico.

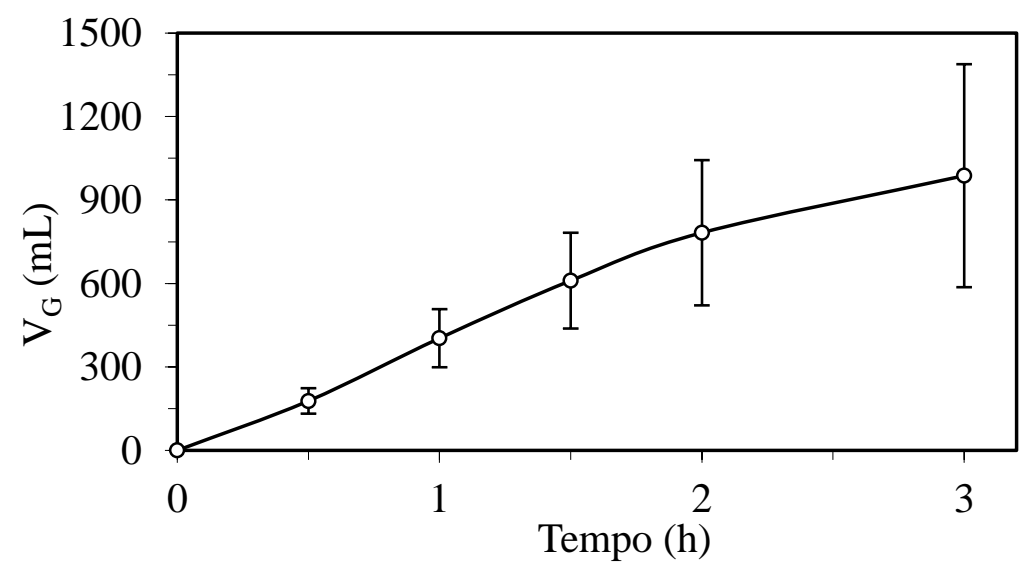

Figura 5.143. Produção volumétrica média acumulada do biogás durante o ciclo no Ensaio 15.
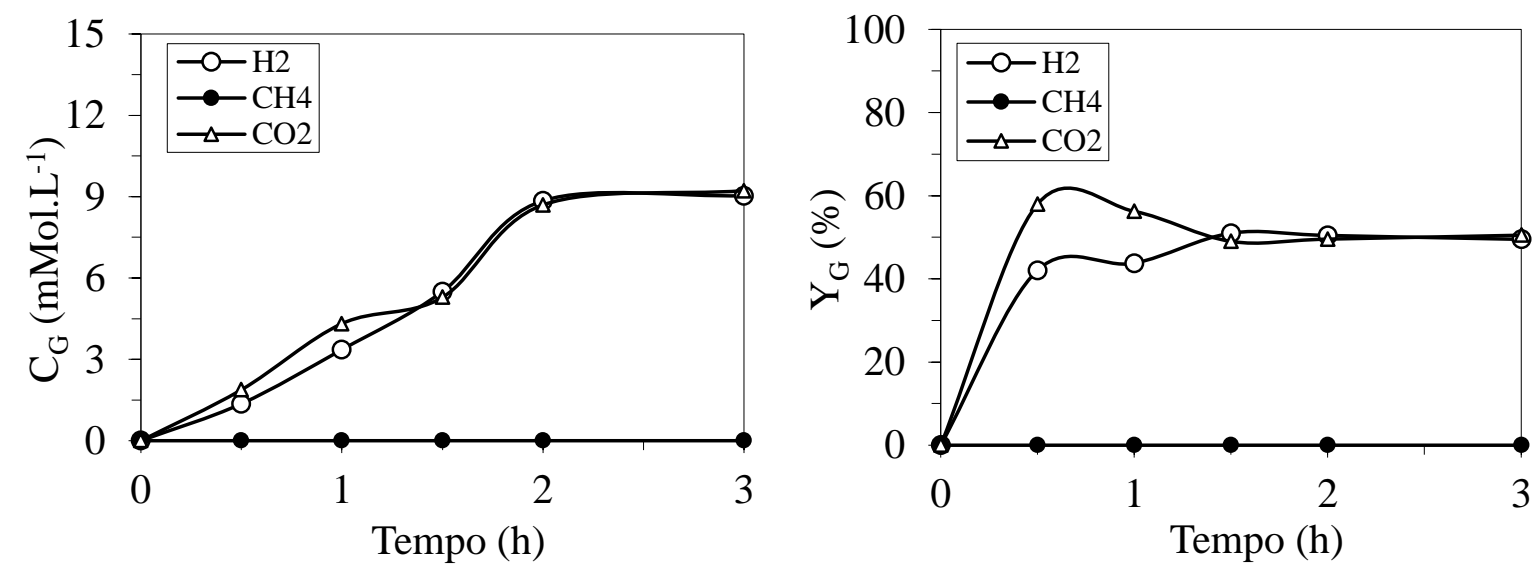

Figura 5.144. Concentração dos compostos do biogás durante o ciclo e suas respectivas porcentagens no Ensaio 15: $\odot-\mathrm{H}_{2} ; \bullet-\mathrm{CH}_{4} ; \Delta-\mathrm{CO}_{2}$. 
5.4.4 Análise comparativa entre os Ensaios 13, 14 e 15 (Fase IV)

Nesta seção, será avaliada a influência do tempo de ciclo e do tempo de enchimento, tendo como comparação o Ensaio 12, que foi a melhor condição encontrada até agora, conforme Tabela 5.27.

Tabela 5.27. Resumo das condições experimentais para comparação da Fase IV.

\begin{tabular}{cccccc}
\hline Ensaio & $\begin{array}{c}\text { COAV } \\
\left(\mathrm{kgDQO} . \mathrm{m}^{-3} \cdot \mathrm{d}^{-1}\right)\end{array}$ & $\begin{array}{c}\text { Concentração do } \\
\text { Afluente } \\
\left(\mathrm{mgDQO}^{-1}\right)\end{array}$ & $\begin{array}{c}\text { Tempo } \\
\text { de ciclo } \\
(\mathrm{h})\end{array}$ & $\begin{array}{c}\text { Tempo de } \\
\text { enchimento } \\
(\mathrm{h})\end{array}$ & $\begin{array}{c}\text { Modo de } \\
\text { Operação }\end{array}$ \\
\hline 14 & 36,0 & 7000 & 2 & 1,0 & BA \\
12 & 24,0 & 7000 & 3 & 1,5 & BA \\
13 & 18,0 & 7000 & 4 & 2,0 & BA \\
15 & 24,0 & 7000 & 3 & 0,2 & B \\
\hline
\end{tabular}

Os parâmetros comparados serão a matéria orgânica, carboidratos, glicerina (englobando carga aplicada e removida), pH, alcalinidade e ácidos (AVT e AVI), sólidos e, por último, parâmetros relativos a produção de biohidrogênio, de acordo com a Tabela 5.28.

Analisando as eficiências de remoção de matéria orgânica (19-25\%), de remoção de carboidratos (95-99\%) e de glicerina (87-97\%) dos ensaios, é possível notar que a remoção de substrato foi adequada para todos os ensaios. Em relação a variação do tempo de ciclo, é possível notar que a remoção aumenta concomitantemente com o aumento do tempo de ciclo. Observa-se também que o uso do modo batelada alimentada (comparando os Ensaios 12 e 15) aumentou a eficiência de remoção, devido a liberação gradual de substrato que possibilita a melhor assimilação do mesmo pelos microrganismos.

Em relação ao $\mathrm{pH}$, não houve grandes variações da medida do mesmo em relação a variação do tempo de ciclo e do tempo de enchimento, desconsiderando o período de instabilidade no Ensaio 12.

Considerando agora a biomassa no reator, os valores indicam que quanto maior a carga orgânica (ou seja, menor o tempo de ciclo), maior é a quantidade da mesma, o que é o mesmo padrão encontrado na análise comparativa da Fase III. As lavagens periódicas novamente se mostraram necessárias para o bom desempenho do reator (por volta de $80 \%$ de remoção por lavagem) e a série de sólidos indica que não há desprendimento da biomassa imobilizada no suporte inerte em nenhuma das condições (Tabela 5.29). 
Tabela 5.28. Estabilidade e desempenho nas variáveis monitoradas nos Ensaios 12 a 15.

\begin{tabular}{|c|c|c|c|c|c|}
\hline Parâmetro & & 14 & 12 & 13 & 15 \\
\hline Soro: Glicerina & $(\%)$ & $75: 25$ & $75: 25$ & $75: 25$ & $75: 25$ \\
\hline$\varepsilon_{\mathrm{MO}, \mathrm{F}}$ & $(\%)$ & $21 \pm 4^{(12)}$ & $19 \pm 6^{(11)}$ & $25 \pm 6^{(13)}$ & $21 \pm 4^{(12)}$ \\
\hline$\varepsilon_{\mathrm{C}, \mathrm{F}}$ & $(\%)$ & $95 \pm 6^{(11)}$ & $98 \pm 2^{(11)}$ & $99 \pm 1^{(10)}$ & $95 \pm 7^{(10)}$ \\
\hline$\varepsilon_{\mathrm{G}, \mathrm{F}}$ & $(\%)$ & $87 \pm 12^{(11)}$ & $97 \pm 4^{(11)}$ & $97 \pm 3^{(10)}$ & $97 \pm 3^{(10)}$ \\
\hline $\mathrm{M}_{\mathrm{SVT}}$ & (g) & 26,6 & 18,4 & 8,0 & 12,3 \\
\hline COAV & $\left(\operatorname{kgDQO} \cdot \mathrm{m}^{-3} \cdot \mathrm{d}^{-1}\right)$ & 36,4 & 23,9 & 17,9 & 23,3 \\
\hline CORV & $\left(\mathrm{kgDQO} \cdot \mathrm{m}^{-3} \cdot \mathrm{d}^{-1}\right)$ & 7,6 & 4,7 & 4,5 & 4,9 \\
\hline \multirow{3}{*}{ Afluente } & $\mathrm{pH}(\mathrm{u})$ & $8,0 \pm 0,1^{(11)}$ & $7,7 \pm 0,2^{(11)}$ & $7,8 \pm 0,1^{(11)}$ & $7,9 \pm 0,1^{(10)}$ \\
\hline & $\mathrm{AT}\left(\mathrm{mgCaCO}_{3} \cdot \mathrm{L}^{-1}\right)$ & $681 \pm 70^{(11)}$ & $522 \pm 200^{(11)}$ & $612 \pm 77^{(11)}$ & $688 \pm 71^{(10)}$ \\
\hline & $\operatorname{AVT}\left(m g H A c . L^{-1}\right)$ & $193 \pm 53^{(11)}$ & $137 \pm 16^{(11)}$ & $169 \pm 14^{(11)}$ & $187 \pm 61^{(10)}$ \\
\hline \multirow{3}{*}{ Efluente } & $\mathrm{pH}(\mathrm{u})$ & $4,7 \pm 0,4^{(11)}$ & $4,3 \pm 0,4^{(11)}$ & $4,6 \pm 0,3^{(11)}$ & $4,7 \pm 0,2^{(10)}$ \\
\hline & $\mathrm{AT}\left(\mathrm{mgCaCO}_{3} \cdot \mathrm{L}^{-1}\right)$ & $245 \pm 176^{(11)}$ & $196 \pm 283^{(11)}$ & $252 \pm 169^{(11)}$ & $253 \pm 103^{(10)}$ \\
\hline & $\operatorname{AVT}\left(m g H A c . L^{-1}\right)$ & $2228 \pm 726^{(11)}$ & $1461 \pm 561^{(11)}$ & $2123 \pm 783^{(11)}$ & $2198 \pm 708^{(10)}$ \\
\hline \multirow{8}{*}{$\begin{array}{c}\text { Compostos } \\
\text { intermediários } \\
\text { (molar) }\end{array}$} & Etanol $(\%)$ & 0,0 & 38,3 & 24,2 & 14,9 \\
\hline & Butanol (\%) & 0,0 & 0,3 & 0,2 & 0,3 \\
\hline & Ácido Acético (\%) & 72,9 & 30,1 & 46,3 & 60,3 \\
\hline & Ácido Propiônico (\%) & 19,5 & 13,2 & 15,0 & 16,9 \\
\hline & Ácido Butírico (\%) & 4,6 & 10,7 & 8,1 & 5,1 \\
\hline & Ácido Valérico (\%) & 2,5 & 6,8 & 5,5 & 2,2 \\
\hline & Ácido Capróico (\%) & 0,5 & 0,7 & 0,7 & 0,3 \\
\hline & $\begin{array}{l}\text { Concentração total } \\
\left(\text { mmol. } \mathrm{L}^{-1}\right)\end{array}$ & 36,7 & 42,6 & 55,8 & 51,7 \\
\hline PrM & $\left(\mathrm{molH}_{2} \cdot \mathrm{m}^{-3} \cdot \mathrm{d}^{-1}\right)$ & 92,1 & 129,0 & 62,2 & 63,0 \\
\hline PrME & $\left(\mathrm{molH}_{2} \cdot \mathrm{kgSVT}^{-1} \cdot \mathrm{d}^{-1}\right)$ & 24,4 & 29,5 & 27,0 & 17,6 \\
\hline RMCA & $\left(\mathrm{molH}_{2} \cdot \mathrm{kgDQO}^{-1}\right)$ & 2,5 & 5,4 & 3,5 & 2,7 \\
\hline RMSA & $\left(\mathrm{molH}_{2}\right.$ molSubstrato $\left.^{-1}\right)$ & 0,7 & 1,4 & 1,0 & 0,7 \\
\hline \multirow{2}{*}{$\mathrm{Y}_{\mathrm{G}}$} & $(\%) \mathrm{H}_{2}$ & 56 & 62 & 54 & 62 \\
\hline & (\%) $\mathrm{CO}_{2}$ & 44 & 38 & 46 & 38 \\
\hline
\end{tabular}

Tabela 5.29. Comparação entre os valores médios da série de sólidos entre os Ensaios 12 e 15.

\begin{tabular}{|c|c|c|c|c|c|c|c|c|c|}
\hline \multirow{2}{*}{ Parâmetro } & & \multicolumn{2}{|c|}{14} & \multicolumn{2}{|c|}{12} & \multicolumn{2}{|c|}{13} & \multicolumn{2}{|c|}{15} \\
\hline & & Afluente & Efluente & Afluente & Efluente & Afluente & Efluente & Afluente & Efluente \\
\hline $\mathrm{M}_{\mathrm{SVT}}$ & (g) & \multicolumn{2}{|c|}{26,6} & \multicolumn{2}{|c|}{18,4} & \multicolumn{2}{|c|}{8,0} & \multicolumn{2}{|c|}{12,3} \\
\hline \multirow{2}{*}{$\begin{array}{l}\text { Biomassa } \\
\text { removida por } \\
\text { lavagem }\end{array}$} & (g) & \multicolumn{2}{|c|}{24,7} & \multicolumn{2}{|c|}{14,4} & \multicolumn{2}{|c|}{6,0} & \multicolumn{2}{|c|}{10,1} \\
\hline & $(\%)$ & \multicolumn{2}{|c|}{93,0} & \multicolumn{2}{|c|}{74,7} & \multicolumn{2}{|c|}{74,9} & \multicolumn{2}{|c|}{83,9} \\
\hline ST & $\left(\mathrm{mg} \cdot \mathrm{L}^{-1}\right)$ & 3008 & 2121 & 5086 & 3879 & 2151 & 1402 & 5258 & 3344 \\
\hline SVT & $\left(\mathrm{mg} \cdot \mathrm{L}^{-1}\right)$ & 2363 & 1439 & 3977 & 2854 & 1735 & 998 & 4162 & 2240 \\
\hline SST & $\left(\mathrm{mg} \cdot \mathrm{L}^{-1}\right)$ & 48 & 121 & 62 & 91 & 37 & 339 & 89 & 136 \\
\hline SSV & $\left(\mathrm{mg} \cdot \mathrm{L}^{-1}\right)$ & 32 & 70 & 44 & 82 & 42 & 343 & 62 & 115 \\
\hline
\end{tabular}

Em relação aos compostos intermediários, é difícil identificar um padrão em relação ao tempo de ciclo ou o tempo de enchimento. Observa-se que a concentração de AVI aumenta 
com o tempo de ciclo $\left(36,7,42,6\right.$ e 55,8 mmol. $\left.\mathrm{L}^{-1}\right)$. É interessante notar que no Ensaio 14 (tempo de ciclo de 2h) não houve produção de etanol, o que é bom considerando que há estudos que focam na minimização da produção deste composto. Em relação a influência do tempo de enchimento nos compostos intermediários, nota-se que o ensaio em batelada (15) teve predominância de ácido acético $(60,3 \%)$ e o ensaio em batelada alimentada (12) teve predominância de etanol $(38,3 \%)$, mas a produção de hidrogênio foi significativamente maior no ensaio em BA; então isso demonstra que não é possível observar apenas os compostos intermediários para inferir sobre a produção de biogás, pois a rota de produção de hidrogênio a partir do ácido acético é teoricamente melhor para o desempenho do reator. Vale a pena mencionar que o modo batelada alimentada também minimizou a produção de ácidos voláteis.

A Figura 5.145 mostra a produção de biogás e de hidrogênio em todas as condições. $\mathrm{O}$ uso do modo batelada alimentada permitiu produtividades $\left(63,0-129,0 \mathrm{molH}_{2} \cdot \mathrm{m}^{-3} \cdot \mathrm{d}^{-1}\right.$ e 17,6 29,5 $\left.\mathrm{molH}_{2} \cdot \mathrm{kgSVT}^{-1} \cdot \mathrm{d}^{-1}\right) \quad$ e rendimentos $\quad\left(2,7-5,4 \mathrm{molH}_{2} \cdot \mathrm{kgDQO}^{-1}\right.$ e $\quad 0,7-$ 1,4 molH $_{2}$.molsubstrato ${ }^{-1}$ ) muito maiores, mesmo com qualidades de biogás semelhantes; provavelmente devido a liberação gradual de substrato que possibilita a melhor assimilação do mesmo pelos microrganismos e permite velocidades maiores de produção de hidrogênio.

A performance do reator em relação a produção de hidrogênio considerando a influência do tempo de ciclo mostra claramente um ponto de ótimo quando tc $=3 \mathrm{~h}$ (Ensaio 12). No entanto, o Ensaio $14(2 \mathrm{~h})$ também alcançou bons resultados: $92,1 \mathrm{molH}_{2} \cdot \mathrm{m}^{-3} \cdot \mathrm{d}^{-1} \mathrm{e}$ $24,4 \mathrm{molH}_{2} \cdot \mathrm{kgSVT}^{-1} \cdot \mathrm{d}^{-1}$, o que mostra que a produtividade molar aumenta com o tempo de ciclo, mas há um ponto ótimo $(3 \mathrm{~h})$. Provavelmente, $4 \mathrm{~h}$ de ciclo é muito tempo para o processo acidogênico e há o consumo de $\mathrm{H}_{2}$ ao longo do ciclo.

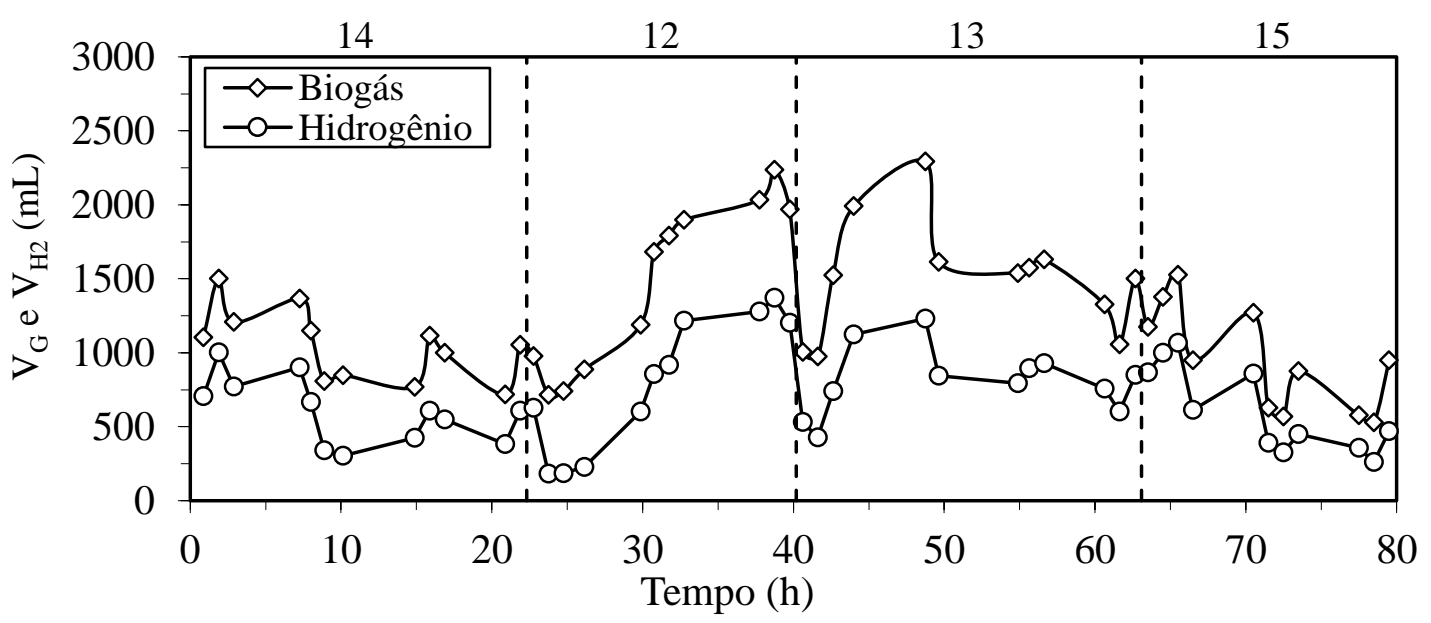

Figura 5.145. Produção volumétrica por ciclo de Biogás $(\diamond)$ e Hidrogênio (○) nos Ensaios 12 a 15. 


\subsubsection{Modelagem Cinética para os Ensaios 13, 14 e 15}

A Figura 5.146 mostra os valores obtidos experimentalmente (marcadores) e os valores obtidos pelo modelo cinético ajustado (linhas), ambos ao longo do ciclo, para as principais variáveis monitoradas e que estão relacionadas com o entendimento do metabolismo acidogênico para os Ensaios 13, 14 e 15. A Tabela 5.30 mostra os parâmetros cinéticos ajustados.

Analisando essas figuras é possível notar, novamente, que o modelo foi eficiente em predizer os dados experimentais em relação à concentração de substrato, ácidos acético, propiônico, butírico, valérico e hidrogênio, validando a interpretação do comportamento dos parâmetros cinéticos nas diferentes condições experimentais implementadas.
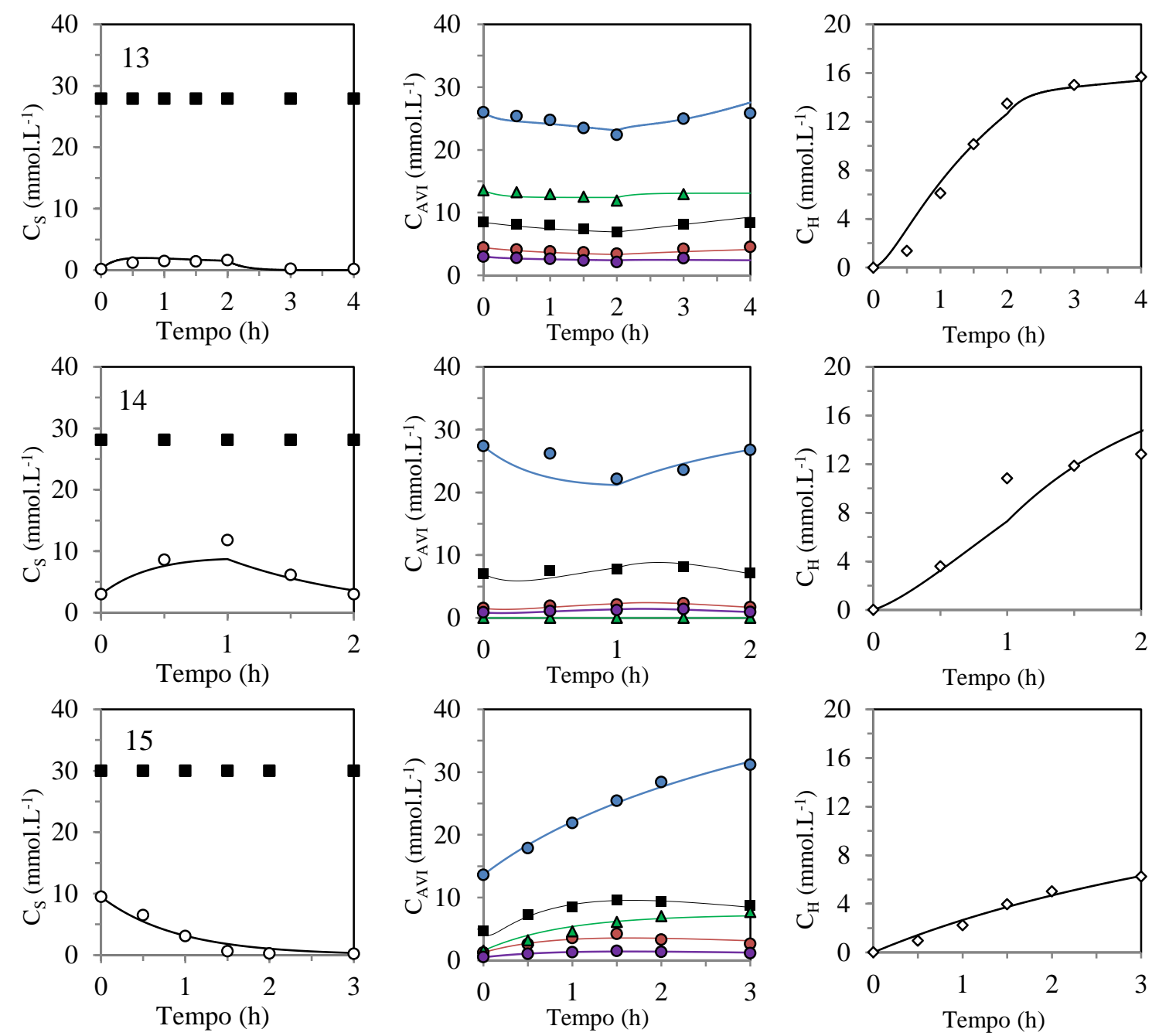

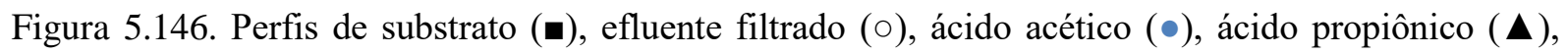
ácido butírico $(\bullet)$, etanol $(\Delta)$, ácido valérico $(\bullet)$ e hidrogênio $(\diamond)$ (valores experimentais e calculados pelo modelo). 
Tabela 5.30. Parâmetros do modelo cinéticos para a Fase IV.

\begin{tabular}{|c|c|c|c|c|c|}
\hline Fase & Parâmetro & 14 & 12 & 13 & 15 \\
\hline \multirow{7}{*}{$\begin{array}{l}\text { Hidrólise e } \\
\text { Acidogênese } \\
\text { (positivo para } \\
\text { produção } \mathrm{H}_{2} \text { ) }\end{array}$} & $\mathrm{k}_{1 \mathrm{~S}}^{\prime}\left(\mathrm{h}^{-1}\right)$ & 0,9 & 3,4 & 3,9 & 1,1 \\
\hline & $\mathrm{k}_{1 \mathrm{HAc}}\left(\mathrm{h}^{-1}\right)$ & 1,0 & 0,0 & 2,7 & 1,0 \\
\hline & $\mathrm{k}_{1 \mathrm{H}}\left(\mathrm{h}^{-1}\right)$ & 0,4 & 1,4 & 1,7 & 0,3 \\
\hline & $\mathrm{k}_{3 \mathrm{HBu}}\left(\mathrm{h}^{-1}\right)$ & 0,9 & 0,0 & 0,0 & 0,5 \\
\hline & $\mathrm{k}_{3 \mathrm{H}}\left(\mathrm{h}^{-1}\right)$ & 0,4 & 1,4 & 1,7 & 0,9 \\
\hline & $\mathrm{k}_{4 \mathrm{HVa}}\left(\mathrm{h}^{-1}\right)$ & 0,6 & 0,1 & 0,3 & 0,2 \\
\hline & $\mathrm{k}_{4 \mathrm{H}}\left(\mathrm{h}^{-1}\right)$ & 0,4 & 1,5 & 1,1 & 0,8 \\
\hline \multirow{3}{*}{$\begin{array}{c}\text { Hidrólise e } \\
\text { Acidogênese } \\
\text { (negativo para } \\
\text { produção } \mathrm{H}_{2} \text { ) }\end{array}$} & $\mathrm{k}_{2 \mathrm{HPr}}\left(\mathrm{h}^{-1}\right)$ & 2,3 & 0,9 & 0,0 & 0,0 \\
\hline & $\mathrm{k}_{2 \mathrm{H}}\left(\mathrm{h}^{-1}\right)$ & 0,0 & 0,1 & 0,2 & 0,6 \\
\hline & $\begin{array}{c}\mathrm{k}_{5 \mathrm{ETOH}}\left(\mathrm{h}^{-}\right. \\
1)\end{array}$ & 0,0 & 1,8 & 1,7 & 0,7 \\
\hline \multirow{9}{*}{$\begin{array}{c}\text { Acetogênese } \\
\text { (positivo para } \\
\text { produção de } \mathrm{H}_{2} \text { ) }\end{array}$} & $\mathrm{k}_{6 \mathrm{HPr}}\left(\mathrm{h}^{-1}\right)$ & 1,7 & 6,0 & 0,4 & 18,6 \\
\hline & $\mathrm{k}_{6 \mathrm{HAc}}\left(\mathrm{h}^{-1}\right)$ & 0,0 & 19,7 & 3,3 & 0,4 \\
\hline & $\mathrm{k}_{6 \mathrm{H}}\left(\mathrm{h}^{-1}\right)$ & 0,0 & 0,0 & 0,0 & 0,0 \\
\hline & $\mathrm{k}_{7 \mathrm{HPr}}\left(\mathrm{h}^{-1}\right)$ & 0,0 & 7,5 & 1,1 & 49,5 \\
\hline & $\mathrm{k}_{7 \mathrm{HBu}}\left(\mathrm{h}^{-1}\right)$ & 2,6 & 0,5 & 0,2 & 6,8 \\
\hline & $\mathrm{k}_{7 \mathrm{H}}\left(\mathrm{h}^{-1}\right)$ & 0,0 & 0,0 & 0,0 & 0,5 \\
\hline & $\mathrm{k}_{8 \mathrm{HBu}}\left(\mathrm{h}^{-1}\right)$ & 0,0 & 1,2 & 0,5 & 17,3 \\
\hline & $\mathrm{k}_{8 \mathrm{HVa}}\left(\mathrm{h}^{-1}\right)$ & 3,1 & 0,0 & 0,0 & 0,2 \\
\hline & $\mathrm{k}_{8 \mathrm{H}}\left(\mathrm{h}^{-1}\right)$ & 0,0 & 0,0 & 0,2 & 0,0 \\
\hline \multirow{4}{*}{$\begin{array}{l}\text { Metanogênese } \\
\text { (negativo para } \\
\text { produção de } \mathrm{H}_{2} \text { ) }\end{array}$} & $\mathrm{k}_{9 \mathrm{HAc}}\left(\mathrm{h}^{-1}\right)$ & 0,0 & 0,0 & 0,0 & 0,0 \\
\hline & $\mathrm{k}_{9 \mathrm{M}}\left(\mathrm{h}^{-1}\right)$ & 0,0 & 0,0 & 0,0 & 0,0 \\
\hline & $\mathrm{k}_{10 \mathrm{H}}\left(\mathrm{h}^{-1}\right)$ & 0,0 & 0,0 & 0,0 & 0,0 \\
\hline & $\mathrm{k}_{10 \mathrm{M}}\left(\mathrm{h}^{-1}\right)$ & 0,0 & 0,0 & 0,0 & 0,0 \\
\hline $\begin{array}{l}\text { Crescimento } \\
\text { celular }\end{array}$ & $\mathrm{k}_{11 \mathrm{HAc}}\left(\mathrm{h}^{-1}\right)$ & 0,0 & 8,5 & 1,0 & 0,0 \\
\hline
\end{tabular}

Analisando primeiramente a influência do modo de alimentação nos caminhos metabólicos, é possível notar que a produção de hidrogênio no modo batelada $\left(\mathrm{k}_{1 \mathrm{HAc}}=1,0 \mathrm{~h}^{-1}\right.$, $\mathrm{k}_{1 \mathrm{H}}=0,3 \mathrm{~h}^{-1}, \mathrm{k}_{3 \mathrm{HBu}}=0,5 \mathrm{~h}^{-1}, \mathrm{k}_{3 \mathrm{H}}=0,9 \mathrm{~h}^{-1}, \mathrm{k}_{4 \mathrm{HVa}}=0,2 \mathrm{~h}^{-1}, \mathrm{k}_{4 \mathrm{H}}=0,8 \mathrm{~h}^{-1}$ ) vem principalmente da conversão do substrato em ácidos butírico e valérico (Equações 3 e 4). No entanto, quando o modo batelada alimentada é aplicado, a produção de hidrogênio vem similarmente das rotas de produção de ácido acético, butírico e valérico $\left(\mathrm{k}_{1 \mathrm{HAc}}=0,0 \mathrm{~h}^{-1}, \mathrm{k}_{1 \mathrm{H}}=1,4 \mathrm{~h}^{-1}, \mathrm{k}_{3} \mathrm{HBu}=0,0 \mathrm{~h}^{-1}\right.$, $\left.\mathrm{k}_{3 \mathrm{H}}=1,4 \mathrm{~h}^{-1}, \mathrm{k}_{4 \mathrm{HVa}}=0,1 \mathrm{~h}^{-1}, \mathrm{k}_{4 \mathrm{H}}=1,4 \mathrm{~h}^{-1}\right)$. Está é uma tendência encontrada no Ensaio 14 que obteve a segunda melhor produtividade molar de hidrogênio $\left(\mathrm{k}_{1 \mathrm{HAc}}=1,0 \mathrm{~h}^{-1}, \mathrm{k}_{1 \mathrm{H}}=0,4 \mathrm{~h}^{-1}\right.$, $\left.\mathrm{k}_{3 \mathrm{HBu}}=0,9 \mathrm{~h}^{-1}, \mathrm{k}_{3 \mathrm{H}}=0,4 \mathrm{~h}^{-1}, \mathrm{k}_{4 \mathrm{HVa}}=0,6 \mathrm{~h}^{-1}, \mathrm{k}_{4 \mathrm{H}}=0,4 \mathrm{~h}^{-1}\right)$.

Em relação às reações prejudiciais a produção de hidrogênio (Equações 4.52 e 4.55), pode ser inferido que o modo batelada alimentada diminui o consumo de hidrogênio para 
produção de ácido propiônico $\left(\mathrm{k}_{2 \mathrm{H}}=0,1 \mathrm{~h}^{-1}\right)$ e o ciclo de $2 \mathrm{~h}$ eliminou a produção de etanol $\left(\mathrm{k}_{5 \mathrm{ETOH}}=0,0 \mathrm{~h}^{-1}\right)$, o que é corroborado pelos dados experimentais.

A acetogênese (Equações 4.56, 4.57 e 4.58) teve uma influência maior no Ensaio 15, que foi operado em batelada, mas mesmo assim seu peso na produção de hidrogênio é menor do que o da acidogênese, como pode ser visto pelos parâmetros $\mathrm{k}_{6 \mathrm{H}}, \mathrm{k}_{7 \mathrm{H}}, \mathrm{k}_{8 \mathrm{H}}$ em todos os ensaios.

A ausência de metano cancelou a metanogênese em todos os ensaios, justificando os valores de $\mathrm{k}_{9 \mathrm{HAc}}, \mathrm{k}_{9 \mathrm{M}}, \mathrm{k}_{10 \mathrm{H}}, \mathrm{k}_{10 \mathrm{M}}$ iguais a zero em todos os ensaios.

Finalmente, em relação ao consumo de ácido acético para crescimento celular, é possível observar que ele tem uma maior importância nos Ensaios $12\left(\mathrm{k}_{11 \mathrm{HAc}}=8,5 \mathrm{~h}^{-1}\right)$ e 13 $\left(\mathrm{k}_{11 \mathrm{HAc}}=1,0 \mathrm{~h}^{-1}\right)$, indicando uma relação com ambientes contendo lactose fermentada e preferencialmente com cargas orgânicas mais baixas.

\subsection{FASE V - PRODUÇÃO DE BIOHIDROGÊNIO - INFLUÊNCIA DA TEMPERATURA}

A Fase V compreendeu os Ensaios 16, 17 e 18 e teve como objetivo encontrar a melhor temperatura para o sistema dentro da faixa mesofílica, sendo que todos os ensaios foram conduzidos com a razão ótima de mistura entre soro e glicerina (75:25), com a concentração ótima de afluente (7000 mgDQO.L $\mathrm{L}^{-1}$ ) e com o tempo de ciclo ótimo (3 h) operado em batelada alimentada (1,5 h de alimentação) encontrados nas Fases II, III e IV, respectivamente.

O Ensaio 16 foi realizado a $20^{\circ} \mathrm{C}$, o Ensaio 17 foi realizado a $25^{\circ} \mathrm{C}$ e, finalmente, o Ensaio 18 foi realizado a $35^{\circ} \mathrm{C}$. O Ensaio 12 da Fase III $(75 \%$ soro e $25 \%$ glicerina, $7000 \mathrm{mgDQO} . \mathrm{L}^{-1}, 3 \mathrm{~h}, \mathrm{BA}$ e $30^{\circ} \mathrm{C}$ ) foi utilizado para comparação nesta Fase V.

\subsubsection{Ensaio 16 (75\% Soro e $25 \%$ Glicerina - $\left.7000 \mathrm{mgDQO} . \mathrm{L}^{-1}-3 \mathrm{~h}-\mathrm{BA}-20^{\circ} \mathrm{C}\right)$}

O Ensaio 16 foi feito com concentração do afluente de $7000 \mathrm{mgDQO} . \mathrm{L}^{-1}$ (75\% de soro e $25 \%$ de glicerina), tempo de ciclo de $3 \mathrm{~h}$, tempo de alimentação de $1,5 \mathrm{~h} \mathrm{e} 20^{\circ} \mathrm{C}$. Os parâmetros médios deste ensaio se encontram na Tabela 5.31 .

Os valores obtidos de COAV e CORV foram de, respectivamente, 24,4 gDQO.L $\mathrm{L}^{-1} \cdot \mathrm{d}^{-1} \mathrm{e}$ 4,7 gDQO.L $\mathrm{L}^{-1} \cdot \mathrm{d}^{-1}$, o que significa que o sistema apresentou uma baixa remoção de matéria orgânica. A adição de $75 \%$ da DQO total em soro significou que o afluente teve, em média, 4166 mgCarboidratos. $\mathrm{L}^{-1}$ (COAV foi de 14,5 gCarboidratos. $\mathrm{L}^{-1} \cdot \mathrm{d}^{-1}$ e a CORV atingida foi de 12,4 gCarboidratos. $\mathrm{L}^{-1} \cdot \mathrm{d}^{-1}$ ) e $1227 \mathrm{mgGlicerina} . \mathrm{L}^{-1}$ (COAV foi de 3,2 gGlicerina. $\mathrm{L}^{-1} \cdot \mathrm{d}^{-1}$ e a CORV atingida foi de 2,4 gGlicerina. $\left.\mathrm{L}^{-1} \cdot \mathrm{d}^{-1}\right)$. 
Tabela 5.31. Parâmetros médios monitorados no Ensaio 16.

\begin{tabular}{|c|c|c|c|c|c|c|c|c|c|c|c|c|}
\hline \multicolumn{2}{|r|}{ Parâmetro } & \multicolumn{5}{|c|}{ Afluente } & \multicolumn{6}{|c|}{ Efluente } \\
\hline $\mathrm{C}_{\mathrm{MOT}}$ & $\left(\mathrm{mgDQO} \cdot \mathrm{L}^{-1}\right)$ & 7020 & \pm 151 & ( & 14 & ) & 5892 & \pm & 306 & ( & 13 & \\
\hline $\mathrm{C}_{\mathrm{MOF}}$ & $\left(\mathrm{mgDQO} \cdot \mathrm{L}^{-1}\right)$ & & & & & & 5677 & \pm & 382 & ( & 13 & \\
\hline$\varepsilon_{\text {МOT }}$ & $(\%)$ & & & & & & 16 & \pm & 5 & ( & 13 & \\
\hline$\varepsilon_{\mathrm{MOF}}$ & $(\%)$ & & & & & & 19 & \pm & 6 & ( & 13 & \\
\hline $\mathrm{C}_{\mathrm{CT}}$ & $\left(\right.$ mgCarboidratos. $\left.\mathrm{L}^{-1}\right)$ & 4166 & \pm 256 & ( & 13 & ) & 638 & \pm & 634 & ( & 11 & \\
\hline $\mathrm{C}_{\mathrm{CF}}$ & $\left(\mathrm{mgCarboidratos} . \mathrm{L}^{-1}\right)$ & & & & & & 604 & \pm & 633 & ( & 11 & \\
\hline$\varepsilon_{\mathrm{CT}}$ & $(\%)$ & & & & & & 88 & \pm & 16 & ( & 11 & \\
\hline$\varepsilon_{\mathrm{CF}}$ & $(\%)$ & & & & & & 88 & \pm & 16 & ( & 11 & \\
\hline $\mathrm{C}_{\mathrm{GT}}$ & (mgGlicerina.L $\mathrm{L}^{-1}$ ) & 1227 & \pm 105 & ( & 13 & ) & 299 & \pm & 296 & ( & 11 & \\
\hline $\mathrm{C}_{\mathrm{GF}}$ & $\left(\mathrm{mgGlicerina} . \mathrm{L}^{-1}\right)$ & & & & & & 273 & \pm & 363 & ( & 11 & \\
\hline$\varepsilon_{\mathrm{GT}}$ & $(\%)$ & & & & & & 78 & \pm & 25 & ( & 11 & \\
\hline$\varepsilon_{\mathrm{GF}}$ & $(\%)$ & & & & & & 76 & \pm & 30 & ( & 11 & ) \\
\hline $\mathrm{pH}$ & (u) & 7,7 & $\pm 0,2$ & ( & 12 & ) & 4,5 & \pm & 0,1 & ( & 12 & \\
\hline AVT & $\left(m g H A c . L^{-1}\right)$ & 159 & \pm 61 & ( & 12 & ) & 2223 & \pm & 931 & ( & 12 & ) \\
\hline $\mathrm{AT}$ & $\left(\mathrm{mgCaCO}_{3} \cdot \mathrm{L}^{-1}\right)$ & 575 & \pm 207 & ( & 12 & ) & 270 & \pm & 195 & ( & 12 & ) \\
\hline $\mathrm{AP}$ & $\left(\mathrm{mgCaCO}_{3} \cdot \mathrm{L}^{-1}\right)$ & 410 & \pm 151 & ( & 12 & ) & 4 & \pm & 13 & ( & 12 & \\
\hline AI & $\left(\mathrm{mgCaCO}_{3} \cdot \mathrm{L}^{-1}\right)$ & 165 & \pm 59 & ( & 12 & ) & 266 & \pm & 187 & ( & 12 & ) \\
\hline $\mathrm{AB}$ & $\left(\mathrm{mgCaCO}_{3} \cdot \mathrm{L}^{-1}\right)$ & 462 & \pm 213 & ( & 12 & ) & 0 & \pm & 0 & ( & 12 & \\
\hline ST & $\left(\mathrm{mg} \cdot \mathrm{L}^{-1}\right)$ & 5289 & \pm 229 & ( & 5 & ) & 3175 & \pm & 399 & ( & 5 & ) \\
\hline SVT & $\left(\mathrm{mg} \cdot \mathrm{L}^{-1}\right)$ & 4251 & \pm 146 & ( & 5 & ) & 2156 & \pm & 369 & ( & 5 & ) \\
\hline SST & $\left(\mathrm{mg} \cdot \mathrm{L}^{-1}\right)$ & 83 & \pm 23 & ( & 5 & ) & 128 & \pm & 30 & ( & 5 & ) \\
\hline SSV & $\left(\mathrm{mg} \cdot \mathrm{L}^{-1}\right)$ & 51 & $\pm \quad 24$ & ( & 5 & ) & 91 & \pm & 50 & ( & 5 & ) \\
\hline $\mathrm{M}_{\mathrm{SVT}}$ & (g) & & - & & & & & 17,7 & & & & \\
\hline $\mathrm{Cx}$ & $\left(\mathrm{g} . \mathrm{L}^{-1}\right)$ & & & & & & & 5,0 & & & & \\
\hline $\mathrm{Cx}^{\prime}$ & $\left(\right.$ g.gsuporte $\left.{ }^{-1}\right)$ & & & & & & & 011 & & & & \\
\hline $\mathrm{V}_{\mathrm{G}}$ & $\left(\mathrm{mL} . \mathrm{ciclo}^{-1}\right)$ & & 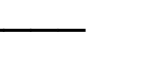 & & & & 991 & \pm & 198 & ( & 11 & \\
\hline $\mathrm{V}_{\mathrm{H} 2}$ & $\left(\mathrm{~mL} \cdot \mathrm{ciclo}^{-1}\right)$ & & 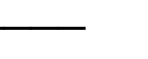 & & & & 496 & \pm & 198 & ( & 11 & ) \\
\hline $\mathrm{COAV}_{\text {MOT }}$ & $\left(\mathrm{gDQO} \cdot \mathrm{L}^{-1} \cdot \mathrm{d}^{-1}\right)$ & & 4,4 & & & & & 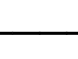 & & & & \\
\hline $\mathrm{CORV}_{\mathrm{MOF}}$ & $\left(\mathrm{gDQO} \cdot \mathrm{L}^{-1} \cdot \mathrm{d}^{-1}\right)$ & & & & & & & 4,7 & & & & \\
\hline $\mathrm{COAV}_{\mathrm{CT}}$ & (gCarboidratos. $\left.\mathrm{L}^{-1} \cdot \mathrm{d}^{-1}\right)$ & & 4,5 & & & & & & & & & \\
\hline $\mathrm{CORV}_{\mathrm{CF}}$ & $\left(\right.$ gCarboidratos. $\left.\mathrm{L}^{-1} \cdot \mathrm{d}^{-1}\right)$ & & & & & & & 12,4 & & & & \\
\hline $\mathrm{COAV}_{\mathrm{GT}}$ & (gGlicerina. $\mathrm{L}^{-1} \cdot \mathrm{d}^{-1}$ ) & & 3,2 & & & & & & & & & \\
\hline $\mathrm{CORV}_{\mathrm{GF}}$ & $\left(\right.$ gGlicerina. $\left.L^{-1} \cdot d^{-1}\right)$ & & & & & & & 2,4 & & & & \\
\hline COAE $_{\text {MOT }}$ & $\left(\mathrm{gDQO}_{\mathrm{gSVT}}{ }^{-1} \cdot \mathrm{d}^{-1}\right)$ & & 4,9 & & & & & & & & & \\
\hline $\mathrm{CORE}_{\mathrm{MOF}}$ & $\left(\mathrm{gDQO} \mathrm{gSVT}^{-1} \cdot \mathrm{d}^{-1}\right)$ & & & & & & & 0,9 & & & & \\
\hline $\mathrm{COAE}_{\mathrm{CT}}$ & $\left(\right.$ gCarboidratos.gSVT $\left.{ }^{-1} \cdot \mathrm{d}^{-1}\right)$ & & 2,9 & & & & & & & & & \\
\hline $\mathrm{CORE}_{\mathrm{CF}}$ & $\left(\right.$ gCarboidratos.gSVT $\left.{ }^{-1} \cdot \mathrm{d}^{-1}\right)$ & & & & & & & 2,5 & & & & \\
\hline $\mathrm{COAE}_{\mathrm{GT}}$ & (gGlicerina.gSVT ${ }^{-1} \cdot \mathrm{d}^{-1}$ ) & & 0,6 & & & & & & & & & \\
\hline $\mathrm{CORE}_{\mathrm{GF}}$ & (gGlicerina.gSVT ${ }^{-1} \cdot \mathrm{d}^{-1}$ ) & & & & & & & 0,5 & & & & \\
\hline $\mathrm{n}_{\mathrm{H} 2}$ & $\left(\mathrm{molH}_{2} \cdot \mathrm{d}^{-1}\right)$ & & & & & & & 0,2 & & & & \\
\hline PrM & $\left(\mathrm{molH}_{2} \cdot \mathrm{m}^{-3} \cdot \mathrm{d}^{-1}\right)$ & & & & & & & 50,2 & & & & \\
\hline PrME & $\left(\mathrm{molH}_{2} \cdot \mathrm{kgSVT}^{-1} \cdot \mathrm{d}^{-1}\right)$ & & 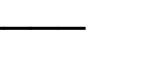 & & & & & 10,0 & & & & \\
\hline RMCA & $\left(\mathrm{molH}_{2} \cdot \mathrm{kgDQO}^{-1}\right)$ & & 2,1 & & & & & & & & & \\
\hline RMSA & $\left(\mathrm{molH}_{2} \cdot \mathrm{molSubstrato}^{-1}\right)$ & & 0,6 & & & & & & & & & \\
\hline RMSR & $\left(\mathrm{molH}_{2} \cdot \mathrm{molSubstrato}^{-1}\right)$ & & & & & & & 0,8 & & & & \\
\hline $\mathrm{V}_{\mathrm{A}}$ & $(\mathrm{L})$ & 1,53 & $\pm 0,11$ & ( & 13 & ) & & & & & & \\
\hline
\end{tabular}

(*) Entre parênteses o número de amostras considerado no cálculo da média. 
O monitoramento diário revelou um baixo consumo de matéria orgânica na forma de DQO, com média de concentração afluente não filtrada de $7020 \mathrm{mgDQO}$. $^{-1}$, efluente não filtrada de $5892 \mathrm{mgDQO} . \mathrm{L}^{-1}$ e de efluente filtrada de $5677 \mathrm{mgDQO} . \mathrm{L}^{-1}$, o que representa uma remoção média para amostras não filtradas de $16 \%$ e filtradas de $19 \%$, conforme a Figura 5.147 .
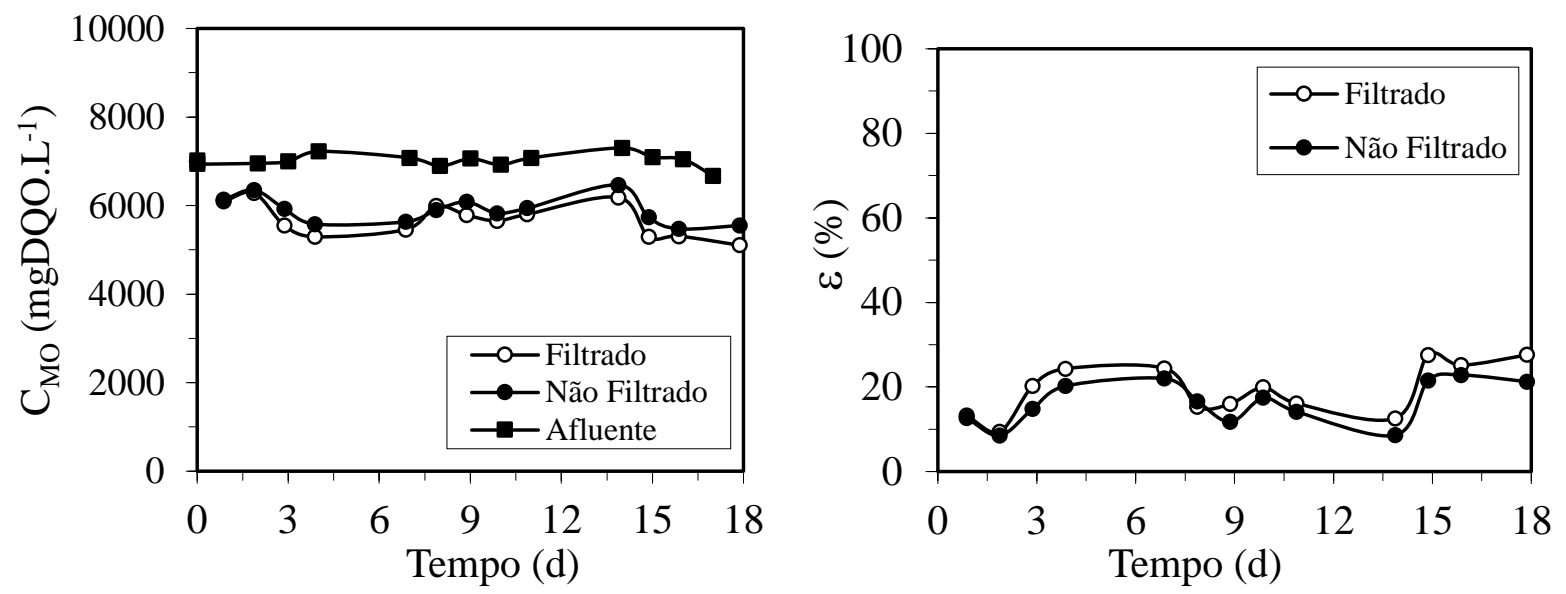

Figura 5.147. Concentração $\left(\mathrm{C}_{S}\right)$ e eficiência de remoção na forma de DQO $\left(\varepsilon_{S}\right)$ no Ensaio 16: - - afluente amostras não filtradas; • - efluente amostras não filtradas; $\bigcirc$ - efluente amostras filtradas.

Em relação ao monitoramento diário de carboidratos, o sistema apresentou um bom consumo, de acordo com a Figura 5.148, com média de concentração afluente não filtrada igual a $4166 \mathrm{mgLactose} . \mathrm{L}^{-1}$, efluente não filtrado igual a $638 \mathrm{mgLactose} . \mathrm{L}^{-1}$ e de efluente filtrado igual a $604 \mathrm{mgLactose} . \mathrm{L}^{-1}$. Isto representou uma eficiência de remoção média para amostras não filtradas e filtradas de $88 \%$.
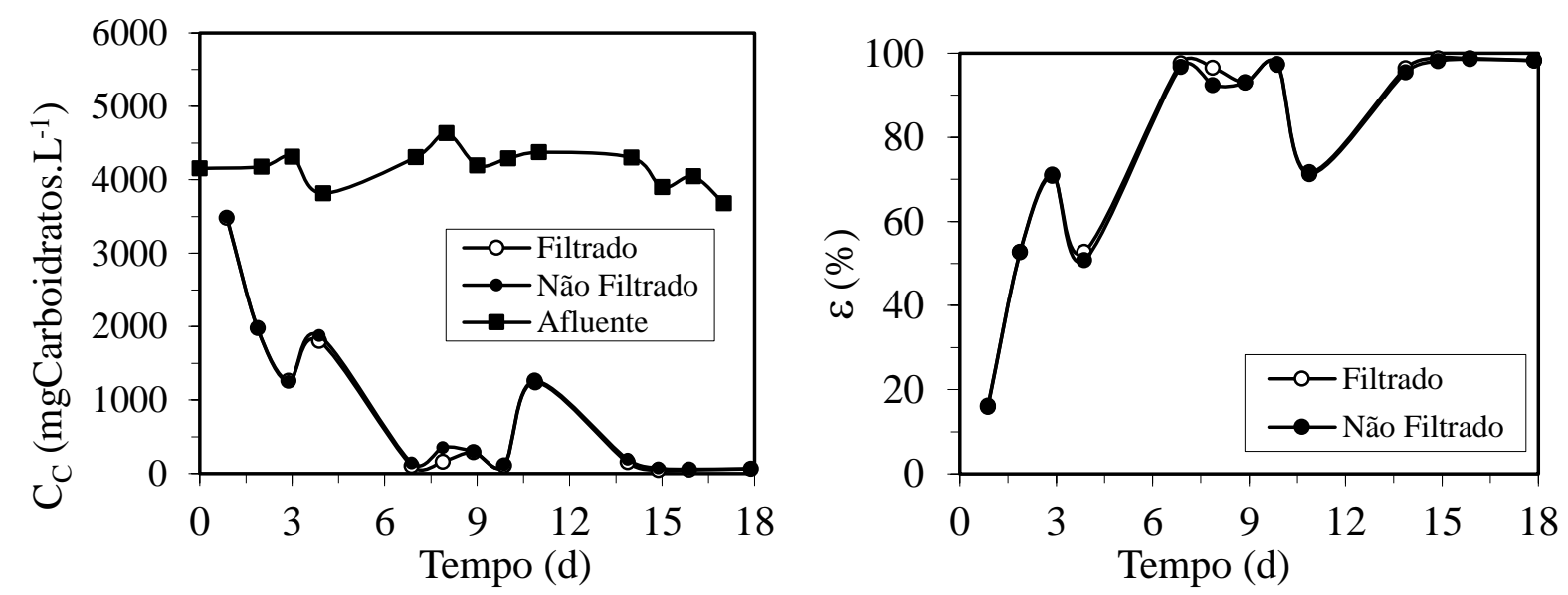

Figura 5.148. Concentração $\left(C_{C}\right)$ e eficiência de remoção na forma de carboidratos $\left(\varepsilon_{C}\right)$ no Ensaio 16: - - afluente amostras não filtradas; • - efluente amostras não filtradas; $\bigcirc-$ efluente amostras filtradas. 
Houve também o monitoramento diário de glicerina, que apresentou média de concentração afluente não filtrada igual a 1227 mgGlicerina. $\mathrm{L}^{-1}$, efluente não filtrado igual a $299 \mathrm{mgGlicerina} . \mathrm{L}^{-1}$ e de efluente filtrado igual a $273 \mathrm{mgGlicerina} . \mathrm{L}^{-1}$, o que representa uma eficiência média de remoção para amostras não filtradas igual a 78\%, e para filtradas de $76 \%$, de conforme mostrado na Figura 5.149.
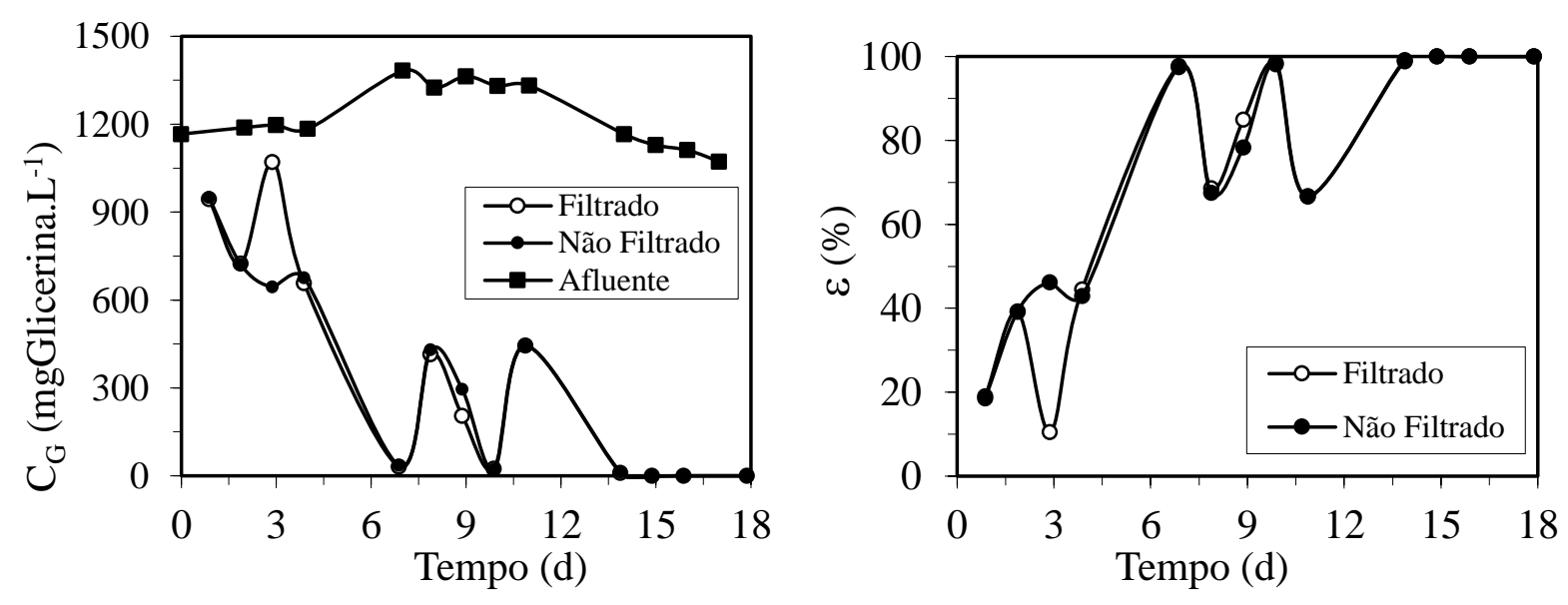

Figura 5.149. Concentração $\left(C_{G}\right)$ e eficiência de remoção na forma de glicerina $\left(\varepsilon_{G}\right)$ no Ensaio 16: - - afluente amostras não filtradas; • - efluente amostras não filtradas; $\bigcirc-$ efluente amostras filtradas.

A média de $\mathrm{pH}$ do afluente foi igual a 7,7, enquanto que a do efluente foi igual a 4,5. A alcalinidade total no afluente teve média de $575 \mathrm{mgCaCO}_{3} \cdot \mathrm{L}^{-1}$ sendo consumida até uma média de $270 \mathrm{mgCaCO}_{3} \cdot \mathrm{L}^{-1}$. A média de AVT no afluente foi de $159 \mathrm{mgHAc} . \mathrm{L}^{-1} \mathrm{e}$ a média de AVT no efluente de $2223 \mathrm{mgHAc} . \mathrm{L}^{-1}$.

A produção de biogás, em aspecto quantitativo, e a distribuição dos gases que compõem o biogás no final do ciclo podem ser observadas pela Figura 5.150, com média de $991 \mathrm{~mL}$ de biogás e $496 \mathrm{~mL}$ de hidrogênio, sendo que a porcentagem média de hidrogênio e sua produtividade molar foram iguais $49 \%$ e $50,2 \mathrm{molH}_{2} \cdot \mathrm{m}^{-3} \cdot \mathrm{d}^{-1}$, respectivamente. 

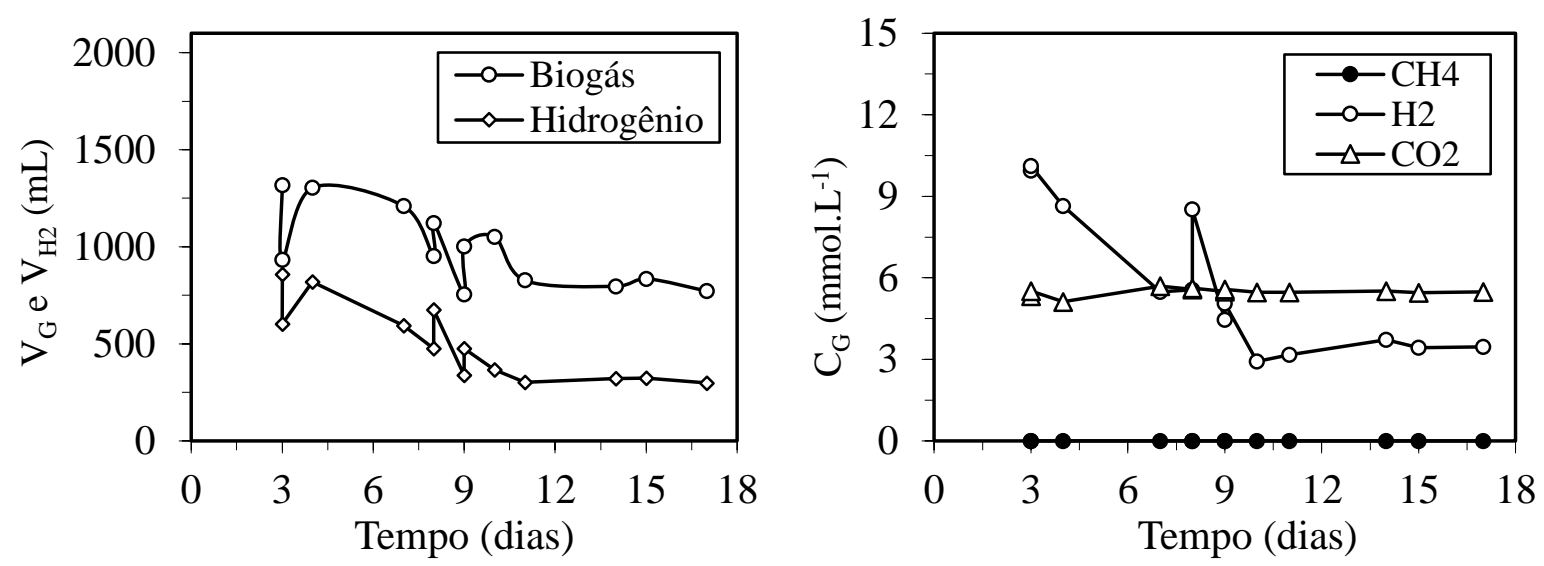

Figura 5.150. Volume de biogás $\left(\mathrm{V}_{\mathrm{G}}\right)$ e de hidrogênio $\left(\mathrm{V}_{\mathrm{H} 2}\right)$ nas CNTP e concentrações dos componentes do biogás no final do ciclo $\left(\mathrm{C}_{\mathrm{G}}\right)$ no Ensaio 16: $\diamond$ - Biogás; $\bullet$ - Metano; ○ - Hidrogênio; $\Delta$ - Dióxido de Carbono.

A Figura 5.151 apresenta os perfis de DQO, carboidratos e glicerina. Novamente, notou-se uma pequena variação na medida de DQO durante o ciclo, ao passo que os perfis de carboidrato e de glicerina apresentaram variações significativas. Em ambos os perfis, foi possível observar um ponto de máxima concentração no tempo de 1,5 h (que representa o final da alimentação do afluente), com o consumo desses dois substratos até o final do ciclo.
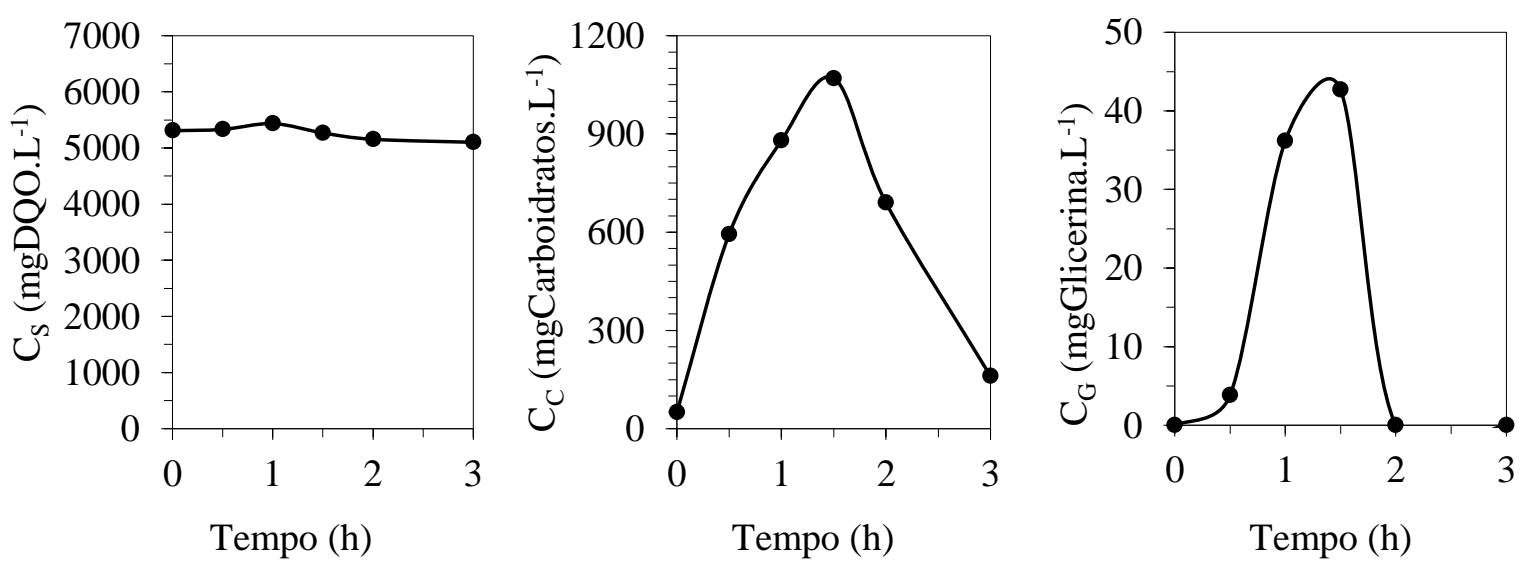

Figura 5.151. Concentrações de matéria orgânica na forma de DQO $\left(\mathrm{C}_{\mathrm{S}}\right)$, carboidratos $\left(\mathrm{C}_{\mathrm{C}}\right)$ e de glicerina $\left(\mathrm{C}_{\mathrm{G}}\right)$ durante o ciclo no Ensaio 16.

A Figura 5.152 apresenta os perfis de $\mathrm{pH}$, alcalinidade total e ácidos voláteis totais ao longo do ciclo. $\mathrm{O}$ pH permanece praticamente constante ao longo do ciclo (por volta de 4,4), assim como os ácidos voláteis totais (em torno de $2685 \mathrm{mgHAc} . \mathrm{L}^{-1}$ ). A alcalinidade fornecida pelo afluente foi consumida e depois gerada pela produção de $\mathrm{CO}_{2}$, com um valor final de $211 \mathrm{mgCaCO} 3 . \mathrm{L}^{-1}$. 

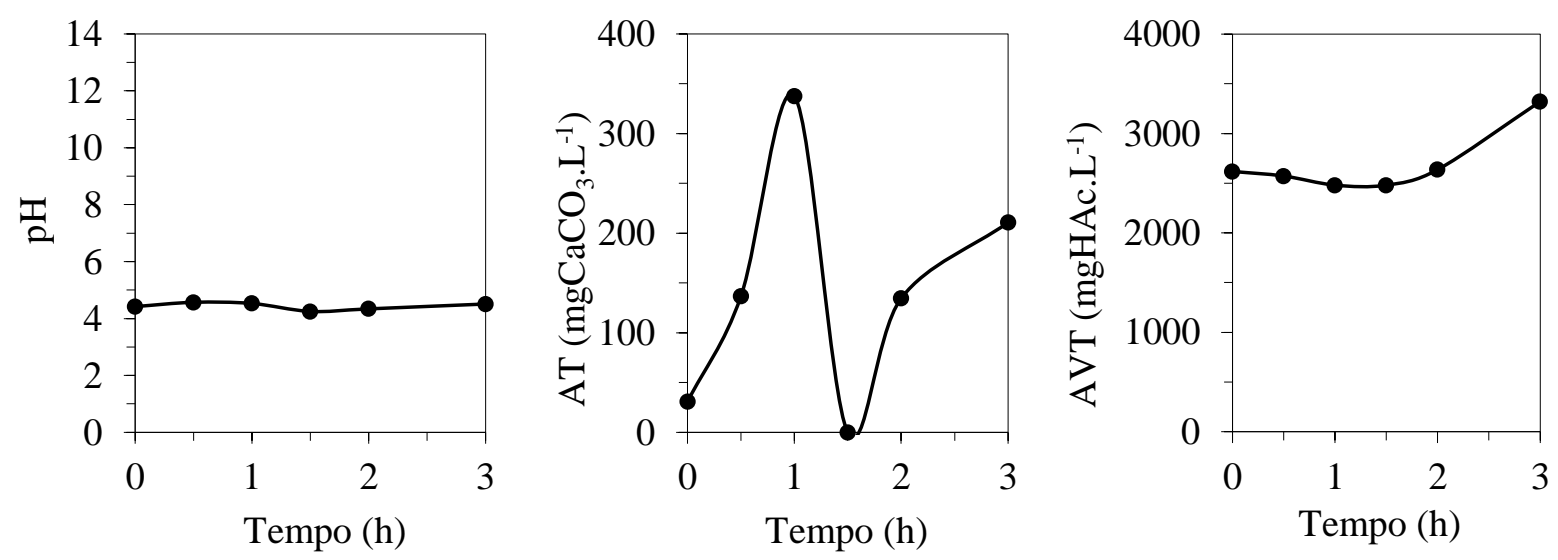

Figura 5.152. Valores de pH, alcalinidade total (AT)e de ácidos voláteis totais (AVT) no Ensaio 16.

O perfil dos compostos intermediários do metabolismo é apresentado na Figura 5.153. Neste ensaio, é possível verificar que há a predominância de ácido acético e de ácido propiônico.

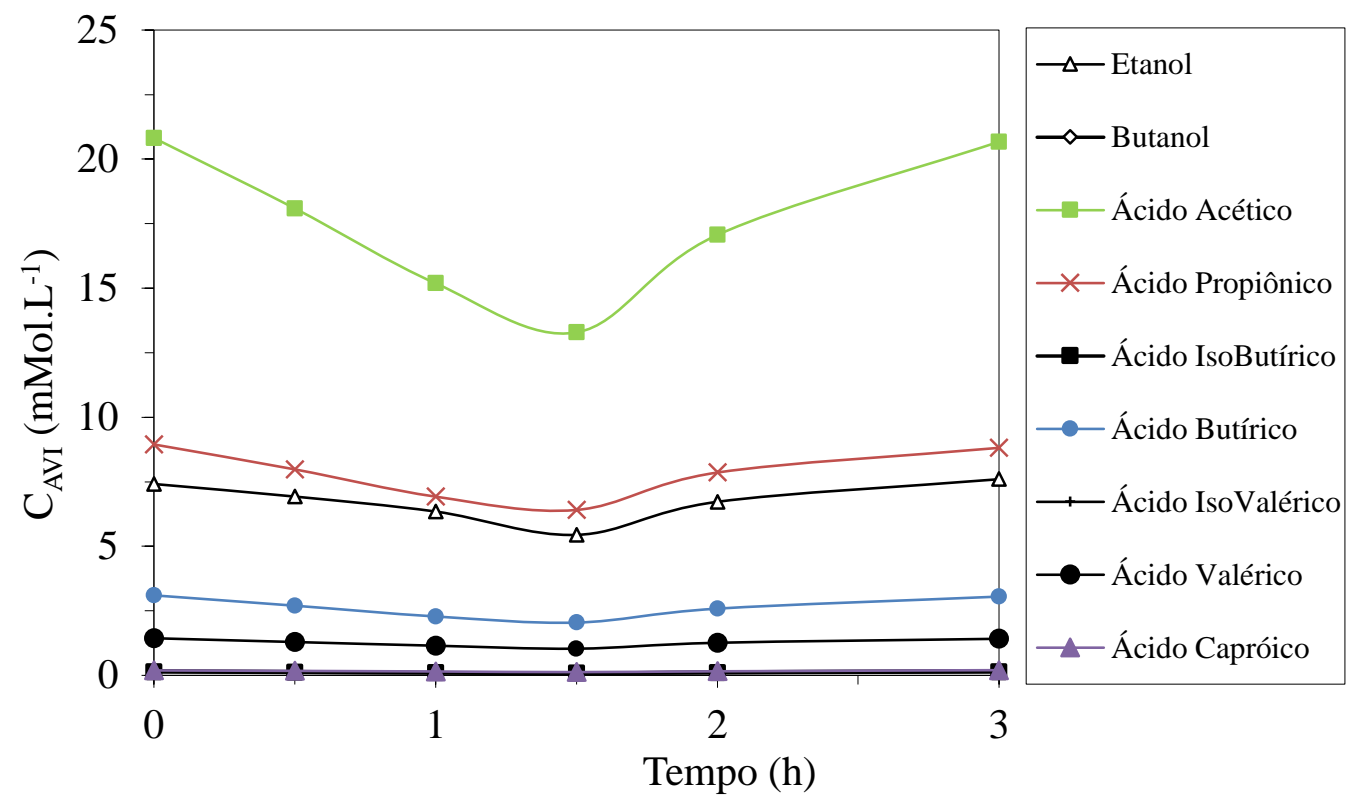

Figura 5.153. Concentração dos compostos intermediários ao longo do ciclo no Ensaio 16: $\Delta$ - etanol; $\diamond$ butanol; $\square$ - ácido acético; -X-ácido propiônico; — - ácido isobutírico; • - ácido butírico; + ácido isovalérico $\bullet$ - ácido valérico; $\Delta$-ácido capróico.

A produção volumétrica acumulada de biogás e os desvios padrões de cada um dos pontos podem ser observados na Figura 5.154, enquanto que o perfil das concentrações dos gases e suas respectivas porcentagens podem ser observados na Figura 5.155. Ao final do ciclo, obteve-se $61 \%$ de $\mathrm{CO}_{2}$ e $39 \%$ de $\mathrm{H}_{2}$, sem traços de metano. 


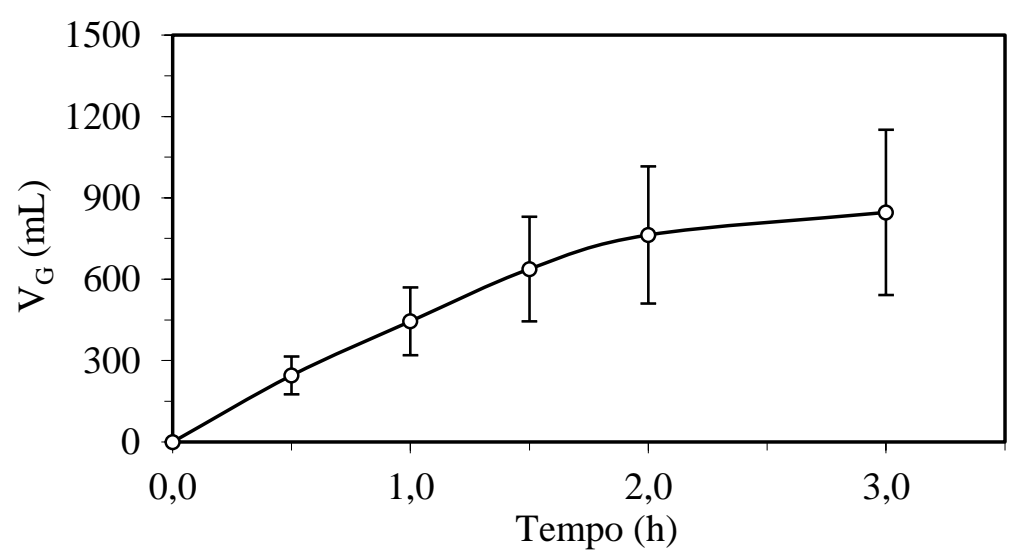

Figura 5.154. Produção volumétrica média acumulada do biogás $\left(\mathrm{V}_{\mathrm{G}}\right)$ durante o ciclo no Ensaio 16.
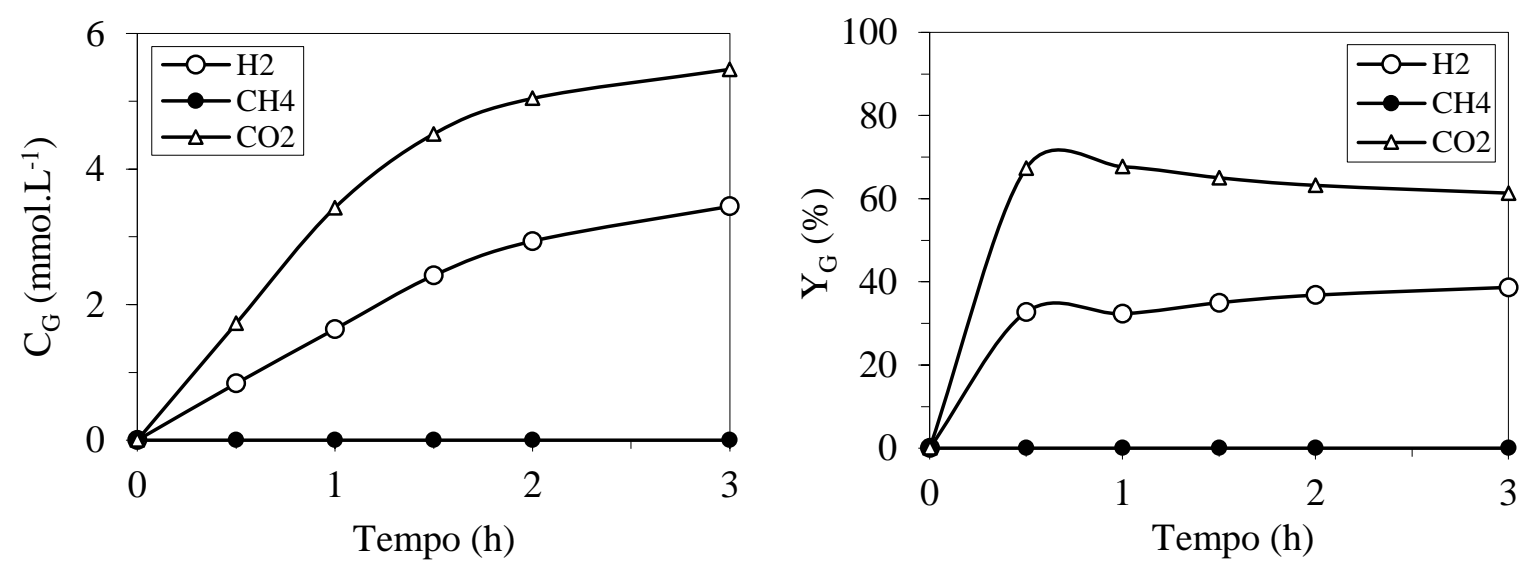

Figura 5.155. Concentração dos compostos do biogás durante o ciclo $\left(\mathrm{C}_{\mathrm{G}}\right)$ e suas respectivas porcentagens $\left(\mathrm{Y}_{\mathrm{G}}\right)$ no Ensaio 16: $\odot-\mathrm{H}_{2} ; \bullet-\mathrm{CH}_{4} ; \Delta-\mathrm{CO}_{2}$.

\subsubsection{Ensaio $17\left(75 \%\right.$ Soro e $25 \%$ Glicerina - $\left.7000 \mathrm{mgDQO} . \mathrm{L}^{-1}-3 \mathrm{~h}-\mathrm{BA}-25^{\circ} \mathrm{C}\right)$}

Para o segundo ensaio que estuda a influência da temperatura, utilizou-se uma concentração de afluente de $7000 \mathrm{mgDQO}^{-1}$ (75\% de soro e $25 \%$ de glicerina) para um tempo de ciclo de $3 \mathrm{~h}$ e um tempo de alimentação igual a 1,5 h, operado a uma temperatura de $25^{\circ} \mathrm{C}$. A Tabela 5.32 mostra os parâmetros médios monitorados no Ensaio 17.

Os valores obtidos de $\mathrm{COAV}_{\text {MOT }}$ e $\mathrm{CORV}_{\mathrm{MOF}}$ foram iguais, respectivamente, a 24,0 gDQO.L $\mathrm{L}^{-1} \cdot \mathrm{d}^{-1}$ e 4,8 gDQO.L $\mathrm{L}^{-1} \cdot \mathrm{d}^{-1}$ - uma baixa remoção de matéria orgânica. O afluente

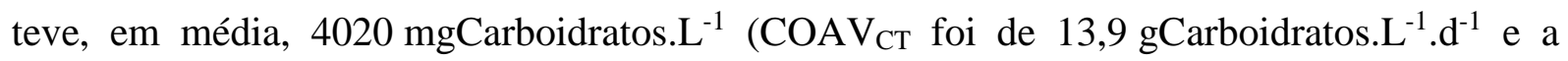
$\mathrm{CORV}_{\mathrm{CF}}$ atingida foi de 13,4 gCarboidratos. $\left.\mathrm{L}^{-1} \cdot \mathrm{d}^{-1}\right)$ e $1145 \mathrm{mgGlicerina.L^{-1 }}\left(\mathrm{COAV}_{\mathrm{GT}}\right.$ foi de 3,0 gGlicerina. $\mathrm{L}^{-1} \cdot \mathrm{d}^{-1}$ e a $\mathrm{CORV}_{\mathrm{GF}}$ atingida foi de $\left.2,7 \mathrm{gGlicerina} \cdot \mathrm{L}^{-1} \cdot \mathrm{d}^{-1}\right)$. 
Tabela 5.32. Parâmetros médios monitorados no Ensaio 17.

\begin{tabular}{|c|c|c|c|c|c|c|c|c|c|c|c|}
\hline \multicolumn{2}{|r|}{ Parâmetro } & \multicolumn{5}{|c|}{ Afluente } & \multicolumn{5}{|c|}{ Efluente } \\
\hline $\mathrm{C}_{\mathrm{MOT}}$ & $\left(\mathrm{mgDQO} . \mathrm{L}^{-1}\right)$ & 6929 & \pm 197 & ( & 11 & ) & 5704 & \pm 469 & ( & 11 & \\
\hline $\mathrm{C}_{\mathrm{MOF}}$ & $\left(\mathrm{mgDQO} \cdot \mathrm{L}^{-1}\right)$ & & & & & & 5530 & \pm 321 & ( & 11 & ) \\
\hline$\varepsilon_{\mathrm{MOT}}$ & $(\%)$ & & & & & & 18 & \pm 6 & ( & 11 & \\
\hline$\varepsilon_{\mathrm{MOF}}$ & $(\%)$ & & & & & & 20 & \pm & ( & 11 & ) \\
\hline $\mathrm{C}_{\mathrm{CT}}$ & (mgCarboidratos. $\mathrm{L}^{-1}$ ) & 4020 & \pm 129 & ( & 11 & ) & 133 & \pm 224 & ( & 9 & ) \\
\hline $\mathrm{C}_{\mathrm{CF}}$ & (mgCarboidratos. $\left.\mathrm{L}^{-1}\right)$ & & & & & & 130 & \pm 224 & ( & 9 & ) \\
\hline$\varepsilon_{\mathrm{CT}}$ & $(\%)$ & & & & & & 97 & \pm 6 & ( & 9 & ) \\
\hline$\varepsilon_{\mathrm{CF}}$ & $(\%)$ & & & & & & 97 & \pm 6 & ( & 9 & ) \\
\hline $\mathrm{C}_{\mathrm{GT}}$ & (mgGlicerina.L $\mathrm{L}^{-1}$ ) & 1145 & \pm 77 & ( & 11 & ) & 96 & \pm 133 & ( & 9 & 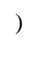 \\
\hline $\mathrm{C}_{\mathrm{GF}}$ & (mgGlicerina. $\mathrm{L}^{-1}$ ) & & & & & & 84 & \pm 116 & ( & 9 & ) \\
\hline$\varepsilon_{\mathrm{GT}}$ & $(\%)$ & & & & & & 92 & $\pm \quad 11$ & ( & 9 & ) \\
\hline$\varepsilon_{\mathrm{GF}}$ & $(\%)$ & & 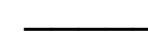 & & & & 93 & $\pm \quad 10$ & ( & 9 & ) \\
\hline $\mathrm{pH}$ & (u) & 7,7 & $\pm \quad 0,2$ & ( & 11 & ) & 4,8 & $\pm \quad 0,8$ & ( & 10 & ) \\
\hline AVT & $\left(\right.$ mgHAc. $\left.L^{-1}\right)$ & 144 & \pm 33 & ( & 11 & ) & 2439 & \pm 880 & ( & 10 & ) \\
\hline $\mathrm{AT}$ & $\left(\mathrm{mgCaCO}_{3} \cdot \mathrm{L}^{-1}\right)$ & 480 & \pm 164 & ( & 11 & ) & 221 & \pm 253 & ( & 10 & \\
\hline AP & $\left(\mathrm{mgCaCO}_{3} \cdot \mathrm{L}^{-1}\right)$ & 328 & \pm 118 & ( & 11 & ) & 26 & $\pm \quad 65$ & ( & 10 & ) \\
\hline AI & $\left(\mathrm{mgCaCO}_{3} \cdot \mathrm{L}^{-1}\right)$ & 152 & $\pm \quad 48$ & ( & 11 & ) & 194 & $\pm \quad 193$ & ( & 10 & \\
\hline $\mathrm{AB}$ & $\left(\mathrm{mgCaCO}_{3} \cdot \mathrm{L}^{-1}\right)$ & 378 & \pm 155 & ( & 11 & ) & 0 & \pm & ( & 10 & ) \\
\hline $\mathrm{ST}$ & $\left(\mathrm{mg} \cdot \mathrm{L}^{-1}\right)$ & 5157 & \pm 310 & ( & 4 & ) & 2747 & \pm 407 & ( & 4 & , \\
\hline SVT & $\left(\mathrm{mg} \cdot \mathrm{L}^{-1}\right)$ & 4307 & \pm 299 & ( & 4 & ) & 1936 & \pm 354 & ( & 4 & 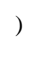 \\
\hline SST & $\left(\mathrm{mg} \cdot \mathrm{L}^{-1}\right)$ & 70 & $\pm \quad 32$ & ( & 4 & ) & 96 & $\pm \quad 68$ & ( & 4 & 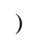 \\
\hline SSV & $\left(\mathrm{mg} \cdot \mathrm{L}^{-1}\right)$ & 97 & $\pm \quad 59$ & ( & 4 & ) & 110 & \pm 115 & ( & 4 & ) \\
\hline $\mathrm{M}_{\mathrm{SVT}}$ & (g) & & & & & & & 41,8 & & & \\
\hline $\mathrm{Cx}$ & $\left(\mathrm{g} . \mathrm{L}^{-1}\right)$ & & & & & & & 11,9 & & & \\
\hline $\mathrm{Cx}^{\prime}$ & $\left(\right.$ g.gsuporte $\left.{ }^{-1}\right)$ & & & & & & & 029 & & & \\
\hline $\mathrm{V}_{\mathrm{G}}$ & $\left(\mathrm{mL} . \mathrm{ciclo}^{-1}\right)$ & & - & & & & 756 & \pm 306 & ( & 13 & \\
\hline $\mathrm{V}_{\mathrm{H} 2}$ & $\left(\mathrm{~mL} \cdot \mathrm{ciclo}^{-1}\right)$ & & & & & & 383 & \pm 19 & ( & 13 & \\
\hline $\mathrm{COAV}_{\text {Mот }}$ & $\left(\mathrm{gDQO} \cdot \mathrm{L}^{-1} \cdot \mathrm{d}^{-1}\right)$ & & 4,0 & & & & & & & & \\
\hline $\mathrm{CORV}_{\mathrm{MOF}}$ & $\left(\mathrm{gDQO} \cdot \mathrm{L}^{-1} \cdot \mathrm{d}^{-1}\right)$ & & & & & & & 4,8 & & & \\
\hline $\mathrm{COAV}_{\mathrm{CT}}$ & (gCarboidratos. $\left.\mathrm{L}^{-1} \cdot \mathrm{d}^{-1}\right)$ & & 3,9 & & & & & & & & \\
\hline $\mathrm{CORV}_{\mathrm{CF}}$ & (gCarboidratos. $\mathrm{L}^{-1} \cdot \mathrm{d}^{-1}$ ) & & & & & & & 13,4 & & & \\
\hline $\mathrm{COAV}_{\mathrm{GT}}$ & (gGlicerina. $L^{-1} \cdot d^{-1}$ ) & & 3,0 & & & & & & & & \\
\hline $\mathrm{CORV}_{\mathrm{GF}}$ & (gGlicerina. $\mathrm{L}^{-1} \cdot \mathrm{d}^{-1}$ ) & & & & & & & 2,5 & & & \\
\hline $\mathrm{COAE}_{\text {MOт }}$ & $\left(\mathrm{gDQO} \cdot \mathrm{gSVT}^{-1} \cdot \mathrm{d}^{-1}\right)$ & & 2,0 & & & & & & & & \\
\hline $\mathrm{CORE}_{\mathrm{MOF}}$ & $\left(\mathrm{gDQO}_{\mathrm{gSVT}}{ }^{-1} \cdot \mathrm{d}^{-1}\right)$ & & & & & & & 0,4 & & & \\
\hline $\mathrm{COAE}_{\mathrm{CT}}$ & $\left(\right.$ gCarboidratos.gSVT $\left.^{-1} \cdot \mathrm{d}^{-1}\right)$ & & 1,2 & & & & & & & & \\
\hline $\mathrm{CORE}_{\mathrm{CF}}$ & $\left(\right.$ gCarboidratos.gSVT $\left.^{-1} \cdot \mathrm{d}^{-1}\right)$ & & & & & & & 1,1 & & & \\
\hline $\mathrm{COAE}_{\mathrm{GT}}$ & (gGlicerina.gSVT ${ }^{-1} \cdot \mathrm{d}^{-1}$ ) & & 0,3 & & & & & & & & \\
\hline $\mathrm{CORE}_{\mathrm{GF}}$ & (gGlicerina.gSVT ${ }^{-1} \cdot \mathrm{d}^{-1}$ ) & & & & & & & 0,2 & & & \\
\hline $\mathrm{n}_{\mathrm{H} 2}$ & $\left(\mathrm{molH}_{2} \cdot \mathrm{d}^{-1}\right)$ & & & & & & & 0,1 & & & \\
\hline PrM & $\left(\mathrm{molH}_{2} \cdot \mathrm{m}^{-3} \cdot \mathrm{d}^{-1}\right)$ & & & & & & & 38,8 & & & \\
\hline PrME & $\left(\mathrm{molH}_{2} \cdot \mathrm{kgSVT}^{-1} \cdot \mathrm{d}^{-1}\right)$ & & 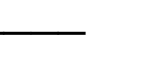 & & & & & 3,3 & & & \\
\hline RMCA & $\left(\mathrm{molH}_{2} \cdot \mathrm{kgDQO}^{-1}\right)$ & & 1,6 & & & & & & & & \\
\hline RMSA & $\left(\mathrm{molH}_{2} \cdot \mathrm{molSubstrato}^{-1}\right)$ & & 0,5 & & & & & & & & \\
\hline RMSR & $\left(\mathrm{molH}_{2} \cdot \mathrm{molSubstrato}^{-1}\right)$ & & & & & & & 0,6 & & & \\
\hline $\mathrm{V}_{\mathrm{A}}$ & $(\mathrm{L})$ & 1,52 & $\pm 0,04$ & ( & 9 & ) & & & & & \\
\hline
\end{tabular}

(*) Entre parênteses o número de amostras considerado no cálculo da média 
Assim como nos ensaios anteriores, o monitoramento diário relevou um baixo consumo de matéria orgânica na forma de DQO, com média de concentração afluente não filtrada de $6929 \mathrm{mgDQO} . \mathrm{L}^{-1}$, efluente não filtrada de $5704 \mathrm{mgDQO} . \mathrm{L}^{-1}$ e de efluente filtrada de $5530 \mathrm{mgDQO} . \mathrm{L}^{-1}$, o que representa uma remoção média para amostras não filtradas de $18 \%$ e para amostras filtradas de $20 \%$ (Figura 5.156).
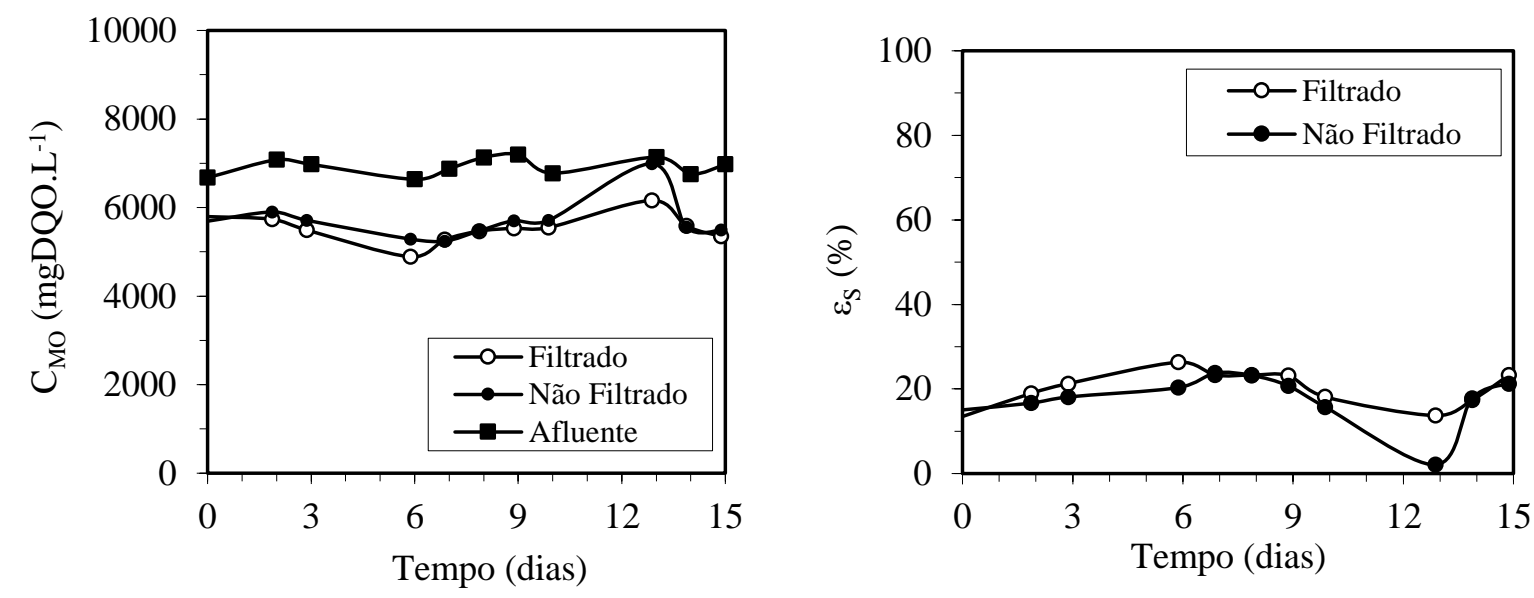

Figura 5.156. Concentração $\left(\mathrm{C}_{S}\right)$ e eficiência de remoção na forma de DQO $\left(\varepsilon_{S}\right)$ no Ensaio 17: - - afluente amostras não filtradas; • - efluente amostras não filtradas; $\bigcirc-$ efluente amostras filtradas.

Em relação ao monitoramento diário de carboidratos, o sistema apresentou um ótimo consumo, de acordo com a Figura 5.157, com média de concentração afluente não filtrada

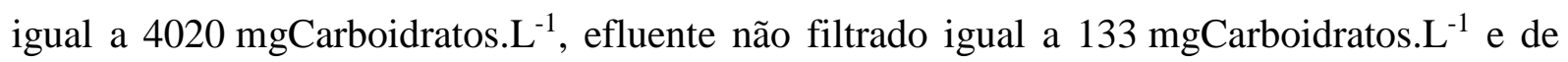

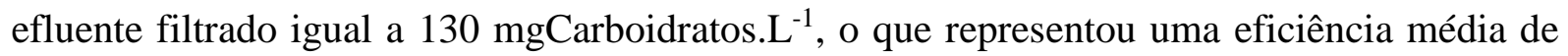
remoção de 97\%, tanto para amostras não filtradas quanto para amostras filtradas.
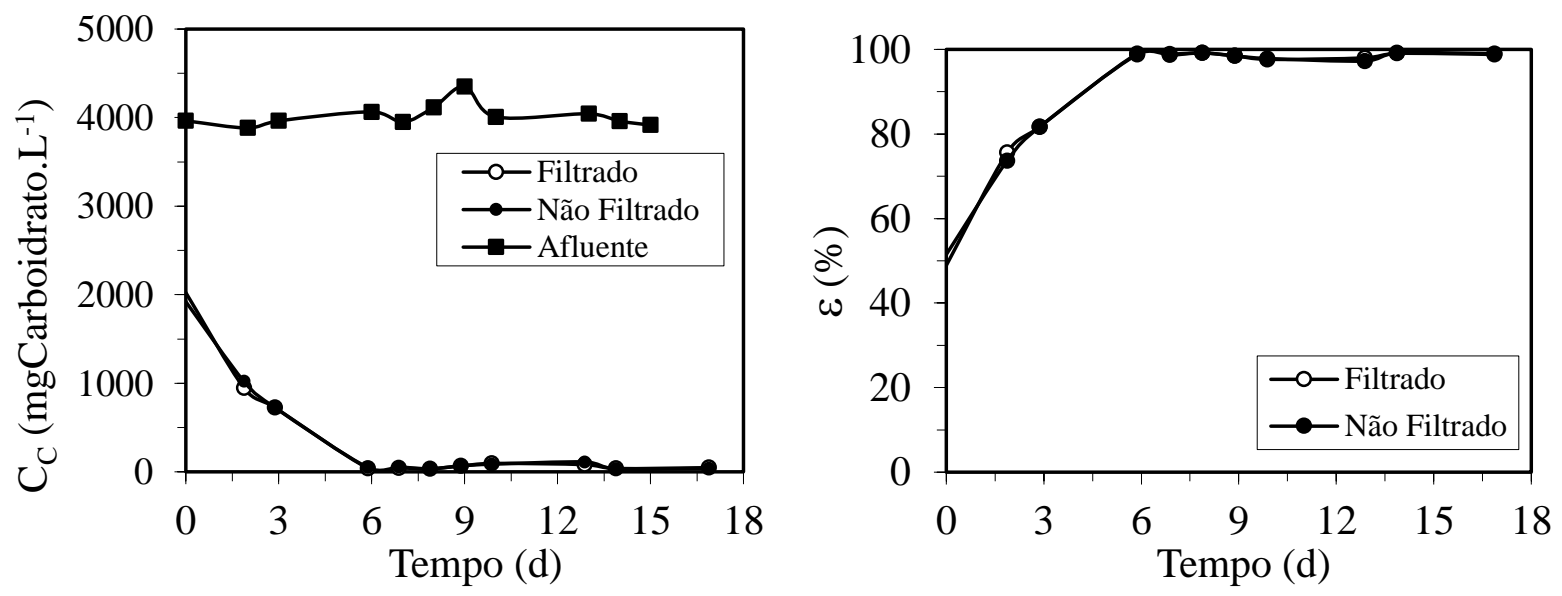

Figura 5.157. Concentração $\left(C_{C}\right)$ e eficiência de remoção na forma de carboidratos $\left(\varepsilon_{C}\right)$ no Ensaio 17: - - afluente amostras não filtradas; • - efluente amostras não filtradas; $\bigcirc-$ efluente amostras filtradas.

O monitoramento diário de glicerina apresentou média de concentração afluente não filtrada igual a $1145 \mathrm{mgGlicerina} . \mathrm{L}^{-1}$, efluente não filtrado igual a $96 \mathrm{mgGlicerina.} \mathrm{L}^{-1}$ e de 
efluente filtrado igual a $84 \mathrm{mgGlicerina} . \mathrm{L}^{-1}$, o que representa uma eficiência média de remoção para amostras não filtradas de $92 \%$, e para amostras filtradas de $93 \%$, de acordo com a Figura 5.158.
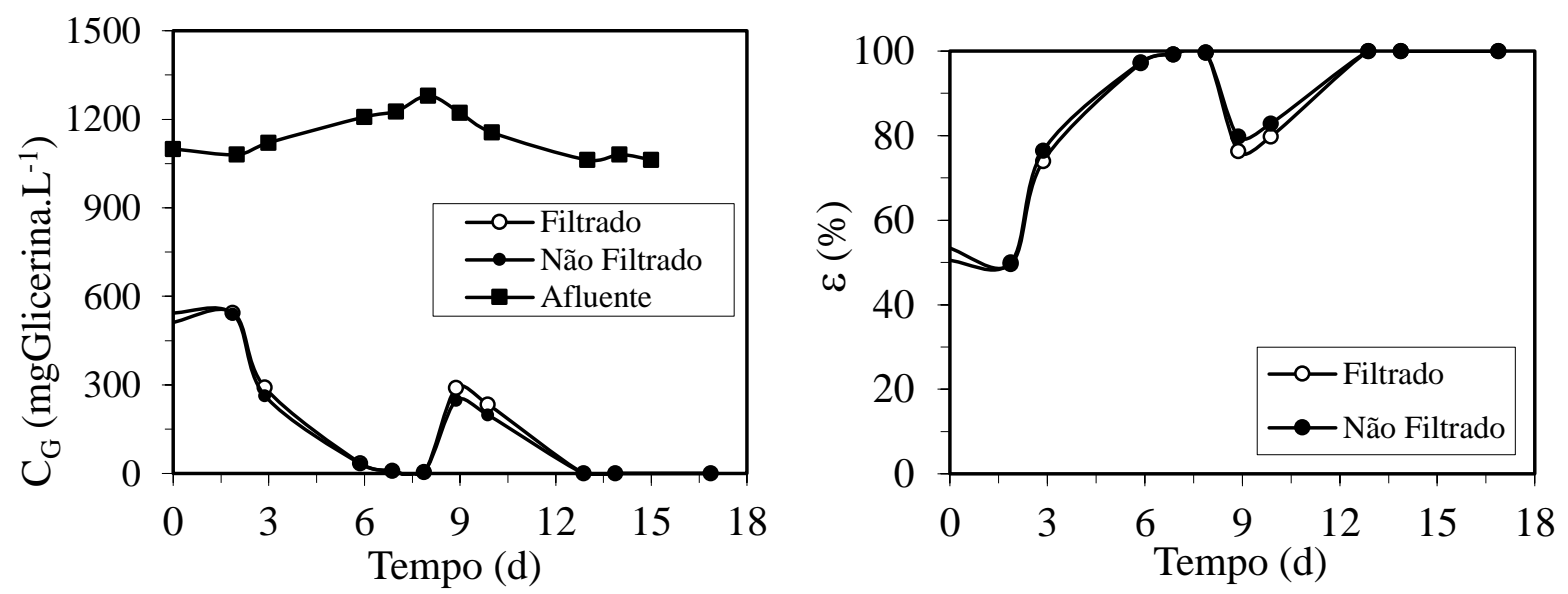

Figura 5.158. Concentração $\left(\mathrm{C}_{\mathrm{G}}\right)$ e eficiência de remoção na forma de glicerina $\left(\varepsilon_{\mathrm{G}}\right)$ no Ensaio 17: afluente amostras não filtradas; • - efluente amostras não filtradas; $\bigcirc$ - efluente amostras filtradas.

A média de $\mathrm{pH}$ do afluente foi igual a 7,71, enquanto que a do efluente foi igual a 4,8. A alcalinidade total no afluente teve média de $480 \mathrm{mgCaCO}_{3} \cdot \mathrm{L}^{-1}$, sendo consumida até uma média de $221 \mathrm{mgCaCO}_{3} \cdot \mathrm{L}^{-1}$, ao passo que as médias de AVT no afluente e no efluente foram iguais a 144 e $2439 \mathrm{mgHAc} . \mathrm{L}^{-1}$, respectivamente.

A produção de biogás, em aspecto quantitativo, e a distribuição dos gases que compõem o biogás no final do ciclo podem ser observadas pela Figura 5.159, com média de $756 \mathrm{~mL}$ de biogás e $383 \mathrm{~mL}$ de hidrogênio, sendo que a porcentagem média de hidrogênio e sua produtividade molar foram iguais a $49 \%$ e a $38,8 \mathrm{molH}_{2} \cdot \mathrm{m}^{-3} \cdot \mathrm{d}^{-1}$ e respectivamente.
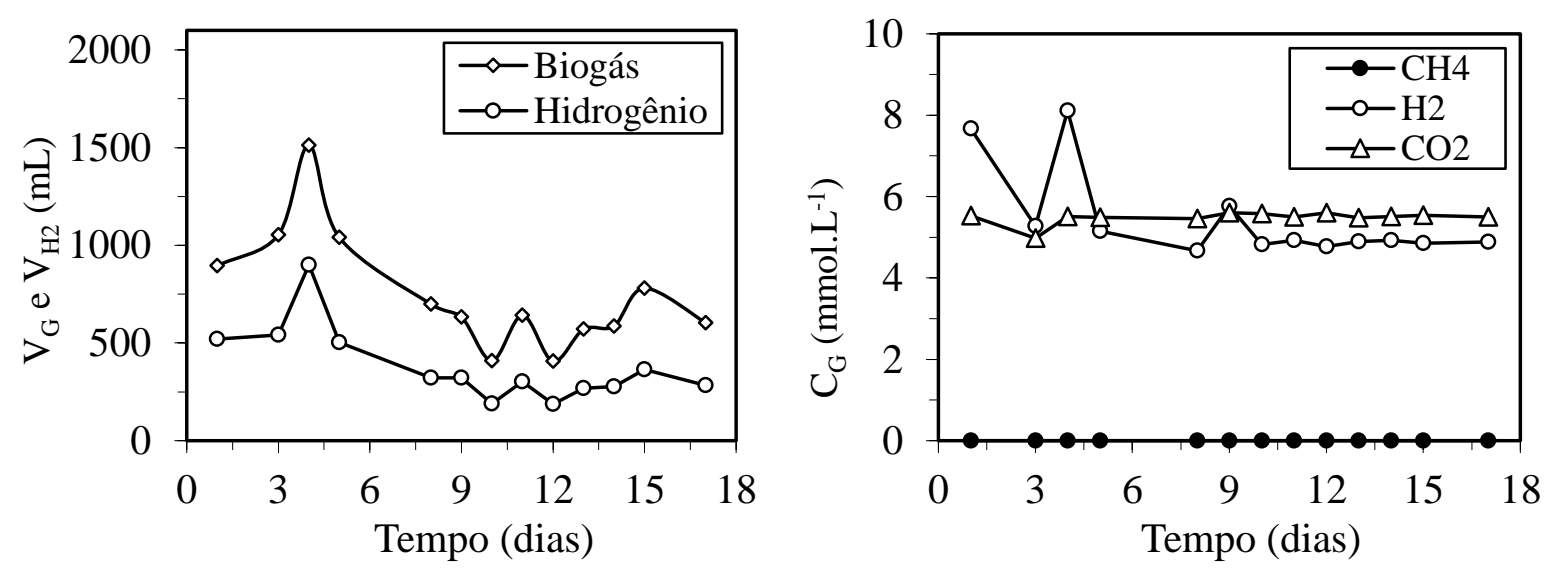

Figura 5.159. Volume de biogás $\left(\mathrm{V}_{\mathrm{G}}\right)$ e de hidrogênio $\left(\mathrm{V}_{\mathrm{H} 2}\right)$ nas CNTP e concentrações dos componentes do biogás no final do ciclo $\left(\mathrm{C}_{\mathrm{G}}\right)$ no Ensaio 17: $\diamond$-biogás; •-metano; ○-hidrogênio; $\Delta$ - dióxido de carbono. 
A Figura 5.160 apresenta os perfis de DQO, carboidratos e glicerina, onde se nota o mesmo comportamento encontrado nos ensaios anteriores.
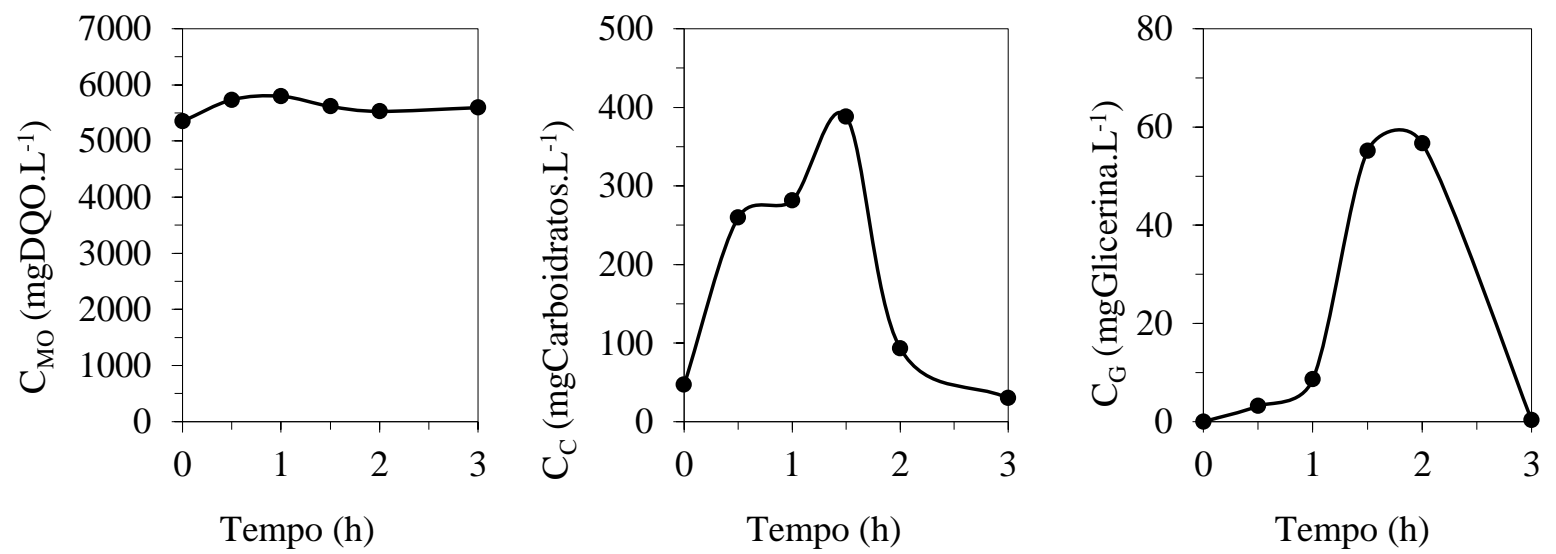

Figura 5.160. Concentrações de matéria orgânica na forma de DQO $\left(\mathrm{C}_{\mathrm{S}}\right)$, carboidratos $\left(\mathrm{C}_{\mathrm{C}}\right)$ e de glicerina $\left(\mathrm{C}_{\mathrm{G}}\right)$ durante o ciclo no Ensaio 17.

A Figura 5.161 apresenta os perfis de $\mathrm{pH}$, alcalinidade total e ácidos voláteis totais ao longo do ciclo. $\mathrm{O}$ pH permanece praticamente constante ao longo do ciclo (por volta de 4,44), assim como os ácidos voláteis totais (em torno de $3633 \mathrm{mgHAc} . \mathrm{L}^{-1}$ ) e a alcalinidade, esta com um valor final de $144 \mathrm{mgCaCO} 3 . \mathrm{L}^{-1}$.
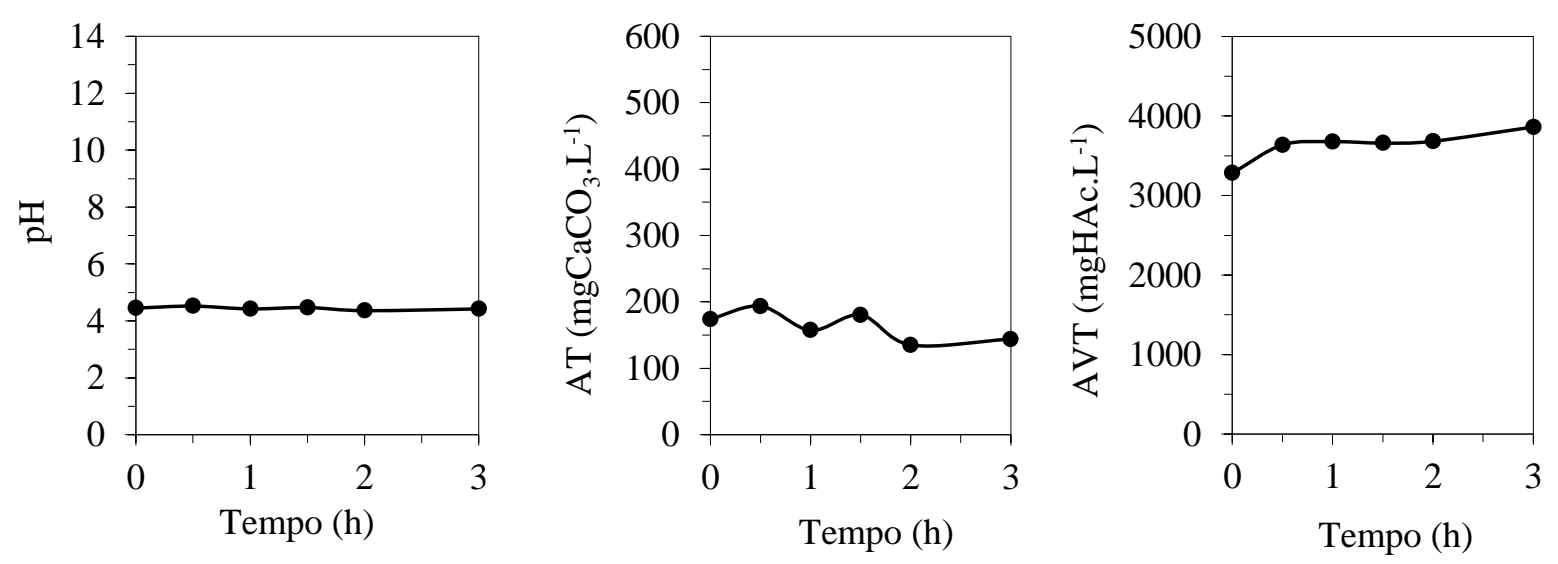

Figura 5.161. Valores de pH, alcalinidade total (AT) e de ácidos voláteis totais (AVT) no Ensaio 17.

O perfil dos compostos intermediários do metabolismo é apresentado na Figura 5.162. Novamente, é possível verificar que há a predominância de ácido acético e de ácido propiônico. 


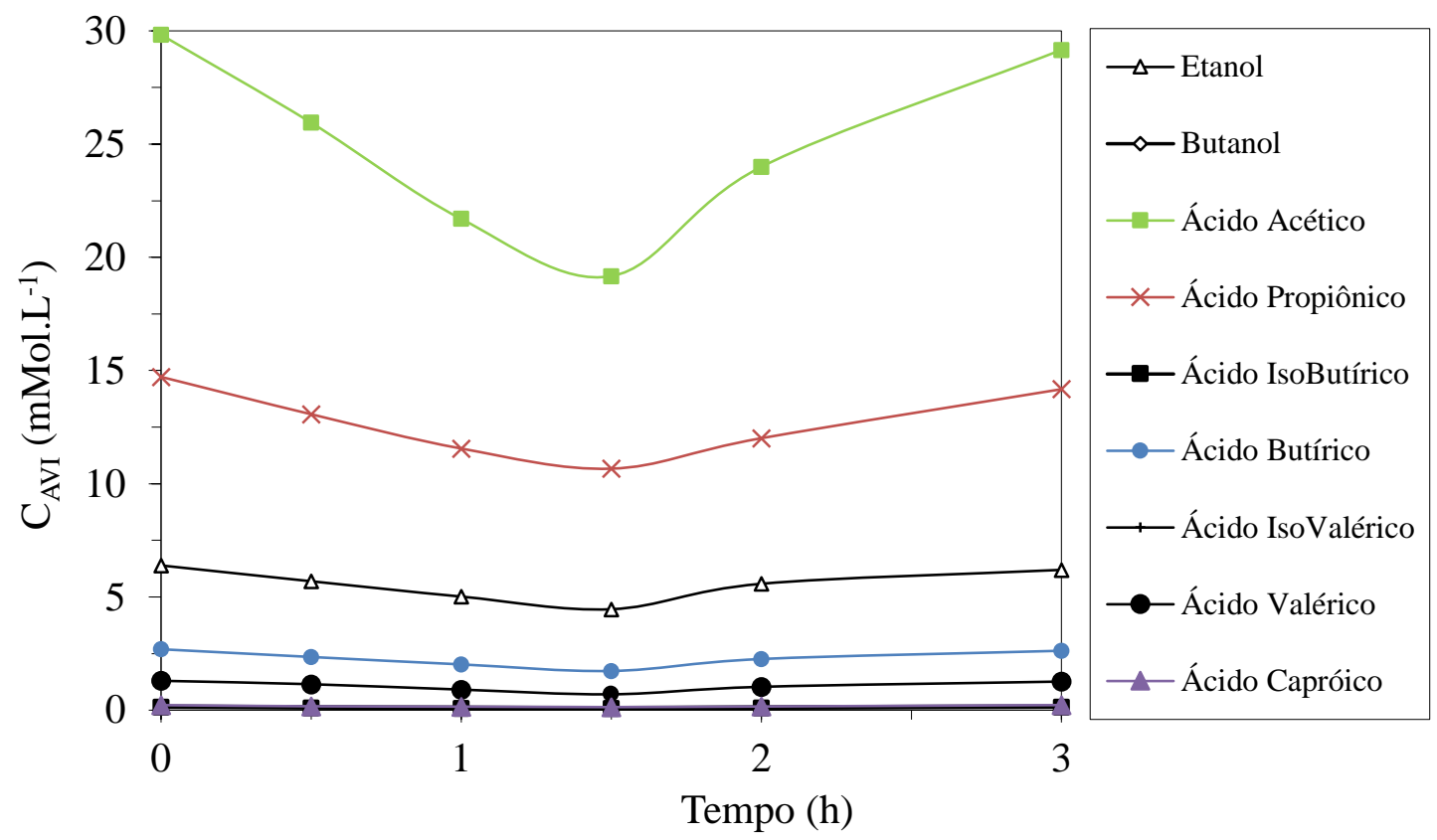

Figura 5.162. Concentração dos compostos intermediários ao longo do ciclo no Ensaio 17: $\Delta$ - etanol; $\diamond$ butanol; - - ácido acético; -X- ácido propiônico; - ácido isobutírico; $\bullet$ - ácido butírico; + ácido isovalérico $\bullet$ - ácido valérico; $\boldsymbol{\Delta}$ - ácido capróico.

A produção volumétrica acumulada de biogás e os desvios padrões de cada um dos pontos podem ser observados na Figura 5.163, enquanto que o perfil das concentrações dos gases e suas respectivas porcentagens podem ser observados na Figura 5.164. No final do ciclo, a composição do biogás gerado era de $53 \%$ de $\mathrm{CO}_{2}$ e $47 \%$ de $\mathrm{H}_{2}$, não havendo metano.

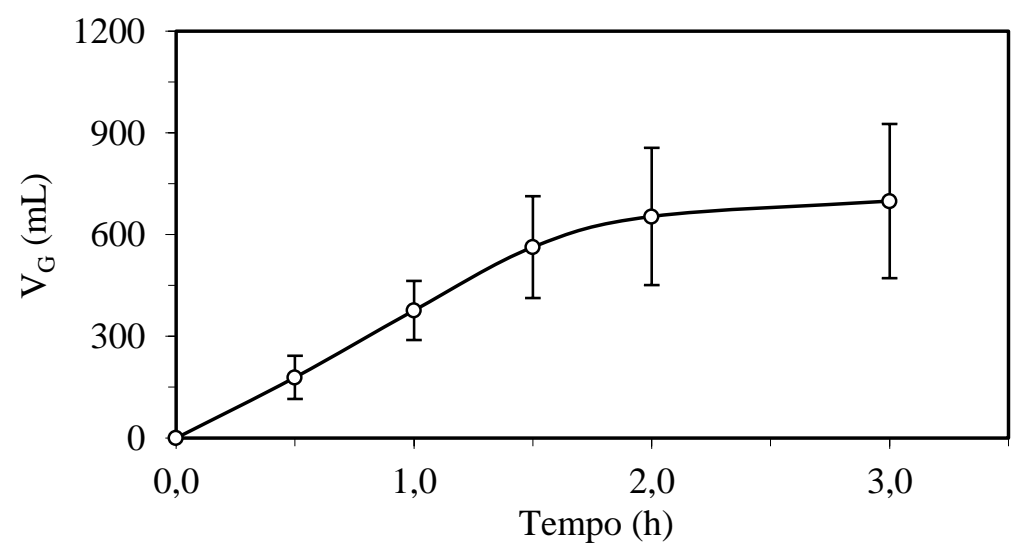

Figura 5.163. Produção volumétrica média acumulada do biogás $\left(\mathrm{V}_{\mathrm{G}}\right)$ durante o ciclo no Ensaio 17. 

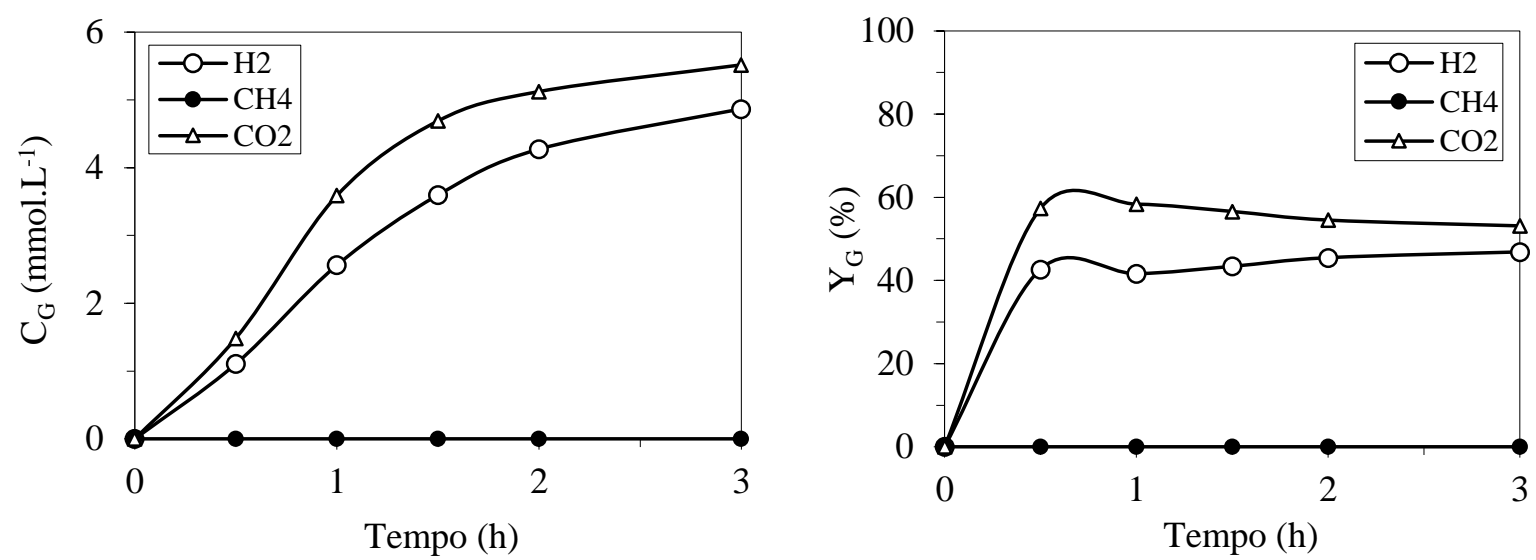

Figura 5.164. Concentração dos compostos do biogás durante o ciclo $\left(\mathrm{C}_{\mathrm{G}}\right)$ e suas respectivas porcentagens $\left(\mathrm{Y}_{\mathrm{G}}\right)$ no Ensaio 17: $\odot-\mathrm{H}_{2} ; \bullet-\mathrm{CH}_{4} ; \Delta-\mathrm{CO}_{2}$.

\subsubsection{Ensaio $18\left(75 \%\right.$ Soro e $25 \%$ Glicerina - $\left.7000 \mathrm{mgDQO} . \mathrm{L}^{-1}-3 \mathrm{~h}-\mathrm{BA}-35^{\circ} \mathrm{C}\right)$}

Finalmente, para o terceiro ensaio que estuda a influência da temperatura e o último desta tese, utilizou-se uma concentração de afluente de 7000 mgDQO.L ${ }^{-1}$ (75\% de soro e $25 \%$ de glicerina), tempo de ciclo de $3 \mathrm{~h}$ e tempo de alimentação igual a 1,5 h, operando a uma temperatura de $35^{\circ} \mathrm{C}$. A Tabela 5.33 mostra os parâmetros médios monitorados no Ensaio 18 .

Os valores obtidos de $\mathrm{COAV}_{\text {MOT }}$ e $\mathrm{CORV}_{\mathrm{MOF}}$ foram iguais, respectivamente, a 24,0 gDQO.L $\mathrm{L}^{-1} \cdot \mathrm{d}^{-1}$ e 5,5 gDQO.L $\mathrm{L}^{-1} \cdot \mathrm{d}^{-1}$ - uma baixa remoção de matéria orgânica, como nos outros ensaios. O afluente teve, em média, 4404 mgCarboidratos. $\mathrm{L}^{-1}\left(\mathrm{COAV}_{\mathrm{CT}}\right.$ foi de 15,1 gCarboidratos. $\mathrm{L}^{-1} \cdot \mathrm{d}^{-1}$ e a $\mathrm{CORV}_{\mathrm{CF}}$ atingida foi de 14,6 gCarboidratos. $\mathrm{L}^{-1} \cdot \mathrm{d}^{-1}$ ) e 1288 mgGlicerina. $L^{-1}\left(\operatorname{COAV}_{\mathrm{GT}}\right.$ foi de 4,4 gGlicerina. $\mathrm{L}^{-1} \cdot \mathrm{d}^{-1}$ e a $\mathrm{CORV}_{\mathrm{GF}}$ atingida foi de 4,2 gGlicerina. $\left.\mathrm{L}^{-1} \cdot \mathrm{d}^{-1}\right)$.

O monitoramento diário de matéria orgânica na forma de DQO teve média de concentração afluente não filtrada de $7004 \mathrm{mgDQO} . \mathrm{L}^{-1}$, efluente não filtrada de $5564 \mathrm{mgDQO} . \mathrm{L}^{-1}$ e de efluente filtrada de $5389 \mathrm{mgDQO}^{-1} \mathrm{~L}^{-1}$ o que representa uma remoção média para amostras não filtradas de $21 \%$ e para amostras filtradas de $23 \%$, conforme mostrado na Figura 5.165. 
Tabela 5.33. Parâmetros médios monitorados no Ensaio 18.

\begin{tabular}{|c|c|c|c|c|c|c|c|c|c|c|c|c|}
\hline \multicolumn{2}{|r|}{ Parâmetro } & \multicolumn{6}{|c|}{ Afluente } & \multicolumn{5}{|c|}{ Efluente } \\
\hline $\mathrm{C}_{\mathrm{MOT}}$ & $\left(\mathrm{mgDQO} \cdot \mathrm{L}^{-1}\right)$ & 7004 & \pm & 218 & ( & 11 & ) & 5564 & \pm 361 & ( & 11 & \\
\hline $\mathrm{C}_{\mathrm{MOF}}$ & $\left(\operatorname{mgDQO} . L^{-1}\right)$ & & & & & & & 5389 & \pm 435 & ( & 11 & ) \\
\hline$\varepsilon_{\mathrm{MOT}}$ & $(\%)$ & & & & & & & 21 & $\pm \quad 5$ & ( & 11 & ) \\
\hline$\varepsilon_{\mathrm{MOF}}$ & $(\%)$ & & & & & & & 23 & \pm & ( & 11 & ) \\
\hline $\mathrm{C}_{\mathrm{CT}}$ & (mgCarboidratos. $\left.\mathrm{L}^{-1}\right)$ & 4404 & \pm & 359 & ( & 11 & ) & 158 & \pm 229 & ( & 9 & ) \\
\hline $\mathrm{C}_{\mathrm{CF}}$ & (mgCarboidratos. $\left.\mathrm{L}^{-1}\right)$ & & & & & & & 139 & \pm 229 & ( & 9 & ) \\
\hline$\varepsilon_{\mathrm{CT}}$ & $(\%)$ & & & & & & & 96 & \pm & ( & 9 & ) \\
\hline$\varepsilon_{\mathrm{CF}}$ & $(\%)$ & & & & & & & 97 & \pm & ( & 9 & ) \\
\hline $\mathrm{C}_{\mathrm{GT}}$ & $\left(\right.$ mgGlicerina. $\left.L^{-1}\right)$ & 1288 & \pm & 141 & ( & 11 & ) & 53 & \pm 86 & ( & 9 & ) \\
\hline $\mathrm{C}_{\mathrm{GF}}$ & (mgGlicerina. $\left.\mathrm{L}^{-1}\right)$ & & & & & & & 52 & \pm 84 & ( & 9 & ) \\
\hline$\varepsilon_{\mathrm{GT}}$ & $(\%)$ & & & & & & & 96 & \pm & ( & 9 & ) \\
\hline$\varepsilon_{\mathrm{GF}}$ & $(\%)$ & & 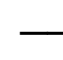 & & & & & 96 & \pm & ( & 9 & ) \\
\hline $\mathrm{pH}$ & (u) & 7,7 & \pm & 0,2 & ( & 11 & ) & 4,7 & $\pm \quad 0,5$ & ( & 11 & ) \\
\hline AVT & $\left(\mathrm{mgHAc} . \mathrm{L}^{-1}\right)$ & 149 & \pm & 11 & ( & 11 & ) & 2535 & \pm 985 & ( & 11 & ) \\
\hline $\mathrm{AT}$ & $\left(\mathrm{mgCaCO}_{3} \cdot \mathrm{L}^{-1}\right)$ & 688 & & 208 & ( & 11 & ) & 334 & \pm 260 & ( & 11 & ) \\
\hline $\mathrm{AP}$ & $\left(\mathrm{mgCaCO}_{3} \cdot \mathrm{L}^{-1}\right)$ & 481 & & 159 & ( & 11 & ) & 7 & $\pm \quad 22$ & ( & 11 & ) \\
\hline AI & $\left(\mathrm{mgCaCO}_{3} \cdot \mathrm{L}^{-1}\right)$ & 207 & \pm & 52 & ( & 11 & ) & 327 & \pm 245 & ( & 11 & ) \\
\hline $\mathrm{AB}$ & $\left(\mathrm{mgCaCO}_{3} \cdot \mathrm{L}^{-1}\right)$ & 582 & \pm & 213 & ( & 11 & ) & 7 & $\pm \quad 24$ & ( & 11 & ) \\
\hline $\mathrm{ST}$ & $\left(\mathrm{mg} \cdot \mathrm{L}^{-1}\right)$ & 5124 & \pm & 299 & ( & 5 & ) & 3212 & \pm 627 & ( & 5 & ) \\
\hline SVT & $\left(\mathrm{mg} \cdot \mathrm{L}^{-1}\right)$ & 3990 & \pm & 242 & ( & 5 & ) & 2164 & \pm 612 & ( & 5 & ) \\
\hline SST & $\left(\mathrm{mg} \cdot \mathrm{L}^{-1}\right)$ & 88 & \pm & 43 & ( & 5 & ) & 94 & $\pm \quad 70$ & ( & 5 & 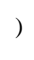 \\
\hline SSV & $\left(\mathrm{mg} \cdot \mathrm{L}^{-1}\right)$ & 78 & \pm & 61 & ( & 5 & ) & 92 & $\pm \quad 78$ & ( & 5 & ) \\
\hline $\mathrm{M}_{\mathrm{SVT}}$ & (g) & & & & & & & & 65,5 & & & \\
\hline $\mathrm{Cx}$ & $\left(\right.$ g. $\left.\mathrm{L}^{-1}\right)$ & & & & & & & & 18,7 & & & \\
\hline $\mathrm{Cx}^{\prime}$ & $\left(\right.$ g.gsuporte $\left.{ }^{-1}\right)$ & & & & & & & & 0,04 & & & \\
\hline $\mathrm{V}_{\mathrm{G}}$ & $\left(\mathrm{mL}\right.$. ciclo $\left.^{-1}\right)$ & & 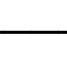 & & & & & 656 & \pm 42 & ( & 11 & \\
\hline $\mathrm{V}_{\mathrm{H} 2}$ & $\left(\mathrm{~mL} . \mathrm{ciclo}^{-1}\right)$ & & 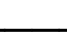 & & & & & 381 & \pm 310 & ( & 11 & ) \\
\hline $\mathrm{COAV}_{\text {мот }}$ & $\left(\mathrm{gDQO} \cdot \mathrm{L}^{-1} \cdot \mathrm{d}^{-1}\right)$ & & 4,0 & & & & & & - & & & \\
\hline $\mathrm{CORV}_{\mathrm{MOF}}$ & $\left(\mathrm{gDQO} \cdot \mathrm{L}^{-1} \cdot \mathrm{d}^{-1}\right)$ & & & & & & & & 5,5 & & & \\
\hline $\mathrm{COAV}_{\mathrm{CT}}$ & (gCarboidratos. $\mathrm{L}^{-1} \cdot \mathrm{d}^{-1}$ ) & & 5,1 & & & & & & & & & \\
\hline $\mathrm{CORV}_{\mathrm{CF}}$ & (gCarboidratos. $\mathrm{L}^{-1} \cdot \mathrm{d}^{-1}$ ) & & & & & & & & 14,6 & & & \\
\hline $\mathrm{COAV}_{\mathrm{GT}}$ & (gGlicerina. $\mathrm{L}^{-1} \cdot \mathrm{d}^{-1}$ ) & & 4,4 & & & & & & & & & \\
\hline $\mathrm{CORV}_{\mathrm{GF}}$ & (gGlicerina. $\mathrm{L}^{-1} \cdot \mathrm{d}^{-1}$ ) & & & & & & & & 4,2 & & & \\
\hline $\mathrm{COAE}_{\text {MOT }}$ & $\left(\mathrm{gDQO}_{\mathrm{gSVT}} \mathrm{gS}^{-1} \mathrm{~d}^{-1}\right)$ & & 1,3 & & & & & & & & & \\
\hline $\mathrm{CORE}_{\mathrm{MOF}}$ & $\left(\mathrm{gDQO} \cdot \mathrm{gSVT}^{-1} \cdot \mathrm{d}^{-1}\right)$ & & & & & & & & 0,3 & & & \\
\hline $\mathrm{COAE}_{\mathrm{CT}}$ & (gCarboidratos.gSVT ${ }^{-1} \cdot \mathrm{d}^{-1}$ ) & & 0,8 & & & & & & & & & \\
\hline $\mathrm{CORE}_{\mathrm{CF}}$ & (gCarboidratos.gSVT ${ }^{-1} \cdot \mathrm{d}^{-1}$ ) & & & & & & & & 0,8 & & & \\
\hline $\mathrm{COAE}_{\mathrm{GT}}$ & (gGlicerina.gSVT ${ }^{-1} \cdot \mathrm{d}^{-1}$ ) & & 0,2 & & & & & & & & & \\
\hline $\mathrm{CORE}_{\mathrm{GF}}$ & (gGlicerina.gSVT ${ }^{-1} \cdot \mathrm{d}^{-1}$ ) & & & & & & & & 0,2 & & & \\
\hline $\mathrm{n}_{\mathrm{H} 2}$ & $\left(\mathrm{molH}_{2} \cdot \mathrm{d}^{-1}\right)$ & & & & & & & & 0,1 & & & \\
\hline PrM & $\left(\mathrm{molH}_{2} \cdot \mathrm{m}^{-3} \cdot \mathrm{d}^{-1}\right)$ & & & & & & & & 38,9 & & & \\
\hline PrME & $\left(\mathrm{molH}_{2} \cdot \mathrm{kgSVT}^{-1} \cdot \mathrm{d}^{-1}\right)$ & & 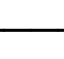 & & & & & & 2,1 & & & \\
\hline RMCA & $\left(\mathrm{molH}_{2} \cdot \mathrm{kgDQO}^{-1}\right)$ & & 1,6 & & & & & & & & & \\
\hline RMSA & $\left(\mathrm{molH}_{2} \cdot \mathrm{molSubstrato}^{-1}\right)$ & & 0,5 & & & & & & & & & \\
\hline RMSR & $\left(\mathrm{molH}_{2} \cdot \mathrm{molSubstrato}^{-1}\right)$ & & & & & & & & 0,5 & & & \\
\hline $\mathrm{V}_{\mathrm{A}}$ & $(\mathrm{L})$ & 1,50 & \pm & 0,09 & ( & 11 & ) & & & & & \\
\hline
\end{tabular}

(*) Entre parênteses o número de amostras considerado no cálculo da média 

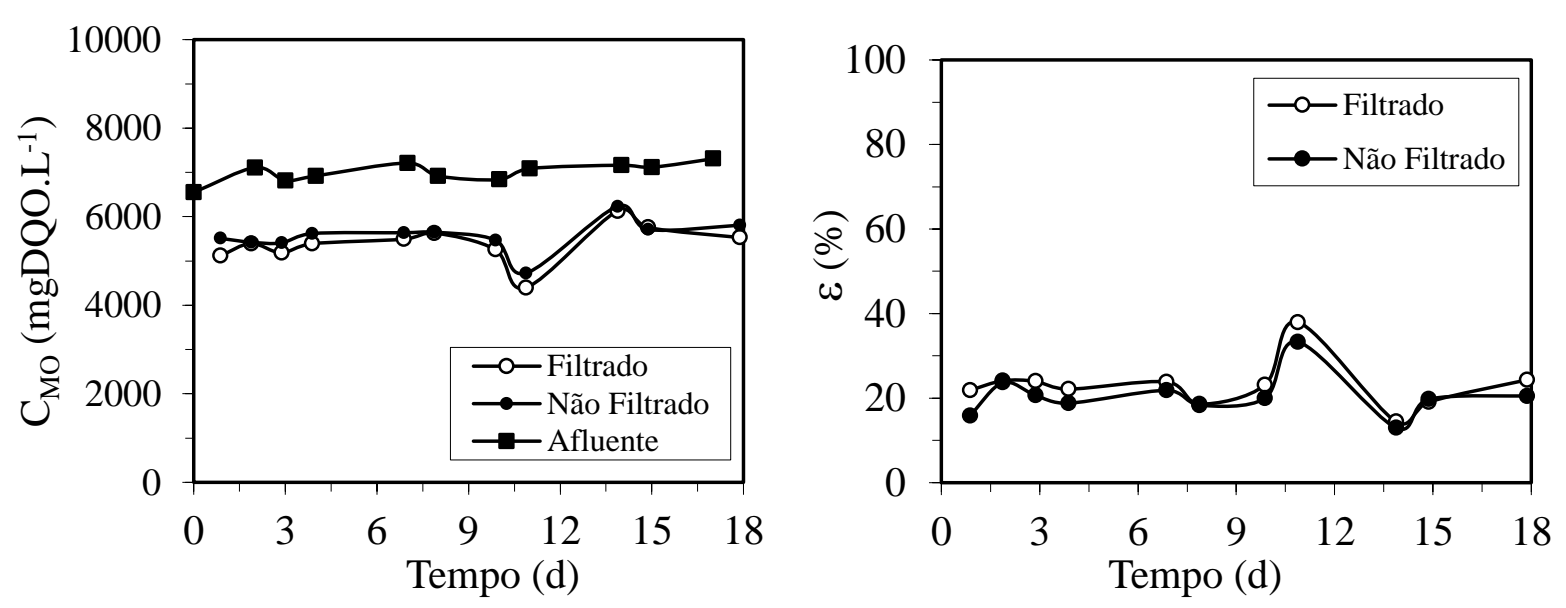

Figura 5.165. Concentração $\left(C_{S}\right)$ e eficiência de remoção na forma de DQO $\left(\varepsilon_{S}\right)$ no Ensaio 18: - - afluente amostras não filtradas; • - efluente amostras não filtradas; $\bigcirc$ - efluente amostras filtradas.

Em relação ao monitoramento diário de carboidratos, o sistema apresentou um ótimo consumo, de acordo com a Figura 5.166, com média de concentração afluente não filtrada

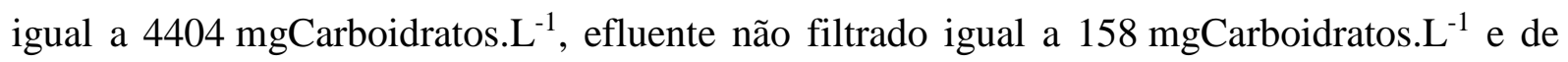
efluente filtrado igual a $139 \mathrm{mgCarboidratos.} \mathrm{L}^{-1}$, o que representou uma eficiência média de remoção de $96 \%$ para amostras não filtradas e de $97 \%$ para amostras filtradas.
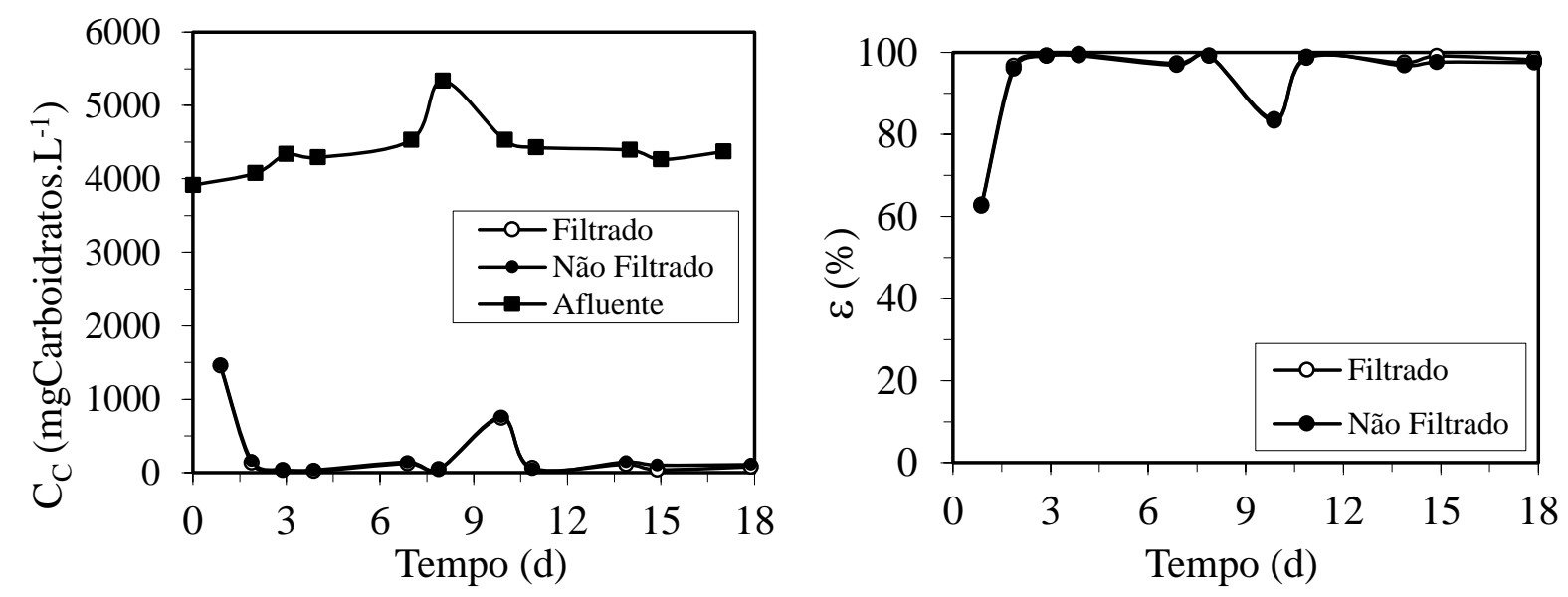

Figura 5.166. Concentração $\left(\mathrm{C}_{\mathrm{C}}\right)$ e eficiência de remoção na forma de carboidratos $\left(\varepsilon_{\mathrm{C}}\right)$ no Ensaio 18 : - - afluente amostras não filtradas; • - efluente amostras não filtradas; $\bigcirc$ - efluente amostras filtradas.

No monitoramento diário de glicerina, a concentração afluente não filtrada média foi igual a $1288 \mathrm{mgGlicerina.} \mathrm{L}^{-1}$, efluente não filtrado igual a $53 \mathrm{mgGlicerina} . \mathrm{L}^{-1}$ e de efluente filtrado igual a $52 \mathrm{mgGlicerina} . \mathrm{L}^{-1}$, o que representa uma eficiência média de remoção para amostras não filtradas e filtradas de 96\%, de acordo com a Figura 5.167. 

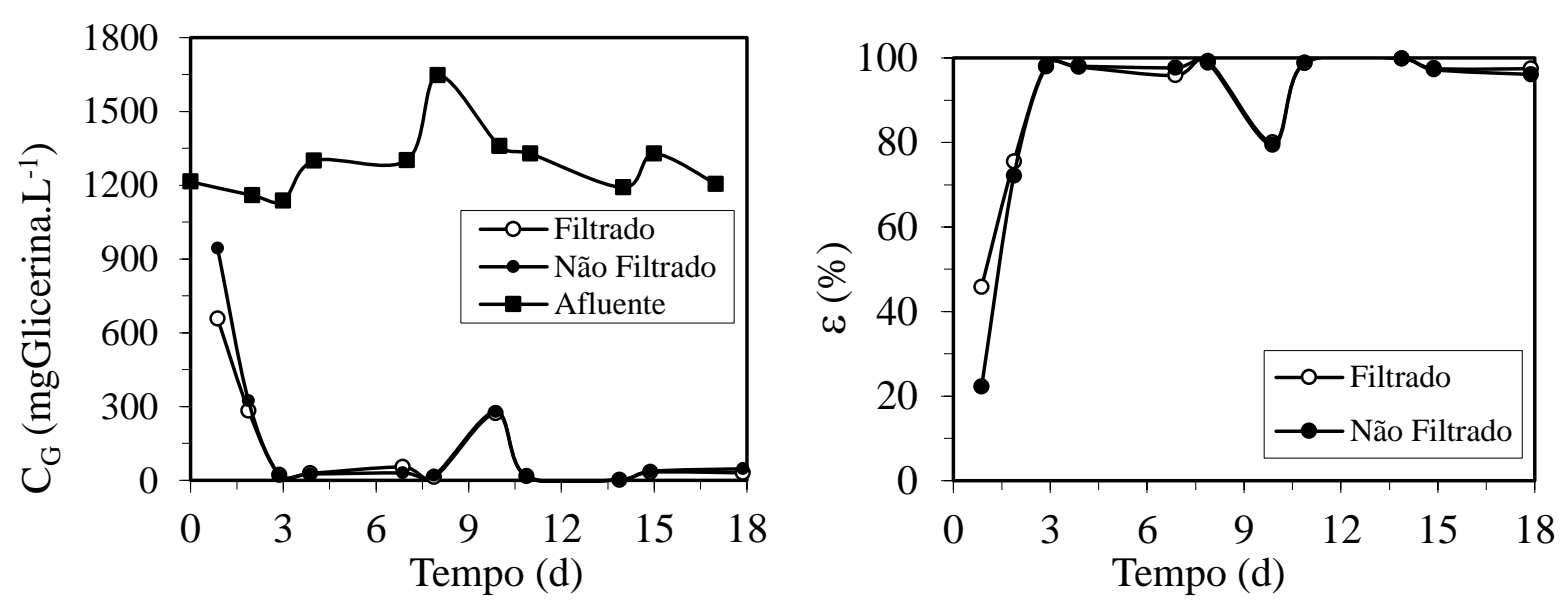

Figura 5.167. Concentração $\left(\mathrm{C}_{\mathrm{G}}\right)$ e eficiência de remoção na forma de glicerina $\left(\varepsilon_{\mathrm{G}}\right)$ no Ensaio 18: - - afluente amostras não filtradas; • - efluente amostras não filtradas; ○ - efluente amostras filtradas.

A média de $\mathrm{pH}$ do afluente foi igual a 7,7, enquanto que a do efluente foi igual a 4,7. A alcalinidade total no afluente teve média de $688 \mathrm{mgCaCO}_{3} \cdot \mathrm{L}^{-1}$, sendo consumida até uma média de $334 \mathrm{mgCaCO}_{3} \cdot \mathrm{L}^{-1}$, ao passo que as médias de AVT no afluente e no efluente foram iguais a 149 e $2535 \mathrm{mgHAc} . \mathrm{L}^{-1}$, respectivamente.

A produção de biogás, em aspecto quantitativo, e a distribuição dos gases que compõem o biogás no final do ciclo podem ser observadas pela Figura 5.168, com média de $656 \mathrm{~mL}$ de biogás e $381 \mathrm{~mL}$ de hidrogênio, sendo que a porcentagem média de hidrogênio e sua produtividade molar foram iguais a $52 \%$ e a $38,9 \mathrm{molH}_{2} \cdot \mathrm{m}^{-3} \cdot \mathrm{d}^{-1}$, respectivamente.
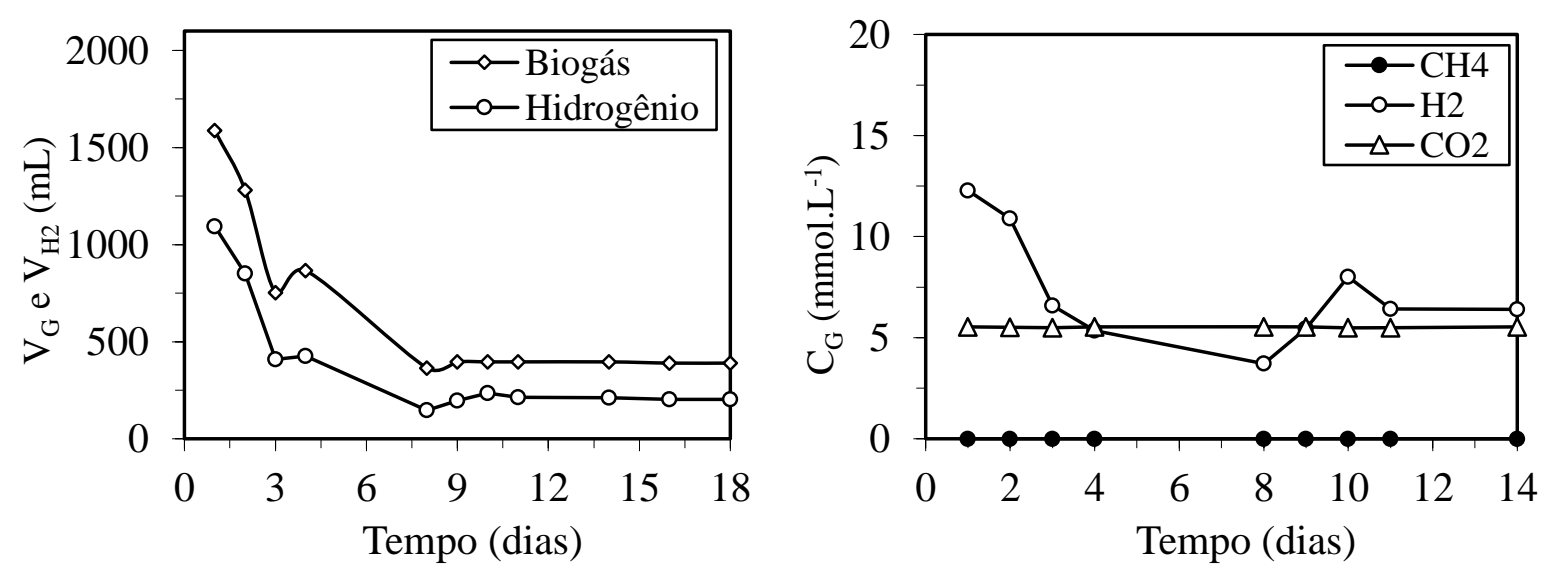

Figura 5.168. Volume de biogás $\left(\mathrm{V}_{\mathrm{G}}\right)$ e de hidrogênio $\left(\mathrm{V}_{\mathrm{H} 2}\right)$ nas CNTP e concentrações dos componentes do biogás no final do ciclo $\left(\mathrm{C}_{\mathrm{G}}\right)$ no Ensaio 18: $\diamond$-Biogás; $\bullet$ - Metano; ○ - Hidrogênio; $\Delta$ - Dióxido de Carbono.

A Figura 5.169 apresenta os perfis de DQO, carboidratos e glicerina. Novamente, notou-se uma pequena variação na medida de DQO durante o ciclo. No perfil de carboidratos 
e de glicerina, observa-se um ponto de máxima concentração no tempo de $1,5 \mathrm{~h}$ (que representa o final da alimentação do afluente) e o consumo dos substratos até o final do ciclo.
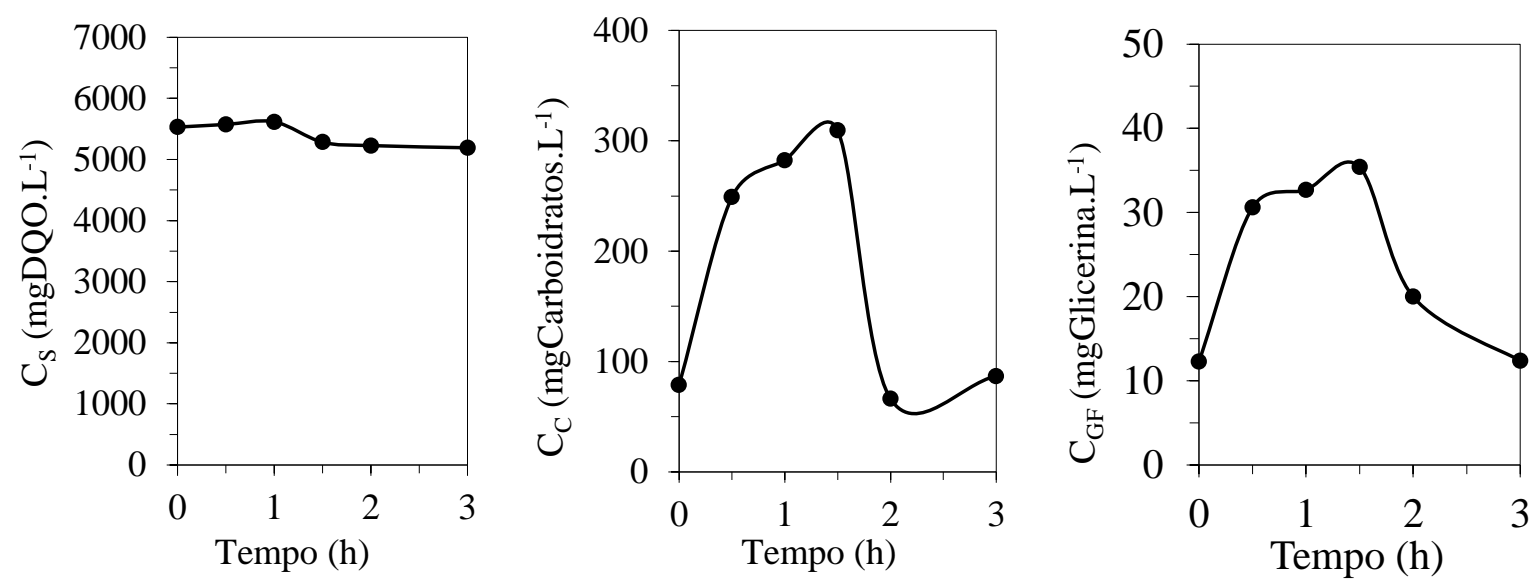

Figura 5.169. Concentrações de matéria orgânica na forma de DQO $\left(\mathrm{C}_{\mathrm{S}}\right)$, carboidratos $\left(\mathrm{C}_{\mathrm{C}}\right)$ e de glicerina $\left(\mathrm{C}_{\mathrm{G}}\right)$ durante o ciclo no Ensaio 18 .

A Figura 5.170 apresenta os perfis de $\mathrm{pH}$, alcalinidade total e ácidos voláteis totais ao longo do ciclo. $\mathrm{O}$ pH permanece praticamente constante ao longo do ciclo (por volta de 4,47), com os ácidos voláteis variando de 1415 a 2088 mgHAc. $\mathrm{L}^{-1}$, atingindo um valor máximo de 3093 mgHAc. $\mathrm{L}^{-1} \mathrm{~A}$ alcalinidade fornecida pelo afluente foi consumida e, depois, gerada na parte final do ciclo, com um valor final de $574 \mathrm{mgCaCO}_{3} \cdot \mathrm{L}^{-1}$.
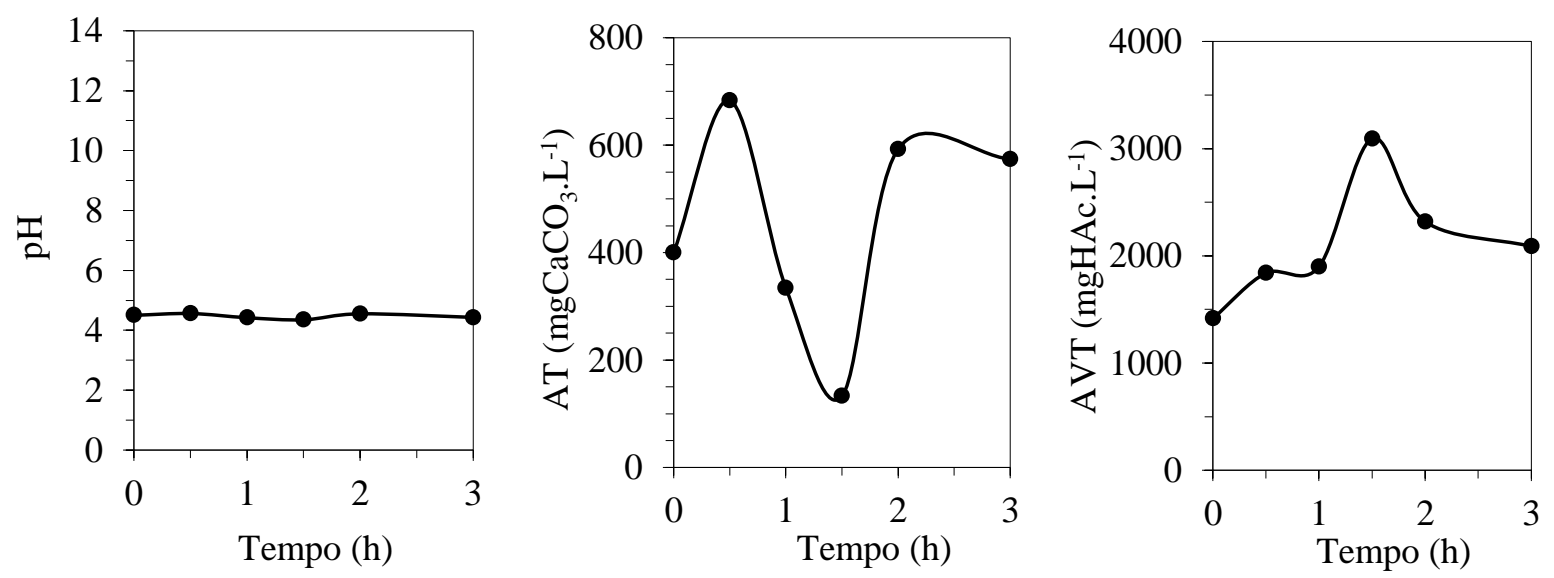

Figura 5.170. Valores de pH, alcalinidade total (AT) e de ácidos voláteis totais (AVT) no Ensaio 18.

O perfil dos compostos intermediários do metabolismo é apresentado na Figura 5.171, sendo possível verificar a predominância de ácido acético e de etanol. 


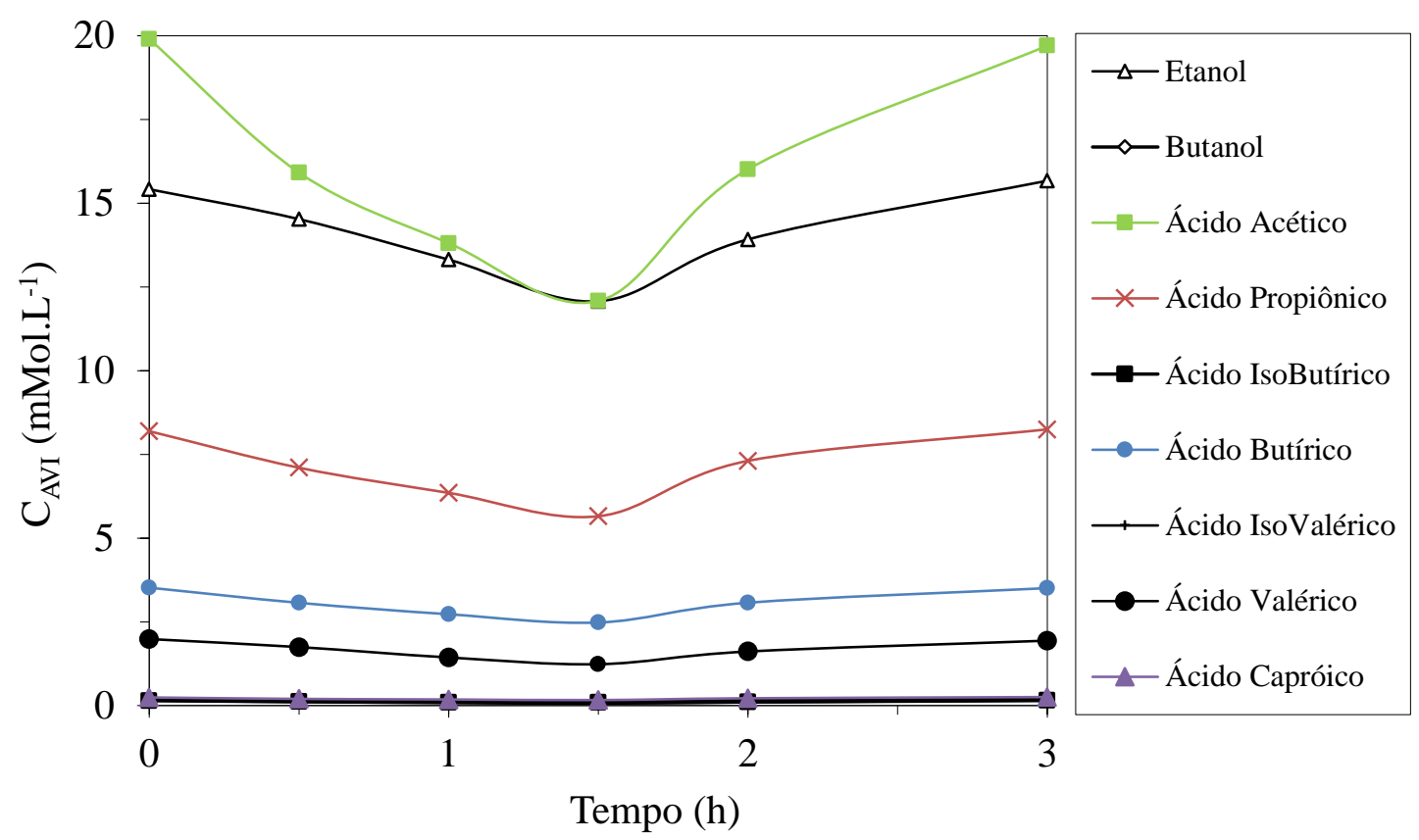

Figura 5.171. Concentração dos compostos intermediários ao longo do ciclo no Ensaio 18: $\Delta$ - etanol; $\diamond$ butanol; $\square$ - ácido acético; -x-ácido propiônico; - ácido isobutírico; • - ácido butírico; + ácido isovalérico $\bullet$ - ácido valérico; $\Delta$-ácido capróico.

A produção volumétrica acumulada de biogás e os desvios padrões de cada um dos pontos podem ser observados na Figura 5.172, enquanto que o perfil das concentrações dos gases e suas respectivas porcentagens podem ser observados na Figura 5.173. No final do ciclo, a composição do biogás gerado era de $46 \%$ de $\mathrm{CO}_{2}$ e $54 \%$ de $\mathrm{H}_{2}$, com ausência de metano.

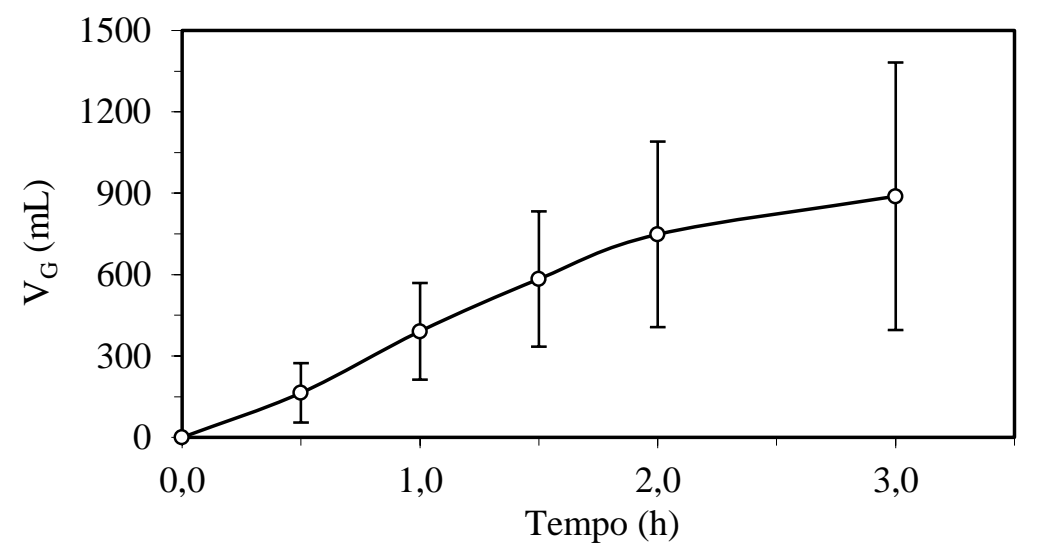

Figura 5.172. Produção volumétrica média acumulada do biogás $\left(\mathrm{V}_{\mathrm{G}}\right)$ durante o ciclo no Ensaio 18. 

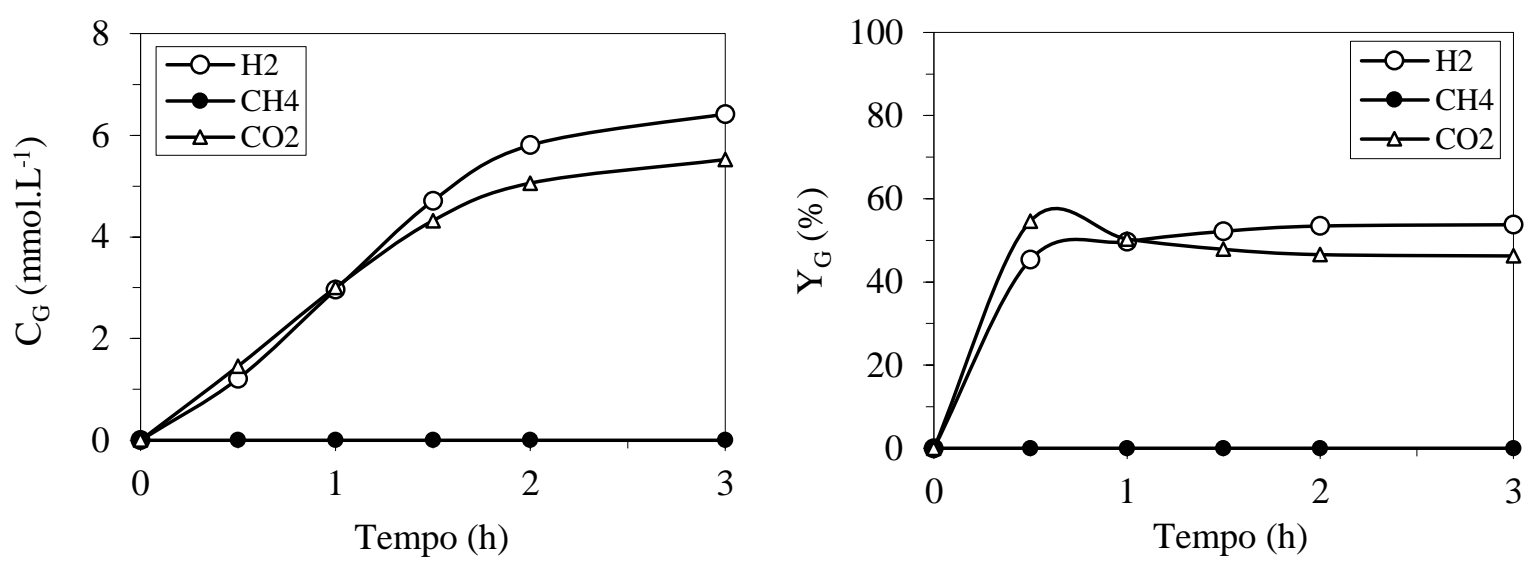

Figura 5.173. Concentração dos compostos do biogás durante o ciclo $\left(\mathrm{C}_{\mathrm{G}}\right)$ e suas respectivas porcentagens $\left(\mathrm{Y}_{\mathrm{G}}\right)$ no Ensaio 18: $\odot-\mathrm{H}_{2} ; \bullet-\mathrm{CH}_{4} ; \Delta-\mathrm{CO}_{2}$.

\subsubsection{Análise comparativa entre os Ensaios 16, 17 e 18 (Fase V)}

O objetivo desta seção é avaliar a influência da temperatura, dentro da faixa mesofílica, no processo de produção de biohidrogênio, tendo como comparação o Ensaio $12\left(30^{\circ}\right)$, conforme Tabela 5.34.

Tabela 5.34. Resumo das condições experimentais para comparação da Fase V.

\begin{tabular}{cccc}
\hline Ensaio & $\begin{array}{c}\text { COAV } \\
\left(\mathrm{kgDQO} . \mathrm{m}^{-3} \cdot \mathrm{d}^{-1}\right)\end{array}$ & Modo de Operação & $\begin{array}{c}\text { Temperatura } \\
\left({ }^{\circ} \mathrm{C}\right)\end{array}$ \\
\hline 16 & 24.0 & BA & 20 \\
17 & 24.0 & BA & 25 \\
12 & 24.0 & BA & 30 \\
18 & 24.0 & BA & 35 \\
\hline
\end{tabular}

Os parâmetros analisados foram a matéria orgânica, carboidratos, glicerina (englobando carga aplicada e removida), $\mathrm{pH}$, alcalinidade e ácidos (AVT e AVI), sólidos e, por último, parâmetros relativos a produção de biogás e biohidrogênio, de acordo com a Tabela 5.35.

A remoção de matéria orgânica, apesar de baixa, ocorreu de forma estável em todos os ensaios e com reduzida variação (19-23\%). Esse fenômeno era novamente esperado, já que a remoção de matéria orgânica, na forma de DQO, contabiliza tanto os substratos removidos quanto os ácidos orgânicos e solventes gerados durante a etapa de acidogênese. 
Tabela 5.35. Estabilidade e desempenho nas variáveis monitoradas na Fase V

\begin{tabular}{|c|c|c|c|c|c|}
\hline & Parâmetro & $\begin{array}{c}\text { Ensaio } 16 \\
\left(20^{\circ} \mathrm{C}\right)\end{array}$ & $\begin{array}{c}\text { Ensaio } 17 \\
\left(25^{\circ} \mathrm{C}\right)\end{array}$ & $\begin{array}{c}\text { Ensaio } 12 \\
\left(30^{\circ} \mathrm{C}\right)\end{array}$ & $\begin{array}{c}\text { Ensaio } 18 \\
\left(35^{\circ}\right)\end{array}$ \\
\hline$\varepsilon_{\mathrm{MOF}}$ & $(\%)$ & $19 \pm 6$ & $20 \pm 4$ & $19 \pm 6$ & $23 \pm 6$ \\
\hline$\varepsilon_{\mathrm{CF}}$ & $(\%)$ & $88 \pm 16$ & $97 \pm 6$ & $98 \pm 2$ & $97 \pm 5$ \\
\hline$\varepsilon_{\mathrm{GF}}$ & $(\%)$ & $76 \pm 30$ & $93 \pm 10$ & $97 \pm 4$ & $96 \pm 6$ \\
\hline $\mathrm{M}_{\mathrm{SVT}}$ & $(\mathrm{g})$ & 17,7 & 41,8 & 18,4 & 65,5 \\
\hline $\mathrm{COAV}_{\text {мот }}$ & $\left(\mathrm{gDQO} \cdot \mathrm{L}^{-1} \cdot \mathrm{d}^{-1}\right)$ & 24,4 & 24,0 & 23,9 & 24,0 \\
\hline $\mathrm{CORV}_{\mathrm{MOF}}$ & $\left(\mathrm{gDQO} \cdot \mathrm{L}^{-1} \cdot \mathrm{d}^{-1}\right)$ & 4,7 & 4,8 & 4,7 & 5,52 \\
\hline $\mathrm{COAV}_{\mathrm{CT}}$ & (gCarboidratos. $\mathrm{L}^{-1} \cdot \mathrm{d}^{-1}$ ) & 14,5 & 13,9 & 15,4 & 15,1 \\
\hline $\mathrm{CORV}_{\mathrm{CF}}$ & (gCarboidratos. $\left.\mathrm{L}^{-1} \cdot \mathrm{d}^{-1}\right)$ & 12,4 & 13,4 & 15,2 & 14,6 \\
\hline $\mathrm{COAV}_{\mathrm{GT}}$ & (gGlicerina. $\mathrm{L}^{-1} \cdot \mathrm{d}^{-1}$ ) & 3,2 & 3,0 & 5,1 & 4,4 \\
\hline \multirow[t]{2}{*}{ CORV $_{\mathrm{GF}}$} & (gGlicerina.L $\left.L^{-1} \cdot \mathrm{d}^{-1}\right)$ & 2,4 & 2,5 & 4,9 & 4,2 \\
\hline & $\mathrm{pH}(\mathrm{u})$ & $7,7 \pm 0,2$ & $7,7 \pm 0,2$ & $7,7 \pm 0,2$ & $7,7 \pm 0,2$ \\
\hline \multirow[t]{2}{*}{ Afluente } & AVT (mgHAc. $\left.\mathrm{L}^{-1}\right)$ & $159 \pm 61$ & $144 \pm 33$ & $137 \pm 16$ & $149 \pm 11$ \\
\hline & $\mathrm{AT}\left(\mathrm{mgCaCO}_{3} \cdot \mathrm{L}^{-1}\right)$ & $575 \pm 207$ & $480 \pm 164$ & $522 \pm 200$ & $688 \pm 208$ \\
\hline \multirow{3}{*}{ Efluente } & $\mathrm{pH}(\mathrm{u})$ & $4,5 \pm 0,1$ & $4,8 \pm 0,8$ & $4,3 \pm 0,4$ & $4,7 \pm 0,5$ \\
\hline & $\operatorname{AVT}\left(m g H A c . L^{-1}\right)$ & $2223 \pm 931$ & $2439 \pm 880$ & $1461 \pm 561$ & $2535 \pm 985$ \\
\hline & $\mathrm{AT}\left(\mathrm{mgCaCO}_{3} \cdot \mathrm{L}^{-1}\right)$ & $270 \pm 195$ & $221 \pm 253$ & $196 \pm 283$ & $334 \pm 260$ \\
\hline \multirow{6}{*}{$\mathrm{C}_{\mathrm{AVI}}$} & Etanol (\%) & 18,1 & 11,5 & 38,6 & 31,7 \\
\hline & Ácido Acético (\%) & 49,4 & 54,2 & 30,4 & 39,9 \\
\hline & Ácido Propiônico (\%) & 21,0 & 26,4 & 13,3 & 16,7 \\
\hline & Ácido Butírico (\%) & 7,6 & 5,1 & 10,8 & 7,4 \\
\hline & Ácido Valérico (\%) & 3,9 & 2,7 & 6,9 & 4,3 \\
\hline & Total (mmol.L-1 $)$ & 42,2 & 54,2 & 42,5 & 49,8 \\
\hline PrM & $\left(\mathrm{molH}_{2} \cdot \mathrm{m}^{-3} \cdot \mathrm{d}^{-1}\right)$ & 50,2 & 38,8 & 129,1 & 38,9 \\
\hline PrME & $\left(\mathrm{molH}_{2} \cdot \mathrm{kgSVT}^{-1} \cdot \mathrm{d}^{-1}\right)$ & 10,0 & 3,3 & 29,5 & 2,1 \\
\hline RMCA & $\left(\mathrm{molH}_{2} \cdot \mathrm{kgDQO}^{-1}\right)$ & 2,1 & 1,6 & 5,4 & 1,6 \\
\hline RMSA & $\left(\mathrm{molH}_{2} \cdot \mathrm{molSubstrato}^{-1}\right)$ & 0,6 & 0,5 & 1,4 & 0,5 \\
\hline RMSR & $\left(\mathrm{molH}_{2} \cdot \mathrm{molSubstrato}^{-1}\right)$ & 0,8 & 0,6 & 1,9 & 0,5 \\
\hline $\mathrm{n}_{\mathrm{H} 2}$ & $\left(\mathrm{mmolH}_{2} \cdot \mathrm{d}^{-1}\right)$ & 177,1 & 136,8 & 452,3 & 136,0 \\
\hline $\mathrm{V}_{\mathrm{G}}$ & $\left(\mathrm{mL} \cdot \mathrm{ciclo}^{-1}\right)$ & $991 \pm 198$ & $756 \pm 306$ & $2034 \pm 146$ & $656 \pm 425$ \\
\hline $\mathrm{V}_{\mathrm{H} 2}$ & $\left(\mathrm{~mL} \cdot \mathrm{ciclo}^{-1}\right)$ & $496 \pm 198$ & $383 \pm 194$ & $1267 \pm 77$ & $381 \pm 311$ \\
\hline \multirow{2}{*}{$\mathrm{Y}_{\mathrm{G}}$} & $\mathrm{H}_{2}(\%)$ & 39 & 47 & 61 & 54 \\
\hline & $\mathrm{CO}_{2}(\%)$ & 61 & 53 & 39 & 46 \\
\hline
\end{tabular}


Em termos de remoção de carboidratos, nota-se novamente uma ótima eficiência de remoção entre 88 e $98 \%$ para os ensaios. A eficiência de remoção de glicerina foi um pouco inferior a remoção de carboidratos: 76-97\%, o que também é esperado devido à sua biodegradabilidade. É possível observar que, em relação à remoção de matéria orgânica e substratos, o ensaio operado com menor temperatura $\left(20^{\circ} \mathrm{C}\right)$ foi o que atingiu as menores eficiências, o que pode ser atribuído a uma atividade metabólica menor devido à temperatura reduzida (Espinoza-Escalante et al., 2009).

Em relação ao pH, novamente, não são notáveis variações significativas na medida do mesmo em relação a temperatura, desconsiderando o período de instabilidade no Ensaio 12. A alcalinidade total e os ácidos voláteis do afluente ficaram em torno de $550 \mathrm{mgCaCO} 3 . \mathrm{L}^{-1} \mathrm{e}$ $150 \mathrm{mgHAc} . \mathrm{L}^{-1}$, respectivamente. A alcalinidade total e os ácidos voláteis do efluente, no entanto, foram variáveis conforme a temperatura, mas não apresentaram uma tendência definida. A ordem de grandeza dessas medidas para o efluente foi de $250 \mathrm{mgCaCO}_{3} \cdot \mathrm{L}^{-1}$ para a alcalinidade total e $2100 \mathrm{mgHAc} . \mathrm{L}^{-1}$ para os ácidos voláteis totais, o que significa que a alcalinidade foi consumida durante a geração dos ácidos.

Nota-se que os ensaios de temperatura mais baixa $\left(20\right.$ e $\left.25^{\circ} \mathrm{C}\right)$ tiveram predomínio de ácido acético (49,4 e 54,2 \%, respectivamente) e que os de temperatura mais elevada (30 e $35^{\circ} \mathrm{C}$ ) tiveram predomínio de ácido acético e etanol (Ensaio $30^{\circ} \mathrm{C}$ : 30,4 e 38,6 \%, Ensaio $35^{\circ} \mathrm{C}: 39,9$ e $31,7 \%$, respectivamente). As mudanças nos metabolitos solúveis com a variação da temperatura resultam da mudança da via metabólica induzida pelos diferentes microorganismos que eram dominantes a cada temperatura (Wang e Wan, 2008).

O desempenho do reator quanto à produção de biogás foi significativamente melhor no Ensaio a $30^{\circ} \mathrm{C}$, no qual foram produzidos $2034 \mathrm{~mL} \mathrm{Biogás.ciclo}{ }^{-1}$ e $1267 \mathrm{~mL} \mathrm{H}_{2}$.ciclo ${ }^{-1}$, com $61 \%$ de hidrogênio, atingindo $129,0 \mathrm{molH}_{2} \cdot \mathrm{m}^{-3} \cdot \mathrm{d}^{-1}$. Analisando a Figura 5.174 e a Tabela 5.36, percebe-se que a temperatura de $35^{\circ} \mathrm{C}$ tinha potencial para uma alta produção de hidrogênio, mas a quantidade exacerbada de biomassa que foi produzida no reator durante essa condição causou uma rápida queda na produção de hidrogênio, com consequente impossibilidade de retorno às condições iniciais (mesmo realizado a lavagem periódica no reator normalmente). No entanto, a série de sólidos indica que não houve desprendimento da biomassa imobilizada do suporte inerte em nenhum dos ensaios e as lavagens periódicas removeram por volta de $70 \%$ da biomassa por lavagem.

Analisando os rendimentos em relação a carga aplicada em termos de DQO e substrato, e a carga removida em termos de substrato, verifica-se que o melhores resultados foram 
novamente obtidos a $30^{\circ} \mathrm{C}: \quad 5,4 \mathrm{molH}_{2} \cdot \mathrm{kgDQO}^{-1}, \quad 1,4$ molH $_{2} \cdot \mathrm{molSubstrato}^{-1}$ e 1,9 $\mathrm{molH}_{2} \cdot \mathrm{molSubstrato}^{-1}$, respectivamente.

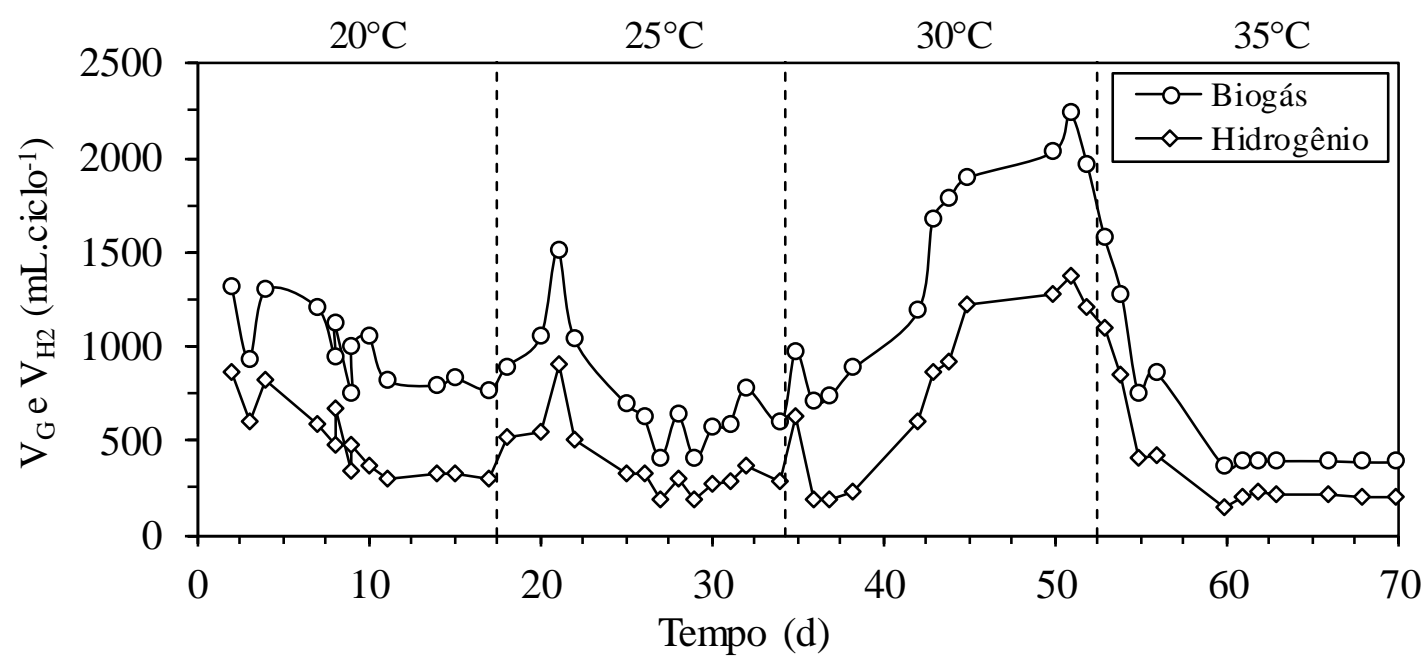

Figura 5.174. Produção volumétrica por ciclo de biogás $(\circ)$ e hidrogênio $(\diamond)$ nos Ensaios da Fase V.

Tabela 5.36. Comparação entre os valores médios da série de sólidos entre os Ensaios 16, 17, 12 e 18.

\begin{tabular}{|c|c|c|c|c|c|c|c|c|c|}
\hline \multirow{2}{*}{\multicolumn{2}{|c|}{ Parâmetro }} & \multicolumn{2}{|c|}{$20^{\circ} \mathrm{C}$} & \multicolumn{2}{|c|}{$25^{\circ} \mathrm{C}$} & \multicolumn{2}{|c|}{$30^{\circ} \mathrm{C}$} & \multicolumn{2}{|c|}{$35^{\circ} \mathrm{C}$} \\
\hline & & Afluente & Efluente & Afluente & Efluente & Afluente & Efluente & Afluente & Efluente \\
\hline $\mathrm{M}_{\text {SVT }}$ & (g) & \multicolumn{2}{|c|}{17,7} & \multicolumn{2}{|c|}{67} & \multicolumn{2}{|c|}{18,4} & \multicolumn{2}{|c|}{65,5} \\
\hline ST & $\left(\mathrm{mg} . \mathrm{L}^{-1}\right)$ & 5283 & 3175 & 5157 & 2747 & 5086 & 3879 & 5124 & 3212 \\
\hline SVT & $\left(\mathrm{mg} \cdot \mathrm{L}^{-1}\right)$ & 4251 & 2156 & 4307 & 1936 & 3977 & 2854 & 3990 & 2164 \\
\hline SST & $\left(\mathrm{mg} . \mathrm{L}^{-1}\right)$ & 83 & 128 & 70 & 96 & 62 & 91 & 88 & 94 \\
\hline SSV & $\left(\mathrm{mg} . \mathrm{L}^{-1}\right)$ & 51 & 91 & 96 & 110 & 44 & 82 & 78 & 92 \\
\hline
\end{tabular}

Lin (2004) também descobriu que a produção de hidrogênio aumenta a uma faixa temperatura entre $30-34^{\circ} \mathrm{C}$ em comparação com temperaturas variando entre $28-32^{\circ} \mathrm{C}$. Em um reator anaeróbio contínuo alimentado com glicose (um substrato simples, de fácil assimilação por microrganismos), houve um aumento de 290 para $359 \mathrm{molH}_{2} \cdot \mathrm{m}^{-3} \cdot \mathrm{d}^{-1}$ quando a faixa de temperatura foi aumentada. Wang e Wan (2008), por outro lado, realizaram testes em batelada para a produção anaeróbia de biohidrogênio partir de glicose e descobriram que o aumento da temperatura do processo é benéfico para a produtividade do mesmo, atingindo um ponto ótimo a $40^{\circ} \mathrm{C}$. No entanto, seu estudo também mostrou que a produção de biomassa aumentou com a temperatura, mas isso não causou instabilidade no processo (provavelmente porque seus estudos em batelada tinham um volume de apenas de $150 \mathrm{~mL}$ ); o que foi a principal causa da falha do processo a $35^{\circ} \mathrm{C}$ deste estudo. 
5.5.5 Modelagem cinética dos Ensaios 16, 17 e 18

A Figura 5.175 mostra os valores obtidos experimentalmente (marcadores) e os valores obtidos pelo modelo cinético ajustado (linhas), ambos ao longo do ciclo, para as principais variáveis monitoradas e que estão relacionadas com o entendimento do metabolismo acidogênico para os Ensaios 16, 17 e 18. A Tabela 5.37 mostra os parâmetros cinéticos ajustados para todos os Ensaios na Fase V.
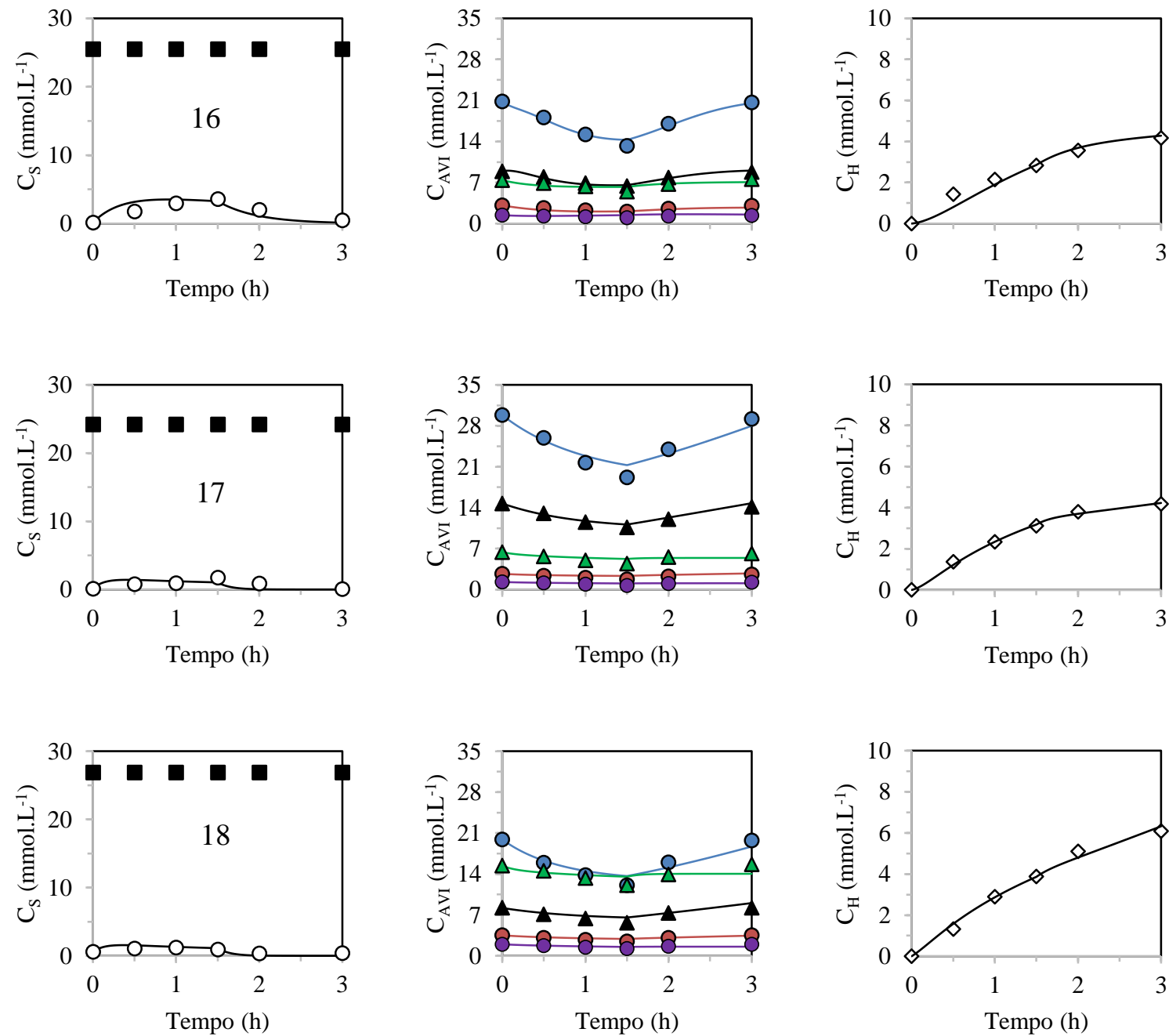

Figura 5.175. Perfis de substrato $(\boldsymbol{\bullet})$, efluente filtrado (०), ácido acético $(\bullet)$, ácido propiônico $(\boldsymbol{\Delta})$, ácido butírico $(\bullet)$, etanol $(\boldsymbol{\Delta})$, ácido valérico $(\bullet)$ e hidrogênio $(\diamond)$ (valores experimentais e calculados pelo modelo).

Analisando essas figuras é possível notar, novamente, que o modelo foi eficiente em predizer os dados experimentais em relação à concentração de substrato, etanol, ácidos acético, propiônico, butírico, valérico e hidrogênio, validando a interpretação do 
comportamento dos parâmetros cinéticos nas diferentes condições experimentais implementadas.

Tabela 5.37. Parâmetros do modelo cinético para a Fase V.

\begin{tabular}{|c|c|c|c|c|c|}
\hline \multirow{2}{*}{ Fase } & \multirow{2}{*}{ Parâmetro } & \multicolumn{4}{|c|}{ Ensaio } \\
\hline & & $20^{\circ} \mathrm{C}$ & $25^{\circ} \mathrm{C}$ & $30^{\circ} \mathrm{C}$ & $35^{\circ} \mathrm{C}$ \\
\hline \multirow{7}{*}{$\begin{array}{c}\text { Hidrólise e } \\
\text { Acidogênese } \\
\text { (positivo para } \\
\text { produção } \mathrm{H}_{2} \text { ) }\end{array}$} & $\mathrm{k}^{\prime}{ }_{1 \mathrm{~S}}\left(\mathrm{~h}^{-1}\right)$ & 2,1 & 6,1 & 3,4 & 6,8 \\
\hline & $\mathrm{k}_{1 \mathrm{HAc}}\left(\mathrm{h}^{-1}\right)$ & 0,0 & 0,0 & 0,0 & 0,0 \\
\hline & $\mathrm{k}_{1 \mathrm{H}}\left(\mathrm{h}^{-1}\right)$ & 0,2 & 0,6 & 1,4 & 0,4 \\
\hline & $\mathrm{k}_{3 \mathrm{HBu}}\left(\mathrm{h}^{-1}\right)$ & 0,0 & 0,3 & 0,0 & 0,3 \\
\hline & $\mathrm{k}_{3 \mathrm{H}}\left(\mathrm{h}^{-1}\right)$ & 0,2 & 0,6 & 1,4 & 0,5 \\
\hline & $\mathrm{k}_{4 \mathrm{HVa}}\left(\mathrm{h}^{-1}\right)$ & 0,2 & 0,2 & 0,1 & 0,2 \\
\hline & $\mathrm{k}_{4 \mathrm{H}}\left(\mathrm{h}^{-1}\right)$ & 0,3 & 0,6 & 1,4 & 0,6 \\
\hline \multirow{3}{*}{$\begin{array}{l}\text { Hidrólise e } \\
\text { Acidogênese } \\
\text { (negativo para } \\
\text { produção } \mathrm{H}_{2} \text { ) }\end{array}$} & $\mathrm{k}_{2 \mathrm{HPr}}\left(\mathrm{h}^{-1}\right)$ & 0,0 & 0,0 & 0,9 & 0,0 \\
\hline & $\mathrm{k}_{2 \mathrm{H}}\left(\mathrm{h}^{-1}\right)$ & 0,0 & 0,0 & 0,1 & 0,2 \\
\hline & $\mathrm{k}_{5 \mathrm{EtOH}}\left(\mathrm{h}^{-1}\right)$ & 0,6 & 1,1 & 1,8 & 3 \\
\hline \multirow{9}{*}{ Acetogênese } & $\mathrm{k}_{6 \mathrm{HPr}}\left(\mathrm{h}^{-1}\right)$ & 4,9 & 0,2 & 6,0 & 0,0 \\
\hline & $\mathrm{k}_{6 \mathrm{HAc}}\left(\mathrm{h}^{-1}\right)$ & 9,7 & 1,7 & 19,7 & 3,2 \\
\hline & $\mathrm{k}_{6 \mathrm{H}}\left(\mathrm{h}^{-1}\right)$ & 0,0 & 0,0 & 0,0 & 0,0 \\
\hline & $\mathrm{k}_{7 \mathrm{HPr}}\left(\mathrm{h}^{-1}\right)$ & 16,4 & 1,8 & 7,5 & 0,5 \\
\hline & $\mathrm{k}_{7 \mathrm{HBu}}\left(\mathrm{h}^{-1}\right)$ & 1,6 & 0,1 & 0,5 & 0,1 \\
\hline & $\mathrm{k}_{7 \mathrm{H}}\left(\mathrm{h}^{-1}\right)$ & 0,1 & 0,1 & 0,0 & 0,2 \\
\hline & $\mathrm{k}_{8 \mathrm{HBu}}\left(\mathrm{h}^{-1}\right)$ & 2,8 & 0,4 & 1,2 & 0,5 \\
\hline & $\mathrm{k}_{8 \mathrm{HVa}}\left(\mathrm{h}^{-1}\right)$ & 2,8 & 0,4 & 0,0 & 0,5 \\
\hline & $\mathrm{k}_{8 \mathrm{H}}\left(\mathrm{h}^{-1}\right)$ & 0,0 & 0,2 & 0,0 & 0,6 \\
\hline \multirow{4}{*}{ Metanogênese } & $\mathrm{k}_{9 \mathrm{HAc}}\left(\mathrm{h}^{-1}\right)$ & 0,0 & 0,0 & 0,0 & 0,0 \\
\hline & $\mathrm{k}_{9 \mathrm{M}}\left(\mathrm{h}^{-1}\right)$ & 0,0 & 0,0 & 0,0 & 0,0 \\
\hline & $\mathrm{k}_{10 \mathrm{H}}\left(\mathrm{h}^{-1}\right)$ & 0,0 & 0,0 & 0,0 & 0,0 \\
\hline & $\mathrm{k}_{10 \mathrm{M}}\left(\mathrm{h}^{-1}\right)$ & 0,0 & 0,0 & 0,0 & 0,0 \\
\hline $\begin{array}{l}\text { Crescimento da } \\
\text { biomassa }\end{array}$ & $\mathrm{k}_{11 \mathrm{HAc}}\left(\mathrm{h}^{-1}\right)$ & 4,2 & 0,7 & 8,5 & 1,3 \\
\hline
\end{tabular}


Analisando a influência da temperatura nas rotas metabólicas, nota-se que a produção de hidrogênio acontece de forma semelhante pela conversão de substrato em ácido acético, butírico e valérico $\left(20^{\circ} \mathrm{C}: \mathrm{k}_{1 \mathrm{H}}=0,2 \mathrm{~h}^{-1}, \mathrm{k}_{3 \mathrm{H}}=0,2 \mathrm{~h}^{-1}, \mathrm{k}_{4 \mathrm{H}}=0,3 \mathrm{~h}^{-1} ; 25^{\circ} \mathrm{C}: \mathrm{k}_{1 \mathrm{H}}=0,6 \mathrm{~h}^{-1}, \mathrm{k}_{3 \mathrm{H}}=\right.$ $0,6 \mathrm{~h}^{-1}, \mathrm{k}_{4 \mathrm{H}}=0,6 \mathrm{~h}^{-1} ; 30^{\circ} \mathrm{C}: \mathrm{k}_{1 \mathrm{H}}=1,4 \mathrm{~h}^{-1}, \mathrm{k}_{3 \mathrm{H}}=1,4 \mathrm{~h}^{-1}, \mathrm{k}_{4 \mathrm{H}}=1,4 \mathrm{~h}^{-1} ; 35^{\circ} \mathrm{C}: \mathrm{k}_{1 \mathrm{H}}=0,4 \mathrm{~h}^{-1}, \mathrm{k}_{3 \mathrm{H}}=$ $\left.0,5 \mathrm{~h}^{-1}, \mathrm{k}_{4 \mathrm{H}}=0,6 \mathrm{~h}^{-1}\right)$, o que é uma tendência encontrada no ensaio realizado em batelada alimentada neste trabalho. Porém, o Ensaio 12 , a $30^{\circ} \mathrm{C}$, apresentou os maiores valores dos parâmetros cinéticos.

Analisando as reações prejudiciais para a produção de hidrogênio, pode-se inferir que o aumento de temperatura aumenta o consumo de hidrogênio na rota do ácido propiónico $\left(20^{\circ} \mathrm{C}\right.$ to $35^{\circ} \mathrm{C}: \mathrm{k}_{2 \mathrm{H}}=0,0 \mathrm{~h}^{-1}, \mathrm{k}_{2 \mathrm{H}}=0,0 \mathrm{~h}^{-1}, \mathrm{k}_{2 \mathrm{H}}=0,1 \mathrm{~h}^{-1}, \mathrm{k}_{2 \mathrm{H}}=0,2 \mathrm{~h}^{-1}$ ) e na produção de etanol $\left(\mathrm{k}_{5 \mathrm{ETOH}}=0,6 \mathrm{~h}^{-1}, \mathrm{k}_{5 \mathrm{ETOH}}=1,1 \mathrm{~h}^{-1}, \mathrm{k}_{5 \mathrm{ETOH}}=1,8 \mathrm{~h}^{-1}, \mathrm{k}_{5 \mathrm{ETOH}}=3,0 \mathrm{~h}^{-1}\right)$, embora o aumento da temperatura também tenha aumentado a produção de hidrogênio a partir da acidogênese.

A acetogênese, novamente, teve um papel muito menor na produção de hidrogênio quando comparada com a acidogênese, como é possível ver pelos parâmetros $\mathrm{k}_{6 \mathrm{H}}, \mathrm{k}_{7 \mathrm{H}}, \mathrm{k}_{8 \mathrm{H}} \mathrm{de}$ todos os ensaios.

Com relação à metanogênese, a mesma foi completamente inibida, desta forma são justificados os valores de $\mathrm{k}_{9 \mathrm{HAc}}, \mathrm{k}_{9 \mathrm{M}}, \mathrm{k}_{10 \mathrm{H}}, \mathrm{k}_{10 \mathrm{M}}$ iguais a $0,0 \mathrm{~h}^{-1}$ em todos os Ensaios. Finalmente, quanto ao consumo de ácido acético (para o crescimento de microorganismos como Megasphaera), é possível observar que o mesmo teve maior importância no Ensaio 12 $\left(\mathrm{k}_{11 \mathrm{HAc}}=8,5 \mathrm{~h}^{-1}\right)$.

\subsubsection{Modelo de Arrhenius e estimativa da energia de ativação}

Uma vez que o ensaio realizado a $35^{\circ} \mathrm{C}$ foi muito influenciada pelo crescimento da biomassa, suas constantes cinéticas foram excluídas do ajuste. As constantes cinéticas que foram efetivamente utilizadas são apresentadas na Tabela 5.38. A Figura 5.176 mostra o ajuste à Equação Arrhenius linearizada.

A partir da Figura 5.176 e do ajuste linearizado, foi possível estimar as seguintes energias de ativação para as Equações 4.51 a 4.54: 135,1 kJ.mol ${ }^{-1}, 220,9$ kJ.mol${ }^{-1}, 146,3$ $\mathrm{kJ} . \mathrm{mol}^{-1}$ e $109,5 \mathrm{~kJ} \cdot \mathrm{mol}^{-1}$, respectivamente. 
Tabela 5.38. Constantes cinéticas usadas para o ajuste na Equação de Arrhenius.

\begin{tabular}{cccc}
\hline Constante Cinética & $20^{\circ} \mathrm{C}$ & $25^{\circ} \mathrm{C}$ & $30^{\circ} \mathrm{C}$ \\
\hline $\mathrm{k}_{1 \mathrm{H}}\left(\mathrm{h}^{-1}\right)$ & 0,2 & 0,6 & 1,4 \\
$\mathrm{k}_{2 \mathrm{H}}\left(\mathrm{h}^{-1}\right)$ & 0,0 & 0,0 & 0,1 \\
$\mathrm{k}_{3 \mathrm{H}}\left(\mathrm{h}^{-1}\right)$ & 0,2 & 0,6 & 1,4 \\
$\mathrm{k}_{4 \mathrm{H}}\left(\mathrm{h}^{-1}\right)$ & 0,3 & 0,6 & 1,4 \\
\hline
\end{tabular}

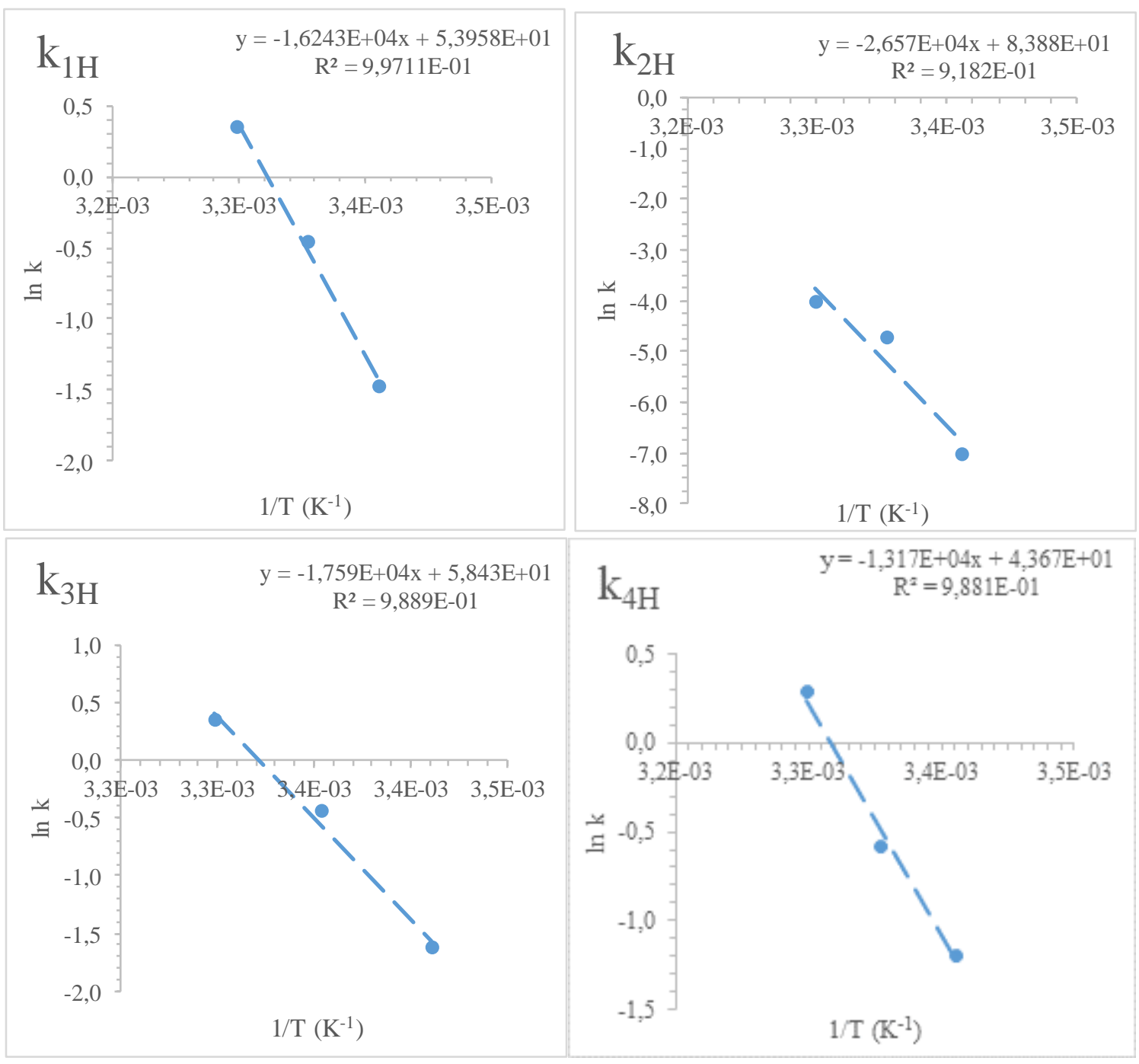

Figura 5.176. Ajuste das constantes cinéticas ao modelo linearizado da equação de Arrhenius. 


\subsection{CARACTERIZAÇÃO FILOGENÉTICA DO CONSÓRCIO MICROBIANO - PRODUÇÃO DE BIOHIDROGÊNIO}

Visando um melhor entendimento do processo de codigestão do soro com a glicerina para a produção de hidrogênio realizou-se a caraterização filogenética do consórcio bacteriano presente no AnSBBR quando se obteve o melhor desempenho em relação à produção de biogás (Ensaio 12). Para isso, ao final do período operacional (18 dias) amostra de biomassa foi coletada e, a partir dela, 87 clones (fragmentos de 16s RNAr) foram analisados. A população dominante no reator nesta condição foi de microrganismos filogeneticamente afiliados com o Filo Firmicutes $(96,5 \%)$ e, em reduzida porcentagem, com o Filo Bacteroidetes $(3,5 \%)$. A classificação dos clones dentro do filo dominante foi a seguinte: 52,4 \% gênero Ethanoligenens; 41,6 \% Megasphaera, 3,6 \% Pectinatus e 2,4 \% Lactococcus (Figura 5.177).

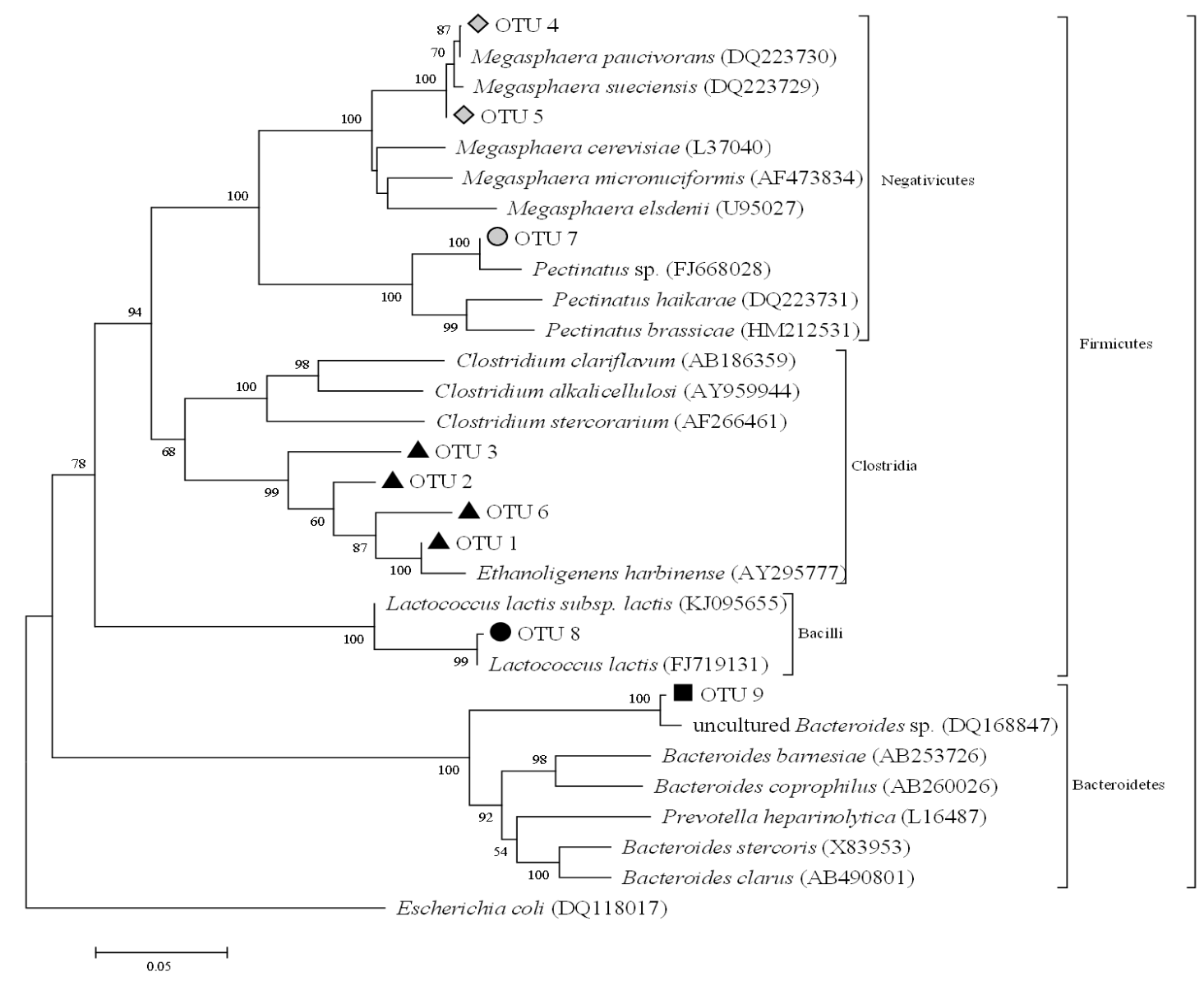

Figura 5.177. Árvore filogenética construída com 30 sequências de nucleotídeos a partir de distâncias evolutivas inferidas usando o método Neighbor-Joining (Saitou e Nei, 1987). A porcentagem de réplicas da árvore está apresentada próximo aos ramos e foi calculada com base em teste de bootstrap com 1000 réplicas (Felsenstein, 1985). As distâncias evolutivas foram calculadas usando o método de Jukes e Cantor (1969). 
As sequências dos 87 clones foram agrupadas em 9 Unidades Taxonômicas Operacionais (OTU) com similaridade entre si de $95 \%$. Posteriormente ao agrupamento das sequências, encontrou-se a sequência representativa de cada UTO, a qual foi comparada com aquelas depositadas no banco de dados (Tabela 5.39).

Tabela 5.39. Caracterização filogenética do consórcio microbiano no AnSBBR (Ensaio 12).

\begin{tabular}{|c|c|c|c|c|c|c|c|c|}
\hline \multirow[b]{2}{*}{ OTU } & \multirow[b]{2}{*}{ Classificação } & \multirow{2}{*}{$\begin{array}{c}\text { Número } \\
\text { de } \\
\text { clones }\end{array}$} & \multicolumn{3}{|c|}{ Afiliação filogenética } & \multirow{2}{*}{$\begin{array}{c}\text { Produtos de } \\
\text { fermentação* }\end{array}$} & \multirow{2}{*}{$\begin{array}{l}\text { Produtor } \\
\text { de } \mathrm{H}_{2} *\end{array}$} & \multirow[b]{2}{*}{ Referência } \\
\hline & & & $\begin{array}{l}\text { Espécie do } \\
\text { Genbank }\end{array}$ & $\begin{array}{l}\text { Número } \\
\text { de acesso }\end{array}$ & $\begin{array}{c}\text { Similaridade } \\
(\%)\end{array}$ & & & \\
\hline 1 & \multirow{4}{*}{ Ruminococcaceae } & 38 & & & 99,5 & \multirow{4}{*}{$\begin{array}{c}\text { Etanol, ácido } \\
\text { acético }\end{array}$} & \multirow{4}{*}{+} & \multirow{4}{*}{$\begin{array}{l}\text { Xing et al., } \\
2006\end{array}$} \\
\hline 2 & & 4 & Ethanoligenens & $\Delta \mathrm{Y} 205777$ & 99,3 & & & \\
\hline 3 & & 1 & harbinense & AY $295 / / 1$ & 94,9 & & & \\
\hline 6 & & 1 & & & 99,2 & & & \\
\hline 4 & & 33 & $\begin{array}{c}\text { Megasphaera } \\
\text { elsdenii }\end{array}$ & U95027 & 94,1 & $\begin{array}{c}\text { Ácidos } \\
\text { acético, } \\
\text { butírico e } \\
\text { capróico }\end{array}$ & + & $\begin{array}{c}\text { Hino et al., } \\
1991\end{array}$ \\
\hline 5 & Veillonellaceae & 2 & $\begin{array}{l}\text { Megasphaera } \\
\text { sp. }\end{array}$ & AB717067 & 100 & - & + & $\begin{array}{l}\text { Yamamoto } \\
\text { et al., } 2014\end{array}$ \\
\hline 7 & & 3 & Pectinatus sp. & FJ668028 & 99,7 & $\begin{array}{c}\text { Ácido } \\
\text { acético e } \\
\text { propiônico }\end{array}$ & + & $\begin{array}{c}\text { Castelló et } \\
\text { al., } 2009\end{array}$ \\
\hline 8 & Streptococcaceae & 2 & $\begin{array}{c}\text { Lactococcus } \\
\text { lactis }\end{array}$ & AY626142 & 100 & Ácido lático & - & $\begin{array}{l}\text { Sikora et } \\
\text { al., } 2013\end{array}$ \\
\hline 9 & Bacteroidaceae & 3 & Bacteroides sp. & DQ168847 & 99,1 & - & + & $\begin{array}{l}\text { Ren } \text { et al., } \\
\quad 2007\end{array}$ \\
\hline
\end{tabular}

As sequências representativas das UTOs 1, 2, 3 e 6 foram semelhantes a Ethanoligenens harbinense (AY295777) com elevada similaridade (Tabela 5.39). Este microrganismo foi isolado a partir de lodo de reator CSTR tratando água residuária da produção de melaço (Xing et al. (2006). Trata-se de uma bactéria gram positiva, anaeróbia obrigatória, não formadora de endósporos, que cresce em ampla faixa de temperatura $\left(20-44{ }^{\circ} \mathrm{C}\right)$ e $\mathrm{pH}(3,5-9,0)$ e possui elevada capacidade auto-agregativa (Xing et al., 2006). É capaz de fermentar vários mono, di e oligossacarídeos, e os produtos da fermentação da glicose são o ácido acético, o etanol, o hidrogênio e o gás carbônico. A presença dominante de microrganismos relacionados com a espécie Ethanoligenens harbinense justifica a distribuição dos compostos intermediários formados, entre os quais o etanol e o ácido acético perfazem mais que $70 \%$ do total.

Devido à elevada capacidade auto-agregativa e ao desempenho na produção de hidrogênio, Ethanoligenens harbinense YUAN-3 tem sido utilizado em diversos trabalhos acerca de produção do referido gás. Xing et al. (2008) utilizaram E. harbinense YUAN-3 como inóculo e avaliaram a produção de hidrogênio em CSTR alimentado com glicose em 
condições não estéreis. Ao final do período experimental (21 dias), os autores identificaram que microrganismos invasores (Filo Firmicutes e Bacteroidetes) estavam presentes no reator, mas a população dominante era de YUAN-3 muito provavelmente devido a elevada capacidade agregativa deste microrganismo (Ren et al., 2009).

Recentemente, a caracterização filogeneticamente da biomassa presente nos biorreatores produtores de hidrogênio têm sido realizada com o objetivo de melhorar o entendimento sobre como os parâmetros operacionais podem selecionar diferentes grupos microbianos e, qual é o efeito dessa seleção no desempenho dos biorreatores. Etchebehere et al. (2016) compilaram informações acerca da caracterização de biomassa proveniente de diversos biorreatores e, segundo os autores os gênero microbianos encontrados podem ser divididos em três grande grupos: (1) gêneros, como Clostridium e Enterobacter, os quais agrupam espécies com elevada capacidade de produção de hidrogênio; (2) microrganismos pertencentes a gêneros, tais como Pectinatus, Megasphaera, Prevotella, que exibem metabolismo fermentativo com reduzido rendimento de produção de hidrogênio e (3) gêneros que agrupam microrganismos que não são capazes de produzir hidrogênio, tais como as bactérias láticas (Lactobacillus).

O segundo grupo de microrganismos dominantes ao final do período experimental foi relacionado com membros da Família Veillonellaceae (Megasphaera e Pectinatus). Cerca de $40 \%$ do total de clones analisados foram afiliados com membros do gênero Megasphaera. A UTO 4, que agrupou 33 clones, foi relacionada com Megasphaera elsdenii (94.1\%). Trabalhos recentes sobre a produção de hidrogênio em diversas configurações de reator, utilizando diferentes águas residuárias como fonte de carbono e diferentes fontes de inóculo têm reportado a presença de microrganismos afiliados ao gênero Megasphaera (Ren et al., 2007; Castelló et al., 2009, Anzola-Rojas et al., 2015). A maioria das espécies do gênero Megasphaera não consome açúcares e possui capacidade de consumir ácidos orgânicos e produzir reduzidas quantidades de hidrogênio. Destaca-se que a presença destes microrganismos em reatores produtores de hidrogênio poderia aumentar a produção de hidrogênio após o consumo dos açúcares, todavia, eles são observados em reatores que apresentam reduzido/mediano desempenho (Etchebehere et al. (2016)).

A espécie Megasphaera elsdenii é um microrganismo gram negativo, anaeróbio obrigatório e que normalmente é encontrada no rumem bovino. Uma das características marcantes deste microrganismo envolve a capacidade que ele possui em utilizar o ácido lático produzido no rumem, desempenhando assim um papel fundamental na prevenção da acidose nos animais. É também capaz de fermentar glicose produzindo principalmente ácido butírico, 
além de ácido acético e capróico, e liberando hidrogênio, o qual é substrato para a produção de metano nos bovinos (Hino et al., 1991).

A elevada proporção (41.6 \%) de microrganismos afiliados ao gênero Megasphaera poder ser justificada pela capacidade metabólica que estes microrganismos possuem em utilizar ácidos orgânicos como substrato. No caso do presente estudo, sugere-se que o ácido acético proveniente da fermentação dos carboidratos realizada por microrganismos do gênero Ethanoligenens e, também, o ácido lático, componente do soro (Ensaio 7, 75\% soro e 25\% glicerina), tenham favorecido a seleção de microrganismos semelhantes à Megasphaera. Ressalta-se também que, segundo Hino et al. (1991), a presença de ácido acético estimula o crescimento de Megasphaera elsdenii e promove a produção de ácido butírico, todavia, neste caso a produção de hidrogênio não ocorre. Certamente a ocorrência desse microrganismo em diversos reatores acidogênicos aplicados à produção de hidrogênio deve-se à versatilidade metabólica exibida por ele, uma vez que eles podem atuar fermentando glicose com a produção de ácidos orgânicos e hidrogênio e, também, podem desempenhar papel de consumidores de ácidos orgânicos.

Conforme apresentado no início desta seção, o consórcio microbiano estudado apresentou dominância de microrganismos relacionados aos gêneros Ethanoligenens e Megasphaera (94\% do total) e, em reduzida porcentagem foram observados clones afiliados com microrganismos dos gêneros Pectinatus (OTU 7), Lactococcus (OTU 8), ambos pertencentes ao Filo Firmicutes e, também Bacteroides (OTU 9) (Tabela 5.39).

Microrganismos do gênero Pectinatus são capazes de consumir ácido lático produzindo ácido propiônico. Castelló et al., (2009) observaram microrganismos relacionados com esse gênero em reator UASB aplicado à produção de hidrogênio a partir de soro. No referido estudo, tais microrganismos foram responsáveis pelo consumo de ácido lático gerado a partir da fermentação da lactose do soro. Ferraz Júnior et al. (2015) avaliaram a produção de hidrogênio a partir de vinhaça bruta e também observaram a predominância de microrganismos relacionados com Pectinatus em diversas condições experimentais.

Em diversos estudos a presença de bactérias láticas é bastante frequente em reatores alimentados com soro (Castelló et al., 2009; Castelló et al., 2011), todavia, sabe-se que não se trata de microrganismo produtor de hidrogênio e, muitas vezes, o reduzido desempenho dos biorreatores é justificado pela predominância de bactérias lácticas em detrimentos das produtoras de hidrogênio. Acredita-se que no presente estudo a aplicação da codigestão (75:25 \% soro:glicerina), além das condições operacionais, tenha atuado de maneira a contribuir para seleção de microrganismos produtores de hidrogênio ao invés das bactérias 
láticas. Somente $2.4 \%$ dos clones foram relacionas com bactérias láticas (OTU 8). A última OTU 9, que agrupou somente 3 clones, foi a única não relacionada com o Filo Firmicutes. Trata-se de clones filogeneticamente afiliados com bactéria não cultivada do gênero Bacteroides, que podem produzir hidrogênio (REF).

Em suma, pode-se dizer que nesta condição operacional, a comunidade microbiana presente no AnSBBR foi dominada por Ethanoligenens e Megasphaera. Sugere-se que os carboidratos podem ter sido consumidos por microrganismos tais como Ethanoligenens com a produção de ácido acético etanol, hidrogênio. Acredita-se que microrganismos semelhantes a Megasphaera podem ter sido responsáveis pelo consumo de ácido acético observado e, também, pela fermentação de carboidratos e produção de ácido butírico. Sugere-se que o melhor desempenho do reator nesta condição operacional em relação às outras pode residir na seleção de microrganismos produtores de hidrogênio e não de bactérias láticas. 


\section{CONCLUSÕES}

A codigestão entre soro e glicerina foi avaliada em um AnSBBR com recirculação da fase líquida aplicado à produção de biometano e biohidrogênio.

Para a produção de biometano:

- A condição com $75 \%$ de soro e $25 \%$ de glicerina obteve os melhores resultados: produtividade molar de $101,8 \mathrm{molCH}_{4} \cdot \mathrm{m}^{-3} \cdot \mathrm{d}^{-1}$ e rendimento por carga aplicada com base em matéria orgânica de $13,3 \mathrm{molCH}_{4} \cdot \mathrm{kgDQO}^{-1}$;

- $\quad$ Esses resultados representam um aumento de produtividade de cerca de $9 \%$ e $30 \%$ quando a produtividade obtida é comparada com a digestão anaeróbia de soro e glicerina puros, respectivamente;

- $\quad$ A produção de metano no melhor ensaio aconteceu predominantemente pela rota hidrogenotrófica.

Para a produção de biohidrogênio:

- A melhor razão de mistura entre soro e glicerina foi de $75 \%$ soro e $25 \%$ glicerina (base DQO);

- A melhor condição operacional de produção de hidrogênio foi de $7000 \mathrm{mgDQO} . \mathrm{L}^{-1}$, tempo de ciclo de $3 \mathrm{~h}$ e tempo de enchimento de 1,5 h (modo batelada alimentada), o que representa uma COAV de 23,9 $\mathrm{kgDQO} \cdot \mathrm{m}^{-3} \cdot \mathrm{d}^{-1}$, a $30^{\circ} \mathrm{C}$;

- $\quad$ ensaio com essas condições operacionais obteve uma produtividade molar de $129,0 \mathrm{molH}_{2} \cdot \mathrm{m}^{-3} \cdot \mathrm{d}^{-1}$ e rendimento de $5,4 \mathrm{molH}_{2} \cdot \mathrm{kgDQO}^{-1}$;

- $\quad$ Esses resultados representam um aumento de produtividade de $145 \%$ em relação a mono-digestão do soro, o que indica o benefício significativo da adição de glicerina ao afluente, provavelmente devido à sua capacidade tamponante, e à otimização das condições operacionais;

- Tanto o aumento da concentração do afluente quanto a utilização do modo batelada alimentada foram benéficos para a produção de $\mathrm{H}_{2}$;

- $\quad$ A adição de glicerina e o aumento da COAV balancearam as rotas de produção de hidrogênio, pois o hidrogênio foi produzido de forma mais equilibrada pelas vias do ácido acético, butírico e valérico; 
- A caracterização do consórcio microbiano do melhor ensaio (COAV de 23,9 kgDQO. $\mathrm{m}^{-3} \cdot \mathrm{d}^{-1}$ a $30^{\circ} \mathrm{C}$ em modo batelada alimentada) indicou que a comunidade microbiana presente no AnSBBR foi dominada por Ethanoligenens e Megasphaera, indicando que os carboidratos possam ter sido consumidos por microrganismos tais como Ethanoligenens com a produção de ácido acético etanol e hidrogênio, e que microrganismos semelhantes a Megasphaera possam ter sido responsáveis pelo consumo de ácido acético observado e, também, pela fermentação de carboidratos e produção de ácido butírico, ou seja, o melhor desempenho do reator pode ser atribuído à seleção de microrganismos produtores de hidrogênio e não de bactérias láticas. 


\section{SUGESTÕES PARA TRABALHOS FUTUROS}

Considerando os resultados obtidos no presente trabalho, são apresentadas sugestões para futuros estudos de produção de hidrogênio em reatores anaeróbios de biomassa imobilizada realizando a codigestão entre soro e glicerina:

- Estudar a influência dos seguintes parâmetros: velocidade ascensional, tipo de suporte e solução de sais;

- Estudar o controle do crescimento da biomassa em temperaturas superiores a $30^{\circ} \mathrm{C}$, pois houve indícios de que a produção de biohidrogênio poderia ter sido ainda maior a uma temperatura de $35^{\circ} \mathrm{C}$ caso houvesse maior controle do crescimento da biomassa;

- Realizar caracterização filogenética em cada ensaio (e não apenas na melhor condição) para identificar a influência da adição de cosubstrato e da variação da carga orgânica nos microrganismos;

- Realizar ensaios com a glicerina bruta e o soro de leite industrial para determinar a melhor condição de operação do sistema proposto. 


\section{REFERÊNCIAS BIBLIOGRÁFICAS}

Ak, N., 2013. Organic waste feedstocks to energy. Life Sciences Journal, 10, 233-241.

Alibardi, L., Cossu, R., 2015. Composition variability of the organic fraction of municipal solid waste and effects on hydrogen and methane production potentials. Waste Management, 36, 147-155, 2015.

Alzate-Gaviria, L.M.; Sebastian, P.J.; Pérez, A.; Eapen, D. 2007 Comparison of two anaerobic systems for hydrogen production from the organic fraction of municipal solid waste and synthetic wastewater. International Journal of Hydrogen Energy, 32, 31413146.

Anzola-Rojas, M.P.; Fonseca, S.G.; Silva, C.C.; Oliveira, V.M.; Zaiat, 2015. M. The use of the carbon/nitrogen ratio and specific organic loading rate as tools for improving biohydrogen production in fixed-bed reactors. Biotechnology. Reports, 5, 46-54.

Argun, H.; Kargi, F.; Kapdan, I.; Oztekin, R. 2008. Biohydrogen production by dark fermentation of wheat powder solution: Effects of $\mathrm{C} / \mathrm{N}$ an $\mathrm{C} / \mathrm{P}$ ratio hydrogen yield and formation rate. International Journal of Hydrogen Energy, 33, 1813-1819.

Ashworth, G. S., Azevedo, P. 2009. Preface. “Agricultural Wastes” Ed.: Nova Science, New York.

Astals, S., Ariso, M., Galí, A., Mata-Alvarez, J. 2011. Co-digestion of pig manure and glycerine: Experimental and modelling study. Journal of Environmental Management, 92, 1091-1096.

Astals, S., Nolla-Ardèvol, V., Mata-Alvarez, J. 2012. Anaerobic co-digestion of pig manure and crude glycerol at mesophilic conditions: Biogas and digestate. Bioresource Technology, 110, 63-70.

Baba, Y.; Tada, C.; Watanabe, R.; Fukuda, Y.; Chida, N.; Nakai, Y., 2013. Anaerobic digestion of crude glycerol from biodiesel manufacturing using a large-scale pilot plant: Methane production and application of digested sludge as fertilizer. Bioresource Technology, 140, 342-348.

Bagley, D.M.; Brodkorb, T.S., 1999. Modeling microbial kinetics in an anaerobic sequencing batch reactor - model development and experimental validation. Water and Environment Research, 71, 1320-1332.

Batstone, D.J., Keller, J., Angelidaki, I., Kalyuzhnyi, S.V., Pavlostathis, S.G., Rozzi, A., Sanders, W.T., Siegrist, H., Vavilin, V.A. 2002. The IWA Anaerobic Digestion Model No 1 (ADM1). Water Science and Technology, 45, 65-73. 
Bezerra, R.A., Rodrigues, J.A.D., Ratusznei, S.M., Zaiat, M., Foresti, E., 2007. Whey treatment by AnSBBR with circulation: Effects of organic loading, shock loads, and alkalinity supplementation. Applied Biochemistry and Biotechnology, 143, 257-275.

Bezerra, R.A.; Rodrigues, J.A.D.; Ratusznei, S.M.; Zaiat, M.; Foresti, E., 2009.Effects of feed time, organic loading and shock loads in the anaerobic whey treatment by an AnSBBR with circulation. Applied Biochemistry and Biotechnology, 157, 140-158.

Bezerra, R.A.; Rodrigues, J.A.D.; Ratusznei, S.M.; Zaiat, M.; Foresti, E., 2011. Effect of organic load on the performance and methane production of an AnSBBR treating effluent from biodiesel production. Applied Biochemistry and Biotechnology, 165, 347368.

Bondioli, P.; Bella, L.D., 2005. An alternative spectrophotometric method for the determination of free glycerol in biodiesel. European Journal of Lipid Science and Technology, 107, 153-157.

Borges, A.C.; Siman, R.R.; Rodrigues, J.A.D.; Ratusznei, S.M.; Zaiat, M.; Foresti, E.; Borzani, W. 2004. Stirred anaerobic sequencing batch reactor containing immobilized biomass: a behavior study when submitted to different fill times. Water Science and Technology, 49, 311-318.

Bouallagui, H., Lahdheb, H., Romdan, E. B., Rachdi, B., Hamdi, M., 2009. Improvement of fruit and vegetable waste anaerobic digestion performance and stability with cosubstrates addition. Journal of Environmental Management, 90, 1844-1849.

Boubaker, F., Ridha, B.C., 2008. Modelling of the mesophilic anaerobic co-digestion of olive mill wastewater with olive mill solid waste using anaerobic digestion model No. 1 (ADM1). Bioresource Technology, 99, 14, 6565-6577.

Bravo, I.S.M.; Lovato, G.; Rodrigues, J.A.D.; Ratusznei, S.M.; Zaiat, M. 2015. Biohydrogen Production in an AnSBBR Treating Glycerin-Based Wastewater: Effects of Organic Loading, Influent Concentration, and Cycle Time. Applied Biochemistry and Biotechnology, 175, 1892-1914.

Carvalhinha, P.P., Flôres, A, Rodrigues, J.A.D.; Ratusznei, S.M.; Zaiat, M.; Foresti, E 2010. AnSBBR applied to the treatment of metalworking fluid wastewater: effect of organic and shock load. Applied Biochemistry and Biotechnology, 162, 1708-1724.

Carvalho, F.; Prazeres, A.R.; Rivas, J., 2013. Cheese whey wastewater: Characterization and treatment. Science of Total Environment, 445, 385-396. 
Castelló, E.; Garcia Santos, C.; Iglesias, T.; Paolino, G.; Wenzel, J.; Borzacconi, L.; Etchebehere, C. 2009. Feasibility of biohydrogen production from cheese whey using a UASB reactor: Links between microbial community and reactor performance. International Journal of Hydrogen Energy, 34, 5674-5682.

Castelló, E.; Perna, V.; Wenzel, J.; Borzacconi, L.; Etchebehere, C. 2011 Microbial community composition and reactor performance during hydrogen production in a UASB reactor fed with raw cheese whey inoculated with compost. Water Science and Technology, 64, 2265-2273.

Chandra, R.; Takeuchi, H.; Hasegawa, T. 2012. Methane production from lignocellulosic agricultural crop wastes: A review in context to second generation of biofuel production. Renewable and Sustainable Energy Reviews, 16, 1462-1476.

Cheong, D.; Hansen, C.L. 2008. Effect of feeding strategy on the stability of anaerobic sequencing batch reactor responses to organic loading conditions, Bioresource Technology, 99, 5058-5068.

Chernicharo, C.A.L. 1997. Reatores Anaeróbios. Princípios do Tratamento Biológico de Águas Residuárias. Ed.: DESA/UFMG, Belo Horizonte, 1997.

Dague, R.R.; Habben, C.E.; Pidaparti, S.R. 1992 Initial studies on the anaerobic sequencing batch reactor. Water Science and Technology 26, 2429-2432.

Dai, X., Duan, N., Dong, B., Dai, L. 2013. High-solids anaerobic co-digestion of sewage sludge and food waste in comparison with mono digestions: Stability and performance. Waste Management., 33, 2, 308-316.

Damasceno, L.F.D.; Rodrigues, J.A.D.; Ratusznei, S.M.R.; Zaiat, M.; Foresti, E. 2007 Effects of feeding time and organic loading in an anaerobic sequencing batch biofilm reactor (ASBBR) treating diluted whey. Journal of Environmental Management, 85(4), 927935.

Das, D.; Veziroglu, T. N. 2001. Hydrogen production by biological processes : a survey of literature. International Journal of Hydrogen Energy, 26, 13-28.

Del Nery, V. 1987. Utilização de Lodo Anaeróbio Imobilizado em Gel no Estudo de Partida de Reatores de Fluxo Ascendente com Manta de Lodo. Dissertação (Mestrado em Engenharia Civil - Hidráulica) - Universidade de São Paulo.

Deng, Y.Y; Blok, K.; Van der Leun, K. 2012. Transition to a fully sustainable global energy system. Energy Strategy Reviews, 1, 109-121. 
Dubois, S. M.; Gilles, K.A.; Hamilton, J.L.; Rebers, P.A.; Smith, F., 1956. Colorimetric Methods for determination of sugar and related substance. Analytical Chemistry, 228, 1321.

Espinoza-Escalante, F. M., Pelayo-Ortíz, C., Navarro-Corona, J., González-García, Y., Bories, A., \& Gutiérrez-Pulido, H., 2009. Anaerobic digestion of the vinasses from the fermentation of agave tequilana weber to tequila: The effect of $\mathrm{pH}$, temperature and hydraulic retention time on the production of hydrogen and methane. Biomass and Bioenergy, 33(1), 14-20.

Esposito, G., Frunzo, L., Giordano, A., Liotta, F., Panico, A., Pirozzi, F., 2012. Anaerobic codigestion of organic wastes. Reviews in Environmental Science and Bio/Technology 11, 325-341.

Etchebehere, C.; Castelló, E.; Wenzel, J.; Anzola-Rojas,M.P.; Borzacconi, L.; Buitrón, G.; Cabrol, L.; Carminato, V.M.; Carrillo-Reyes, J.; Cisneros-Pérez, C.; Fuentes, L.; Moreno-Andrade, I.; Razo-Flores, E.; Filippi, G.R.; Tapia-Venegas, E.; Toledo-Alarcón, J.; Zaiat, M. 2016. Microbial communities from 20 different hydrogen-producing reactors studied by 454 pyrosequencing. Applied Microbiology and Biotechnology, 1, 114.

Felsenstein, J., 1985. Confidence limits on phylogenies: An approach using the bootstrap. Evolution, 39, 783-791.

Fernández, C.; Carracedo, B.; Martínez, E. J.; Gómez, X.; Morán, A., 2014. Application of a packed bed reactor for the production of hydrogen from cheese whey permeate: Effect of organic loading rate. Journal of Environmental Science and Health, 49, 210-217.

Ferraz Júnior, A.D. N.; Etchebehere, C.; Zaiat, M., 2015. Mesophilic hydrogen production in acidogenic packed-bed reactors (APBR) using raw sugarcane vinasse as substrate: Influence of support materials. Anaerobe, 34, 94-105.

Fountoulakis, M.S., Petousi, I., Manios, T., 2010. Co-digestion of sewage sludge with glycerol to boost biogas production. Waste Management, 30, 1849-1853.

Fuzzato, M.C.; Adorno, M.A.T.; Pinho, S.C. 2009. Simplified mathematical model for an anaerobic sequencing batch biofilm reactor treating lipid-rich wastewater subject to rising organic loading rates. Environmental Engineering Science, 26, 1197-1206.

Garcia, M.L.; Lapa, K.R.; Foresti, E.; Zaiat, M., 2008. Effects of bed materials on the performance of an anaerobic sequencing batch biofilm reactor treating domestic sewage. Journal of environmental management, 88, 1471-1477. 
Goberna, M., Schoen, M.A., Sperl, D., Wett, B. Insam, H., 2010. Mesophilic and thermophilic co-fermentation of cattle excreta and olive mill wastes in pilot anaerobic digesters. Biomass Bioenergy, 34, 340-346.

Hagelqvist, A., 2013. Batchwise mesophilic anaerobic co-digestion of secondary sludge from pulp and paper industry and municipal sewage sludge. Waste Management, 33, 820824.

Hartmann, H., Ahring, B.K., 2005. Anaerobic digestion of the organic fraction of municipal solid waste: Influence of co-digestion with manure. Water Research, 39 1543-1552.

Hino, T.; Miyazaki, K.; Kuroda, S., 1991. Role of extracellular acetate in the fermentation of glucose by a ruminal bacterium Megasphaera elsdenii. Journal of General and Applied Microbiology, 37, 121-129.

Inoue, R.K.; Lima, D.M.F.; Rodrigues, J.A.D.; Ratusznei, S.M.; Zaiat, M., 2014. Effect of organic loading rate and fill time on the biohydrogen production in a mechanically stirred AnSBBR treating synthetic sucrose based wastewater. Journal of Environmental Management, 174, 2326-2349.

Ito, T.; Nakashimada, Y.; Senba, K.; Matsui, T.; Nishio, N., 2005. Hydrogen and ethanol production from glycerol containing wastes discharges after biodiesel manufacturing process. Journal of Bioscience and Bioengineering, 100, 260-265.

Jiménez, J., Guardia-Puebla, Y., Cisneros-Ortiz, M.E., Morgan-Sagastume, J.M., Guerra, G., Noyola, A., 2015. Optimization of the specific methanogenic activity during the anaerobic co-digestion of pig manure and rice straw, using industrial clay residues as inorganic additive. Chemical Engineering Journal, 259, 703-714, 2015.

Jukes, T.H.; Cantor, C.R., 1969. Evolution of protein molecules. In: Munro HN, editor, Mammalian Protein Metabolism. Academic Press, New York.

Kacprzak, A., Krzystek, L., Ledakowicz, S., 2010. Co-digestion of agricultural and industrial wastes. Chemical Papers, 64, 127-131.

Kim, S; Han, S; Shin, H., 2006. Effect of substrate concentration on hydrogen production and $16 \mathrm{~S}$ rDNA-based analysis of the microbial community in a continuous fermenter. Process Biochemistry, 41, 199-207.

Kumar, S., 2008. Anaerobic Biotechnology for Bioenergy Production. Principles and Aplications. Ed.: Wiley-Blackwell, Nova Deli.

Lay, J.J.; Lee, Y.J.; Noike, T., 1999. Feasibility of biological hydrogen production from organic fraction of municipal solid waste. Water Research, 33, 2579-2586. 
Lee, D.-J.; Show, K.-Y.; Su, A., 2011. Dark fermentation on biohydrogen production: pure culture. Bioresource Technology, 102, 8393-8402.

Leite, J.A.C.; Fernandes, B.S.; Pozzi, E.; Barboza, M.; Zaiat, M., 2008 Application of an anaerobic packed-bed bioreactor for the production of hydrogen and organic acids. International Journal of Hydrogen Energy, 33, 579-586.

Lettinga, G.; Haandel, A.C., 1993. Anaerobic Digestion for Energy Production and Environmental Protection. In: Johansson, T.B. et al. (Ed.) Renewable Energy: Sources for Fuels and Electricity. Island Press, California.

Lima, D.M.F.; Inoue, R.K.; Rodrigues, J.A.D.; Ratusznei, S.M.; Zaiat, M., 2015. Biohydrogen from cheese whey treatment in an AnSBBR: achieving process stability. Brazilian Journal of Chemical Engineering, 32, 397-408.

Lima, D.M.F.; Lazaro, C.Z.; Rodrigues, J.A.D.; Ratusznei, S.M.; Zaiat, M., 2016. Optimization performance of an AnSBBR applied to biohydrogen production treating whey. Journal of Environmental Managment, 169, 191-201.

Lin, C.; Lay, C., 2005. A nutrient formulation for fermentative hydrogen production using anaerobic sewage sludge microflora. International Journal of Hydrogen Energy, 30, 285292.

Lin, C.C.R., 2004. Fermentative hydrogen production at ambient temperature. International Journal of Hydrogen Energy, 29, 715-720.

Lovato, G.; Bezerra, R.A.; Rodrigues, J.A.D.; Ratusznei, S.M.; Zaiat, M., 2012. Effect of feed strategy on methane production and performance of an AnSBBR treating effluent from biodiesel production. Applied Biochemistry and Biotechnology, 166, 2007-2029.

Lovato, G.; Moncayo Bravo, I.S.; Ratusznei, S.M.; Rodrigues, J.A.D.; Ratusznei, S.M.; Zaiat, M., 2015. The effect of organic load and feed strategy on biohydrogen production in an AnSBBR treating glycerin-based wastewater. Journal of Environmental Management, 154, 128-137.

Ma, J., Van Wambeke, M., Carballa, M., Verstraete, W., 2008. Improvement of the anaerobic treatment of potato processing wastewater in a UASB reactor by co-digestion with glycerol. Biotechnology Letters, 30, 861-867.

Manssouri, M.; Rodrigues, J.A.D.; Ratusznei, S.; Zaiat, M., 2013. Effects of organic loading, influent concentration and feed time on biohydrogen production in a mechanically stirred AnSBBR treating sucrose based wastewater. Applied Biochemistry and Biotechnology, $171,1832-1854$. 
Mata-Alvarez, J.; Dosta, J.; Romero-Güiza, M.S.; Fonoll, X.; Peces, M.; Astals, S., 2014. A critical review on anaerobic co-digestion achievements between 2010 and 2013. Renewable and Sustainable Energy Reviews, 36, 412-427.

Mockaitis, G.; Ratusznei, S.M.; Rodrigues, J.A.D.; Zaiat, M.; Foresti, E., 2006 Anaerobic whey treatment by a stirred sequencing batch reactor (ASBR): effects of organic loading and supplemented alkalinity. Journal of Environmental Management, 79, 198-206.

Mor, S.; Ravindra, K.; De Visscher, A.; Dahiya, R.P.; Chandra, A., 2006. Municipal solid waste characterization and its assessment for potential methane generation: A case study. Science of Total Environment, 371, 1-10.

Oliveira, D.S.; Prinholato, A.C.; Ratusznei, S.M.; Rodrigues, J.A.D.; Zaiat, M.; Foresti, E., 2009. AnSBBR applied to the treatment of wastewater from a personal care industry: effect of organic load and fill time. Journal of Environmental Management, 90, 30703081 .

Oliveira, R.P., Ghilardi, J.A., Ratusznei, S.M., Rodrigues, J.A.D., Zaiat, M., Foresti, E., 2008. Anaerobic sequencing batch biofilm reactor applied to automobile industry wastewater treatment: Volumetric loading rate and feed strategy effects. Chemical Engineering and Processing: Process Intensification, 47, 1380-1389.

Oliveira, R.P.; Ratusznei, S.M.; Rodrigues, J.A.D.; Zaiat, M.; Foresti, E., 2010. Interaction Effects of Organic Load and Cycle Time in an ASBR Applied to a Personal Care Industry Wastewater Treatment. Journal of Environmental Management, 91, 2499-2504.

Ottaviano, L.M., 2014. Produção de hidrogênio em reator anaeróbio de leito fluidificado a partir de água residuária de soro de queijo em condição termófila. 2014. Dissertação (Mestrado em Hidráulica e Saneamento) - Escola de Engenharia de São Carlos, Universidade de São Paulo, São Carlos.

Perna, V.; Castellé, E.; Wenzel, J.; Zampol, C.; Fontes Lima, D.M.; Borzacconi, L.; Varesche, M.B.; Zaiat, M.; Etchebehere, C., 2013. Hydrogen production in an upflow anaerobic packed bed reactor used to treat cheese whey. International Journal of Hydrogen Energy, 38, 54-62.

Ramos, A.C.T.; Ratusznei, S.M.; Rodrigues, J.A.D; Zaiat, M., 2003. Mass transfer improvement of a fixed bed anaerobic sequencing batch reactor with liquid-phase circulation. Interciencia, 28, 214-219.

Ratusznei, S.M.; Rodrigues, J.A.D.; Camargo, E.F.M.; Zaiat, M.; Borzani, W., 2000. Feasibility of a stirred anaerobic sequencing batch reactor containing immobilized biomass for wastewater treatment. Bioresource Technology, 75, 127-132. 
Ren, N.; Defeng Xing, D.; Rittmann, B.E.; Zhao, L.; Xie, T.; Zhao, X., 2007. Microbial community structure of ethanol type fermentation in bio-hydrogen production. Environmental Microbiology, 9, 1112-1125.

Ren, N.; Li, J.; Li, B.; Wang, Y.; Liu, S., 2006. Biohydrogen production from molasses by anaerobic fermentation with a pilot-scale bioreactor system. International Journal of Hydrogen Energy, 31, 2147-2157.

Ren, N.; Xie, T.; Xing, D., 2009. Composition of extracellular polymeric substances influences the autoaggregation capability of hydrogen-producing bacterium Ethanoligenens harbinense. Bioresource Technology, 100, 5109-5113.

Ripley, L.E.; Boyle, W.C.; Converse, J.C., 1986. Improved Alkalimetric Monitoring for AnaerobicDigestor of High-Strength Wastes. Journal of Water Pollution Control Federation, 58, 406-411.

Rittman, B.; Mccarty, P., 2001. Biotecnología del Medio Ambiente: Principios y Aplicaciones. Ed.: McGraw-Hill, New York.

Rivero, M.; Solera, R.; Perez, M., 2014. Anaerobic mesophilic co-digestion of sewage sludge with glycerol: Enhanced biohydrogen production. International Journal of Hydrogen Energy, 39, 2481-2488.

Robra, S.; Cruz, R.S.; Oliveira, A.M.; Neto, J.A.A.; Santos, J.V., 2010. Generation of biogas using crude glycerin from biodiesel production as a supplement to cattle slurry. Biomass and Bioenergy, 34, 1330-1335.

Rodrigues, J.A.D.; Oliveira, R.P.; Ratusznei, S.; Zaiat, M., 2011. AnSBBR applied to a personal care industry wastewater treatment: effects of fill time, volume treated per cycle, and organic load. Applied Biochemistry and Biotechnology, 163, 127-142.

Rodrigues, J.A.D.; Pinto, A.G.; Ratusznei, S.M.; Zaiat, M.; Gedraite, R., 2004. Enhancement of the performance of an anaerobic sequencing batch reactor treating low strength wastewater through implementation of a variable stirring rate program. Brazilian Journal of Chemical Engineering, 21, 423-434.

Rosa, P.R.F.; Santos, S.C.; Silva, E.L. 2014. Different ratios of carbon sources in the fermentation of cheese whey and glucose as substrates for hydrogen and ethanol production in continuous reactors. International Journal of Hydrogen Energy, 39, 12881296.

Russell, J.B., 1980. General Chemistry. McGraw-Hill Education. 
Sá, L.R.V; Cammarota, M.C.; Oliveira, T.C.; Oliveira, E.M.M.; Matos, A.; Leitão, V.S.F., 2013. Pentoses, hexoses and glycerin as substrates for biohydrogen production: An approach for Brazilian biofuel integration. International Journal of Hydrogen Energy, 38, 2986-2997.

Saitou, N.; Nei, M., 1987. The neighbor-joining method: A new method for reconstructing phylogenetic trees. Molecular Biology and Evolution, 4, 406-425.

Selma, V.C.; Cotrim, L.H.B.; Rodrigues, J.A.D.; Ratusznei, S.M.; Zaiat, M.; Foresti, E., 2010. ASBR applied to the treatment of biodiesel production effluent: effect of organic load and fill time on performance and methane production. Applied Biochemistry and Biotechnology, 162, 2365-2380.

Shah, F.A.; Mahmood, Q.; Rashid, N.; Pervez, A.; Raja, I.A.; Shah, M.M., 2015. Codigestion, pretreatment and digester design for enhanced methanogenesis. Renewable and Sustainable Energy Reviews, 42, 627-642.

Shanmugam, P., Horan, N.J., 2009. Optimising the biogas production from leather fleshing waste by co-digestion with MSW. Bioresource Technology, 100, 4117-4120.

Shi, X.S.; Yuan, X.Z.; Wang, Y.P.; Zeng, S.J.; Qiu, Y.L.; Guo, R.B.; Wang, L.S., 2014. Modeling of the methane production and $\mathrm{pH}$ value during the anaerobic co-digestion of dairy manure and spent mushroom substrate. Chemical Engineering Journal, 244, 258263.

Sialve, B.; Bernet, N.; Bernard, O., 2009. Anaerobic digestion of microalgae as a necessary step to make microalgal biodiesel sustainable. Biotechnology Advances, 27, 409-416.

Siddique, M.N.I.; Munaim, M.A.S.; Zularisam, A.W., 2014. Mesophilic and thermophilic biomethane production by co-digesting pretreated petrochemical wastewater with beef and dairy cattle manure. Jounal of Industrial Engineering Chemistry, 20, 331-337.

Sikora, A.; Błaszczyk, M.; Jurkowski, M.; Zielenkiewicz, U., 2013. Lactic Acid Bacteria in Hydrogen-Producing Consortia: On Purpose or by Coincidence? Lactic Acid Bacteria R\&D for Food, Health and Livestock Purposes.

Silva, R.C.; Ratusznei, S.M.; Rodrigues, J.A.D.; Zaiat, M., 2013. Anaerobic treatment of industrial biodiesel wastewater by an ASBR for methane production. Applied Biochemistry and Biotechnology, 170, 105-118.

Standard Methods for the Examination of Water and Wastewater. 2012. APHA, AWWA, WPCF. $22^{\text {th }}$ edition, American Public Health Association, Washington. 
Tamura K.; Stecher G.; Peterson D.; Filipski, A.; Kumar, S., 2013. MEGA6: Molecular Evolutionary Genetics Analysis version 6.0. Molecular Biology and Evolution, 30, 2725-2729.

Tanisho, S., 2001. A scheme for developing the yield of hydrogen by fermentation. An Approach to Environmentally Acceptable Technology, 131-140.

Teghammar, A.; Forgács, G.; Horváth, I.S.; Taherzadeh, M.J., 2014. Techno-economic study of NMMO pretreatment and biogas production from forest residues. Applied Energy, $116,125-133$.

Temudo, M.F.; Poldermans, R.; Kleerebezem, R.; Van Loosdrecht, M.C.M. 2008. Glycerol Fermentation by (Open) Mixed Cultures: A Chemostat Study. Biotechnology and Bioengineering, 100, 1088-1098.

Tokumoto, H., Bandow, H., Kurahashi, K., Wakamatsu, T., 2012. Utilization of Crude Glycerin from Biodiesel Production: A Field Test of a Crude Glycerin Recycling Process. Biodiesel - Feedstocks, Production and Applications, 363-383.

Turcot, J.; Bisaillon, A.; Hallenbeck, P., 2008. Hydrogen production by continuous cultures of Escherichia coli under different nutrient regimes. International Journal of Hydrogen Energy, 33, 1465-1470.

Vlassis, T.; Stamatelatou, K.; Antonopoulou, G.; Lyberatos, G., 2013. Methane production via anaerobic digestion of glycerol: A comparison of conventional (CSTR) and high-rate (PABR) digesters. Journal of Chemical Technology and Biotechnology, 88, 2000-2006.

Wang, J., Wan, W., 2008. Effect of temperature on fermentative hydrogen production by mixed cultures. International Journal of Hydrogen Energy, 33, 5392-5397.

Wang, J.; Wan, W., 2009. Factors influencing fermentative hydrogen production: A review. International Journal of Hydrogen Energy, 34, 799-811.

Wang, M.; Sahu, A.K.; Rusten, B.; Park, C., 2013. Anaerobic co-digestion of microalgae Chlorella sp. and waste activated sludge. Bioresource Technology, 142, 585-590.

Wu, X.; Zhu, J.; Dong; C., Miller, C.; Li, Y.; Wang, L.; Yao, W., 2009. Continuous biohydrogen production from liquid swine manure supplemented with glucose using an anaerobic sequencing batch reactor. International Journal of Hydrogen Energy, 34, 6636-6645.

Wu, X.; Zhu, J.; Miller, C., 2013. Kinetics study of fermentative hydrogen production from liquid swine manure supplemented with glucose under controlled $\mathrm{pH}$. Journal of Environmental Science and Health, Part B: Pesticides, Food Contaminants, and Agricultural Wastes, 48, 477-485. 
Xing, D.; Ren, N.; Li, Q.; Lin, M.; Wang, A.; Zhao, L., 2006. Ethanoligenens harbinense gen. nov., sp. nov., isolated from molasses wastewater. International Journal Of Systematic And Evolutionary Microbiology, 56, 755-760.

Xing, D.; Ren, N.; Wang, A.; Li, Q.; Feng, Y.; Fang, M., 2008. Continuous hydrogen production of auto-aggregative Ethanoligenens harbinense YUAN-3 under non-sterile condition. International Journal of Hydrogen Energy, 33, 1489-1495.

Yamamoto, S.; Suzuki, K.; Araki, Y.; Mochihara, H.; Hosokawa, T.; Kubota, H.; Chiba, Y.; Rubaba, O.; Tashiro, Y.; Futamata, H., 2014. Dynamics of different bacterial communities are capable of generating sustainable electricity from microbial fuel cells with organic waste. Microbes and Environments, 29, 145-153.

Yan, J.Q.A; Lo, K.V.; Liao, P.H., 1989 Anaerobic digestion of cheese whey using up-flow anaerobic sludge blanket reactor. Biological Wastes, 27, 289-305.

Yen, H.W., Brune, D.E., 2007. Anaerobic co-digestion of algal sludge and waste paper to produce methane. Bioresource Technology, 98, 130-134.

Zafar, S. Anaerobic Digestion of Animal Manure http://www.bioenergyconsult.com/anaerobic-digestion-of-cow-manure (Accessed March 23, 2015).

Zupančič, G.D.; Uranjek-Ževart, N.; Roš, M., 2008. Full-scale anaerobic co-digestion of organic waste and municipal sludge. Biomass and Bioenergy, 32, 162-167. 